\author{
UNIVERSIDADE DE SÃO PAULO \\ INSTITUTO DE ESTUDOS BRASILEIROS \\ PROGRAMA DE PÓS-GRADUAÇÃO \\ CULTURAS E IDENTIDADES BRASILEIRAS
}

VIVIAN CHIEREGATI COSTA

Codificação e formação do Estado-nacional brasileiro:

o Código Criminal de 1830 e a positivação das leis no pós-

Independência

São Paulo

2013 


\author{
UNIVERSIDADE DE SÃO PAULO \\ INSTITUTO DE ESTUDOS BRASILEIROS \\ PROGRAMA DE PÓS-GRADUAÇÃO \\ CULTURAS E IDENTIDADES BRASILEIRAS
}

\title{
Codificação e formação do Estado-nacional brasileiro: o Código Criminal de 1830 e a positivação das leis no pós- Independência
}

\author{
Vivian Chieregati Costa \\ Dissertação apresentada ao Programa de \\ Pós-Graduação Culturas e Identidades \\ Brasileiras do Instituto de Estudos Brasileiros da \\ Universidade de São Paulo, para a \\ obtenção do título de Mestre em Filosofia. \\ Área de concentração: Estudos Brasileiros \\ Orientadora: Prof ${ }^{\mathrm{a}}$. Dr ${ }^{\mathrm{a}}$. Monica Duarte Dantas
}


Para Terezinha (in memoriam), Alice e Luciana Minhas flores de abacate, maracujá e canela 
A etimologia da palavra studium torna-se, então, aparente. Ela remonta a uma raiz, st- ou $s p$-, que designa o embate, o choque. Estudo e espanto (studiare e stupire) são, pois, aparentados nesse sentido: aquele que estuda encontra-se no estado de quem recebeu um choque e fica estupefato diante daquilo que o tocou, incapaz, tanto de levar as coisas até ao fim, como de se libertar delas. Aquele que estuda fica, portanto, sempre um pouco estúpido, atarantado. Mas se por um lado ele fica assim perplexo e absorto, se o estudo é essencialmente sofrimento e paixão, por outro lado, a herança messiânica que ele traz consigo incita-o incessantemente a prosseguir e concluir. Esta festina lente, esta alternância de estupefação e de lucidez, de descoberta e de perda, de paixão e de ação constituem o ritmo do estudo.

$[\ldots]$

Mas a mais extrema e exemplar encarnação do estudo na nossa cultura não é, nem a do grande filólogo, nem a do doutor da Lei. É antes a do estudante, tal como ele aparece em certos romances de Kafka ou de Walser. O modelo destes é o do estudante de Melville, que passa a vida numa mansarda baixa "em tudo semelhante a um túmulo", os cotovelos apoiados nos joelhos e a cabeça entre as mãos. E a sua figura mais acabada é a de Bartleby, o escritor que deixou de escrever. Neste caso, a tensão messiânica do estudo foi invertida, ou antes, está para lá de si mesma. O seu gesto é o de uma potência que não precede o seu ato, mas se lhe segue e o deixou para sempre atrás de si: é o gesto de um Talmud que não só renunciou à reconstrução do Templo, mas pura e simplesmente o esqueceu. Deste modo, o estudo liberta-se da tristeza que o desfigurava, para regressar à sua verdadeira natureza: não a obra, mas a inspiração, a alma que se alimenta de si própria.

(Giorgio Agamben - Ideia do estudo) 


\section{Agradecimentos}

A lista que segue é longa, em verdade, enorme, mas os agradecimentos que dispenso a cada um, não poderiam ser mais verdadeiros. Que, por meio deles, transpareça a potência coletiva que, desde sempre, possuiu este trabalho.

Primeiramente, agradeço à Monica Duarte Dantas, pela orientação e amizade de que tive a sorte de usufruir nos últimos seis anos. Sem suas leituras mais que cuidadosas, suas indicações bibliográficas, suas ideias e reflexões compartilhadas, restaria muito pouco desta dissertação. A ela devo o que de bom tiver resultado disso tudo e agradeço pelo incentivo constante, pela confiança depositada, pela rara generosidade acadêmica e por ter tornado o percurso da pesquisa muito mais complexo, rico e divertido.

No terreno da minha formação, não poderia faltar uma menção especial aos professores que acompanharam minha passagem pelo colégio. Dentre os tantos a marcar minha trajetória de maneira profunda, agradeço em especial, à Patrícia, às queridas professoras de História, Clara e Graça, à Valéria, Beth, Julia, Glória e Ricardo. Sem seu apoio constante, antes, durante e depois de minha passagem pelo Colégio Palmares, sabe-se lá que direção teria tomado minha vida.

No âmbito universitário, agradeço especialmente aos professores Antonio Penalves Rocha (pelas conversas freqüentes nos meus dois primeiros anos de graduação e pelo interesse desinteressado que depositou em minha formação), Ana Paula Megiani, Andréia Slemian e António Manuel Hespanha (pelo privilégio de poder acompanhar suas aulas na Faculdade de Direito da Universidade Nova de Lisboa).

Aos professores Márcia Regina Berbel e Rafael Mafei Queiroz, agradeço pela participação em minha banca de qualificação, pela leitura atenta do capítulo apresentado na ocasião e pelas indicações de leitura e encaminhamento à pesquisa.

Aos professores Airton Seelaender, Ricardo Marcelo Fonseca, Thomas Duve, Ezequiel Abásolo e Víctor Tau Anzoátegui, agradeço pela possibilidade de integrar o primeiro encontro da Escola de Graduados Alemã-Argentino-Brasileira, pela 
seriedade e atenção dedicada a meu trabalho e pela companhia agradável em Buenos Aires. No âmbito deste encontro, agradeço ainda à querida Nina Keller, pela amizade que se formou em tão poucos dias.

Aos amigos do peito, que tive a sorte de encontrar na FFLCH, e em suas adjacências, e que hão de ficar para sempre: Victor Vigneron de la Jousselandière, Danilo Chaves Nakamura, Fernando Monteiro, Osvaldo Tagliavini (o querido Vadão), Dayan de Castro, Gabriel Nascimento, Alexandre Igrecias, Caio de Andrea, Fernando Sarti Ferreira (Ramone), Emmanuel Nakamura e Cristiano Kato. E às queridas meninas: Lais Silveira, Renata Bernabé, Juliana Mantovani, Júlia Fernandez, Cássia Laureano, Tânia Mendonça, Rosa Negrini, Íris Moser, Tama Savaget e Nathalia Castro Leite. Pela interlocução constante, sobre os mais variados temas, nos últimos anos; por tudo que dividiram comigo, cada qual à sua maneira; e pelas risadas infinitas. Há um pouquinho de cada um de vocês, sedimentado ou em potência pura, ao longo deste trabalho.

Dentre todos, agradeço, especialmente, ao Victor, pela amizade que se anunciou antes mesmo de as aulas começarem, em 2004, e pela força que me deu, sem titubear, na reta final da escrita da dissertação. À Lais, enfim, agradeço pela amizade e companhia diária nos últimos dois anos e por me lembrar cotidianamente do valor da indignação. Sigamos indignadas, assim, mas sem perder a ternura jamais.

Aos bravos companheiros de biblioteca, "bandeijão" e inúmeros cafés, dia após dia, Anouch Kurkdjian, Ugo Rivetti, Bruna Della Torre e Eduardo Altheman, fica um obrigada especial. A eles somam-se todos aqueles que, um pouco mais de longe, mas sempre ali, compraram a briga (ainda não vencida) de fazer da Biblioteca Florestan Fernandes um espaço digno de trabalho e reflexão acadêmica.

Um agradecimento todo especial aos meninos do grupo de estudos do "Império Expandido" que, talvez sem o saber, foram verdadeiros mestres para mim: Tâmis Parron, Alain El Youssef, Pedro Aubert, Waldomiro Lourenço, Bruno Estefanes e André Nicacio. 
Às companheiras de pesquisa, orientação e aventuras pelo mundo acadêmico, Marina Garcia de Oliveira, Jéssica de Oliveira e Flavia Gonçalves, agradeço pelas circunstâncias em que não hesitaram em me auxiliar. À Marina, agradeço especialmente, pela solicitude interminável e pela confiança que, por motivos que desconheço, sempre depositou no meu trabalho.

Agradeço ainda aos colegas da Faculdade de Direito do Largo de São Francisco: Gilberto Gornati, Mariana Macário e Felipe Oliva, pelo apoio que deram à minha incursão nesta seara até então desconhecida. Aproveito o ensejo para agradecer também ao professor José Reinaldo de Lima Lopes, pela oportunidade de acompanhar, na qualidade de ouvinte, seu curso de "Metodologia da História do Pensamento Jurídico".

Aos amigos de toda uma vida, em cuja companhia (ainda que, por vezes, distante) escolho permanecer: Ricardo Janovitz, Larissa Oseki, Renata Bevilacqua, Max Packer, Marcos Amado e Ian Packer. Ao Ian, avec qui j'ai parcouru un chemin très important de ma vie, cabe um agradecimento e um carinho especial, pelas marcas que são suas, e que não posso negar.

A Marcy Junqueira e Martim Pelisson, agradeço por terem me acolhido quando eu mais precisei, pela confiança no meu trabalho e por tudo que me ensinaram em um ano atribulado e revelador. Aproveito para agradecer também a Antonio Carlos Robert Moraes, o Tonico, por sempre me receber tão bem em sua casa, pela companhia nas viagens ao Rio de Janeiro, Curitiba e Salvador, e por ter dividido comigo algumas de suas incríveis histórias de vida.

A Simon Pahle agradeço pela parceria, confiança e por tudo que, ao seu lado, e em tão pouco tempo, pude aprender.

À Capes/CNPq agradeço pelo financiamento inicial desta pesquisa e à Fundação de Amparo à Pesquisa do Estado de São Paulo, pelo apoio recebido ao longo de 13 importantes meses. 
Aos funcionários do Arquivo da Câmara dos Deputados (à Ligia, em especial) e do Senado federal, de Brasília, agradeço pelo auxílio prestado em minhas primeiras incursões nos arquivos nacionais e pela paciência que tiveram, então, em me auxiliar. Agradeço ainda aos funcionários dos diversos arquivos do Rio de Janeiro pelos quais peregrinei em duas ocasiões diferentes. Dentre eles, fica minha admiração especial ao Oswaldo, da seção de Obras Gerais da Biblioteca Nacional, e a Pedro Tórtima, do Arquivo do IHGB. Agradeço ainda, com grande carinho, aos funcionários mais antigos da Biblioteca Florestan Fernandes (Isabel, Cacá, Marines, Roseli, dentre outros) com quem pude trabalhar no ano de 2005 e que tive a alegria de rever, dia após dia, nos últimos anos de pesquisa e escrita da dissertação. Aos funcionários terceirizados da biblioteca, especialmente àqueles que cuidam das chaves e armários, agradeço ainda por tornarem minhas chegadas e saídas da biblioteca mais leves e divertidas.

Cabe uma menção, ainda, aos funcionários e estagiários da Secretaria de PósGraduação do IEB/USP, em especial à Cristina, pelos inúmeros auxílios prestados ao longo da pesquisa.

Aos queridíssimos Cleusa, Renato e Karina Otsuka, agradeço por terem carinhosamente me acolhido em sua família e me proporcionado almoços e jantares divertidos e deliciosos. Peço desculpas, contudo, por ter praticamente seqüestrado seu filho e irmão nos últimos dois anos. Se serve de consolo, ele tornou minha vida imensamente mais feliz neste período, contribuindo muitíssimo à elaboração deste trabalho.

A meu pai, agradeço pela dedicação dispensada à minha educação (em todos os seus aspectos) desde pequena. À seriedade com que sempre tratou os meus estudos e ao seu coração enorme, sempre disfarçado por uma certa rabugice, devo grande parte da minha personalidade. Se as escolhas que fui realizando ao longo da vida não foram aquelas que ele muito provavelmente almejou para mim, agradeço, ainda assim, pelo respeito com que sempre as aceitou. À Simone, agradeço pelo carinho de sempre, que não senti diminuir quando, aparentemente, ela concluiu pelo equívoco da minha dedicação integral aos estudos. Para sua sorte, sei do amor e apoio que, vindos dela, me acompanharão por toda a vida. 
À Luciana, minha irmã geniosa, cuja falta sinto tanto, todos os dias, agradeço pela amizade de sangue e de alma. Ela foi, além de tudo, uma interlocutora valiosa ao longo destes anos, com quem pude dividir minha paixão por Giorgio Agamben e por tantas outras coisas sérias e estúpidas da vida. A seu marido, e amigo querido, Ibon Salvador Bikandi, agradeço por não me levar a sério como os outros, pelas infinitas conversas sobre tudo e sobre nada, por ser uma pessoa tão incrível. Aproveito para agradecer também à sua querida família, que me recebeu de braços abertos e com tanto carinho no deslumbrante País Basco.

À minha mais que amada mãe, faltam palavras para agradecer. Por uma vida inteira dedicada a mim e a minha irmã, e por todas as oportunidades que me proporcionou, ou das quais não me deixou escapar. Devo muito, ou quase tudo, a ela. Apesar de nossas personalidades fortes e, por tantas vezes, em rota de colisão, formamos, afinal, uma bela dupla.

No âmbito doméstico, aproveito para agradecer ainda a Neusa e Beth, que tornaram a vida muito mais fácil nos últimos tempos, cuidando com amor de nossa casa e do meu querido Ugui.

Por fim, agradeço a Alexandre Otsuka, por sua paciência inesgotável, por seu carinho incomensurável, por segurar minha mão dia após dia e por um amor como eu nunca vi igual. Alê, você está em todas as linhas e entrelinhas deste trabalho, que também é seu. 


\section{Resumo}

A presente dissertação realiza um exame histórico-jurídico do Código Criminal do Império do Brasil, aprovado em 16 de dezembro de 1830. Frequentemente interpretado como um documento liberal elaborado às pressas e artificialmente sobreposto à sociedade brasileira, o Código Criminal de 1830 foi muito pouco estudado pela historiografia nacional. Buscando desvendar a complexidade dos trabalhos e escolhas jurídicas e políticas envolvidas em sua composição, analisamos pormenorizadamente o trâmite parlamentar seguido por este documento (centrandonos nos debates legislativos e comissões de trabalho dedicadas à sua elaboração), relacionando-o, ainda, ao movimento codificacionista ocidental em curso na virada do século XVIII ao XIX. Para além de examinar os projetos de código criminal apresentados ao legislativo brasileiro, entre 1826 e 1827, por José Clemente Pereira e Bernardo Pereira de Vasconcelos, realizamos uma análise comparativa cuidadosa entre o conteúdo destes projetos e o texto final do código aprovado, somando, ainda, a tal análise, uma comparação entre o Código de 1830 e os textos de dez códigos ou projetos de codificação penal existentes no mundo ocidental àquela altura. Partindo do corpus documental supracitado e da conjuntura política de aprovação deste diploma, a pesquisa desnudou as relações então travadas entre o direito penal e a política do Primeiro Reinado, articulando os dispositivos adotados pelo Código de 1830 às particularidades inerentes ao momento de sua aprovação e aos projetos de Estado, justiça e cidadania defendidos pelos parlamentares imperiais. Inserida e influenciada por um movimento internacional de larga escala e pautada por concepções jurídicas extremamente modernas, a positivação das leis penais no Império brasileiro atrelou-se à configuração do novo Estado-nacional e ao desejo de seus representantes de conformação de uma nova realidade. 


\begin{abstract}
This thesis proposes a historical-juridical study of the Brazilian Imperial Criminal Code (Código Criminal do Império do Brasil), approved in December $16^{\text {th }}, 1830$. Frequently interpreted as a liberal document hastily elaborated and artificially imposed upon the Brazilian society, the Criminal Code of 1830 has been neglected by national historiography. To try to unveil the complexity of the juridical and political choices and maneuvers involved in its composition, I analyze in detail the parliamentary process of proposal and approval of this document (focusing on the legislative debates and the legislative commissions committed to its elaboration), aiming to relate its content to the western codification movement that started at the turn of the $18^{\text {th }}$ century. The scope of my analysis goes beyond the analysis of the projects for the criminal code presented to the Brazilian legislative by José Clemente Pereira and Bernardo Pereira de Vasconcelos between 1826 and 1827, in order to produce a careful comparison between the content of such projects and the final text of the approved criminal code. The present thesis also includes a detailed comparison between the Code of 1830 and the contents of ten codes or projects of penal codification available in the western world at the time. Using the aforementioned documental corpus and bearing in mind the political situation contemporary to the approval of this code, the research has revealed the relations between penal law and politics during the First Reign (Primeiro Reinado), articulating the juridical statements embedded on the Code of 1830, and social-political particularities specific to the moment of its approval, with different projects regarding the State's organization, prospects of justice and citizenship expected by the nation's representatives. Imbedded in and influenced by a large-scale international movement and based on extremely modern juridical conceptions, the proposition of penal laws in the Brazilian Empire was connected to the configuration of the new national State and to the desire of its representatives to conform a new reality.
\end{abstract}




\section{Sumário}

Introdução

Capítulo 1. Enquadramento jurídico e conjuntura política na primeira década no Brasil independente .47

1.1. A legislação penal na América portuguesa e nos anos iniciais do Império do Brasil...... 47

1.2. Regime constitucional, poder Judiciário e direito penal no Primeiro Reinado brasileiro

1.3. A oposição política parlamentar e o enfraquecimento de $\mathrm{d}$. Pedro nas primeiras

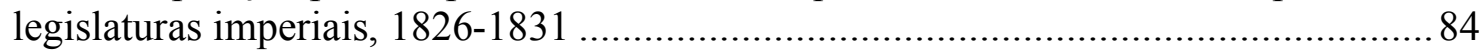

1.4. Os projetos para o primeiro Código Criminal do Império do Brasil................... 101

Capítulo 2. O trâmite parlamentar do Código de 1830: debates procedimentais, comissões de trabalho e a manutenção da pena de morte............................................ 125

2.1. Cronologia de elaboração do Código Criminal de 1830 .................................. 128

2.2. O debate procedimental em torno à elaboração do Código de $1830 \ldots \ldots \ldots \ldots \ldots \ldots . . . . . .134$

2.3. A atuação das comissões parlamentares na composição do Código de $1830 \ldots . . .154$

2.4. Os debates sobre a pena de morte e sua manutenção no Código Criminal .......... 174

Capítulo 3. O Código Criminal de 1830: matrizes e influências .................................203

3.1. Os projetos do Código Criminal e a versão final do diploma brasileiro de $1830 \ldots 209$

3.2. Matrizes e influências penais do Código brasileiro de 1830 ............................. 238

3.3. O Código de 1830 como arma política estratégica do legislativo nacional e engrenagem do aparelhamento jurídico da nação ...................................................2 274

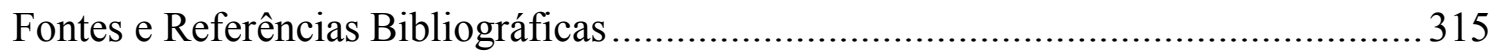

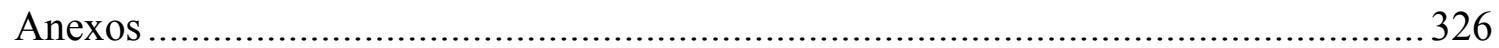

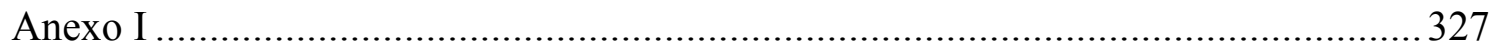

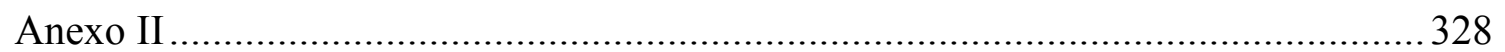

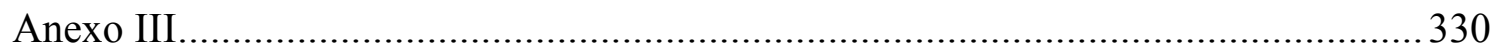

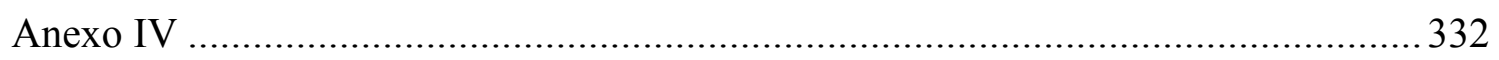

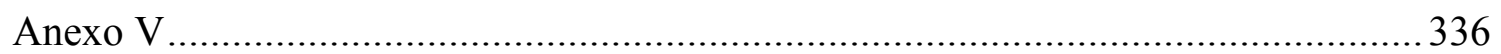

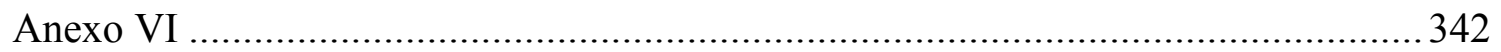

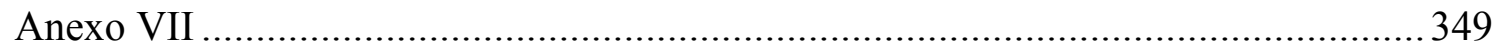

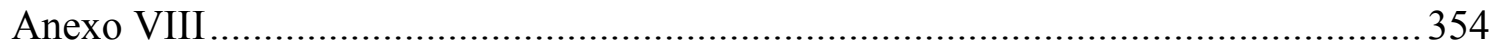

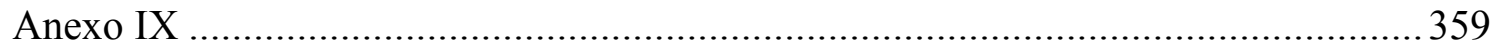




\section{Introdução}

No dia 11 de setembro de 1830, em meio à bateria final de discussões parlamentares que precederam a aprovação do Código Criminal do Império do Brasil, o deputado Francisco de Paula Souza e Melo, exortando seus companheiros a se esforçarem pela promulgação do referido diploma ainda naquele ano, pronunciou a seguinte fala:

Evitemos que os inimigos da constituição digão que nós nada fazemos. A massa da nação não póde ajuizar dos nossos trabalhos senão pelos seus resultados, e poupemo-nos a que os boatos espalhados pelos mal intencionados sejão acreditados. Comparemos os trabalhos da assembléa geral este anno com os dos corpos legislativos de todo o mundo em um tão curto espaço, e não se poderá dizer que temos trabalhado pouco. As leis não se improvisão como os antigos decretos do governo absoluto.

Nós temos muitos inimigos, é preciso fallarmos claro. Muitas vezes quando nos parece que o inimigo recua, é um novo estratagema, um novo plano que medita: é portanto preciso tirar ao inimigo todas as armas que nos combatão.

Mandarei à mesa um requerimento, no qual exporei as idéas que acabo de expender. Os Srs. deputados que se lembrarem de outros meios mais fáceis, que os proponhão; comtanto que o codigo se adopte já e já.

O trecho então enunciado por Paula Souza possui a qualidade de sintetizar algumas das principais preocupações dos deputados brasileiros no momento de positivação das leis penais no Império: o desejo de finalizar, o quanto antes - por meio da aprovação do código criminal -, mais uma importante etapa no processo de aparelhamento do Estado brasileiro e diferenciação de seu edifício legal daquele típico do Antigo Regime - processos a que o Parlamento vinha se dedicando intensamente desde sua abertura, em 1826 -; e a expectativa de que a aprovação deste diploma operasse positivamente no juízo da nação sobre o trabalho dos deputados (expondo sua importância, seriedade e dedicação), afastando do poder legislativo seus principais inimigos e preservando a segurança nacional.

Os "inimigos da constituição" a que Paula Souza faz referência eram não só aqueles que criticavam, nos debates públicos e na imprensa política da época, o regime representativo e a atuação parlamentar brasileira - ferindo a imagem dos deputados frente à opinião pública nacional -, mas também aqueles contra cujos “estratagemas" e possíveis golpes políticos era desejado que a aprovação do código criminal viesse atuar. Especialmente para a consecução da batalha contra este segundo grupo de inimigos, fazia-se necessário que o código passasse “já e já". 
Uma ampla gama de questões e disputas políticas amalgamou-se, ao longo do Primeiro Reinado, em torno do movimento codificacionista do Império brasileiro. Tratava-se de embates que, permeando os campos simbólico e prático da afirmação do novo Estado e de seu regime representativo e legal, revelavam a multiplicidade de projetos e expectativas para a nova unidade política que se formava e o aumento das tensões entre os diferentes grupos por trás destes planos.

A proposta de positivação das leis penais no Brasil gerava ainda, por conta de seus significados jurídicos e teóricos intrínsecos, uma disputa em torno do discurso legal a ser encampado pelo novo país e do conteúdo ideológico a ser materializado no diploma penal. Neste sentido, os debates em torno da faceta a ser assumida pelo direito criminal brasileiro repercutiram e refletiram diretamente sobre os projetos institucionais arquitetados para a nova nação.

O processo que desembocaria em discussões como aquela de que participou Paula Souza vinha se desenrolando, assim, desde pelo menos a abertura dos trabalhos legislativos do Império, quando, ainda em maio de 1826, tocou-se no tema da codificação penal e tiveram início os trabalhos parlamentares com vistas à sua efetivação. Passados quatro anos e meio, duas legislaturas, três projetos de código criminal, quatro comissões parlamentares e diversas discussões nas câmaras alta e baixa da Assembleia legislativa, aos 16 de dezembro de 1830 foi enfim sancionado, pelo imperador d. Pedro, o primeiro e único código penal do Império do Brasil.

\section{História e Direito: o pólo jurídico da formação do Estado brasileiro}

Haja vista a importância assumida por semelhante temática ao longo de praticamente todo o Primeiro Reinado, chama a atenção a ausência quase completa de estudos historiográficos dedicados ao fenômeno da codificação penal no Império do Brasil. Mais do que isso, assumindo-se o importante papel historicamente desempenhado pelo direito e, em especial, pelo direito penal, no processo de formação dos modernos Estados ocidentais na passagem do século XVIII ao XIX, sobressai a carência de pesquisas dedicadas a um exame do pólo jurídico do fenômeno de construção do Estado-nacional brasileiro. Quando realizadas, tais pesquisas mostraram-se potentes, revelando aspectos cruciais à compreensão dos 
primeiros passos e arranjos políticos adotados pelo país e à apreensão das particularidades inerentes ao Estado aí inicialmente projetado e ordenado ${ }^{1}$.

A pesquisa aqui desenvolvida pretende se inscrever, assim, na já larga vereda de estudos dedicados à compreensão do fenômeno estatal em terras brasílicas, assumindo, contudo, como perspectiva privilegiada de observação, o caráter jurídicolegislativo de semelhante processo e, mais do que isso, o papel nele jogado pela positivação das leis penais finalizada em 1830. Objetiva-se, com isso, articular à análise do processo codificacionista penal desenrolado na primeira década do país independente, o estudo das discussões, embates e projetos políticos então travados no Parlamento nacional.

Se atentarmos à concepção de justiça corrente em Portugal desde, pelo menos, o século XVI, veremos que, sobreposta a todas as outras, esta prática do poder materializava a função de manutenção dos equilíbrios e autonomias político-jurídicas vigentes entre os diferentes corpos que compunham a sociedade. O caráter essencialmente corporativo e jurisdicional que marcara a monarquia lusitana de Antigo Regime (de que falaremos com maior cuidado à frente), manifestou-se também na América portuguesa, constituindo uma sociedade que, no âmbito institucional, foi apenas fragilmente regulada pela metrópole, enquanto, no âmbito do direito, foi pluralista e altamente autônoma.

\footnotetext{
${ }^{1}$ Para além do já clássico trabalho de Thomas Flory, têm se dedicado a semelhante linha de estudos os seguintes pesquisadores: Ivan Vellasco, Andréa Slemian, José Reinaldo de Lima Lopes, Monica Duarte Dantas, dentre outros. Thomas Flory. El juez de paz y el jurado en el Brasil imperial, 1808-1871: control social y estabilidad política en el nuevo Estado. México: Fondo de Cultura Econômica, 1986. Ivan Vellasco. As seduções da ordem: violência, criminalidade e administração da Justiça - Minas Gerais, século XIX. São Paulo: EDUSC, 2004. Andréa Slemian. Sob o Império das Leis: Constituição e unidade nacional na formação do Brasil (1822-1834). São Paulo: Aderaldo \& Rothschild: Fapesp; 2009; e Idem. "À nação independente, um novo ordenamento jurídico: a criação dos Códigos Criminal e do Processo Penal na primeira década do Império do Brasil. In: Gladys Sabina Ribeiro (org.) Brasileiros e cidadãos: modernidade política, 1822-1890. São Paulo: Alameda, 2008. José Reinaldo de Lima Lopes. O Oráculo de Delfos: o Conselho de Estado no Brasil-Império. São Paulo: Editora Saraiva: Fundação Getúlio Vargas, 2010; e Idem. "Iluminismo e jusnaturalismo no ideário dos juristas da primeira metade do século XIX". In: István Jancsó, Brasil: formação do Estado e da nação, São Paulo: Hucitec: Fapesp: Unijui, 2003. Monica Duarte Dantas. "Revoltas, Motins, Revoluções: das Ordenações ao Código Criminal". In: Idem (org.). Revoltas, motins, revoluções: homens livres pobres e libertos no Brasil do século XIX. São Paulo: Alameda Editorial, 2011; e Idem. "Dos Statutes ao Código brasileiro de 1830: o levante de escravos como crime de insurreição". Revista do Instituto Histórico e geográfico Brasileiro, vol. 452, pp. 273-309, 2011.
} 
Tal conformação político-jurídica da colônia fez com que, também aí, a distribuição da justiça e a garantia dos direitos das localidades fossem extremamente valorizadas, representativas que eram das autonomias locais e da certeza de manutenção dos equilíbrios conquistados e garantidos com o passar dos anos. Nesse sentido, não é de se estranhar a importância representada pelo âmbito jurídico quando da separação política formal entre Brasil e Portugal, bem como a centralidade das reformas aí empreendidas nos primeiros anos do país independente.

No período formativo do Estado brasileiro, questões como a manutenção da unidade territorial, a necessária reforma da máquina burocrática herdada do período colonial e a consolidação de um novo arranjo de poder - mais especificamente, a afirmação de um poder central capaz de exercer jurisdição sobre a totalidade do território -, ocuparam o primeiro plano da arena política. Nesta conjuntura, a montagem do sistema judiciário assumiu papel central, concentrando algumas das principais expectativas em torno da reforma administrativa em andamento e revelando-se um ponto nodal da construção e consolidação do poder estatal ${ }^{2}$.

No bojo deste aparelhamento jurídico assumiu importância significativa a aprovação, em 1830, do código criminal do Império. Elemento fundamental à conquista e manutenção da desejada ordem interna, para além de representativo de um projeto político e de aparelhamento institucional da nova nação, o processo de elaboração e aprovação deste documento desempenhou papel importante no interior das disputas políticas vividas pelos deputados das primeiras legislaturas.

Não deve nos escapar, neste contexto, a radicalidade subjacente à concepção normativa implícita na elaboração de um código moderno e as expectativas depositadas sobre semelhante elaboração pelos artífices do novo Estado. A aprovação de um código criminal representava não apenas a supressão de todo o direito previgente, mas também a sua substituição por uma fonte doutrinária única e completa, produzida, por sua vez, exclusivamente pelo Estado. Para além disso, por destinar-se a um único, e socialmente indiferenciado, tipo de destinatário, os códigos pressupunham a paridade jurídico-formal dos cidadãos ${ }^{3}$.

\footnotetext{
${ }^{2}$ Thomas Flory. El juez de paz y el jurado en el Brasil imperial, 1808-1871: control social y estabilidad política en el nuevo Estado. México: Fondo de Cultura Econômica, 1986; p. 71. Ivan Vellasco. As Seduções da Ordem: violência, criminalidade e administração da justiça: Minas Gerais - século 19. Bauru, SP; São Paulo: EDUSC; ANPOCS, 2004; pp. 15-18.

${ }^{3}$ Adriano Cavanna. Storia del diritto moderno in Europa: le fonti e il pensiero giuridico; vol. 2. Milano: Dott. A. Giuffrè Editore, 2005; p. 42.
} 
O papel político e estratégico assumido pelo direito penal neste período formativo, deve-se frisar, não foi privilégio do Brasil, haja vista a importância histórica por ele desempenhada também na construção dos modernos Estados europeus na passagem do século XVIII ao XIX. Inserida, assim, num processo internacional de larga escala, a codificação brasileira aliou às peculiaridades do caso nacional (uma ex-colônia portuguesa, escravocrata, sem um pensamento jurídico próprio - haja vista a ausência de universidades até o final da década de 1820 -, dentre outros aspectos), padrões e expectativas comuns ao fenômeno ocidental como um todo.

Nesse sentido, ainda que pretendamos unir à análise da codificação penal pósindependência, um exame da política brasileira no período e dos projetos de Estado e de nação então esboçados (e em constante disputa) - contribuindo, quiçá, ao delineamento de mais uma via de acesso à compreensão do fenômeno estatal e nacional no país -, esta pesquisa não poderia se desenvolver sem recorrer a um exame de conjunto do processo codificacionista penal no mundo ocidental, utilizando-o como base de comparação e parâmetro de aproximação e identificação das generalidades e peculiaridades do caso brasileiro.

\section{A codificação do direito no mundo ocidental: historiografia jurídica}

Ao elucidar este processo, contudo, vale atentar aos riscos envolvidos num exame de longa duração do fenômeno codificacionista. Referimo-nos, fundamentalmente, ao fato de a forma código, tal como compreendida pelo Direito contemporâneo, não poder ser encontrada, em parte alguma da Europa ou do mundo ocidental, previamente às revoluções liberais de fins do século XVIII. Ainda que o termo código, como veremos, tivesse existência e uso prévios, a especificidade inerente ao sistema conceitual e normativo representados por um código, constituía, nas palavras de Bartolomé Clavero, um “impossível histórico" no período que antecedeu às revoluções americana e francesa.

Buscando desvendar o conteúdo implícito a este conceito ardiloso, Bartolomé Clavero adverte seus leitores de que, partindo-se unicamente da coleta e reunião ordenada de documentos normativos sob o título de "código", deparamo-nos com uma história tão heterogênea quanto dilatada no tempo. Para o autor, portanto, algumas reduções são necessárias à definição do objeto:

Temporalmente resulta ulterior a las revoluciones que han dado entrada a nuestro actual periodo histórico. Antes en concreto de la Revolución Francesa no había 
alcanzado existencia por parte alguna de Europa la misma forma de derecho que puede conferirle al Código su autoridad normativa: Ley constituyente. Y de contenido también se trata. Para ser norma extensa, que cubre un ordenamiento de materia, y articulada, que lo hace con coherencia, la Codificación también precisaba de un requisito sustantivo no menos moderno ni menos en sí revolucionario: Sujeto unitario. ${ }^{4}$

Daí a necessidade prévia, a seu ver, de revoluções e, no âmbito normativo, Constituições ou, mais particularmente, declarações constitucionais, para a conquista da forma código: com as primeiras obter-se-ia o tipo específico de lei e com as segundas o tipo específico de sujeito necessários ao seu aparecimento 5 . Para Clavero, ainda que se tenda frequentemente a retroceder o ponto de partida da história da codificação pelo século XVIII adentro, buscando nas normatizações legais produzidas pelo iluminismo jurídico os vestígios do codificacionismo oitocentista, antes do período constitucional e, mais especificamente ainda, antes do século XIX (quando, somente então, o termo código adquire sentido próprio e circula, portando este sentido, por toda a Europa), tal fenômeno não existe. O período que antecede, enfim, esta construção conceitual específica não pode ser considerado, para o autor, senão a pré-história da codificação ${ }^{6}$.

Ainda que a maioria dos autores interessados no fenômeno codificacionista concorde com as colocações de Clavero, parte considerável deles, em especial aqueles dedicados ao exame da codificação das leis penais, tende efetivamente a recuar as origens de suas análises ao século XVIII, recuperando ali os primeiros sinais de desgaste do sistema pluralista e jurisprudencial de Antigo Regime e a edificação simultânea dos primeiros pilares da codificação contemporânea ${ }^{7}$.

\footnotetext{
${ }^{4}$ Bartolomé Clavero. "Codificación y constitución: paradigmas de un binomio”. In: Quaderni Fiorentini per la storia del pensiero giuridico moderno; XVIII (1989). Milano: Giuffrè editore; pp. 79-145; p. 81.

${ }^{5}$ Idem; p. 82. O mesmo tipo de reflexão do autor pode também ser encontrada nas páginas iniciais do artigo "Código como fuente de derecho y achique de constitución en Europa". In: Revista Española de Derecho Constitucional; Año 20; Núm. 60; Septiembre-Diciembre, 2000; pp. 11-43.

6 "No parece que se tenga una experiencia precedente [ao Código Civil napoleônico] conduciendo, como fruta madura de cultivo moroso, a este determinado producto, según suele en cambio imaginarse la historiografía, incluso más especializada en el derecho. No hay tal a lo que alcanzo. Como es de sobre conocido y en seguida comprobaremos para ver de precisarlo, la idea de base del Código identifica derecho con ley, dirección del ordenamiento con determinación política. Pues bien, ni siquiera esta ocurrencia de partida existe como tal en unas vísperas.". Bartolomé Clavero. "Código como fuente de derecho y achique de constitución en Europa". Op. Cit.; 2000; pp. 15-16.

7 "Per 'codificazione' in senso ristretto e tecnico, si intende quel processo culturale e storico attraverso cui si è resa possibile la menzionata idea ottocentesca; e cioè il processo che
} 
Sujeitos aos riscos teleológicos implícitos na recuperação e alinhamento, temporal e processual, de fenômenos cujo resultado final não se poderia então prever $^{8}$, tais estudos possuem, contudo, a vantagem de, ao empreender uma avaliação de mais longa duração, delinear e ajudar a compor um quadro mais completo e significativo do momento de passagem do direito de Antigo Regime ao direito positivado no mundo ocidental.

Cientes, assim, das dificuldades inerentes à temática escolhida e dos debates existentes em torno à delimitação do objeto selecionado, optamos por somar às vantagens analíticas trazidas pela produção de autores como Adriano Cavanna e Giovanni Tarello - em especial no que tange à composição de um quadro histórico alargado da transição do modelo de Antigo Regime para a contemporaneidade -, as problematizações colocadas, por exemplo, por Bartolomé Clavero e António Manuel Hespanha a este tipo de análise historiográfica.

Base comum a este conjunto de autores é, de todo modo, a perspectiva de que a forma código não deve ser encarada como fenômeno natural e irreversível da história do direito ocidental, constituindo-se, antes, na mais recente criação de uma cultura jurídica milenar9 ${ }^{9}$. Daí a necessidade de que problematizemos e, especialmente, desnaturalizemos o complexo trajeto percorrido rumo à codificação, reconhecendo no percurso setecentista que antecedeu a positivação do direito penal na Europa, uma dose significativa de intencionalidade e teor político - ainda que, na segunda metade do século XVIII, não se pudesse de forma alguma prever aonde este movimento iria desembocar.

conduce ai Codici concreti, cui i giuristi ottocenteschi (continentali) si riferivano. Ma, per comprendere questo processo, è necessario un oggetto di attenzione piú vasto e piú sfumato di quello che avremmo prendendo pari pari come parametro alcune idee ottocenteschi di codice, infati, occorre considerare quelle idee ottocentesche nelle loro peculiarità storiche, quali si sono determinate e precisate alla fine di una lunga vicenda, all'inizio della qualle le idee erano, tavolta, meno precise e piú vaghe." Giovanni Tarello. Storia della cultura giuridica moderna. Bologna: Società editrice il Mulino, 2010; pp. 19-20.

${ }^{8}$ Quentin Skinner. "Meaning and Understanding in the History of Ideas". In: Idem. Visions of politics. Volume I: regarding method. Cambridge University Press, 2002; pp.57-89.

${ }^{9}$ Nas palavras de Adriano Cavanna: "Fu il frutto di un grande processo critico del pensiero giuridico occidentale l'idea di ridurre in principi il diritto de un popolo, di compendiarlo in un testo dal rigore geometrico, di affidare il governo di una società a un sistema di assiomi privo di contraddizioni e di lacune, concepito da un'unica mente, cioè creato in blocco e all'istante da un legislatore sovrano, sottratto ad ogni arbitrio di giudici e interpreti ed all concorrenza di ogni consuetudine. Né si trattò di pura e semplice evoluzione della vita del diritto sul continente. Divenuta scelta tecnico-politica consapevole, la codificazione constituì un traguardo che risultò di arduo raggiungimento.”. Adriano Cavanna. Op. cit.; p. 35. 
Se a forma código, em sua especificidade legal, só pôde ser vislumbrada e materializada em decorrência dos sucessos revolucionários de 1776 e 1789, o anseio por uma reforma racionalizadora do direito vinha de mais longa data e, pouco a pouco, concentrou-se em torno do direito penal.

\section{O direito penal de Antigo Regime e sua lenta superação}

A análise da trajetória ocidental de superação da estrutura jurídica típica do Antigo Regime, e da consecução, no século XIX, de um complexo de direito codificado, deve se pautar, entre outros aspectos, (i) pelo reconhecimento da estrutura legal herdada, pela modernidade européia, do período medieval, (ii) pela compreensão da "crise" em que semelhante estrutura se encontrava na segunda metade do século XVIII e, finalmente, (iii) pela averiguação do percurso então trilhado com vistas à sua superação.

Em linhas gerais, a experiência jurídica do medioevo e de grande parte da modernidade pode ser compreendida a partir do papel central então representado pela justiça no horizonte das práticas do poder. Dominado pela ideia da existência de uma ordem natural universal (cosmos) em que cada coisa e cada pessoa tinham o seu lugar - uma ordem objetiva, superior a qualquer vontade e orientada a um telos específico , o pensamento político e social medieval atribuía à justiça (distribuída pelo monarca) a função de dar, a cada um, o que lhe fosse devido, mantendo a ordem das coisas tal qual objetivamente designada pela Criação ${ }^{10}$.

Aliado a esta visão de mundo estava um largo consenso sobre o caráter naturalmente desigual das pessoas e grupos sociais, pelo que as diferenças de estatuto não eram, por si sós, contestadas. Pelo contrário, a especificidade de cada órgão social (e de sua atuação particular com vistas à realização do destino cósmico) era não só reconhecida, como também apreciada, compreendendo-se o poder fundamentalmente a partir de sua repartição (ainda que desigual) pelos diferentes corpos da sociedade ${ }^{11}$.

A estes corpos sociais reivindicava-se, por sua vez, a autonomia necessária ao cumprimento de suas funções particulares; autonomia político-jurídica, portanto, diretamente relacionada à ideia de autogoverno (iurisdictio) e materializada no poder

\footnotetext{
${ }^{10}$ António Manuel Hespanha. História de Portugal Moderno: político e institucional. Lisboa: Universidade Aberta, 1995.

${ }^{11}$ Nas palavras de António Manuel Hespanha: "Tão monstruoso como um corpo que se reduzisse à cabeça, seria uma sociedade em que todo o poder estivesse concentrado no soberano.” António Manuel Hespanha. Idem; p. 29.
} 
local de fazer leis e estatutos, constituir magistrados, julgar conflitos e emitir comandos.

No interior de um regime político pluralista como este - vigente, com variações nas diferentes partes da Europa, até pelo menos a segunda metade do século XVIII -, a atuação primordial da coroa fundava-se na manutenção dos equilíbrios (jurídicos, políticos e sociais) pré-estabelecidos nas localidades. Longe de querer alterá-los, o rei buscava unicamente arbitrá-los, defendendo sua hegemonia simbólica de sumo dispensador da justiça e da graça e abdicando do papel de centro único do poder; assumindo-se, portanto, como pólo coordenador de uma sociedade poli-centrada ${ }^{12}$.

A metáfora, típica do Antigo Regime, da ordem social como um corpo em que a cada órgão competia uma função distinta - hierarquizada de acordo com sua importância para a subsistência do todo -, e no qual à cabeça (poder do príncipe) competia a representação da unidade e a harmonização de todos os membros atribuindo a cada um o que lhe fosse próprio e garantindo a cada qual o seu estatuto -, representava bem a ideia de justiça deste período, compreendida como a primeira, senão única, atividade do poder, e diretamente relacionada à manutenção da ordem e do bom funcionamento social.

Limitada pelas autonomias corporativas e senhoriais locais, mas com preeminência sobre elas, a monarquia de Antigo Regime era representada, portanto, por sua função de "fazer justiça" e, nesse sentido, regular a relação das partes entre si e manter o equilíbrio do todo.

Como este equilíbrio do todo preexiste à vontade do Poder e é indisponível em relação a ela, o exercício do Poder baseia-se não numa vontade arbitraria (arbitrium, alvedrio, alvitre), mas numa ciência prática (prudentia). E, como esta prudentia se dirige à manutenção dos equilíbrios estabelecidos, dos direitos radicados, ela é orientada pelo direito - a prudentia politica coincide, em grande medida, com a jurisprudentia. ${ }^{13}$

De acordo com António Manuel Hespanha, ao instaurar a jurisprudência como ciência do governo, o pensamento social e político medieval aceitava que a definição de poder escapasse à vontade de seus próprios detentores, ficando restrita a outra categoria social: os juristas. Para o autor, foi a partir deste momento que o sistema do

\footnotetext{
${ }^{12}$ António Manuel Hespanha. "Da 'iustitia' à 'disciplina'. Textos, poder e política penal no Antigo Regime.”. In: Anuario de Historia del Derecho Español. Madrid, 1988; pp. 493-578; pp. 500-527.

${ }^{13}$ António Manuel Hespanha. "Conclusão". In: José Mattoso (org.). História de Portugal; vol. IV: “O Antigo Regime (1620-1807)”. Lisboa: Editorial Estampa; pp. 466-468.
} 
direito doutrinal europeu, ou "direito comum", adquiriu uma função que hoje denominaríamos "constitucional", na medida em que definidora das esferas de ação e dos meios legítimos de efetivação do poder do monarca e, nesse sentido, limitadora deste poder.

Vejamos, portanto, no que consistia este direito doutrinal de Antigo Regime, comumente denominado "direito comum" (ius commune), analisando, ainda, a efetividade de seu emprego e sua convivência com instâncias jurídicas como a dos direitos particulares (iuria propria) e tradicionais, frequentemente empregados nas localidades dos reinos.

Conhecida pelo nome de "direito comum"", a doutrina jurídica européia dos séculos XV, XVI e XVII fundava-se numa tradição literária - ou seja, numa cadeia de textos cuja unidade decorria de sua referência comum aos mesmos textos fundadores -, composta, fundamentalmente, pelo direito canônico (constituído pelas Escrituras e pelo Corpus iuris canonici) e pelos textos do direito romano (contidos no Corpus iuris civilis). Para além destes, os juristas, intérpretes e cultores do "direito comum" recorriam, com certa freqüência, à Glosa de Acúrsio, aos Comentários de Bártolo e à opinio communis doctorum, ou seja, a "opinião comum” dos (juristas) Doutores do período.

A autoridade destes textos - fundada, respectivamente, na revelação divina (caso do direito canônico) e na razão escrita (natureza de ratio escripta designada ao direito romano) -, era indiscutível e, neste sentido, não instrumentalizável pelo poder. No plano da aplicação cotidiana do "direito comum", tal indisponibilidade da tradição literária obrigava os juristas a observarem seus textos fundadores, cultivando um discurso "dogmático" e erigindo sua autoridade e seus poderes de forma

\footnotetext{
${ }^{14}$ De acordo com Hespanha: "A doutrina jurídica dos séculos XV, XVI e XVII tem recebido designações muito variadas - 'bartolismo', 'escolástica jurídica', 'mos italicus', etc; mas a sua designação mais correta é a de 'direito comum' por se revelar menos unilateral do que qualquer das anteriores e por nos dar, desde logo, esta ideia: a de que ela apresenta, como característica primeira, a unidade - (i) quer enquanto unifica as várias fontes do direito (direito justinianeu, direito canônico e direitos locais; (ii) quer enquanto constitui um objeto único (ou comum) de todo o discurso jurídico europeu; (iii) quer ainda enquanto 'trata' este objeto segundo métodos e estilos de raciocinar comuns; (iv) forjados num ensino universitário do direito que era idêntico por toda a Europa; e (v) vulgarizados por uma literatura escrita numa língua então universal - o latim”. António Manuel Hespanha. Cultura jurídica européia: sintese de um milênio. Portugal: Publicações Europa-América, 2003; p. 89.
} 
independente, ou mesmo superior, em relação ao poder político - uma vez que a razão gozava, então, de uma autoridade mais elevada que a vontade dos príncipes ${ }^{15}$.

Utilizadores constantes e atualizadores por excelência do corpus textual do direito comum (inserido em novas problemáticas e conteúdos a cada novo julgamento e, nesse sentido, apenas aparentemente imobilista ou conservador), os juristas do Antigo Regime acabaram por assumir o papel de mediadores exclusivos desta tradição dogmática e doutrinal agregativa (na qual, diferentemente da tradição legislativa atual - em que novas leis derrogam suas antecedentes - cada nova interpretação passava a coexistir com as anteriores) $)^{16}$, obtendo, assim, autonomia máxima nos julgamentos e larga margem de arbítrio ${ }^{17}$.

Se a tradição textual do "direito comum" constituía, portanto, o centro do direito oficial dos reinos de toda a Europa central e ocidental, e se os juristas letrados de então protagonizavam a aplicação cotidiana desta tradição, uma e outros não monopolizavam, contudo, o universo da prática normativa social. Nesse sentido, não só o "direito comum" coexistia, àquela altura, com os direito particulares das localidades (iuria propria, compostos pelos costumes, estilos de decisão dos tribunais locais e privilégios) e com formas tradicionais e informais de funcionamento da justiça (caso do chamado "direito dos rústicos" $" 18$ ), como também dividia espaço com outras fontes, não escritas, de regulamentação social, tais como a moral, a religião, a rotina e o senso comum. No que tange, por sua vez, ao protagonismo dos juristas eruditos, deve-se atentar ao fato de que estes dividiam sua atuação com juízes ordinários locais e escrivães: figuras intermediárias entre o mundo da justiça oficial e

\footnotetext{
${ }^{15}$ Hespanha. Op. cit.; 1995; p. 81.

${ }^{16}$ Hespanha. Op. cit.; 1995; p. 82.

${ }^{17}$ A concentração de poderes nas mãos dos juristas do período deve ser relacionada ainda, à oposição da doutrina jurídica medieval e moderna à redução do direito a normas rígidas, privilegiando, antes, a prática de se encontrar a solução justa e específica a cada caso julgado; prática por meio da qual se incentivava, ainda mais, o arbítrio dos juízes nos julgamentos e estabelecimento das sentenças. Nas palavras de Hespanha: "Naturalmente, esta situação potenciava muito o poder do grupo dos magistrados e pode divisar-se uma estratégia sua no sentido de defender estas prerrogativas contra qualquer programa de 'generalização' ou 'legalização' da ordem jurídica, como o que foi posto em marcha pelos monarcas ilustrados da segunda metade do século XVIII." Hespanha. Op. cit.; 1995; p. 89.

${ }^{18}$ António Manuel Hespanha. "Sábios e Rústicos: a violência doce da razão jurídica". In: Revista Critica de Ciências Sociais; nº 25/26; dezembro de 1988; pp. 31-60.
} 
o da justiça comunitária tradicional, responsáveis por uma aproximação crescente entre o direito e a vida cotidiana da população analfabeta ${ }^{19}$.

No interior deste universo múltiplo, o direito das localidades, bem como os costumes tradicionais, impunham-se, com freqüência, às regras do direito letrado e erudito. Para tanto, fundavam-se na doutrina corporativa da autonomia dos corpos sociais e na concepção de que a regra comum não era outra coisa senão o equilíbrio entre as regras particulares. A este modelo jurídico típico do Antigo Regime europeu denominou-se comumente "pluralismo jurídico".

Se até pouco tempo atrás, foram comuns análises historiográficas centradas no protagonismo desempenhado pelo direito culto europeu (ius commune) no processo de centralização do poder monárquico na modernidade, as evidências descritas acima enfatizam, pelo contrário: (i) o caráter "constitucional" - e, neste sentido, limitador do poder real - imposto por este direito (bem como pelos usos e práticas jurídicas locais); (ii) a ausência de primazia do mesmo no contexto jurídico do Antigo Regime; e (iii) o modo com que os "particularismos" então em voga contribuíram à periferização dos poderes, na contra-mão dos intentos centralizadores ${ }^{20}$.

Ou seja, em oposição aos intentos centrípetos dos monarcas europeus do século XVII e parte do XVIII, a particular configuração jurídica do Antigo Regime privilegiou, pelo menos até meados dos setecentos, a afirmação das normas jurídicas particulares dos diferentes corpos da sociedade, preconizando, por conta de sua própria lógica interna, a atividade dos juristas perante a atividade do rei, e coexistindo com tradições jurídicas populares eminentemente iletradas que, por sua vez, desarticulavam a subordinação dos costumes à lei.

Se havia, contudo, na passagem do século XVII ao XVIII, um forte consenso sustentando o regime de pluralismo jurídico, as medidas progressivamente empreendidas com vistas à sua superação e ao aumento progressivo dos poderes da

\footnotetext{
${ }^{19}$ Hespanha. "Justiça e Administração entre o Antigo Regime e a Revolução". In: Hispania: entre derechos propios y derechos nacionales. Atti dell'incontro di studio. Firenze-Lucca 25, 26, 27 Maggio, 1989. Per la storia del pensiero giuridico moderno; 34/35; Tomo I. Milano: Giuffrè editore; pp. 135-203; pp. 163-193.

${ }^{20}$ Nas palavras de António Manuel Hespanha: "É só na segunda metade do século XVIII, com o advento de novas ideias (racionalistas, axiomáticas) sobre o direito e com o aparecimento de novos projectos políticos de exaltação da coroa (e da sua legislação) e de consequente abatimento dos juristas como fonte autónoma de direito que se imporão medidas tendentes a erigir a lei em primeira fonte de direito, os «princípios gerais do direito» em fundamento da ciência jurídica e a obediência cega à lei em norma deontológia dos juristas.” Hespanha. Op. cit.; 1995; p. 89.
} 
Coroa, foram, pouco a pouco, corroendo as bases de sustentação desta composição judicial.

Nas palavras de Adriano Cavanna:

[...] se lungo i secoli dell'età moderna il regime medievale di diritto comune sopravvive vigorosamente, ciò non impedisce che in questi stessi secoli vengano via via a delinearsi i segni di una crisi del sistema: una crisi di credibilità prima ancora che di funzionalità. E infatti, col progressivo accentrarsi in senso assolutistico di monarchie e di principati, prendono vita ideologie e dottrine dirette a legittimare il governo autocratico. Ma queste dottrine suonano necessariamente in senso ostile alla tradizione delle pluralità delle fonti e alla loro gestione giurisprudenziale, poiché vi emerge il concetto alternativo da diritto quale legge dello Stato e dello Stato quale sua unica fonte ${ }^{21}$.

A superação dos antigos consensos populares acerca da justiça e de sua administração repartida, bem como o esvaziamento dos centros políticos periféricos em nome da consolidação da coroa como centro único do poder e da ordenação social encontraram, contudo, ao longo de sua afirmação, inúmeras dificuldades e resistências: em especial por conta da atuação corporativa dos juristas práticos e magistrados do período ${ }^{22}$, mas também devido às dificuldades técnicas e políticas implicadas na substituição do velho pluralismo por um sistema unitário de direito. Resistências partiram ainda, àquela altura, das ordens nobres, eclesiásticas e "populares" da sociedade setecentista, para quem o pluralismo representava não só a garantia de estabilidade e manutenção da ordem natural, mas também uma forma de obstaculização do poder do monarca.

Cercadas de resistências, a suplantação do regime pluralista de direito e a edificação de um novo sistema de fontes (futuramente materializado na codificação), não podem ser devidamente compreendidas se desarticuladas do papel desempenhado, junto aos monarcas, pelos teóricos da centralização do poder, juristas acadêmicos e intelectuais iluministas do período. ${ }^{23}$

O reconhecimento de uma demanda crescente pela simplificação técnica e racionalização prática do direito, bem como por sua atuação em nome de um aparato

\footnotetext{
${ }^{21}$ Adriano Cavanna. Op. cit.; p. 39.

22 Apesar da inegável resistência apresentada pela classe dos magistrados, o processo de superação da estrutura pluralista de direito da modernidade contou, a seu favor, com críticas cada vez maiores destinadas à multiplicação do corpus iuris original com que lidavam os juristas. Proliferado, assim, por conta da atuação interpretativa dos magistrados, o direito comum do período passou a ser considerado muito volumoso e carente de certeza, permitindo que a opinião pública o identificasse negativamente com particularismos e arbítrio. Adriano Cavanna. Op. cit.; pp. 40-41.

${ }^{23}$ Idem.; pp. 53-59.
} 
administrativo e judiciário centralizado, burocratizado e secularizado, não explicam por si sós, portanto, a consecução da forma moderna dos códigos, devendo-se conjugar e enfatizar, no interior desta equação, a força ideológica desempenhada pela cultura jurídica européia do período.

Cientes das dificuldades impostas à administração dos novos Estados em razão do regime pluralista de direito, e reivindicando uma reforma modernizadora e racionalizadora da estrutura jurídica então vigente, os teóricos iluministas a que fizemos referência teriam aberto o caminho rumo à codificação. Para Adriano Cavanna, inclusive, sem o aporte intelectual do jusnaturalismo, a força política dos soberanos do século XVIII teria sido insuficiente ao cumprimento da obra de unificação jurídica nacional que, àquela altura, assumia proporções formidáveis ${ }^{24}$.

Visando à conquista de uma reforma científica do direito positivo - passível, portanto, de reduzi-lo a sistema -, tal intelligentsia ${ }^{25}$ articulou sua oposição à estrutura jurídica pré-vigente sobre um campo de batalha eminentemente ideológico, atuando junto aos soberanos com vistas a convencê-los de que uma reforma no campo do direito era legítima e realizável. Diretamente ligados ao iluminismo, tais homens de letras atuaram fundamentalmente a partir da publicização da teoria do contrato social - explicitando as garantias que a aceitação do pacto originário dava aos monarcas e o reconhecimento que trazia à superioridade da razão de Estado sobre os interesses dos indivíduos e das classes -, ao mesmo tempo em que incentivavam reflexões acerca dos limites implícitos ao exercício legítimo do poder dos soberanos, com o intuito de barrar possíveis abusos de sua parte. ${ }^{26}$

Ainda que possa parecer estranha a intervenção iluminista junto aos monarcas ditos "absolutos" e a possibilidade de agregação dos últimos em torno de doutrinas diretamente relacionadas ao elogio do indivíduo e da liberdade de opinião pública em confronto, portanto, com o ordenamento constituído e a autoridade política -, tal composição concretizou-se, nas palavras de Cavanna, na medida em que a certeza do direito ligada à codificação atuou, antes de tudo, em sentido autoritário e estatal, reforçando o poder que a havia garantido. Se nenhuma autoridade poderia governar a

\footnotetext{
${ }^{24}$ Idem. Ibidem.

${ }^{25}$ Dentre os teóricos identificados por Cavanna e Tarello como pertencentes a este grupo figuram: Grotius, Hobbes, Locke, Puffendorf, Thomasius, Leibniz, Wolff, Domat e Pothier.

${ }^{26}$ Adriano Cavanna. Op. cit.; pp. 60-61. Nas palavras do autor: "Una legge certa potrà anche essere illiberale. Ma limiterà per se stessa il medesimo potere che l'ha promulgata e consentirà ai suoi destinatari, almeno, la libertà di compiere in piena tranquillità quel tanto che essa non vieta.”; p. 62.
} 
não ser que efetivamente obedecida, tal obediência só seria infalível sob o jugo de imperativos inequívocos ${ }^{27}$.

Foi nesse sentido que, visando ao pleno controle de um reformado e racionalizado ordenamento positivo, a política absolutista gerou, em virtude da própria lógica então vivenciada, o problema da necessária unificação das fontes jurídicas: "la concentrazione del potere deve per forza passare attraverso la concentrazione del diritto. ${ }^{28}$. O intuito de modificar, enfim, radical e rapidamente, uma sociedade por meio do direito, não poderia atuar senão reconhecendo a supremacia absoluta da lei como instrumento ordenante: "Ecco perché non c'è rivoluzione che non sia caratterizzata da una ostilità verso la giurisprudenza e insieme da un intenso e concitato movimento legislativo., 29

À união entre soberanos absolutos e intelectuais iluministas denominou-se, de um modo geral, absolutismo iluminista ou iluminismo penal, haja vista o surgimento deste arranjo específico de poder ter sido marcado, fundamentalmente, por discussões acerca do direito soberano de punir e dos limites a ele inerentes. Neste sentido, a vertente ideológica surgida do questionamento à estrutura jurídica pluralista das monarquias corporativas do Antigo Regime concentrou cada vez mais seus esforços e reflexões em torno da questão penal.

Ainda que discordemos da ideia de que nestes primeiros passos dados rumo à positivação do direito já se pudesse identificar plenamente o sistema conceitual e normativo que, alguns anos mais tarde, se sedimentaria em torno dos códigos modernos, reconhecemos neste momento o início efetivo de um processo com vistas à unificação, sistematização e racionalização do direito, assumindo a forma de uma positivação legal que, como veremos, conectou-se diretamente, num primeiro momento, à instância criminal.

\footnotetext{
${ }^{27}$ Idem; p. 62.

${ }^{28}$ Idem; p. 39.

${ }^{29}$ Paolo Grossi. APUD: Cavanna, p. 45. Nas palavras de Samuel Rodrigues Barbosa: “[...] a substituição da jurisdictio pela potestas legislatoria, ou a substituição do paradigma jurisdicionalista pelo absolutista é um caminho sem volta. É nesse período que se aprofunda a alteração decisiva no tempo histórico, destacada por Koselleck. [...] Para o direito essa mudança se manifesta como o fenômeno da positivação. $O$ direito é vivenciado como contingente; vale por uma decisão e não por sua consistência com o direito antigo. O volume e a importância da legislação no século XIX podem ser compreendidos nesse enquadramento maior." Samuel Rodrigues Barbosa. "Complexidade e Meios Textuais de Difusão e Seleção do Direito Civil Brasileiro Pré-Codificação". In: Ricardo Marcelo Fonseca, Airton Cerqueira Leite Seelander (orgs.). História do Direito em Perspectiva. Curitiba: Juruá, 2009; pp. 361374; pp. 362-363.
} 
O processo codificacionista vivenciado, assim, no período do chamado absolutismo iluminista, teve, como analisaremos na sequência, importância fundamental na configuração e projeção que a partir de então se fez acerca do direito criminal e do papel a ser cumprido pelos códigos penais no contexto de formação e afirmação dos Estados modernos ${ }^{30}$. Nesse sentido, teóricos e governantes atentaram às características estratégicas desta codificação, buscando o efeito garantista da certeza do direito por ela proporcionado, com vistas, entre outras coisas, à manutenção e confirmação de seu poder.

\section{Os primeiros códigos do mundo ocidental: penais}

"Forse in nessun periodo come nella seconda metà del secolo XVIII è stato intensamente dibatutto il problema penale". A afirmação, de Giovanni Tarello, dá destaque às estreitas relações estabelecidas, ao longo dos setecentos, entre o iluminismo e o direito penal ${ }^{31}$. Haja vista a atuação dos intelectuais iluministas junto aos monarcas absolutos no momento crucial da afirmação da autoridade estatal e do estabelecimento de um poder central com pretensa jurisdição sobre a totalidade do território e monopólio jurídico sobre a violência, não é de se estranhar o protagonismo então desempenhado pelo pensamento em torno do direito penal - capaz de atuação direta sobre a garantia da ordem e estabilidade internas e com incidência palpável sobre a vida cotidiana da população.

Não só por conta da conjuntura política vivida pela Europa em fins do século XVIII, contudo, o direito penal assumiu a dianteira das polêmicas reformistas iluministas, tendo representado ainda, aos intelectuais que protagonizaram aquele movimento, a capacidade de agregar questões imediatamente referentes às concepções de soberania, contrato social, igualdade jurídica, liberdade e racionalidade então publicizadas.

Resumindo em poucas linhas no que consistia o dito "problema penal" dos setecentos, Tarello o classifica como um complexo de questões interconectadas,

\footnotetext{
${ }^{30}$ Para além de sua influência sobre o codificacionismo penal, foi justamente a partir das técnicas de governo e dos modos de racionalização administrativa com que o absolutismo iluminista deu início à reconstrução do ordenamento político europeu que, na opinião de Cavanna, abriu-se a via ao moderno Estado de direito no continente. Tais técnicas, de acordo com o autor, sobreviveram ao ocaso do regime de governo praticado sob o absolutismo iluminista e continuaram a funcionar a serviço do ordenamento estatal de estrutura liberal. Adriano Cavanna. Op. cit.; p. 63.

${ }^{31}$ Giovanni Tarello. Op. cit.; p. 383.
} 
dentre as quais se destacavam aquelas referentes ao questionamento da existência e legitimidade do poder de punir um semelhante; à identificação do portador, ou portadores, legítimo(s) deste direito; às formas justas e razoáveis de seu exercício; às punições consideradas lícitas; às ações que constituíam pressuposto ao direito de punir; e ainda à existência, ou não, de relações "naturais" entre os tipos específicos de ação e as punições a elas previstas ${ }^{32}$.

É com referência privilegiada a estas questões, portanto, que o direito penal se configura, em finais do século XVIII, num dos mais ativos campos de debate e polêmica do iluminismo. De acordo com Franco Venturi, as questões penais então frequentemente debatidas e, dentre elas, em especial, o problema do direito de punir, tocavam num pólo e noutro do pensamento iluminista: abarcando simultaneamente questões de princípio, relativas aos vínculos existentes entre indivíduo e Estado, e uma consideração de problemas concretos, referentes aos métodos específicos de punição e aos exemplos, práticas e possibilidades de modificação do sistema vigente à sua disposição.

Dentre a produção intelectual iluminista (e penalista) do período figura, com grande destaque, a obra Dos delitos e das penas, lançada, em 1764, pelo italiano Cesare Beccaria. Obtendo sucesso imediato por toda a Europa, a obra de Beccaria estimulou ainda mais os debates acerca do direito de punir, bem como de seus pressupostos e conseqüências ${ }^{33}$, contribuindo à identificação doravante freqüente entre a ideia de um direito penal reformado e de sua organização por meio de um código. ${ }^{34}$

O cenário jurídico que Beccaria tinha sob os olhos em Milão, ao escrever seu livro, não se distinguia em muito do regime pluralista, jurisprudencial e, em última instância, arbitrário, do direito de Antigo Regime descrito acima. Tratava-se, enfim, de uma justiça atuante com vistas à manutenção do status quo ${ }^{35}$, contra a qual Beccaria levantou uma série de questionamentos, dirigindo-os, eminentemente, ao

\footnotetext{
${ }^{32}$ Idem. Ibidem.

${ }^{33}$ Para uma inserção nos múltiplos debates despertados, pela obra de Beccaria, entre os iluministas europeus, ver: Franco Venturi. Utopia e Reforma no Iluminismo. Bauru, SP: EDUSC, 2003; capítulo 4 ("O direito de Punir"); pp. 181-215.

${ }^{34}$ A análise apresentada, neste e nos próximos parágrafos, sobre a produção de Cesare Beccaria, baseou-se, fundamentalmente, nos livros supracitados de Adriano Cavanna (pp. 190-222) e Giovanni Tarello (pp.462-483).

${ }^{35}$ Ricardo Campa. "Prefácio". In: Cesaria Beccaria. Dos delitos e das penas. São Paulo: Martins Fontes, 2005; pp. 7-26; p. 10.
} 
direito estatal de punir, aos limites de semelhante poder e à função a ser desempenhada pelas punições.

Ainda que não questionasse a legitimidade propriamente dita do poder de punição dos soberanos - implícita, conforme sua leitura rousseauniana, no contrato social -, Beccaria punha em questão os limites inerentes ao seu exercício, causando grande impacto na ideologia política do período. De acordo com sua argumentação, no momento do contrato social, os homens haviam concedido ao soberano apenas uma mínima parcela da sua liberdade natural, com o direito de punir devendo limitar-se ao mínimo necessário à defesa da sociedade. Para Beccaria, a atrocidade das penas era não só inútil, como contrária à justiça.

Dentre os princípios essenciais ao justo funcionamento do direito penal, estavam, na opinião do autor, o de que as leis emanassem exclusivamente do legislador soberano, representante de toda sociedade, e o de que, consequentemente, os juízes a elas se subordinassem, aplicando mecanicamente o seu conteúdo e privando-se de qualquer atividade interpretativa e arbitrária. Beccaria alçava, desta forma, os princípios de legalidade e certeza do direito à condição de valores jurídicos supremos.

A concepção de crime defendida pelo autor era, por sua vez, totalmente estatal e laica, limitando-se o delito, na sua visão, a um atentado ao Estado e à soberania, cuja punição deveria se pautar pela defesa da ordem social, e nunca pela ideia de restituição de uma harmonia perdida ou de retribuição do mal com mal. Para Beccaria, o fundamento da punição estava na necessidade de abalar as paixões dos indivíduos, buscando, com isso, a adoção de princípios estáveis de conduta social ${ }^{36}$. O papel a ser desempenhado pelas penas, consequentemente, fundava-se na prevenção das agressões sociais, no desvio dos delinquentes da repetição de seus delitos e na remoção do restante dos cidadãos de caminhos semelhantes ("prevenção geral" e “prevenção especial”); nunca, portanto, em sua intimidação ou neutralização. Daí a necessidade de que as penas admitidas por um país fossem claras e poucas, escritas em língua vulgar, reunidas em um único código e de fácil e infalível aplicação.

No livro de Beccaria encontravam-se ainda traços típicos às três principais ideologias penais do iluminismo setecentista: a utilitária, a humanitária e a

\footnotetext{
${ }^{36}$ Cesare Beccaria. Op. cit.; p. 31. Nas palavras de Beccaria: "Qual o fim político dos castigos? O terror que imprimem nos corações inclinados ao crime [...] Um crime já cometido, para o qual já não há remédio, só pode ser punido pela sociedade para impedir que outros homens cometam outros semelhantes na esperança da impunidade".
} 
"proporcionalista". Partindo das mesmas, o autor defendia, entre outras coisas: a proporcionalidade entre os crimes e as penas, ou seja, que à gravidade proporcional dos delitos (racionalmente divididos, no interior dos códigos, de acordo com os interesses lesados ${ }^{37}$ ) correspondessem penas de diferentes severidades; a abolição da pena de morte, recusando o direito estatal de infligir a morte a seus cidadãos e questionando a necessidade lógica de semelhante punição ${ }^{38}$; e a aceitação de um sujeito único ao qual se destinasse, generalizadamente, o direito penal, recusando, nesse sentido, quaisquer diferenciações penais fundadas no status do réu ou da pessoa ofendida.

No interior da teoria penal de Beccaria, e no quadro de subordinação do direito à lei por ele defendido, a codificação aparecia, enfim, como condição antijurisprudencial indispensável à certeza do direito e, logo, à liberdade de cada cidadão poder fazer o que não fosse proibido por lei.

Exemplar e referente extremo dos debates do chamado iluminismo penal ${ }^{39}$, a obra de Beccaria ofereceu substrato à produção efetiva de parte dos códigos iluministas do

${ }^{37}$ De acordo com Giovanni Tarello, a proposta organizativa de Beccaria para os códigos penais fundava-se no estabelecimento de uma escala de delitos embasada na ideia de utilidade social e no grau de interesse lesado pelo crime. Neste sentido, figuravam, em primeiro lugar, os crimes contra a existência da sociedade política, a lesa majestade e o contrabando; na sequência, os crimes contra os privados (vida, bens e honra de um indivíduo); e, por último, os crimes contra a pública tranquilidade, futuramente denominados, nos diferentes códigos criminais, contravenções ou crimes policiais. Giovanni Tarello. Op. cit.; p. 476.

38 "Para Beccaria, o contratualismo serve para apoiar a condenação da pena de morte, a condenação, isto é, de uma ação efetuada pelo Estado em nome da vontade geral, que, na verdade, não pode aceder nenhuma resolução que seja lesiva à sua própria constituição. 'Para Beccaria, o princípio contratual servia especialmente para fundamentar um dos argumentos aduzidos contra a pena de morte: a de que ela é injusta porque a vontade geral, não sendo mais do que porções de liberdade a que os indivíduos renunciaram no pacto, não pode ter o direito de tirar a vida de ninguém, pois, certamente, esse item não se encontra entre as porções de direito renunciadas. Argumento esse que, apesar de lhe parecer, quem sabe, o mais forte e válido, carece completamente de vigor persuasivo para quem não aceita a suposição contratualista na forma em que ele o afirma; a verdadeira força de sua argumentação, neste caso e em outros, está, ao contrário, em demonstrar como, em qualquer que seja o fim que a sociedade se proponha a respeito de certas penas (por exemplo, a morte) e de certos procedimentos (a tortura), este mesmo fim tem menos possibilidade de ser conseguido por esse caminho'." Ricardo Campa. "Prefácio". In: Cesaria Beccaria. Dos delitos e das penas. São Paulo: Martins Fontes, 2005; pp. 7-26; pp. 14-15.

${ }^{39}$ Outro pensador italiano que desempenhou grande influência nos debates iluministas sobre o direito penal foi Gaetano Filangieri (1753-1788), especialmente com sua Scienza della legislazione, obra inacabada, em diversos volumes, publicada a partir de 1780 e de grande sucesso na Europa de finais do século XVIII. Defensor convicto da extirpação do arbítrio judiciário e, logo, da mecanicidade da atuação dos juízes como condição fundamental à liberdade política, Filangieri organizou a seção de direito penal de sua obra com intentos eminentemente prospectivos, compilando a doutrina penal de autores como Montesquieu, 
período, explicitando, nas décadas finais do século XVIII, o alto teor político assumido pelo direito penal e os atores sociais a serem privilegiadamente influenciados por ele:

Quantunque nata come manifesto ideologico, questa dottrina [iluminista, de codificação do direito penal] era gravida di potenzialità positivistiche: da un lato la legislazione penale com'è, dall'altro lato la scienza di (come deve essere la) legislazione. L'accoglimento, da parte dei sovrani desiderosi di riorganizzazione legislativa e amministrativa, del programma politico di Beccaria, fu anche dettato dall'ovvio corrispettivo, in termini di funzionalità e di ordine repressivo, che l'adozione di una riforma 'beccariana' avrebe comportato. Sotto questo aspetto, piú che Voltaire, che Condorcet, che Morellet, che Hommel, i veri seguaci [seguidores] e fautori [defensores, partidários] di Beccaria vanno visti in Giuseppe II, in Pietro Leopoldo e, perché no, in Napoleone Bonaparte. ${ }^{40}$

A estes detentores efetivos do poder político, portanto, mais do que aos intelectuais dos setecentos, a força representada pelo direito penal viria se impor na passagem ao século XIX, resultando nos códigos penais do absolutismo iluminista. A codificação deste período, como veremos, diferentemente do pensamento penal àquela altura desenvolvido na Europa - com epicentros na França, Itália e Inglaterra , concentraria seus resultados na Prússia, Áustria e nos estados da península itálica mais diretamente influenciados pela cultura austríaca, como a Lombardia e a Toscana.

Dentre as concretizações, em forma de lei, dos debates e reflexões impulsionados pelo iluminismo penal, a mais famosa certamente é a que toma lugar no Grão-ducado da Toscana, com a aprovação, em 1786, do diploma popularmente conhecido como

\section{Leopoldina.}

Em confluência com as observações de Giovanni Tarello (no que tange à atração desempenhada pelo direito penal por sobre os monarcas iluministas do período), destaque seja dado ao protagonismo de Leopoldo II, grão-duque da Toscana (futuro imperador do Sacro Império), na reforma penal da região. Convencido a tomar as rédeas do processo reformista, Leopoldo II reuniu ao seu redor uma série de "ministros" esclarecidos e juristas influenciados pela produção de Beccaria e compilou, por conta própria, grande quantidade de material (de considerações teóricas iluministas a estatísticas criminais) sobre a situação penal na Toscana, esboçando os rumos a serem seguidos pela reforma.

Rousseau e Beccaria e propondo uma modificação profunda no ordenamento jurídico tradicional com vista à consecução de novas e boas leis para o país. Adriano Cavanna. Op. cit.; pp. 174-181.

${ }^{40}$ Giovanni Tarello. Op. cit.; pp. 479-480. 
A partir do material agregado, Leopoldo mandou elaborar um projeto de código penal que, finalizado no ano de 1785, foi aprovado, em 1786, sob o título de "Reforma da legislação criminal da Toscana", posteriormente Código Leopoldino ou Leopoldina.

Ainda que seja problemática a classificação do diploma toscano de 1786 como um código propriamente moderno - haja vista a distância que, em quesitos essenciais, este documento apresentava em relação à codificação oitocentista que lhe seguiu ${ }^{41}$ não se pode ignorar o papel desempenhado pela Leopoldina ao materializar, em direito positivo, parte importante das ideias então publicizadas e debatidas pelo iluminismo penal europeu, apresentando respostas concretas às grandes demandas jurídicas do período.

Nesse sentido, a Leopoldina concretizou aspirações iluministas como a abolição das penas de morte e de confisco, a adoção da ideologia proporcionalista no estabelecimento das punições, a redução do número e da qualidade das penas admitidas, bem como sua relativa amenização. No âmbito criminal substantivo, destacou-se a significativa abolição do delito de lesa majestade e a autonomização consequencial de uma série de crimes anteriormente compreendidos sob esta categoria (dentre os quais se destacava o crime de falsificação de moedas) ${ }^{42}$, enquanto, no que tangia ao processo penal, a modernização imposta pela Leopoldina perpassou esferas como a da afirmação da publicidade do processo e a de superação do então vigente sistema de provas legais e do uso da tortura.

Se nos âmbitos acima destacados a aprovação deste diploma justificava a ampla repercussão obtida à época, em outros de seus aspectos transparecia pertencer, ainda,

\footnotetext{
${ }^{41}$ De acordo com Adriano Cavanna, são elementos indispensáveis de um código moderno: a sua exclusividade enquanto fonte de direito e a unidade tipológica dos sujeitos a ele submetidos. Nesse sentido, um código moderno deve apresentar-se como um sistema de normas abstratas e não hetero-integráveis. Nas palavras do autor: "Il principio della completezza logica del codice postula che l'intero diritto positivo venga formalmente ad identificarsi nel codice stesso (o meglio, settore per settore, nei codici): codicocentrismo mi sembra il termine più efficace per definire l'idea secondo cui nel sistema codificato non sono pensabili lacune.”. Adriano Cavanna. Op. cit.; pp. 42-45.

${ }^{42}$ No que diz respeito à abolição do crime de lesa majestade pela Leopoldina, Adriano Cavanna afirma: "È chiaro che la dirompente scelta legislativa del granduca ha per fondamento un radicale ribaltamento di piani della filosofia del potere e della sovranità. Quale monarca provvisto di pedigree illuministico a tutta prova Leopoldo ha fatto sua l'idea dell'etica del servizio: autodesacralizzandosi, si presente ai sudditi come sovrano che detiene il potere non per diritto ma per puro consenso dei governati. Dunque egli è il servitore di uno Stato la cui origine è contrattuale: caduto l'involucro artificiale della lesa maestà, l'attentato o l'offesa alla sua persona appaiono in realtà come diretti contro la sicurezza dello Stato stesso.”. Idem; pp. 355-356.
} 
à tradição criminalista do Antigo Regime. Nesse sentido, para além da ausência de qualquer diferenciação ou divisão interna adotada para o tratamento dos conteúdos adjetivo e substantivo do direito penal ali positivado ${ }^{43}$, destacava-se o estilo discursivo e demonstrativo adotado por seu texto, com longas explanações filosóficas em determinados pontos e uma diferença marcante com relação à estrutura normativa linear e imperativa adotada pelos códigos modernos.

Também no que respeitava às relações com o direito previgente, à solução do problema da heterointegração legal ${ }^{44}$ e à margem de arbítrio dada aos juízes em sua relação com as leis, o código da Toscana não pode ser considerado moderno. Isto porque a reforma não ab-rogava e substituía por completo o direito previgente, mas apenas aquela parte do direito considerada inconciliável e incompatível com os ideais reformadores do grão-duque. Mantidos em vigor, os resquícios do direito penal anterior podiam ser mobilizados pelos juízes em seus julgamentos, confirmando a aceitação do recurso à heterointegração e a não extinção dos arbítrios processuais.

De acordo com Giovanni Tarello, as relações entre juízes e leis previstas pela Leopoldina não eram mais aquelas antigas, típicas do "direito comum" (ius commune), nem aquela moderna a ser estabelecida pelos códigos do século XIX. Ao invés de acatar, portanto, o princípio da completude - fundamental à compreensão dos códigos modernos por pressupor uma ab-rogação completa das leis anteriores e a plena aceitação dos novos códigos enquanto fontes exclusivas de direito -, a Leopoldina teria adotado um sistema de "semicompletude" que não levava às últimas conseqüências as ideias de legalidade e certeza do direito penal ${ }^{45}$.

Assim como a Leopoldina, também os diplomas penais austríacos de 1787 e 1803, e a codificação prussiana de 1794, considerados, todos, produtos do absolutismo iluminista, situam-se numa posição intermediária entre os códigos modernos e o direito penal de Antigo Regime. Isto porque, como dissemos acima, ainda não havia

\footnotetext{
${ }^{43}$ Enquanto o direito substantivo caracteriza-se pela estipulação de direitos e deveres, definindo o complexo de normas que regem as relações jurídicas, o adjetivo refere-se às formas de efetivação, manutenção, validação ou recuperação daqueles direitos e deveres, atuando, portanto, no âmbito processual da justiça. Assim, enquanto o direito substantivo materializa-se nos códigos civil, penal e constitucional de um país, o direito adjetivo materializa-se nos códigos de processo civil e penal ou em códigos como os de direito trabalhista.

${ }^{44} \mathrm{O}$ recurso à heterointegração consiste na aceitação de normas outras, que não as estritamente previstas pelos códigos, no julgamento dos crimes.

${ }^{45}$ Giovanni Tarello. Op. cit.; p. 549.
} 
surgido e se concretizado plenamente, em finais do século XVIII, parte importante das condições necessárias ao alcance da forma moderna dos códigos ${ }^{46}$.

Apesar disso, o julgamento dos diplomas resultantes da positivação penal setecentista unicamente por sua adequação ou inadequação aos modernos critérios oitocentistas nos parece inadequado se aceito sem qualquer mediação. Ainda que seja difícil analisar estes documentos, aqui, senão a partir de seu posicionamento no percurso rumo à codificação do século XIX, o reconhecimento de suas "falhas", "lacunas" e "limites", quando comparados aos códigos modernos, não deve se fundar num juízo negativo, mas sim na aceitação de que foram o resultado de um período histórico específico, anterior às revoluções liberais.

Concluindo a análise dos primeiros passos dados rumo à codificação moderna do direito penal ocidental, tenhamos em mente o processo histórico a partir do qual, pouco a pouco, concentraram-se em torno do direito penal perspectivas fundamentais ao exercício do poder e à afirmação da autoridade estatal na passagem do século XVIII ao XIX, reconhecendo-se o papel a ser cumprido pelos códigos penais num contexto transformador. Nesse sentido, ainda que ausentes critérios e princípios unicamente conquistados com o advento das revoluções liberais burguesas, os códigos nascidos neste período formalizaram a existência de uma nova ordem social, em harmonia com os novos aparatos administrativo e judiciário centralizados, burocratizados e secularizados ${ }^{47}$.

No contexto de superação da estrutura jurídica das monarquias corporativas européias de Antigo Regime, e de suplantação de toda a visão de mundo a ela relacionada, não deve ter sido pequeno o impacto causado por estas primeiras codificações penais, em que o direito aparecia como um discurso único, racional, universal e, acima de tudo, voluntarista.

\section{A Revolução Francesa e sua importância no âmbito do direito penal}

Protagonista da moderna codificação do direito vivida pelo continente europeu, a França não conheceu, no período do absolutismo iluminista, uma transformação significativa de seu direito penal. Nas palavras de Franco Venturi:

\footnotetext{
46 Para uma avaliação pormenorizada de cada um destes diplomas, seus avanços e manutenções, ver: Adriano Cavanna. Op. cit.; pp. 236-335. E Giovanni Tarello. Op. cit.; pp.486-536.

${ }^{47}$ Adriano Cavanna. Op. cit.; p. 61.
} 
Na realidade, na França, a despeito de Voltaire, a despeito da influência de Beccaria, a despeito da boa vontade dos filósofos, a reforma do direito penal procedeu lenta e incerta no quarto de século que se seguiu à publicação de Dei delitti e delle pene. A França tardou a abolir a tortura, não seguiu o exemplo da Toscana em rejeitar por completo a pena de morte, não procedeu a uma nova codificação e manteve um regime carcerário cruel. ${ }^{48}$

As razões para tal fenômeno são múltiplas e fundam-se, em especial, nas dificuldades administrativas e financeiras então vividas pelo país, na falência encontrada pela grande maioria das reformas e inovações tentadas à época, no imobilismo político gerado diante desta situação incerta e na recomposição estrutural e social por que passava então o reino, com a dissolução gradual do "carisma" monárquico e de seus mais antigos e sólidos fundamentos ${ }^{49}$.

Apenas com o advento da Revolução, portanto, o país conheceu uma efetiva modernização de sua legislação, com a aprovação de declarações de direitos, Cartas constitucionais e códigos de direito privado e penal, substantivos e adjetivos. No âmbito específico do direito penal substantivo, podem ser considerados frutos do processo revolucionário dois códigos de grande importância: o de 1791, rapidamente promulgado nos primeiros momentos da Revolução, e o de 1810, pertencente já ao período napoleônico.

Fundados no desejo de regeneração política, social e moral da França, os revolucionários acreditavam piamente no papel a ser desempenhado pelas leis na consecução de seus projetos. Depositando sobre o direito uma função central na batalha que então se iniciava, não se furtaram a instrumentalizá-lo e politizá-lo de acordo com os programas então em pauta ${ }^{50}$. Se, no que tange à positivação das leis civis, o diploma francês de 1804 materializou o modelo, por excelência, de um código moderno, no âmbito do direito penal, o processo vivido pela França foi complexo e marcado por rupturas, continuidades e várias contradições, resultando num código (1810) que, por moderno que fosse, não configurou o exemplar absoluto da positivação dos princípios de direito penal propostos pelo iluminismo jurídico.

Do processo de codificação penal francesa, interessa-nos, portanto, fundamentalmente, o papel de destaque desempenhado pela positivação das leis

\footnotetext{
${ }^{48}$ Franco Venturi. Op. cit.; p. 207.

${ }^{49}$ Adriano Cavanna. Op. cit.; p. 65-67.

50 "L'intreccio abnorme fra gli assiomi che sacralizzano il diritto e la prassi politica che lo subordina alla ragion di Stato costituisce dunque il nocciolo drammatico della Rivoluzione, che sul piano teorico enuncia i fondamenti dello Stato di diritto, su quello storico attua il totalitarismo." Idem; p. 408.
} 
penais num contexto revolucionário e de transformações políticas e sociais profundas. Centremo-nos, nesse sentido, na prioridade dada, pela Revolução francesa, à codificação deste âmbito do direito.

Fundados sobre princípios como o da lei enquanto expressão da vontade geral, o da tripartição de poderes e o do primado do poder legislativo, e baseados, ainda, na afirmação da soberania nacional e da onipotência da lei - garantias firmadas pela Constituição de 1791 -, os revolucionários franceses lutaram arduamente contra as forças do Antigo Regime e, em especial, contra a organização pluralista e jurisprudencial do direito de então.

A preeminência do legislativo, advogada por estes revolucionários, e a árdua batalha então travada contra a organização judiciária precedente não explicam, contudo, por si sós, por que foi justamente o código penal o primeiro a tomar corpo durante a Revolução.

De acordo com Roberto Martucci, a opção prioritária pela codificação do direito penal na França revolucionária deveu-se a três fatores principais: a situação de instabilidade gerada pela reorganização judiciária empreendida nos primeiro anos da Revolução, já que as novas instituições tinham de conviver, então, com a aplicação de penas antigas e com o conteúdo das Ordenanças de 1670; a atuação política de um grupo de parlamentares (reconhecido nas figuras de Adrien Du Port, Bon-Aubert Briois de Beaumetz e Le Peletier de Saint-Fargeau) que se utilizou de expedientes variados para colocar a questão do direito penal na agenda da Assembleia Constituinte; e a necessidade de dar uma resposta à reivindicação de parte considerável da sociedade no tocante à criminalização dos delitos de Lèse-Nation e das condutas políticas consideradas suspeitas no contexto revolucionário ${ }^{51}$.

Para Adriano Cavanna, por sua vez, tal prioridade associou-se a uma multiplicidade de circunstâncias - em especial, o fato de o debate jurídico iluminista

51 Segundo o autor, a tônica dominante inicial dos constituintes franceses, tanto na Assembleia quanto em seus comitês específicos, foi a de uma reforma estrutural do ordenamento jurídico recebido do Antigo Regime, e de uma pressão, especialmente sensível entre as autoridades revolucionárias parisienses, para que os crimes de Lèse-Nation fossem tipificados e sancionados penalmente. Se a primeira postura partia da ideia de legalidade dos delitos e das penas, a segunda posição mostrava já uma tendência, fortemente sentida no desenrolar do processo revolucionário, de criminalização de toda e qualquer heterodoxia política. Roberto Martucci. "Logiche della transizione penale. Indirizzi di politica criminale e codificazione in Francia dalla rivoluzione all'Imperio (1789-1810).”. In: Quaderni Fiorentini per la storia del pensiero giuridico moderno. 36 (2007), Tomo I. Giuffrè editore milano; pp. 131-274; pp.140-157. 
ter se concentrado já, em finais do século XVIII, em torno da questão das penas e do direito de punir; e a circunstância de a reforma do direito penal aparecer, então, como o meio mais fácil e rápido de dar vida à justiça projetada pela Revolução, fundada nas ideias de liberdade e segurança individual -, podendo ser prioritariamente explicada, contudo, pelo caráter altamente político do direito penal e pelo papel de destaque frequentemente desempenhado pelo mesmo em fases de transição e mudança social. De acordo com o autor, portanto, se é consensual o reconhecimento de que, em meio a um processo revolucionário, não se pode elaborar um bom código civil, é igualmente verdadeiro que a maioria das revoluções iniciou sua marcha sobre o campo da justiça penal ${ }^{52}$.

Se formalmente, portanto, a Revolução trouxera o sujeito unitário, a lei constituinte, a afirmação da legalidade e da certeza do direito penal, a presunção de inocência e a ab-rogação definitiva da legislação anterior, ela enfatizara também, desde o seu início, as diretrizes políticas implícitas à reforma do direito penal, subsumindo-o, com o passar dos anos, às necessidades práticas de edificação do novo Estado e de imposição da ordem ao conjunto da população.

Uma rápida comparação entre os códigos penais de 1791 e 1810 pode explicitar, com maior propriedade, o problemático percurso traçado pela codificação das leis criminais na França revolucionária e pós-revolução. Em termos gerais, a historiografia dedicada ao exame deste processo reconhece nele a presença da dialética implícita aos sistemas repressivos modernos: de um lado, as exigências da ordem pública e, de outro, a busca pela proteção aos direitos individuais dos suspeitos, acusados ou condenados; opondo um modelo revolucionário garantista das liberdades a um outro, fundado na defesa da ordem ${ }^{53}$.

No encalço das reformas transformadoras da justiça francesa iniciadas já pela Assembleia Constituinte em 1790 - que identificou como uma de suas tarefas prioritárias a conformação do direito penal francês aos princípios estabelecidos, em 1789, pela Declaração de Direitos do Homem e do Cidadão ${ }^{54}$, o código penal

\footnotetext{
${ }^{52}$ Cavanna. Op. cit.; pp. 478-479.

${ }_{53}$ Bernard Schnapper. "Les systemes repressifs français de 1789 a 1815". In: Xavier Rousseaux, Marie-Sylvie Dupont-Bouchat et Claude Vael (org). Révolutions e Justice Pénale en Europe: modèles français et tradition nationales (1780-1830). L'Harmattan : Paris, 1999; pp. 17-35 ; p. 17. Pierre Lascoumes. "Revolution ou Reforme Juridique? Les codes pénaux français de 1791 a 1810". In: Idem; pp. 61-69; p. 61.

${ }^{54}$ No texto da Declaração de Direitos do Homem e do Cidadão, os artigos 7, 8 e 9 fazem referência explícita a princípios do direito penal (mais especificamente à proibição de prisões
} 
aprovado em 1791 priorizou a afirmação dos princípios de legalidade, garantismo e certeza do direito, bem como a racionalização e proporcionalidade das relações entre crimes e penas. Simultaneamente, contudo, este diploma manteve elementos de discricionaridade, como uma criminalização embrionária dos suspeitos.

Durante sua elaboração, baseada no projeto altamente reformista de Le Peletier de Saint-Fargeau, a Constituinte francesa acatou um sistema fixo de punições aos crimes, tolhendo dos juízes qualquer margem de arbítrio. Ao mesmo tempo, o crime de lesapátria (Lèse-Nation) não apareceu no código, tentando-se enquadrar as demandas por sua regulamentação na estrita legalidade dos delitos e das penas, ou seja, por meio da individuação de condutas mais precisas (reunidas sob as categorias de crimes contra a segurança interna e externa do Estado). Em franca contradição com o conjunto desta legislação, contudo, as penas de morte, trabalhos públicos forçados e deportação por toda a vida foram mantidas, permanecendo ainda uma indistinção entre crime consumado e crime tentado ${ }^{55}$, compatível com a tendência já presente de criminalização dos comportamentos suspeitos. ${ }^{56}$

Entre a aprovação deste documento, contudo, e o ano de 1801, em que tiveram início efetivo os trabalhos de elaboração do novo código penal, houve um refluxo geral no processo de modernização que levara à sua promulgação. Os anos que se seguiram ao de 1791 foram marcados, assim, por uma crescente instabilidade política e pelo aumento do recurso a procedimentos penais especiais e discrionários que, por

e acusações arbitrárias; à utilidade das penas e a não retroatividade das leis; e ainda ao princípio de presunção de inocência), tendo constituído, na opinião de Martucci, o primeiro marco legal revolucionário em matéria de direito penal. Para este autor, inclusive, teria cabido aos redatores deste documento a escolha de colocar na ordem do dia o tema da repressão e das condutas delituosas num novo contexto, estritamente disciplinado pela lei. Por seu teor declaratório, ainda, esse documento teria permitido a um determinado grupo da Constituinte hipotecar o que fosse feito posteriormente em matéria constitucional e legal. Roberto Martucci. Op. cit.; p. 167. Para o conteúdo da Declaração, ver: http://www.legifrance.gouv.fr/Droit-francais/Constitution/Declaration-des-Droits-de-1Homme-et-du-Citoyen-de-1789.

55 Ainda que não tenha sido formalmente declarada, tal indiferenciação entre crimes consumados e simplesmente tentados pode ser facilmente reconhecida nos artigos 13 e 15 da Section I, Titre II, da Deuxième Partie do Código de 1791. Para além disso, uma indistinção entre os autores e cúmplices de um delito pode ser identificada nos artigos 1, 2 e 3 do Titre III da mesma Deuxième Partie do diploma francês de 1791. Ver, sobre o tema: Roberto Martucci. Op. cit.; pp. 190-194.

${ }^{56}$ Roberto Martucci. Op. cit.; pp. 172-194. Para mais análises do código de 1791 ver os artigos de Bernard Schnapper e Pierre Lascoumes citados acima (In: Xavier Rousseaux, Marie-Sylvie Dupont-Bouchat et Claude Vael (org). Révolutions e Justice Pénale en Europe: modèles français et tradition nationales (1780-1830). L'Harmattan : Paris, 1999), bem como o livro de Adriano Cavanna. Op. cit.; pp. 479-494. 
sua vez, limitavam em muito os efeitos do diploma vigente. Ainda que no período posterior ao "Terror" - marcado pelos regimes da Convenção, do Diretório, do Consulado e do Império - tenha prevalecido o discurso de retomada da defesa dos direitos dos cidadãos, a fragilidade política em que se encontrava o país e as dificuldades vividas pelos diferentes governos na tarefa de manutenção da ordem, fizeram com que diversas das medidas de exceção jurídica adotadas no período do "Terror" ${ }^{, 57}$ fossem mantidas pelos governos subseqüentes, tornando as ações penais então empreendidas em quase tudo opostas ao discurso garantista que as acompanhava $^{58}$.

A inauguração dos trabalhos legislativos de elaboração do futuro código penal foi marcada, assim, por um aumento constante da instabilidade política na França e pelo crescimento concomitante da criminalidade comum no país, atestando um desejo de reforço no caráter punitivo do direito penal. As discussões sobre o novo código partiram, fundamentalmente, de uma crítica ao diploma anterior, considerado excessivamente brando. Neste sentido, o projeto inicial do novo diploma, datado de 1801, adotou uma postura bastante repressiva, associando práticas proscritas pela Revolução (como as penas corporais) às novas exigências de caráter policial do Estado. Apesar de ter sofrido uma considerável amenização entre os anos de $1801 \mathrm{e}$ 1810, o espírito deste diploma manteve-se, na opinião da maioria dos autores, indubitavelmente autoritário e repressivo.

${ }^{57}$ Dentre os mecanismos de exceção judiciária que marcaram o período revolucionário do Terror, destaque seja dado aos procedimentos extraordinários empreendidos pelos tribunais revolucionários, à lógica de suspeitabilidade que se apoderara do direito penal, à substituição (então efetuada) da presunção de inocência pela presunção de culpa, e à proliferação dos sentenciamentos à morte. Neste sentido, Raymonde Monnier afirma: "Le champ de la peine de mort fut progressivement étendu à tous les adversaires du gouvernement, émigrés, prêtes réfractaires, déserteurs, fédéralistes, accapareurs, fournisseurs infidèles, à des délits relatifs aux subsistances, aux biens nationaux. La liste s'allongeait avec les difficultés politiques. La mise hors la loi qui entraînait l'exécution sans jugement a visé d'abord les rebelles pris les armes à la main (décret du 19 mars 1793), avant de s'étendre à d'autres catégories d'exclus. La Terreur, avec ses lois e ses tribunaux révolutionnaires, répond certes dans les débuts aux circonstances et à une forte pression populaire, mais épouse de plus en plus la logique qui conduit à la loi du 22 prairial an II, founées et aux supplices en masse de l'été 1794.". Raymond Monnier: "La question de la peine de mort sous la révolution française". In: Xavier Rousseaux, Marie-Sylvie Dupont-Bouchat et Claude Vael (org). Révolutions e Justice Pénale en Europe : modèles français et tradition nationales (1780-1830). L'Harmattan : Paris, 1999 ; pp. 225-242; pp. 237-238.

${ }_{58}$ Bernard Schnapper. Op. cit. De acordo, ainda, com Roberto Martucci, o período de vigência do Código penal de 1791 coincide com o momento em que a legalidade revolucionária se revela uma exceção sistemática em nome da salvação nacional. Martucci. Op. cit.; pp. 200-201. 
Dividido em quatro partes principais, o código penal francês de 1810 vinha precedido por cinco disposições gerais referentes ao princípio de irretroatividade das leis, à definição do crime de tentativa e à tripartição dos comportamentos delituosos em "crimes", "delitos" e "contravenções". Comparando o sistema de sanções do código de 1810 àquele de 1791, Adriano Cavanna detecta um retrocesso entre os documentos, fundado no abandono do princípio da temporalidade das penas, no reaparecimento das penas corporais e de confisco e, finalmente, num uso amplo das penas de trabalho forçado. Assim, ainda que a pena de morte tenha sido por mais vezes prescrita no código de 1791 (45 casos), em 1810 (prescrita por 39 vezes) ela vinha acompanhada por um cardápio punitivo bastante mais cruel ${ }^{59}$.

Dos 484 artigos de que se compunha o código napoleônico, 197 destinavam-se à defesa da segurança interna e externa do Estado. Entre 1791 e 1810, portanto, toda a legislação especial criada (ao longo da Convenção, do Diretório e do Consulado) para tipificar condutas políticas heterodoxas foi sistematizada e incluída num código extremamente draconiano. O código penal de 1810 configurou-se, enfim, num compêndio de ameaças e intimidações expedidas por um legislador que tinha por objetivos principais a manutenção da ordem e a afirmação do seu poder.

O que se percebe, portanto, é que, à possibilidade de positivação legal despertada pela individuação do sujeito e pelo culto revolucionário do direito e crença no seu poder de criação de uma nova realidade, seguiu-se um processo codificacionista que, com o desenrolar da Revolução, e diante da permanente instabilidade vivida na França, marcou-se, fundamentalmente, pelo controle das condutas individuais, imposição da ordem e recurso ao autoritarismo quando necessário.

Se nos momentos iniciais da Revolução, quando da Declaração dos Direitos do Homem e do Cidadão, cabia já o questionamento acerca da declarada inviolabilidade dos direitos fundamentais do homem, ou seja, colocava-se em dúvida se tal inviolabilidade fundava-se no primado absoluto e pré-estatal da subjetividade jurídica natural do homem, ou afirmava-se enquanto tal unicamente porque a lei da nação assim a proclamava, o tempo transcorrido e os rumos tomados pela Revolução, e pela "regeneração" judiciária então levada a cabo, vieram confirmar o predomínio absoluto da lei positiva e a conseqüente submissão dos direitos individuais à mesma.

\footnotetext{
59 Adriano Cavanna. Op. cit.; pp. 592-597. Para uma comparação entre o conjunto das punições adotadas em cada caso ver as tabelas organizadas por Roberto Martucci. Op. cit.; pp. 189 e $272-273$.
} 


\section{Para voltar ao Brasil}

A trajetória de positivação das leis penais vivida pelo mundo ocidental demonstra, enfim, com distintos acentos nas diferentes localidades e épocas em que se deu, a importância assumida pelos códigos de direito penal substantivo em momentos de profunda transformação política e social. Para além disso, destaque seja dado ao papel desempenhado pelos diplomas penais no tocante à superação do modelo jurídico pluralista de Antigo Regime e à configuração de novos paradigmas políticos e sociais, típicos da contemporaneidade.

No Brasil oitocentista, processos semelhantes aos analisados acima tiveram lugar, adquirindo força e materialidade a partir da instalação de um regime constitucional e representativo no período pós-Independência. Nesse sentido, o importante papel desempenhado pela positivação das leis na configuração dos modernos Estados ocidentais - tanto no que tangia à manutenção da ordem interna, quanto no que respeitava à reivindicação de limites aos poderes punitivos estatais e à garantia de direitos aos cidadãos -, fez-se sentir também no Novo Mundo.

Com movimentos de Independência, constitucionalismo e codificação do direito imersos na onda revolucionária e "legicentrista" do mundo ocidental, tais processos apresentaram, no Brasil, inúmeras características semelhantes àquelas vividas pelos países europeus. Dentre elas, destaque seja dado às ligações do direito penal em vias de codificação com a conjuntura política específica vivida pelo país e com os projetos arquitetados no Parlamento para a construção do novo Estado.

A aprovação do Código Criminal brasileiro de 1830 inseriu-se no momento de conformação de um campo de direito nacional no Império, momento em que o constitucionalismo e a codificação ligaram-se, na visão dos artífices da nova unidade política em construção, aos ideais de formação de um governo e de um Estado. Inseridos num movimento levado a cabo em grande parte do mundo ocidental, os primeiros legisladores do país valeram-se de concepções modernas de justiça e lei e acreditaram no seu poder de conformação de uma nova realidade. ${ }^{60}$

\footnotetext{
${ }^{60}$ Andréa Slemian. "À nação independente, um novo ordenamento jurídico: a criação dos Códigos Criminal e do Processo Penal na primeira década do Império do Brasil." In: Gladys Sabina Ribeiro (org.). Brasileiros e cidadãos. Modernidade política. São Paulo: Alameda, 2008; pp.175-206.
} 
Para tanto, contaram com a ampla circulação de ideias políticas e jurídicas então em voga, recebendo e exportando teorias, concepções, metodologias e modelos jurídicos da e para a Europa e América. Localizado entre os primeiros códigos do mundo ocidental, o diploma penal de 1830 foi amplamente reconhecido à época, dentro e fora do Brasil, por sua modernidade, liberalidade e equilíbrio, e pelas qualidades identificadas em vários de seus dispositivos específicos. Inspirado pelas codificações espanhola, francesa, toscana e até norte-americana (como veremos com cuidado à frente), o diploma criminal do Império brasileiro influenciou, por sua vez, a codificação penal de diversos países da América Latina, a produção dos códigos penais espanhol, de 1848, e português, de 1852, e a elaboração da lei belga de liberdade de imprensa, de $1831^{61}$.

Para além desta inserção internacional, chamam a atenção também as especificidades e peculiaridades do código de 1830, afeitas às circunstâncias da sociedade brasileira de então. Nesse sentido, a prescrição de penas específicas aos escravos do país, a manutenção da pena de morte paralelamente à adoção de penas extremamente modernas, como a de prisão com trabalho, e a regulamentação especificamente adotada para os crimes públicos, revelam as adequações deste diploma à realidade do país recém-independente e às expectativas sobre ele depositadas no processo de afirmação e estabilização do novo Estado-nacional.

No interior de um governo representativo e constitucional, a elaboração do código criminal deu ensejo a importantes debates e reflexões de cunho político, diretamente relacionados aos modelos de Estado e de Justiça almejados ao país e à determinação dos direitos e deveres dos cidadãos. Às vésperas da aprovação do novo código, o trabalho das comissões parlamentares dedicadas à sua composição final e os debates

${ }^{61}$ Ladislau Thót. "O Código Criminal Brasileiro de 1830. Estudo histórico-jurídico comparativo. Conferência no Instituto de Advogados Brasileiros". In: Pandectas Brasileiras: registro de doutrina, jurisprudência dos tribunais e legislação. Rio de Janeiro, v. $8,1^{\circ}$ e $2^{\circ}$ semestre de 1930; pp. 119-126; p. 126. Vale destacar ainda que, após sua promulgação, o Código Criminal do Império do Brasil foi rapidamente traduzido, para o francês, por Victor Foucher (Victor Foucher. Code Criminel de L'Empire du Brésil. Paris: A L'Imprimerie Royale, 1834), tendo sido louvado em diversos países, e por diversos juristas, enquanto exemplar do novo direito penal a ser desenvolvido pelas nações civilizadas. Ver, nesse sentido: José Reinaldo de Lima Lopes. O Direito na História: lições introdutórias. São Paulo: Atlas, 2009; p. 265. De acordo com Helvécio Carlos da Silva Gusmão "Consta que a perfeição de sua fórma enthusiasmou a tal ponto o jurisconsulto belga Haus, que este chegou a aprender o portuguez para melhor aprecial-o, affirmando ser a melhor codificação que tinha lido em sua vida." Helvécio Carlos da Silva Gusmão. "Ligeiras notas sobre o Código Criminal de 1830" In: Revista do Instituto Histórico e Geográfico Brasileiro. I Congresso de História Nacional, Rio de Janeiro, v.4, 1914; pp. 415-127; ver especialmente p. 423. 
então gerados entre os deputados do Império (especialmente nos anos de 1829 e 1830), explicitaram a importância assumida por este documento e o modo com que sua promulgação esteve relacionada à materialização de determinados projetos para o país e à oposição a modelos específicos de governo e de nação.

Se entre os deputados envolvidos em sua elaboração, portanto, foi consensual o desejo de afirmação da indisponibilidade das leis ao monarca, aprovando-se, como veremos, um código criminal explicitamente oposto aos intentos autoritários de d. Pedro I, a análise pormenorizada do trâmite parlamentar seguido por este documento revelou como, no interior do grupo que fazia oposição ao imperador, havia já fissuras significativas no tocante aos modelos de Estado, Justiça e cidadania reivindicados para o Brasil.

Haja vista a complexidade das questões envolvidas na aprovação deste diploma, a pesquisa que aqui apresentamos fundou-se, simultaneamente, num exame jurídico e histórico do Código de 1830. Sendo assim, paralelamente à análise da organização e do conteúdo jurídico preciso deste documento, buscamos examinar a conjuntura específica de sua aprovação. Se, por um lado, a presença de determinados crimes e penas no código nacional, bem como a identificação de suas principais matrizes jurídicas ocidentais, revelou algo sobre a concepção de direito e de lei por que se pautaram os representantes brasileiros, a inserção conjuntural deste diploma nos últimos anos do Primeiro Reinado e a avaliação dos debates suscitados por sua aprovação manifestaram a importância assumida pela positivação das leis penais no país recém-independente e as expectativas políticas então depositadas sobre o código criminal.

Visando compreender o cenário jurídico e penal com que a primeira legislatura brasileira se deparou - e com que teve de lidar na tarefa de conformação de um campo de direito nacional no Império -, no primeiro capítulo desta dissertação, "Enquadramento jurídico e conjuntura política na primeira década do Brasil independente", apresentamos a legislação criminal em vigor no período colonial, sua configuração às vésperas da Independência do país e sua reconfiguração nos anos iniciais da separação política formal entre Brasil e Portugal. Para tanto, examinamos o modo com que o direito penal foi compreendido e aplicado no âmbito geral das práticas de poder da monarquia corporativa portuguesa de Antigo Regime estendida, como veremos, à colônia americana - e observamos as modificações impostas a este regime específico de direito - lá e cá - pelas reformas pombalinas e 
revoluções liberais de inícios do século XIX; delineando, enfim, o completo quadro legislativo a que o Código de 1830 veio se sobrepor.

Haja vista nossa preocupação em contextualizar politicamente a elaboração do diploma penal do Império, analisando a forma e o conteúdo específicos assumidos por seu texto final, apresentamos ainda, no primeiro capítulo, a conjuntura política e parlamentar vivida no Primeiro Reinado e os primeiros projetos de código criminal apresentados aos legisladores do país.

O segundo capítulo, "O trâmite parlamentar do Código de 1830: debates procedimentais, comissões de trabalho e a manutenção da pena de morte" apresenta, por sua vez, como o próprio título indica, a trajetória percorrida pelos projetos de código penal apresentados à Câmara dos deputados em 1827 e o modo com que um novo texto foi ganhando forma com o passar dos anos. No interior deste percurso, são apresentados os principais debates articulados em torno à sua elaboração, bem como o trabalho efetivamente empreendido por deputados e senadores - na forma de comissões parlamentares - durante a trajetória de codificação das leis penais. Ao final do capítulo, um exame especificamente dedicado à manutenção da pena de morte no texto do código criminal, contribui ao reconhecimento dos cuidadosos trabalhos e complexas escolhas jurídicas envolvidas na elaboração deste diploma, recusando o argumento de que sua composição fundou-se, eminentemente, na pressa dos parlamentares brasileiros em superarem o modelo penal materializado no Livro V das Ordenações Filipinas.

Por fim, no terceiro capítulo, intitulado "O Código Criminal de 1830: matrizes e influências" analisamos, em profundidade, o texto do Código Criminal do Império do Brasil, explicitando o projeto político de fundo por ele representado. Para tanto, comparamos o texto final deste diploma aos projetos que o antecederam no Brasil, explicitando o que se manteve e o que foi eliminado daqueles textos entre um momento e outro - atentando às possíveis causas e fontes destas transformações para, em seguida (munidos dos resultados de um estudo comparativo cuidadoso entre o Código de 1830 e outros dez códigos ou projetos de codificação penal existentes àquela altura no mundo ocidental), apresentarmos as principais matrizes penais internacionais utilizadas na elaboração do código brasileiro.

Ainda no terceiro capítulo, encaminhando as principais conclusões da pesquisa, analisamos dispositivos específicos adotados pelo Código de 1830, em especial no tocante às suas penas e à regulamentação dos crimes públicos, mostrando o quanto 
tais dispositivos estiveram ligados à conjuntura específica vivida pelo país e aos projetos políticos e jurídicos mais amplos dos representantes brasileiros. Nesse sentido, para além do conteúdo final do Código de 1830, analisamos parte das modificações impostas ao seu texto nos anos que se seguiram à Abdicação de d. Pedro I, reconhecendo, na ampla vigência deste documento, o sucesso em materializar a teoria jurídica liberal do período, moldando-a, quando necessário, à realidade nacional.

A pesquisa visa demonstrar, enfim, os primeiros movimentos feitos no sentido da conformação de uma cultura jurídica brasileira e o modo com que tal conformação esteve relacionada ao desejo de afirmação da nova unidade política nacional. Espelhado no movimento codificacionista ocidental da virada do século XVIII ao XIX, o Código Criminal do Império do Brasil não representou a adaptação de instituições modernas, liberais e burguesas a uma sociedade atrasada e estamental. Apesar de parte da historiografia se centrar nos "limites" deste diploma e nas pretensas contradições existentes entre seus dispositivos modernos e a sociedade escravista brasileira de então, procuramos privilegiar, ao longo da pesquisa, as similitudes existentes entre os casos brasileiro, europeu e norte-americano na construção de um modelo jurídico liberal e, a princípio, de garantia de direitos aos cidadãos.

Neste sentido, não são os "desvios" ou "adaptações" do caso brasileiro ao modelo jurídico ocidental a configurar o objetivo central da análise, mas antes a tentativa de situar e compreender, no interior de um estudo de caso, o próprio modelo codificacionista em sua historicidade. Se pautarmos, assim, a leitura deste processo, pelo reconhecimento do caráter essencialmente contestável e aporético dos conceitos políticos modernos - e, logo, dos inúmeros "pontos cegos” intrínsecos aos mesmos -, nos daremos conta de que, fundamentalmente, a importância dos estudos da história jurídica do século XIX brasileiro não reside na identificação dos pontos de conformação ou descompasso de suas instituições em relação ao modelo liberal europeu do período (ou no fornecimento de respostas provisórias a tais adaptações), mas antes na identificação das contradições inerentes aos próprios conceitos políticos, revelando a radical contingência de sua instituição ${ }^{62}$.

${ }^{62}$ Elias José Palti. "O século XIX brasileiro, a nova história política e os esquemas teleológicos". In: José Murilo de Carvalho e Lucia Maria Bastos das Neves (org.). 
Nas palavras de Elias José Palti:

A questão é que só se recuperamos esse fundamento aporético subjacente à política moderna podemos recuperar um sentido substantivo para as controvérsias que se inquietaram ao longo do século XIX em torno de conceitos tais como os de soberania, nação, cidadania etc e podemos começar a compreender por que os tipos de questões propostas no século XIX não eram ociosos nem tinham uma resposta evidente. [...] Só na medida em que adotamos uma perspectiva mais forte da historicidade, a contingência dos processos políticos, que não remeta meramente ao grau de realização empírica de certos modelos supostos, mais que penetre nesses mesmos modelos, revelando-nos sua natureza intrinsecamente aporética (e, portanto, essencialmente contestável), pode o século XIX se tornar significativo como objeto próprio (e não apenas como um momento transicional rumo a outra coisa diferente dele, o que o converte em período deslocado, que encontra seu sentido alojado em outro lugar diferente de si), que demanda, portanto, chaves interpretativas que lhe sejam próprias. ${ }^{63}$

Neste sentido, ao recorrermos constantemente, ao longo da pesquisa, à afirmação das paridades existentes entre os processos codificacionistas vividos pela Europa, Estados Unidos e Brasil, não intentamos, de alguma forma, "redimir" a história escravista e autoritária que também marcou o Império brasileiro, mas antes demonstrar que, ao menos em âmbito jurídico, o modelo adotado pelos primeiros legisladores nacionais não deixou nada a desejar, com todas as suas contradições e problemáticas internas, àquele presente nos países europeus. Por este prisma de análise, o Brasil imperial deixa de representar um organismo excêntrico e repleto de descompassos (visão que facilita, de certa forma, o lugar confortável que assumimos perante nossos problemas sociais, políticos e econômicos) para figurar ao lado das contradições jurídicas e políticas implícitas ao modelo liberal ocidental como um todo.

Repensando o Brasil do Oitocentos. Cidadania, politica e liberdade. Rio de Janeiro: Civilização Brasileira, 2009; pp. 581-597.

${ }^{63}$ Idem; p. 596. 


\section{Capítulo 1}

\section{Enquadramento jurídico e conjuntura política na primeira década do Brasil independente}

\subsection{A legislação penal na América portuguesa e nos anos iniciais do Império do Brasil}

No dia 16 de dezembro de 1830, d. Pedro I, "por Graça de Deus, e Unânime Aclamação dos Povos, Imperador Constitucional, e Defensor Perpétuo do Brazil" promulgou o Código Criminal do Império, diploma penal a que a historiografia brasileira comumente atribuiu a façanha de ter posto fim, no país, à vigência do Livro V das Ordenações Filipinas - compilação legal portuguesa em vigor, na metrópole e em suas colônias, desde o ano de 1603, cujo quinto livro regulava a matéria criminal $^{64}$.

Louvado por materializar o deslanche do Brasil rumo a uma codificação integralmente nacional, o texto do Código de 1830 e seus novos institutos foram frequentemente comparados àqueles presentes no Livro $\mathrm{V}$ das Ordenações, enfatizando-se os "avanços" implementados pela nova legislação ante a "barbárie" e "monstruosidade" do diploma anterior e transmitindo-se a impressão geral de que a substituição de um documento pelo outro se dera sem quaisquer mediações.

Tomando-se por verdadeiras, neste sentido, as falas dos deputados brasileiros mais diretamente envolvidos na elaboração do código penal - cujas avaliações pejorativas do Livro $\mathrm{V}$, em defesa de sua rápida substituição no país, foram freqüentes -, consolidou-se a interpretação de que, na colônia, como no Império do Brasil (pelo

\footnotetext{
${ }^{64}$ Seguidora de compilações legislativas portuguesas de caráter semelhante, tais como as Ordenações Afonsinas, de meados do século XVI (possivelmente aprovadas entre 1446 e 1447), e as Ordenações Manuelinas, de 1521 - fundadas, ambas, na reunião das várias fontes do direito com aplicação em Portugal e agregando, portanto: leis anteriores, respostas a capitulos apresentados em Cortes, concórdias e concordatas, costumes, normas das Siete Partidas e disposições dos direitos romano e canônico -, a sistematização legal que desembocaria nas Ordenações Filipinas teve provável início entre 1583 e 1585, passando a vigorar, contudo, unicamente no início do reinado de Filipe II de Portugal (III de Espanha). De caráter escassamente inovador, as Ordenações Filipinas buscaram reunir, num único texto, as Ordenações Manuelinas (atualizando-as), a Coleção de Leis Extravagantes compilada por Duarte Nunes de Leão, em 1569, e o conjunto de leis a ambas posteriores. Sua organização seguiu ainda o sistema adotado desde a legislação afonsina, com a divisão das matérias reguladas em cinco livros principais. Nuno J. Espinosa Gomes da Silva. História do Direito português: fontes de direito. Lisboa: Fundação Calouste Gulbenkian, 2006; pp. 299-366.
} 
menos até 1830), aplicara-se cotidianamente uma justiça penal beata, extremamente cruel e ritualística embasada no texto das Ordenações ${ }^{65}$.

Para além do caso específico do diploma penal, também o restante do percurso codificacionista trilhado pelo Império foi frequentemente analisado na chave das sucessivas revogações operadas em relação à legislação portuguesa, que lentamente (na sequência dos códigos individualmente aprovados no Brasil) teria deixado de vigorar no país. Neste sentido, em 1832, com a aprovação do Código de Processo Criminal, ter-se-ia suprimido por completo o Livro V das Ordenações e segmentos de outros livros referentes ao processo; em 1850, com a aprovação do Código Comercial, parte de seu Livro IV; e, enfim, com a aprovação do Código Civil brasileiro de 1916, o restante de seu conteúdo normativo ${ }^{66}$.

Haja vista a extensão cronológica deste processo, tais análises - centradas numa leitura da codificação como elemento central, senão único, de revogação dos institutos anteriores - fizeram constante menção à longa vigência das Ordenações Filipinas no mundo luso brasileiro, enfatizando que, tendo perpassado toda a colônia, tal legislação teria, inclusive, sobrevivido ao período monárquico e adentrado pelos primeiros anos da República ${ }^{67}$.

O que este tipo de leitura oblitera, ou ignora, contudo, é que a vigência das Ordenações Filipinas no Brasil, bem como sua aplicação efetiva nestas paragens -

${ }^{65}$ Fundado numa indiferenciação geral entre princípios religiosos, morais e propriamente jurídicos, o direito penal regulado pelo Livro V das Ordenações confundia crimes e pecados. Para além disso a punição aos delitos aí regulamentados pautava-se por uma naturalização das distinções e privilégios sociais (condizente, de todo modo, com a visão de mundo do Antigo Regime a que nos referimos na Introdução), tornando a conduta delitiva e a sanção aplicada diferentes em cada caso e gerando uma imprevisibilidade generalizada no que se referia à punição destinada ao delinqüente a título de expiação do delito. Diretamente associadas ao poder régio, as punições previstas pelo Livro $\mathrm{V}$ visavam ainda afirmar a lei de forma exemplar e ritualizada, atingindo o corpo do condenado, impressionando os súditos e reafirmando o poder da lei e do monarca.

${ }^{66}$ Desde a legislação afonsina a divisão das matérias reguladas pelas Ordenações portuguesas seguia a seguinte organização, em cinco livros principais: Livro I. Cargos e atribuições públicas, civis e militares, com o delineamento das atribuições, direitos e deveres dos magistrados e oficiais de Justiça; Livro II. Legislação referente ao clero e à nobreza, com o estabelecimento dos privilégios e direitos fiscais de ambas, e definição das relações entre Estado e Igreja; Livro III. Processo civil; Livro IV. Direito civil, referente ao direito das coisas e pessoas, estabelecendo regras para contratos, testamentos, tutelas, formas de distribuição e aforamento de terras; e Livro V. dedicado ao direito e ao processo penal, estipulando os crimes e suas penas

${ }^{67}$ Silvia Hunold Lara (org.). Ordenações Filipinas: Livro V. São Paulo: Companhia das Lestras, 1999; p. 39; e Mozart Linhares da Silva. "O Código Criminal de 1830 e as idéias que não estão fora do lugar". In: Elizabeth Cancelli (org.) Histórias de Violência, Crime e Lei no Brasil. Brasília: Editora Universidade de Brasília, 2004; pp. 77-100; p. 83. 
assim como em Portugal - foi em muito distinta do que a princípio se faz crer. Neste sentido, se não foram produzidos códigos propriamente ditos anteriormente aos anos de 1830, 1832, 1850 e 1916 no país, houve, contudo, ao longo dos períodos colonial e monárquico, uma ampla produção legislativa sobre diversas áreas do direito.

No período colonial, por exemplo, tal produção se manifestou, na maioria das vezes, sob a forma das chamadas "Leis Extravagantes",68, possuidoras, muitas vezes, de caráter revogatório em relação às Ordenações. No Império, por sua vez, as leis regulamentares tiveram efeito semelhante, mesmo no caso da legislação civil, cujo código só viria a ser aprovado na República, mas cuja abundância de normas legislativas circulou pelo Império, a partir de fins da década de 1850, na forma de uma "Consolidação das Leis Civis",69.

Para além disso, no ambiente jurídico pluralista metropolitano e colonial de Antigo Regime, o conteúdo especificamente previsto pelas Ordenações Filipinas não era necessariamente aquele a que se recorria com prioridade no julgamento dos processos, haja vista a convivência bastante próxima estabelecida entre as Ordenações e as fontes do chamado "direito comum" do período (direitos romano e canônico, doutrina e jurisprudência), ou ainda a prevalência que tiveram os costumes e tradições locais em parte importante das decisões judiciais tomadas em todo o reino.

\footnotetext{
${ }^{68}$ De acordo com Nuno Espinosa Gomes da Silva: "Por leis extravagantes designam-se, de acordo com a própria etimologia da expressão, aquelas leis que, ocupando-se de matéria que foi objeto de compilação ou codificação oficial, não vêm em momento posterior a ser aí incorporadas, ficando a vigorar "por fora'." N. E. G. da Silva. Op. cit.; 2006; p. 347. Tratavase, portanto, da legislação promulgada posteriormente à edificação das Ordenações Filipinas e que, desta forma, não chegou a ser compilada num documento legal oficial. Entre as páginas 373 e 374 de seu livro, Nuno da Silva faz referência a uma série de coleções, de caráter particular, responsáveis pela compilação da legislação extraordinária portuguesa promulgada entre as Ordenações Filipinas e o ano de 1750. Para um exame da legislação extraordinária promulgada por Portugal entre 1603 e 1801 consultar a coleção de leis disponibilizadas pelo site Ius Lusitaniae, em: http://iuslusitaniae.fcsh.unl.pt./consulta.php.

${ }^{69}$ Para ficarmos com o caso a que mais comumente se recorre nas asseverações concernentes à durabilidade do direito das Ordenações, atentemos à vasta produção do Império brasileiro no campo do direito civil e, em especial, à obra de Teixeira de Freitas, a Consolidação das Leis Civis brasileiras, finalizada em 1858, reeditada por no mínimo três vezes e frequentemente citada nas ações de liberdade no Tribunal da Relação do Rio de Janeiro. Como mostra Samuel Rodrigues Barbosa, ao selecionar a complexidade da legislação civil reduzindo a multiplicidade das fontes legais a proposições claras e sucintas -, a Compilação de Teixeira de Freitas "concorria no foro com os praxistas e servia como um Código de fato". Samuel Rodrigues Barbosa. "Complexidade e Meios Textuais de Difusão e Seleção do Direito Civil Brasileiro Pré-Codificação". In: Ricardo Marcelo Fonseca, Airton Cerqueira Leite Seelander (orgs.). História do Direito em Perspectiva. Curitiba: Juruá, 2009; pp. 361374.
} 
Para que possamos identificar, assim, o quadro das fontes do direito penal efetivamente vigentes nos últimos anos da colônia portuguesa e primeiros do Brasil independente, faz-se necessário examinar brevemente o modo com que o direito penal foi compreendido e aplicado no âmbito geral das práticas de poder da monarquia corporativa portuguesa de Antigo Regime - estendida, como veremos, à colônia americana $^{70}$ - e, a partir daí, observar as modificações impostas a este regime específico de direito - lá e cá - pelas reformas pombalinas e revoluções liberais de inícios do século XIX, delineando o verdadeiro quadro legislativo a que o Código de 1830 veio se sobrepor.

Se, como vimos na Introdução, o regime político pluralista das monarquias corporativas européias de Antigo Regime fundava-se numa distribuição simbólica da justiça pelo monarca e numa atuação jurídica bastante comedida de sua parte voltada à manutenção dos equilíbrios (políticos, jurídicos e sociais) pré-estabelecidos nas localidades e à prevenção de conflitos com os poderes locais -, não espanta que no âmbito específico da justiça penal portuguesa de Antigo Regime, as coisas se dessem de forma mais ou menos semelhante. Ausentes, portanto, os recursos necessários a uma aplicação cotidiana e efetiva da justiça penal (e desconhecidos, acima de tudo, os princípios que viriam a nortear o direito penal moderno), tal justiça assumiu - pelo menos entre os séculos XVI e a primeira metade do XVIII - um caráter cada vez mais virtual, caracterizando-se, afinal, por uma ausência, muito mais do que por uma presença.

De facto, a função político-social determinante do direito penal real não parece ser, na sociedade "sem Estado" dos séculos XVI e XVII, a de efectivar, por si mesmo, uma disciplina social. Para isso lhe falta tudo - os meios institucionais, os meios humanos, o domínio efectivo do espaço e, por fim, o domínio do próprio aparelho de justiça, expropriado ou pelo "comunitarismo" das justiças populares ou pelo "corporativismo" dos juristas letrados. Essa função parece ser, em contrapartida, a de afirmar, também aqui, o sumo poder do rei como dispensador, tanto da justiça como da graça ${ }^{71}$.

Neste sentido, ainda que a legislação penal portuguesa do período, materializada pelo dito Livro V das Ordenações Filipinas, previsse, para uma grande quantidade de casos, a aplicação de penas corporais e infamantes como as galés, açoites, amputação

\footnotetext{
${ }^{70} \mathrm{~A}$ análise que segue nos próximos cinco parágrafos acerca do sistema penal da monarquia corporativa portuguesa de Antigo Regime foi desenvolvida por António Manuel Hespanha no artigo: "Da 'iustitia' à 'disciplina'. Textos, poder e política penal no Antigo Regime.". In: Anuario de Historia del Derecho Español, Madrid, 1988; pp. 493-578.

${ }^{71}$ Idem; pp. 500-501.
} 
de membros, marcas de ferro, degredos e a própria pena capital, tais dispositivos careciam de eficiência real, permanecendo, na maioria das vezes, restritos à letra da lei. Se tal descompasso entre o estabelecido pelo diploma penal e o efetivamente posto em prática pelos tribunais portugueses pode parecer, à primeira vista, fruto de uma inadequação jurídica do país, para António Manuel Hespanha, o segredo da específica eficácia do sistema penal de Antigo Regime encontrava-se justamente nesta "inconseqüência" de ameaçar sem cumprir: "De se fazer temer ameaçando; de se fazer amar não cumprindo",72.

No interior deste regime penal específico, cumpriam papel fundamental, como não poderia deixar de ser, os expedientes de graça e perdão prodigalizados pelo rei. Neste âmbito estratégico de atuação, paralelamente à função de senhor da Justiça, o monarca cumpria o papel de mediador da Graça, essencial à legitimação de seu poder. Longe, portanto, de contrariarem os esforços de construção positiva (pela ameaça) da ordem penal régia, o perdão e outras medidas de graça ${ }^{73}$ os corroboravam num plano complementar, reforçando o poder real em dois de seus traços decisivos: summum ius e summa clementia.

Confrontados os dispositivos penais presentes no Livro V das Ordenações Filipinas à efetiva prática dos tribunais portugueses, conclui-se, portanto, por uma aplicação muito pequena de penas como a morte, os açoites, a marca de ferro e o "cortamento" de membros, deduzindo-se que, diferentemente do que fazem crer certas análises - centradas no caráter martirizante de um direito penal pretensamente típico do Antigo Regime -, a justiça criminal deste período não era, na grande maioria das vezes, nem muito efetiva, nem sequer muito aparente ou teatral ${ }^{74}$.

\footnotetext{
${ }^{72}$ Idem; p. 518.

${ }^{73}$ Para além do perdão, portanto, podem ser contabilizadas, entre as medidas de graça despendidas pelo monarca, a emissão de "cartas de seguro", "alvarás de fiança", "indultos", "livramentos" por perdão ou comutação, dentre outras, constantemente incentivadas pelo poder. Da parte dos súditos, diz-nos Hespanha, tal modelo de legitimação do poder criava um certo habitus de obediência no interior do qual o temor do castigo não quebrava os laços de submissão ao rei, haja vista a esperança constante do perdão. Nas palavras do autor: "Tratase, afinal, de um modelo de exercício do poder coercitivo que evita, até a consumação final da punição, a 'desesperança' dos súditos em relação ao poder; e que, por isso mesmo, tem uma capacidade quase ilimitada de prolongar (ou reiterar) a obediência e o consenso, fazendo economia dos meios violentos de realizar uma disciplina não consentida.". António Manuel Hespanha. "Da 'iustitia' à 'disciplina'. Textos, poder e política penal no Antigo Regime". Op. cit.; pp. 523-526.

${ }^{74}$ Idem; pp. 500-521.
} 
Haja vista o caráter pouco orientado à efetivação de castigos por parte desta justiça penal, o que, afinal, pergunta-se, garantia o controle dos comportamentos e a manutenção da ordem social no Portugal do período? De acordo com Hespanha, tal garantia repousava sobre mecanismos de constrangimento periféricos e cotidianos, como a família, a Igreja e a pequena comunidade, imbuídos de regras e valores próprios e de grande penetração social. Neste contexto, a justiça penal da coroa acabava respondendo prioritariamente a uma função política: defender a supremacia simbólica do rei como titular do poder punitivo e do correspondente poder de agraciar, e livrá-lo de uma desnecessária punição cotidiana ou estratégica dos atentados mais graves ao convívio social, encarregados que estavam desta função os níveis infra-estatais de ordenação.

Se era esta, em suma, a moldura do direito penal vigente no Antigo Regime português, a extensão do modelo político e jurídico corporativo-pluralista da metrópole à colônia americana (cuja validade foi recentemente demonstrada por António Manuel Hespanha) ${ }^{75}$ faz com que, também no Ultramar, o impacto e a aplicação cotidiana da justiça criminal tenham de ser reconsiderados sob novas luzes.

No interior desta reavaliação, assume importância fundamental o reconhecimento da influência desempenhada pela flexibilidade do "direito comum" europeu sobre o direito cotidianamente aplicado na América portuguesa. Tal flexibilidade se caracterizava, como vimos, pelo fato de o direito local se impor, com freqüência, ao direito geral (composto pelos direitos romano e canônico, a Glosa de Acúrsio, os Comentários de Bártolo e a communis opinio doctorum) ou ao direito pátrio (consubstanciado, no caso português, pelas Ordenações), tornando as especificidades de cada caso - e não as regras abstratas - decisivas à solução jurídica, com larga margem de arbítrio aos juízes na avaliação dos casos particulares. No âmbito colonial, tal flexibilidade podia assumir facetas ainda mais pluralistas, haja vista a presença, aí, de uma administração fundada na autonomia de diversos funcionários e poderes locais e na independência do âmbito decisório dos tribunais superiores - exemplificados por diversos documentos relativos ao descumprimento de ordens metropolitanas por

\footnotetext{
${ }^{75}$ Para a validade do modelo corporativo-pluralista do direito português às suas colônias ver: António Manuel Hespanha. "A Constituição do Império português. Revisão de alguns enviesamentos correntes.". In: João Fragoso, Maria Fernanda Bicalho e Maria de Fática Gouvêa (orgs.). O Antigo Regime nos Trópicos. A dinâmica imperial portuguesa (séculos XVI-XVIII). Rio de Janeiro: Civilização Brasileira; 2001; pp. 163-188; e Idem. "Depois do Leviathan”. In: Almanack Brasiliense, $\mathrm{n}^{\circ}$ 5, maio de 2007; pp. 55-65.
} 
instituições localmente criadas, com a conseqüente afirmação dos poderes locais e o surgimento de insanáveis conflitos de jurisdição ${ }^{76}$.

A partir deste quadro geral de identidades entre os modelos de direito metropolitano e colonial, também no âmbito estritamente penal somos levados a crer (haja vista a carência de pesquisas) numa proximidade entre as situações vividas por Portugal e a América portuguesa, com uma submissão dos fortes dispositivos punitivos do Livro V das Ordenações, pelo menos até a metade do século XVIII, a práticas infra-estatais de controle dos comportamentos - emanados das comunidades locais, familiares e religiosas - , e a âmbitos muitas vezes autônomos e localmente constituídos de resolução de conflitos. O que demonstra que, também no âmbito colonial, a justiça penal do Antigo Regime esteve distante de uma atuação disciplinadora ${ }^{77}$.

Se uma leitura totalitária do direito penal de Antigo Regime não possui, portanto, validade para o exame dos séculos XVI, XVII e a primeira metade do XVIII na colônia americana, as mudanças introduzidas pelo "despotismo iluminista" metropolitano, materializado nas reformas pombalinas empreendidas sobre o direito na segunda metade dos setecentos, modificaram de forma sensível o quadro da atuação penal no Império português.

A concepção penal da nova política pombalina fundou-se numa inversão quase completa da matriz criminal anterior, substituindo um modelo de distribuição simbólica da justiça penal por um novo projeto de atuação política diretamente ligado à perspectiva de concentração de poderes e disciplinarização da sociedade por meio de uma atuação normativa efetiva e prática - esvaziando, para tanto, os centros políticos periféricos. O mesmo movimento de superação dos pluralismos políticos e jurídicos analisado na Introdução pode ser reconhecido, portanto, no âmbito específico do direito penal português.

Evidencia-se, assim, um agravamento do rigor do sistema punitivo articulado pelo poder central, materializado, por exemplo, num aumento das aplicações da pena de morte e numa clara utilização desta punição em nome dos objetivos políticos conjunturais da coroa. Neste sentido, se a documentação metropolitana não apontava,

\footnotetext{
${ }^{76}$ António Manuel Hespanha. "Depois do Leviathan”. Op. cit.; p. 62.

${ }^{77}$ Ver Arno Wehling e Maria José Wehling. Direito e Justiça no Brasil Colonial: o Tribunal da Relação do Rio de Janeiro (1751-1808). Rio de Janeiro: Renovar, 2004. Especialmente capítulo 28: "O direito penal entre o antigo e o moderno"; pp. 545-592.
} 
até aquele momento, para qualquer diferenciação entre uma política de salvaguarda dos bens públicos da nação e a defesa de seus bens privados, a partir do século XVIII pode-se identificar um decréscimo progressivo das punições a ofensas "particulares" e um aumento correspondente das punições dirigidas aos atentados a valores públicos, nomeadamente políticos, em Portugal ${ }^{78}$.

Visando, entre outras coisas, a um aumento real da eficácia da justiça penal portuguesa, foram empreendidas, na segunda metade dos setecentos, as chamadas reformas pombalinas do direito - continuadas pelos ministros ilustrados de D. Maria I -, com impacto decisivo sobre a administração do direito também no Novo Mundo. Dentre estas medidas, destacamos aqui: a aprovação da lei de 18 de agosto de 1769, conhecida como Lei da Boa Razão, a reforma dos Estatutos Jurídicos da Universidade de Coimbra, de 1772, e o deslanche do Projeto do Novo Código - que, de acordo com Hespanha, podem ser resumidas sob uma única palavra de ordem: promoção do legalismo e limitação do arbítrio doutrinal e judiciário ${ }^{79}$.

A reforma legislativa empreendida no período, traduzida no aumento significativo do ritmo de promulgação de textos legais, visou transferir da doutrina dos juristas para a legislação régia a normativização de questões políticas ou socialmente críticas. Tal produção por si só, contudo, era insuficiente enquanto não se modificasse o quadro das fontes de direito, pondo fim à precedência da doutrina e da jurisprudência sobre a lei do soberano ${ }^{80}$. E foi justamente isto que visou realizar a Lei da Boa Razão.

Fortemente ancorada no ambiente cultural iluminista e jusracionalista português, a Lei da Boa Razão impunha critérios novos à interpretação das leis portuguesas e à integração de suas lacunas, impedindo que os juízes recorressem ao direito romano, ou a textos doutrinários, nos casos em que houvesse regulamentações afins nas Ordenações Filipinas, costumes do reino (com mais de 100 anos de existência) e assentos da Casa de Suplicação ${ }^{81}$. Ainda quando ausentes tais regulamentações, ou

\footnotetext{
${ }^{78}$ A. M. Hespanha. "Da 'iustitia' à 'disciplina'. Textos, poder e política penal no Antigo Regime.”. Op. cit.; pp. 508-517.

${ }^{79}$ Idem; p. 532.

80 A. M. Hespanha. História de Portugal Moderno: político e institucional. Lisboa: Universidade Aberta, 1995; p. 92. Para um vôo de pássaro sobre a legislação extravagante produzida no âmbito penal entre 1752 e 1808 ver: Arno e Maria José Wehling. Op. cit., 2004; pp. 556-559.

${ }^{81}$ Ricardo Marcelo Fonseca. "Dall diritto coloniale ala codificazione: appunti sulla cultura giuridica braziliana tra settecento e novecento". In: Quaderni Fiorentini per la storia del pensiero giuridico moderno; n.33/34, 2004/2005: "L' Europa e gli 'Altri': Il diritto coloniale fra Otto e Novecento" - Tomo I; pp. 964-983; para as reflexões referentes à Lei da Boa
} 
seja, nos casos de verdadeira lacuna legal, só de poderia recorrer ao direito romano, dizia a lei de 1769, se as disposições nele presentes estivessem de acordo com a boa razão - ou seja, fundadas no direito natural e no direito das gentes, ou nas leis políticas, econômicas e marítimas das "nações civilizadas" da Europa ${ }^{82}$. Para além disso, a Lei da Boa Razão proibia a vigência do direito canônico no foro civil, aceita, até aquele momento, em matérias de caráter temporal relacionadas com questões de fé ou disciplina (casos mixti fori) $)^{83}$.

De forma resumida, pode-se dizer que a Lei da Boa Razão buscou modernizar o direito português, assegurando a supremacia da lei em relação ao costume ${ }^{84}$. No âmbito de sua influência sobre o direito aplicado na América Portuguesa, a análise desenvolvida por Arno e Maria José Wehling sobre os processos que ascenderam ao Tribunal da Relação do Rio de Janeiro e à Casa de Suplicação do reino entre 1752 e 1808 , concluiu por sua efetiva aplicação na colônia ${ }^{85}$.

Já no que diz respeito à reforma dos Estatutos Jurídicos da Universidade de Coimbra, empreendida em 1772, deve-se ter em mente o fato de que, até então, o

Razão, ver pp. 965-968. O preâmbulo da lei da Boa Razão definia assim que a mesma buscava precaver com sábias providências "as interpretações abusivas, que ofendem a majestade das leis, desautorizam a reputação dos magistrados e têm perplexa a justiça dos litigantes". APUD: Lenine Nequete. O Poder Judiciário no Brasil a partir da Independência. Porto Alegre: Livraria Sulina Editora, 1973; pp. 7-9.

${ }^{82}$ Arno Wehling e Maria José Wehling. "Cultura jurídica e julgados do Tribunal da Relação do Rio de Janeiro: a invocação da Boa Razão e o uso da doutrina. Uma amostragem.". In: Maria Beatriz Nizza da Silva (coord.). Cultura Portuguesa na Terra de Santa Cruz. Lisboa: Editorial Estampa, 1995; pp. 235-247; pp. 239-240. Ver também, Antonio Carlos Wolkmer. História do Direito no Brasil. Rio de Janeiro: Forense, 2009; p. 62.

${ }^{83}$ A. M. Hespanha. "Conclusão". José Mattoso (org.). História de Portugal; p. 464.

${ }^{84}$ Ruth Gauer. "Fundamenta-se um moderno pensamento jurídico brasileiro.". In: Elizabeth Cancelli (org.) Histórias de Violência, Crime e Lei no Brasil. Brasília: Editora Universidade de Brasília, 2004; pp. 41-76; p. 53.

${ }^{85}$ Nas palavras dos próprios autores: "Pelas investigações até aqui realizadas, e considerando o universo do Tribunal da Relação do Rio de Janeiro, podemos afirmar, pois - e preliminarmente, repetimos - que a legislação pombalina, tanto no consulado do ministro, como no período posterior, foi efetivamente observada, com as limitações históricas estruturais que teve a justiça colonial igualmente em momentos anteriores". Arno Wehling e Maria José Wehling. "Cultura jurídica e julgados do Tribunal da Relação do Rio de Janeiro: a invocação da Boa Razão e o uso da doutrina. Uma amostragem". Op. cit.; 1995; p. 247. Dos mesmos autores, ver ainda: Direito e Justiça no Brasil colonial: o Tribunal da Relação do Rio de Janeiro (1751-1808). Rio de Janeiro: Renovar, 2004. Os Tribunais da Relação consistiam numa espécie de corte jurídica de apelação, com prerrogativas semelhantes aos tribunais superiores do Reino (como, por exemplo, a Casa de Suplicação). Na América portuguesa, para além do Tribunal da Relação do Rio de Janeiro, vigente desde o ano de 1751, funcionava, desde 1609, o Tribunal da Relação da Bahia. Samuel Rodrigues Barbosa levanta algumas dúvidas sobre o sucesso efetivo da lei no Brasil. Ver, do autor: "Complexidade e Meios Textuais de Difusão e Seleção do Direito Civil Brasileiro PréCodificação". Op. cit.; p. 365 e 369. 
ensino do direito naquela instituição fundava-se nos Estatutos Velhos de 1598, divididos - como em grande parte da Europa - entre os cursos de Cânones e de Leis, nos quais se ensinava, respectivamente, o Corpus Iuris Canonici e o Corpus Iuris Civilis. Com a Reforma de 1772, o Direito Natural assume papel de destaque no ensino - suplantando a "Segunda Escolástica", predominante na Península Ibérica até então -, com a inserção, na grade jurídica de Coimbra, das disciplinas de "Direito Pátrio" e "História do Direito português", orientadas a preparar os estudantes à compreensão e execução das leis ${ }^{86}$. Para além de influenciar, assim, a produção de um recorte jurídico "nacional" condizente com o projeto da ilustração portuguesa na virada do século XVIII para o XIX, a reforma de 1772 "foi generalizando o sistema sintético e compendiário no qual o professor deveria, de forma ordenada e sucinta, expor todo o sistema do Direito e abandonar a exegese de textos clássicos e casuísticos e o recurso à opinio communis dos doutores da Igreja. ${ }^{.87}$.

No que tange à influência desta reforma sobre o direito colonial brasileiro, ela pode ser percebida não só na criação dos cursos jurídicos de São Paulo e Olinda, em 1827, mas também, e principalmente, na formação individual de juristas que, educados em Coimbra nas últimas décadas do século XVIII - a "geração de 1790", ou "geração coimbrã" -, seriam os principais administradores do Estado brasileiro recém-fundado. Os magistrados brasileiros formados por Coimbra neste período e também posteriormente, entre 1816 e 1826, predominaram, assim, no interior da classe política nacional, até a metade do século XIX, compondo o quadro político por excelência do período de consolidação do sistema imperial ${ }^{88}$.

Por fim, no âmbito do designado "Projeto do Novo Código", deve-se frisar os esforços realizados por D. Maria I com vistas à organização de uma nova legislação

\footnotetext{
${ }^{86}$ Ruth Gauer. "Fundamenta-se um moderno pensamento jurídico brasileiro.”. Op. cit.; pp. 54-55.

${ }^{87}$ Mozart Linhares da Silva. "O Código criminal de 1830 e as idéias que não estão fora do lugar"; Op. cit.; pp. 91-92. Ver também: Gizlene Neder. "Coimbra e os juristas brasileiros". In: http://gladiator.historia.uff.br/artigos/neder_coimbra.pdf, acessado em 15 de janeiro de 2013.

${ }^{88}$ Segundo Roderick J. Barman, à altura de 1820, entre 5 e 6 por cento do corpo estudantil de Coimbra era composto por estudantes brasileiros. A falta de pessoal suficiente ao preenchimento do sistema judicial do Novo Mundo, antes e depois da Independência, garantiu a estes indivíduos o emprego nos quadros jurídicos do país, tornando-os conhecidos dentre a população e facilitando, assim, sua eleição às Assembleias Constituinte, de 1823, e Geral, de 1826. Roderick J. Barman. Brazil: the forging of a nation, 1798-1852. Califórnia: Stanford University Press, 1988; pp. 138-139.
} 
para Portugal. Durante seu reinado, oficialmente transcorrido entre 1777 e $1816^{89}$, a rainha criou uma junta de magistrados (1778) com a finalidade de elaborar uma nova compilação legal para o país, a qual, contudo, nunca chegou a ser concluída ${ }^{90}$. No âmbito específico do direito penal, foi Pascoal de Melo Freire o jurista incumbido da sistematização de um novo código criminal (antes dele, outro jurista havia recebido esta função, não tendo apresentado, contudo, qualquer resultado ao governo). Avaliando os dispositivos penais presentes no Livro V das Ordenações portuguesas, Melo Freire os considerava revogados pelo uso, em especial nas partes que se chocavam abertamente com uma política utilitarista do direito penal ${ }^{91}$. Finalizado em 1786 e apresentado à avaliação em 1789, seu projeto, considerado demasiadamente moderno para a época, foi rejeitado pela comissão e publicado pela primeira vez unicamente em $1823^{92}$.

Apesar de recusado e desconhecido por vários anos, este projeto de código

${ }^{89}$ Apesar de oficialmente rainha de Portugal entre os anos de 1777 e 1816, a instabilidade mental de d. Maria I fez com que, já no início da década de 1790, seu filho d. João assumisse a direção dos negócios públicos do Estado português, recebendo o título oficial de Príncipe Regente do reino em 1799 e assumindo, desde então, a denominação de d. João VI. Proclamada Rainha do Reino Unido de Portugal, Brasil e Algarves em 1815, d. Maria I viria a falecer, no Brasil, em 1816.

${ }^{90}$ Silvia Hunold Lara. Op. cit.; p. 37. No decreto expedido aos 31 de março de 1778 com vistas à criação da Junta, a rainha fez referência à necessária reforma da justiça no reino, que se encontrava em dificuldades devido à multiplicidade e antiguidade das leis, que o tempo tornava impraticáveis. Neste sentido, d. Maria I estabelecia, dentre outras coisas, que a Junta averiguasse quais leis se achavam antiquadas, "e pela mudança das coisas, inúteis para o presente e o futuro", quais encontravam-se já revogadas em todo ou em parte, e quais pediam reformas e renovações em benefício público, demonstrando sua sintonia com o movimento de renovação legal então em curso na Europa (vide Introdução). Para o decreto de 31 de março de 1778 , acessar: http://www.iuslusitaniae.fcsh.unl.pt/verlivro.php?id_parte=109\&id_obra $=73 \&$ pagina $=253$

${ }_{91}$ António Manuel Hespanha. "A evolução da doutrina e do ensino do direito penal em Portugal C.1800-C.1910". In: Quaderni Fiorentini per la storia del pensiero giuridico moderno; 36 (2007); pp. 429-502; p. 446.

${ }^{92}$ Nas palavras de Mozart Linhares da Silva: "É notória a influência de Cesare Beccaria no tomo quinto da obra de Mello Freire, intitulado Elementa Juris Criminalis. Todavia, onde se faz mais concreta essa influência é no projeto de Código Criminal, que d. Maria I o incumbiu de redigir em 1783. Depois de seis anos de trabalho no Código, Mello Freire apresentou-o para ser avaliado pela comissão nomeada pela Coroa. Seu Código foi considerado avançado demais para a época. De qualquer maneira, o Código é de grande interesse pelo manancial das ideias reformistas. Opondo-se radicalmente às Ordenações, o Código de 1789 [sic] congrega todo o pensamento iluminista." Mozart Linhares da Silva. "O Código Criminal de 1830 e as idéias que não estão fora do lugar.”. Op. cit.; p. 93. Ver também: Nuno J. Espinosa Gomes da Silva. Op. cit.; 2006; pp. 478-482. É senso comum entre a historiografia do direito a avaliação da inspiração de Melo Freire na obra de Beccaria para a elaboração de seu projeto de código criminal. Para a avaliação dos "progressos" e "limites" inerentes ao projeto Melo Freire, ver: Patrícia Ann Aufderheide. Order and Violence: Social Deviance and Social Control in Brazil, 1780-1840. University of Minnesota. Ph.D., 1976; pp. 262-264. 
criminal alcançou grande prestígio no mundo jurídico luso-brasileiro, influenciando diretamente, como veremos, parte dos dispositivos adotados pelo projeto de código criminal elaborado por Bernardo Pereira de Vasconcelos para o Brasil e, enfim, pelo próprio Código de 1830 .

Influenciadas pelos impactos do movimento jus-racionalista em Portugal no século XVIII, as reformas pombalinas defenderam e disseminaram, portanto, um direito fundado em bases racionais e científicas, com certos acenos humanistas ${ }^{93}$, representando um movimento de renovação que, entre outras características, privilegiou a racionalização e sistematização do direito penal.

As medidas especificamente direcionadas ao âmbito criminal neste contexto foram, dentre outras: (i) a redefinição do conceito de delito (distanciado, agora, dos crimes religiosos e morais, evitando esforços desnecessários aos aparelhos de justiça na prevenção de comportamentos indiferentes à manutenção da ordem social ${ }^{94}$ ); (ii) o alargamento do espaço punitivo sob influência régia (restringindo-se, consequentemente, os espaços punitivos periféricos); (iii) a combinação das virtudes disciplinares do direito penal com tecnologias de controle como a educação, a ridicularização e a propaganda (integrando a coerção pela lei e pelo direito num conjunto mais vasto de técnicas de condicionamento dos comportamentos sociais); (iv) a promoção de uma nova técnica de sistematização para a redação das leis (fundada num método sintético, compendiário e sistemático), no sentido de uma “democratização" progressiva de sua leitura (com textos dirigidos aos cidadãos, escritos em linguagem acessível e organizados de modo a serem facilmente apreendidos e memorizados ${ }^{95}$ ); e, por fim, (v) um reforço da legitimação ideológica da punição, obtida no plano do discurso penal (a partir da valorização de conceitos agora dominantes, como a utilidade e a liberdade civil) e a partir de modificações normativas e institucionais relativas à manifestação pública das punições (neste ponto,

\footnotetext{
${ }^{93}$ Mozart Linhares da Silva. "O Código criminal de 1830 e as idéias que não estão fora do lugar". Op. cit.

${ }^{94}$ Para mais sobre este assunto ver: Giovanni Tarello. Storia della cultura giuridica moderna. Bologna: Società editrice il Mulino: 2010; pp. 385-387.

${ }^{95}$ Qualquer semelhança com a orientação beccariana (analisada na Introdução) de que as leis fossem claras, em pequena quantidade, escritas em língua vulgar, reunidas em um único código e de fácil e infalível aplicação, não é mera coincidência.
} 
era preciso que a pena fosse legitimada aos olhos do público, proscrevendo-se, neste sentido, as penas cruéis e a desproporção entre as mesmas e os delitos cometidos) ${ }^{96}$.

Tais linhas mestras do novo direito penal português, materializadas no projeto recusado de Pascoal de Melo Freire, seriam implementadas aos poucos na metrópole e no Brasil, fazendo-se sentir na promulgação de leis extravagantes referentes ao direito penal, na mudança de atitude de juristas e juízes envolvidos na interpretação e aplicação cotidiana das leis e, posteriormente, na promulgação de códigos penais modernos como o brasileiro de 1830 e o português de 1852 .

Em 1808, quando da vinda da família real ao Brasil - em conseqüência da presença de tropas napoleônicas em território português -, era este, em linhas gerais, o quadro das fontes e da prática cotidiana da justiça penal em terras americanas. Aos dispositivos presentes no Livro V das Ordenações Filipinas - sobre cuja efetiva aplicação, como vimos, pode-se levantar uma série de dúvidas mesmo para o período compreendido entre o final do século XVIII e o início do XIX: caracterizado por um visível incremento punitivo na colônia e pela busca por uma maior exemplaridade nos castigos destinados aos crimes políticos -, somavam-se uma infinidade de leis extravagantes (diferenciadas na forma de "Cartas", "Alvarás", "Provisões", "Decretos", "Cartas Régias", "Resoluções", "Avisos" e "Portarias"), e ainda a jurisprudência dos tribunais e o recurso à doutrina jurídica nos casos lacunares. Contra os excessos de doutrinarismo e jurisprudência, como vimos, vigorava desde 1769, a Lei da Boa Razão, aliada a iniciativas como a unificação das decisões judiciais nos assentos da Casa de Suplicação $^{97}$ e a reforma do ensino jurídico em Coimbra.

Paralelamente a este indubitável direcionamento legislativo modernizador e racionalizador, sobreviviam, contudo, como não poderia deixar de ser, práticas e

\footnotetext{
${ }^{96}$ A. M. Hespanha. "Da 'iustitia' à 'disciplina'. Textos, poder e política penal no Antigo Regime.”. In: Anuario de Historia del Derecho Español. Madrid, 1988; pp. 532-536.

${ }^{97}$ A Casa de Suplicação funcionava, em Portugal (mais especificamente, em Lisboa), como Tribunal Superior do reino, para onde seguiam os recursos, em última instância, de processos originários da Europa, Brasil e demais colônias portuguesas. Os "assentos" por ela produzidos deliberavam sobre pontos incertos e problemáticos da legislação portuguesa, determinando, em linhas gerais, a atuação que deveriam seguir juízes e juristas no julgamento de casos particulares e cotidianos, evitando, assim, o recurso libérrimo às fontes jurídicas do "direito comum" e determinando uma diretriz geral a ser seguida nos julgamentos. No Brasil, os "assentos" produzidos pela Casa de Suplicação atuaram no sentido de acelerar e direcionar os julgamentos realizados nos Tribunais da Relação.
} 
concepções penais tradicionais, aliando o antigo e o moderno numa coexistência entre leis e usos informais de resolução de conflitos.

No que se refere estritamente às fontes do direito penal aplicadas na América portuguesa, portanto, o translado da Corte ao Brasil não impôs nenhuma alteração fundamental, mantendo-se a vigência, para todos os efeitos, do Livro $\mathrm{V}$ das Ordenações Filipinas e das leis extravagantes promulgadas até então.

Já no âmbito das instituições encarregadas da execução da justiça em terras brasileiras, o ano de 1808 marcou o início da implementação de uma série de mudanças com vistas à independentização e expansão do aparelho de administração judiciária. Do conjunto das medidas então tomadas, a mais significativa consistiu na transformação do Tribunal da Relação do Rio de Janeiro em Casa de Suplicação do Brasil (por meio do alvará de 10 de maio de 1808), provendo o país de um tribunal superior de última instância e tornando-o, assim, independente de Portugal no âmbito jurídico.

Por alvará de 22 de abril de 1808 foram constituídas, por sua vez, a Mesa do Desembargo do Paço e a Mesa de Consciência e Ordem no Rio de Janeiro (destinadas, entre outras coisas, a assessorar os assuntos de justiça e administração legal, elaborar leis e avaliar o desempenho dos funcionários régios; isentas, portanto, de quaisquer funções de julgamento), criando-se ainda, na sequência, as Relações do Maranhão (1812) e Pernambuco (1821), e inúmeros postos e ofícios de justiça por todo o território colonial, efetivando-se uma considerável expansão do quadro judiciário na nova sede da monarquia ${ }^{98}$.

A criação da Casa da Suplicação do Brasil e os estabelecimentos das relações ampliavam e facilitavam os recursos às decisões tomadas em primeira instância. A expansão dos cargos de ouvidor e juiz de fora representou uma intervenção direta na administração da justiça em níveis locais, antes exercida sobretudo pelos juízes ordinários, eleitos localmente e membros do Senado das Câmaras. [...] Enquanto o cargo de juiz ordinário era exercido por homens da própria localidade, em geral despreparados e que tinham de seguir cuidando de seus interesses - interesses esses que não raro influenciavam suas decisões jurídicas -, o cargo de juiz de fora era profissionalizado, como parte da burocracia judiciária, e ocupado por homens de formação jurídica, que a princípio guardavam uma posição de externalidade em relação aos interesses locais ${ }^{99}$.

\footnotetext{
${ }^{98}$ Ivan Vellasco. As seduções da ordem: violência, criminalidade e administração da Justiça - Minas Gerais, século XIX. São Paulo: EDUSC, 2004; p. 94.

${ }^{99}$ Idem; pp. 96-97.
} 
Ao limitar, portanto, a intervenção de poderes privados no âmbito da justiça local e expandir o quadro burocrático de oficiais do poder judiciário no Brasil, o governo português possibilitou um novo, mais eficiente e mais bem controlado funcionamento da justiça penal, já a partir do final da primeira década do século XIX ${ }^{100}$.

Proposições para uma reforma das fontes, propriamente ditas, do direito penal luso-brasileiro, por sua vez, só foram realizadas no contexto da Revolução liberal do Porto e da reunião das Cortes Constituintes de Lisboa, originando os primeiros debates codificacionistas travados por Portugal.

Influenciados pelos movimentos revolucionários francês, norte-americano e, especialmente, gaditano, os revolucionários liberais do Porto expressaram suas insatisfações com a situação político-econômica vivida por Portugal desde a transmigração da família real ao Brasil - e com a recusa do rei em retornar ao continente europeu, expressa no contexto do Congresso de Viena (1814-1815) e da elevação do Brasil a "Reino Unido" -, embasados no ideário constitucional. Por meio do mesmo, reivindicaram um sistema de leis que ampliasse a visibilidade das ações do governo, com controle e separação dos poderes políticos, garantia dos direitos dos indivíduos e soberania plena à nação ${ }^{101}$.

Sintonizados com a reunião das Cortes constitucionais em curso em Madri desde junho de 1820 e diretamente influenciados pela vitoriosa revolução realizada havia pouco no país vizinho - quando, em março de 1820, Fernando VII jurou a Constituição elaborada pelas Cortes de Cádis ${ }^{102}$, materializando, ali, a formação de

\footnotetext{
${ }^{100}$ Para um quadro mais completo das reformas jurídicas empreendidas pela coroa portuguesa no Brasil e uma indicação precisa de parte da legislação extravagante produzida no período ver: Patrícia Ann Aufderheide. Op. cit.; pp. 255-267. Para um exame abrangente das reformas empreendidas no Brasil quando da transferência da Corte portuguesa e para uma análise do modo com que a reorganização da metrópole na colônia, operada neste período, recrudesceu a colonização portuguesa dos séculos anteriores ver: Maria Odila Leite da Silva Dias. "A interiorização da metrópole (1808-1853)". In. Carlos Guilherme Mota. 1822: Dimensões. São Paulo: Perspectiva, 1972.

${ }^{101}$ Andréa Slemian. Sob o Império das Leis: Constituição e unidade nacional na formação do Brasil (1822-1834). São Paulo: Aderaldo \& Rothschild: Fapesp, 2009; pp. 19-20. As ideias esboçadas nos próximos parágrafos foram desenvolvidas por Márcia Regina Berbel nos capítulos 1 e 2 do livro A Nação como Artefato e no artigo "A Constituição Espanhola no mundo luso-americano (1820-1823)". Márcia Regina Berbel. A Nação como Artefato: deputados do Brasil nas Cortes portuguesas (1821-1822). São Paulo: Hucitec: Fapesp, 1999; e Idem. "A Constituição Espanhola no mundo luso-americano (1820-1823)". In: Revista das Índias, 2008, vol. LXVIII, num. 242; pp. 225-254.

${ }^{102}$ Nas palavras da historiadora Márcia Regina Berbel: "Essa Constituição foi elaborada entre 1810 e 1812 por Cortes reunidas na cidade de Cádis quando quase todo o território espanhol estava ocupado pelos exércitos napoleônicos. O texto final insistia na soberania da nação
} 
uma Monarquia Constitucional -, os grupos que deram impulso à revolução vintista (deflagrada em agosto de 1820) propunham a reunião, em Portugal, de Cortes Constituintes que, compostas de forma distinta em relação às Cortes tradicionais, redigissem novas leis para o país, buscando uma alternativa liberal aos desmandos do monarca.

Reunidas em Lisboa, as "Cortes Gerais, Extraordinárias e Constituintes da nação Portuguesa" inauguraram seus trabalhos em 26 de janeiro de 1821, com a presença de 100 deputados do reino de Portugal. No que dizia respeito ao Brasil, ainda que parte das províncias do Norte e Nordeste tivesse aderido às Cortes já nos meses de janeiro e fevereiro - antes, portanto, de qualquer declaração oficial da parte do monarca sobre o movimento metropolitano -, era esperado que o rei se pronunciasse formalmente acerca do reconhecimento, ou não, da legitimidade deste movimento, para que somente então fossem realizadas as eleições dos deputados de Ultramar que viriam a tomar assento nas Cortes ${ }^{103}$.

Procedendo aos trâmites necessários ao pleno funcionamento do "soberano Congresso", foram eleitos seus principais funcionários e criadas comissões específicas de trabalho. Dentre estas, a primeira a apresentar resultados concretos foi a Comissão de Constituição, com uma proposta de "bases" ao futuro texto constitucional da nação. Diretamente inspiradas no constitucionalismo de Cádis, tais bases foram aprovadas pelas Cortes de Lisboa em 9 de março de 1821, após uma série de discussões polêmicas sobre a liberdade de imprensa, o direito de veto do rei e a composição bicameral do Parlamento.

Divididas em duas seções principais, a primeira destinada a uma declaração de direitos (liberdade, segurança, propriedade, livre comunicação) e a segunda à definição das bases políticas e constitucionais da futura organização do Estado liberal

espanhola contra o invasor francês e, para atingir este objetivo, tornava-se radical na limitação dos poderes atribuídos ao monarca, e nos critérios de participação do 'povo' na escolha dos representantes constitucionais. Atribuía somente a Fernando VII, o rei destituído, o direito legítimo de dirigir o Estado espanhol. Tornou-se, porém, instrumento contra este mesmo rei quando, a partir de janeiro de 1820, foi retomada pelos liberais em movimento revolucionário contra o absolutismo.". Márcia Regina Berbel. Op. cit.; 1999; pp. 46-47. A Constituição de Cádis pode ser acessada em : http://www.fd.unl.pt/Anexos/Investigacao/987.pdf

${ }^{103}$ De acordo com Andréa Slemian: "A resposta favorável e quase imediata dos portugueses de além-mar [à convocação das Cortes em Portugal] era, sem dúvida, reflexo de expectativas de transformação na situação política vigente, por meio do 'soberano Congresso', que assumia para si a tarefa de reforma da nação portuguesa.” Andréa Slemian. Op. cit.; 2009; p. 22. 
(definindo o regime político português como uma monarquia constitucional hereditária, católica e presidida pela Casa de Bragança, com divisão entre os poderes executivo, legislativo e judiciário, e soberania residente na Nação), as bases à Constituição portuguesa abriram caminho a uma renovação político-legislativa no país e apontaram para a substituição das velhas leis e da velha ordem em Portugal ${ }^{104}$.

No âmbito do direito penal, enquanto os artigos 4, 5 e 6 da primeira seção das bases rompiam expressamente com a tradição de perseguições e prisões arbitrárias, comuns ao direito penal de Antigo Regime (definindo, assim, que nenhum indivíduo fosse preso sem culpa formada e que, mesmo nos casos de prisão arbitrária previstos pela Constituição, o juiz fosse obrigado a passar, por escrito e dentro de 24 horas, a razão da prisão, punindo-se propriamente os que agissem em contrário), os artigos de números 11 e 12 estabeleciam a igualdade jurídica e a unidade tipológica dos sujeitos submetidos às leis (eliminando, portanto, os privilégios de foro), e asseguravam a presença dos critérios de utilidade e proporcionalidade na definição dos crimes e suas penas, eliminando, ainda, a pena de confisco e as demais penas infamantes ou cruéis ${ }^{105}$.

São plenamente visíveis, assim, nesta legislação, reflexos do pensamento penal iluminista de finais do século XVIII - previamente analisados na Introdução. À altura das Cortes Constituintes de Lisboa, não nos esqueçamos, Portugal já havia intentado a aprovação de um código criminal moderno que, elaborado por Pascoal de Melo Freire em 1786, fora, contudo, recusado pelos dirigentes da nação por seu acentuado vanguardismo.

No contexto de proposição e aprovação das bases constitucionais portuguesas, a temática da codificação penal ocupou novamente a agenda reformista do país, evidenciando-se nas constantes críticas apresentadas pela deputação à vigência do Livro V das Ordenações Filipinas e fazendo-se sentir na organização pelas Cortes, ainda em 1821, de uma comissão encarregada de elaborar um projeto de Código Penal e outro de Processo Penal para o país.

\footnotetext{
104 Para o conteúdo completo das bases ver: http://www.arqnet.pt/portal/portugal/liberalismo/bases821.html. Acessado em janeiro de 2013.

${ }^{105}$ Artigo 12: "Nenhuma lei, e muito menos a penal, será estabelecida sem absoluta necessidade. Toda a pena deve ser proporcionada ao delito, e nenhuma deve passar da pessoa do delinquente. A confiscação de bens, a infâmia, os açoites, o baraço e pregão, a marca de ferro quente, a tortura e todas as mais penas cruéis e infamantes ficam em consequência abolidas." In: http://www.arqnet.pt/portal/portugal/liberalismo/bases821.html.
} 
Ainda em 1821, consta que Jeremy Bentham teria oferecido às Cortes lisboetas três projetos de código (um penal, um civil e um constitucional) que, no entanto, foram recusados ${ }^{106}$. Malogradas as tentativas então impulsionadas de uma codificação penal, coube à Constituição portuguesa, aprovada em 1822, reforçar os direitos previamente consagrados pelas bases - tais como a defesa contra perseguições e prisões arbitrárias; a garantia de igualdade jurídica dos sujeitos submetidos à lei; a fundamentação dos crimes e penas nos critérios de utilidade e proporcionalidade; e a abolição das penas infamantes e cruéis -, regulamentando ainda questões fundamentais ao exercício pleno e autônomo do poder judiciário.

Fundada, portanto, na mesma compreensão de soberania, divisão de poderes, representatividade e nacionalidade consagrada já pelas Bases de 1821, a Constituição de 1822 regulava, em seu Titulo V ("Do poder judicial"; artigos 176 a 211), as atribuições e especificidades do exercício da Justiça no Reino Unido. Neste sentido, compreendia o poder "judicial" como independente dos outros dois poderes e exclusivamente pertencente aos juízes (artigo 176: "Nem as Cortes nem o Rei o poderão exercitar em tempo algum"), atribuindo ainda ao Supremo Tribunal de Justiça de Lisboa o conhecimento dos delitos dos agentes do poder Executivo (artigo 191, § I). Pelo mesmo Titulo V, ficavam determinadas as diferentes classes dos juízes nacionais, bem como a atuação específica de cada uma delas, pressupondo-se ainda, sem, contudo, dizê-lo explicitamente, que a regulamentação da questão judicial fosse complementada pela elaboração de "códigos" no país (artigo 177) ${ }^{107}$.

Posteriormente à aprovação da Constituição de 1822, que teria vida bastante curta em Portugal, os representantes das Cortes Gerais Extraordinárias e Constituintes de Lisboa, em mais uma tentativa de implementar a codificação criminal no país, convidaram os sábios portugueses, aos 14 de fevereiro de 1823, a elaborar um Código Penal, não recebendo, contudo, uma vez mais, retornos da nação ${ }^{108}$. Portugal só viria a conhecer, assim, um código de direito penal próprio no ano de 1852.

\footnotetext{
${ }^{106}$ Maria José Moutinho Santos. "Liberalismo, legislação criminal e codificação. O Código Penal de 1852. Cento e cinqüenta anos da sua publicação.". In: Revista da Faculdade de Letras/HISTÓRIA. Universidade do Porto, III série, vol. 3, 2002; pp. 97-102. Disponível em: http://ler.letras.up.pt/uploads/ficheiros/2281.pdf

107 A Constituição portuguesa de 1822 pode ser acessada pelo endereço eletrônico: http://www.estig.ipbeja.pt/ ac direito/Const_1822.pdf . Último acesso em 22 de março de 2013.

${ }^{108}$ Maria José Moutinho Santos. "Liberalismo, legislação criminal e codificação. O Código Penal de 1852. Cento e cinqüenta anos da sua publicação.”. Op. cit.
} 
Vê-se, portanto, o modo com que a temática iluminista e liberal da racionalização, sistematização e secularização do direito penal por via da elaboração de um código se fez presente no contexto revolucionário português da década de 1820 , associando diretamente a "regeneração" política do país à renovação de sua legislação criminal e de seus princípios fundadores.

Como não poderia deixar de ser, o debate penal iniciado nas Cortes portuguesas se estendeu ao Novo Mundo quando da Independência do Brasil e da formação de uma Assembleia Constituinte e Legislativa para o país, desdobrando-se no texto do projeto constitucional de 1823, na Constituição outorgada de 1824, e na composição, desde o início de 1826, de parte importante dos debates parlamentares travados no Império.

Em 24 de fevereiro de 1821, como é sabido, d. João VI, sediado no Rio de Janeiro e pressionado por inúmeras frentes, jurou as bases constitucionais portuguesas e se comprometeu a retornar a seu país de origem. O regresso do rei a Lisboa e a permanência de seu filho, d. Pedro, como regente do Brasil, foram seguidos por decretos em que se mandava proceder às eleições de deputados no Novo Mundo, distribuindo-se ainda, pelas províncias brasileiras, exemplares das Bases da Constituição portuguesa.

Recém-chegados às Cortes em agosto de 1821, os primeiros deputados brasileiros não puderam acompanhar os debates que desembocaram nos famosos Decretos de Outubro - destinados, fundamentalmente, a reduzir a centralidade e as autonomias administrativas conquistadas pela América desde a transmigração da família real portuguesa -, a partir de cuja promulgação as relações entre Brasil e Portugal não foram mais as mesmas.

Os Decretos, como se sabe, estabeleciam, entre outras medidas, a extinção da Casa de Suplicação e de todos os tribunais superiores instalados no Brasil desde 1808, sugerindo a reinstalação da antiga Relação do Rio de Janeiro e destituindo a autonomia jurídica conquistada pela ex-colônia. Para além disso, solicitavam o retorno do príncipe regente à Europa, "retirando do Brasil o estatuto de uma unidade política com relativa autonomia"109. Tornados pontos de divergência entre as diferentes deputações brasileiras - que concordavam, contudo, até pelo menos

${ }^{109}$ Márcia Regina Berbel. "Os apelos nacionais nas cortes constituintes de Lisboa (18211822)". In: Jurandir Malerba. A Independência brasileira: novas dimensões. Rio de Janeiro: Editora FGV, 2006; pp.181-208; p. 189. 
meados de 1822, na defesa da integridade do Império luso-brasileiro ${ }^{110}$ - e contrariados pelo próprio príncipe regente (que, aos 9 de janeiro de 1822 decidiu-se pela permanência no Rio de Janeiro), os Decretos geraram um conflito crescente entre os governos sediados de ambos os lados do Atlântico.

A defesa do Programa de São Paulo entre os meses de fevereiro e junho consolidou as divergências: os deputados de Portugal não aceitavam o estatuto de Reino para o Brasil, dispensavam os poderes sediados no Rio de Janeiro e descartavam a necessidade de leis adaptadas às particularidades da América. Os debates seguiram formalmente durante o segundo semestre de 1822, pois já se sabia que a conciliação entre as partes tornara-se impossível. ${ }^{111}$ [grifo meu]

O esgotamento das possibilidades de consenso entre as duas partes do Reino Unido e a evidência de que uma alternativa de independência passara a ser gestada na América portuguesa, manifestaram-se no Decreto do príncipe regente d. Pedro - aos 3 de junho de 1822 - prevendo a instalação de uma Assembleia Constituinte no Rio de Janeiro. Após o abandono da casa legislativa lisboeta, nos meses seguintes, por parte importante dos deputados brasileiros (descrentes de qualquer possibilidade de acordo), muitas das demandas de grupos regionais do país voltaram-se à promessa de d. Pedro e à expectativa de que uma Assembleia Constituinte em solo nacional se dedicasse a questões específicas e urgentes da América portuguesa, dotando-a, assim, de uma Constituição própria ${ }^{112}$.

Proclamada a Independência do Brasil e reconhecidos os poderes do novo imperador, tornou-se cada vez mais maior a insistência pela efetivação da Assembleia

\footnotetext{
${ }^{110}$ Neste sentido, mesmo o projeto apresentado pelos deputados de São Paulo às Cortes de Lisboa - concebido em defesa da condição de Reino alcançada pela América em 1815 e ancorado na permanência do príncipe regente d. Pedro no Brasil e na manutenção de um centro de poder Executivo no Rio de Janeiro -, comumente reconhecido por ter explicitado divergências entre os projetos políticos defendidos por um lado e outro do Atlântico, fundavase na possibilidade de formação de um braço legislativo na América que pudesse reforçar uma unidade de propósitos constitucionais com seu congênere lisboeta. Para esta discussão ver: Andréa Slemian. Op. cit.; 2009; Cap. 1.

${ }^{111}$ Márcia Regina Berbel; Op. cit.; 2008; p. 246.

${ }^{112}$ No artigo "Os panfletos políticos e a cultura política da Independência do Brasil", Lucia Bastos das Neves afirma que, no momento específico de convocação de uma Assembleia Constituinte por d. Pedro, ainda se acreditava na manutenção da unidade do Império português, sendo o decreto de 3 de junho pensado por parte dos deputados brasileiros como a formação de um braço legislativo na América que pudesse reforçar a unidade de propósitos com as Cortes lisboetas. De qualquer modo, afirma a autora, a partir daquele momento, interpretado como de rompimento pelos deputados portugueses, o consenso não mais foi possível e a unidade do Império foi posta em xeque. Lucia Maria Bastos Pereira das Neves, "Os panfletos políticos e a cultura política da Independência do Brasil". In: István Jancsó (org.), Independência: história e historiografia. São Paulo: Hucitec: Fapesp, 2005; pp. 637675.
} 
nacional (estimulada, por exemplo, pelo oficio de 7 de agosto de 1822, em que se solicitava às províncias o envio de informações referentes às melhorias necessárias nas localidades, a serem remetidas aos deputados que comporiam a Assembleia), demonstrando que o vintismo significou, para o Brasil, uma clivagem a partir da qual qualquer alternativa política deveria passar pela convocação de uma instituição representativa similar às Cortes. ${ }^{113}$

\subsection{Regime constitucional, poder Judiciário e direito penal no Primeiro Reinado brasileiro}

Os anos de 1820 a 1822 foram marcados, em Portugal e no Brasil, pela ebulição de novas ideias políticas e pela proposição de alternativas ao modelo relacional até então estabelecido entre os "indivíduos" e a lei. No interior deste processo, foi cada vez mais valorizada a perspectiva de uma Constituição para o Brasil, legitimando-se progressivamente o Parlamento como lugar dos representantes da nação e espaço de imposição de limites às ações do governo pelos cidadãos ${ }^{114}$.

Quando da abertura dos trabalhos da Assembleia Constituinte e Legislativa brasileira de 1823, no encalço das promessas de d. Pedro I, os representantes eleitos pelo país depararam-se com as inúmeras dificuldades inerentes à construção de um novo ordenamento nacional e um novo regime de poder sob o arranjo constitucional. Paralelamente às disputas travadas em torno das atribuições dos poderes Executivo e Legislativo (haja vista a preocupação constante, naquele momento, com a resolução do papel a ser desempenhado pela monarquia no novo regime), a criação de uma nova ordem jurídica para o Brasil, fundada em leis positivas e garantidoras dos direitos dos cidadãos, foi de interesse crucial dos deputados, materializando-se em diversos enfrentamentos políticos e proposições legais.

\footnotetext{
113 Andréa Slemian. Op. cit.; 2009; p. 24. Para um breve exame da cultura política da Independência brasileira e dos principais acontecimentos imediatamente anteriores à separação política formal entre Brasil e Portugal, ver também: Lucia Maria Bastos Pereira das Neves. Op. cit.; 2005.

${ }^{114}$ Para uma análise das transformações sofridas, no contexto independentista brasileiro, pelo conceito de "Constituição", e para um exame da progressiva força então assumida pelo Parlamento ver: Andréa Slemian. Op. cit.; 2009; pp. 17-44; e Lucia Maria Bastos Pereira das Neves, "Constituição: usos antigos e novos de um conceito no Império do Brasil (1821-1860). In: José Murilo de Carvalho e Lucia Maria Bastos Pereira das Neves (org.), Repensando o Brasil do Oitocentos. Cidadania, política e liberdade, Rio de Janeiro: Civilização Brasileira, 2009; pp. 183-205.
} 
Neste contexto, o juízo da Assembleia Constituinte sobre a administração da justiça no país e a situação de suas fontes de direito foi, em geral, bastante negativo. Guiados por novos conceitos e perspectivas quanto ao campo judiciário, os deputados brasileiros de 1823 não pouparam críticas à magistratura e às leis então em vigor, preocupando-se constantemente, contudo, em adaptar as inovações jurídicas pretendidas às circunstâncias específicas do Brasil.

Num primeiro momento, haja vista a indefinição legislativa em que se encontrava o país por conta de sua recente separação de Portugal (momento em que, teoricamente, havia caducado toda a legislação previgente), os deputados consideraram necessário que, previamente à elaboração de novas leis - processo que, sabiam, demandaria tempo - ficasse decidido por que normas o país se regeria neste intervalo de tempo. Na sessão de 5 de maio de 1823 (dois dias após a abertura dos trabalhos da Constituinte, portanto), o deputado Antonio Luiz Pereira da Cunha (eleito pela província do Rio de Janeiro) apresentou uma proposta de regulamentação da legislação do Império.

Fundado numa avaliação de longa duração acerca das compilações legais portuguesas e de sua validade na colônia, Pereira da Cunha reconhecia que, apesar da Independência do Brasil - que, a princípio, atingira "todos os ramos que constituem a administração politica, civil e economica de um estado" -, o novo país mantivera, juntamente aos costumes e à língua, a antiga legislação da metrópole. Criticando abertamente as Ordenações Filipinas ("summamente diminutas e defeituosas, cheias de crassos erros, pela ignorancia dos principios de direito publico universal e ecclesiastico, que naquele tempo prevalecia") e o grande volume de normas a ela aditado, tais como os assentos da Casa de Suplicação, decretos e consultas, o deputado reconhecia as inúmeras dificuldades "de saber-se perfeitamente a jurisprudencia patria, pretextando por isso os juizes as malfeitorias de seus julgados.". Neste sentido, Pereira da Cunha estabelecia a exigência imperiosa de uma medida que regulasse a legislação brasileira "emquanto se não conclue a nossa constituição, e se não forma um código civil e criminal de que tanto necessitamos." $" 115$.

Após uma breve avaliação das confusões possivelmente geradas pela promulgação de leis por d. João VI (entre 1808 e seu retorno a Portugal, em abril de 1821) e d. Pedro (na qualidade de príncipe regente no Brasil, até outubro de 1822), e ainda por

115 Anais da Assembleia Geral Constituinte e Legislativa de 1823; sessão de 5 de maio de 1823; p.20. Acessível em: http://imagem.camara.gov.br/constituinte principal.asp. 
decretos passados pelas Cortes constituintes de Lisboa - mandados aplicar diretamente no Brasil ou submetidos à avaliação do príncipe regente por meio do "Cumpra-se" -, Pereira da Cunha propunha que as leis, regimentos, alvarás, decretos e resoluções portuguesas promulgadas até a data de 25 de abril de 1821 , e todas as outras aprovadas por d. Pedro daquela data em diante, ficassem em inteiro vigor, nas partes em que não tivessem sido revogadas, para a regulação dos negócios políticos, civis e econômicos do Brasil, enquanto não se organizassem novos códigos.

A aprovação de seu projeto de lei, contudo, demandou tempo no interior da Assembleia, em especial por conta do exame cuidadoso pleiteado pelos deputados com relação à validade, ou não, no Brasil, dos inúmeros decretos publicados pelas Cortes de Lisboa entre os anos de 1821 e 1822. Com vistas a uma avaliação meticulosa da questão propôs-se, em 28 de agosto de 1823, a elaboração de uma tabela - que deveria acompanhar a futura lei -, em que figurassem os decretos válidos no Brasil. Haja vista a demora e as polêmicas envolvidas na elaboração desta tabela (vide discussões travadas nos dias 22, 24 e 27 de setembro), o projeto de lei inicialmente apresentado por Pereira da Cunha foi aprovado unicamente aos 20 de outubro de 1823 (publicado com a dita tabela, composta por 11 decretos e 9 cartas de lei ${ }^{116}$ ) configurando uma dentre as seis únicas leis que a Assembleia conseguiu, no curto período de sua vigência, sancionar.

Reconhecida e ratificada a legislação vigente no Império recém-independente, as críticas da Assembleia ao funcionamento da justiça e às fontes do direito no país voltaram a aparecer nos debates travados, entre 21 e 25 de outubro de 1823 , em torno do artigo 13 do projeto constitucional então em discussão. Em complemento ao parágrafo III do artigo $7^{\circ}$ do mesmo projeto, de acordo com o qual ficava garantido, a todos os brasileiros, o direito a um juízo por jurados, o artigo 13 estabelecia que, "por enquanto", houvesse jurados unicamente nas causas criminais, continuando as cíveis a serem decididas por juízes e tribunais.

Os discursos enunciados pelos deputados em torno desta questão apontaram, em linhas gerais: para uma aceitação da instituição do júri no Brasil (ainda que parte deles tenha se colocado contra semelhante adoção, principalmente em razão do

\footnotetext{
${ }^{116}$ A Lei de 20 de outubro de 1823, assim como a Tabela de Leis que a acompanhava, podem ser consultadas por meio da Coleção de Leis do Império Brasileiro, digitalizada no site da Câmara dos Deputados: http://www2.camara.leg.br/atividadelegislativa/legislacao/publicacoes/doimperio.
} 
suposto despreparo da população brasileira para o exercício de semelhante função); para a reivindicação de sua atuação imediata também nas causas cíveis; para uma crítica generalizada à atuação corrupta dos magistrados brasileiros, demandando sua rápida substituição pelos jurados (houve, contudo, discursos em defesa dos magistrados e críticos à generalização de seu pretenso mau procedimento) ${ }^{117}$; e para a necessidade e urgência de substituição das antigas leis penais do país por um novo código criminal.

Neste último aspecto, vale destacar, as avaliações dos deputados perpassaram diversos argumentos. Assim, enquanto Luis José de Carvalho e Melo (representante eleito pela Bahia), em discurso pronunciado aos 21 de outubro de 1823, defendeu a adoção do artigo 13 paralelamente à demanda pela elaboração de um novo código criminal para o país ${ }^{118}$, José da Silva Lisboa (BA; futuro Visconde de Cairu) e Joaquim Manuel Carneiro da Cunha (eleito pela Paraíba do Norte) opuseram-se à aprovação do artigo fundados, respectivamente, na necessária reforma da legislação criminal do país (nas palavras de Silva Lisboa, absurda e desumana) previamente à adoção do júri ${ }^{119}$, e nos riscos representados pela ausência de um bom código penal

${ }^{117}$ De acordo com Thomas Flory, a corrupção dos juízes foi constantemente destacada nas objeções dirigidas à magistratura brasileira herdada do período colonial e constantemente reiterada depois da Independência. Listando os principais veículos utilizados para este ataque, Flory cita desde editoriais de jornais liberais, como A Astréia, passando pela fala de deputados na Câmara, até chegar a exemplos advindos de observadores estrangeiros, como o reverendo Robert Walsh, acerca do funcionamento da justiça na sociedade brasileira da década de 1820. Thomas Flory. El juez de paz y el jurado en el Brasil imperial, 1808-1871: control social y estabilidad política en el nuevo Estado. México: Fondo de Cultura Econômica, 1986; pp. 66-71.

${ }^{118}$ De acordo com Carvalho e Melo, as leis criminais sobre as quais se baseariam os jurados deveriam ser claras, precisas e plenamente aplicáveis. Neste sentido, o deputado se pergunta: "Quem dirá, Sr. Presidente, que o codigo actual esteja nesta circumstancia? Faltão nelle penas para alguns delictos, e as que há forão escriptas com penna de sangue. Os tempos calamitosos, em que foi promulgado fizerão delicto o que de sua natureza o não era, e puzerão pennas que não são hoje em dia applicaveis, e com tanta crueldade e falta de proporção, que perderão por sua mesma natureza o uso e applicação. [...] É pois necessário e justo que haja um codigo criminal novo, formado segundo as luzes do século em que vivemos, em que mãos amestradas firmando o direito da segurança, e justa liberdade do cidadão, previnão a impunidade do crime com penas justas, proporcionadas aos delictos, e as mais humanas que forem compativeis com o bem estar da sociedade." Disponível em: http://imagem.camara.gov.br/constituinte_principal.asp; sessão de 21 de outubro de 1823; p. 124.

119 Discursos pronunciados em 21 de outubro de 1823. Acessíveis em: http://imagem.camara.gov.br/constituinte principal.asp; pp. 120-122 e pp. 124-125. 
(vigente que estava o Livro $\mathrm{V}$ das Ordenações Filipinas) aos possíveis julgamentos realizados por jurados ${ }^{120}$.

Fugindo, assim, às discussões centradas sobre as atribuições recíprocas dos poderes Legislativo e Executivo no novo Império, os debates articulados em torno da questão do júri chamaram a atenção, também, à necessidade de se constituir um Judiciário independente, fundado na boa prática de seus magistrados e em boas leis pensadas para o país ${ }^{121}$.

Dissolvida pelo imperador d. Pedro I aos 12 de novembro de 1823, a Assembleia Constituinte legou à posteridade, dentre outras coisas, um projeto constitucional composto por 272 artigos (ainda que, destes, apenas 24 tenham sido discutidos e votados), no qual foram incluídas questões fundamentais à organização do Judiciário no país ${ }^{122}$.

Baseado no modelo de declaração de direitos adotado pelas bases constitucionais das Cortes de Lisboa e pela Constituição portuguesa de 1822, o projeto de 1823, obra coletiva, mas muito devedora das ideias de Antonio Carlos de Andrada Machado, reconhecia, entre seus artigos 7 e 28, para além do direito de juízo por jurados e de sua limitação às causas criminais, a proibição de prisões arbitrárias no Brasil. Entre os artigos 33 e 35, por sua vez, o projeto estabelecia os deveres dos "brasileiros",

${ }^{120}$ Nas palavras de Carneiro da Cunha: "Os damnos que pódem resultar dos juízos por jurados, quando as leis são más, se tornão mais aggravantes nos processos crimes, porque a lei aqui póde offender mais directamente a pessoa do cidadão, na sua existência natural ou civil. A mais leve reflexão sobre a formalidade estricta, com que se deve praticar o juízo por jurados, para não dar lugar a arbitrariedade, e sobre a barbaridade das penas do liv. $5^{\circ}$ das ordenações, que ainda hoje nos regem, nos convencerá da lamentável sorte, a que ficão expostos os nosso concidadãos, se admittirmos já os jurados nas causas crimes com um codigo penal tão sanguinário, que para os mais leves delictos não achou outra pena, que a de morte ou degredo." Ver: http://imagem.camara.gov.br/constituinte_principal.asp; sessão de 24 de outubro de 1823; pp. 138-139.

${ }^{121}$ Para um acompanhamento mais minucioso dos debates travados em torno desta questão ver: José Honório Rodrigues. A Assembléia Constituinte de 1823. Petrópolis: Editora Vozes, 1974; pp. 145-158.

122 De acordo com Andréa Slemian, apesar de ter sido abortado, o trabalho legislativo produzido pela Assembleia Constituinte não pode ser ignorado: "Sem contar o regimento e o projeto de Constituição, cuja discussão iniciou-se em 15 de setembro, foram apresentados 38 projetos de lei, além de centenas de propostas, indicações e pareceres das Comissões instaladas. Os que chegaram a ser aprovados como leis foram seis: um sobre a vigência da legislação que regia o Brasil até abril de 1821, outro sobre a revogação do decreto de 16 de fevereiro de 1822 que criara o Conselho de Procuradores, o seguinte para estabelecimento da forma como deveria ser observada a promulgação dos decretos da Assembleia, outro acerca da proibição aos deputados de exercerem qualquer outro emprego durante sua deputação (ou aceitarem qualquer graça), outro para revogação do alvará de 30 de março de 1818 que proibia o funcionamento das sociedades secretas, e um último para criação de uma nova forma para o governo das Províncias.” Andréa Slemian. Op. cit.; 2009; p. 80. 
fundado-os na necessária obediência à lei e no sofrimento dos castigos por ela impostos, em caso de infração.

Reconhecendo o Brasil como uma monarquia representativa e hereditária, o Titulo III do projeto identificava os poderes políticos do país no Legislativo, Executivo e Judiciário, garantindo sua atuação na qualidade de delegações da nação, em cuja ausência o exercício do poder não seria senão usurpação.

No âmbito específico das fontes de direito, que nos interessam primordialmente, o artigo 57 do projeto de 1823 reconhecia a urgência na elaboração de novos códigos para o país. Nesse sentido, previa que, anteriormente à sua promulgação, as sessões do Legislativo, que normalmente poderiam ser prorrogadas, pelo imperador, pelo período de um mês, pudessem sê-lo por até três meses, durante os quais as Câmaras, contudo, não discutiriam senão os futuros códigos.

Dentre as atribuições do poder Executivo, deve-se frisar, constava a concessão de perdão ou minoração das penas aos condenados ${ }^{123}$. Já no âmbito do poder Judiciário, composto por juízes e jurados plenamente responsáveis por seus erros e abusos (artigos 190 a 195), o projeto de 1823 estabelecia a uniformidade e validade, para toda a extensão do Império, dos códigos futuramente promulgados (artigo 199), vedando a extensão das penas para além da pessoa do delinquente (artigo 200), abolindo o rigor desnecessário nas punições, e proibindo a tortura, a marca de ferro quente, o baraço e pregão, a infâmia, o confisco de bens e todas as demais penas cruéis e infamantes (artigo 201). Ainda no âmbito do Judiciário, os artigos 203 a 208 regulavam questões relativas ao estado das prisões no Império do Brasil e estabeleciam a formação de uma "Comissão de Visita" responsável pela vigilância dos presídios e pela prestação de contas ao restante da Assembleia.

Pelo Titulo XIII do projeto, relativo à "Instrução Pública, Estabelecimentos de Caridade, Casas de Correção, e Trabalho”, ficava prevista a construção de casas de correção, trabalho, penitência e melhoramento para os criminosos condenados (artigo 255), prevendo-se, por fim, entre os artigos 260 e 262 do Titulo XIV, a igualdade jurídica e unidade tipológica dos sujeitos submetidos à lei.

\footnotetext{
123 “Art. 142: São atribuições do Imperador”; “§8: Agraciar os condenados perdoando em todo, ou minorando as penas, exceto aos Ministros de Estado, a quem poderá somente perdoar a pena de morte". "Projeto de Constituição para o Império do Brasil (Projeto Antônio Carlos), elaborado pela Comissão da Assembleia Geral Constituinte e Legislativa (30 de setembro de 1823)". In: Paulo Bonavides e Roberto Amaral. Textos políticos da história do Brasil. Brasília: Senado Federal, 2002, vol. VIII, pp. 140-165.
} 
A partir deste sobrevôo, vê-se o modo com que o Projeto Constitucional de 1823 introjetara as reformas jurídicas previamente previstas pelas bases constitucionais portuguesas de 1821 e pela Constituição portuguesa de 1822, projetando, dentre outras coisas, a elaboração de códigos nacionais para o Brasil, a utilidade, proporcionalidade e humanização das punições aí presentes e uma reflexão acerca do modelo prisional a ser implementado no país ${ }^{124}$.

$\mathrm{Na}$ trilha deixada por este projeto, que revelava já os termos da construção de uma nova alternativa política para o Brasil, a Carta Constitucional de 1824, outorgada pelo imperador d. Pedro I, materializava uma ruptura fundamental com a ordem jurídica existente no país, lançando para um futuro próximo a regulamentação de várias instituições e cargos e estabelecendo igualmente a urgente feitura de códigos para o Império $^{125}$.

Neste sentido, ainda que o novo texto constitucional, ao introduzir o Poder Moderador e estender as atribuições do Executivo, tenha alterado a dinâmica de equilíbrio dos poderes materializada no projeto anterior - permitindo, por exemplo, que, no âmbito do Legislativo, o imperador suspendesse a Câmara dos Deputados (artigo 101) e que, no que tange ao Judiciário, suspendesse os magistrados nos casos de queixas contra os mesmos (artigos 101 e 154) ${ }^{126}$-, a Carta Constitucional de 1824

\footnotetext{
${ }^{124}$ Para análises mais completas sobre o projeto de 1823 , referentes a outros aspectos que não exclusivamente o seu âmbito jurídico, ver: Monica Duarte Dantas. "Constituição, poderes e cidadania na formação do Estado-nacional brasileiro." In: Fórum Rumos da Cidadania. São Paulo: Instituto Prometheus de Estudos Ambientais, Culturais e Políticos; 2010; e Andréa Slemian. Op. cit.; 2009; pp. 126-129.

${ }^{125}$ Andréa Slemian, "À nação independente, um novo ordenamento jurídico: a criação dos Códigos Criminal e do Processo Penal na primeira década do Império do Brasil.” In: Gladys Sabina Ribeiro (org.), Brasileiros e cidadãos. Modernidade política. São Paulo: Alameda, 2008, pp.175-206; pp. 181-182.

${ }^{126}$ Nas palavras de Andréa Slemian: “[...] o equilíbrio interno entre ambos os Projetos resolvia-se com ênfases distintas: enquanto o texto da comissão de Constituição, sob a influência de Antônio Carlos de Andrada, primava pela construção de uma equação entre os poderes que, apesar da preservação da majestade do monarca, tendia a criar maiores mecanismos de autocontrole mútuo entre os poderes, a Constituição de 1824 transferia ao imperador um papel-chave (fosse de ativo interventor ou de simples mediador na cena política, de acordo com as posteriores interpretações divergentes) no ordenamento político. Trata-se de duas tendências que, não de todo divergentes, propunham uma ação distinta para as instituições no centro do governo. $O$ projeto de 1823 apontava na direção de uma preocupação - que fora cara aos norte-americanos - por maior autonomia (note-se no caso do Judiciário) e ao mesmo tempo certa ingerência entre os poderes para sua neutralização mútua (veja-se a intervenção prevista dos deputados e dos senadores no Executivo). A mesma preocupação não estaria totalmente ausente da Carta - cuja linha de força central situa-se na ação dos braços do Executivo em relação aos outros poderes - mas encontra nele relevância menor." Andréa Slemian. Op. cit.; 2009; p. 136. Para uma análise dos limites na atuação do
} 
garantia, em seu Titulo VIII, os direitos civis e políticos dos cidadãos brasileiros (seguindo, para tanto, o modelo adotado pela Constituição portuguesa de 1822 e pelo projeto de 1823), prevendo ainda uma reestruturação completa no âmbito jurídico do país.

Ao estabelecer, portanto, as atribuições do poder "Judicial" no Império do Brasil (Titulo VI; artigos 151 a 164), a Carta definia, de saída, sua independência ${ }^{127}$ e composição exclusiva por juízes e jurados, delimitando a atuação dos mesmos, no cível e no crime, "pelo modo que os Códigos determinarem" (artigo 151). Diferentemente do projeto de 1823, o texto de 1824 precisava, neste Titulo, as instâncias jurídicas superiores que comporiam o poder judiciário brasileiro, e o modo da sua organização e divisão pelo território (Tribunais da Relação nas províncias e um Supremo Tribunal de Justiça na capital do Império), prevendo ainda que, para além dos chamados juízes de direito e demais oficiais de justiça, o Império contasse com juízes de paz eleitos nas localidades, destinados a intentar a conciliação entre as partes previamente à abertura de processos.

Pelo artigo 159 ficava estabelecido que, nas causas crimes, a inquirição das testemunhas e demais atos do processo, depois da pronúncia, fossem públicos, enquanto os artigos 154, 155, 156, 157 e 164 regulavam a questão da responsabilidade dos juízes e empregados públicos da nação pelos abusos de poder e prevaricações cometidas no exercício de suas funções.

No âmbito dos direitos dos cidadãos, o artigo 179 da Constituição assegurava que as leis não fossem estabelecidas sem utilidade pública e que sua disposição não tivesse efeito retroativo (parágrafos II e III); proibia por completo as prisões arbitrárias e sem culpa formada no Império, garantindo ao preso o direito de fiança (parágrafos VIII, IX e X); determinava a precedência da lei na definição da conduta delituosa, a igualdade jurídica dos sujeitos a ela submetidos e a independência do "Poder Judicial" (parágrafos XI, XIII e XII); abolia todos os privilégios, foros

Poder Moderador, conforme regulamentação da Carta constitucional de 1824, e para os pontos em que o texto tendia a pesar a balança dos poderes favoravelmente ao Executivo, em detrimento do Legislativo, ver: Monica Duarte Dantas. Op. cit.; 2010; pp. 19-26.

${ }^{127}$ Monica Duarte Dantas chama a atenção ao fato de o Título da Carta de 1824 referente ao Poder Judicial ser o único a se iniciar com tal afirmação de independência, a despeito da divisão e harmonia de poderes ter sido previamente declarada na parte referente aos "Poderes e Representação Nacional". Para a autora, várias das especificidades e garantias jurídicas presentes na Constituição outorgada só podem ser entendidas a partir de sua contraposição à experiência pregressa de justiça no Antigo Regime português. Op. cit.; 2010; pp. 38- 40. 
privilegiados e comissões especiais nos julgamentos criminais e civis (parágrafos XVI e XVII); garantia a organização, o quanto antes, de um "Código Civil e Criminal fundado nas sólidas bases de justiça e equidade" (parágrafo XVIII); extinguia os açoites, a tortura, a marca de ferro quente e as demais penas cruéis, impedindo também que as punições passassem aos descendentes e familiares do delinquente abolindo, automaticamente, portanto, as penas de confisco e de infâmia (parágrafos XIX e XX); e estabelecendo, por fim, que as cadeias fossem limpas, seguras, bem arejadas e divididas de acordo com a necessidade de separação dos réus, conforme sua circunstância e a natureza de seus crimes (parágrafo XXI).

Vê-se, assim, o modo com que a Carta constitucional de 1824 - apesar de seus "limites" e "retrocessos" com relação ao texto português de 1822 ou ao projeto brasileiro de $1823^{128}$-, garantia aos cidadãos do Império um conjunto importante de direitos e salvaguardas jurídicas, ao mesmo tempo em que previa um moderno aparelhamento institucional ao novo Estado e o funcionamento independente e organizado de seu poder Judiciário.

Diversas das determinações presentes na Constituição, contudo, não passavam de projeções à altura de 1824, jogando para o futuro, e de forma gradual, a substituição do antigo modelo jurídico e institucional do país. No âmbito específico do direito penal, frisemos uma vez mais, à parte as garantias de imediata aplicabilidade reguladas pelo artigo 179 (como a abolição das penas infamantes e cruéis, a proibição de prisões arbitrárias e a extinção dos privilégios nos julgamentos civis e criminais),

${ }^{128}$ A maioria das análises sobre o texto da Carta Constitucional de 1824 não se furta a confirmar sua sintonia com o pensamento político ocidental da época, enfatizando, principalmente, o quanto este documento buscou conter o radicalismo (na esteira dos acontecimentos da Revolução Francesa) e conciliar liberalismo e ordem estabelecida. De acordo com José Reinaldo de Lima Lopes, por exemplo, ainda que neste texto possam ser encontradas bases comuns às constituições do século XIX, não se teria arquitetado, por seu intermédio, um sistema amplamente democrático ou liberal. Neste sentido, para o autor, a Carta brasileira pode ser comparada às constituições restauradoras européias, que tentaram afastar a soberania popular por meio de uma representação pública paralela a um corpo conservador (Senado) e por meio de uma representação nacional de incumbência do Poder Moderador, encarnada pelo imperador. Ver: José Reinaldo de Lima Lopes. "Iluminismo e jusnaturalismo no ideário dos juristas da primeira metade do século XIX". In: István Jancsó, Brasil: formação do Estado e da nação, São Paulo: Hucitec: Fapesp: Unijui, 2003, pp. 195218; p. 201-203. Lucia Bastos das Neves. "Constituição: usos antigos e novos de um conceito no Império do Brasil (1821-1860). In: José Murilo de Carvalho e Lucia Maria Bastos Pereira das Neves (org.), Repensando o Brasil do Oitocentos. Cidadania, política e liberdade, Rio de Janeiro: Civilização Brasileira, 2009, pp. 183-205; p. 196. Ilmar Rohloff de Mattos. "Construtores e herdeiros. A trama dos interesses na construção da unidade política". Almanack Braziliense. Vol.1, maio de 2005, pp. 8-26; pp. 21-22. 
todas as outras determinações da Carta, e do próprio artigo citado, demandavam reformas de amplo alcance ou a aprovação de leis regulamentares no país. Para além disso, as fontes disponíveis à aplicação cotidiana da justiça criminal eram, no momento de aprovação da Constituição, praticamente as mesmas vigentes quando da vinda da família real e da Independência do Brasil: o livro V das Ordenações Filipinas, as leis extravagantes promulgadas em Portugal até 1808 e as demais leis e decretos reconhecidos pela lei de 20 de outubro de 1823 .

Se, como vimos anteriormente, a organização corporativa da monarquia portuguesa durante o período colonial e o modo específico com que esta encarava a aplicação cotidiana da justiça penal, garantiram um baixo emprego dos dispositivos do Livro V das Ordenações Filipinas e o exercício de uma justiça penal pouco aparente e teatral no cotidiano da América portuguesa, isso não significa, contudo, que nos crimes que mais chamavam a atenção da metrópole, os processos criminais tenham sido relegados ou as punições amenizadas. Pelo contrário, o exemplo dos julgamentos dispensados aos principais líderes das rebeliões coloniais demonstram o modo com que, periodicamente, e nos casos mais graves de atentado à ordem pública, o poder punitivo da coroa portuguesa fez-se de fato sentir sobre a população americana.

As mudanças sofridas pela concepção estatal e monárquica portuguesa na passagem do século XVIII ao XIX e a nova posição assumida pelo poder centralizado na corte do Rio de Janeiro, agravaram, como vimos, a concepção punitiva do governo sobre o Brasil. A partir de então, a exemplificação pública de seus poderes sobre a população e a imposição de limites claros às manifestações políticas contrárias ao governo central foram consideradas de primeira necessidade, aproximando a população - ainda que, em todo caso, de forma pouco sistemática e nada cotidiana da crueldade do direito penal prescrito pelas Ordenações Filipinas e - haja vista as novidades político-ideológicas em curso naquele momento - da necessidade premente de sua substituição.

Coeva ao contexto de aprovação da Carta Constitucional brasileira de 1824, a repressão infligida à Confederação do Equador representa um bom exemplo dos extremos a que podia chegar o direito penal de Antigo Regime ainda vigente no Brasil. Deflagrada em oposição à política imperial de d. Pedro I, vista como a expressão do antigo absolutismo e ameaçadora das conquistas liberais de diversas províncias da então região Norte do Brasil, a Confederação do Equador, cujo centro 
de irradiação foi Pernambuco, opôs-se, entre outras coisas, à montagem do Estado nacional tal como conduzida pelo imperador e expressa na Carta outorgada em $1824^{129}$.

Com uma base política liberal e constitucionalista em processo de mobilização desde a dissolução da Assembleia Constituinte de 1823, as reivindicações da Confederação do Equador ultrapassavam o âmbito específico da luta provincial, demandando uma mais radical aplicação do princípio da soberania da nação e uma organização estatal que contemplasse mais largamente os diferentes interesses das províncias - fosse no que tangia à escolha dos dirigentes provinciais, fosse no tocante ao controle das rendas e das forças armadas - , alcançando, nesse sentido, significado nacional $^{130}$

Haja vista a ameaça à ordem representada por semelhante movimento político, ainda em julho de 1824 d. Pedro deu início à repressão, suspendendo, por toda a província de Pernambuco, as disposições contidas no parágrafo $8^{\circ}$ do artigo 179 da Constituição (referente à proibição de prisões arbitrárias no Império), ordenando que uma Comissão Militar, presidida pelo Brigadeiro Francisco de Lima e Silva, processasse de forma sumária - e, logo, inconstitucional - os líderes da rebelião assim que capturados, e enviando uma divisão naval para bloquear os portos de Pernambuco. Sofrendo com ataques por mar e terra, a revolta seria contida nos últimos meses do ano e, aos 29 de novembro de 1824, teria lugar a capitulação geral dos revoltosos ${ }^{131}$

A Comissão Militar responsável pelo julgamento dos participantes do movimento, reunida em Pernambuco, aos 20 de dezembro de 1824, especialmente para este fim, indicou desde o início as intenções de condenação por parte do governo, independentemente das versões apresentadas pela defesa dos réus. De acordo com Glacyra Lazzari Leite, desde sua criação, a Comissão Militar pressupunha que os chefes e cabeças da revolta fossem punidos com pronto castigo, como convinha para "extirpar tão contagioso mal".

${ }^{129}$ Denis Antonio de Mendonça Bernardes. "A gente infima do povo e outras gentes na Confederação do Equador". In: Monica Duarte Dantas (org.). Revoltas, motins, revoluções: homens livre pobres e libertos no Brasil do século XIX. São Paulo: Alameda, 2011; pp. 131166; pp. 148-152.

${ }^{130}$ Idem. Ibidem.

${ }^{131}$ Glacyra Lazzari Leite. Pernambuco, 1824: A Confederação do Equador. Recife: Fundaj, Editora Massangana, 1989; pp. 121-136. 
Como resultado deste processo, 16 revoltosos foram condenados à morte - dentre eles, frei Joaquim do Amor Divino Caneca, Agostinho Bezerra Cavalcante e Sousa, Joaquim Loureiro e Antonio Macário de Morais - e executados ao longo do ano de 1825 pela incursão nos crimes de "sedição e revolta" - tendo por base o estabelecido no Titulo VI do Livro V das Ordenações Filipinas, intitulado "Do crime de lesamajestade"132 —, reforçando o caráter preventivo e atemorizador das punições como forma de impedir que fossem novamente contrariados os desígnios imperiais:

O trabalho da Comissão Militar tinha uma diretriz. O primeiro objetivo era provar o grau de poder do Governo do Rio de Janeiro e a extensão ilimitada do seu alcance. $\mathrm{O}$ segundo era demonstrar às outras nações a viabilidade do Império Brasileiro manter-se como tal, isto é, como um todo integrado, sem a tutela da ex-metrópole. Uma forma de atingir esses objetivos era aplicar imediatamente a pena capital aos elementos cujas atividades mais repercutiam entre a população. [...] Era necessário, então, impor, o rigor da lei não só pelo que representava a sua aplicação naquele momento mas, muito mais, para marcar um exemplo, uma posição de firmeza dentro do Império e uma posição de força perante o mundo ocidental. Os culpados de maior evidência deviam, portanto, ser penalizados ao máximo. ${ }^{133}$

A repressão imposta pelo governo do Rio de Janeiro à Confederação do Equador, assim como aquela previamente destinada à Revolução pernambucana de 1817, marcaram profundamente a classe política nacional, influenciando diretamente, como veremos, seu posicionamento nos debates em torno à elaboração do futuro código criminal.

Para ficarmos com apenas um exemplo desta influência, vale destacar que, aos 15 de setembro de 1830, debatendo-se no plenário da Câmara dos deputados a validade, ou não, da manutenção da pena de morte no texto do futuro código criminal, mais de um deputado se oporia à mesma - ou à sua aplicação nos casos de crimes políticos -, fundado no histórico de sua execução e em exemplos legitimadores de tal preocupação. É emblemática, neste sentido, a fala de Joaquim Manuel Carneiro da Cunha (representante eleito pela província da Paraíba do Norte), para quem era inadmissível que o modelo punitivo adotado pelo governo no controle das revoltas provinciais, se mantivesse no país:

Se não existisse esta pena não recordariamos com dôr esses dias de luto, e de amarguras em que exhalarão o ultimo suspiro nos cadafalsos da inquisição politica um Antonio Henriques, os Satyros, os Canécas e outros martyres da patria que se

\footnotetext{
${ }^{132}$ Monica Duarte Dantas. "Revoltas, motins, revoluções: das Ordenações ao código criminal.”. Op. cit.; 2011; pp. 10-12.

${ }^{133}$ Glacyra Lazzari Leite. Op. cit.; p. 133.
} 
sacrificarão defendendo corajosamente nossos direitos, nossa independencia e liberdade. $^{134}$

Fundados nestas e noutras justificativas, veremos à frente, os deputados brasileiros aprovaram a abolição da pena de morte nos crimes políticos do código nacional, impondo a este documento uma grande novidade e avanço frente à codificação do mundo ocidental.

Se à altura da inauguração dos trabalhos parlamentares no Império do Brasil, portanto, a questão da necessária codificação das leis penais apareceu de forma quase imediata nas falas e proposições dos deputados, tal não se deveu unicamente às prescrições que, na Carta Constitucional de 1824, apontavam neste sentido, mas também, e talvez principalmente, ao desejo de reforma e modernização da justiça penal partilhado pelos representantes brasileiros - influenciados pelo movimento codificador em curso no mundo ocidental desde finais do século XVIII -, aliado à vontade de substituir, o quanto antes, o conjunto da legislação criminal previgente ${ }^{135}$.

Com exemplos bastante próximos, nas histórias nacional e internacional, das problemáticas envolvidas na aplicação (mesmo que esporádica) de uma justiça penal de Antigo Regime, estes deputados se opuseram ao direito penal vigente no Brasil com tamanho ardor que, discursando em favor de sua reforma, pintaram um quadro da atuação cotidiana da justiça no Brasil e da aplicação do Livro V das Ordenações Filipinas que, como vimos, não era necessariamente real. De qualquer forma, a força retórica de semelhantes discursos foi capaz de, seguindo o desejo de seus oradores, impulsionar a reforma das leis penais no país, encaminhando o processo codificacionista que desembocou na lei de 16 de dezembro de 1830 .

Abertos os trabalhos da primeira legislatura brasileira, em 1826, ficou rapidamente explícita, nas palavras de José Reinaldo de Lima Lopes, a presença de um programa político consciente e bem dirigido com vistas à reorganização do cotidiano do Estado brasileiro sob um perfil liberal, fazendo-se uso, para tanto, da faculdade de legislar como primeira fonte de todo direito. A produção legislativa

\footnotetext{
${ }^{134}$ APB-CD; sessão de 15 de setembro de 1830; p. 517.

${ }^{135}$ Nas palavras de Monica Dantas: "Não que o determinado pela Constituição fosse uma preocupação secundária para os deputados, mas não há dúvidas que a importância do Código Criminal era tanto maior que o desejo de deixar para trás a legislação portuguesa, especialmente aquela que dispunha sobre matéria penal, e que a outorga da carta tornara difícil de ser aplicada." Monica Duarte Dantas. "Revoltas, Motins, Revoluções: das Ordenações ao Código Criminal”. Op. cit.; 2011; p. 5.
} 
inicial do Parlamento viria demonstrar, assim, para o autor, a consciência partilhada por seus representantes (herdeiros, em grande medida, da voga ilustrada e jusnaturalista do ensino jurídico de Coimbra), do papel a ser desempenhado pelas leis na construção de uma nova $\operatorname{ordem}^{136}$. Valendo-se de uma concepção de lei como fonte de direitos e instrumento de controle da ordem pública (fundada no modelo oriundo da revolução francesa), os primeiros representantes do país se apropriaram de seu sentido mais moderno na confecção de uma legislação positiva para o país ${ }^{137}$.

A ideia de centralização das fontes do direito e codificação das leis nacionais (ou seja, de sua organização num conjunto de disposições principiológicas, ordenadas, sistematizadas, racionais e abrangentes de toda a matéria a que se referiam ${ }^{138}$ ), imposta pela própria Constituição de 1824, formava, como vimos, parte indispensável do pensamento jurídico oitocentista, sendo rapidamente assumida e posta em prática pelos legisladores do Brasil.

A concentração de esforços e as disputas levadas a cabo pelos deputados em torno do Poder Judiciário demonstram, assim, a força desempenhada por esta esfera do poder na imposição de limites ao soberano e no controle da ordem interna do país, bem como sua configuração numa via de acesso privilegiada à reestruturação do Estado, à formação de um campo de direito nacional para o Império brasileiro e à garantia dos direitos constitucionais dos cidadãos. Neste sentido, as medidas jurídicas tomadas no período que Thomas Flory denominou de "década liberal" - transcorrido entre 1827 e 1837 -, indicam a presença de um projeto político estatal que, se não foi aquele que afinal venceu no país, deve, de todo modo, ser historicamente recuperado pelas alternativas que propôs ao aparelhamento institucional da nova nação ${ }^{139}$.

Reunido o legislativo, portanto, rapidamente tiveram lugar as primeiras proposições relativas à elaboração de códigos de direito substantivo e adjetivo para o Brasil $^{140}$. Aos 12 de maio de 1826, numa das primeiras sessões regulares da

\footnotetext{
136 José Reinaldo de Lima Lopes, "Iluminismo e jusnaturalismo no ideário dos juristas da primeira metade do século XIX". In: István Jancsó, Brasil: formação do Estado e da nação, São Paulo: Hucitec: Fapesp: Unijui, 2003, pp. 195-218.

${ }^{137}$ Andréa Slemian. "À nação independente, um novo ordenamento jurídico: a criação dos Códigos Criminal e de Processo Penal na primeira década do Império do Brasil". Op. cit,; 2008; pp.71-78.

${ }^{138}$ José Reinaldo de Lima Lopes. Op. cit.; 2003; p.199.

${ }^{139}$ Thomas Flory. Op. cit.; pp. 17-35.

${ }^{140}$ Como visto na Introdução, enquanto o direito substantivo caracteriza-se pela estipulação de direitos e deveres, definindo o complexo de normas que regem as relações jurídicas, o adjetivo refere-se às formas de efetivação, manutenção, validação ou recuperação daqueles
} 
legislatura, foram apresentadas propostas visando a incentivar a elaboração de um código civil e criminal para o Império, enviadas, respectivamente, pelos deputados José Antonio da Silva Maia (eleito por Minas Gerais) e Domingos Malaquias de Aguiar Pires Ferreira (deputado por Pernambuco). Haja vista o tempo necessário à composição e discussão dos primeiros códigos no Parlamento, contudo, sua aprovação acabou precedida por uma importante sequência de leis de cunho eminentemente liberal, voltadas à criação de uma nova estrutura institucional e à reorganização dos aparelhos administrativos do país.

Em termos de direito adjetivo foram aprovadas assim, com relativa rapidez: a lei de 15 de outubro de 1827, responsável pela criação e regulamentação das funções do juiz de paz - magistrado previsto pela Constituição de 1824 , eleito ao nível das freguesias e com atribuições administrativas, judiciais e policiais referentes, entre outras coisas, à justiça conciliatória, ao julgamento de causas cujo valor e/ou pena não ultrapassasse certo limite, à imposição de termos de bem viver, manutenção da ordem, emprego da força pública, vigilância do cumprimento das posturas municipais e condução das eleições ${ }^{141}$; o Novo Regimento das Câmaras, ou lei de reorganização dos municípios, de $1^{\circ}$ de outubro de 1828 , retirando destes órgãos o poder judiciário que tradicionalmente detinham, restringindo sua atuação ao nível meramente administrativo e esvaziando seu poder político em favor da autoridade provincial; e a criação do Supremo Tribunal de Justiça do Brasil, aos 18 de setembro 1828, a ser sediado no Rio de Janeiro.

Enquanto a lei do juizado de paz apostava no princípio de representação popular na judicatura e nos ideais de autonomia defendidos pelos liberais - opositores ferrenhos da administração colonial da justiça, e do poder e corrupção dos

direitos e deveres, atuando, portanto, no âmbito processual da justiça. Enquanto o direito substantivo materializa-se, assim, nos códigos civil, penal e constitucional de um país, o direito adjetivo materializa-se nos códigos de processo civil e penal ou em códigos como os de direito trabalhista.

${ }^{141}$ Ivan Vellasco. Op. cit.; 2004; p. 100. Nas palavras de Andréa Slemian: “Após sua implementação, esses juizes teriam seus poderes aumentados no início da Regência pelo Código Processual, que ampliou sua jurisdição penal e de vigilância, além de instituir definitivamente o sistema de jurados. Este, como órgão eletivo popular, também significou uma tentativa de relativização do poder dos magistrados formais e, junto aos juízes de paz, teria papel importante na participação da sociedade civil na estrutura da justiça. Na prática, o funcionamento de ambos geraria tensões as mais diversas, mas, posteriormente, com o Regresso, começariam a perder força.”. Andréa Slemian. Op. cit.; 2009; p. 186. 
magistrados letrados de origem portuguesa ${ }^{142}$-, o Novo Regimento das Câmaras, ao esvaziar o poder político tradicional destes órgãos e dos "homens bons" que nele acumulavam funções e prestígio, afirmava a Província como unidade políticoadministrativa e nova esfera de poder do Império ${ }^{143}$. Já a criação do Supremo Tribunal de Justiça, previsto pelos artigos 163 e 164 da Carta constitucional de 1824, buscava dotar o país de um tribunal superior moderno (extinguindo, para tanto, o Desembargo do Paço e a Casa de Suplicação), responsável pela averiguação da validade das revistas nas causas judiciais, pelo conhecimento dos delitos e erros de ofício cometidos pelos ministros, empregados do corpo diplomático e presidentes das províncias do país, e ainda pela decisão sobre os conflitos de jurisdição e competência das Relações provinciais (tribunais locais de julgamentos em segunda e última instância $)^{144}$.

Outra lei de importância fundamental à composição, equilíbrio e bom funcionamento do governo imperial, foi a Lei de Responsabilidade dos Ministros, Secretários e Conselheiros de Estado, aprovada em 15 de outubro de 1827 e prevista também por dispositivos da Carta constitucional de 1824. Regulando questões de direito tanto substantivo quanto adjetivo, a Lei de Responsabilidade definia, em seu primeiro capítulo, os crimes de traição, suborno, abuso de poder, falta de observância da lei, atentados aos cidadãos e dissipação dos bens públicos, possivelmente cometidos por Ministros e Secretários de Estado; regulando ainda, no capítulo II, os delitos dos Conselheiros de Estado e, no capítulo III a maneira de se proceder contra os mesmos funcionários ${ }^{145}$.

De acordo com a lei, pelo crime de traição ao país, Ministros e Secretários de Estado poderiam receber, no grau máximo, a pena de morte. As penas para os crimes de suborno, abuso de poder, falta de observância das leis e demais delitos regulados pelo capítulo I incluíam, por sua vez, a perda, suspensão ou inabilidade para a

${ }^{142}$ Para uma análise profunda acerca do instituto do juizado de paz no Brasil ver: Thomas Flory. Op. cit.;1986; e Ivan Vellasco. Op. cit.; 2004.

${ }^{143}$ Andréa Slemian. Op. cit.; 2009; pp. 186-195. Para as relações existentes entre as leis do juizado de paz e das Câmaras e o projeto federalista dos políticos liberais brasileiros ver: Miriam Dolhnikoff. O Pacto imperial: origens do federalismo no Brasil do século XIX. São Paulo: Globo, 2005; pp. 83-89.

144 A lei de criação do Supremo Tribunal de Justiça pode ser visualizada em: http://www2.camara.leg.br/legin/fed/lei sn/1824-1899/lei-38214-18-setembro-1828-566202publicacaooriginal-89822-pl.html

145 A lei de Responsabilidade Ministerial pode ser acessada através do endereço: http://www2.camara.leg.br/legin/fed/lei sn/1824-1899/lei-38389-15-outubro-1827-566674publicacaooriginal-90212-pl.html. 
manutenção do emprego, a prisão, a multa ou a remoção para fora da Corte. No que tangia aos delitos dos Conselheiros de Estado, cometidos no caso de emissão de conselhos opostos às leis, contrários aos interesses do Estado, ou manifestamente dolosos, as penas eram similares às previstas aos Ministros e Secretários, não sendo nunca inferiores, contudo, à suspensão do emprego por entre um e dez anos. De acordo com o artigo $8^{\circ}$ da lei, todo cidadão poderia denunciar, na forma do artigo 179 , parágrafo 30, da Constituição, os respectivos funcionários estatais pelos delitos especificados na lei, assim como as comissões da câmara deveriam denunciar os delitos que encontrassem no exame de quaisquer negócios. Na sequência, o capítulo III definia ainda a forma da denúncia, acusação e julgamento dos crimes regulados.

Originando discussões acirradas na Câmara dos deputados e no Senado brasileiros desde maio/junho de 1826, a aprovação da Lei de Responsabilidade esteve diretamente relacionada ao estabelecimento, na prática, do equilíbrio entre as competências executiva, legislativa e judiciária no Império, e ainda à criação de garantias de transparência e controle político das ações governamentais. Nesse sentido, foi amplamente defendida pelos deputados brasileiros e diretamente associada à salvaguarda da Constituição, de competência direta da Câmara dos deputados, conforme atribuição do texto constitucional (artigo 15, parágrafo 9$)^{146}$.

Como parte do processo de aparelhamento da administração estatal, reformulação da legislação existente e modernização do poder judiciário nacional, a Câmara dos deputados trabalhava, desde 1827, na composição do texto do futuro código criminal do Império, escolhido como o primeiro da nova nação. De acordo com Andréa Slemian, a aprovação do Código criminal de 1830 dava-se, portanto, na esteira de um projeto liberal de ampliação dos direitos dos cidadãos, aposta na construção de um moderno sistema penitenciário para o Império e valorização da ação judiciária das autoridades locais, numa tentativa de negação da herança portuguesa ${ }^{147}$.

\footnotetext{
${ }^{146}$ Para uma discussão bastante interessante acerca das relações existentes entre a elaboração do texto da Lei de Responsabilidade dos Ministros, Secretários e Conselheiros de Estado e o tratado antitráfico assinado entre Brasil e Inglaterra no ano de 1826, ver: Tâmis Parron. $A$ política da escravidão no Império do Brasil, 1826-1865. Dissertação de Mestrado; DH/FFLCH/USP; 2009; pp. 50-63. Outra análise interessante do percurso de aprovação da Lei de Responsabilidade, bem como da importância assumida por sua aprovação naquele momento específico da história do Brasil, pode ser encontrada em: Andréa Slemian. Op. cit.; 2009; pp. 179-185.

${ }^{147}$ Andréa Slemian. Op. cit.; 2008; pp. 178.
} 
Para além de compor o quadro de reformas jurídicas impulsionadas pelo Parlamento desde 1826, a aprovação deste documento desempenhou papel político fundamental nas mãos dos deputados brasileiros, então em franca oposição ao governo de d. Pedro I, materializando um esforço consensual particularmente interessante se observadas as tensões vigentes no interior das Câmaras legislativas ao longo do Primeiro Reinado.

\subsection{A oposição política parlamentar e o enfraquecimento de d. Pedro nas primeiras legislaturas imperiais, 1826-1831.}

Entre a aprovação da Carta Constitucional de 1824 e o início efetivo do regime representativo no Brasil, com a abertura da Assembleia Geral, dois anos se passaram. Neste interregno, o país enfrentou profundas tensões, decorrentes, em grande medida, das decisões equívocas tomadas pelo imperador e do descontrole por elas desencadeado nas esferas política, social e econômica do país.

A dissolução da Assembleia Constituinte, em 1823, e a outorga da Constituição, em 1824, já haviam acirrado os ânimos de setores importantes da classe dominante e da população de norte a sul do país. As preocupações do governo central com as agitações populares e contestações de rua no período podem ser observadas por meio dos procedimentos de vigilância adotados pela Intendência de Polícia, e pela legislação aprovada, especialmente a partir de 1825, com vistas ao controle da $\operatorname{ordem}^{148}$.

Em Pernambuco, como vimos, uma rebelião armada, apoiada pelo Rio Grande do Norte, Paraíba e Ceará - e atraindo a simpatia de toda a região Norte -, havia proclamado uma república independente, a Confederação do Equador, opondo-se, entre outras coisas, à outorga da Constituição por d. Pedro I e ao modelos de soberania e liberdade implementados no país pelo imperador. Rigorosamente reprimida, os desdobramentos desta revolta contribuíram à articulação da forte oposição que se formava ao monarca ${ }^{149}$.

\footnotetext{
${ }^{148}$ Iara Lis Carvalho Souza. Pátria Coroada: o Brasil como corpo político autônomo - 17801831. São Paulo: Fundação Editora da UNESP, 1999; pp. 327-329. Gladys Sabina Ribeiro e Vantuil Pereira. "O Primeiro Reinado em revisão". In: Keila Grinberg e Ricardo Salles (orgs.). O Brasil Imperial, volume I: 1808-1831. Rio de Janeiro: Civilização Brasileira, 2011; pp. 137-173; p. 154.

${ }^{49}$ Leslie Bethell e José Murilo de Carvalho. "O Brasil da Independência a meados do século XIX”. In: Leslie Bethell (org). História da América Latina. Vol 3: Da Independência a 1870. São Paulo, EDUSP, Imprensa Oficial/ Brasília, FUNAG, 2001; pp. 695-769; p. 701-702.
} 
Outro ponto de merecido destaque no contexto que antecedeu a abertura dos trabalhos legislativos no país, encontra-se no tratado de reconhecimento da Independência brasileira por Portugal, arquitetado com a intermediação inglesa de Charles Stuart e assinado, pelo Brasil, aos 29 de agosto de 1825, sob a denominação de "Tratado de Paz e Amizade".

Ainda que a cláusula secreta indenizatória anexada a esta convenção - foco das maiores objeções à sua assinatura - tenha sido revelada apenas em junho de 1826 (iniciados, portanto, os trabalhos da Assembleia Geral), alguns detalhes de seu texto já haviam desagradado os futuros representantes da nação e levantado dúvidas quanto ao lócus da soberania brasileira.

Dentre eles, deve-se atentar ao reconhecimento de d. João VI como imperador do Brasil e de d. Pedro I, consequentemente, como simples herdeiro do título, anulandose, desta forma, o peso das conquistas e rupturas advindas da Independência brasileira e dando-se às mesmas o caráter de heranças naturais ou concessões da coroa portuguesa. Para além disso, por meio deste tratado, o monarca brasileiro não abdicara expressamente de seus direitos de sucessão ao trono português, gerando o receio de que, em caso de vacância, quando da morte de d. João VI, Brasil e Portugal fossem automaticamente reunificados e o primeiro uma vez mais submetido à condição colonial $^{150}$.

Às suspeitas erguidas com relação à solidez da Independência do país e à concretude da filiação do imperador aos ideais representativos e parlamentares de governo, somar-se-iam, nos anos seguintes, o envolvimento desastroso do Brasil na Guerra da Cisplatina e o agravamento da crise financeira, exasperando ainda mais os oponentes do imperador.

Zona de contendas centenárias entre as administrações portuguesa e espanhola, a Banda Oriental havia sido incorporada ao território brasileiro, em 1821, sob o nome de Província Cisplatina. Em outubro de 1825, obcecado com a reconquista da parcela espanhola da região, o governo de Buenos Aires anunciou a incorporação da Banda Oriental às Províncias Unidas do Rio da Prata, declarando indiretamente guerra ao Brasil. Apesar de, num primeiro momento, o conflito parecer de fácil e rápida

${ }^{150}$ Sobre o "Tratado de Paz e Amizade", ver: John Armitage. História do Brasil: desde o período da chegada da família de Bragança, em 1808, até a abdicação de d. Pedro I, em 1831, compilada à vista dos documentos públicos e outras fontes originais formando uma continuação da História do Brasil, de Southey. Belo Horizonte: Ed. Itatiaia; São Paulo: EDUSP, 1981; pp. 108-111; Leslie Bethell e José Murilo de Carvalho. Op. cit.; pp. 702-703. 
resolução, agradando, inclusive, ao monarca, as sucessivas derrotas e reveses vividos pelo exército imperial obrigaram o Brasil a assinar um tratado com Buenos Aires, em 1828, admitindo a criação de um novo país na região, o Uruguai ${ }^{151}$.

Declarada unilateralmente pelo imperador, a guerra desagradou os brasileiros desde o seu início. Fundado numa concepção de soberania fortemente alicerçada na defesa da unidade territorial e dos limites políticos e geográficos do reino legado por seu pai, d. Pedro I considerara a atitude do governo de Buenos Aires uma afronta à sua honra, além de potencialmente fragilizadora do Império brasileiro (confundido, então, com a sua pessoa) frente a seus opositores ${ }^{152}$.

Financeiramente, a guerra teve efeitos desastrosos, impondo um ônus extra às já frágeis finanças nacionais e gerando um rombo crescente no orçamento imperial. Prejudicada pelos conflitos que se seguiram à Independência nas regiões Norte e Nordeste do país e pelos altos custos envolvidos na repressão à Confederação do Equador, a economia imperial sofria ainda com as conseqüências da crise financeira instituída quando do retorno de d. João VI a Portugal, em 1821. Levando consigo quantias consideráveis do Banco do Brasil, o séqüito real deixara os cofres brasileiros em franca decadência. As medidas tomadas a partir de 1822 com vistas ao saneamento da crise, como o aumento na fabricação de dinheiro e a conseqüente elevação da circulação de moedas, especialmente as de cobre, desembocaram, contudo, a partir do ano seguinte, numa derrama de moedas falsas e na perturbação generalizada das relações travadas nas praças comerciais ${ }^{153}$.

Ainda no período que antecedeu à abertura da Assembleia Geral, o envolvimento de d. Pedro na crise sucessória portuguesa agravou o quadro de desconfiança nacional em relação ao imperador. Com a morte de d. João VI, em março de 1826, d. Pedro I foi aclamado sucessor do trono português - conforme indefinição legada pelo "Tratado de Paz e Amizade", de 1825 - e viu-se obrigado a tomar um posicionamento perante a questão. Abdicando da coroa européia em favor de sua filha, d. Maria da Glória, e outorgando uma Constituição ao país de além-mar (forjada nos moldes da

\footnotetext{
${ }^{151}$ Leslie Bethell e José Murilo de Carvalho. Op. cit.; pp. 701-705. Gladys Sabina Ribeiro e Vantuil Pereira. Op. cit.; pp. 157-158.

${ }^{152}$ Aline P. Pereira. Domínios e Império: o Tratado de 1825 e a Guerra da Cisplatina na construção do Estado no Brasil. Dissertação de Mestrado; UFF, 2007; pp. 86-98.

${ }^{153}$ Vantuil Pereira. Ao Soberano Congresso: direitos do cidadão na formação do Estado Imperial brasileiro (1822-1831). São Paulo: Alameda, 2010; pp. 125-126.
} 
Carta brasileira de 1824), d. Pedro acreditava estar provando ao Brasil a veracidade de seus sentimentos no tocante à causa nacional ${ }^{154}$.

A proximidade de suas ligações com a filha de sete anos, contudo, e as suspeitas geradas em torno de seu irmão d. Miguel - que, na qualidade de marido da sobrinha, deveria atuar como regente até que esta completasse 25 anos -, deixaram rapidamente explícita aos brasileiros a interferência duradoura que os assuntos portugueses teriam no cotidiano do imperador.

Somada a esta conjuntura tensa, a demora de d. Pedro I na escolha dos senadores que comporiam a Assembleia Geral $^{155}$ (realizadas as eleições ainda em 1825) e o conseqüente atraso na abertura da Casa legislativa, fizeram com que os trabalhos parlamentares no Brasil fossem inaugurados num clima de preocupação ainda maior com relação aos verdadeiros desígnios do monarca ${ }^{156}$. Para piorar o quadro, as primeiras medidas tomadas pelo imperador no contexto parlamentar geraram a sensação de que, no jogo político por ele articulado, o Executivo usurpava atribuições do Legislativo, deixando simultaneamente descontentes e atentos os primeiros representantes do Império.

Se no intervalo de tempo transcorrido, portanto, entre novembro de 1823 e maio 1826, o vácuo parlamentar vigente no país permitira ao imperador um regime extremamente centralizado, ainda que não sem oposição social e política, a abertura da Assembleia Geral revelou, quase imediatamente, um antagonismo de difícil conciliação no seio da classe política nacional. Sendo assim, a um ataque frontal do

${ }^{154}$ Roderick J. Barman. Brazil: the forging of a nation, 1798-1852. Califórnia: Stanford University Press, 1988; pp. 142-143.

${ }^{155}$ Para Roderick J. Barman, a inabilidade demonstrada por d. Pedro I na composição do Senado nacional, retirando da Câmara dos deputados cerca de 13 indivíduos cujos antecedentes - em especial a formação em Coimbra anteriormente a 1816 e o treinamento nos serviços jurídicos do Estado nacional -, poderiam ter garantido apoio ao seu governo, foi um incentivo aos desequilíbrios políticos rapidamente surgidos. $\mathrm{O}$ preenchimento das vagas remanescentes da Câmara dos deputados por indivíduos de convicção política mais radical do que os encaminhados ao Senado - sendo oito deles anteriormente deputados na Assembleia Constituinte de 1823 -, aliado à escolha dos demais representantes provinciais, advindos de uma camada política liberal que não via com bons olhos o legado autoritário do país, teriam contribuído, assim, à perda gradual de forças por parte do imperador. Roderick J. Barman. Op. cit.; pp. 136-139.

${ }^{156}$ Tâmis Parron sugere que o período transcorrido entre a outorga da Constituição e o início das atividades parlamentares pode ter sido calculado com vistas à finalização das negociações em torno do comércio negreiro no Brasil; haja vista a presença do embaixador britânico Charles Stuart no país, desde 1825, e sua missão de auxílio no reconhecimento português da independência brasileira e no estabelecimento de um tratado antitráfico com o país. Tâmis Parron. Op. cit.; p. 47. 
imperador aos deputados, articulado pela "Fala do Trono" que inaugurara os trabalhos legislativos, e a uma atuação inicialmente reticente dos representantes nacionais possivelmente relacionada à memória do abrupto fechamento da Assembleia Constituinte, em 1823, mas, ainda mais, nos parece, ao ineditismo de sua tarefa e às dificuldades procedimentais com que inicialmente se defrontaram -, seguiu-se a articulação de um grupo no interior da Câmara baixa que passou a rivalizar cada vez mais com d. Pedro I, divergindo abertamente de suas decisões e das propostas articuladas por seus ministros e senadores, e reivindicando a Câmara dos deputados como o verdadeiro espaço de representação da Nação.

Os embates então abertos revelaram, dia após dia, a insatisfação dos representantes com o encaminhamento dado às problemáticas vividas pelo país, explicitando a presença de uma oposição que, nas palavras de Roderick J. Barman, materializava um desacordo nevrálgico e profundo acerca do futuro do Brasil como nação:

A clash between two conflicting ideologies underlay all the battles that raged from 1826 to 1831 over the organization of governance, the functioning of the political process, and the goals to be pursued in international affairs. A conception of nation as polity based on traditional forms of inherited authority and directed by a ruler of heroic stature was increasingly challenged by a conception that equated the nation with the people and derived all authority from the popular will. (...) compromise solutions to the outstanding problems would not, therefore, have easily been found. ${ }^{157}$

Ao aprofundamento da distância entre as concepções e projetos nacionais reivindicados pela Câmara baixa, de um lado, e pelo imperador, seus ministros e o Senado, de outro, seguiu-se de perto a validação e o exercício cotidiano, por parte dos deputados, dos amplos poderes a eles atribuídos pela Constituição. Nesse sentido, os representantes brasileiros tiraram rápido proveito das prerrogativas que possuíam na elaboração de leis, fixação das despesas nacionais, criação de empregos públicos e determinação das forças de mar e terra do Império, articulando um jogo político e um enfrentamento vigoroso ao monarca a partir de suas atribuições constitucionais ${ }^{158}$.

\footnotetext{
${ }^{157}$ Roderick J. Barman. Op. cit.; p. 131.

158 "The emperor held ultimate authority because of his possession of the regulating power, 'the key to the whole political system', and his control of the national government, as head of the executive. Nonetheless, the powers the General Assembly wielded under the Constitution gave it the means of exerting a considerable, even decisive, influence on the conduct of government. [...] If the legislators were sufficiently skilled and determined, they could employ these powers to circumscribe the government's freedom of action, to restrain and even block unwelcome policies, and to influence the emperor's choice of ministers." Roderick J. Barman. Op. Cit; pp. 132-133. Sobre a latitude de poderes atribuídos pela
} 
No complicado cotidiano político do Primeiro Reinado, a Câmara dos Deputados mostrou-se, assim, cada dia mais apta a fazer frente ao governo de d. Pedro I, chamando a si parte do peso do sistema representativo do país e opondo-se a parte significativa das propostas ministeriais. Partindo, nesse sentido, das falhas e problemáticas intrínsecas à atuação do próprio monarca, a deputação brasileira soube gerar um espaço legítimo de oposição, logrando, afinal, somar forças com a população e as tropas e afastar o governante de seu cargo.

Ao imperador, não passaram despercebidos os poderes do Legislativo nacional e, no seu afã de contornar a oposição que a ele se construía no seio da Câmara utilizando-se das prerrogativas constitucionalmente adscritas ao Poder Moderador escolheu senadores que lhe eram favoráveis (a partir das listas das províncias) e fortaleceu sua ligação com os mesmos a partir da concessão de títulos nobiliárquicos. Aliás, o necessário fortalecimento de uma base política em seus primeiros anos de governo fica explícito a partir dos 104 títulos por ele concedidos, entre 1825 e 1826, a ministros, conselheiros de Estado e comandantes militares do país - fração superior a dois terços de todas as concessões realizadas no Primeiro Reinado ${ }^{159}$.

Diferentemente do que podem fazer crer certas análises, portanto, antes de confirmarem a pessoa do imperador enquanto fonte absoluta da autoridade nacional, os títulos por ele concedidos parecem ter composto um quadro de barganhas políticas conscientemente arquitetado com vistas à facilitação de seu governo ${ }^{160}$.

No contexto de crise econômica em que se inauguraram os trabalhos legislativos no país, a cláusula indenizatória imposta pelo "Tratado de Paz e Amizade", revelada à Câmara unicamente em junho de 1826, coincidiu com as dificuldades do Tesouro em honrar seus compromissos. Somada à insistência do governo - desaprovada pelos deputados - em buscar reconhecimento da independência brasileira nas cortes

Constituição de 1824 ao Legislativo no Brasil e, ainda, sobre os limites inerentes ao exercício dos poderes Executivo e Moderador no jogo representativo nacional, ver: Monica Duarte Dantas. Op. cit.; 2010; pp. 19-26.

${ }^{159}$ Leslie Bethell e José Murilo de Carvalho. Op. cit.; p. 706.

${ }^{160}$ Marina Garcia de Oliveira. Entre nobres lusitanos e titulados brasileiros: práticas, políticas e significados dos títulos nobiliárquicos entre o Periodo Joanino e o alvorecer do Segundo Reinado. Dissertação de Mestrado; DH-FFLCH/USP, 2013; pp. 110-134. Para a visão contrária acerca da concessão de títulos nobiliárquicos por $\mathrm{d}$. Pedro nos primeiros momentos de seu governo ver: Roderick J. Barman. Op. cit.; p. 130; e Leslie Bethell e José Murilo de Carvalho. Op. cit.; p. 706. 
estrangeiras, a situação gerou, nas palavras de Gladys Ribeiro e Vantuil Pereira: "as primeiras insinuações de que a liberdade do Brasil teria sido comprada" ${ }^{\text {161 }}$.

Já no âmbito do tratado antitráfico assinado com a Inglaterra no recesso parlamentar de 1826 - tornando ilegal o tráfico de escravos no Brasil dentro de três anos -, o clima de segredo sustentado pelos políticos mais diretamente envolvidos na questão e a ratificação unilateral do compromisso pelo imperador, sem consulta prévia à Assembleia, tornaram praticamente inalcançável, daí em diante, uma trégua entre a Câmara e o monarca ${ }^{162}$. Fundados numa interpretação conjuntural do parágrafo $8^{\circ}$ do artigo 102 da Constituição outorgada - relativo aos papéis a serem desempenhados por Executivo e Legislativo no estabelecimento de tratados internacionais -, os deputados brasileiros argumentaram "que o governo não podia ratificar convenções momentosas sem consulta prévia da Câmara e que, se o fizesse, devia ser penalizado pela Lei de Responsabilidade." $"$.

Ainda que os meandros específicos desta questão e a avaliação particular dos deputados sobre a abolição do tráfico negreiro não nos interessem diretamente, as discussões políticas suscitadas pela desaprovação coletiva da Câmara à assinatura do tratado importam por aludirem à batalha desde então travada sobre a justa divisão dos poderes da monarquia e o bom funcionamento da Assembleia Geral. Os diversos grupos de deputados progressivamente articulados em torno da questão e seu posicionamento unívoco no tocante ao desrespeito praticado pelo imperador dão uma boa medida da importância assumida pela questão.

[...] se a matéria em pauta polemizou e dividiu a Casa em vários grupelhos, o problema mais amplo das disputas entre Legislativo e Executivo plasmou os últimos conjuntos em sólida oposição ao gabinete e a D. Pedro I.

Após as discussões, restou um aprendizado: se o ajuste já fora concluído, se era irretocável ao Parlamento, seu uso ainda estava em aberto. De 1827 em diante, deputados da oposição passaram a evocá-lo menos para defender o comércio que para agredir o Executivo ${ }^{164}$.

Ao longo de 1827, o desenrolar traumático da guerra na Banda Oriental agravou ainda mais o quadro político do país. Críticos ferozes dos descaminhos tomados pelo conflito, os deputados da oposição aproveitaram-se de suas péssimas conseqüências sobre o orçamento para fazer uso das prerrogativas que detinham sobre a questão -

${ }^{161}$ Gladys Sabina Ribeiro e Vantuil Pereira. Op. cit.; p. 159.

162 Tâmis Parron. Op. cit.; pp. 49-50.

${ }^{163}$ Idem; pp. 72-74.

${ }^{164}$ Idem; p. 78. 
haja vista ser da responsabilidade da Câmara dos deputados, em acordo com a Constituição outorgada, a marcação do orçamento anual dos ministérios. Nesse sentido, usaram o orçamento como meio de barganha e forma de influenciar os rumos da guerra - interferindo nas reais possibilidades de o país obter sucesso no combate-, e criticaram tenazmente os gastos despendidos na Cisplatina quando da discussão do primeiro orçamento do Império ${ }^{165}$.

$\mathrm{Na}$ vida cotidiana dos moradores do Império, a guerra também produziu cada vez mais sofrimento, em especial por conta dos constantes recrutamentos para a frente de combate - provavelmente a medida governamental mais detestada no Brasil do século XIX, debatida e criticada pelos deputados em diversas ocasiões ${ }^{166}$ - e da crise gerada, em conseqüência do conflito, no fornecimento de gêneros de subsistência básicos para a região sul e o restante do país. Para além destes problemas, as dificuldades econômicas e, consequentemente, financeiras advindas, dentre outras causas, do declínio dos preços dos principais produtos exportados pelo país, do tratado comercial anglo-brasileiro assinado em 1827 e da tormentosa política bancária de d. Pedro resultando no fechamento do Banco do Brasil, em 1829 -, empurraram para cima o custo de vida nas grandes cidades e frustraram ainda mais a população ${ }^{167}$.

Entre 1826 e o início de 1828, milhares de mercenários alemães e irlandeses instalaram-se no Rio de Janeiro, vindo lutar na Guerra da Cisplatina (haja vista a falta de contingente no interior do Exército brasileiro e o agravamento cotidiano do conflito), atrelados a contratos que lhes prometiam, após um período de serviço entre as tropas (manifesto, no caso dos contratos alemães, e oculto, no caso dos irlandeses, até seu desembarque no Brasil), o acesso a terras e a uma vida livre no novo país. $\mathrm{Na}$ realidade, contudo, estes imigrantes viram-se rapidamente numa situação de extrema precariedade e constantes atritos com as camadas mais pobres da população do Rio de

\footnotetext{
${ }^{165}$ Gladys Sabina Ribeiro e Vantuil Pereira. Op. cit.; pp. 157-158.

${ }^{166}$ Leslie Bethell e José Murilo de Carvalho. Op. cit.; pp. 705-706.

${ }^{167}$ Nas palavras de Iara Lis Carvalho Souza: "Entre 1825 e 1830, a cidade assistiu a um processo de empobrecimento das camadas populares, em razão dos altos impostos sobre o abastecimento local, encarecendo os víveres, de uma desvalorização da moeda no câmbio internacional, para arcar com o ônus das guerras de independência, o novo custo militar e financeiro da Cisplatina, o pagamento de uma indenização a Portugal, e a circulação de dinheiro falso." Idem. Pátria Coroada: o Brasil como corpo político autônomo - 1780-1831. São Paulo: Fundação Editora da UNESP, 1999; p. 329. Para Vantuil Pereira, o aumento no preço dos gêneros alimentícios e sua concomitância com o aumento da impopularidade do imperador, entre 1826 e 1828, podem contribuir à explicação da derrota eleitoral que o governo sofreria, entre 1828 e 1829 , na escolha dos representantes da segunda legislatura imperial. Vantuil Pereira. Op. cit.; 2010; pp. 125-129.
} 
Janeiro. Recusando-se a ir às frentes de batalha, a presença dos mercenários irlandeses, e de parte dos alemães, na Corte, gerou ainda o rumor de que os mesmos haviam sido trazidos para formar a guarda pessoal do imperador, temeroso de que uma revolta eclodisse, na cidade, contra a sua pessoa ${ }^{168}$.

As revoltas dos mercenários estrangeiros (alemães e irlandeses), ocorridas em junho de 1828, a derrota na Guerra da Cisplatina, em agosto do mesmo ano, e o desdobramento da crise sucessória portuguesa, com o golpe que transformara $\mathrm{d}$. Miguel em soberano absoluto de Portugal - atraindo a atenção e energia de d. Pedro I num momento já suficientemente complicado da história brasileira -, tensionaram ainda mais a situação do imperador, contribuindo à consolidação dos grupos que lhe faziam oposição na Câmara dos deputados.

Perdendo o controle, portanto, sobre a situação política nacional (e internacional), o imperador se deparou com a falência de qualquer tentativa de acordo e o colapso dos canais de comunicação com a Câmara baixa. A partir deste momento, os deputados passaram a interferir audaciosamente nos rumos do governo, atacando frontalmente o imperador e instando-o a prestar contas sobre a atuação de seus $\operatorname{ministros}^{169}$.

Entre 1828 e 1829, as eleições para a nova legislatura do país, estratégicas a uma possível guinada política, trouxeram novamente à tona as armas à disposição de cada uma das facções em disputa. Apesar das tentativas do governo de reverter a radicalidade da Câmara baixa, controlando seus representantes nas localidades e trocando os presidentes de província previamente às eleições ${ }^{170}$, o partido do monarca amargou um resultado desalentador ${ }^{171}$.

\footnotetext{
${ }^{168}$ Ver Iara Lis Carvalho Souza. Op. cit; pp. 327-335; e Gilmar de Paiva dos Santos Pozo. Imigrantes irlandeses no Rio de Janeiro: cotidiano e revolta no primeiro reinado. Dissertação de Mestrado; FFLCH/USP; 2010.

${ }^{169}$ Gladys Sabina Ribeiro e Vantuil Pereira. Op. cit.; p. 160. Roderick J. Barman. Op.cit.; p. 150 .

${ }^{170}$ Gladys Ribeiro e Vantuil Pereira. Op. cit.; pp. 161-162.

${ }^{171}$ De acordo com Vantuil Pereira, ainda que dois terços da Câmara dos deputados tenham sido renovados com o novo pleito, assistiu-se, neste momento, não só à eleição de velhas figuras da Constituinte de 1823, como José de Alencar, Venâncio Pires Resende e Martim Francisco Ribeiro de Andrada, como ainda à estréia de futuros expoentes políticos da vida nacional, como Antonio Pereira Rebouças, Evaristo da Veiga e Honório Hermeto Carneiro Leão; o que, a médio prazo, significou uma diminuição do grupo próximo ao imperador e um enfraquecimento da política adotada por Clemente Pereira e Teixeira de Gouvêa. Vantuil Pereira. Op. cit.; 2010; p. 217.
} 
Ao longo do processo eleitoral, a politização progressiva da opinião pública brasileira, com a radicalização de parte dos periódicos em circulação ${ }^{172}$ e a campanha eleitoral por eles realizada a favor dos opositores de d. Pedro, serviu para aproximar o povo e as tropas no cenário político em ebulição.

No interior da Câmara baixa, por sua vez, para além de uma divisão política mais geral entre os grupos dos "Exaltados", Moderados e Corcundas, o dia-a-dia parlamentar demonstrava como, a depender do assunto então em pauta, subgrupos eram articulados e rearticulados. No que tange, por exemplo, ao Código Criminal do Império do Brasil, a análise dos debates travados e das modificações empreendidas sobre seu texto entre 1829 e 1830, revelam como, comumente opostos a d. Pedro I e comumente fundados nos preceitos do liberalismo jurídico então em voga, os deputados mais diretamente envolvidos em sua elaboração articularam-se em diferentes subgrupos ao longo da tramitação parlamentar do diploma, com projetos distintos de organização judiciária e estatal para o país.

Se havia, portanto, um bloco político bastante explícito de oposição a d. Pedro I no interior da Câmara dos deputados - formado por indivíduos como Bernardo Pereira de Vasconcelos (eleito por Minas Gerais), Lino Coutinho (BA), Francisco de Paula Sousa e Melo (SP), Antonio Ferreira França (BA), Luis Francisco de Paula Cavalcanti de Albuquerque (PE), dentre tantos outros -, ao adentrarem em temáticas específicas, como, no caso, o código penal, estes deputados mostravam-se defensores de opiniões e propostas nem sempre confluentes para o futuro do país.

Apesar das polarizações políticas vividas no período, o ano de 1829 terminou com uma aparente desmobilização na Câmara dos deputados. Acontece que, cientes da vitória conquistada nas eleições para a legislatura seguinte, mas subestimando a capacidade de reação do governo, parte dos deputados havia se envolvido, entre maio e junho deste ano, numa tentativa malograda de instituir um processo de responsabilidade contra os então Ministros da Justiça, Lucio Soares Teixeira de Gouveia, e da Guerra, Joaquim Oliveira Álvares, resultando na desarticulação momentânea da oposição ${ }^{173}$.

\footnotetext{
${ }^{172}$ De acordo com Gladys Ribeiro e Vantuil Pereira, jornais "moderados", como a Astréa e $A$ Aurora Fluminense aproximaram-se, a partir de 1829, dos jornais ditos "exaltados", como $A$ Luz Brasileira, A Nova Luz Brasileira, O Tribuno do Povo e O Republico, passando a fazer oposição mais radical ao imperador. Idem. Op. cit.; p. 164.

${ }^{173}$ Vantuil Pereira. Op. cit.; 2010; pp. 217-221; e Gladys Ribeiro e Vantuil Pereira. Op. cit.; pp. 162-163. Ver também: Mariana Pedron Macário. José Clemente Pereira e o debate
} 
A troca de Gabinete arquitetada por d. Pedro I nesta conjuntura, como forma de aquietar definitivamente a oposição - retirando do governo os ministros Teixeira de Gouvêa e Clemente Pereira (diretamente ligados ao imperador) e introduzindo o Marquês de Caravelas, o Marquês de Barbacena e Miguel Calmon du Pin e Almeida, mostrou-se, contudo, de alcance reduzido e ineficaz perante o recrudescimento das tensões políticas. De acordo com Roderick J. Barman, o confronto entre as facções em disputa no país havia sido unicamente postergado pelas ações de d. Pedro, não sendo modificadas, em verdade, suas causas mais profundas. Para o autor, portanto, o Gabinete formado em dezembro de 1829, composto por elementos bastante heterogêneos da cena coeva, não conseguiria se equilibrar entre as duas facções políticas dominantes àquela altura, com o apoio a uma delas implicando, necessariamente, numa oposição indireta à outra ${ }^{174}$. O dilema tornou-se ainda maior quando da reunião, em 1830, da nova deputação eleita, com uma parcela ainda mais significativa de opositores ao governo de d. Pedro.

Em meio a esta conjuntura politicamente cambiante $\mathrm{e}$ às incertezas enfrentadas quanto ao futuro da nação, os primeiros legisladores do Império não se furtaram, contudo, a tomar medidas essenciais à construção de um novo ordenamento jurídicoadministrativo para o Brasil. Pertencentes, muitas vezes, a grupos políticos opostos, souberam, por diversas vezes, no período entre 1826 e 1829, direcionar seus esforços a um compromisso comum e consensual com vistas ao estabelecimento de uma nova ordem para o país. Daí que, apesar dos conflitos e perturbações vividas pela primeira legislatura, diversas leis tenham se efetivado e diversos projetos sido encaminhados com vistas ao aparelhamento da nação ${ }^{175}$.

jurídico do Império: 1830-1850. Dissertação de Mestrado. Faculdade de Direito/USP; 2011; p. 34 .

${ }^{174}$ Roderick J. Barman. Op. cit.; p. 156.

175 Para Iara Lis Carvalho Souza, por exemplo, o novo regimento das câmaras municipais, aprovado em 1828, e as leis judiciárias promulgadas pela Assembleia na década de 1820 (como a criação do juizado de paz e do Supremo Tribunal de Justiça do Brasil), contribuíram para o desmonte progressivo da persona de d. Pedro I, ao limitarem o seu poder e os mecanismos tradicionais de controle social a ele relacionados. Iara Lis Carvalho Souza. Op. cit.; pp. 340-341. Ver também: Andréa Slemian, "À nação independente, um novo ordenamento jurídico: a criação dos Códigos Criminal e do Processo Penal na primeira década do Império do Brasil.". Op. cit., 2008. Pedro Octávio Carneiro da Cunha. "A Fundação de um Império Liberal. Primeiro Reinado: reação e revolução". In: Sérgio Buarque de Holanda (org.). História Geral da Civilização Brasileira. Tomo II: O Brasil Monárquico. Vol.I: O Processo de Emancipação. São Paulo: DIFEL, 1970; pp. 379-404. 
Inequivocamente fadada a enfrentar a conturbação política em que se enredara o país e a dar prosseguimento às medidas propriamente legislativas iniciadas pela deputação anterior, os trabalhos da nova legislatura prometiam ocorrer num clima de intensa agitação. A chegada ao Brasil dos emigrados portugueses saídos da Inglaterra $^{176}$ e a oposição cotidianamente incentivada pela imprensa do país à permanência, às desordens e aos pretensos privilégios recebidos por esta população, aguçaram a antipatia entre brasileiros e portugueses ${ }^{177}$, incentivando a união entre as tropas, o grupo dos liberais "exaltados" e o povo contra o imperador.

Nas ruas, a situação era conturbada, com o empobrecimento crescente das camadas populares - em razão da difícil conjuntura econômica vivida pelo país -, gerando disputas por espaços e empregos entre os mais pobres e tensionando as relações cotidianas. À oposição crescente entre brasileiros e portugueses, geralmente envolvidos no comércio e frequentemente culpabilizados pela falta de mantimentos ou pelos altos preços do mercado, somaram-se assim, no período, os conflitos gerados pela presença de emigrados alemães e irlandeses nas ruas do Rio de Janeiro ${ }^{178}$. O descontrole sobre a situação desembocou no motim envolvendo alemães, irlandeses e a população local do Rio de Janeiro em junho de $1828^{179}$ e gerou insegurança entre as diversas camadas da sociedade, chamando ainda mais a atenção para a inabilidade de Pedro I e de seu ministério em acalmarem a situação.

Da Guerra da Cisplatina e do tratado antitráfico, portanto, à crise financeira e ao envolvimento de d. Pedro nas questões sucessórias portuguesas, passando pela vida privada irregrada e indiscreta do imperador, por sua personalidade difícil e pelo ódio cumulativamente gerado na população pelo "gabinete secreto" formado por seus amigos portugueses, tem-se, entre 1826 e 1831, o esgarçamento completo da figura do

\footnotetext{
${ }^{176}$ Para os motivos de sua emigração à Inglaterra e os acontecimentos que os direcionaram ao Brasil ver: John Armitage. Op. cit.; 1981; pp. 177-184.

177 Gladys Sabina Ribeiro. A Liberdade em Construção. Identidade nacional e conflitos antilusitanos no Primeiro Reinado. Rio de Janeiro: Relume Dumará: FAPERJ, 2002.

178 "Desse modo, as ruas tornavam-se um barril de pólvora; proliferaram as tensões do cotidiano, o roubo dos escravos, as fugas, as brigas entre os brancos e mulatos livres e pobres, as bebedeiras, a circulação dos escravos de ganho, e toda uma soldadesca descontente com os uniformes rotos e velhos, com o preço e a escassez de víveres.”. Iara Lis Carvalho Souza. Op. cit.;1999; pp. 327-337.

${ }^{179}$ Gilmar de Paiva dos Santos Pozo. Op. cit. Ver especialmente o capítulo 5.
} 
chefe de Estado, com apoio insustentável, à altura de sua abdicação, inclusive no Senado nacional ${ }^{180}$.

A política ministerial de d. Pedro I chegou, enfim, a um limite. Com trocas constantes de ministros entre 1826 e 1831 (período em que o Gabinete foi alterado por seis vezes), ficava claro que o "sistema pretendido por d. Pedro era frágil, [e] não se baseava em maiorias parlamentares ou em sustentáculos que estabilizassem o sistema político"181. Entre 1830 e 1831 a situação chegou a seu ápice, com uma inconstância política acentuada, uma desconfiança generalizada em qualquer político que aceitasse cargos ministeriais propostos por $d$. Pedro e a inviabilidade de se enxergar um possível desdobramento à crise.

Neste contexto, destaquemos uma vez mais, até mesmo os senadores diminuíram o enfrentamento imposto à Câmara dos deputados, passando a admitir a reunião das duas casas em Assembleia Geral para a votação de projetos de lei emperrados e enfraquecendo ainda mais a posição do imperador, já sem qualquer anteparo político.

Com a morte de Libero Badaró, aos 20 de novembro de 1830, e os conturbados acontecimentos que se seguiram, como a viagem de d. Pedro a Minas Gerais ${ }^{182}$, a conhecida "Noite das Garrafadas" e o enfrentamento de parte dos deputados à prisão de oficiais contrários ao monarca envolvidos no episódio, as idas e vindas ministeriais do imperador - que, em cerca de um mês, nomeou um Gabinete composto por

\footnotetext{
${ }^{180}$ Vale ressaltar que, ao longo da primeira legislatura imperial, a relação entre a Câmara dos Deputados e o Senado brasileiro foi quase sempre de hostilidade e tensão, com a casa vitalícia atuando, por diversas vezes, como anteparo do imperador na interceptação de projetos oriundos da Câmara baixa. Chama a atenção, nesse sentido, que entre os anos de 1830 e 1831 o Senado tenha prescindindo do papel de defensor do monarca e, em circunstâncias específicas, se unido aos deputados em sua oposição ao governo. Para esta temática ver: Vantuil Pereira. Op. cit.; 2010; pp. 157-169.

${ }^{181}$ Gladys Ribeiro e Vantuil Pereira. Op. cit.; p. 162.

182 Em Minas Gerais, aos 22 de fevereiro de 1831, d. Pedro publicou uma polêmica declaração em que, referindo-se à presença de um "partido desorganizador" no Império do Brasil, associou os pretensos intentos oposicionistas de tal partido às circunstâncias revolucionárias vividas pela França em 1830, quando Carlos X fora deposto pela população e o "rei cidadão" Luis Felipe assumira o trono. A associação explicitamente realizada por d. Pedro I e a importância que teve, no Brasil, a revolução ocorrida na França em julho de 1830 (com referências nos debates parlamentares e até mesmo em discussões do Conselho de Estado), deram ensejo a uma série de análises nas quais a crise da monarquia absoluta na França é diretamente relacionada ao exacerbamento da oposição articulada pela Câmara dos deputados brasileira ao imperador. Ver: Roderick J. Barman. Op. cit.; pp. 157-158; Leslie Bethell e José Murilo de Carvalho. Op. cit.; p. 708; e José Maria Frederico de Sousa Pinto e Bernardes Augusto Nascentes Azambuja. O Código Criminal Explicado ou Analyse Jurídica e Philosophica da Carta de Lei de 16 de Dezembro de 1830. Rio de Janeiro: Na Typographia de Gueffier e Ca $C^{\text {a }}$ 1832; pp. 144-145. A íntegra da declaração de d. Pedro pode ser encontrada em: John Armitage. Op. cit. ; 1981; p. 215.
} 
membros da oposição e o dissolveu em nome de outro formado por seus mais próximos conselheiros -, acirraram incontornavelmente os ânimos da população e das tropas e desembocaram na abdicação do trono, aos 6 de abril de $1831^{183}$.

[Àquela altura] Mais do que o Parlamento, as ruas passaram a dar a tônica dos acontecimentos. Era a manifestação de que a soberania e a representação da nação deveriam ser alteradas, a opinião pública fundia-se em torno de uma nova interpretação acerca da liberdade. Momentaneamente, e ao contrário de 1823, a Câmara dos Deputados curvara o imperador e o trono. Venceu a disputa iniciada em 1827 sem, contudo, superar os impasses nela contidos ${ }^{184}$.

Às vésperas da abdicação, o enfraquecimento de d. Pedro I era tão patente que resultara na incapacidade, ou impossibilidade, sua e do Senado brasileiro, de se opor à aprovação de leis explicitamente elaboradas em contraposição ao governo. Foi assim, por exemplo, com a lei da liberdade de imprensa e com o Código Criminal do Império do Brasil.

A discussão de uma lei sobre os abusos da liberdade de imprensa havia sido uma prioridade dos deputados brasileiros desde a abertura da Assembleia Geral, em 1826. Deste modo, aos 10 de junho deste ano, Joaquim Gonçalves Ledo (envolvido na defesa da liberdade de imprensa desde pelo menos 1822, na qualidade de redator do Revérbero Constitucional Fluminense e de debatedor das questões concernentes à liberdade de expressão no Brasil ${ }^{185}$ ) apresentou à Câmara um projeto sobre o assunto, que prontamente desencadeou debates entre os parlamentares. De acordo com Tassia Toffoli Nunes, naquele momento, a liberdade de imprensa foi identificada, pelos deputados, com a consolidação do regime constitucional-representantivo do país, e a liberdade de expressão pública defendida em oposição à instauração de qualquer tipo de censura prévia aos impressos ${ }^{186}$.

Os debates gerados pelo projeto de Ledo logo deixaram clara a presença de dois grupos com opiniões distintas acerca da questão. Enquanto o primeiro, formado por deputados mais próximos a d. Pedro, defendia limites mais estreitos para o exercício

${ }^{183}$ Para os últimos atos da novela da abdicação ver: Iara Lis Carvalho Souza. Op. cit.; pp. 342-348.

${ }^{184}$ Gladys Ribeiro e Vantuil Pereira. Op. cit.; p. 165-166. Para os desdobramentos políticos do Primeiro Reinado e o desenlace na abdicação de d. Pedro ver também: "A Fundação de um Império Liberal. Primeiro Reinado: reação e revolução". In: Sérgio Buarque de Holanda (org.). História Geral da Civilização Brasileira. Tomo II: O Brasil Monárquico. Vol.I: O Processo de Emancipação. São Paulo: DIFEL, 1970; pp. 379-404.

${ }^{185}$ Ver: Tassia Toffoli Nunes. Liberdade de imprensa no Império brasileiro: os debates parlamentares (1820-1840). Dissertação de Mestrado; FFLCH/USP; 2010; pp.39-46.

186 Idem. Para a discussão desenvolvida neste e nos dois próximos parágrafos ver especialmente o capítulo 3 da dissertação de Nunes: pp.70-108. 
da imprensa, buscando conter as então constantes críticas à atuação do imperador e ressaltando o potencial destrutivo e desagregador que a imprensa poderia desempenhar numa nação em formação, como o Brasil, o segundo grupo, composto por deputados pertencentes à oposição parlamentar que então se formava na Câmara, advogava por uma abordagem mais permissiva da atividade periodística, valorizando a crítica e o debate, e identificando na repressão a verdadeira ameaça à coesão nacional e às instituições representativas.

Em 1827, após três discussões na Câmara baixa, o projeto da futura lei de imprensa seguiu para o Senado, onde entrou em discussão apenas em maio de 1829. Nos debates travados no interior da Câmara alta, notou-se, uma vez mais, a identificação realizada pelos representantes brasileiros entre a promulgação da lei de liberdade de imprensa, o bom funcionamento do regime representativo no país, a educação, ou esclarecimento, da população, e a manutenção da segurança estatal.

Nas Falas do Trono enunciadas por d. Pedro I em 1829 e 1830, nota-se a preocupação crescente, de sua parte, com a atuação dos jornalistas da oposição e seu apelo ao Parlamento pela adoção de medidas contrárias aos abusos da imprensa. A lei aprovada aos 20 de setembro de 1830, contudo, diferentemente dos desígnios do imperador, possuía caráter bastante liberal - em especial se comparada ao decreto sobre o abuso da liberdade de imprensa que a antecedeu, promulgado aos 22 de novembro de 1823, a partir do projeto elaborado pela comissão de constituição da Assembleia constituinte ${ }^{187}$-, representando uma vitória da oposição.

Ainda que promulgada unicamente em setembro de 1830, devemos atentar ao fato de a lei contra os abusos da liberdade de imprensa já estar praticamente pronta em

\footnotetext{
${ }^{187}$ Comparando-se o texto de 1823 ao de 1830 nota-se, dentre outras coisas: (i) a prescrição de penas menores, em 1830, à maioria dos delitos regulados, com especial atenção à diminuição das penas estabelecidas para o crime de incitamento à rebelião, considerado o mais grave da lei de 1823; (ii) a permissão, presente em 1830, de se empreender análises "razoáveis" dos princípios e usos religiosos da Constituição do Império e demais leis existentes; e (iii) a não criminalização das censuras realizadas aos atos do governo e à administração pública, desde que apresentadas em termos decentes e comedidos. Destaca-se ainda, no âmbito processual: (i) o fato de o júri passar a ser integralmente eletivo em 1830, diferentemente do caso da lei de 1823, em que o corpo de jurados era indicado pelo juiz de direito, funcionário direto do governo central; e (ii) o fato de as apelações em segunda instância retornarem, pela lei de 1830, a um novo julgamento por jurados, enquanto em 1823 eram julgadas pela segunda vez por magistrados togados. As leis de imprensa de 1823 e 1830 podem ser consultadas, em: http://www.camara.gov.br/Internet/InfDoc/conteudo/colecoes/Legislacao/Legimp-F 107.pdf (1823; pp. 89-94) e http://www2.camara.leg.br/legin/fed/lei_sn/1824-1899/lei-37987-20setembro-1830-565654-publicacaooriginal-89402-pl.html (1830).
} 
1827, quando enviada pela Câmara ao Senado nacional. Já àquela altura, portanto, os deputados brasileiros encontravam-se imbuídos de um espírito amplamente liberal e de oposição ao imperador. No que diz respeito ao Senado brasileiro, como dissemos, ainda que este houvesse tentado atrasar a aprovação da lei o máximo possível, como fizera também com outros projetos vindos da Câmara, como a Lei de Responsabilidade dos Ministros de Estado, postergando sua discussão e votação, à altura de 1829 não era mais possível ignorar as dificuldades por que passava o governo e a força da oposição. Neste sentido, tornou-se necessária a avaliação da lei elaborada pela deputação nacional, a qual retornou à Câmara baixa, com algumas emendas, em 1830, sendo finalmente aprovada no mês de setembro.

Passado pouquíssimo tempo de sua aprovação, foi promulgado, aos 16 de dezembro de 1830, o Código Criminal do Império do Brasil, que englobou a competência relativa à questão do abuso da liberdade de imprensa. Regulados entre os crimes públicos, particulares e policiais do diploma penal imperial, os delitos relacionados ao abuso da liberdade de imprensa foram ainda mais liberalizados pelo Código de $1830^{188}$.

Como no caso da lei de imprensa, a aprovação do código penal é também reveladora da fragilidade absoluta em que, à altura de 1830, encontrava-se o governo de d. Pedro I. Em tramitação no Parlamento brasileiro desde 1827, o texto do código penal sofreu alterações significativas entre 1829 e 1830 (empreendidas, especialmente, pelas três últimas comissões de trabalho dedicadas ao seu texto), refletindo as disputas políticas vividas pela nação naquele momento e materializando a audácia assumida pelos deputados em seu enfrentamento ao monarca. $\mathrm{O}$ fato de nem o monarca, nem o Senado terem conseguido, ou ao menos tentado, barrar a aprovação

\footnotetext{
${ }^{188}$ Sendo assim, nos casos de incitamento a crimes políticos, como a tentativa de destruição da independência do Império ou de parte do texto de sua Constituição, a pena de prisão foi diminuída em alguns anos pelo artigo 90 do código penal; já o crime de incitamento à rebelião por meio da imprensa foi eliminado do Código de 1830, sendo substituído, contudo, pela possibilidade de incitamento à sedição, insurreição e resistência à execução das ordens legais das autoridades constituídas, cuja pena foi, uma vez mais, consideravelmente diminuída; no que dizia respeito aos crimes de injúria ou calúnia contra particulares, por sua vez, as penas foram aumentadas pelo texto do código criminal em relação à lei anterior; por fim, no âmbito dos crimes contra a religião, moral e bons costumes, o Código de 1830 diminuiu novamente as punições anteriormente reguladas pela lei de 20 de setembro que, de prisão de dois a seis anos, passaram a admitir a prisão por um a seis meses, demonstrando já não ser esta uma preocupação do governo imperial. Cabe ainda frisar que, no tocante ao processo judicial a ser empreendido nos casos de crimes de abuso da liberdade de imprensa, o Código de Processo Criminal brasileiro de 1832 também viria liberalizar ainda mais os procedimentos penais previamente determinados pela lei de 20 de setembro de 1830 .
} 
deste documento, nos parece demonstrativo da insustentabilidade do governo àquela altura e da força conquistada pela oposição ${ }^{189}$.

O Código Criminal de 1830 eliminou, assim, a pena de morte de seus crimes políticos, não regulou delitos especificamente dirigidos contra vida do Imperador (como fizeram praticamente todos os códigos do período), aboliu de suas prescrições o crime de alta traição, e optou por uma regulamentação bastante particular de delitos públicos como os de conspiração, rebelião, insurreição e falsificação de moedas. Como procuraremos demonstrar à frente, tais particularidades do texto do diploma penal foram marcadas pelo momento político específico de sua elaboração e pelos projetos de Justiça e Estado nacional mobilizados por parte da deputação.

De acordo com Thomas Flory, nada reflete melhor a tensão existente entre o Parlamento brasileiro e d. Pedro I, às vésperas da abdicação, do que as cláusulas amplamente liberalizantes do Código de 1830 no tocante à definição e castigo dos crimes políticos. Para o autor, os liberais que se opunham ao imperador e desejavam restringir seu poder de perseguição a inimigos políticos, teriam atuado (sob a desculpa de humanização das leis penais portuguesas) inclinando o código penal a favor dos dissidentes e revolucionários que, em última instância, eram eles mesmos.

Faltaban cinco meses para la abdicación del emperador cuando se aprobó el Código Penal. Probablemente Pedro I ya preveía lo que iba a suceder, y la erosión gradual pero constante de su autoridad judicial por estatutos aprobados desde 1827 debe haber contribuido a que formara su decisión. Al irle quitando a la Corona sus prerrogativas judiciales tradicionales (primero con la creación de una magistratura local independiente, y luego codificando leyes que colocaban a la oposición, al emperador, fuera del alcance de los tribunales superiores conservadores), la oposición liberal había legislado que el emperador quedara inmovilizado para gobernar. ${ }^{190}$

Também para Monica Duarte Dantas, as cláusulas penais adotadas pelo Código Criminal de 1830 no tocante aos crimes políticos revelam a centralidade assumida por este documento no combate ao imperador. Para além disso, a autora destaca a importância que a detecção das fontes estrangeiras utilizadas pelos legisladores

\footnotetext{
${ }^{189}$ Aprovado na Câmara dos deputados aos 23 de outubro de 1830, o texto final do futuro código foi analisado, na sequência, pela Comissão de Legislação do Senado que emitiu, aos 23 de novembro, parecer confirmando sua admissão. Na sessão em que leu o parecer, o senador Rodrigues de Carvalho aconselhou a adoção do código sem quaisquer alterações, deixando as possíveis correções de seu texto para o que a prática fosse mostrando digno de reforma, sem, desta forma, privar o Império do benefício que resultaria de sua admissão. Anais do Senado Federal/Anais do Império; 1830; vol. 3; sessão de 23 de novembro; p. 578. Disponível em: http://www.senado.gov.br/anais/.

${ }^{190}$ Thomas Flory. Op. cit.; p. 174.
} 
brasileiros na elaboração do diploma penal do Império pode ter no desvendamento dos significados mais profundos inerentes a este documento. Para Dantas, o modo específico com que foram elaborados os códigos criminal, de 1830, e de processo penal, de 1832, é indicativo da crença partilhada pelos legisladores brasileiros no poder de alteração da realidade pela via do direito, bem como de seu desejo de edificação de uma justiça cidadã (de modelo anglo-saxônico) e de cunho extremamente liberal, para o Império do Brasil ${ }^{191}$.

Seguindo, assim, as pistas abertas por estes historiadores, analisemos cuidadosamente, na sequência, o processo de elaboração parlamentar do texto do Código Criminal de 1830 (capítulo 2) e os institutos especificamente adotados em sua composição final (capítulo 3). Neste percurso, atentemos às reviravoltas políticas envolvidas em sua elaboração, investigando os trabalhos realizados pelas diferentes comissões parlamentares por que passou o seu texto, e comparemos seu resultado final àquele de um conjunto importante de códigos penais que o precederam no mundo ocidental, destacando as semelhanças e diferenças existentes entre seus textos e as especificidades inerentes ao código nacional.

Antes disso, contudo, vale analisar brevemente os projetos de Código Criminal apresentados à Câmara dos deputados brasileira, em 1826 e 1827, pelos deputados José Clemente Pereira e Bernardo Pereira de Vasconcelos.

\subsection{Os projetos para o primeiro Código Criminal do Império do Brasil}

A separação política formal entre Brasil e Portugal, em 1822, e a Constituição brasileira de 1824 desencadearam mudanças há muito discutidas no âmbito da legislação penal ocidental. Na esteira da aprovação da Carta Constitucional, que previa a realização (urgente) de um Código Civil e Criminal para a nova unidade política que se formava ("fundado nas sólidas bases da justiça e equidade"192), houve

\footnotetext{
${ }^{191}$ Monica Duarte Dantas. "Constituição, poderes e cidadania na formação do Estadonacional brasileiro." In: Fórum Rumos da Cidadania. São Paulo: Instituto Prometheus de Estudos Ambientais, Culturais e Políticos, 2010. Idem. "Revoltas, Motins, Revoluções: das Ordenações ao Código Criminal". In: Idem (org.) Revoltas, motins, revoluções: homens livres pobres e libertos no Brasil do século XIX. São Paulo: Alameda Editorial, 2011. Idem. "O Código de Processo Criminal e a Reforma de 1841: dois modelos de organização do Estado (e suas instâncias de negociação)." Conferência apresentada junto ao IV Congresso do Instituto Brasileiro de História do Direito - Autonomia do direito: configurações do jurídico entre a política e a sociedade. São Paulo, Faculdade de Direito/USP, 2009.

192 Artigo 179, parágrafo $18 . \quad$ Em: http://www.planalto.gov.br/ccivil 03/constituicao/constituiçao24.htm.
} 
consenso entre os parlamentares para que se legislasse prioritariamente sobre matérias criminais.

Aos 12 de maio de 1826, numa das primeiras sessões regulares da legislatura, discutiu-se já o tema da codificação penal. Enquanto o deputado Silva Maia propôs, na ocasião, que se convidasse com urgência a comissão de legislação da Câmara a indicar as medidas a serem tomadas para a organização dos códigos civil e criminal do Brasil, Pires Ferreira enviou à mesa uma moção nos seguintes termos: "Proponho que se decrete um premio a quem dentro do espaço de dois annos apresentar o melhor projecto de codigo." 193

De acordo com Andréa Slemian, este fato por si só indica a importância e grandiosidade que a tarefa da codificação assumia naquele contexto, tocando fundo no desafio de construção de um campo de direito nacional para o Império do Brasil por mais que subsistissem conflitos entre os contemporâneos sobre as bases de sua unidade política (herdeira da implosão da unidade imperial portuguesa) ${ }^{194}$.

$\mathrm{Na}$ sessão de $1^{\circ}$ de agosto de 1826 o deputado José da Cruz Ferreira (eleito pelo Rio de Janeiro) leu um parecer da comissão de legislação e justiça civil e criminal da Câmara (emitido aos 16 de julho do mesmo ano) em que, partindo-se das propostas de Silva Maia e Pires Ferreira, prescrevia-se uma ordem à elaboração dos códigos de que necessitava o país recém-independente. Para além de uma interessante análise da inadequação das leis então em vigor no país, o parecer estabelecia a forma com que se deveriam organizar os códigos civil, criminal, comercial e militar brasileiros, bem como o modo com que se deveriam desenvolver os trabalhos relativos a esta elaboração. Dizia o parecer - ao qual retornaremos com maior cuidado à frente:

Para se obterem estes codigos, parece à commissão ser conveniente que a camara convide os sabios e jurisconsultos a emprehender este arduo trabalho por todos aquelles meios que podem excitar o genio [...]. Os que quizerem concorrer ao premio deverão apresentar os codigos de que se tiverem encarregado à assembléa dentro de dous annos. ${ }^{195}$

\footnotetext{
${ }^{193}$ Anais do Parlamento Brasileiro - Câmara dos Deputados (doravante APB-CD). Sessão de 12 de maio de 1826. Disponível em: http://imagem.camara.gov.br/diarios.asp.

194 Andréa Slemian, "À nação independente, um novo ordenamento jurídico: a criação dos Códigos Criminal e do Processo Penal na primeira década do Império do Brasil." In: Gladys Sabina Ribeiro (org.), Brasileiros e cidadãos. Modernidade política. São Paulo: Alameda, 2008, pp.175-206; pp. 175-179.

${ }^{195}$ APB-CD, sessão de 1 de agosto de 1826. Em: http://imagem.camara.gov.br/diarios.asp; p. 16
} 
A esta altura o deputado José Clemente Pereira já havia apresentado à Câmara, em sessão de 3 de Junho de 1826, as possíveis bases de um código criminal para o Império do Brasil. Nas sessões de 4 de maio e 16 de maio de 1827 seriam apresentados, por sua vez, dois projetos completos de Código Criminal para o país, respectivamente elaborados pelos deputados Bernardo Pereira de Vasconcelos e (novamente) José Clemente Pereira.

\section{As "Bases" ao Código Criminal de José Clemente Pereira}

$\mathrm{Na}$ sessão de 3 de junho de 1826, falando a seus colegas de plenário, José Clemente Pereira (deputado de origem lusitana eleito pelo Rio de Janeiro) ${ }^{196}$ confirmava a preocupação comum aos primeiros legisladores do Império com a organização de um diploma criminal para o país recém-independente. Não era, entretanto, um projeto completo o que o deputado vinha apresentar à Câmara naquela ocasião, mas antes o arrolamento de alguns princípios e regulamentações gerais que, em sua opinião, deveriam tomar parte no futuro documento.

Em seu discurso, Clemente Pereira reconhecia a inaplicabilidade das Ordenações Filipinas (especialmente de seu Livro V, no caso) ao Império do Brasil e afirmava advirem da falta de uma codificação penal nacional os males cotidianamente experimentados na administração da justiça no país.

Sendo, pois, conhecida a utilidade e necessidade que temos deste codigo, que não poderá ser obra de um momento, por depender de profunda meditação e estudo, emprehendi ordenar um projecto sobre os principios modernamente admittidos e comecei a formar alguns dos titulos que necessariamente deverão entrar no codigo criminal. Porém, depois de ter adiantado algum trabalho sobre as bases que havia estabelecido, lembrei-me que talvez estas mesmas bases houvessem que soffrer grandes alterações, e que neste caso estava derribado todo o edificio que houvesse levantado sobre ellas, e todo o meu trabalho perdido. ${ }^{197}$

\footnotetext{
${ }^{196}$ José Clemente Pereira nasceu em Portugal no ano de 1787 e morreu no Rio de Janeiro em 1854, aos 66 anos. Ainda em Portugal, cursou Direito e Cânones na Universidade de Coimbra. Veio ao Brasil em 1815 onde inicialmente exerceu o cargo de juiz de fora na vila da Praia Grande, hoje cidade de Niterói. Foi eleito deputado pelo Rio de Janeiro para a legislatura de 1826 e novamente para 1830 e 1838. D. Pedro II nomeou-o ministro da Guerra em 23 de março de 1841, senador em 31 de dezembro de 1842, conselheiro de estado em 14 de setembro de 1850 e primeiro presidente do Tribunal do Comércio em 4 de setembro do mesmo ano. Organizações e programas ministeriais. Regime parlamentar no Império, $2^{\mathrm{a}}$ ed., Rio de Janeiro, 1962, 279-289 (obra redigida em 1889, por determinação da Câmara dos deputados, pelo barão de Javari): S. A. Sisson. Galeria dos Brasileiros Ilustres. Brasília: Senado federal, 1999, vol.1, pp. 41-46. Também disponível em: http://www.brasiliana.usp.br/bbd/handle/1918/01139110\#page/1/mode/1up.

${ }_{197}$ APB-CD; sessão de 3 de junho de 1826. Em: http://imagem.camara.gov.br/diarios.asp; p.15.
} 
Clemente Pereira optava, portanto, por publicizar as premissas que havia organizado para o futuro código criminal brasileiro - submetendo-as às possíveis reformas e melhoramentos julgados necessários por seus colegas -, para somente então retomar seu trabalho compositivo.

Por este modo não só poderão ellas suscitar algumas idéas a qualquer outro, que se tenha dado a este trabalho, mas servir-me-hão depois para proseguir no meu plano com mais segurança, esperando que na proxima futura sessão me seja possivel apresentar o projecto do codigo criminal fundado nas bases que forem approvadas.

Transcritas nos Anais da Câmara dos deputados em sequência à fala de Clemente Pereira (sessão de 6 de junho de 1826), tais bases compunham-se de um Livro Primeiro, denominado Dos Crimes e das Penas, e de seus dois primeiros Títulos, respectivamente (I) "Dos crimes em Geral e seus autores", dividido em dois capítulos, e (II) "Das Penas", composto por 8 capítulos ${ }^{198}$.

O primeiro artigo do documento definia, ao longo de quatro parágrafos, a compreensão de "crime" adotada por Clemente Pereira. De acordo com este artigo, era crime $\left(\S 1^{\circ}\right)$ toda infração voluntária das leis penais; $\left(\S 2^{\circ}\right)$ a omissão voluntária de um fato mandado praticar por lei; $\left(\S 3^{\circ}\right)$ a desobediência aos mandados das autoridades constituídas; e, por fim, $\left(\S 4^{\circ}\right)$ a tentativa de perpetrar um crime que se não completasse em razão de forças estranhas à vontade do delinqüente.

Delimitado o entendimento de crime, o artigo $2^{\circ}$ das bases estabelecia que: "A violação das leis economicas ou de policia, são contravenções e não crimes, que a lei pune com as penas meramente correccionaes.”. Já nos artigos terceiro e quarto tinhase que "a simples tentativa para violar estas leis, em nenhum caso póde ser julgada contravenção" e que nenhum fato ou omissão poderia ser julgado crime ou contravenção sem prévia declaração de lei anterior.

O Capítulo II ("Dos autores e dos crimes") do mesmo Titulo I definia, por sua vez, os critérios de autoria e cumplicidade acatados pelas bases, estabelecendo ainda limites etários fixos à responsabilização penal.

Já o Titulo II do mesmo documento contava com oito capítulos dedicados à tipificação das penas admitidas e à regulamentação da sua aplicação. Tendo-se separado os delitos do diploma em "crimes" e "contravenções" (artigos $1^{\circ}$ e $2^{\circ}$ ), o

\footnotetext{
${ }^{198}$ O índice das "Bases" apresentadas por Clemente Pereira encontra-se transcrito no Anexo I desta dissertação.
} 
autor apresentava também a categorização das punições previstas em cada caso ${ }^{199}$. Referindo-se à aplicação de "penas meramente correccionaes" aos casos de crimes de contravenção, Clemente Pereira não definiu, contudo, ao longo do projeto, quais seriam precisamente as punições aplicadas a tais ocorrências.

O Capítulo I do título em questão, pretensamente referente às "Penas em geral", dizia respeito, portanto, sem explicitá-lo, unicamente às chamadas penas criminais, divididas, segundo o modelo penal francês, em "aflitivas e infamatórias" ou unicamente "aflitivas" (art. 12). A primeira destas categorias compunha-se das penas de morte, desnaturalização, trabalhos perpétuos e prisão perpétua, e a segunda do degredo perpétuo ou temporário, trabalhos temporários, prisão temporária, suspensão dos direitos políticos e multa ${ }^{200}$.

Para Clemente Pereira, portanto, à parte as penas correcionais, o código criminal brasileiro deveria admitir sete tipos de punição: morte, trabalhos públicos, prisão, desnaturalização, degredo, suspensão dos direitos políticos e multa; reconhecendo-se ainda três graus à sua imputação - máximo, médio e mínimo -, a serem definidos a partir da presença ou ausência de circunstâncias agravantes ou "agravantíssimas" em cada caso.

No primeiro capítulo do Titulo II ficava estabelecido ainda que, em caso de reincidência, as punições seriam duplicadas, e que o crime cometido durante o

\footnotetext{
${ }^{199}$ A divisão adotada por parte dos códigos penais oitocentistas entre as categorias de crime, delito e contravenções de polícia, com as conseqüentes divisões punitivas daí advindas, foi bastante controversa durante o século XIX. Para parte dos juristas envolvidos na questão, tal categorização dos crimes - pautada por suas diferenças de gravidade - cumpria papel fundamental na organização dos códigos penais. Já para os juristas opostos à classificação, tal divisão não era admissível por fundar-se em critérios unicamente referentes à materialidade das punições, negando quaisquer princípios classificatórios intrínsecos à natureza dos fatos criminais ou à sua maior ou menor gravidade. É nesse sentido, por exemplo, que no livro Tratado de Direito Penal Rossi afirma: "É dizer ao público: não vos embaraceis de examinar a natureza intrínseca das ações humanas, olhai para o poder: se fizer cortar a cabeça de um homem, daí conclui que este homem é um grande malvado." (p. 61) Para Thomaz Alves Jr., por sua vez: "Se a maior gravidade de uns [crimes] e menor de outros servisse para essa distinção, ela devia ser a priori conhecida, e não feita segundo a gravidade da pena, que vem a ser em última análise o único meio de se conhecer essa divisão.” (p. 63) APUD: Thomaz Alves Jr. Annotações teoricas e practicas ao Código Criminal. Rio de Janeiro: Francisco Luiz Pinto \& Ca. Tomo I; 1864; pp. 59-64.

${ }^{200} \mathrm{O}$ Código Penal francês de 1810 que, veremos à frente, exerceu grande influência sobre a produção penal de José Clemente Pereira, não apenas dividiu suas infrações nas categorias de "contravention" "crime" e "délit", como também suas penas em "matière criminelle" e "matière correctionnelle", separando ainda as primeiras em "peines afflictives et infamantes" e "peines infamantes". "Code des délits et de peines ». In : Corps de Droit Français, civil commercial et criminel. Par L. Rondonneau. Paris, Garnery Libraire, 1810 ; pp. 439-486.
} 
cumprimento de sentença seria considerado circunstância "agravantíssima" para a imposição do máximo da pena prevista. Vale ressaltar também que se o artigo 15 das bases de Clemente Pereira recusava o acúmulo de punições corporais em uma única sentença (estabelecendo que o réu acusado por mais de um crime a que estivessem impostas penas corporais sofresse apenas a maior dentre elas), seu artigo 17 excluía desta regulamentação os réus escravos - passíveis de serem condenados às penas de trabalhos públicos e açoites, por exemplo, em uma só sentença.

Por fim, dentre os capítulos I e VIII do Titulo II definia-se os detalhes referentes ao entendimento e aplicação precisa das sete punições admitidas pelas bases.

Como se vê, os dois títulos apresentados por Clemente Pereira à Câmara estabeleciam de fato os princípios gerais sobre os quais o deputado pretendia desenvolver o restante de seu projeto de código criminal; destacando-se a atitude de Clemente Pereira de expô-los ao restante da deputação, sujeitando-os às suas críticas e possíveis reformas.

Um parecer emitido aos 10 de julho de 1826 (e lido em sessão de $1^{\circ}$ de agosto do mesmo ano) pela comissão de legislação e justiça civil e criminal da Câmara composta pelos deputados José da Cruz Ferreira (eleito pelo Rio de Janeiro), Antonio Augusto da Silva (BA) e Antonio da Silva Telles (BA) - vinha, neste sentido, responder aos anseios de Clemente Pereira. Admitia-se, por meio dele: a conformidade das "Bases" do deputado aos princípios de justiça e equidade prescritos pela Constituição de 1824 , e a anuência da comissão ao uso das mesmas para a elaboração de um código completo. O parecer estabelecia ainda que, independentemente dos méritos do documento, os interessados em apresentar outros projetos à Assembleia não estariam obrigados a fundar-se nos mesmos princípios ali esquematizados, ficando livres para, em conformidade com a Constituição, o direito universal e as luzes do século, elaborarem códigos fundados em sistemas diversos ou em um distinto ordenamento das matérias ${ }^{201}$.

\section{O Projeto de Código Criminal de Bernardo Pereira de Vasconcelos}

Aos 04 de maio de 1827 foi a vez do deputado Bernardo Pereira de Vasconcelos (eleito por Minas Gerais) $^{202}$ entregar à Câmara um exemplar do projeto de código

\footnotetext{
${ }^{201}$ APB-CD: http://imagem.camara.gov.br/diarios.asp, p.16.

${ }^{202}$ Bernardo Pereira de Vasconcelos nasceu em Ouro Preto, Minas Gerais, em 1795; em 1813 foi a Portugal, onde estudou Direito na Universidade de Coimbra e de onde retornou ao Brasil
} 
criminal por ele elaborado nos meses anteriores. Nos anais da referida sessão consta uma vaga referência à entrega do projeto, transcrita nos seguintes termos: "O Sr. Vasconcellos mandou à mesa um projecto de codigo criminal, que ficou para se lhe dar destino." ${ }^{203} \mathrm{Na}$ sessão do dia seguinte, 5 de maio de 1827, a leitura do projeto passou já à ordem do dia, tendo sido dispensada na sequência - a partir de proposta do deputado Francisco de Paula Souza e Melo (SP), presidente da sessão - por ter sido considerada de conteúdo muito volumoso:

Perguntou o Sr. presidente, que destino se devia dar ao projecto do $\mathrm{Sr}$. Vasconcellos; e o Sr. Cavalcante lembrou que seria bom crear uma commissão especial, visto ser objecto de muita importancia; e depois de fallarem no mesmo sentido os Srs. Clemente Pereira, Souza França e Vasconcellos; venceu-se que ficasse adiado o destino deste projecto, até que apresentado o seu parecer pela commissão especial para a refórma do regimento, se fizessem as que fossem approvadas.

O texto dos anais é dúbio quanto ao destino dado ao projeto de Vasconcelos: teria este documento passado às mãos de uma comissão especial da Câmara quase imediatamente após sua entrega, ou a decisão pelo adiamento do seu destino o teria deixado de lado por um determinado espaço de tempo? Ainda que não possamos responder precisamente esta questão, sabemos que, talvez por não ter sido lido nas sessões de 4 e 5 de maio de 1827, o projeto de Vasconcelos (diferentemente das bases de Clemente Pereira) não se encontra transcrito nos Anais deste ano, constando apenas ao final do $3^{\circ}$ tomo dos Anais da Câmara do ano de 1829.

Ao final da transcrição do projeto tem-se a seguinte observação:

Este projecto não se encontra, em sua integra, nem nos Diarios da Camara, nem nas actas impressas, nem nas actas manuscriptas, e nem nos jornaes do tempo. Inserimol-o porque foi sobre suas disposições que se formulou o codigo criminal, monumento legislativo de nossos maiores. À solicitude do illustrado representante da nação o Sr. Conselheiro Tristão de Alencar Araripe devemos o avulso impresso que servio de base a esta publicação ${ }^{204}$.

em 1820. Foi deputado geral, por Minas Gerais, entre 1826 e 1837, senador de 1838 até 1850 (ano de sua morte), conselheiro de Estado também de 1842 até sua morte, Ministro da Fazenda entre 1831 e 1832, Ministro da Justiça e do Império de 1837 a 1839 e Ministro do Império em 1840. José Murilo de Carvalho (org.). Bernardo Pereira de Vasconcelos. São Paulo: Ed. 34, 1999; pp. 9-34.

${ }^{203}$ APB-CD, sessão de 4 de maio de 1827; em: http://imagem.camara.gov.br/diarios.asp, p.16. 204 APB-CD; pp. 95-109; buscar pela sessão de 03 de setembro de 1829. Embora não possamos confirmar se o exemplar do projeto de Vasconcelos cedido por Tristão de Alencar Araripe havia sido, ou não, fruto da impressão e distribuição deste documento aos membros do Parlamento (impressão e distribuição esta determinada pela Comissão especial do código criminal, em parecer lido aos 14 de agosto de 1827), sabemos, contudo, que este projeto havia sido posto à venda no país, em janeiro de 1827 , e anunciado pelo jornal $O$ Universal. Otavio 
O "Projecto do Codigo Criminal" elaborado pelo deputado mineiro compunha-se de uma única parte (Parte Primeira) denominada Dos crimes e das penas, em cujo interior encontravam-se distribuídos os cinco seguintes títulos: (I) "Dos crimes e penas em geral", (II) "Dos crimes policiaes", (III) "Dos crimes particulares", (IV) "Dos delictos públicos" e (V) "Disposição Geral”; totalizando 334 artigos ${ }^{205}$.

Seu Titulo I, "Dos crimes e penas em geral”, compunha-se de seis capítulos - (I) "Dos criminosos", (II) "Dos delictos justificáveis", (III) "Das circumstancias aggravantes e attenuantes dos delictos", (IV) "Da satisfacção", (V) "Das penas ou castigos (palavras synonimas!)" e, por fim, (VI) "Da prescripção e do perdão das penas" - totalizando 109 artigos. Tratava-se do título do projeto de Vasconcelos com o maior número de artigos.

Como se nota pela própria denominação dada a estes capítulos, seus artigos definiam os entendimentos de crime e criminoso presentes no projeto, as circunstâncias agravantes e atenuantes dos delitos e o modo com que os réus deveriam satisfazer os danos causados por seus crimes. O Titulo I regulava ainda, ao longo de seus capítulos V e VI, as penas acatadas pelo código e os detalhes referentes à sua aplicação. Neste sentido, vê-se que o projeto de Vasconcelos se iniciava com o estabelecimento de uma teoria geral do delito e da pena, ou seja, com uma definição dos axiomas do direito penal aí regulado.

O projeto admitia onze punições: morte, galés, prisão com trabalho, simples prisão, banimento, desterro, infâmia, multa, perda dos objetos do crime, caução e vigilância da justiça; todas elas listadas pelo artigo 56 .

Diferentemente das bases apresentadas por Clemente Pereira, para além do estabelecimento de princípios gerais para a imputação de crimes e penas, o projeto de Vasconcelos contava com outros quatro títulos dedicados à regulamentação de disposições referentes a delitos policiais, particulares e públicos (apresentados nesta ordem)

O Titulo II do projeto, denominado "Dos crimes policiais", compunha-se de 17 artigos e regulava, em um só bloco, crimes como os de uso de armas proibidas,

Tarquínio de Sousa. História dos fundadores do Império do Brasil, v.5: Bernardo Pereira de Vasconcelos. Rio de Janeiro: Livraria José Olympio, 1960; p.61.

205 "Projecto do código Criminal apresentada em sessão de 4 de maio de 1827 pelo deputado Bernardo pereira de Vasconcellos", APB-CD, 1829, tomo $3^{\circ}$, Rio de Janeiro, Typographia de H. J. Pinto, 1877; pp. 95-109. O índice do "Projecto do Código Criminal" elaborado por Bernardo Pereira de Vasconcelos encontra-se transcrito no Anexo II desta dissertação. 
ajuntamentos ilícitos, sociedades secretas, ofensas à religião e uso indevido da imprensa. O Titulo III ("Dos crimes particulares"), subdividido em sete capítulos específicos e composto por 99 artigos, tratava, por sua vez, de crimes contra as pessoas, a honra, a propriedade, o estado doméstico e civil, e ainda dos crimes morais.

Composto por quatro capítulos e totalizando 107 artigos, o Titulo IV, referente aos delitos públicos, regulava os crimes contra a ordem interior do Império (inclusos aí os crimes dos funcionários públicos da nação e o delitos de resistência, forçamento de cadeia, sedição e falsidade) e o tesouro público, e os casos de ameaça à segurança interna e externa do país (compreendidos aí, dentre outros, os delitos de traição, atentado à Constituição, rebelião, provocação de nação estrangeira a guerrear com o Brasil, violação de tratados e pirataria).

O Titulo V, por fim, dedicado às "Disposições Gerais" do projeto, contava com dois artigos dedicados a esclarecer que o código apresentado não compreendia os crimes militares ou os delitos contra o comércio, os quais, na ausência de códigos próprios, continuariam a ser julgados da mesma forma com que o vinham sendo até então.

Se no que diz respeito à sua estruturação binária - dividida em regras gerais válidas para o conjunto do texto e numa regulamentação posterior dos casos específicos de crimes policiais, particulares e públicos - pode-se reconhecer, de maneira geral, a adequação do projeto de Vasconcelos à arquitetura do direito penal coevo $^{206}$, a organização adotada na regulamentação dos crimes específicos do projeto e, particularmente, o ordenamento dado às matérias dos Títulos II, III e IV, não nos parecem condizentes com o "padrão organizacional" dos códigos e projetos de codificação penal modernos existentes no período.

Orientado, primeiramente, pela divisão dos códigos penais em uma Parte Geral e uma Parte Especial - contendo a primeira as regras gerais de "crime" e "respostas penais" e, a segunda, as disposições específicas e variáveis de cada delito, organizadas segundo o bem jurídico protegido (vida, patrimônio, segurança interna etc.) - tal padrão regulava-se ainda, na maioria dos códigos existentes, por um

\footnotetext{
${ }^{206}$ Rafael Mafei Rabelo Queiroz. A teoria penal de P.J.A. Feuerbach e os juristas brasileiros do século XIX: a construção do direito penal contemporâneo na obra de P.J.A. Feuerbach e sua consolidação entre os penalistas do Brasil. Tese de Doutorado. São Paulo: FD/USP; 2009; p. 83.
} 
ordenamento específico, no interior da Parte Especial, dos tipos de crime previstos, organizados em função da distinta gravidade dos interesses atingidos ${ }^{207}$.

Embora, como vimos, o Projeto de Vasconcelos se conformasse à divisão dos códigos do período em Parte Geral e Parte Especial, ele configurava exceção no que dizia respeito ao ordenamento ou disposição dos delitos ao longo de sua parte específica.

Pudemos reconhecer, no interior da Parte Especial dos códigos consultados ${ }^{208}$, a predominância de um tratamento inicial dado aos crimes públicos, seguidos pelos crimes particulares e, em alguns casos, pelas infrações de polícia. Organizavam-se desta forma os Códigos penais austríacos de 1787 (Josefina) $^{209}$ e $1803^{210}$; os Códigos penais franceses de 1791 e $1810^{211}$; a Algemeines Landrecht prussiana de $1794^{212}$; e o Código espanhol de $1822^{213}$. A única exceção real dentre os códigos analisados (no que diz respeito a este ordenamento), encontrava-se no Código Bávaro de $1813^{214}$, cujo texto dividia-se não só em um livro para crimes e outro para delitos, mas cujo ordenamento, no interior de cada livro, prescrevia primeiramente crimes/delitos particulares e posteriormente crimes/delitos públicos ${ }^{215}$.

\footnotetext{
${ }^{207}$ Rafael Mafei Rabelo Queiroz. Op. cit.; p. 77

${ }^{208}$ Como afirmado na Introdução, recorremos, ao longo da pesquisa, à análise de dez códigos penais, ou projetos de codificação penal, vigentes, no Ocidente, quando da elaboração do projeto de Vasconcelos e da aprovação do Código brasileiro de 1830. Para além de uma análise interna ao texto destes códigos ocidentais, seu conteúdo foi detalhadamente comparado ao dos projetos brasileiros apresentados em 1827 e ao do Código de 1830.

${ }^{209}$ The Emperor New Code of Criminal Laws. Published at Vienna, the $15^{\text {th }}$ of January, 1787. Translated from the German, by an officer. Dublin: Printed by John Rea, 1787.

${ }^{210}$ Codice Penale Universale Austriaco coll' Appendice delle Piú Recenti Norme Generali. Seconda edizione ufficiale. Milano, Dall'Imp. Regia Stamperia, 1815. Code Pénal Général de l'empire d'Autriche, par M. Victor Foucher, Paris, Imprimerie Royale, 1833, disponível em http://gallica.bnf.fr.

${ }^{211}$ Lois de la Rébublique Française an IV [...] Code des Delits et des Peines, 1791; disponível em http://gallica.bnf.fr, consultado em 07/07/2010; e «Code des délits et de peines ». In : Corps de Droit Français, civil commercial et criminel. Par L. Rondonneau. Paris, Garnery Libraire, 1810 ; pp. 439-486.

${ }^{212}$ Code General pour lês États Prussiens, traduit por les Membres du bureau de Législation étrangère, et publié par ordre du Ministre de la Justice. Paris, Imprimerie de la République, ano IX (1801), 3 volumes. Ver Titulo XX : « Des délits et des peines »; pp. 136-356.

${ }^{213}$ Código Penal Español, Decretado por las Cortes en 8 de Junio, Sancionado por El Rey, y mandado promulgar en 9 de julio de 1822. Madrid, Imprenta Nacional, año de 1822.

${ }^{214}$ Code Penal du Royame de Bavière (1813). Traduit de l'Allemand par Ch. Vatel. Paris, Auguste-Durand, Libraire-Éditeur, 1852.

215 Excluímos desta análise comparativa a Leopoldina (Código da Toscana de 1786) e o Projeto português de Pascoal de Melo Freire (também de 1786), por sua organização em quase tudo distinta das anteriormente citadas. Para uma avaliação específica do caso do
} 
Vê-se assim que, por motivos que por hora desconhecemos, Vasconcelos optou por uma organização bastante diferente da sistemática predominante à época ao elaborar o seu projeto de código penal. Como comentado na Introdução desta dissertação, o percurso histórico traçado pelos códigos penais do mundo ocidental expôs, progressivamente, a importância política desempenhada por estes documentos e os bens públicos e estatais privilegiadamente protegidos pelos mesmos. Nesse sentido, não é de se estranhar o fato de a grande maioria dos códigos do período regulamentar prioritariamente seus crimes públicos e políticos, tornando-os assim os primeiros de suas partes especiais.

Haja vista a adequação do projeto de Vasconcelos a uma série de outros parâmetros da codificação do período e, ainda, o fato de o mesmo basear-se explicitamente, como veremos, em modelos prévios da positivação penal - fundados na divisão crimes públicos, particulares e policiais - chama a atenção a originalidade impressa pelo deputado neste quesito específico de seu código criminal.

\section{O Projeto completo de José Clemente Pereira}

Dentre os estudos dedicados ao Código de 1830 sempre constou que os projetos entregues à Câmara dos deputados foram, respectivamente, as bases de Clemente Pereira e o projeto completo de Bernardo Pereira de Vasconcelos. Uma leitura atenta dos Anais do Parlamento brasileiro e, especialmente, do parecer emitido aos 14 de agosto de 1827 pela Comissão especial do código criminal - "encarregada de examinar os dous projectos do codigo criminal, apresentados a esta camara pelos illustres deputados, os Srs. Clemente Pereira e Vasconcellos [... $]^{, 216}$-, apontou, contudo, desde o início da pesquisa, à possibilidade de José Clemente Pereira ter apresentado também, para além de suas bases, um projeto completo de código penal.

A pesquisa nos Anais revelou que, de fato, em sessão de 16 de maio de 1827, Clemente Pereira submeteu à Câmara baixa a primeira parte de um projeto completo de código criminal. $\mathrm{Na}$ ocasião, o deputado relembrou seus colegas das bases apresentadas em 1826 e comentou o parecer então emitido sobre as mesmas. Agora, dizia:

[...] tenho a honra de apresentar hoje a esta camara (e remetteu) a primeira parte do projecto criminal, isto é, o livro primeiro que trata dos crimes e penas, e não ultimei

Projeto Melo Freire ver: António Manuel Hespanha. Da Iustitia à Disciplina, especialmente pp. 543-544.

${ }^{216}$ Idem; sessão de 14 de agosto de 1827, pp. 130-131. 
o trabalho do processo, que deve fazer o objecto do livro segundo do codigo criminal, por alguns embaraços e difficuldades sobre a marcha que deve ter o mesmo processo, que se me offerecerão, e para aplanar, as quaes pretendo consultar primeiro a vontade da camara.

Demais o processo sobre que deve marchar a machina do codigo dos crimes e penas, sobre o merecimento deste mesmo projecto e systema seguido nelle, decidirá a camara: e se elle merecer a sua consideração terei a honra de apresentar a segunda parte em harmonia com o projecto que trata dos crimes e das penas.

Como este projeto não se encontra transcrito em nenhum dos volumes dos Anais da Câmara dos deputados, sua existência passou despercebida, até hoje, pela historiografia nacional. Descobrimos recentemente, contudo, a existência de um exemplar impresso do projeto completo de Clemente Pereira na seção de obras raras do Arquivo da Biblioteca Nacional (RJ) ${ }^{217}$, o qual pretendemos analisar brevemente na sequência.

O projeto de código criminal oferecido à Câmara dos deputados, em 16 de maio de 1827, por José Clemente Pereira compunha-se de 33 Títulos - subdivididos, em alguns casos, em capítulos específicos -, totalizando $278 \operatorname{artigos}^{218}$. Os Títulos I e II deste projeto, denominados respectivamente "Dos crimes em geral, e seus autores" e "Das penas", configuravam o que poderíamos denominar a Parte Geral do documento, prescrevendo regras gerais (para a imputação de crimes e penas) válidas para todo o seu conteúdo subseqüente.

No Titulo I, subdividido em dois capítulos ("Dos crimes" e "Dos autores dos crimes"), definiam-se os entendimentos de crime, autoria e responsabilidade penal acatados pelo projeto. Neste ponto, vale ressaltar, o documento de 1827 era exatamente igual às bases de 1826 .

No Titulo II, composto por cinco capítulos - (I) "Das penas em geral”, (II) "Da pena de morte", (III) "Da pena de trabalhos públicos", (IV) "Da pena de prizão", e (V) "Da pena de multa" - definia-se e regulava-se o modo de aplicação de cada uma das punições admitidas pelo diploma. Em termos gerais, as disposições presentes neste documento e nas bases de 1826 eram também as mesmas, havendo, contudo, uma diferença interessante no que dizia respeito às punições admitidas em cada caso. Enquanto em 1826 tínhamos a prescrição de sete tipos de penas (morte, trabalhos

\footnotetext{
${ }^{217}$ José Clemente Pereira. "Projecto do Código Criminal do Império do Brasil". Biblioteca Nacional; seção de obras raras. Ex. 2: C, 05, 11. Projeto Especial (2001). Localização do microfilme: OR 00168[2].

${ }^{218}$ O índice do Projeto de José Clemente Pereira encontra-se transcrito no Anexo III desta dissertação.
} 
públicos, prisão, desnaturalização, degredo, suspensão dos direitos políticos e multa), em 1827 elas eram unicamente quatro (morte, trabalhos públicos, prisão e multa). Suas definições específicas, apesar de bastante parecidas às de 1826, sofreram também, em alguns casos, modificações pontuais.

No que dizia respeito, portanto, aos dois títulos previamente regulados pelas bases de 1826, Clemente Pereira não acrescentou nada além de alterações pontuais na regulamentação das penas; tendo retirado, contudo, deste conjunto de artigos, a prescrição de punições específicas.

No que se referia, por sua vez, à "Parte Especial" do documento, pode-se dizer que, assim como na Leopoldina ${ }^{219}$ e no Projeto Melo Freire ${ }^{220}$, o projeto de Clemente Pereira não estabelecia uma disposição precisa à regulamentação dos delitos. Apesar de existir, dentre o conjunto de títulos de sua Parte Especial, um ordenamento geral que partia dos crimes públicos, passava pelos particulares e desembocava nos policiais, havia, no meio do caminho, alguns desvios de rota ${ }^{221}$. Além disso, a Parte Especial deste projeto não se encontrava dividida, como no caso de Vasconcelos e da maioria dos outros códigos analisados, em três ou quatro grandes partes ou títulos relativos a tipos penais gerais (públicos, policiais, particulares), abordando-se cada crime, ou conjunto de crimes - bem como suas regulamentações específicas -, ao longo de 31 títulos variados e sequencialmente numerados ${ }^{222}$.

${ }^{219}$ Nouveau Code Criminel pour le Grande Duche de Toscane (1786). Publié par ordre de Son Altesse Royale Monseigneur Le Grand Duc. Traduit de L'Italien a Lausanne, chez François Grasset et Comp. Libraires \& Imprimeurs, 1787.

${ }^{220}$ Pascoal José de Mello Freire, Código criminal intentado pela Rainha D. Maria I, Coimbra, Imprensa da Universidade, 1844, "Provas do Direito Criminal" (disponível no site http://www.fd.unl.pt).

${ }^{221}$ Apesar de os crimes públicos e particulares terem sido regulados sequencialmente seguidos, ao final do projeto, por um título (XXXII) exclusivamente dedicado às contravenções de polícia -, os crimes que o entendimento presente no Código de 1830 definiria como policiais foram prescritos em diversas partes deste documento, fosse entre o conjunto dos crimes públicos, fosse entre os particulares. No segundo capítulo de sua dissertação de Mestrado, Mariana Pedron Macário (a quem cedemos uma cópia do microfilme com o Projeto de Clemente Pereira) faz uma boa descrição da organização deste projeto. Mariana Pedron Macário. Op. cit.; pp. 63-67.

222 Os 31 Títulos que compõem a "Parte Especial" deste Projeto são: (III) "Dos crimes contra a Religião do Império"; (IV) "Das injurias feitas ao Imperador, e Familia Real"; (V) "Dos crimes contra as garantias da Constituição Política do Império"; (VI) "Dos crimes contra a segurança externa do Império"; (VII) Dos crimes contra a segurança interna do Império"; (VIII) "Das sociedades secretas"; (IX) "Dos crimes de resistencia publica"; (X) "Dos crimes de desobediencia aos mandados das Authoridades constituídas"; (XI) "Da falta de respeito devido aos que exercem Poder"; (XII) "Dos crimes contra a tranquilidade publica"; (XIII) "Das prevaricações, abusos, e ommissões dos Empregados Públicos"; (XIV) "Do crime de Moeda falsa"; (XV) "Do crime de Falsidade"; (XVI) "Do crime de Perjúrio"; (XVII) "Do 
É possível que a matriz organizacional do projeto de Clemente Pereira tenha advindo do projeto elaborado por Pascoal de Melo Freire, para Portugal, em 1786, já que, dentre todos os códigos e projetos analisados, o de Melo Freire foi o único a se organizar (como o de Clemente Pereira) inteiramente por títulos. Na disposição especificamente adotada em cada caso, contudo, os dois documentos se distinguem pela admissão, por Clemente Pereira, de artigos seqüenciais (numerados, ininterruptamente, do 1 ao 278), enquanto os "artigos" (na verdade parágrafos) dos títulos do Projeto Melo Freire são totalmente independentes uns dos outros referentes unicamente aos Títulos de que fazem parte e numerados, portanto, desde o número 1 , a cada novo título.

Uma vez mais, portanto, o conhecimento prévio dos padrões ocidentais da codificação penal e o recurso efetivo a tal repertório na elaboração de um código penal para o Brasil não impediram que, como Vasconcelos, o projeto finalmente apresentado por Clemente Pereira mantivesse inúmeras particularidades e se distinguisse, em vários aspectos, do conjunto que indubitavelmente lhe servira de referência.

No que tange aos delitos especificamente regulados entre os Títulos III e XXXIII deste projeto, podemos reconhecer aí a presença dos principais tipos penais previstos pelos códigos do período, tais como os crimes contra a Constituição política e a segurança interna e externa do Império, os cometidos pelos funcionários da nação, os de resistências às autoridades, falsificações e perjúrios, para além, obviamente, dos crimes particulares regulados em defesa da pessoa, honra e propriedade, e dos crimes, ditos policiais, de vadiagem, mendicância e jogos proibidos.

\section{Projetos em diálogo}

Se à análise das particularidades presentes na organização geral de cada um destes projetos somarmos uma comparação substantiva de seus conteúdos, veremos saltar

crime de Calumnia"; (XVIII) "Do crime de Injuria"; (XIX) "Dos crimes de Sodomia, Bestialidade, e Molície"; (XX) "Do crime de Bigamia"; (XXI) "Do crime de adultério"; (XXII) "Do crime de Rapto e Estupro"; (XXIII) "Do crime de Lenocínio"; (XXIV) "Do crime de Homicídio"; (XXVI) "Do crime de Ferimentos"; (XXVII) "Do crime de Furto"; (XXVIII) "Do crime de quebra dolosa"; (XXIX) "Dos crimes contra o Commercio Publico"; (XXX) "Dos que usão nomes, titulos, uniformes, condecorações, ou distinctivos indevidos"; (XXXI) Do damno causado por culpa, ou dolo"; (XXXII) "Dos vadios, mendigos e jogadores"; (XXXII) "Das contravenções de Policia, e boa ordem Publica"; (XXXIII) "Disposições Geraes". 
aos olhos, de imediato, as diferenças existentes entre os documentos apresentados por Vasconcelos e Clemente Pereira no ano de 1827.

Atentando, primeiramente, à Parte Geral dos dois projetos, nota-se que as mesmas se distinguem, entre outros fatores, pelo conjunto das matérias reguladas, pelas penas admitidas em cada caso, por seus distintos entendimentos de crime e criminoso e ainda pela utilização das matrizes do direito penal ocidental.

No que se refere ao conjunto de matérias reguladas pela Parte Geral de cada um dos documentos nota-se, pela simples citação dos títulos e capítulos que as compunham $^{223}$, que o Projeto de Vasconcelos é bem mais completo que o de Clemente Pereira neste ponto: regulando, para além das definições de crime e criminoso e das punições acatadas pelo código, os casos de crimes justificáveis, as circunstâncias agravantes e atenuantes dos delitos, a necessidade de satisfação, pelos réus, dos danos causados por seus crimes e as possibilidades de prescrição e perdão das penas.

Também na definição de crime presente em cada um dos documentos encontramos diferenças interessantes. Assim, enquanto o Projeto de Clemente Pereira entendia como crime as ações e omissões voluntárias contrárias às leis penais, as tentativas frustradas e a desobediência às ordens legais, no texto de Vasconcelos, para além de não se especificar a questão do voluntarismo na perpetração de um crime (característica que analisaremos com maior cuidado à frente), tem-se duas definições suplementares às de Clemente Pereira: o abuso de poder (uso do poder conferido por lei contra os interesses públicos ou em prejuízo de particulares) e a negação de auxílio àquele que se encontrasse em perigo.

$\mathrm{Na}$ configuração dada por cada um dos documentos ao crime de tentativa nos deparamos, simultaneamente, com um substrato teórico comum aos dois autores (código penal francês de 1810) e com duas distintas interpretações do mesmo. Sendo assim, se tanto Vasconcelos quanto Clemente Pereira haviam optado pela concepção francesa do crime de tentativa - concepção bastante autoritária, de acordo com a qual a tentativa era punida com as mesmas penas previstas ao crime consumado -, o fato de apenas Clemente Pereira ter acatado a divisão francesa entre "crimes" e “contravenções” (“art. $2^{\circ}$. As infracções que as Leis punem com penas correccionaes,

\footnotetext{
${ }^{223}$ Para uma melhor visualização dos títulos e capítulos da Parte Geral de cada um dos documentos ver os anexos II e III desta dissertação.
} 
são contravenções, e não crimes." ${ }^{224}$ ), mudou o modo com que a questão foi resolvida em cada caso. Seguindo, portanto, o modelo de 1810, Clemente Pereira estabelecia que, diferentemente da tentativa de se perpetrar um crime, a tentativa de contravenção não poderia, de forma alguma, ser punida ${ }^{225}$, enquanto o projeto de Vasconcelos, que não acatara a divisão entre crimes e contravenções, estabelecia um limite penal preciso abaixo do qual não se poderia punir a mera tentativa ${ }^{226}$

É na definição e regulamentação das penas, contudo, que aparecem as maiores diferenças entre as Partes Gerais dos dois projetos. Tais diferenças, por sua vez, advêm não só do entendimento geral que se tem das punições em cada caso, mas também dos diferentes conjuntos de penas tipificados por cada um dos documentos.

Nesse sentido, enquanto Vasconcelos igualou, ao menos nominalmente, as penas a castigos ("palavras synonimas"), e estabeleceu que os criminosos fossem punidos com uma ou mais dentre as onze punições estabelecidas no artigo 56 de seu projeto, Clemente Pereira compartimentalizou as quatro punições (criminais) previstas em seu diploma em dois conjuntos principais: primeiramente, o das penas aflitivas e infamatórias, formado pelas penas de morte e trabalhos públicos perpétuos, e, em segundo lugar, o das penas somente aflitivas, composto pelas penas de trabalhos públicos temporários, prisão e multa.

Como na diferenciação entre crimes e contravenções, também neste caso pode-se notar a forte influência exercida pelo Código penal francês de 1810 sobre o deputado lusitano. De acordo com o sexto artigo do código francês: "Les peines en matière criminelle sont ou afflictives et infamantes, ou seulement infamantes.".

\footnotetext{
${ }^{224}$ Apesar de claramente inspirado no direito penal francês, nota-se aqui o empreendimento de uma adaptação nacional à categorização das infrações criminais tal como presente no código francês de 1810: "Art.1. L'infraction que les lois punissent de peines de police est une contravention. L'infraction que les lois punissent de peines correctionnelles est un délit. L'infraction que les lois punissent d'une peine afflictive ou infamante est un crime." É interessante notar ainda como, no primeiro artigo de seu projeto, também sob clara influência da definição francesa de 1810, Clemente Pereira faz uso da palavra "infracção" ("Art.1. He crime / Toda a infracção voluntária das Leis criminaes") sem, no entanto, utilizá-la em nenhum outro momento do código.

${ }^{225}$ Comparemos, nesse sentido, o terceiro artigo do código francês de 1810 , ao também terceiro artigo de Clemente Pereira: "Les tentatives de délits ne sont considérées comme délits, que dans le cas déterminés par une disposition spéciale de la loi." e "A simples tentativa para violar estas Leis [que a lei pune com penas correcionais], em nenhum caso pode ser punida."

${ }^{226}$ No segundo parágrafo de seu artigo $1^{\circ}$, portanto, Vasconcelos estabelecia: “[...]Não é punível a tentativa de crime, a que não esteja imposta maior pena, que a de dous mezes de prisão ou desterro para fóra da comarca, salvo havendo especial declaração de lei."
} 
Diferentemente do caso francês, portanto, à parte as penas simultaneamente aflitivas e infamatórias, o projeto de Clemente Pereira individualizou as penas unicamente aflitivas (enquanto o francês compartimentalizou as infamatórias) e prescreveu a cada um destes conjuntos um rol de punições bastante distinto do admitido pelo diploma francês; mostrando como, também neste ponto, a herança francesa foi elaborada e resignificada por Clemente Pereira.

Ainda sob a influência do Código francês, Clemente Pereira distinguiu das punições criminais de seu projeto aquelas especificamente correcionais. Diferentemente do diploma estrangeiro novamente, que estabelecera penas específicas aos casos correcionais ("emprisonnement à temps dans un lieu de correction", "interdiction à tempe de certains droits civiques, civils ou de famille" e "amende"), o projeto brasileiro fez referência, em seu artigo 38, unicamente à "prisão correccional", prescrevendo-a por 16 vezes em sua Parte Especial ${ }^{227}$, sem definir o modo preciso de sua aplicação.

No que diz respeito, por sua vez, à regulamentação das penas de morte e trabalhos públicos, nota-se uma vez mais a influência exercida pelo diploma penal francês sobre Clemente Pereira. Como nos outros casos citados, contudo, há "originalidade" no uso feito pelo deputado desta fonte ocidental. Assim, ainda que seu projeto se aproxime do código penal francês em diversos momentos (não apenas em sua Parte Geral, mas ao longo de parcela significativa de seus 31 títulos subseqüentes, como veremos), não se pode reduzir tal inspiração a uma simples cópia da parte de Clemente Pereira. Na grande maioria dos casos, houve, antes, adaptações das prescrições originais às particularidades do projeto brasileiro, dando-se às mesmas uma feição própria e condizente ao conjunto do texto que se pretendia discutir.

Como vimos, das sete punições previstas nas "Bases" de Clemente Pereira, apenas quatro permaneceram em seu texto final, tendo sido eliminadas do projeto as penas de desnaturalização, degredo e suspensão dos direitos políticos. No que diz respeito ainda à pena de trabalhos públicos (presente em ambos os documentos), entre $1826 \mathrm{e}$ 1827 Clemente Pereira a dividiu, assim como no código francês, em dois tipos principais: trabalhos públicos perpétuos e trabalhos públicos temporários ${ }^{228}$.

\footnotetext{
${ }^{227}$ Mais especificamente nos artigos 137 e 138 (crime de desafio); 241, 242 e 244 (dano causado por culpa ou dolo); 248 e 251 (vadiagem); 252, 253, 254 e 256 (mendicância); 258 e 262 (jogadores); e 265, 266 e 267 (contravenções de polícia).

${ }^{228}$ Enquanto pelas bases de 1826 os réus condenados a trabalhos públicos perpétuos ou temporários deveriam ser empregados em serviço da Nação a arbítrio do governo, com
} 
Às quatro penas reguladas pelo projeto de Clemente Pereira, contudo, poderíamos somar ainda as seguintes punições, que, inexistentes em sua Parte Geral, apareceram em artigos específicos de sua Parte Especial: perda ou suspensão do emprego, prescrita em cerca de 13 artigos do projeto; perda de armas ou mercadorias proibidas, prevista em seis casos; e ainda um caso de prescrição da pena de desnaturalização (supostamente eliminada deste projeto entre 1826 e 1827, como vimos acima), no artigo 80 deste documento ${ }^{229}$.

O projeto de Vasconcelos, por sua vez, listava em seu artigo 56 as onze punições admitidas: morte, galés, prisão com trabalho, simples prisão, banimento, desterro, infâmia, multa, perda dos objetos do crime, caução e vigilância da justiça. Vale a pena observar, contudo, que destas 11 punições, duas não apareceram em momento algum do código (penas de infâmia e de caução), sendo que uma terceira, a de vigilância da justiça, foi prescrita uma única vez ao longo dos 225 artigos que compunham sua Parte Especial.

Dentre as outras oito penas elencadas pelo artigo 56, devemos somar ainda, fazendo jus ao real conteúdo daquele documento, não somente a pena de açoites, prescrita pelo artigo 97, ainda que não elencada no 56, mas também as penas de suspensão e perda do emprego (que juntas apareceram por cerca de 61 vezes ao longo de todo o projeto) e a pena de talião, prescrita quatro vezes ao longo de sua Parte Especial.

calceta no pé e corrente de ferro, juntos ou separados (segundo a qualidade do serviço); pelo projeto de 1827 (Artigo 30), tal regulamentação se aplicaria apenas aos condenados a trabalhos públicos em caráter perpétuo. Quanto aos réus sentenciados a trabalhos públicos temporários, o novo projeto previa o seu emprego em serviço da Nação análogo às suas forças, a ser cumprido no interior das casas de prisão e sem calceta nos pés. Quanto às mulheres, que pelo texto de 1826 não poderiam ser empregadas nos mesmos serviços que os homens e nem utilizar calceta nos pés, pelo artigo 30 do projeto de 1827 tinha-se que as mesmas deveriam cumprir suas sentenças também no interior das casas de prisão, ainda quando condenadas a trabalhos públicos perpétuos. Por fim, o artigo 30 definia que os escravos cumpririam sempre a pena de trabalhos públicos (fossem estes perpétuos ou temporários) em lugares públicos. Interessante atentar para o fato de que o artigo 31 deste Projeto (assim como o artigo 29 das "Bases" de 1826) estabelecia que sob hipótese alguma poderiam ser presos na mesma corrente réus condenados por crimes de diversa natureza, nem homens livres com escravos ou aqueles com notável diferença na cor ou idade.

229 "Art. 80. Se algum Brasileiro pegar em armas a favor de huma Nação inimiga, que estiver em guerra com o Brasil, e chegar a entrar em acção contra as Tropas do Imperio, será condemnado á morte: se esta circunstancia se não verificar, será desnaturalisado." 
$\mathrm{Na}$ definição de parte destas penas por Vasconcelos, podemos notar novamente (como no Projeto de Clemente Pereira) a influência exercida pelo Código penal francês de 1810. Se na pena de morte, como vimos, o Projeto de Clemente Pereira já se baseara neste diploma penal, em Vasconcelos tal inspiração é ainda mais clara. No que diz respeito à pena de galés, por exemplo, o deputado mineiro a definia de maneira bem próxima à pena de trabalhos forçados do código francês ${ }^{230}$. Para além destas, também as penas de banimento e vigilância da justiça compunham o conjunto das punições previamente reguladas pelo diploma francês de 1810 e acatadas por Vasconcelos.

Vê-se, portanto, que a inspiração dos dois deputados em uma mesma fonte penal não significou, necessariamente, a adoção de prescrições comuns ou a construção de um edifício penal fundado nos mesmos critérios e definições. Diferentemente disto, a absorção da influência francesa por cada um dos documentos mostrou-se bastante distinta, dando origem a códigos com feições extremamente diversas, fosse em termos organizacionais, fosse no que diz respeito ao conteúdo específico de suas Partes Geral e Especial.

Para finalizar a comparação entre as Partes Gerais destes projetos, vale a pena atentarmos brevemente ao fato de que ambos possuíam ao menos uma regulamentação especificamente destinada aos réus escravos. Nesse sentido, o artigo 18 de Clemente Pereira definia que os réus escravos poderiam ser condenados a duas penas corporais (como a de trabalhos públicos e a de açoites) em uma só sentença, e que nunca receberiam as penas de prisão ou multa. Nos crimes em que a prisão tivesse lugar, os cativos receberiam a pena de trabalhos públicos pelo mesmo tempo, e nos casos em que se prescrevia a multa como punição, seriam eles açoitados de $100 \mathrm{a}$ 200 vezes. Assim que tivesse sido executado o castigo, dizia o artigo, o escravo deveria ser devolvido a seu senhor. Em seu artigo 30, o projeto estabelecia, por fim,

\footnotetext{
${ }^{230}$ Enquanto o artigo 15 do código francês de 1810 estabelecia, assim, que: "Les hommes condamnés aux travaux forcés seront employés aux travaus les plus pénibles; ils traîneront a leurs pieds un boulet, ou seront attachés deux à deux avec une chaine, lorsque la nature du travail auquel ils seront employés le permettra."; o artigo 72 do projeto de Vasconcelos previa: "Os réos condemnados a galés andarão com calceta no pé, e corrente de ferro, juntos dous a dous, ou separados segundo a qualidade do serviço. [...]”".
} 
que os réus escravos condenados a trabalhos públicos temporários cumprissem suas penas em espaços abertos e nunca no interior das prisões, como os homens livres ${ }^{231}$.

$\mathrm{O}$ artigo 97 do diploma de Vasconcelos, por sua vez, estabelecia que: "Se o réo fôr escravo e o crime capital, soffrerá a pena de morte; se o crime porem não fôr capital será depois de açoutado entregue a seu senhor a quem o deva ser." De acordo com este projeto, portanto, os réus escravos poderiam receber apenas as penas de morte ou açoites, não lhes cabendo nenhuma outra punição, independentemente de sua presença no diploma penal.

A presença comum de semelhantes regulamentações diz muito não apenas sobre a sociedade brasileira de então, e a extensão do sistema escravista em seu interior, mas também sobre a importância assumida por esta questão no momento de positivação das leis penais nacionais. Em se tratando da garantia da ordem pública no Império do Brasil e da proteção jurídica do país contra possíveis convulsões políticas, não espanta a preocupação dos deputados envolvidos nesta tarefa com a presença da escravidão, bem como a "sintonia" encontrada nas regulamentações especificamente prescritas por Clemente Pereira e Vasconcelos no que tangia aos réus escravos.

Elaborados, ambos, em 1827, período de conturbações políticas no Império brasileiro e indefinição quanto aos rumos a serem seguidos pelo novo país, os projetos de código penal apresentados não se furtaram a buscar no texto do diploma francês as diretrizes gerais de imposição da ordem e controle da população (que haviam marcado profundamente, como vimos, o código aprovado em 1810). A extensa utilização de prescrições francesas pelo diploma de Clemente Pereira pode, contudo, explicar sua rejeição futura pelos deputados brasileiros que, como veremos, buscariam se distanciar cada vez mais, no jogo político e no aparelhamento judiciário da nova nação, do modelo napoleônico de governo.

A comparação entre as "Partes Especiais" dos dois projetos é consideravelmente mais difícil de ser empreendida, haja vista as inúmeras distinções organizacionais e de conteúdo, especialmente punitivo, existentes entre elas. O que não se pode deixar de registrar a este respeito, contudo, é que apesar das inegáveis similitudes entre os documentos, uma análise cuidadosa dos mesmos revela a predominância absoluta de

\footnotetext{
${ }^{231}$ Não esqueçamos, neste ponto, que o projeto de Clemente Pereira fora explícito ainda quanto à proibição de se prender numa mesma corrente, para a execução de trabalhos públicos forçados a céu aberto, réus livres e escravos ou homens com diferenças consideráveis de cor (artigo 31).
} 
suas diferenças sobre suas semelhanças. Ainda que se tenha, assim, artigos cujas regulamentações se aproximem bastante nos dois casos, no geral, o modo de definir especificamente cada tipo de crime, ou conjunto de crimes, e suas penas, difere substancialmente entre os dois.

Não podemos deixar de nos referir, contudo, ainda que brevemente, a casos em que as semelhanças existentes entre estes diplomas nos saltaram à vista. Temos assim, na parte referente aos crimes contra a segurança externa do Império - auxílio a nações estrangeiras em "dano" do Império, prática de hostilidades contra nações amigas ou seus representantes, entre outros (Titulo VI no Projeto de Clemente Pereira e Cap. IV do Titulo IV no Projeto de Vasconcelos) - semelhanças bastante significativas devidas, indubitavelmente, à consulta comum a parte dos crimes públicos do Código penal francês de $1810^{232}$.

No que se refere a crimes mais específicos espalhados pelos documentos, tem-se casos emblemáticos de semelhanças, muito provavelmente devidas também à utilização de fontes penais comuns (que, na maioria destes casos, não pudemos identificar) ou ainda a algum tipo de regulamentação legal corrente no país desde a independência ou mesmo desde os tempos coloniais. Os artigos 72 de Clemente Pereira e 131 de Vasconcelos, referentes ao livre trânsito dos cidadãos para fora do Império brasileiro, são, neste sentido, bastante significativos ${ }^{233}$. Também na regulamentação dos crimes de sociedades secretas (Titulo VIII de Clemente Pereira e arts. 122 e 123 de Vasconcelos) e de peculato (arts. 143 de Clemente Pereira e 298 de Vasconcelos) pudemos identificar uma provável fonte comum aos dois projetos ${ }^{234}$.

${ }^{232}$ Para além do código francês de 1810, contudo, a regulamentação dos crimes contra a segurança externa seguiu, nos diferentes países em processo de codificação penal na passagem do século XVIII ao XIX, padrões bastante aproximados.

${ }^{233}$ Dizem o seguinte cada um destes artigos; Clemente Pereira: "Art. 72. Se alguma pessoa obrigar a sahir do Imperio algum Cidadão Brasileiro, sem ser por Sentença do Poder Judiciario; ou impedir, que alguem delle saia, querendo, huma vez que guarde os regulamentos policiaes, e salvo o prejuizo de terceiro, será punido com prizão temporaria, e multa; e se for empregado publico, a pena de multa lhe será commutada na de perdimento do seu Emprego."; Vasconcelos: "Art. 131. O que impedir que alguem se conserve em qualquer parte do imperio, ou saia delle como lhe convenha, levando comsigo os seus bens, guardados os regulamentos policiaes, e salvo o prejuizo de terceiro, será punido com as penas do artigo 129, e com a perda do emprego." Como se vê, são inegáveis as semelhanças existentes entre eles, semelhanças que ultrapassam o que se poderia considerar uma coincidência.

${ }^{234}$ Para o caso do crime de sociedades secretas foi possível reconhecer, na lei de 20 de outubro de 1823, revogatória do alvará passado em 30 de março de 1818 sobre as ditas sociedades, a fonte comum aos dois autores. Destaque seja dado, contudo, ao fato de ambos terem amenizado, em muito, as penas estabelecidas por esta lei, que prescrevia a morte natural e altos períodos de degredo aos réus incursos no crime de sociedade secretas. $\mathrm{O}$ 
Temos ainda, nos dois textos, a regulamentação dos crimes de "molicie"235 e de "alcovitar"236, cuja prescrição desaparecerá completamente do texto final do Código de 1830 .

Pudemos notar ainda, no que diz respeito às Partes Especiais dos dois projetos, um “equilíbrio penal” bastante parecido, com destaque numérico, em ambos os casos, às penas de prisão simples e multa, um aparecimento relativamente pequeno (se comparado ao total das punições previstas) das penas de trabalhos públicos forçados, ou galés, como denominadas por Vasconcelos, e uma regulamentação ainda menor da pena de morte (prevista pelos arts. 80, 100, 133, 197, 198 e 204 do Projeto de Clemente Pereira, e pelos arts. 103, 149, 289, 311 e 313 do Projeto de Vasconcelos).

Já no que se refere às diferenças existentes entre os projetos, podemos analisá-las a partir de dois conjuntos de fatores principais: o dos crimes que, ainda que similarmente denominados, receberam definições quase absolutamente distintas em cada caso (de que damos como exemplos, os crimes de ofensas à religião do Estado, pirataria, furto, vadiagem, mendicância, dano ao patrimônio alheio, entre outros), e o

conteúdo da lei de 20 de outubro de 1823 pode ser acessado através da Coleção de Leis do Império do Brasil, digitalizada no site da Câmara dos deputados: http://www2.camara.leg.br/atividade-legislativa/legislacao/publicacoes/doimperio.

${ }^{235}$ Temos, assim, pelo artigo 180 de Clemente Pereira: "Se alguem commetter crime de sodomia, bestialidade, ou molicie, será punido com seis a doze mezes de prizão no gráo minimo, treze a dezoito no medio, e dezenove a vinte e quatro no maximo.". Já o artigo 184 de Vasconcelos diz: "A molicie, ou a tentativa, será punida com multa correspondente a quinze dias a tres mezes de trabalhos". No dicionário de Antonio de Moraes Silva, o termo "mollicie" vem definido da seguinte forma: "Regalo, coisa conforme aos desejos e gosto da gente molle e afeminada. [...] Peccado da mollicie: pecado opposto à castidade, que consiste na masturbação de homem a homem.”. Antonio de Moraes Silva. Diccionario da Lingua Portugueza, Lisboa, Typographia Lacerdina, 1813. Disponível em: 143.107.31.159/catalogo_eletronico/consultaDicionarios.asp.

${ }^{236}$ No que diz respeito ao crime de "alcovitar", vejamos o conteúdo dos artigos 195 de Clemente Pereira e 182 e 183 de Vasconcelos: "Art. 195. Qualquer pessoa que alcovitar mulher cazada, solteira, que não estiver publicamente prostituida, ou viuva honesta de boa fama, ou consentir, que em sua caza tenha ajuntamento illicito com homem, será condemnada a prizão temporaria."; "Art. 182. Os alcoviteiros, isto é, os que prestarem serviços para se verificarem os crimes desde o art. 176, e tendo este officio por modo de vida, serão punidos com prisão por dous a seis mezes, e multa correspondente." e "Art. 183. Será dobrada a pena do artigo antecedente, quando o alcoviteiro fôr pessoa a quem cumpre zelar a reputação das mulheres offendidas.". Tanto no dicionário de Bluteau quanto no de Moraes e Silva, consta o termo alcovitar. Enquanto pelo de Bluteau consta: "Ser terceiro para concertar illicitos ajuntamentos.", pelo de Moraes e Silva, o termo fica definido como: "Procurar a prostituição de alguma mulher, inculcá-la a quem peque com ella carnalmente." Raphael Bluteau, Vocabulário portuguuez e latino, Coimbra, Colegio das Artes da Companhia de Jesus, 1712; Antonio de Moraes Silva. Op. cit. Ambos disponíveis em: 143.107.31.159/catalogo_eletronico/consultaDicionarios.asp 
dos crimes exclusivamente prescritos em um ou outro documento: fosse no Projeto de Clemente Pereira, que regulou crimes como os de desafio, tumulto, assuada ou ainda, crimes contra o comércio publico, que em momento algum apareceram no Projeto de Vasconcelos; fosse no de Vasconcelos que, por sua vez, regulou com exclusividade crimes como os de estelionato, roubo, matrimônio irregular, simulação e ajuntamentos ilícitos.

Da mesma forma com que pudemos imputar parte das semelhanças identificadas entre estes projetos à consulta concomitante, das partes de Clemente Pereira e Vasconcelos, a uma fonte legal comum, fosse esta estrangeira ou nacional, assim também nos parece possível atribuir suas principais diferenças à consulta a fontes distintas do direito penal.

A principal fonte comum aos dois projetos, como pudemos observar, foi certamente o Código Penal francês de 1810 e, nesse sentido, várias de suas semelhanças podem ser a ele atribuídas. Para além do Código francês, contudo, e para além de uma matriz codificacionista penal comum a quase todo o ocidente àquela altura (da qual dificilmente um código elaborado no período poderia escapar), não pudemos detectar outras matrizes penais concomitantes aos projetos de 1827 .

Se tomarmos como referência, por exemplo, o Projeto de Código Criminal elaborado por Pascoal de Melo Freire para Portugal, veremos que, para além de ter possivelmente servido de inspiração à organização por títulos adotada pelo projeto de Clemente Pereira, este documento não foi utilizado no estabelecimento de qualquer regulamentação específica de seu diploma penal. Situação diferente da encontrada, por sua vez, no texto do projeto elaborado por Bernardo Pereira de Vasconcelos, em que diversos artigos (Gerais e Especiais) remontam indubitavelmente à consulta $\mathrm{e}$ utilização do projeto lusitano ${ }^{237}$

$\mathrm{Na}$ composição de seu projeto de código criminal, como veremos à frente, Vasconcelos faria largo uso ainda dos dispositivos presentes no Código Penal espanhol de 1822; o que, por si só, torna o leque de fontes consultadas por

${ }^{237}$ São exemplos emblemáticos da utilização do Projeto Melo Freire por Vasconcelos, o artigo 44 da sua Parte Geral, baseado no $\$ 35$ do Tit. IV de Melo Freire; o artigo 111, referente aos crimes policiais, baseado no $\$ 7$ do Tit. XXIII de Melo Freire; o $§ 2$ do artigo 213 dos crimes particulares, baseado no $\S 9$ do Tit. XXXIX de Melo Freire; e o artigo 284 dos crimes públicos, baseado no $\S 15$ do Tit. II do Projeto português; entre diversos outros exemplos. 
Vasconcelos significativamente maior que o pretensamente utilizado na redação do diploma penal de Clemente Pereira.

Diferentemente do que tal afirmação pode fazer crer, não ignoramos o fato de que estes deputados estavam elaborando projetos de código criminal para o Brasil, podendo, portanto, muitas vezes, não se basear em nenhum outro diploma penal específico, mas antes em parte da legislação em vigor no país, ou ainda inovarem em muitas de suas prescrições. Neste sentido, inclusive, a análise de cada um destes projetos revelou sua extrema originalidade. Nos parece, assim, que a consulta a diversas fontes do direito penal ou a influência de uma matriz codificacionista ocidental (representada especialmente pelas obras de autores como Cesare Beccaria, Filangieri, Bentham, entre outros) não os teria impedido (especialmente a Bernardo Pereira de Vasconcelos) de elaborar diplomas bastante originais e pensados para a realidade a que deveriam se aplicar. 


\section{Capítulo 2}

\section{O trâmite parlamentar do Código de 1830: debates procedimentais, comissões de trabalho e a manutenção da pena de morte}

Entre 1826 e 1830 os parlamentares brasileiros discutiram com regularidade a necessária positivação das leis penais do Império. $\mathrm{O}$ aparecimento da temática se deu em meio a debates normativos de cunho geral que se foram especificando em torno à questão criminal com o passar dos anos. Se, num primeiro momento, predominaram discussões procedimentais não imediatamente referentes ao conteúdo do código penal planejado para o Império do Brasil, às vésperas da aprovação deste documento travaram-se interessantes embates teóricos e de princípio no plenário da Câmara dos deputados. Paralelamente ao que se discutia no âmbito das sessões da Câmara e do Senado, diversas comissões parlamentares trabalhavam sobre os textos dos projetos de código criminal apresentados por Bernardo Pereira de Vasconcelos e José Clemente Pereira, debruçando-se especialmente sobre o primeiro deles e alterando-lhe o conteúdo e a forma nos pontos considerados necessários.

Este capítulo tem o objetivo de analisar os principais debates travados no Parlamento brasileiro em torno da temática codificacionista como um todo, e do código penal em especial, bem como examinar os trabalhos efetivamente empreendidos por três das cinco comissões parlamentares que, entre 1827 e 1830, dedicaram-se à composição do referido diploma.

Tal proposta de análise tomou corpo fundamentalmente a partir de um exame cuidadoso dos Anais digitalizados da Câmara dos deputados e do Senado brasileiro ${ }^{238}$. Neles encontramos, para além de indícios do caminho percorrido pelos projetos de Vasconcelos e Clemente Pereira, discussões relativas a múltiplos aspectos da elaboração do Código Criminal do Império do Brasil. Ao apresentarmos, entretanto, o trâmite do código penal no Parlamento, não pretendemos permanecer restritos aos registros dos Anais, mas antes unir à sua análise uma nova gama documental que traga novidades factuais e interpretativas à pesquisa.

Dentre os poucos estudos dedicados ao exame do Código Criminal do Império do Brasil, são sensivelmente reduzidos aqueles preocupados em analisar, ou mesmo apresentar, em algum momento, o itinerário de sua elaboração. Dentre as análises

238 Disponíveis em: http://imagem.camara.gov.br/diarios.asp
http://www.senado.gov.br/anais/


empenhadas em tal apresentação, podemos reconhecer a formação de dois grandes grupos: de um lado, o conjunto dos estudos dedicados a uma descrição geral do aparecimento da temática codificacionista penal nas sessões da Câmara e do Senado, citando as diferentes datas em que se abordou o tema e o que se discutiu e decidiu, em termos gerais, em cada um destes momentos ${ }^{239}$ e, de outro lado, uma somatória de trabalhos concentrados sobre um ponto específico deste percurso, qual seja, o dos debates travados em setembro de 1830, na Câmara dos deputados, em torno à manutenção, ou não, da pena de morte no texto do código criminal ${ }^{240}$.

Haja vista a maioria destes estudos ter se baseado exclusivamente nos Anais do Parlamento brasileiro, não surpreende que suas interpretações tenham se mantido restritas ao que foi dito (e registrado), em plenário, por deputados e senadores. À exceção de Monica Duarte Dantas, no artigo Revoltas, Motins, Revoluções: das Ordenações ao Código Criminal ${ }^{241}$, nenhum dos pesquisadores dedicados à questão preocupou-se em aliar verdadeiramente ao exame da documentação fornecida pelos Anais, a investigação de outros documentos relativos à elaboração do Código penal imperial: fossem os projetos apresentados à Câmara em 1827, fossem os registros dos trabalhos de quaisquer das comissões formadas entre 1827 e 1830 (dedicadas ao exame e reformulação dos projetos de código criminal), fosse ainda um exame cuidadoso do texto final do diploma imperial.

${ }^{239}$ Zahidé Machado Neto. Direito penal e estrutura social: comentário sociológico ao Código Criminal de 1830. São Paulo: Saraiva, EDUSP, 1977; pp. 47-72. Bernardino Bravo Lira. "Bicentenario del Código Penal de Austria: Su proyección desde el Danubio a Filipinas", Revista de estudios histórico - jurídicos. Valparaíso, 2004, $\mathrm{n}^{\circ}$. 26. Thomas Flory. El juez de paz y el jurado en el Brasil imperial, 1808-1871: control social y estabilidad política en el nuevo Estado. México: Fondo de Cultura Econômica, 1986; pp. 171-175. Mariana Pedron Macário. José Clemente Pereira e o debate jurídico do Império: 1830-1850. Dissertação de Mestrado. Faculdade de Direito/USP; 2011; pp. 54-63. Andréa Slemian. "À nação independente, um novo ordenamento jurídico: a criação dos Códigos Criminal e do Processo Penal na primeira década do Império do Brasil.” In: Gladys Sabina Ribeiro (org.), Brasileiros e cidadãos. Modernidade política. São Paulo: Alameda, 2008, pp.175-206.

${ }^{240}$ Jurandir Malerba. Os Brancos da Lei: liberalismo, escravidão e mentalidade patriarcal no Império do Brasil. Paraná: Editora da Universidade Estadual de Maringá, 1994; pp. 105-113. Patricia Ann Aufderheide. Order and violence: social deviance and social control in Brazil, 1780-1840. Tese de doutorado, Universidade de Minnesota, 1976; pp. 307-310. João Luiz Ribeiro. No meio das galinhas as baratas não têm razão: a lei de 10 de junho de 1835: os escravos e a pena de morte no Império do Brasil, 1822-1889. Rio de Janeiro: Renovar: 2005; pp. 22-28.

${ }^{241}$ Monica Duarte Dantas. "Revoltas, Motins, Revoluções: das Ordenações ao Código Criminal". In: Idem (org.). Revoltas, motins, revoluções: homens livres pobres e libertos no Brasil do século XIX. São Paulo: Alameda Editorial, 2011; pp. 7-67; pp. 16-37. 
No artigo supracitado, Monica Dantas pôde superar grande parte das análises consagradas acerca deste código justamente ao unir a um exame cuidadoso dos Anais da Câmara e do Senado, uma leitura igualmente minuciosa (e comparativa) do projeto de Bernardo Pereira de Vasconcelos e do texto final do Código de 1830. A partir, portanto, desta análise conjunta e, à primeira vista, bastante simples (já que efetuada sobre um rol documental acessível há bastante tempo), Dantas pôde reavaliar a leitura historiográfica "oficial" acerca da elaboração deste documento e abrir uma série de frentes para a renovação dos estudos da História do direito no Império do Brasil.

No âmbito da presente dissertação, pretendemos levar a pesquisa relativa à elaboração deste documento ainda além, incorporando a uma leitura atenta dos Anais do Parlamento, o exame dos projetos de Vasconcelos e Clemente Pereira - para além do próprio Código Criminal de 1830 - e uma análise dos trabalhos desenvolvidos pelas comissões parlamentares responsáveis pela elaboração do texto de que se comporia, enfim, o código aprovado.

A renúncia a um exame detalhado da elaboração do Código penal brasileiro tem feito com que os diferentes estudos a ele dedicados deixem passar em branco as minúcias envolvidas em sua composição. Baseado nestes estudos, o conjunto da historiografia nacional tem insistido em teses como as que imputam a autoria do código criminal a Bernardo Pereira de Vasconcelos ${ }^{242}$, ou que destacam em demasia a pretensa pressa e pragmatismo dos deputados brasileiros em aprová-1o ${ }^{243}$, tomando estes elementos como explicação privilegiada para a faceta geral assumida pelo diploma e para várias de suas peculiaridades.

Apesar, portanto, de abordarmos neste capítulo um percurso previamente conhecido pelos interessados na temática codificacionista nacional, pretendemos trabalhá-lo aqui de forma inovadora, incorporando à documentação tradicional fontes ainda inéditas e destacando debates teóricos e procedimentais geralmente negligenciados; enfatizando, enfim, não a pressa, mas antes os detalhes e cuidados empreendidos na elaboração de um código que respondesse às necessidades políticas e projetos estatais e de organização judiciária dos representantes nacionais.

\footnotetext{
${ }^{242}$ É bastante significativo desta vertente o artigo de Bernadino Bravo Lira, "Bicentenario del Código Penal de Austria: Su proyección desde el Danubio a Filipinas”. Op. Cit.; 2004.

${ }^{243}$ Uma análise privilegiada da rapidez e falta de discussões com que pretensamente o Código de 1830 foi aprovado, pode ser encontrada no livro de Thomas Flory. Op. cit.; 1986; especialmente em sua segunda parte, capítulo VII, pp. 171-175.
} 
Organizaremos nossa análise, para tanto, da seguinte maneira: num primeiro momento delinearemos, de forma breve, o percurso geral de elaboração do código criminal de 1830, estabelecendo uma espécie de linha do tempo que facilite a posterior compreensão das etapas e características específicas deste processo; numa segunda etapa, analisaremos algumas das principais discussões procedimentais travadas na Câmara dos deputados no tocante aos trâmites necessários à elaboração e aprovação deste código, destacando as mudanças reconhecíveis nas mesmas entre os anos de 1826 e 1830; num terceiro momento, examinaremos detidamente a composição e os trabalhos empreendidos por três das cinco comissões parlamentares formadas, entre 1829 e 1830, para a elaboração do código penal; e por fim, num quarto e último subcapítulo, analisaremos parte dos debates travados em setembro de 1830 sobre a temática da manutenção, ou não, da pena de morte, no texto do futuro código criminal do Império.

\subsection{Cronologia de elaboração do Código criminal de 1830}

A importância assumida pela positivação das leis no contexto pós-Independência pode ser detectada pela rapidez com que a primeira legislatura do Império trouxe à tona esta questão. Numa das primeiras sessões regulares da Câmara dos Deputados, portanto, aos 12 de maio de 1826, duas propostas referentes à codificação foram enviadas à mesa ${ }^{244}$.

A primeira delas, do deputado José Antonio da Silva Maia (eleito por Minas Gerais), propunha que se convidasse com urgência a comissão de legislação da Câmara a indicar as medidas a serem tomadas para a organização dos códigos civil e criminal do Brasil. Já a segunda, enviada por Domingos Malaquias de Aguiar Pires

\footnotetext{
${ }^{244}$ Como comentamos acima, não é objetivo deste item esmiuçar o processo de elaboração do código criminal no interior do Parlamento brasileiro, mas antes apresentar ao leitor suas principais datas e marcos para que, nos três próximos subcapítulos, aprofundemos nossa análise em pontos específicos deste processo. Para uma cronologia completa do Código Criminal do Império do Brasil ver: Zahidé Machado Neto. Op. cit.; pp. 47-72. Para além dos debates especificamente referentes ao código criminal, a autora descreve uma série de discussões travadas no Parlamento brasileiro que, a seu ver, teriam influenciado a elaboração deste diploma. Para outras boas abordagens da cronologia de elaboração do Código de 1830 ver: A. Slemian. Andréa Slemian.Op. cit.; 2008; pp. 175-206.; 2008 e Monica Duarte Dantas. Op. cit.; 2011.
} 
Ferreira (deputado por Pernambuco), propunha o estabelecimento de um prêmio a quem, no prazo de dois anos, apresentasse o melhor projeto de código ${ }^{245}$.

As propostas de Silva Maia e Pires Ferreira foram enviadas à comissão de legislação e justiça civil e criminal da Câmara ${ }^{246}$, que, no dia 16 de julho de 1826 , emitiu um parecer comentando a necessidade premente de códigos para o Brasil, criticando a legislação criminal então em vigor no país (especificamente o Livro V das Ordenações Filipinas) e sugerindo o modo com que se deveriam organizar os futuros códigos civil, criminal, comercial, penal militar de terra e penal militar de marinha nacionais. No mesmo parecer, a comissão propunha que se convidassem homens sábios e jurisconsultos a desenvolver projetos para os códigos nacionais, e que uma recompensa fosse oferecida a quem de fato levasse a cabo semelhante tarefa. O parecer indicava ainda um prazo de dois anos para a entrega dos projetos e sugeria um trâmite específico a ser seguido pelas propostas encaminhadas. Por fim, a comissão afirmava que reduziria a projeto as propostas ali enunciadas assim que a câmara o ordenasse.

$\mathrm{Na}$ mesma data em que foi lido o parecer acima - $1^{\circ}$ de agosto de 1826 -, foi transcrito nos Anais da Câmara um segundo parecer da comissão de legislação e justiça civil e criminal (emitido aos 10 de julho de 1826 e analisado no capítulo anterior), referente às bases apresentadas por José Clemente Pereira para o futuro código nacional.

Em 17 de agosto de 1826 entraram em discussão os dois pareceres acima citados. Quanto ao primeiro deles, referente às propostas de Maia e Pires Ferreira, ficou decidido que o parecer retornasse (sem discussão) à comissão de legislação, para que esta apresentasse ao plenário um projeto de lei com os passos necessários à elaboração dos códigos nacionais e à premiação dos autores dos melhores projetos. Quanto ao parecer referente às bases de Clemente Pereira, após uma pequena discussão, recheada de mal entendidos ${ }^{247}$, foi o próprio deputado quem sugeriu o

\footnotetext{
${ }^{245}$ APB-CD. Sessão de 12 de maio de 1826; pp. 58-60. Disponível em: http://imagem.camara.gov.br/diarios.asp.

${ }^{246}$ Comissão regular composta, naquele momento, pelos deputados José da Cruz Ferreira (RJ), Antonio Augusto da Silva (BA) e Antonio da Silva Telles (BA).

${ }^{247}$ Para Bernardo Pereira de Vasconcelos, por exemplo, o parecer emitido acerca do projeto de Clemente Pereira não havia concluído coisa alguma no que tangia à sua aceitação, ou não, pelo Parlamento, devendo, portanto, retornar à comissão. No entendimento de Cruz Ferreira (membro da comissão), por sua vez, a comissão havia concluído, sobre o projeto, o que the era possível concluir (a qualidade de seu texto e a desobrigação de que os futuros projetos
} 
adiamento do debate para depois da entrega do projeto sobre a elaboração dos códigos e premiação de seus autores, a ser apresentado pela comissão de legislação.

$\mathrm{Na}$ abertura dos trabalhos do segundo ano da legislatura, mais especificamente no dia 3 de maio de 1827, d. Pedro I, em sua "Fala do Trono", exortou a Câmara a organizar a legislação criminal do país recém-independente.

Aos 4 de maio de 1827, Bernardo Pereira de Vasconcelos mandou então à mesa 0 seu projeto de código criminal que, após certa discussão (travada no dia seguinte), foi redirecionado a uma comissão especial da Câmara, eleita aos 12 do mesmo mês. Esta comissão, denominada Comissão especial do código criminal, foi composta pelos deputados José Antonio da Silva Maia (MG), Candido José de Araujo Vianna (MG), José da Costa Carvalho (BA), Manuel Caetano de Almeida e Albuquerque (PE) e João Candido de Deus e Silva (PA).

Aos 16 de maio de 1827 foi a vez de José Clemente Pereira entregar à Câmara o seu projeto completo de código criminal (lembremos que, como discutido no capítulo anterior, em 3 de junho de 1826, o mesmo deputado havia apresentado à Câmara as possíveis bases de um código penal para o Império do Brasil), composto por um único livro em que se regulavam os crimes e suas penas. Na ocasião desta entrega, Clemente Pereira afirmou que o segundo livro de seu projeto, contendo a ordem do processo, e ainda não desenvolvido, poderia ser futuramente elaborado caso seu primeiro livro merecesse a consideração dos deputados.

No dia 14 de agosto de 1827, a Comissão especial do código criminal, "encarregada de examinar os dous projetos do codigo criminal apresentados á camara", deu o seu parecer acerca dos projetos de Vasconcelos e Clemente Pereira, determinando, entre outras coisas, que ambos fossem recebidos com agrado pela deputação brasileira e impressos para análise dos deputados, jurisconsultos e sábios da nação.

Na sessão de 8 de maio de 1828, após um caloroso debate acerca da instituição do júri criminal no Brasil e da possibilidade de se discutir, ou não, sua efetivação antes de aprovado o código penal, a Câmara dos deputados decidiu convidar o Senado a

apresentados se mantivessem apegados ao mesmo). Neste ponto, nota-se, as divergências dizem respeito não só ao relativo desconhecimento dos deputados acerca dos trâmites necessários à elaboração de novas leis para o país, mas também à indefinição do conteúdo do projeto apresentado por Clemente Pereira; já que, por não se configurar num projeto de código penal propriamente dito, mas sim na apresentação de possíveis bases à sua elaboração, não fazia sentido que este documento fosse aprovado e mandado transformar em lei pelo Parlamento. 
nomear uma comissão que, juntamente à Comissão especial do código criminal, formada na Câmara, revisse os projetos até então apresentados. A ideia de formação de uma comissão mista fundava-se, para os deputados, na possibilidade de se facilitar as discussões e acelerar o processo de aprovação do código penal imperial.

Aos 9 de maio de 1828 foi então enviado ao Senado um ofício convidando a Câmara alta a eleger cinco senadores para, juntamente com os deputados, compor a dita comissão mista. Tais senadores foram eleitos no dia 12 de maio de 1828, na forma de uma comissão ad hoc.

A primeira comissão mista da Câmara e do Senado dedicada ao exame do código criminal compôs-se, assim, pelos deputados José Antonio da Silva Maia (MG), Candido José de Araujo Vianna (MG), José da Costa Carvalho (BA), Manuel Caetano de Almeida e Albuquerque (PE) e João Candido de Deus e Silva (PA) e pelos senadores Visconde de Alcântara (MA), Marquês de Caravelas (BA), Francisco Carneiro de Campos (BA), Marquês de Inhambupe (PE) e João Antonio Rodrigues de Carvalho (BA).

Pouco depois, aos 7 de junho de 1828, o deputado José Bento Ferreira de Melo (eleito por MG) fez uma indicação para que se convidasse o Senado a marcar dia, hora e local para a reunião da comissão mista. Nos debates que se seguiram a esta indicação, os deputados lamentaram, a todo o momento, a ausência de encontros por parte da comissão. Na sessão de 12 de junho de 1828, leu-se na Câmara um oficio do Senado determinando que o encontro se desse no dia 14 de junho, às 18 horas, no paço da Câmara.

Não se voltou a falar do código criminal pelo resto das sessões de 1828 e somente aos 14 de maio de 1829 a questão foi retomada, na Câmara dos deputados, quando da discussão de um projeto (elaborado pela comissão de legislação e justiça civil e criminal) contendo os trâmites necessários à escolha e premiação dos melhores códigos apresentados. A ideia deste projeto surgira a partir do parecer emitido por esta mesma comissão no mês de agosto de 1826 e o projeto apresentado acabaria rejeitado pelos deputados.

Nas sessões de 21 e 22 de maio de 1829, respectivamente na Câmara dos deputados e no Senado nacional, declarou-se o recebimento, a partir da oferta do cidadão João Clemente Vieira Souto, de exemplar da tradução do projeto de código penal elaborado pelo jurisconsulto norte-americano Edward Livingston para o estado da Luisiana. 
No dia 26 de Maio de 1829, o primeiro secretário do Senado leu um oficio proveniente da Câmara dos deputados - exortando a continuação dos trabalhos da comissão mista do código criminal -, por meio do qual os senadores eram convidados a um encontro. Na mesma ocasião, os membros da Câmara alta foram avisados da redução da comissão a apenas três representantes de cada Casa (e da permanência dos deputados José da Costa Carvalho, João Candido de Deus e Silva e José Antonio da Silva Maia) e, assim, procederam a nova votação, elegendo os senadores Nicolau Pereira de Campos Vergueiro (MG), Visconde de Alcântara e Carneiro de Campos (os dois últimos já presentes entre os cinco senadores anteriormente eleitos) para a composição da nova comissão mista.

Na sessão de 31 de Agosto de 1829 as câmaras alta e baixa do Parlamento nacional receberam o parecer elaborado pela segunda comissão "mixta" encarregada de analisar os projetos do código criminal nacional. Neste parecer, para além de uma avaliação da tarefa de que se incumbira, a comissão confirmava ter desenvolvido, a partir do texto de Vasconcelos, um novo projeto de Código penal, estabelecendo um plano a ser seguido para sua rápida aprovação parlamentar ${ }^{248}$. Este parecer entrou em discussão apenas no dia 6 de maio de 1830, já nos quadros da segunda legislatura imperial.

No dia 7 de maio de 1830 foi eleita na Câmara baixa uma comissão especial encarregada de receber, até o dia $1^{\circ}$ de junho, as emendas e memórias oferecidas pelos deputados ao projeto de código elaborado pela comissão mista. Esta comissão ad hoc, também conhecida como Comissão especial das emendas, foi composta pelos deputados Antonio Pinto Chichorro da Gama (MG), Honório Hermeto Carneiro Leão (MG) e Joaquim Francisco Alves Branco Munis Barreto (BA).

No dia 12 de Maio de 1830, os Anais registram a entrega à Câmara baixa, pelo cidadão Silvestre Rebello, de um exemplar do Projeto de Código Criminal da Luisiana escrito por Edward Livingston; levando os deputados a discutir, por um bom espaço de tempo, o destino deste projeto, e se ele deveria ou não ser traduzido para o português $^{249}$.

\footnotetext{
${ }^{248}$ O Projeto da Comissão Mista, impresso pela Tipografia Nacional em 1830, foi posto à venda, no mesmo ano, no Império do Brasil - vide ofício lido na sessão de 21 de maio de 1830 na Câmara dos Deputados: APB-CD; sessão de 21 de maio de 1830, p.183. Tal Projeto, entretanto, não foi encontrado até o momento.

${ }^{249}$ Como veremos à frente, para além do projeto de código criminal, Silvestre Rebello entregara à Câmara cópias de outros dois projetos da autoria de Edward Livingston,
} 
Na sessão de 06 de julho de 1830, um parecer informava a Câmara dos deputados que a comissão ad hoc, recentemente eleita, havia analisado as emendas enviadas ao projeto de código e que as mandava publicar, juntamente com um parecer, pela tipografia que mais conviesse.

A partir do dia 10 de Setembro de 1830, os deputados passaram a discutir diretamente o conteúdo do projeto de código criminal apresentado pela comissão mista. Especificamente na sessão do dia 10, admitiu-se por completo o projeto oferecido e passou-se a discutir as emendas selecionadas pela comissão ad hoc. Num primeiro momento, os deputados se concentraram na questão da cumplicidade e da autoria nos crimes, discutindo as formulações do projeto e das emendas neste sentido. Notando-se, porém, o tempo que tomava a discussão de um único ponto do projeto e a grande quantidade de emendas existentes, os debates foram rapidamente redirecionados à temática da organização a ser adotada nas discussões finais do código criminal.

$\mathrm{Na}$ sessão de 11 de setembro de 1830 foram aprovadas propostas de encaminhamento para estas discussões, sendo as principais dentre elas: a que estabelecia a criação de uma comissão especial dedicada a apresentar, a partir do conjunto de emendas impressas ou ainda manuscritas, aquelas consideradas indispensáveis ao código, e a que estabelecia que, antes desta comissão iniciar seus trabalhos, ficasse decidido se deveriam ser conservadas, ou não, no código brasileiro, as penas de morte e de galés.

No próprio dia 11 tiveram início as falas acerca da manutenção das penas de morte e galés no código penal, elegendo-se ainda a última das comissões especiais da Câmara a mexer no texto do diploma, composta pelos deputados Antonio Paulino Limpo de Abreu (MG), Francisco de Paula Souza e Melo (SP; doravante Paula Souza) e Luiz Francisco de Paula Cavalcanti de Albuquerque (PE; doravante Luiz Cavalcanti).

previamente impressos. Nas palavras de Monica Dantas: "se pode depreender de carta enviada por José Silvestre Rebello, em 1827, ao próprio Edward Livingston, [que] o norteamericano lhe ofertara então cópias dos seus três códigos já impressos - ou seja, o código penal, o código de processo penal, e o código prisional - , as quais Rebello repassou à câmara em 1830". Monica Duarte Dantas. Projeto para Bolsa Produtividade CNPq - "O Código do Processo Criminal e a reforma de 1841: debates legislativos e influências estrangeiras na disputa pela implementação de diferentes modelos de organização do Estado"; 2012; p. 12 (cópia cedida pela autora). 
Nas sessões de 11, 13, 14 e 15 de setembro discutiu-se com afinco a questão da pena de morte (deixando-se a pena de galés um pouco de lado) e no próprio dia 15 votou-se pela sua manutenção no código penal brasileiro.

Aos 19 de outubro de 1830 a última comissão especial apresentou seu parecer à Câmara, junto com a versão final do Código Criminal do Império do Brasil. Na sessão de 22 de outubro este texto foi aprovado na Câmara dos deputados, passando pela votação do Senado aos 24 de novembro e sendo, enfim, sancionado pelo Imperador d. Pedro I aos 16 de dezembro de 1830.

\subsection{O debate procedimental em torno à elaboração do Código de 1830}

A leitura dos debates travados na Câmara dos deputados em torno do código criminal chama a atenção pela quantidade de vezes em que a questão codificacionista foi abordada no interior de embates procedimentais. Trata-se de debates em que, no geral, foram deixadas de lado discussões de conteúdo e priorizados argumentos relativos aos trâmites necessários à composição e aprovação final do diploma penal. Tem-se ainda, no interior destas contendas, discussões cuja temática específica não foi o código penal, mas que, especialmente por perpassarem questões relativas à justiça criminal, diziam-lhe respeito e tratavam de sua necessária implementação no Brasil e da forma que aí ele deveria assumir.

Apesar de percorrerem os cinco anos de tramitação do código no Parlamento brasileiro, as discussões que nos propomos a analisar neste subcapítulo não parecem responder aos mesmos objetivos por todo o período. Inicialmente previsíveis, num contexto de relativo desconhecimento dos meandros do trâmite parlamentar e do modo com que se materializaria, no cenário nacional, o ideário codificacionista ocidental, os debates procedimentais parecem ter assumido uma nova e diferente faceta nos meses imediatamente anteriores à aprovação do diploma penal. Desta feita, buscaremos salientar estes dois momentos dos debates, chamando a atenção às suas semelhanças e diferenças e aos possíveis significados da alteração por eles sofrida entre 1826 e 1830.

Atentemos assim, uma vez mais, às discussões iniciais em torno à positivação das leis no país recém-independente. Na sessão de 12 de maio de 1826, após o envio de moção sugerindo um prêmio ao autor do melhor projeto de código entregue à Câmara no espaço de dois anos, o deputado Pires Ferreira foi questionado por José da Cruz Ferreira (representante eleito pelo Rio de Janeiro) acerca da especificidade do código 
mencionado ${ }^{250}$. Pires Ferreira respondeu ao colega referir-se a um "código geral", sendo replicado com a declaração da impossibilidade de semelhante código no país, haja vista a inexistência de cabeça capacitada à sua elaboração.

Para além de bastante interessante em si mesmo, este breve diálogo permite que identifiquemos o relativo desconhecimento, partilhado pelos deputados, dos passos a serem seguidos na empreitada codificacionista nacional. Estava em questão, portanto, se tal empreitada visava à organização de um código ou de códigos para o país. Ademais, não estava claro como estes deveriam ser organizados - ou seja, de que partes ou livros deveriam ser compostos - e, menos ainda, quem seriam os responsáveis por sua redação. Tampouco se sabia, de antemão, como deveria ser empreendida a discussão dos projetos e como eles se articulariam a outras matérias legislativas necessárias ao país.

O relativo desconhecimento e inexperiência dos deputados que compunham a primeira legislatura imperial, para além do ineditismo da tarefa em que se empenhavam, parecem responder ao por quê do debate codificacionista ter se iniciado com discussões sobre os procedimentos necessários à elaboração dos códigos, à organização de seus debates ou à melhor maneira de se reconhecer os méritos dos atores empenhados na tarefa ${ }^{251}$.

Atentemos, neste sentido, ao parecer emitido em julho de 1826, pela comissão de legislação e justiça civil e criminal da Câmara (relativo às primeiras propostas apresentadas para a elaboração de códigos ao país recém-independente), e à sua discussão, em plenário, aos 17 de agosto do mesmo ano.

Desde seu início o parecer reconhecia "que o objecto de maior importancia, e que mais contribue para a felicidade dos povos, é um codigo completo de sua legislação, que contenha todos os direitos e obrigações nos diversos estados e relações

\footnotetext{
${ }^{250}$ Para Cruz Ferreira, os códigos a se elaborar no Brasil deveriam "ser pelo menos 5 ou 6 . Ha o codigo civil, criminal, maritimo, mercantil, rural, etc., etc.". APB-CD; sessão de 12 de maio de 1826, p. 60.

${ }^{251}$ Para alguns autores, o cuidado assumido pelos deputados no início dos trabalhos legislativos de 1826 deve ser relacionado também ao receio de que, como na Assembleia Constituinte de 1823, a defesa inveterada de seus posicionamentos resultasse na dissolução da Câmara, ou em medida similar, da parte de d. Pedro I. Ao nosso ver, contudo, a coragem demonstrada pela Câmara no enfrentamento ao imperador e na defesa do projeto que consideravam o mais apropriado para o Brasil pode ser reconhecida desde os primeiros momentos de sua atuação, tornando, em grande medida, a reticência com que se iniciaram seus trabalhos fruto das dificuldades e do ineditismo inerentes à sua tarefa. Roderick J. Barman. Op. cit.; p. 143-144.
} 
sociaes" ${ }^{252}$. Na visão dos membros da comissão, o Brasil, mais do que outras nações, necessitava de códigos, visto não possuir nenhum, não podendo convir ao povo brasileiro a "bárbara" legislação penal portuguesa (Livro V das Ordenações Filipinas) e a infinidade de leis extravagantes recentemente publicadas sem consulta às necessidades e vontades da nação recém-independente.

Introduzido, portanto, o tema da codificação e confirmada sua necessidade no país, o parecer avançava rumo à análise das dificuldades envolvidas em semelhante $\operatorname{tarefa}^{253}$, fixando a organização que deveriam assumir os códigos nacionais e sugerindo que a Câmara convidasse a este trabalho homens sábios e jurisconsultos e os estimulasse com a proposição de prêmios pecuniários e distinções honoríficas. Por fim, o texto estabelecia um encaminhamento possível à elaboração destes códigos no interior do Parlamento ${ }^{254}$ e afirmava que todo o conteúdo exposto pelo parecer seria transformado em projeto, pela própria comissão, assim que a Câmara o ordenasse.

Na sessão de 17 de agosto de 1826 o parecer entrou em discussão na Câmara baixa e os posicionamentos logo se polarizaram entre um grupo de deputados favoráveis à discussão pormenorizada das propostas ali presentes e um grupo defensor do reenvio do texto do parecer à comissão de legislação para sua transformação em um projeto de lei que, somente então, fosse detalhadamente discutido. Decidiu-se afinal que o parecer retornasse à comissão e que um projeto completo para a organização dos códigos e a premiação de seus autores fosse futuramente apresentado aos deputados. A decisão fundava-se na necessidade de aceleração do processo codificacionista nacional e no argumento de que não havia sentido examinar e debater minuciosamente um parecer que, transformado na seqüência em projeto, seria

${ }^{252}$ APB-CD; sessão de $1^{\circ}$ de agosto de 1826; p. 16.

${ }^{253} \mathrm{O}$ parecer fazia uso, para tanto, de exemplos internacionais, afirmando: "De quanta difficuldade, porém, seja fazer-se um codigo tanto civil como criminal completo em todas as suas partes [...] é sabido dos que têm lido os celebres jurisconsultos modernos, principalmente o illustre Jeremias Bentham na introdução ao seu projecto geral de um corpo completo de legislação, e o Dr. Vicente José Ferreira Cardoso, no seu opusculo offerecido à assembléa constituinte de Portugal em 1822, em que mostrão as imperfeições dos codigos que existem e causas dellas." Idem; p.16.

${ }^{254}$ Os projetos enviados em até dois anos deveriam ser remetidos a uma comissão da Câmara baixa que os avaliasse e ranqueasse, passando sua avaliação, na seqüência, por uma segunda comissão, encarregada de indicar os projetos merecedores de prêmios. O mesmo trâmite deveria ser seguido na Câmara alta e, no caso de concordância mútua, os projetos escolhidos seriam impressos juntamente aos pareceres e avaliações emitidas por deputados e senadores. Esta documentação impressa seria reenviada aos autores dos projetos, aos advogados de justiça do Império e aos "sábios da nação" para que, no prazo de seis meses fossem enviadas às Câmaras as observações que lhes parecessem necessárias às discussões finais. 
novamente discutido por no mínimo três vezes em plenário - conforme previsão do regimento interno.

Durante o debate, posicionaram-se pela discussão imediata do parecer os deputados José Ricardo da Costa Aguiar (eleito por São Paulo), José Clemente Pereira, Antonio da Silva Telles e José da Cruz Ferreira - os dois últimos, membros da comissão que o redigira. Na opinião dos quatro representantes, a comissão havia agido corretamente ao apresentar ao plenário primeiramente as bases do projeto que se propunha a desenvolver no futuro, e não o projeto pronto ${ }^{255}$. Os deputados Luiz Cavalcanti, Paula Souza, e Lino Coutinho (BA), por sua vez, foram contrários à discussão do parecer, criticando a comissão por não ter desenvolvido um projeto completo sobre propostas previamente aprovadas pela deputação nacional e insistindo na necessidade de economia de tempo e esforços desnecessários à Câmara.

O projeto enfim elaborado pela comissão de legislação e justiça civil e criminal da Câmara entrou em discussão apenas na sessão de 14 de maio de $1829^{256}$, sendo, então, rejeitado pelos deputados.

Paralelamente à elaboração e discussão deste projeto, temáticas afins à positivação das leis penais no Império do Brasil continuaram a aparecer na forma de embates procedimentais de diferentes facetas. Dois interessantes exemplos apontam para os distintos posicionamentos assumidos pela deputação nacional no tocante à possibilidade de discussão e aprovação, ou não, de matérias penais afins ao código criminal previamente à sua promulgação.

No dia 5 de maio de 1827, na mesma sessão em que foi discutido o destino de seu projeto de código criminal, Bernardo Pereira de Vasconcelos enviou à mesa a seguinte indicação: "Que não se discutão as leis regulamentares, que tiverem relação com o codigo criminal, sem que a camara resolva, se devem, ou não, ser admittidos à discussão os dois projectos do codigo criminal.”. Ao fazer referência às leis regulamentares relacionadas ao código, Vasconcelos aludia especificamente à lei de responsabilidade dos Ministros e Conselheiros de Estado. Na opinião do deputado

\footnotetext{
${ }^{255}$ Afirmava, nesse sentido, o deputado José Clemente Pereira: “a commissão não só não foi ommissa, mas até não devia obrar de outro modo. Ella não devia apresentar um projecto, emquanto a camara não approvasse a medida, que foi lembrada pelos illustres autores das indicações. [...] A commissão não fez mais do que dar o seu parecer sobre ella, dizendo que a julga muito proveitosa e que no caso de ser aceito este seu juízo, organizará o projecto de lei, que a deve autorisar. Logo procedeu em regra." APB-CD; sessão de 17 de agosto de 1826, p. 178.

${ }^{256}$ APB- CD; Sessão de 14 de maio de 1829; pp. 73-74.
} 
mineiro, esta lei deveria compor o código criminal nacional e não se constituir enquanto lei "sui generis", como decidido previamente pela Câmara.

Os deputados interessados na questão perceberam rapidamente o sentido da indicação de Vasconcelos e posicionaram-se predominantemente contra sua proposta. Coincidentemente ou não, o único defensor do deputado mineiro foi José Clemente Pereira, também ele autor de um projeto de código criminal (entregue à Câmara poucos dias depois desta discussão), persistente na ideia de que tudo quanto fosse penal deveria ser discutido unicamente depois de aprovado o diploma.

Os principais opositores da indicação ${ }^{257}$, para além de relembrarem seus colegas que a Câmara já decidira fazer da lei de responsabilidade dos Ministros de Estado uma lei "sui generis" - que não entraria, portanto, no código criminal -, acusaram a proposição de Vasconcelos de tolher a liberdade de iniciativa do restante dos deputados. A seu ver, esta era a faceta mais perversa da indicação, pois, em seu nome, impedir-se-ia a proposição, discussão e possível aprovação de leis urgentes, em nome de outras ainda não sancionadas e sem previsão para tanto (caso do próprio projeto do deputado mineiro) ${ }^{258}$.

Ao longo do debate, Vasconcelos defendeu-se como pode dos ataques direcionados à sua indicação. Paralelamente a um rechaço às leis "sui generis" e a procedimentos penais diferenciados ${ }^{259}$, o deputado rejeitou a proliferação de leis

\footnotetext{
${ }^{257}$ Manifestaram-se contrários à indicação de Vasconcelos os deputados Lino Coutinho (BA), Luiz Cavalcanti (PE), Manuel José de Sousa França (RJ), Almeida e Albuquerque (PE), Vergueiro (MG), Cruz Ferreira (RJ) e Miguel Calmon du Pin e Almeida (BA).

${ }^{258}$ Em 1826, quando das primeiras discussões parlamentares em torno à elaboração de uma lei de responsabilidade dos funcionários públicos do Império, Bernardo Pereira de Vasconcelos desempenhou papel fundamental na Câmara dos deputados, chamando a atenção de seus pares à função de semelhante lei na defesa e efetivação da Constituição nacional. Neste sentido, o deputado mineiro é citado por diversos historiadores como o principal incentivador desta medida. Acontece que, andadas as discussões e apresentados os projetos sobre a lei de responsabilidade, Vasconcelos assumiu a defesa de uma lei que englobasse, para além dos Ministros e Conselheiros de Estado, todos os funcionários públicos da nação. A Câmara, contudo, decidiu que a lei (aprovada em outubro de 1827) se restringisse aos Ministros e Conselheiros, o que pode explicar a oposição de Vasconcelos, em maio de 1827, à aprovação da lei de responsabilidade previamente ao Código Criminal. Sua defesa intransigente de que tal lei fosse incluída no código pode estar relacionada à tentativa de expandir a abrangência da questão, causa a que, veremos à frente, o deputado dedicara parte importante de seu projeto de código penal. Para uma análise do percurso traçado pela lei de responsabilidade na Câmara dos deputados ver: Andréa Slemian. Sob o Império das Leis: Constituição e unidade nacional na formação do Brasil (1822-1834). São Paulo: Aderaldo \& Rothschild: Fapesp; 2009; pp. 179-185.

${ }^{259}$ Neste sentido, o deputado afirmou: "Se o ministro de estado commetteu um delicto, se obrou uma acção contra a lei; se abusou do poder, se commetteu crime de alta traição, etc.,
} 
separadas de um sistema comum. Vasconcelos pediu, enfim, que a Comissão especial do código criminal examinasse seu projeto e que, aprovando-o, submetesse as leis penais “ao codigo e systema geral de nossa constituição; o que não se poderá conseguir, emquanto durar a discussão do codigo e se discutirem outras leis.".

No bojo desta discussão, fez-se constante menção às dificuldades e ao largo tempo necessário à aprovação parlamentar de um código criminal. Parte dos deputados revelou, inclusive, descrer na possibilidade de positivação da legislação nacional num curto espaço de tempo.

O deputado Miguel Calmon du Pin e Almeida (BA) resumiu emblematicamente esta descrença ao ser esclarecido por Vasconcelos sobre o conteúdo de seu projeto de código criminal. Por não ter sido lido em plenário, grande parte dos deputados desconhecia as matérias reguladas pelo projeto do deputado mineiro, tendo acesso unicamente a parte delas em discussão travada aos 5 de maio, quando Vasconcelos aludiu à divisão de seu projeto em três partes principais e assim as descreveu: uma primeira parte, relativa aos crimes e suas penas; uma segunda parte concernente às matérias judiciais; e uma terceira parte em que se regulava a ordem do processo ${ }^{260}$.

Ao final das discussões do dia 5, Calmon du Pin interpelou novamente Vasconcelos, desta vez acerca de prescrições específicas de seu projeto e, ao descobrir a extensão das disposições nele presentes, afirmou:

Tal codigo não seria discutido em toda essa sessão, nem mesmo na seguinte legislatura. A discussão de um codigo exige largo tempo. O que se acha em projecto sobre a mesa não é apresentado ao corpo legislativo pelo príncipe Cambaçares, debaixo dos auspicios de Napoleão, para que seja approvado, guardada apenas a decencia do debate. Se um projecto de regimento interno anda ha tres sessões nesta camara sem ser approvado ainda, e se qualquer lei em projecto exige ordinariamente largas discussões, para ser admittido sómente à ordem dos trabalhos, qual não será a nossa despeza de tempo e paciencia para discutir e approvar um codigo inteiro? ${ }^{261}$

Frente a este juízo comum dos deputados brasileiros e à paralela necessidade de se passar rapidamente um pacote mínimo de leis para o país, chegou-se inclusive a sugerir que as leis penais cuja anuência se desse anteriormente à aprovação do diploma criminal fossem posteriormente comparadas, uma a uma, às disposições

está cumplice, está escripto o delicto, e a pena correspondente no codigo criminal, que é sempre geral para todos." APB-CD; sessão de 5 de maio de 1827; p. 24.

${ }^{260}$ Apesar de Vasconcelos revelar, nesta ocasião, a organização completa de seu projeto de código criminal, a segunda e a terceira partes descritas pelo deputado não constam da versão deste projeto presente no $3^{\circ}$ tomo dos Anais da Câmara de 1829 .

${ }^{261}$ APB-CD; sessão de 5 de maio de 1827 ; p. 26 
presentes nos projetos de código apresentados, e que se decidisse, então, por sua eliminação ou incorporação ao texto finalmente aprovado ${ }^{262}$. Tais propostas de encaminhamento revelam, em nossa opinião, a disposição dos legisladores brasileiros (ao menos neste momento) em trabalhar (ainda que em dobro, caso necessário) pela adoção de leis que lhes pareciam indispensáveis ao país.

Em 1828, mais especificamente na sessão do dia 8 de maio, uma nova discussão procedimental envolvendo o código criminal tomou corpo na Câmara baixa. Protagonizada por praticamente o mesmo grupo de deputados, a temática, desta vez, centrou-se no estabelecimento do sistema de jurados nas matérias criminais. Enquanto parte dos deputados defendeu a rápida formação de uma comissão da Câmara que avaliasse e encaminhasse a instauração deste sistema, um grupo opositor enfatizou as desvantagens que o júri criminal poderia trazer a um país que, como o Brasil, regia-se (em matéria penal) pelo Livro V das Ordenações Filipinas ${ }^{263}$.

Posicionaram-se pela agilização do estabelecimento do júri criminal os deputados Ferreira de Melo (MG; autor da proposta então em discussão) e José Cesário de Miranda Ribeiro (MG). Em sua opinião, o sistema de jurados era um direito fundamental dos cidadãos brasileiros, não podendo ficar adiado perante um desejo de perfeição das leis penais ainda distante da realidade nacional ${ }^{264}$. Bernardo Pereira de Vasconcelos e Lino Coutinho (opositores entre si no debate de maio de 1827) defenderam, por sua vez, a anterioridade do código criminal em relação à instituição do júri. Enquanto, para Vasconcelos, a Câmara não deveria se ocupar de semelhante matéria, haja vista a inclusão da mesma em seu projeto de código criminal (na parte referente ao processo penal); Lino Coutinho enfatizou os riscos que se corria ao

\footnotetext{
${ }^{262}$ Falaram nesse sentido os deputados Luiz Cavalcanti e Vergueiro.

${ }^{263}$ Um debate parecido com este já havia sido realizado, como vimos, no contexto da Assembleia Constituinte brasileira de 1823, mais especificamente, entre os dias 21 e 25 de outubro. Ver, Capítulo 1 desta dissertação, pp. 69-71.

${ }^{264} \mathrm{O}$ deputado Miranda Ribeiro pronunciou-se, quanto a esta questão, da seguinte maneira: "Meus senhores, ácerca do juizo por jurados a minha opinião é esta: estabeleçamol-o e depois cuidemos de aplanar as difficuldades que occorerem, não nos emmarenhemos com as difficuldades consideradas antes, estabeleçamol-o primeiro que tudo; e quando, senhores, havemos de julgar facil o estabelecimento do jury entre nós? Daqui a dous mil annos, se então fosse pela primeira vez adoptado encontrariamos as difficuldades que naturalmente se offerecem a qualquer instituição nova; não esperamos, meus senhores, pelos codigos, para só então gozarmos deste grande bem, sem offensa da constituição podemos muito antes possuilo [...]." APB-CD; sessão de 8 de maio de 1828, p. 25.
} 
delegar à população brasileira julgamentos fundados sobre as "bárbaras" prescrições do Livro $\mathrm{V}^{265}$.

No bojo deste debate, e com vistas a acelerar a aprovação do código penal, Vasconcelos propôs (e viu aceita pelo plenário) a formação de uma comissão parlamentar mista que revisse os projetos apresentados à Câmara por ele e Clemente Pereira, avançando nos melhoramentos necessários à sua aprovação (propostos já, pela comissão especial do código criminal, no parecer emitido em 14 de agosto de 1827). Ao final da discussão, somente esta proposta de Vasconcelos foi aprovada pelo plenário, ficando tudo o mais rejeitado.

Vê-se, portanto, que diferentemente do debate de maio de 1827 , desta vez o deputado mineiro conseguiu fazer prevalecer a sua opinião na Câmara dos deputados, passando a proposta de que não se regulassem matérias de direito penal adjetivo antes de aprovado o código criminal e de que, com vistas a acelerar este processo, fosse formada uma comissão parlamentar mista de trabalho ${ }^{266}$.

A análise deste conjunto de discussões - travadas entre 1826 e 1828 - possibilita que atestemos o empenho da primeira legislatura do Império na tarefa de positivação das leis penais e sua consciência e disposição em trabalhar a longo prazo neste projeto (ainda que o argumento da urgência na aprovação desta legislação tenha se mantido sempre presente). Para além das dúvidas e questionamentos constantemente suscitados com relação aos trâmites deste processo, nota-se o quanto esta legislatura se preocupou em conduzir a positivação das leis penais da maneira que lhe parecia a melhor (ainda que, em alguns casos, mais trabalhosa).

Apesar, portanto, de se reconhecer constantemente as dificuldades envolvidas na elaboração de um código criminal, diversos deputados insistiram na efetivação deste trabalho a qualquer custo, sugerindo, por exemplo, que se postergasse a aprovação de leis penais importantes à nova nação até que aprovado o código criminal, ou ainda,

${ }^{265}$ Foi nesse sentido que o deputado afirmou: “[...] julgo, que emquanto não tivermos um codigo, digno de um paiz constitucional, os jurados em materias crimes não produzirão alguns bens: trabalhemos portanto para que quanto antes saia à luz esse codigo suspirado afim de que os delinquentes sejão punidos rasoavelmente, e não à maneira dos barbaros, entre os quaes tudo é horror e sangue." APB-CD; sessão de 8 de meio de 1828, p. 25.

${ }^{266}$ De acordo com Vantuil Pereira, o recurso à formação de comissões mistas da Câmara e do Senado foi popularizado, a partir de 1828 , com vistas à facilitar a reunião das duas Casas e efetivamente discutir, em conjunto, projetos de lei para o país. Para o autor, inclusive, são reconhecíveis os impactos que tiveram estas comissões sobre a diminuição dos confrontos existentes, desde 1826, entre as duas câmaras. Vantuil Pereira. Ao Soberano Congresso. Direitos do cidadão na formação do Estado Imperial brasileiro (1822-1831). São Paulo: Alameda, 2010; pp. 166-169. 
que se duplicasse todo o trabalho a fim de garantir, ao mesmo tempo, um pacote básico de leis penais indispensáveis ao país - ou o acesso imediato a direitos fundamentais como a instituição do júri criminal e a lei de responsabilidade dos Ministros e Conselheiros de Estado - e um código criminal que, futuramente aprovado, mantivesse a sistematicidade da legislação penal.

Como veremos na sequência, também ao nível específico das atividades desenvolvidas pelas comissões parlamentares de trabalho, o empenho colocado na tarefa da codificação penal foi grande, tornando necessária uma avaliação mais profunda das mudanças de rumo apresentadas no período final de discussões do diploma penal do Império, quando os deputados passaram a advogar insistentemente por sua rápida (ainda que, em suas palavras, imperfeita) aprovação. Um primeiro exemplo desta aparente mudança pode ser encontrado na discussão final, travada na Câmara dos deputados, em torno do projeto que previa a premiação dos melhores códigos desenvolvidos para o país. Esta discussão se deu somente aos 14 de maio de 1829 (lembrando que a Câmara destinara a elaboração deste projeto à comissão de legislação ainda em 1826) e, apesar das dificuldades em se acompanhar os debates (já que se discute sobre o conteúdo de um projeto a que não temos acesso), chama a atenção o predomínio que nele têm questões aparentemente ultrapassadas no estágio em que se encontrava a elaboração do código penal.

Uma interessante fala do deputado Lino Coutinho versa, neste sentido, sobre as desvantagens de se convidar estrangeiros à elaboração de códigos (em geral) para o Brasil $^{267}$ e acerca de suas preferências para a composição de uma comissão dedicada ao código criminal nacional ${ }^{268}$. Lembremos, entretanto, que, a esta altura, dois

267 “[...] Bentham é de parecer que os legisladores sejão antes estrangeiros do que nacionaes, porque não tendo grande co-relação com os habitos e prejuizos proprios da nação podem ver, estando fóra della, mais claramente as cousas [...] O mesmo, diz elle, deve ser para a formação de um codigo civil e criminal, porque um homem estrangeiro póde estar imbuido das leis de qualquer paiz e de seus habitos, sem estar sujeito a vergar debaixo de suas influencias. Por consequencia estou persuadido que o codigo dado por sabios estrangeiros, que tenhão conhecimento dos habitos do paiz, será melhor; mas esperaremos nós que o estrangeiro venha trazer esse codigo, e que o apresente espontaneamente, ou mesmo algum jurisconsulto do Brazil? De certo que não; e se nós havemos de estar á espera sem fructo, não será melhor que uma commissão desta casa e de jurisconsultos de fóra, trabalhe sobre um codigo proprio para o Brazil?" APB -CD; sessão de 14 de maio de 1829; p. 74.

268 "Depois disso, Sr. presidente, não quero que a commissão que trabalhar, principalmente no codigo criminal, seja só de homens de direito, porque estes não podem fazer bem um codigo criminal, que depende de muitas outras luzes, que não são estas de direito positivo; depende do conhecimento physico e moral do homem, e todas as vezes que isto se não leve em conta, ha de sahir um pessimo código [...]." Ibidem. 
projetos de código criminal já haviam sido apresentados à Câmara, uma primeira Comissão especial do código já os havia estudado e emitido seu parecer, e uma segunda comissão de trabalho, desta vez mista, montada e remontada entre 1828 e 1829, elaborava o projeto e o parecer que seriam apresentados em 31 de agosto de 1829. Encontrava-se, portanto, bastante adiantado o processo de elaboração do código por parte da comissão eleita, enquanto, na Câmara, discutia-se ainda sobre quem o deveria elaborar e como se organizariam as comissões de trabalho a ele dedicadas. Nenhum dos deputados envolvidos nestas disputas, contudo, manifestou-se, em momento algum, acerca do conteúdo dos projetos àquela altura apresentados ao Parlamento brasileiro. Haveria uma explicação para este aparente descompasso?

Como vimos acima, em maio de 1828, com o intuito de acelerar a elaboração e aprovação do código criminal, decidiu-se pela criação de uma comissão mista que, inicialmente composta por dez membros (cinco deputados e cinco senadores), reduziu-se a seis membros no ano de 1829 e, em agosto deste mesmo ano, apresentou às Câmaras alta e baixa do Parlamento nacional, juntamente a um parecer referente aos trabalhos desenvolvidos, o seu projeto de Código Criminal ${ }^{269}$.

Por meio de seu parecer, a comissão confirmava à Câmara ter redigido, a partir prioritariamente do projeto de Bernardo Pereira de Vasconcelos, um novo projeto de código criminal, apresentando, então, a sua organização. Apesar de reconhecer explicitamente as imperfeições do projeto que apresentava, a comissão concluía que, de todo modo, o país avançaria rumo à perfeição de sua legislação criminal ao substituir as leis existentes por "um codigo organisado systematicamente sobre uma base solida tomada na natureza social e já consagrada no nosso codigo fundamental.".

Defendendo que o projeto apresentado fosse adotado pelo Parlamento sem passar pelas discussões previstas pelos regimentos das duas Casas, com vistas a acelerar o

\footnotetext{
${ }^{269}$ No que diz respeito às comissões parlamentares de trabalho dedicadas à elaboração do Código Criminal do Império do Brasil, são reveladores os contextos específicos de suas instaurações. Diferentemente do que poderia parecer, o caráter específico assumido, entre 1826 e 1830, por cada uma destas comissões, veio responder a necessidades práticas detectadas por deputados e senadores envolvidos na elaboração do diploma penal. Assim, desde a remessa de projetos a uma comissão regular da Câmara até a eleição de comissões especiais e ad hoc, ou ainda a consideração de se misturar sábios e jurisconsultos de dentro e fora do Parlamento para a análise da questão, todas as possibilidades e discussões referentes a estas instaurações vieram responder a considerações específicas e precisas dos legisladores brasileiros e a seus interesses na aceleração, aprofundamento ou politização do exame do diploma criminal previsto para o Império do Brasil. Desta forma, pode-se concluir que, também no que diz respeito a este ponto do processo de elaboração do código penal, importantes discussões procedimentais ditaram os rumos da questão.
} 
processo, "cuidando-se só em corrigir seus defeitos mais salientes", o parecer propunha aos parlamentares um plano para o encaminhamento da questão. Neste plano, definia-se que o novo projeto fosse impresso e distribuído ao Parlamento e que, assim que os deputados o recebessem, fosse determinado um prazo para o envio de emendas e memórias ao seu texto. Tais emendas e memórias, por sua vez, deveriam ser remetidas a uma comissão ad hoc de três membros que as selecionaria, apresentando à Câmara, impressas, as que lhes parecessem melhores. O plano previa ainda que, apresentadas as emendas selecionadas pela comissão ad hoc, fosse dado o projeto, juntamente a elas, para a ordem do dia:

A discussão começará pela questão, se o projecto deve ou não ser admittido? Vencendo-se que sim, serão discutidos os artigos emendados, tendo-se os outros como approvados.Terminada a discussão, se o projecto fôr adoptado, será remettido à outra camara, onde se procederá do mesmo modo. ${ }^{270}$

Aos 6 de maio de 1830 (já nos quadros da segunda legislatura do Império) entrou em discussão o dito parecer. Passara-se, portanto, quase um ano da sua emissão, a despeito da constantemente reiterada "impaciência da nação"271. No curto debate que se seguiu (analisado com cuidado à frente), fugiu-se quase por completo à discussão do plano proposto para finalização e aprovação do código penal.

No dia 7 de maio de 1830 elegeu-se, na Câmara dos deputados, conforme proposição do parecer, a comissão ad hoc encarregada de receber as emendas e memórias oferecidas ao projeto do diploma criminal. Apresentados os trabalhos desta comissão (em julho de 1830), tiveram início, enfim, em setembro do mesmo ano, as primeiras discussões diretamente referentes ao conteúdo do projeto.

Na sessão de 10 de setembro de 1830 os deputados votaram pela admissão do projeto da comissão mista como um todo e por sua discussão por artigos (ficando rejeitada a proposta de que se discutisse o projeto por capítulos). A discussão teve início pelo artigo quarto do diploma e por sua comparação às emendas apresentadas pela comissão ad hoc de 1830. No decorrer dos debates, novas emendas começaram a ser enviadas à mesa, votando-se prontamente pela sua aceitação ${ }^{272}$.

$\mathrm{O}$ artigo de número quatro, em discussão, referia-se aos critérios de autoria e cumplicidade nos crimes e gerou calorosos debates protagonizados pelos deputados

\footnotetext{
${ }^{270}$ APB-CD; sessão de 31 de agosto de 1829; p. 84.

${ }^{271}$ Monica D. Dantas. Op. cit.; 2011; p. 18.

${ }^{272} \mathrm{Na}$ breve discussão que antecedeu esta decisão posicionaram-se favoravelmente ao envio e aceitação de novas emendas os deputados Lino Coutinho e Maia, e contrariamente às mesmas o deputado Rebouças. APB-CD; sessão de 10 de setembro de 1830, p. 487.
} 
José Antonio da Silva Maia, Antonio Ferreira França (BA) e Lino Coutinho. Enquanto o primeiro defendeu a possibilidade de se ter mais de um autor no mesmo crime e o segundo pediu a restrição do critério de autoria a um único indivíduo, Lino Coutinho, baseado nas prescrições do Projeto de código criminal da Luisiana, defendeu a adoção (para além de autores e cúmplices) da categoria dos “aderentes" de um crime ${ }^{273}$.

Os debates que se seguiram pelas sessões do dia 10 e início do dia 11 de setembro, chamam a atenção por ultrapassarem em muito as especificidades relativas aos critérios de autoria e cumplicidade do código penal. Lino Coutinho, por exemplo, ao sugerir a adoção da categoria de "aderentes", afirmou sua preferência por um código casuístico em comparação a um pequeno, que deixasse muitos vazios aos magistrados na hora de julgarem os criminosos. Neste sentido, afirmou:

[...] porque quando se marca bem os casos, é quando o cidadão está socegado, e não está sujeito a arbitrariedade dos juizes, e por isto eu sou sempre inclinado por um código casuistico, bem como no codigo da Luiziana que ha cabeças, cumplices e autor. $^{274}$

Ferreira França, por sua vez, apesar de igualmente defensor do diploma penal de Edward Livingston, criticou o casuísmo sustentado por Lino Coutinho e, mantendo sua proposta de que o código restringisse o critério de autoria a apenas um indivíduo, afirmou:

\footnotetext{
${ }^{273} \mathrm{O}$ "Code of Offences and Punishments" de Edward Livingston definia, entre seus artigos 57 e 74, os critérios para a definição dos autores principais de um crime (principal offenders), seus cúmplices (accomplices) e aderentes (accessaries). Quanto à última categoria, o artigo 70 do código definia: "Accessaries are those who, knowing that an offence has been committed, conceal the offender, or give him any other aid, in order that he may effect his escape from arrest or trial, or the execution of his sentence [...]." A categoria de "aderentes", portanto, dizia respeito àqueles que, diferentemente dos cúmplices, auxiliavam os criminosos depois de cometido o crime. Interessante observar, contudo, que quando Lino Coutinho defende a adoção desta categoria pelo código penal brasileiro, ele o faz baseado em dois exemplos principais: o de uma mulher que sabe do crime de seu marido e o não denuncia, e o de um filho que não denuncia a seu pai. De acordo com o deputado, portanto, em nenhum destes casos mulher ou filho poderiam ser considerados cúmplices nos crimes de seus respectivos marido e pai. Daí a proposta de que o código adotasse, para casos como estes, a categoria dos "aderentes" de um crime, a quem provavelmente estariam previstas penas bastante inferiores. O "Code of offences and punishments", contudo, em cujas prescrições Lino Coutinho se baseara, prescreve em seu artigo 71, que não poderiam ser considerados e punidos como accessories justamente o marido ou a mulher do delinqüente, seus parentes em linha ascendente ou descente, seus irmãos e irmãs, e empregados domésticos. A System of Penal Law prepared for the State of Louisiana. New-Orleans: printed by Benjamin Levy, 1824 (Cópia do livro original, cedida por Monica Duarte Dantas, e a ela fornecida pela Biblioteca do Congresso norte-americano).

${ }^{274}$ APB-CD; sessão de 10 de setembro de 1830; p. 488.
} 
Reprovo todas as emendas e o mesmo projecto. Vejo nelle uma hydra de crimes e culpados, muitos cumplices, muitos adherentes. Desta maneira, poderão os magistrados envolverem muitas pessoas em um crime, e até uma povoação inteira: isto é uma verdadeira inquisição judiciaria. Os melhores criminalistas e juizes contentão-se em achar um só autor [...]. [...] Senhores! As penas devem ser reduzidas ao menor numero possivel. Todo o legislador que a cada falta impõe uma pena, que só quer achar criminosos, não é certamente digno do nome de homem; é um tigre digno só de legislar para os animaes ferozes. ${ }^{275}$

O posicionamento enfático de Ferreira França rendeu uma resposta do deputado Maia, para quem as emendas da comissão ad hoc eram excelentes e deveriam subsistir.

Após a fala de Maia, contudo, as discussões em torno do artigo quarto foram prontamente interrompidas por deputados que defendiam a necessidade de adoção de um novo modelo para os debates sobre o projeto da comissão mista, capaz de acelerar a aprovação do código penal. A polêmica gerada sobre um só dentre os artigos do projeto (e, quem sabe, o reconhecimento da multiplicidade de questões envolvidas nas prescrições de cada um de seus artigos) refletiu-se rapidamente, portanto, nos rumos previstos para a sua discussão e aprovação final.

O primeiro a se pronunciar neste sentido foi o deputado Antonio Pereira Rebouças (BA), que aprovara o parecer da comissão mista por acreditar que o projeto passaria rapidamente pela Câmara, o que, no momento, lhe parecia impossível perante a extensão das discussões sobre um único artigo. $\mathrm{O}$ deputado se colocava, assim, contra as emendas da comissão ad hoc e pela manutenção do artigo quarto do projeto tal qual originalmente redigido, chamando a atenção da Câmara ao fato de que, ainda que imperfeito, o código futuramente aprovado seria necessariamente superior ao Livro V das Ordenações Filipinas. Em seguida falou, no mesmo sentido, o deputado Joaquim Manuel Carneiro da Cunha (eleito pela província da Paraíba do Norte), defensor de uma rápida aprovação do projeto elaborado pela comissão mista frente à premente necessidade de um código criminal à nação brasileira.

A historia mesma deste codigo nos mostra que o devemos adoptar sem longas discussões: por quantas commissões não tem elle passado desde que se apresentou, tanto na legislatura passada como nesta? Adoptemol-o provisoriamente. A experiencia nos irá mostrando aquelles artigos que devemos reformar para o futuro. Quando se tratou de o admittir eu notei que a discussão fosse por artigos, e se admittissem igualmente à discussão todas as emendas que apparecessem. Mas, agora pensando melhor, conheço que a discutir-se artigo por artigo e as emendas

${ }^{275}$ APB-CD; sessão de 11 de setembro de 1830; p. 489. 
que se apresentarem, não teremos codigo criminal nem na actual sessão nem talvez na seguinte. ${ }^{276}$

Nota-se, portanto, a partir das falas destes deputados, o início de uma recusa à discussão pormenorizada dos artigos emendados do projeto da comissão mista e, desta forma, uma inversão nos rumos previstos à elaboração do código criminal no Parlamento brasileiro. Os caminhos apontados desde 1826/1827 para este processo eram vistos, agora, como de difícil efetivação. Os deputados destacavam, a todo o momento, que o tempo urgia e clamavam pela aceleração da aprovação do texto do código. Chegada, portanto, a hora de se discutir a fundo o conteúdo emendado do projeto do código criminal (que, como veremos à frente, era extenso), examinando-se com cuidado sua organização, seus artigos, capítulos, crimes e definições gerais, voltava o plenário a debater os rumos da discussão em si e a forma que deveriam assumir os debates finais do código.

O deputado Paula Souza (SP) falou em sequência a Carneiro da Cunha e, apesar de reforçar a necessidade de uma aprovação rápida do código penal, defendeu que o texto do projeto ainda necessitava de importantes alterações. O deputado sugeriu, neste sentido, a formação de uma última comissão parlamentar (eleita por escrutínio secreto e maioria absoluta) que recebesse todas as emendas já formuladas - ou mandadas à mesa até o dia seguinte -, e selecionasse aquelas julgadas indispensáveis ao código, colocando-as em discussão. Desta feita, caberia à Câmara votar unicamente sobre a adoção ou rejeição de emendas específicas ${ }^{277}$.

Em sua fala, Paula Souza chamou a atenção da Câmara ao fato de que, da forma como se encaminhava a questão, não se teria um código criminal até o fím do ano. Segundo o deputado, era provável que o número de emendas superasse os 200 e que, discutindo-se todo o projeto e suas emendas, não se chegasse, por um bom espaço de tempo, a um resultado final. O deputado enfatizou ainda o caráter sistemático que, em sua opinião, um código criminal deveria assumir e chamou a atenção para as dificuldades de se emendar determinadas partes de seu texto sem prejudicar o restante

\footnotetext{
${ }^{276}$ APB-CD; sessão de 11 de setembro de 1830, p. 490.

277 Dizia o requerimento do deputado Paula Souza: "Que se crêe uma commissão especial, a qual tendo em vista todas as emendas existentes impressas ou manuscriptas (que estiverem na mesa ou a ella se mandarem até amanhã), nos apresente as emendas que julgar absolutamente indispensaveis, para sobre ella discutir-se e votar-se, indicando-nos os meios mais breves para a discussão, e tudo dentro de seis dias depois da sua eleição." APB-CD; sessão de 11 de setembro de 1830, p. 491.
} 
da obra e de seu método. Paula Souza comparou ainda o sistema de discussão legislativa que se vinha adotando na Câmara brasileira ao de outras nações e destacou que, perante a realidade nacional, não se deveria buscar o impossível.

Em pequenos projectos se nota que as emendas tornão às vezes contradictorios uns artigos com os outros, e que o maior trabalho da commissão encarregada de refundir estes projectos, é poder casar o vencido com o contradictorio que resulta da admissão das emendas, sobre as quaes se vota isoladamente e sem attenção ao que se segue. Que acontecerá em um tão volumoso projecto de codigo? Em lugar de um systema seguido, teremos um repetido de contradições e talvez de disparates! [...] Não me recordo de codigo algum do universo feito por assembléas legislativas. Só se póderá apontar o codigo francez; mas todos sabem que elle foi feito pelo conselho de estado de Napoleão ou pelo ministro mais influente e que mesmo é attribuido em parte a Cambaceres. Se entre nós o codigo pudesse ser todo discutido bom seria; mas não temos nós visto que um só artigo o tempo que tem levado? Nunca uma obra tão extensa póde ser organisada por uma assembléa legislativa. ${ }^{278}$

Complementando as colocações de Paula Souza, falaram ainda os deputados Antonio Pinto Chichorro da Gama (MG) e Ernesto Ferreira França (PE) propondo, por sua vez, que antes de se criar a comissão sugerida pelo deputado paulista, a Câmara deliberasse acerca da manutenção das penas de morte e de galés no código brasileiro. Outros deputados se manifestaram, na seqüência, acerca da questão ${ }^{279}$, ficando aprovados, afinal, o requerimento de Paula Souza e as seguintes emendas de Ernesto Ferreira França:

$1^{\circ}$. Que se nomêe por escrutinio e maioria absoluta, uma commissão de tres membros.

$2^{\circ}$. Que a commissão ouça, mas não seja obrigada a seguir os artigos que lhe forem apresentados por qualquer Sr. deputado.

$3^{\circ}$. Que offerecido este codigo, fique sobre a mesa os dias que se julgarem necessarios, e passado este prazo (que deverá ser breve), se vote sem discussão e em globo, se o codigo se deve ou não adoptar.

$4^{\circ}$. Que antes do trabalho da commissão, a camara resolva, se se deve conservar a pena de morte e de galés. ${ }^{280}$

\footnotetext{
${ }^{278}$ Idem; p. 490.

${ }^{279}$ O deputado Augusto Xavier de Carvalho (eleito pela Paraíba do Norte) defendeu a aprovação do projeto da comissão mista da forma em que este se encontrava. Para o deputado, os possíveis defeitos do código poderiam ser removidos no futuro, enquanto a criação de mais uma comissão especial daria provavelmente origem a um círculo vicioso de comissões formadas para a análise dos trabalhos desenvolvidos pelas comissões anteriores e daí por diante. O deputado Maia, por sua vez, concordou com as propostas de Paula Souza e Ernesto e sugeriu somente que, para além das penas de morte e galés, fossem discutidas também, pelo conjunto da deputação, as penas de banimento, suspensão dos direitos políticos e morte civil. Tais emendas foram, contudo, rejeitadas pela Câmara.

${ }^{280}$ APB-CD; sessão de 11 de setembro de 1830; p. 492.
} 
Desta forma, como apontado no subcapítulo anterior, ainda na data de 11 de setembro elegeu-se a última das comissões especiais dedicadas ao exame do código criminal (composta pelos deputados Antonio Paulino Limpo de Abreu, Francisco de Paula Souza e Melo e Luiz Francisco de Paula Cavalcanti de Albuquerque) e tiveram início as falas dos deputados favoráveis e contrários à manutenção das penas de morte e galés. Nos longos debates que se seguiram (pelos dias 11, 13, 14 e 15 de setembro), podemos encontrar efetivamente as únicas discussões de conteúdo desenvolvidas, ao longo de no mínimo quatro anos, sobre o texto do código que viria a ser aprovado. Apesar de bastante interessantes (teremos a oportunidade de nos debruçar sobre elas ao final deste capítulo), o fato de toda a discussão coletiva sobre o conteúdo do código penal recair sobre a questão da pena de morte não nos parece óbvia ou previsível.

Como dissemos no início deste item, os embates procedimentais travados no Parlamento brasileiro em torno do código criminal não nos pareceram regidos por uma mesma lógica entre os anos de 1826 e 1830. Neste sentido, o predomínio das discussões de método sobre as de conteúdo, inicialmente esperado perante a relativa inexperiência dos deputados nacionais, pareceu responder a novas circunstâncias nos anos de 1829 e, principalmente, 1830.

A análise das discussões procedimentais travadas em 1826, 1827 e 1828 na Câmara dos deputados revela o modo com que, a partir das dúvidas e receios surgidos da própria atuação parlamentar, os representantes brasileiros propuseram caminhos à elaboração do código penal imperial. Neste sentido, o estabelecimento de um plano de trabalho pelo parecer da comissão mista de 1829 veio responder a problemáticas que há muito incomodavam os parlamentares envolvidos com a positivação das leis penais, esclarecendo, em certa medida, o percurso a ser seguido pelo código. Aludindo à necessária superação da legislação penal portuguesa e propondo, nesse sentido, uma aceleração do processo de aprovação do texto do código, o plano proposto pelo parecer estabelecia, contudo, que uma última discussão coletiva se desse sobre os artigos emendados do projeto da comissão mista. Vale a pena lembrar que estas emendas poderiam ser enviadas por qualquer membro da deputação nacional, presumindo-se, àquela altura, que poderiam vir em grande quantidade, e reservando-se, enfim, uma última discussão ao esclarecimento e votação das mesmas pelo conjunto dos parlamentares. 
Poucas horas após o início desta discussão, contudo, mudou-se rapidamente de ideia, rejeitando-se a validade de um debate que tomaria tanto tempo à Câmara. É sobre esta mudança que gostaríamos de levantar, na seqüência, alguns questionamentos, partindo de duas vertentes principais. Enquanto a primeira envolve uma aceitação dos argumentos mobilizados pelos deputados em nome da aceleração da aprovação do código criminal, a segunda pressupõe que, em certa medida, ultrapassemos o conteúdo de suas falas, buscando seus significados mais profundos e sua inserção no contexto político mais amplo então vivido pelo país.

Partindo exclusivamente do conteúdo dos discursos da sessão de 11 de setembro de 1830, podemos atribuir a inversão de rumos nos debates do código criminal à urgência reconhecida pelos legisladores brasileiros na superação da legislação penal portuguesa. Desta forma, tendo em vista a necessidade premente de um código criminal para a nova nação (até então regida pelo "bárbaro e sanguinário" Livro V das Ordenações Filipinas), os deputados teriam rapidamente percebido a impossibilidade de se discutir, em plenário, o conjunto dos artigos emendados do projeto da comissão mista.

O que nos soa estranho nesta explicação, contudo, é o fato de os deputados terem desistido tão rapidamente de qualquer formato coletivo de discussão do projeto do código criminal ou do conjunto de seus artigos emendados, devendo-se, portanto, analisar com cuidado as alternativas adotadas. Como vimos, estas alternativas foram reduzidas, naquele momento, a apenas duas: uma aprovação imediata (ainda que provisória) do projeto da comissão mista (cujas falhas poderiam ser futuramente corrigidas, diziam os deputados) e a proposta de transferência completa das discussões do código a uma reduzida comissão de trabalho (enfim vencedora).

De qualquer maneira, nas falas pronunciadas na sessão de 11 de setembro, podese notar o modo com que os deputados brasileiros se esforçaram para a validação de seus argumentos, utilizando-se, inclusive, de exemplos históricos internacionais para o reforço das propostas de aceleração da aprovação do código criminal. Os argumentos da pressa e da necessidade de superação da legislação penal portuguesa apareceram, assim, nas falas de praticamente todos os deputados e foi, nesse sentido, emblemática, a colocação de um deputado como Lino Coutinho.

Defensor das superioridades de um código casuístico frente a um código sistemático (como o defendido por Paula Souza e Vasconcelos), e absolutamente contrário à aceleração de qualquer tipo de discussão legislativa (já que, para ele, a 
função primeira dos corpos legislativos era a discussão profunda e pormenorizada de todas as leis propostas), Lino Coutinho afirmava concordar com a proposta do deputado Paula Souza unicamente em razão da urgência na aprovação do código criminal.

O corpo legislativo é para discutir tudo quanto é materia legislativa, e discutir maduramente; entretanto, como que ha falta de tempo, e é preciso dar um melhor codigo à nação brazileira, sacrifico esta conveniencia de ter um codigo já, à esta discussão legal, que manda que todas as leis sejão discutidas sejão de que maneira forem, embora não saião com o bello do systema; mas saia com o que é justo e recto para a segurança do cidadão. Sacrifico pois os principios legitimos à falta de tempo, porque é melhor que este codigo philipino que ainda desgraçadamente nos rege, deixa de existir. ${ }^{281}$

Uma segunda possibilidade de interpretação para a inversão de rumos sofrida nos debates de setembro de 1830, funda-se na inserção destes debates num movimento político mais amplo e numa leitura dos Anais que ultrapasse os registros de discussões específicas, atentando ao uso feito pelos deputados brasileiros de determinadas ideias ou conceitos políticos em disputa naquele momento ${ }^{282}$.

Sob esta perspectiva, o desvio das discussões focadas no conteúdo do código criminal em direção, uma vez mais, a debates de cunho procedimental, pode ser lido como parte de uma estratégia política articulada pelos deputados mais diretamente envolvidos na elaboração deste diploma, cientes da importância política representada por seu texto. Buscando evitar, assim, que a multiplicidade de posicionamentos no tocante aos mais diversos dispositivos do código (demonstrada já na discussão do artigo $4^{\circ}$ ) recaísse em duvidosas soluções de consenso, os deputados foram direcionados (pela proposição de Paula Souza) a reservar os ajustes finais sobre o texto do diploma a um reduzido grupo parlamentar.

Para além de facilitar possíveis reformas políticas sobre pontos importantes do código (efetivadas, como veremos, pela última comissão), tal opção de encaminhamento, da forma específica como se deu, parece ter sido pensada de modo a aglutinar parte significativa dos deputados em torno de um argumento comum e de peso àquela altura: o da pressa na aprovação do código e imperiosidade de superação

\footnotetext{
${ }^{281}$ Ibidem.

${ }^{282}$ Para um esclarecimento do modelo de leitura dos discursos políticos em que nos baseamos aqui ver: Tâmis Peixoto Parron. A política da escravidão no Império do Brasil, 1826-1865. Dissertação de Mestrado; DH/FFLCH/USP; 2009; pp.13-14.
} 
do Livro V das Ordenações Filipinas ${ }^{283}$. Reivindicando, portanto, tal urgência, Paula Souza teria conquistado o apoio dos parlamentares à sua proposta.

Não nos esqueçamos que, à altura destes acontecimentos (setembro de 1830), a situação política do imperador brasileiro era bastante complicada, com a oposição a ele articulada na Câmara dos deputados passando a conquistar vitórias - dentre elas, a concordância do Senado, que atuara, até então, como anteparo político do imperador, barrando as propostas da Câmara baixa que ameaçassem seu poder, em se reunir com os deputados em Assembleia Geral para a discussão de projetos de lei emperrados havia muito - e angariar partidários à sua causa. Neste contexto, foi rapidamente reconhecida, no texto do futuro código criminal, a possibilidade de a Câmara se armar de mais uma ferramenta útil no enfrentamento a d. Pedro I.

É nesse sentido que acreditamos poder ser lida a proposta de encaminhamento realizada pelo deputado Paula Souza na sessão de 11 de setembro de 1830. Envolvido com a elaboração do código penal e consciente de sua importância política para a nova nação, o representante de São Paulo pode ter encontrado nesta proposta uma boa alternativa para reduzir os envolvidos na elaboração final do documento e aprovar alterações por ele consideradas necessárias.

As propostas de Ernesto Ferreira França e Pinto Chichorro, por sua vez, teriam conseguido, ao que nos parece, relativizar um pouco da exclusividade projetada por Paula Souza para a reforma do projeto. Ressaltemos, neste ponto, que os Ferreira França, pai e filho, vinham se opondo ao projeto do código criminal então em tramitação de todas as formas possíveis (característica que teremos a oportunidade de analisar com maior cuidado à frente). Neste sentido, a aprovação da proposta de que, anteriormente aos trabalhos da última comissão, fosse discutida, em plenário, a questão da manutenção das penas de morte e de galés possibilitou, a nosso ver, que ao menos neste quesito o texto do futuro código fosse efetivamente debatido pelo conjunto da deputação nacional.

No seio dos opositores ao imperador d. Pedro I, portanto, o reconhecimento da importância representada pelo código às lutas políticas então travadas, não impediu o

\footnotetext{
${ }^{283}$ Argumentos que, vale ressaltar, não eram em absoluto falsos, antes, pelo contrário, por sua força política, tiveram a capacidade de unir opiniões que muito provavelmente se oporiam num debate centrado sobre outras questões. Chama a atenção, contudo, o fato de estes argumentos terem sido articulados pelos deputados brasileiros ao longo de todo o processo de elaboração do código criminal, não nos parecendo suficientes para a explicação das particularidades desta conjuntura final.
} 
aparecimento de grupos de deputados com ideias distintas acerca de sua composição final. Nesse sentido, se tanto Paula Souza, quanto Vasconcelos e os Ferreira França depositavam neste documento papel significativo na configuração de um novo modelo jurídico para Estado brasileiro (em oposição, em grande medida, aos projetos arquitetados pelo imperador), tal não impediu que, no tocante às especificidades deste código (admissão, ou não, da pena de morte para determinados crimes; adoção, ou não, de dispositivos advindos do projeto de Edward Livingston; configuração particular dos crimes públicos do diploma; dentre outros), seus distintos posicionamentos se explicitassem.

As duas vertentes de questionamento elencadas acima não nos parecem, contudo, completamente opostas, podendo ser lidas na chave comum do aprendizado político vivido pelas primeiras legislaturas imperiais. No que diz respeito, assim, à rápida substituição do modelo de discussão parlamentar adotado nos debates finais do código criminal, para além da declarada urgência na superação do Livro V das Ordenações Filipinas, pode-se considerar também o acúmulo de experiências vivenciado pelos deputados brasileiros e sua capacidade de detectar rapidamente, àquela altura, $\mathrm{o}$ iminente fracasso de um modelo de discussão e a premente necessidade de sua substituição.

Para além disso, não se pode ignorar a multiplicidade de interesses e projetos políticos em disputa no momento de elaboração do código penal imperial. Neste sentido, os rumos tomados por este processo podem ser lidos também como a resposta mais apropriada encontrada por deputados que, cientes da batalha envolvida na admissão de determinados preceitos pelo diploma penal, haviam aprendido com sua atuação prévia e souberam encaminhar a questão.

As dúvidas e receios presentes nos debates procedimentais que marcaram o início da tramitação do código criminal no Parlamento brasileiro dariam lugar, assim, às vésperas de sua aprovação, à experiência da deputação e à clareza de que novas soluções deveriam ser buscadas.

Analisando o percurso de elaboração do código criminal no Parlamento brasileiro e partindo de um mesmo estranhamento sobre os rumos assumidos às vésperas de sua aprovação, a historiadora Andréa Slemian chama a atenção para a força desempenhada, naquele momento, pela necessidade de consolidação das previsões constitucionais, materializada, neste caso específico, pela aprovação do código penal imperial: 
De uma forma ou de outra, o consenso entre representantes de posturas tão diversas deve ser pensado no contexto de profunda instabilidade e crise política vivido em fins do Primeiro Reinado, quando o fortalecimento das instituições constitucionais foi visto, mais do que nunca, como fundamental. ${ }^{284}$

Diferentemente, portanto, do que tende a sugerir uma leitura superficial dos debates travados em torno à elaboração do código penal, acreditamos na importância estratégica e nos interesses políticos envolvidos em sua elaboração. Apesar de a insistência dos deputados brasileiros numa rápida aprovação do código ter influenciado largamente as interpretações historiográficas acerca deste processo, o exame atento dos Anais do Parlamento pode apontar para alternativas interpretativas que nos parecem de extremo interesse. Para além dos Anais, uma nova visão do processo codificacionista nacional pode ser forjada a partir da análise dos trabalhos efetivamente empreendidos pelas comissões parlamentares que, entre 1827 e 1830, dedicaram-se à elaboração de seu texto. São justamente estes os trabalhos que passaremos agora a analisar.

\subsection{A atuação das comissões parlamentares na composição do Código de 1830}

Independentemente dos motivos e estratégias políticas envolvidas na configuração final das discussões do código criminal, a análise exclusiva dos Anais do Parlamento brasileiro, como mencionado, tem levado a historiografia nacional a reiterar unicamente a pressa que teria marcado este processo e a pretensa falta de cuidado dos deputados nacionais com a elaboração do diploma imperial. Influenciada pelas insistentes falas dos legisladores neste sentido, a historiografia tem trabalhado repetidamente com a hipótese de que o texto do Código de 1830 descendeu por completo do projeto desenvolvido por Bernardo Pereira de Vasconcelos que, por sua vez, teria sido alterado unicamente em pontos específicos e superficiais.

Pretendemos, contudo, demonstrar justamente o contrário. Partindo, assim, de um exame cuidadoso dos projetos de código criminal apresentados ao Parlamento brasileiro em 1827 e da documentação produzida por uma das comissões dedicadas à sua elaboração, gostaríamos de chamar a atenção do leitor aos minuciosos trabalhos efetivamente desenvolvidos sobre o texto que comporia, enfim, o código penal do Império do Brasil.

${ }^{284}$ A. Slemian. Op. cit.; 2008; pp. 193-194. 
Como vimos nas páginas antecedentes, os projetos apresentados por José Clemente Pereira e Bernardo Pereira de Vasconcelos, em 1827, passaram pelas mãos de duas comissões parlamentares: a Comissão especial do código criminal (formada no ano de 1827 e composta por cinco deputados) e a comissão mista de 1829 (composta por três deputados e três senadores). Como resultado de seus trabalhos, esta última comissão elaborou um novo projeto que, por sua vez, passou por mais duas comissões: a comissão ad hoc das emendas, eleita em maio de 1830 e composta por três deputados, e a última comissão especial do código criminal, eleita em setembro de 1830 e, uma vez mais, composta por três representantes da Câmara baixa.

Tem-se, portanto, ao longo destes anos, a formação de quatro importantes comissões parlamentares responsáveis pela efetiva elaboração do código penal do Império do Brasil. Os trabalhos desenvolvidos no âmbito específico de cada uma delas, contudo, não se encontram registrados nos Anais do Parlamento brasileiro, fazendo com que, para além dos pareceres emitidos e lidos em plenário, não se tenha, nos Anais, quaisquer indícios efetivos de sua produção.

Há, no entanto, registros de que parte importante destes trabalhos teria sido impressa à época. Um ofício lido na Câmara dos deputados aos 21 de maio de 1830 confirmou, por exemplo, terem sido postos a venda, no país, exemplares do projeto de código criminal elaborado pela comissão mista de 1829 (impressos pela Tipografia Nacional) ${ }^{285}$. Um parecer lido na sessão de 06 de julho de 1830 , por sua vez, revelou que a comissão ad hoc eleita em maio do mesmo ano, tendo terminado o trabalho de captação e seleção das emendas enviadas ao projeto da comissão mista, as mandou imprimir "pela tipografia que mais conviesse" 286.

Enquanto o projeto da comissão mista de 1829 infelizmente ainda não pôde ser encontrado, os trabalhos desenvolvidos pela comissão ad hoc das emendas, mandados à impressão em julho de 1830, foram por nós recentemente descobertos num livreto

\footnotetext{
${ }^{285}$ APB-CD; sessão de 21 de maio de 1830, p.183. A leitura do ofício se dá nos seguintes termos: "Officio do Ministro da Fazenda participando em data de 18 do corrente ter expedido as ordens para se pôr à venda os exemplares do codigo criminal do Brazil conforme o officio de 17 que recebera do mesmo Sr. $1^{\circ}$ secretario. - Ficou a camara inteirada devendo declararse à typographia nacional que se mandou pôr à venda o projecto do dito codigo, e não o codigo, para que faça corrigir os annuncios respectivos."

${ }^{286}$ Idem; sessão de 06 de julho de 1830; p. 41. Quanto aos trabalhos da última comissão especial do código criminal, para além do parecer emitido aos 19 de outubro de 1830, sabe-se que os seus esforços resultaram no texto final do Código Criminal do Império do Brasil, impresso nos próprios Anais.
} 
pertencente ao acervo da Fundação Biblioteca Nacional (RJ) ${ }^{287}$. Composto por cerca de 30 páginas, este documento contém, para além das emendas acatadas e sugeridas ao texto do código criminal, um parecer (emitido em 5 de julho de 1830) em que os membros da comissão comentam os trabalhos então desenvolvidos, permitindo-nos identificar o ponto em que se encontrava a elaboração do diploma penal àquela altura.

Partindo, assim, do exame das emendas sugeridas pela comissão ad hoc e da observação de sua ordem e conteúdo, pudemos ter acesso a parte das alterações empreendidas pela comissão mista de 1829 sobre o projeto de Bernardo Pereira de Vasconcelos e detectar quais destas emendas foram, ou não, acatadas pela última comissão do código criminal. Para além disso, o conteúdo das emendas presentes neste livreto permitiu que localizássemos parte dos trabalhos desenvolvidos especificamente no âmbito da última comissão do código criminal.

É eminentemente sobre este material, portanto, que residem as novidades da análise desenvolvida neste subcapítulo. Paralelamente ao livreto da comissão ad hoc, deve-se frisar, trabalharemos também com os registros dos Anais no que tange às atividades das outras comissões citadas, analisando sua formação, seus pareceres e suas principais contribuições à elaboração do código penal imperial. Desta forma, tencionamos explicitar os descompassos tantas vezes existentes entre o que era efetivamente produzido no âmbito específico das comissões parlamentares e aquilo que discutiam, em plenário, deputados e senadores, demonstrando que, diferentemente do que uma leitura desavisada dos discursos dos parlamentares poderia fazer supor, o texto do código penal brasileiro foi trabalhado e retrabalhado, por estas comissões, até que se chegasse, em outubro de 1830, a seu resultado final.

Como vimos por diversas vezes ao longo desta dissertação, nos dias 4 e 16 de maio de 1827, os deputados Bernardo Pereira de Vasconcelos e José Clemente Pereira enviaram, respectivamente, à Câmara, seus projetos de código criminal. No dia seguinte à entrega do projeto de Vasconcelos, discutindo-se seu destino, a Câmara indicou o desejo de formar uma comissão especial encarregada de analisá-lo. Tal Comissão especial do código criminal foi eleita na sessão de 12 de maio de 1827 , sendo escolhidos para compô-la os deputados José Antonio da Silva Maia (MG),

\footnotetext{
${ }^{287}$ Arquivo da Biblioteca Nacional (RJ). Comissão especial do código - emendas ao projecto do código criminal, 1830. Typographia de Lessa \& Pereira, 1830. Localização: V, 257, 3, 8, $n^{\circ} 6$.
} 
Candido José de Araujo Vianna (MG), José da Costa Carvalho (BA), Manuel Caetano de Almeida e Albuquerque (PE) e João Candido de Deus e Silva (PA) ${ }^{288}$.

A comissão emitiu, aos 14 de agosto de 1827, um interessante parecer acerca dos projetos analisados $^{289}$. Já no início deste parecer, seus membros diziam ter se dedicado escrupulosamente à leitura dos dois projetos, comparando o método adotado na classificação dos delitos e distribuição das penas em cada caso e confrontando "mui attentamente as disposições contidas nos seus artigos com os principios da jurisprudencia que mais se amoldão às actuaes circumstancias phisicas, moraes e politicas do imperio". A partir deste trabalho, afirmavam ter reconhecido as dificuldades envolvidas na elaboração de um código criminal nacional e, apesar de destacarem o patriotismo dos autores dos projetos em discussão, confirmavam a necessidade que tinham ambos de "algumas mais ou menos essenciaes alterações, que reduzão à harmonia perfeita as partes como o todo, e este com as supramencionadas circumstancias".

Na seqüência, a comissão alegava ter cogitado formular um novo projeto de código a partir dos dois de que dispunha - "colligido o que de melhor escolha se acha espalhado em ambos" -, tendo rapidamente percebido, contudo, a impossibilidade de semelhante tarefa perante as dificuldades de sua natureza, a estreiteza do tempo, a concorrência de outros trabalhos e as limitações de seus próprios membros.

Haja vista, contudo, a necessidade de deliberar algo, a comissão declarava ter confrontado uma vez mais os sistemas adotados nos projetos de Vasconcelos e Clemente Pereira, emitindo uma opinião que, além de tardia (em suas próprias palavras), limitava-se à "manifestação daquelle dos projectos que entendera dever ser preferido para a discussão, posto que sejão ambos recommendaveis".

Neste sentido, o parecer propunha, primeiramente, que a Câmara recebesse com igual agrado os dois projetos e os mandasse imprimir, possibilitando que o conjunto da deputação formasse sobre eles o seu juízo e que os jurisconsultos e sábios da nação os analisassem, para, num segundo momento, recomendar:

Que para entrar na regular discussão conforme a ordem dos trabalhos, se prefira o do Sr. Vasconcellos por ser aquelle que por mais amplo no desenvolvimento das maximas juridicas, razoaveis, e equitativas, e por mais miudo nas divisão das penas, cuja prudente variedade muito concorre para a bem regulada distribuição dellas, poderá mais facilmente levar-se à possivel perfeição com menor numero de retoques

\footnotetext{
${ }^{288}$ APB- CD; sessão de 12 de maio de 1827; p. 76.

${ }^{289}$ APB-CD; sessão de 14 de agosto de 1827; pp. 130-131.
} 
accrescentados àquelles que já a commissão lhe deu de accordo com o seu illustre autor. $^{290}$

Analisemos rapidamente a força desempenhada por este parecer nas interpretações historiográficas do Código de 1830 e de sua elaboração. Citado em praticamente todos os estudos referentes à matéria, o conteúdo deste documento, especialmente o de sua segunda proposição, tem cumprido o papel de validar a tese segundo a qual o diploma brasileiro de 1830 descendeu imediatamente do projeto de Bernardo Pereira de Vasconcelos. Poucos dentre estes estudos, contudo, atentaram ao fato de que justamente esta proposição do parecer não foi aprovada na sessão de 14 de agosto na Câmara dos deputados, ficando sua votação reservada para depois de impressos os códigos e, ao que tudo indica, nunca ocorrendo. A única resolução tirada pelo conjunto da deputação brasileira a partir do parecer da comissão especial do código criminal, portanto, dizia respeito à aceitação e impressão de ambos os projetos entregues e analisados, não se tendo decidido, mas apenas indicado, naquela ocasião, pela preferência ao projeto de Vasconcelos.

Com esta relativização, não pretendemos invalidar a tese de que o projeto de Vasconcelos tenha servido de base ao texto final do Código de 1830, mas unicamente chamar a atenção ao modo com que, muitas vezes, fez-se um uso equívoco dos registros dos Anais do Parlamento brasileiro para a confirmação de interpretações formuladas previamente à sua leitura. Desta forma, grande parte dos estudos dedicados ao diploma penal do Império brasileiro teria se limitado a reproduzir afirmações de estudos anteriores acerca da autoria do código, buscando no conjunto dos Anais exemplos que confirmassem tais ideias prévias, e não o desenvolvimento de uma releitura (e conseqüente reinterpretação) da documentação ali presente ${ }^{291}$.

Nos anos que se seguiram à emissão e leitura do parecer da Comissão especial, nenhum trabalho foi efetivamente desenvolvido, no Parlamento, sobre o conteúdo do futuro código criminal. Ao que tudo indica, entre 1827 e 1829 (período em que, como vimos, os deputados brasileiros debateram soluções de continuidade para a elaboração

\footnotetext{
${ }^{290}$ APB-CD; sessão de 14 de agosto de 1827; p. 131.

${ }^{291}$ Se o largo uso do projeto de Vasconcelos na elaboração do Código de 1830 pode ser confirmado, tal reconhecimento só é possível a partir de um exame cuidadoso dos respectivos conteúdos destes documentos (que se preocupe em frisar também o que foi modificado entre um e outro) e de um olhar atento sobre o conjunto dos debates parlamentares travados em torno a esta temática, e não unicamente por meio da (repetitiva) ênfase nas resoluções do parecer da comissão especial. O exame acima sugerido será desenvolvido no Capítulo 3 desta dissertação.
} 
e discussão do código), os projetos de Vasconcelos e Clemente Pereira foram deixados de lado tanto na Câmara, como no Senado.

Em maio de 1828, contudo, Vasconcelos propôs - em meio à discussão sobre a implementação, ou não, do júri criminal no país previamente à aprovação do código penal - a formação de uma comissão parlamentar mista dedicada à revisão dos projetos oferecidos ${ }^{292}$. Sua proposta - muito provavelmente fundada no desejo de aceleração das discussões relativas ao código e antecipação, nesse sentido, de sua aprovação -, foi aceita pelo conjunto dos deputados. Seus trabalhos, contudo, só tiveram início efetivamente em maio de 1829, quando, como vimos, esta comissão se encontrava em sua segunda formação (de 10 membros, eleitos em 1828, passara a conter apenas seis em 1829: três deputados e três senadores).

No dia 31 de agosto de 1829, as Câmaras alta e baixa do Parlamento nacional receberam e leram o interessante parecer elaborado pela segunda comissão mista do código criminal. Neste parecer, cujo conteúdo foi parcialmente analisado no item anterior, a comissão das duas Câmaras afirmava ter examinado os projetos de Vasconcelos e Clemente Pereira e elaborado, sobre o primeiro deles (como indicado pela Comissão especial da Câmara dos deputados), um novo projeto. Alterando o projeto de Vasconcelos nos pontos considerados convenientes - "avaliando em mais o damno da demora que o das imperfeições, que com vagar pudesse corrigir" - a comissão apresentava agora a nova organização adotada:

Divide-se este projecto em 4 partes: trata a $1^{\mathrm{a}}$ dos crimes e penas em geral [...]. Pode-se dizer que esta $1^{a}$ parte contem a theoria do systema que nas outras se desenvolve em um quadro classificado de todos os crimes.

A $2^{\mathrm{a}}$ trata dos crimes contra os interesses geraes da nação.

A $3^{\text {a }}$ dos crimes contra os interesses dos individuos.

E a $4^{\mathrm{a}}$ comprehende os crimes policiaes sobre que a autoridade publica deve cuidadosamente velar para prevenir maiores males. ${ }^{293}$

Como explicitado no capítulo anterior, o projeto apresentado por Vasconcelos dividia-se também em quatro partes, organizadas, contudo, na seguinte ordem: (I) "Dos crimes e penas em geral”, (II) "Dos crimes policiaes", (III) “Dos crimes particulares" e (IV) "Dos delictos públicos" - contando ainda com uma pequena "Disposição Geral". Independentemente, portanto, das alterações levadas a cabo em

\footnotetext{
${ }^{292}$ A proposta de Vasconcelos de que se revisse os (dois) projetos de código criminal, e não apenas o seu, indica, a nosso ver, que do ponto de vista dos deputados, não ficara estabelecido que o texto do código criminal se erigiria unicamente sobre as disposições do projeto do deputado mineiro. APB-CD; sessão de 8 de maio de 1828, p. 24.

${ }^{293}$ APB-CD; sessão de 31 de agosto de $1829 ;$ p. 84
} 
seu conteúdo, não há dúvidas de que a organização deste projeto já fora bastante modificada pela comissão mista de 1829.

De acordo com Monica Dantas:

Em termos de distribuição das matérias e da nomenclatura das partes, não se tratava mais do projeto de Vasconcelos, mas tampouco do texto que viria a ser aprovado em 1830. A ordem das matérias era similar àquela do futuro Código Criminal, mas as partes segunda e terceira teriam seus nomes ainda modificados: a parte segunda, intitulada pela comissão "dos crimes contra os interesses gerais da nação", passaria, no Código, a se chamar "Dos crimes públicos"; e a terceira, "dos crimes contra os interesses individuais", viraria "Dos crimes particulares". ${ }^{294}$

Até este ponto do parecer, portanto, ficamos sabendo que a comissão mista se baseara efetivamente no projeto de Bernardo Pereira de Vasconcelos (tendo sempre à vista, e na devida consideração, o de Clemente Pereira), modificando-o, contudo, nos pontos considerados necessários.

Uma vez apresentada a organização do novo projeto, o parecer da comissão passava a refletir acerca da manutenção da pena de morte entre as punições do diploma brasileiro. De acordo com seu texto, a comissão desejara suprimir semelhante pena ("cuja utilidade rarissimas vezes compensa o horror causado na sua applicação"), mas não pudera fazê-lo em razão dos limites da educação primária no Império. Nas palavras de seus membros, o consolo perante esta triste necessidade advinha da proibição de se executar a pena de morte sem o consentimento do poder Moderador e da esperança de que este seguramente a recusaria quando sua substituição conviesse.

Para além desta avaliação, o parecer da comissão manteve a "tradição" de crítica aberta ao Livro V das Ordenações Filipinas, pontuando seus inúmeros “defeitos" e a necessidade premente de sua superação. Apesar de não recomendar como obra perfeita o projeto oferecido, a comissão reconhecia sua utilidade quando comparado à legislação penal em vigor no país. Antes de estabelecer o plano de rápida aprovação do novo projeto (comentado no subcapítulo anterior), o parecer confirmava o princípio da utilidade pública enquanto regulador do novo diploma e atestava que, substituindo-se as leis existentes por "um codigo organisado systematicamente sobre uma base solida tomada na natureza social e já consagrada no nosso codigo fundamental", em muito se avançaria rumo à perfeição das leis penais.

${ }^{294}$ Monica D. Dantas. Op. cit.; 2011; p. 18. 
Como vimos anteriormente, o plano proposto pelo parecer estabelecia que o projeto oferecido fosse adotado sem passar pelas discussões previstas nos regimentos das Câmaras, e que, para tanto, fosse rapidamente impresso e distribuído. As emendas e memórias a ele oferecidas, por sua vez, deveriam ser remetidas a uma comissão ad hoc de três membros. Assim que a comissão selecionasse e imprimisse o material recebido, o plano estabelecia que o projeto fosse dado, junto com as emendas, à ordem do dia. A discussão deveria começar pela admissão, ou não, do projeto como um todo e, em caso afirmativo, seguir pela discussão dos artigos emendados (tendo-se os outros como automaticamente aprovados).

Vale ressaltar, por fim, que este parecer vinha assinado pelos deputados José da Costa Carvalho, João Candido de Deus e Silva e José Antonio da Silva Maia e pelos senadores Nicolau Pereira de Campos Vergueiro e Manoel Caetano de Almeida e Albuquerque. A comissão mista de 1829 compunha-se, contudo, pelos três deputados citados e, conforme votação efetuada aos 26 de maio de 1829 na Câmara alta, pelos senadores Vergueiro, Visconde de Alcântara e Carneiro de Campos. Fato é, portanto, que os dois últimos senadores eleitos, por motivos que desconhecemos, não assinaram o parecer da comissão, tendo sido substituídos na tarefa de composição de um novo código criminal pelo senador Almeida e Albuquerque ${ }^{295}$.

Curta e interessante, a discussão do parecer (realizada aos 6 de maio de 1830, já nos quadros da segunda legislatura imperial, portanto ${ }^{296}$ ), ficou praticamente restrita às falas e proposições de Antonio e Ernesto Ferreira França - pai e filho, baianos, o primeiro eleito por sua província natal e o segundo por Pernambuco.

Foi Ernesto Ferreira França quem abriu a discussão, avaliando como "mui poderoso o parecer da comissão" frente à péssima legislação criminal em vigor no país. Para o deputado, o projeto da comissão mista deveria sim ser adotado pela Câmara, mas, antes de fazê-lo, a legislatura deveria discuti-lo com as emendas apresentadas e, acima de tudo, na forma de uma comissão geral (em que os deputados pudessem falar quando e quantas vezes lhes aprouvesse).

Antonio Ferreira França pronunciou-se em seqüência ao filho e ofereceu ao plenário uma resolução com o seguinte conteúdo: “A assembleia geral resolve: A

\footnotetext{
${ }^{295}$ De acordo com Monica Dantas, o senador Almeida e Albuquerque não era, entretanto, alheio à discussão do código criminal, tendo sido eleito para substituir Carneiro de Campos na primeira conformação da comissão mista do código criminal, àquela altura composta por 5 deputados e 5 senadores. Monica D. Dantas. Op. cit.; 2011; p. 49, nota 33.

${ }^{296}$ APB-CD; sessão de 6 de maio de 1830; pp. 78.
} 
pena de morte está abolida pela constituição. - Paço da Câmara dos deputados, em 6 de maio de 1830.”. De acordo com Antonio Ferreira França, a questão tratada em sua resolução deveria ser priorizada no debate por se referir a um problema constitucional. Ernesto saiu então em defesa do pai, afirmando que a questão da inconstitucionalidade da pena de morte entraria também em suas emendas.

O Presidente da sessão (José da Costa Carvalho, eleito pela província da Bahia), contudo, logo interveio e colocou um ponto final no debate lançado pelos Ferreira França. Para o Presidente, a discussão em curso debruçava-se sobre o código penal e não sobre a pena de morte, devendo-se debater, neste sentido, o parecer da comissão mista e não a inconstitucionalidade de parte dele.

Os registros desta discussão terminam logo em seguida com a apresentação das quatro emendas enviadas à mesa por Ernesto Ferreira França:

$1^{\text {a }}$. Que entre as emendas também se admittão as substitutivas de todo o projecto.

$2^{\mathrm{a}}$. Que quando se discutir o projecto e emendas, a camara se converta em commissão geral.

$3^{\text {a }}$. Que o dia marcado para esta discussão seja declarado 8 dias antes.

$4^{\mathrm{a}}$. Que desde já se supprima no projecto a pena de morte natural, e com este pressuposto se reforme a escala das penas. ${ }^{297}$

Enquanto a primeira e a terceira emendas de Ernesto Ferreira França foram aprovadas pela deputação brasileira, a quarta foi postergada, por deliberação da Câmara, para dela se tratar em ocasião competente.

De acordo com suas intervenções na discussão de 6 de maio - e com a segunda e terceira emendas transcritas acima -, conclui-se que Ernesto era favorável ao projeto desenvolvido pela comissão mista de 1829 e que, para sua aprovação, pedia apenas que fossem discutidas com seriedade, e de forma organizada, as emendas enviadas pelos parlamentares. O conteúdo de sua primeira emenda (prevendo a admissão, dentre o conjunto de emendas enviadas à comissão $a d$ hoc, daquelas que propusessem a substituição total do projeto da comissão mista por um novo diploma penal), bem como uma análise de conjunto de seu posicionamento frente ao projeto de código em tramitação na Câmara, revelam, contudo, sua possível preferência por um outro modelo de código.

Não esqueçamos que, respectivamente nas datas de 21 e 22 de maio de 1829 , os Anais da Câmara e do Senado brasileiro registraram a entrega, pelo cidadão João Clemente Vieira Souto, de exemplares da tradução do "projecto do codigo penal para

${ }^{297}$ Idem. Ibidem. 
a Luisiana", de Edward Livingston. De acordo com Monica Dantas, tais exemplares provavelmente diziam respeito à tradução do plano para o código penal da Luisiana $^{298}$, apresentado pelo jurista nova-iorquino Edward Livingston ao legislativo daquele estado em março de $1822^{299}$. Como teremos a oportunidade de analisar à frente, Ernesto seria um assíduo defensor do Código da Luisiana, podendo esta emenda indicar já suas pretensões de substituição do projeto da comissão mista de 1829 pelo projeto elaborado por Livingston.

A seqüência dos acontecimentos esclarece a interpretação sugerida acima, já que, após a eleição da comissão ad hoc das emendas, realizada, como vimos, em 7 de maio de 1830, a Câmara registrou, aos 12 de maio, o recebimento de um exemplar do código criminal da Luisiana, ofertado pelo cidadão José Silvestre Rebello ${ }^{300}$. Na mesma sessão em que a Câmara recebeu este exemplar, Ernesto Ferreira França (muito rapidamente) mandou à mesa o seguinte requerimento:

Requeiro que se nomêe quanto antes uma commissão de fóra, presidida por um membro desta camara, à qual se encarregue com a possível brevidade a traducção da legislação penal, organisada para o estado da Luisiana por Levington [sic]..$^{301}$

Lido o requerimento, Ernesto pediu ao plenário que deliberasse sobre ele com urgência. Apoiada por parte da deputação, sua proposta de urgência ficou, contudo, rejeitada, deixando-se o requerimento "para delle se tratar em occasião competente". Aos 14 de maio de 1830 sua proposta de formação de uma comissão que traduzisse o código de Livingston entrou novamente em discussão.

O primeiro a se manifestar na ocasião foi o deputado José Bento Ferreira de Melo (MG), favorável ao requerimento, porém não da forma como se encontrava proposto. Para este deputado, os membros da comissão sugerida por Ernesto deveriam pertencer ao conjunto da deputação nacional, podendo-se propor uma comissão de fora que a coadjuvasse, mas não que realizasse todo o seu trabalho. Ernesto se colocou contra a emenda de Ferreira de Melo, declarando que os membros da Câmara baixa encontravam-se suficientemente ocupados no momento. $\mathrm{O}$ deputado baiano manteve

\footnotetext{
${ }^{298}$ Tratava-se, provavelmente, da obra: Rapport fait à l'Asssemblée Générale de l'Etat de la Lousiane sur Le projet d'um Code Pénal por ledit Etat, Nova Orleans, Benjamin Levy \& Co, 1822.

${ }^{299}$ Monica D. Dantas. Op. cit.; 2011; pp. 24-25. Ver especialmente as notas de número 59 a 62.

${ }^{300}$ Para mais detalhes acerca de Silvestre Rebello, ver: Monica D. Dantas. Op. cit.; 2011; p. 25; especialmente nota 63.

${ }^{301}$ APB-CD; sessão de 12 de maio de 1830; p. 123.
} 
a opinião de que a comissão fosse composta por homens de fora da Câmara e presidida por um de seus membros, "que una aos outros conhecimentos o da legislação e o da lingua ingleza".

Antonio Francisco de Paula e Holanda Cavalcanti de Albuquerque (PE; doravante Holanda Cavalcanti), por sua vez, votou "contra o requerimento pela impossibilidade de se pôr em execução". De acordo com o deputado, encontrar homens que traduzissem a língua inglesa, soubessem algo de direito e tivessem os demais conhecimentos necessários seria praticamente impossível, devendo-se antes autorizar o governo a despender uma quantia em dinheiro para a tradução do código norteamericano. Sua proposta de resolução, neste sentido, dizia:

O governo fica encarregado de mandar traduzir e imprimir o codigo penal organisado para o estado da Luisiana por Levington [sic], com a maior brevidade possível, dividindo o trabalho por differentes emprehendedores e provendo ao pagamento destes, segundo fôr mais conducente ao fim da prompta execução da presente resolução. ${ }^{302}$

Vasconcelos falou na seqüência e, de sua parte, votou contra o requerimento de Ernesto Ferreira França e a proposta de resolução de Holanda Cavalcanti. De acordo com o deputado, já ficara decidido o envio do código de Livingston à comissão $a d$ hoc "para esta o examinar e approvar delle o que fôr conveniente e compatível com as nossas circunstancias", não se devendo agora mandá-lo à impressão ou à tradução, com o que se atrasaria o andamento da discussão e aprovação do diploma penal em tramitação.

Holanda Cavalcanti se manifestou ainda uma última vez, concordando com as dificuldades envolvidas na tradução e impressão do código da Luisiana e com a decisão da Câmara de que este código fosse enviado, anfim, na forma em que se encontrava, à comissão $a d$ hoc, para esta o consultar.

Antes de a comissão ad hoc apresentar à Câmara os resultados de seus trabalhos, um interessante requerimento foi enviado à mesa, em 26 de maio de 1830, pelo mesmo Ernesto Ferreira França:

Requeiro que se encarregue a commissão creada para receber as emendas ao codigo criminal, de examinar o organisado por Eduardo Livingston para a Luisiana, e interpôr o seu parecer acerca do merito deste codigo comparativamente com o que serve actualmente de base às emendas. ${ }^{303}$

\footnotetext{
${ }^{302}$ APB-CD; sessão de 14 de maio de 1830; p. 143.

${ }^{303}$ APB-CD; sessão de 26 de maio de 1830; p. 234.
} 
Desta vez Ernesto propunha, com todas as letras, que se avaliasse, no âmbito específico da comissão ad hoc, a possibilidade de substituição integral do projeto da comissão mista pelo código de Edward Livingston.

Aos 6 de julho de 1830 os Anais da Câmara registram a leitura do seguinte parecer da comissão ad hoc:

A commissão especial do codigo recebeu e examinou as emendas, que se mandarão imprimir com urgencia e o parecer, ficando autorisado o Sr. $1^{\circ}$ secretario para incumbir esta impressão á typographia que mais convier, como se venceu na conformidade do requerimento de um deputado. ${ }^{304}$

Como dissemos no início deste item, foi por nós recentemente descoberto no acervo da Biblioteca Nacional um livreto contendo a íntegra do parecer emitido, em 5 de julho de 1830, pela comissão ad hoc das emendas, juntamente com todas as emendas por ela mandadas à impressão.

A comissão ad hoc, que se autodenominava "Comissão especial do Código" neste parecer, afirmava ter recebido e analisado as emendas que durante o mês de maio haviam oferecido ao projeto do código criminal os deputados Pedro de Araújo Lima (PE; futuro marquês de Olinda), Ernesto Ferreira França, Antonio Pereira Rebouças (BA), Lourenço Pinto de Sá Ribas (eleito por São Paulo), José Custodio Dias (MG), Antonio Pinto Chichorro da Gama (MG) e Honório Hermeto Carneiro Leão (MG), bem como a Memoria de William de St. ${ }^{\circ}$ Adolfo. Quanto a esta última, dizia não ter encontrado no documento matéria própria a ser proposta como emenda, apresentando unicamente as emendas selecionadas a partir das proposições dos deputados. A comissão afirmava ainda ter recebido, para além das que mandava imprimir, outras emendas, que por alterarem a doutrina dos artigos a que se referiam, tiveram contudo de ser suprimidas.

De acordo com o parecer, a maior parte das emendas selecionadas e impressas se encontrava em harmonia com o sistema geral do código, devendo, portanto, ser adotadas:

[...] ou porque crião delicto novos, esquecidos no Projecto, mas exigidos pela nossa pozição Social, habitos, e costumes, ou porque correigem e adoção [sic] algumas penas que pareciam nimiamente asperas, ou porque suprimem artigos desnecessarios, e mesmo contrarios a Constituição do Imperio, ou finalmente porque dão clareza e exactidão a outras que a não tinhão. ${ }^{305}$

\footnotetext{
${ }^{304}$ APB-CD; sessão de 6 de julho de 1830; p. 41.

${ }^{305}$ Arquivo da Biblioteca Nacional (RJ). Comissão especial do código - emendas ao projecto do código criminal, 1830. Typographia de Lessa \& Pereira, 1830. Localização: V, 257, 3, 8, $\mathrm{n}^{\circ} 6$; p. I. Para a íntegra do parecer da comissão especial das emendas ver Anexo IX.
} 
Assim como a comissão mista de 1829 o fizera, também a comissão ad hoc dedicava parte de seu parecer ao esclarecimento da manutenção das penas de morte e de galés entre as emendas. De acordo com o parecer, apesar de parte das emendas enviadas pelos deputados França Filho (Ernesto) e Rebouças pedir justamente a supressão dos artigos do projeto em que se impunham estas penas, a comissão não havia podido "concordar inteiramente com a opinião dos Srs. Deputados (que alias não offerecerão como parecia conveniente emendas a esses artigos substituindo as suas penas por outras)", haja vista o atraso da educação primária nacional e a subsistência do "elemento da escravatura" no país. De acordo com a comissão, entretanto, o voto filantrópico destes deputados encontrar-se-ia em parte satisfeito pelas emendas propostas por outros deputados, e acatadas pela comissão:

Nestas se omitte totalmente a pena de galez temporarias; a qual bem como a pena de morte se reservão para rarissimos cazos, e nesses mesmos estabelecendo-se trez penas, para os trez diferentes gráos, se provê ao tempo em que a applicação de semelhantes penas haja de tornar-se desnecessaria, ou ante-nacional, pois sem dependencia de medidas futuras do Poder Legislativo, a sua correcção se póde encontrar no Juro Mestrado, são, e imparcial do Jury. ${ }^{306}$

O parecer dizia ainda que, pelo que pertencia ao código do "Doutor Eduardo Livingston", indicado pelo deputado Ernesto como emenda (substitutiva) ao projeto em andamento, a comissão entendia que, por apreciável que este fosse, não deveria ser preferido ao da comissão mista e nem adotado no Império. Tal recusa baseava-se nas diferenças de governo, costumes e interesses existentes entre os dois países, no fato de que aquele código não punia "algumas acções que a nossa forma de governo, costumes, e peculiares circunstancias exigem que sejão criados delictos" e, ainda, "porque sendo baseadas suas penas em hum Systema completo de Cazas de Correcção, e prizões aperfeiçoadas, não pode por muito tempo ser abraçado no Imperio, onde semelhante Systema por desgraça nem existe esboçado".

Por fim, o parecer afirmava que o projeto da comissão mista deveria ser preferido e adotado com as emendas agora apresentadas, "que são aquellas que a Commissão julga em harmonia com o mesmo projecto, e dignas da attenção da Camara, tendo a lembrar que algumas dellas forão emprestadas do mencionado Codigo do Doutor Livingston."

O parecer vinha assinado pelos três membros da comissão das emendas: Honório Hermeto Carneiro Leão, Joaquim Francisco Alves Branco Munis Barreto e Antonio

${ }^{306}$ Idem; p. II. 
Pinto Chichorro da Gama, mas o último deles dizia fazê-lo "com restricções e vencido quanto às penas de morte e de galez"307.

Por meio da leitura deste parecer, ficamos cientes da multiplicidade das mudanças propostas pela comissão ad hoc ao projeto da comissão mista de 1829. Para além da exclusão da pena de galés temporárias, a comissão explicitava ter acatado emendas que corrigiam e adoçavam penas consideradas ásperas no projeto e outras que davam exatidão e clareza a artigos "obscuros". O parecer revelava ainda a seleção de emendas criadoras de novos delitos e supressoras de outros, confirmando a preocupação constante da comissão com a manutenção da sistematicidade e da doutrina do texto do código criminal. Por fim, a comissão declarava ter efetivamente recebido, da parte do deputado Ernesto Ferreira França, uma proposta de substituição integral do projeto em tramitação no Parlamento pelo Código penal da Luisiana, alegando que, não a tendo acatado, retirara, contudo, do projeto norte-americano, parte importante das emendas agora apresentadas.

Diferentemente da produção historiográfica dedicada ao Código de 1830, em momento algum a comissão se referiu ao projeto em discussão enquanto o projeto de Bernardo Pereira de Vasconcelos, mas apenas enquanto o "Projeto da comissão mista”. Se, como vimos acima, o projeto de 1829 já havia alterado parte do texto apresentado pelo deputado mineiro, há que se questionar acerca de quantas mais alterações não teriam sido propostas pela comissão $a d$ hoc das emendas e efetivadas pela última comissão especial do código criminal.

Em seqüência ao parecer, o livreto contém a íntegra das emendas selecionadas e mandadas à impressão pela comissão ad hoc. Por meio destas emendas, que preenchem 28 páginas, são propostas alterações - maiores ou menores - a cerca de 210 artigos do projeto da comissão mista. Haja vista que o projeto de Vasconcelos e o Código de 1830 possuíam, respectivamente, 334 e 313 artigos, pode-se aventar a hipótese de que a comissão ad hoc sugerira emendas a cerca de dois terços do projeto da comissão mista de 1829, o que indica, a nosso ver, o desenvolvimento de um trabalho detalhista e cuidadoso sobre aquele documento.

A análise deste conjunto de emendas, aliás, revelou características importantes do projeto de 1829, que, como dissemos acima, ainda não foi localizado. Desta forma, a partir da numeração dos artigos emendados (retirada diretamente dos artigos do

\footnotetext{
${ }^{307}$ Idem; p. III.
} 
projeto da comissão mista, sobre o qual se trabalhava), tivemos acesso à organização efetivamente adotada por aquele documento. A observação desta numeração possibilitou, assim, que comprovássemos o fato de a organização do Código de 1830 descender imediatamente daquela adotada pelo projeto elaborado em $1829^{308}$, e não dos projetos apresentados, em 1827, por Clemente Pereira e Vasconcelos.

Para além da questão organizacional, a observação cuidadosa deste conjunto de emendas e sua comparação com o projeto de Vasconcelos, e com o texto final do Código de 1830, revelaram parte do conteúdo efetivamente alterado pela comissão de 1829 sobre o projeto apresentado pelo deputado mineiro.

Ao compararmos o projeto de Bernardo Pereira de Vasconcelos ao texto final do Código de 1830, pudemos perceber, dentre as inúmeras alterações organizacionais e de conteúdo realizadas entre estes documentos, a presença de 88 artigos inéditos (em 1830) e uma quantidade razoável de novos parágrafos no interior de outros tantos artigos. Ademais, a análise das emendas apresentadas pela comissão ad hoc nos permitiu perceber que cerca de 22 destes 88 artigos, foram certamente inseridos pela comissão mista de $1829^{309}$.

Deve-se ressaltar, ainda, que para além dos artigos inéditos de 1830, uma série de outros artigos do projeto de Vasconcelos já havia sido modificada pela comissão

\footnotetext{
${ }^{308}$ As diferenças de numeração dos artigos do projeto da comissão mista em relação aos artigos do Código de 1830 são, portanto, bastante pequenas, com os artigos correspondentes em um e outro documento posicionados pouquíssimo à frente ou atrás no texto de 1830 . Temse, assim, que aos artigos 24 e 71 do projeto da comissão mista correspondiam, no Código de 1830, os artigos 31 e 74; enquanto aos artigos 102 e 218 do projeto correspondiam, em 1830, os artigos 98 e 215 . Há casos ainda em que a numeração dos artigos é idêntica nos dois documentos, como ocorre, por exemplo, com os artigos 262 e 264.

${ }^{309}$ A presença destes artigos no projeto da comissão mista pôde ser detectada através das emendas sugeridas pela comissão $a d$ hoc sobre cada um deles. São estes os artigos a que nos referimos, no Código de 1830: art. 51 (concernente à criação da pena de degredo), art. 67 (relativo ao perdão dos réus), arts. 71 e 86 (correspondentes aos crimes políticos contra a Independência da nação e a Constituição do Império), arts. 93, 95, 96, 97 e 99 (relativos a crimes contra o livre exercício dos poderes políticos), arts. 100, 101, 103, 104 e 105 (referentes a crimes eleitorais), arts. 138, 139, 140 e 141 (relativos ao crime de abuso de autoridade por funcionários públicos), e arts. 215, 216, 217 e 218 (concernentes ao crime de abertura de correspondência alheia). Para além destes artigos, cuja autoria e inserção no projeto do código criminal podemos afirmar dever-se aos trabalhos da comissão mista, uma série de outros institutos presentes no texto de 1830 deixam dúvidas quanto à sua origem. Isto porque, para além dos artigos certamente inseridos em 1829, ou a partir das emendas sugeridas pela comissão $a d$ hoc (como veremos à frente), parte dos artigos inéditos de 1830 pode ter procedido tanto dos trabalhos da comissão de 1829 (não tendo sido emendados em 1830 por nenhum deputado e, desta forma, não constando entre as emendas propostas pela comissão $a d$ hoc), quanto dos trabalhos da última comissão responsável pelo texto do código penal brasileiro - sem que possamos, portanto, precisar suas origens.
} 
mista de 1829. Tal conjunto de alterações - por vezes mais significativas que a própria inserção de novos artigos no texto do diploma -, abarcou desde variações em palavras ou sentenças sem grande importância, até a modificação de parte das punições previstas pelo deputado mineiro ${ }^{310}$. Por não termos acesso, contudo, ao texto completo do projeto da comissão mista, fica difícil especularmos, sem maiores comprovações documentais, os casos em que tais alterações teriam de fato ocorrido. Presume-se, entretanto, pela própria análise dos trabalhos da comissão ad hoc, que tal tipo de modificação tenha de fato sido realizado pela referida comissão mista ${ }^{311}$.

Finalizando as observações que o acesso aos trabalhos da comissão ad hoc nos permitiu realizar sobre o texto do projeto de 1829 (ainda desconhecido), vale a pena enfatizar que, apesar das mudanças organizacionais e da introdução precisa de artigos indicadas acima, a comissão mista não foi a responsável pelas grandes alterações efetivamente empreendidas sobre o texto de Vasconcelos. Se podemos confirmar que o conteúdo do Código de 1830 diferia em muito daquele do projeto do deputado mineiro, podemos atestar também que os trabalhos que deram origem a estas diferenças advieram predominantemente das alterações propostas pela comissão $a d$ hoc das emendas e dos trabalhos empreendidos pela última das comissões especiais da Câmara dedicadas ao código penal.

Dentre as mais de 210 propostas de alteração no texto do projeto da comissão mista de 1829, apenas 18 não entraram no texto do Código de 1830, dispensadas por completo pela última comissão. Todo o restante das emendas, que iam da sugestão de mínimas alterações gramaticais ou de vocabulário no texto dos artigos, à proposição

\footnotetext{
${ }^{310}$ Por meio de discurso enunciado pelo deputado Paula Souza aos 15 de setembro de 1830, ficamos sabendo que o projeto da comissão mista, único de que dispunham os parlamentares à altura dos debates sobre a pena de morte, admitia esta punição unicamente em 4 casos. Nas palavras do deputado: "O codigo admitte a pena de morte em quatro casos sómente, que são aquelles donde podem provir maiores males à sociedade". Haja vista o projeto de Vasconcelos admiti-la por mais vezes, é provável que esta comissão tenha alterado também, portanto, os casos de prescrição da pena capital.

${ }^{311}$ Um exemplo extremamente importante deste tipo de alteração (comprovável a partir do exame das emendas) diz respeito ao desmembramento do artigo 311 do projeto de Vasconcelos, levado a cabo pela comissão mista de 1829. Como veremos com mais calma à frente, este artigo definia, em oito parágrafos, o crime de traição no Império do Brasil. A categoria "traição" já não aparece mais em 1830, apesar de parte de seu conteúdo ter se mantido, sob outras denominações, no texto do Código Criminal. A análise das emendas da comissão ad hoc revela que o desmembramento do artigo 311 de Vasconcelos foi realizado pela comissão de 1829 , o que pode indicar ter sido esta a comissão responsável pela eliminação deste crime do código penal brasileiro.
} 
de novas penas e crimes foi, de alguma forma, considerado e incorporado pelos deputados responsáveis pela última redação do texto do diploma penal.

Desta forma, dos 88 artigos inédito do Código de 1830 (em relação ao projeto de Vasconcelos), 34 advieram essencialmente das emendas propostas pela comissão $a d$ $h o c^{312}$ e acatadas pela última comissão. Como veremos no próximo capítulo, os novos artigos propostos, juntamente a inúmeros outros cujo conteúdo fora modificado pelas emendas, perpassavam pontos de extrema importância para qualquer código criminal: definindo com maior precisão uma série de punições presentes em seu texto, introduzindo crimes públicos de extremo interesse quando pensada a conjuntura política vivida pelo Brasil, reequilibrando as punições previstas para vários destes crimes públicos e criando importantes delitos particulares e policiais previamente inexistentes no texto do projeto.

A título de exemplo, vale observar que, por meio das emendas selecionadas pela comissão ad hoc, passaram a compor o texto do Código de 1830 prescrições referentes ao direito de habeas corpus dos réus e também aos crimes de insurreição escrava e ajuntamentos ilícitos. Para além disso, parte das emendas definiu com maior precisão as penas de prisão simples e prisão com trabalho, diferenciando-as essencialmente da pena de galés e rearranjando, neste sentido, de acordo com uma nova lógica penal, grande parte das punições previstas por Vasconcelos em seu diploma criminal ${ }^{313}$.

Como também teremos a oportunidade de observar no próximo capítulo, parte importante destas emendas, especialmente no que diz respeito às redefinições e

${ }^{312}$ São eles os artigos $6,13,35,51,58,59,79,80,81,94,98,102,113,114,115,137,161$, 183, 184, 185, 186, 187, 188, 196, 271, 286, 287, 288, 289, 291, 292, 293, 294 e 303.

${ }^{313}$ No próximo capítulo veremos em que se baseava esta nova "lógica penal" assumida pelo código brasileiro de 1830 e já anunciada pelas emendas sugeridas pela comissão ad hoc. Para ilustrar o rearranjo penal a que nos referimos, um bom exemplo são as alterações propostas pelas emendas da comissão $a d$ hoc às punições previstas nos artigos 68,69 e 72 do que viria a ser o Código de 1830, referentes a crimes contra a Independência, integridade e dignidade da nação (correspondentes, no projeto de Vasconcelos, respectivamente, ao $\S 7^{\circ}$ do art. 311 e aos arts. 319 e 321). Assim, enquanto o projeto de Vasconcelos previa, por exemplo, ao crime de tentativa de destruição da independência e integridade do Império, a seguinte punição: galés perpétuas no grau máximo, prisão perpétua com trabalho no médio e 10 anos de galés no grau mínimo (misturando, portanto, penas como a de galés e a de prisão com trabalho que, como veremos a frente, não poderiam ser misturadas quando baseadas numa concepção penal moderna); as emendas da comissão ad hoc propunham que, ao mesmo crime, fossem adscritas as seguintes punições: prisão perpétua com trabalho no grau máximo, prisão com trabalho por 15 anos no médio e de banimento no mínimo. A título de exemplo, vale ressaltar que o artigo 68 do Código de 1830 prescreveria, ao mesmo crime, a seguinte punição: prisão com trabalho por cinco a quinze anos. 
reequilíbrios penais e à criação de novos delitos, adveio de fato do projeto de código criminal elaborado pelo jurista nova-iorquino Edward Livingston, entre 1822 e 1824, para o Estado da Luisiana ${ }^{314}$. Desta forma, cerca de quarenta artigos do Código de 1830 podem ter suas origens precisamente atribuídas a este projeto norte-americano.

Como indicado até aqui, para além de fornecer pistas no que tange ao conteúdo do projeto da comissão mista de 1829 , o conjunto das emendas selecionadas pela comissão ad hoc permite que tenhamos acesso também aos trabalhos empreendidos pela última comissão especial do código criminal. Neste sentido, a observação do conteúdo das emendas selecionadas e sua comparação ao texto final do Código de 1830 indicam, para além do conjunto de emendas acatadas por esta última comissão, as novidades e alterações por ela ainda introduzidas no texto final do código criminal.

Eleita na sessão de 11 de setembro de 1830 (a partir de proposta do deputado Francisco de Paula Souza e Melo, como vimos anteriormente) e composta pelos deputados Antonio Paulino Limpo de Abreu, Luiz Francisco de Paula Cavalcanti de Albuquerque e pelo próprio Paula Souza, a última comissão do código criminal se responsabilizou pela revisão das emendas sugeridas pela comissão ad hoc e pelo recebimento das últimas emendas enviadas pela deputação brasileira ao código criminal. Para além disso, coube a ela selecionar, a partir deste conjunto de emendas, aquelas consideradas indispensáveis ao texto do código, indicando os meios mais breves para a sua discussão. Haja vista a abrangência dos trabalhos a ela designados e a rapidez que lhe fora cobrada nesta empreitada, seus três membros foram dispensados, pela Câmara, de comparecerem às sessões regulares enquanto durassem suas atividades ${ }^{315}$.

Na sessão de 19 de outubro de 1830 foi lido, na Câmara dos deputados, o parecer emitido pela "commissão especial encarregada de revisão das emendas ao codigo criminal"316. Em seu primeiro parágrafo, o parecer afirmava que, apesar do relativo atraso na entrega de seus trabalhos, a comissão assim o preferira, "uma vez que o tornasse melhor". Assim como a comissão ad hoc das emendas, também a última comissão do código criminal não afirmou em momento algum ter privilegiado a

\footnotetext{
${ }^{314}$ Edward Livingston. A System of Penal Law prepared for the State of Louisiana. NewOrleans: printed by Benjamin Levy, 1824.

${ }^{315}$ APB-CD; sessão de 11 de setembro de 1830; p. 493.

${ }^{316}$ APB- CD; sessão de 19 de outubro de 1830; pp. 612-613. No que tange a este parecer, vale destacar a declaração de "vencido" emitida pelo deputado Luiz Francisco de Paula Cavalcanti de Albuquerque.
} 
pressa na superação do Livro $\mathrm{V}$ das Ordenações Filipinas, à qualidade de seus trabalhos sobre o diploma penal nacional ${ }^{317}$.

De acordo com o parecer, a comissão não alterara o método com que se organizava o código criminal, tendo se limitado a escolher, dentre as emendas oferecidas, aquelas que lhe pareceram necessárias, propondo ainda novas emendas, a seu ver igualmente indispensáveis.

Dizia a comissão:

Seria muito longo enumerarem-se as alterações e emendas adoptadas pela commissão; isto muito melhor se deprehenderá pela leitura do codigo apresentado; limita-se portanto a commissão a notar que o systema penal soffreu grande alteração, ou fosse na qualidade das penas que quiz melhor proporcionar à natureza dos delictos, ou mesmo em sua quantidade; em todos os delictos classificou gráos e só deixou a pena de morte no delicto de homicidio com certas circumstancias aggravantes e para roubar, e no de cabeças de insurreição de escravos (delicto em que ha sempre homicidios atrozes) e ainda nesses delictos só a deixou em gráo maximo. [...] A commissão finalmente adoptou a suppressão de alguns delictos e mudou a classificação de alguns outros, tendo sempre em vista o que lhe pareceu melhor. ${ }^{318}$

A análise conjunta da documentação de que dispomos permite que atribuamos aos trabalhos desta comissão uma série de alterações e novidades no texto que viria a compor o código criminal. Para além da introdução de cerca de 38 novos $\operatorname{artigos}^{319}$, a própria comissão admitia em seu parecer a inserção de novos crimes, o rearranjo de grande parte das punições presentes no código e a eliminação de diversas penas e definições consideradas inadequadas ou desnecessárias.

Para darmos somente alguns exemplos, que serão analisados em detalhes no próximo capítulo, a comissão revisora das emendas eliminou do código brasileiro penas como as de "vigilância da justiça" e de "banimento", propostas pelo projeto de Vasconcelos e mantidas pela comissão ad hoc; retomou a pena de galés temporárias, que fora eliminada, por sua vez, pela comissão ad hoc; rearranjou por completo as punições prescritas aos crimes do código nacional, modificando praticamente todas as

\footnotetext{
${ }^{317}$ Lembrando que, em praticamente todos os outros pareceres e discursos enunciados no plenário da Câmara, os deputados brasileiros enfatizaram sua maior preocupação com a rapidez na superação da legislação penal portuguesa do que com a qualidade do código criminal que apresentavam à nação, cujos defeitos, diziam, poder-se-ia corrigir com o passar dos anos e a experiência legislativa.

${ }^{318}$ Idem. Ibidem.

${ }^{319}$ São eles: artigos 7, 8, 9, 11, 47, 48, 64, 106, 107, 108, 109, 110, 117, 143, 165, 171, 197, 208, 227, 228, 230, 231, 232, 233, 234, 235, 238, 243, 251, 253, 278, 281, 307, 309, 310, 311,312 e 313 .
} 
punições já revistas pelas emendas; e introduziu no texto do código brasileiro ainda mais prescrições retiradas do projeto de Código penal da Luisiana.

As três últimas comissões do código criminal foram ainda responsáveis - sem que possamos definir, contudo, a exata atuação de cada uma delas - pela eliminação de 59 artigos do projeto de Vasconcelos que, como veremos à frente, desapareceram por completo do texto do código penal ${ }^{320}$.

Como vimos anteriormente, o código criminal proposto, aos 19 de outubro de 1830, pela comissão de revisão das emendas, foi aprovado pela Câmara dos deputados, sem qualquer discussão, aos 22 de outubro do mesmo ano e remetido, na seqüência, à avaliação do Senado nacional. No dia 23 de novembro, a comissão de legislação do Senado leu um parecer indicando a necessidade de rápida aprovação do código penal proposto pela Câmara e, no dia seguinte, votou favoravelmente à sua aprovação. O código foi remetido assim, à Sanção imperial, sendo enfim promulgado, pelo imperador d. Pedro I, aos16 de dezembro de 1830.

A rapidez com que se desenrolaram os atos finais de aprovação deste diploma, nos parece reveladora da conjuntura política vivida pelo país à altura de 1830 e do significado atribuído, por deputados e senadores, à sanção do código penal. Neste sentido, como vimos anteriormente, a Câmara vitalícia não ofereceu qualquer objeção ao texto do código criminal e tampouco o imperador sinalizou a intenção de vetá-lo ou questionar seu conteúdo; ainda que, como veremos, este oferecesse uma ameaça direta a seu poder.

Uma vez mais, enfim, gostaríamos de enfatizar que, paralelamente à pressa que perpassou a elaboração do código criminal, não se deve ignorar os cuidados empreendidos neste processo e a atenção aos detalhes demonstrada pelos deputados ao longo de sua composição. Paralelamente ao argumento da urgência, portanto, defendemos que a atenção dos estudiosos do código criminal se dirija também à perspicácia dos parlamentares nacionais, à sua sintonia em relação ao que se produzia no campo do direito penal no mundo ocidental e à sua preocupação em desenvolver um código penal que se adequasse à realidade vivida pelo Brasil, projetando a ela novas possibilidades.

\footnotetext{
${ }^{320}$ São eles os artigos de número: 5, 10, 11, 12, 25, 26, 27, 29, 37, 39, 47, 48, 49, 50, 56, 62, $64,69,75,76,85,86,87,88,89,94,95,96,98,103,104,111,131,159,163,172,182,183$, $184,187,188,196,204,205,215,218,219,236,238,275,276,277,278,279,280,286$, 291,292 , e 295.
} 


\subsection{Os debates sobre a pena de morte e sua manutenção no Código Criminal}

A manutenção da pena de morte no texto do Código de 1830 tem despertado a atenção de numerosos pesquisadores do século XIX brasileiro e desempenhado papel importante nos estudos especificamente dedicados ao diploma penal imperial. Para além de os principais debates travados ao longo da elaboração do código criminal recaírem justamente sobre a questão da pena capital - fornecendo a pesquisadores interessados na matéria um suporte documental facilmente acessível e extremamente interessante -, a presença desta punição no Brasil oitocentista tem chamado, por si só, a atenção de diversos estudiosos da sociedade e da política de então.

De um modo geral, contudo, os trabalhos dedicados a esta questão têm se limitado a um exame rápido dos debates que, travados na Câmara dos deputados em setembro de 1830, acabaram por definir a presença da pena de morte no texto do diploma penal. Para além de uma análise breve destes debates, a historiografia dedicada ao Código de 1830 tem pautado os estudos da questão privilegiadamente por seus resultados. Desta forma, haja vista a decisão final pela manutenção da pena capital, grande parte dos trabalhos tem favorecido o exame dos discursos proferidos em defesa desta punição, deixando de lado a análise dos argumentos mobilizados também em sua oposição ${ }^{321}$.

O que pretendemos demonstrar, contudo, é que, para além das falas favoráveis à pena de morte, diversos deputados discursaram fervorosamente contra ela em setembro de 1830, discorrendo por horas e sessões a fio acerca de sua ineficácia e de seus possíveis prejuízos ao país. Para além disso, é fundamental que investiguemos os interesses envolvidos na manutenção da pena de morte entre o rol das punições do

\footnotetext{
${ }^{321}$ Jurandir Malerba. Os Brancos da Lei: liberalismo, escravidão e mentalidade patriarcal no Império do Brasil. Paraná: Editora da Universidade Estadual de Maringá, 1994; pp. 105 a 113. Patrícia Ann Afderheide. Op. cit.; especialmente pp. 307-310. João Luiz Ribeiro. No meio das galinhas as baratas não têm razão: a lei de 10 de junho de 1835: os escravos e a pena de morte no Império do Brasil, 1822-1889. Rio de Janeiro: Renovar: 2005; pp. 22-28. Ainda que exponha com relativo cuidado os argumentos mobilizados por cada um dos lados em disputa neste debate, Ribeiro afirma, no início de sua análise que "uma minoria atacou [entre os dias 11 e 15 de setembro de 1830] a manutenção da pena de morte", o que, como veremos à frente, não é verdadeiro. Zahidé Machado Neto. Op. cit.; pp. 75-77. A autora, que é bastante detalhista no exame do conjunto dos debates de setembro de 1830 , enfoca a questão da pena de morte unicamente a partir da decisão por sua manutenção, abdicando de uma análise dos embates efetivamente travados em torno da questão. Fernando Afonso Salla. $O$ encarceramento em São Paulo: das enxovias à Penitenciária do Estado. Tese de Doutorado, USP, 1997; pp.26-29. Neste último estudo, não especificamente dedicado ao Código de 1830, $\mathrm{o}$ autor se refere, em todo caso, unicamente à existência de posicionamentos favoráveis à pena capital.
} 
código criminal, examinando o projeto político implícito a esta decisão. A nosso ver, uma análise que limite esta resolução à "mentalidade escravista" "322 dos legisladores imperiais, peca pela simplificação de um debate lógico e teórico de muito maior alcance, especialmente quando articulado ao movimento codificacionista penal ocidental $^{323}$.

Com isto em mente, buscaremos salientar os argumentos e estratégias discursivas empregados no plenário por deputados favoráveis e contrários à pena de morte, atentando ao uso por eles feito de ideias políticas e teorias penais extremamente modernas à época, ultrapassando em muito os argumentos civilizacionais, religiosos e humanitários que a historiografia constantemente ressaltou.

Já tivemos a oportunidade de analisar o modo com que a manutenção da pena de morte foi justificada pelas diferentes comissões por que passou o texto do código criminal. De um modo geral, a conveniência desta pena foi imputada, pelas comissões, aos atrasos da educação primária no Império (que deixava "vêr hypotheses em que [a pena de morte] será indispensável" "324) e à subsistência do "elemento da escravatura"325 no país. No que diz respeito especificamente às comissões mista de 1829 e ad hoc de 1830, que lamentaram, ambas, semelhante manutenção, enquanto a primeira afirmou seu desejo de supressão da pena capital e sua esperança de que, num futuro próximo, ela não fosse mais necessária, o parecer da comissão ad hoc fez questão de destacar a limitação desta pena a pouquíssimos crimes do código penal e exortou o tempo em que sua aplicação tornar-se-ia dispensável e anti-nacional.

\footnotetext{
${ }^{322}$ No livro Os Brancos da Lei: liberalismo, escravidão e mentalidade patriarcal no Império do Brasil, Jurandir Malerba faz uso constante desta expressão, articulando diretamente à presença da "mentalidade escravista", a manutenção da pena de morte no Brasil. Jurandir Malerba. Op. cit., 1994.

${ }^{323}$ Deve-se ressaltar, neste ponto, que parte importante das análises a que tivemos acesso parece reconhecer na manutenção da pena de morte no Código de 1830, a comprovação do "atraso" e dos "deslocamentos" político-sociais do Brasil oitocentista; interpretando sua presença no texto do diploma penal do Império como prova dos "limites" da modernidade deste documento e da impossibilidade de o país possuir, à época, um código verdadeiramente liberal. Nesse sentido, chamam especialmente a atenção os trabalhos de Jurandir Malerba, como um todo, e Patrícia Ann Afderheide, especialmente no capítulo IX de sua dissertação. Para outros trabalhos cujas interpretações caminham para o reconhecimento das "contradições" e "limites" do Código de 1830 ver: Claudia Moraes Trindade. A Casa de Prisão com Trabalho da Bahia, 1833-1865. Dissertação de Mestrado, UFBA, 2007; especialmente pp. 39-43 e 74-77; e Alexandre Ribas de Paulo. "O discurso jurídico-penal iluminista no direito criminal do império brasileiro". In: Arno dal Ri Júnior [et al.]. Iluminismo e direito penal. Florianópolis: Fundação Boiteux, 2008; pp.153-206.

${ }^{324}$ APB-CD; sessão de 31 de agosto de $1829 ;$ p. 84.

${ }^{325}$ Arquivo da Biblioteca Nacional (RJ); Op. cit.; p. II.
} 
Para além da opinião das comissões parlamentares, recordemos ainda as intervenções de Antonio Ferreira França, em sessão de 6 de maio de 1830, atestando a inconstitucionalidade da manutenção da pena de morte no texto do projeto do código (elaborado e apresentado à Câmara pela comissão mista de 1829). De acordo com o deputado baiano, semelhante pena já havia sido extinta pela Carta Constitucional de 1824 e na opinião de seu filho, Ernesto Ferreira França, tal extinção era indubitável perante a eliminação (operada pelo artigo 179 da Constituição) de "todas as penas cruéis, como são, a tortura, a marca de ferro, etc. ${ }^{, 326}$.

Apenas em setembro de 1830, contudo, a pena de morte foi efetivamente debatida pelo conjunto da deputação nacional. Como vimos, este foi um dos únicos aspectos do conteúdo do código cuja discussão foi aberta à participação de todos os deputados interessados. Os discursos favoráveis e contrários à pena capital tiveram início na sessão de 11 de setembro de 1830, após aprovação do requerimento do deputado Paula Souza - sugerindo a formação de uma última comissão parlamentar dedicada ao código criminal imperial - e das emendas de Ernesto Ferreira França, estabelecendo, entre outras coisas, que antes de se iniciarem os trabalhos da última comissão, a Câmara se posicionasse acerca da manutenção das penas de morte e de galés no texto do futuro código. Como veremos na seqüência, os debates concentraram-se efetivamente sobre a pena de morte, ficando a discussão da pena de galés restrita às falas de pouquíssimos deputados.

Ao longo dos dias 11, 13, 14 e 15 de setembro, portanto, doze deputados brasileiros posicionaram-se, no plenário da Câmara, favorável ou contrariamente à manutenção da pena de morte. Como afirmamos acima, as análises dedicadas a estes debates costumam abordar quase exclusivamente o posicionamento dos deputados favoráveis à manutenção. Diferentemente, contudo, do que a leitura destes trabalhos pode fazer crer, a grande maioria das falas pronunciadas entre os dias 11 e 15 de setembro opôs-se a tal punição. Temos, assim, que de um total de vinte pronunciamentos, quatorze defenderam a abolição da pena de morte do diploma penal imperial e apenas seis declararam-se favoráveis à sua manutenção ${ }^{327}$.

\footnotetext{
${ }^{326}$ APB-CD; sessão de 6 de maio de 1830; p. 78

${ }^{327}$ Colocam-se contrários à pena de morte os deputados Rebouças (que discursou por três vezes); Carneiro da Cunha, Ribeiro de Andrada, Ernesto Ferreira França e Lino Coutinho (que se pronunciaram duas vezes cada um); Henriques de Rezende, Martim Francisco e Antonio Ferreira França (que falaram somente uma vez). Favoravelmente à pena de morte
} 
Para além desta distorção quantitativa, os debates de setembro de 1830 vêm sofrendo também de uma importante distorção qualitativa. Neste sentido, os trabalhos a que tivemos acesso parecem sugerir não apenas a predominância de discursos pela manutenção da pena de morte no plenário da Câmara dos deputados, mas também uma concentração dos argumentos favoráveis e contrários a esta pena em torno de dois eixos principais: de um lado, a presença da escravidão na sociedade brasileira e o conseqüente atraso civilizacional por ela imposto ao país - demandando, assim, a manutenção da pena de morte - e, de outro lado - como justificativa para sua abolição -, o argumento religioso da pena capital enquanto usurpação do direito divino sobre a vida dos homens.

Uma leitura atenta destes debates, contudo, revela a presença de uma gama muito maior e mais complexa de argumentos mobilizados, de lado a lado, em torno daquela punição. Passemos, então, à sua análise.

Os embates que nos propomos a analisar podem ser divididos em três momentos principais: inicialmente, um conjunto de falas favoráveis à abolição da pena de morte, dominando por completo o debate até o dia 15 de setembro; na seqüência, a manifestação de um grupo de deputados defensores da manutenção desta pena e de sua necessidade na legislação penal imperial; e, por fim, ainda no dia 15, um conjunto de falas em resposta às defesas da pena de morte, protagonizadas por deputados que já haviam se manifestado contrariamente a ela nos primeiros dias.

Os primeiros discursos manifestamente avessos a esta pena, enunciados respectivamente pelos deputados Rebouças, Carneiro da Cunha, Ribeiro de Andrada, Ernesto Ferreira França, Martim Francisco e Lino Coutinho, chamam a atenção pela densidade de seus argumentos e pela concordância apresentada em torno da questão em debate. Analisemos, assim, o conteúdo geral destes discursos a partir de suas três principais frentes de argumentação: os argumentos religiosos; o argumento utilitário, fundado em justificativas históricas e materiais para a ineficácia e desnecessidade da pena de morte; e a afirmação da superioridade de um sistema penitenciário moderno em relação à pena capital.

No que tange aos argumentos religiosos, podemos afirmar que estes foram, na grande maioria das vezes, mobilizados no interior de análises e reflexões de cunho político e social, e não estritamente moral, como tem enfatizado parte da vezes), Rego Barros, Luiz Cavalcanti e Paula Souza. 
historiografia $^{328}$. Neste sentido, os discursos que os incluíram, demonstraram um constante esforço por fazê-lo no interior de reflexões teóricas acerca dos fundamentos da vida em sociedade e dos limites dos poderes legislativos sobre os cidadãos.

É sob esta perspectiva que acreditamos poder ler, por exemplo, a primeira fala contrária à pena de morte, locucionada pelo deputado Antonio Pereira Rebouças na sessão de 11 de setembro de 1830. Nesta ocasião, Rebouças relembrou a resolução enviada por Antonio Ferreira França (na sessão de 6 de maio de 1830) acerca da inconstitucionalidade da pena de morte e afirmou que, não só naquela ocasião apoiara o colega, como vinha agora ele próprio, em plenário, afirmar "que a pena de morte está abolida pela Constituição essencial, positiva e virtualmente".

Ao explicar o porquê da abolição "essencial" da pena de morte pela Constituição brasileira, Rebouças recorreu a teorias políticas acerca do pacto social e dos direitos inauferíveis dos homens, confirmando, a partir delas, a impossibilidade de a vida humana entrar em qualquer tipo de convenção política ou ser transferida a outrem por qualquer contrato. Foi neste sentido que o deputado afirmou:

[...] qualquer pretensão sobre a vida do homem não é fundada em direito algum. Logo, é uma iniqüidade, uma invasão do Poder Divino. Logo, a nossa constituição, que importa o pacto social proclamado no Brazil e que essencialmente consagra a inviolabilidade dos direitos do homem, não póde conferir o absurdo de dispôr da vida do mesmo homem, aonde residem esses direitos inauferiveis e inviolaveis, que essencialmente o distingue, e que ella solemnemente reconhece. Logo, finalmente, a nossa constituição baniu, ou essencialmente abolio a pena de morte. ${ }^{329}$ [grifo nosso]

Quanto à abolição "positiva" desta punição pela Carta Constitucional, Rebouças também a justificou mesclando argumentos religiosos a outros de cunho político. Para Rebouças a pena de morte estava abolida positivamente pela Constituição pelo simples fato de a Carta consagrar, como religião de Estado, o catolicismo. O deputado forneceu, neste sentido, três exemplos dos Evangelhos - demonstrando a proibição de derramamento de sangue pela religião católica - e concluiu que: "Logo, a pena de morte é contraria à religião, que a constituição consagra como religião do estado, é também contraria à mesma constituição, e por isso mesmo abolida por ella."

\footnotetext{
${ }^{328}$ Chama bastante atenção o destaque dado pelos estudos dedicados à apresentação dos debates de setembro de 1830 - independentemente de sua "filiação" historiográfica - aos argumentos religiosos mobilizados pelos deputados contrários à pena de morte. Tal ênfase, nos parece, destina-se a reforçar a pretensa "pré-modernidade" política dos argumentos utilizados pelos legisladores nacionais. Ver, por exemplo: Andréa Slemian. Op. cit.; 2008; pp. 194-196; e Jurandir Malerba. Op. cit.; pp. 105-113.

${ }^{329}$ APB-CD; sessão de 11 de setembro de 1830; p. 494.
} 
Para além dos exemplos supracitados, Rebouças seguiu justificando as incompatibilidades "positivas" e "virtuais" da pena de morte com a Constituição brasileira fazendo uso de prescrições da própria Carta (especialmente de seu artigo 179) e não de argumentos de caráter estritamente religioso ou moral - ainda que estes não tenham deixado de aparecer em um ou outro momento específico.

Contra o Poder Divino e igualmente contra a constituição jurada essencial, positiva e virtualmente, como creio haver plenamente demonstrado, a pena de morte desnecessaria, inefficaz, nociva e depravadora a toda a prova, não deve manchar o nosso codigo criminal. Voto absolutamente contra ella. ${ }^{330}$

O deputado Ribeiro de Andrada, por sua vez, atacou com todas as forças a ideia de que a pena de morte seria uma das condições do pacto social, dedicando seu discurso no dia 11 de setembro à desconstrução desta ideia e à afirmação de que o direito sobre a vida dos homens seria "privativo da Divindade: ella só póde retrahir um dom, que ella só póde fazer."

Ernesto Ferreira França, em fala pronunciada no dia 13 de setembro, fez uso de argumentos religiosos também no interior de uma justificativa instrumental para a abolição da pena de morte no Brasil. A certa altura de sua fala, portanto, o deputado afirmou:

Sr. presidente, a pena de morte é injusta, pois que ella é irreparavel. Póde por ventura tirar-se o que não póde dar-se! O direito de tirar póde ser considerado como justo, quando póde haver indemnisação; ora, sendo a vida uma cousa que póde facilmente tirar-se mas não indemnisar-se, isto é, restituir-se a quem a perdeu: está claro que não é concedido ao homem este direito, e só sim pertence à divindade, que só esta póde dar e portanto tirar. Logo, este direito, que os homens indiscretamente exercem, é uma verdadeira usurpação do poder divino. ${ }^{331}$ [grifo nosso]

Já um deputado como Carneiro da Cunha, ciente de que o uso exagerado de argumentos morais e religiosos contra a pena capital poderia ser facilmente desmontado por seus opositores, afirmou em suas falas de 11 e 15 de setembro que, por mais que concordasse com os argumentos de seus colegas, não entraria nos mesmos méritos que eles, restringindo seu discurso à apresentação de considerações acerca dos males que poderiam resultar da manutenção da pena capital. Carneiro da Cunha não mobilizou, portanto, em momento algum de sua fala, argumentos religiosos, fundando sua oposição à pena de morte exclusivamente em exemplos históricos e materiais dos males dela advindos.

\footnotetext{
${ }^{330}$ Idem; p. 496.

${ }^{331}$ APB-CD; sessão de 13 de setembro de 1830; p. 506.
} 
Vê-se, assim, que a questão religiosa foi mobilizada pelos deputados brasileiros contrários à pena de morte de forma quase sempre instrumental e articulada a teorias e fundamentações de cunho político. Neste contexto, o recurso a argumentos religiosos não nos parece devido à pretensa "pré-modernidade" (católica e escravocrata) da deputação nacional, mas antes à sua perspicácia política e à certeza da força que a moral religiosa devia exercer sobre parte significativa da deputação e da sociedade brasileira de então. No interior de um debate polêmico e de difícil partido, eram argumentos como estes, muitas vezes, aqueles capazes de definir os posicionamentos.

Neste sentido, ainda nos casos em que a argumentação dos deputados não conseguiu ultrapassar em muito a moralidade cristã e o humanitarismo filantrópico, deve-se admitir a sagacidade envolvida no uso de argumentos religiosos e em sua mobilização contrariamente à pena capital ${ }^{332}$. Um exemplo deste aparente "malogro" argumentativo pode ser reconhecido na primeira fala de Lino Coutinho na sessão de 15 de setembro de 1830. Falhando, a nosso ver, em sua tentativa de justificar logicamente o impedimento de a sociedade e os jurisconsultos mandarem tirar a vida a seus cidadãos ${ }^{333}$, deve-se admitir, de todo modo, a força que deve ter desempenhado, à época, um discurso que, como o seu, opunha-se à pena de morte a partir dos fundamentos do Decálogo.

Apresentados os discursos religiosos contra a pena capital, analisemos na sequência os argumentos utilitários destinados à comprovação da ineficácia desta pena na repressão do comportamento criminoso e no controle da população escrava do Império do Brasil. A nosso ver, os argumentos de oposição à pena de morte que mais densidade e objetividade revelaram foram justamente estes, em que os esforços

\footnotetext{
${ }^{332}$ No que diz respeito aos argumentos (contrários à pena de morte) centrados no respeito à "humanidade" dos réus e ao clamor pela adoção de punições isentas de suplícios mobilizados por grande parte dos deputados brasileiros -, Michel Foucault aborda, no estudo Vigiar e Punir, justamente o modo com que no período de declínio dos suplícios na Europa, os mesmos passaram a compor grande parte das defesas pela abolição da pena capital. Michel Foucault. Vigiar e Punir. Rio de Janeiro: Editora Vozes, 2005; pp. 46-56. Apud: Nara de Souza Rivitti. $O$ medo nos debates legislativos do Brasil imperial: Análise de debates empreendidos na Câmara dos Deputados no período entre 1826 e 1835. TCC, IBCCRIM, 2010; pp. 32-33. Atesta-se assim, uma vez mais, a "modernidade política" dos argumentos mobilizados, nesta disputa, pelos legisladores nacionais.

${ }^{333}$ As conclusões de Lino Coutinho quanto a este quesito se dão nos seguintes termos: “[...] como é que os homens cederão à sociedade ou aos seus legisladores o direito de lhes tirarem a vida? Isto é absolutamente contra a natureza, e não é crivel, salvo se todos os homens estivessem loucos". APB-CD; sessão de 15 de setembro de 1830; p. 511. São explícitas, a nosso ver, as diferenças existentes entre esta construção argumentativa e as utilizadas por deputados como Rebouças e Ribeiro de Andrada.
} 
dos deputados voltaram-se à exposição da ineficácia material e moral da pena de morte e de sua prescindibilidade no diploma penal imperial. Ressalte-se ainda terem sido estes os argumentos que por mais vezes apareceram nas falas favoráveis à abolição da pena de morte.

No que diz respeito à discussão da ineficácia da pena de morte no controle do comportamento criminoso, paralelamente a discursos teóricos e morais - centrados na ausência de reflexo das execuções públicas sobre os índices de criminalidade nacionais e na incapacidade que a ameaça de morte teria no impedimento de crimes previamente planejados -, vários deputados fizeram uso também de exemplos históricos (nacionais e internacionais) para a confirmação de seu ponto de vista. Foi neste sentido, por exemplo, que Rebouças afirmou:

A abolição da pena de morte na Toscana por Leopoldo fez que no decurso de mais de 20 annos ahi sómente se perpetrassem cinco assassinios; entretanto que os mais atrozes crimes continuarão em Napoles, Roma, etc. A abolição da pena de morte produzio os mesmos felizes effeitos no imperio de Isabel e Catharina II. ${ }^{334}$

Seguindo semelhante raciocínio, Ribeiro de Andrada declarou:

[...] consultai a historia dos povos onde ainda dura em voga pena tão atroz e barbara; consultai a estatistica dos seus crimes, e vós vereis que annualmente se reproduzem com pequenas differenças para menos ou para mais; consultai pelo contrario a estatistica dos crimes dos povos da Pensilvania, de Berne e da Toscana, onde a pena de morte foi riscada dos seus codigos, e comparai-a com a dos primeiros, e vós vos convencereis da superfluidade de semelhante pena, e do melhoramento progressivo de costumes nos ultimos, porque um systema de leis penaes, suaves, mas sempre executadas é o melhor compendio de moral e de instrucção. ${ }^{335}$

De acordo ainda com Ernesto Ferreira França, a ineficácia da pena de morte poderia ser deduzida da leitura dos escritos de Edward Livingston, através dos quais ficava demonstrado que, no espaço de 17 anos, o único crime a que se prescrevia a pena de morte foi o que mais frequentemente se cometeu na Luisiana. Neste discurso, pronunciado aos 13 de setembro de 1830, Ernesto deslegitimou ainda a pena de morte a partir de um argumento que, como o anterior, foi comum à fala de diversos deputados: o de que para além de ineficaz, a pena de morte possuía o agravante de sua difícil execução.

$\mathrm{Na}$ abordagem desta temática, os exemplos mobilizados foram múltiplos, indo desde casos de sumiço de carrascos e "açougueiros" em dias de execução pública no

\footnotetext{
${ }^{334}$ APB-CD; sessão de 11 de setembro de 1830; pp. 495-496.

${ }^{335}$ Idem; p. 498.
} 
Brasil, até a falta de vontade partilhada por juízes e testemunhas em concorrer para a morte de seus semelhantes. Baseado nas dificuldades apresentadas à concretização destas sentenças, diversos deputados citaram ainda a impunidade e o desprezo às leis que necessariamente adviriam de sua manutenção ${ }^{336}$. Vê-se aqui, portanto, também uma preocupação com a infalibilidade das leis criminais. Vale relembrar, então, a teoria penal de Cesare Beccaria, em que já se postulava como uma das principais características das punições modernas, não sua capacidade de ameaçar ou constranger os delinquentes, mas sua infalibilidade, ou seja, a garantia de sua execução.

Partindo da ineficácia e inutilidade da pena de morte, vários representantes negaram também sua qualidade de "remédio civilizacional" para o país. Respondendo, assim, às falas que constantemente recorriam à suposta falta de civilização da população brasileira como justificativa à manutenção da pena de morte, diversos deputados enfatizaram a impossibilidade de, na ausência de mudanças históricas materiais - como o aumento da instrução primária, a adoção de um sistema penitenciário ou a "moralização" da magistratura -, elevar-se o nível de civilização do Brasil.

Assim, enquanto o deputado Martim Francisco afirmou:

Disse-se: a pena de morte é necessaria no Brazil, porque no seu solo existem homens immoraes e faccinorosos que a troco de uma miseravel quantia commettem um assassinato. Este argumento é contradictorio: pois que a pena de morte existe e não faz effeito, logo, ella não é sufficiente, é improficua. ${ }^{337}$

Carneiro da Cunha justificou:

A falta de repressão nos pequenos delictos conduz os réos aos maiores; quantos têm principiado por pequenos furtos e vão gradualmente até constituir-se o maior ladrão e faccinoroso. Proteja o governo a moral publica na boa escolha de empregados, de magistrados rectos; distribua com imparcialidade e justiça os premios e os castigos; economise as rendas da nação para não fazer pesar sobre o pobre grandes tributos, para ter meios de augmentar a instrucção primaria, fazendo espalhar as luzes pelo interior do imperio, que em breve tempo desapparecerão de entre nós esses crimes horrorosos $[\ldots] .{ }^{338}$

\section{E Ernesto Ferreira França finalmente atestou:}

\footnotetext{
${ }^{336}$ Uma mesma "linhagem" de argumentos contrários à pena de morte chamava a atenção ainda aos riscos que se corria quando, ao invés do exemplo público e do temor, as execuções capitais despertavam compaixão pelos criminosos e resistência às autoridades. Assim como os argumentos humanitários, o temor da solidarização entre sociedade e criminoso foi abordado por Michel Foucault enquanto componente dos discursos contrários à pena de morte na Europa. Michel Foucault. Op. cit.

${ }^{337}$ APB-CD; sessão de 14 de setembro de 1830; p. 508.

${ }^{338}$ APB-CD; sessão de 11 de setembro de 1830; p. 497.
} 
Qual será o meio mais capital de promover-se a moral? É promovendo a instrucção publica, para que o homem conhecendo os seus direitos, os saiba respeitar nos seus semelhantes e conheça igualmente os seus deveres para com a nação. As penas não são os verdadeiros meios com que se extirpão os delictos, é sim com casas de correcção, promovendo a instrucção primaria e a moral publica, e não com pessimo systema de sacrificar homens. A pena de morte é muito duvidosa, e bastaria esta circumstancia para votar contra ella. ${ }^{339}$

A segunda grande frente de argumentação fundada na ineficácia da pena capital dirigiu-se, por sua vez, à desconstrução da ideia de que esta seria a única punição capaz de controlar a população cativa residente no país ${ }^{340}$. De um modo geral, os argumentos destinados à comprovação da inutilidade da pena de morte neste quesito fundaram-se no fato de que esta não era uma sentença verdadeiramente pensada para a população escrava, já que a ameaça de morte não teria, sobre os cativos, os mesmos efeitos que sobre os livres. Foi nesse sentido, por exemplo, que Rebouças afirmou:

Os escravos não podem assaz presar a vida, porque assaz a não gozão; se para alguem a morte é menos repressiva é para elles, que sem nenhuma boa esperança se insurgem e morrem brutalmente; os suicídios mais frequentes são os delles, que crêem na transmigração, crêem que morrendo passarão desta para a sua terra. Façase para os escravos uma ordenança separada; e por elles não façamos tamanho mal aos cidadãos, aos homens livres. ${ }^{341}$

Vê-se, portanto, que para além da descrença no terror desempenhado por esta pena sobre a população cativa, Rebouças recusava ainda que, à custa dos escravos ("estes entes miseráveis"), o restante da população livre padecesse de uma legislação penal $\operatorname{ruim}^{342}$.

${ }^{339}$ APB-CD; sessão de 13 de setembro de 1830; p. 506.

${ }^{340}$ Atentemos, neste ponto, ao fato de os discursos até aqui apresentados terem sido os primeiros pronunciados nos debates de setembro de 1830. As oposições levantadas à pena de morte por estas falas dirigiam-se, portanto, de um modo geral, aos argumentos utilizados pelas comissões parlamentares de trabalho (em suas justificativas pela manutenção da pena de morte) e, ao que tudo indica, às opiniões de "senso-comum" trocadas nos bastidores da Assembleia; o que revela, a nosso ver, a força política dos argumentos em defesa da pena de morte no interior do Parlamento nacional.

${ }^{341}$ APB-CD; sessão de 11 de setembro de 1830; p. 496.

${ }^{342}$ A despeito da imputação de "pré-modernidade" política com que tantas vezes foram atacados os primeiros legisladores brasileiros, deve-se reconhecer a extrema modernidade implícita à proposta de Rebouças, haja vista sua sintonia com a legislação penal de parte dos estados escravistas dos EUA, possuidores de códigos criminais exclusivamente dedicados aos réus escravos, os chamados "Black Codes", e com a própria concepção do cativeiro vigente no Brasil, por meio da qual, apesar da inclusão cidadã operada pela Carta Constitucional, operava-se, em verdade, um corte social fundamental entre escravos e não-escravos. Neste sentido, nas palavras de Tâmis Parron, mesmo que o artigo $6^{\circ}$ da Constituição de 1824 reconhecesse como cidadãos do Império os escravos nascidos no país que se alforriassem, ainda que descendentes diretos de africanos, "tal inclusão de mulatos e libertos no campo dos 
O deputado Martim Francisco, por sua vez, recusava o argumento de que, extinta a pena de morte, aumentariam os índices de criminalidade entre os escravos:

\begin{abstract}
Disse-se que os escravos, e outros homens acostumados a serviços penosos commeterião crimes, porque melhorarião de condição indo para uma prisão sem trabalho. Sr. presidente, é sabido, que todo o homem habituado ao trabalho morre quando delle é privado. Sr. presidente, a pena de morte, não é pena para os escravos; é sabido que elles acreditão que morrendo voltão ao seu paiz, e por este lado a pena de morte é um incentivo ao crime. ${ }^{343}$ [grifo nosso]
\end{abstract}

Neste ponto, portanto, os deputados brasileiros mostraram ciência dos critérios iluministas e utilitários com que, desde Beccaria, confrontava-se a pena de morte no mundo ocidental. Para parte dos comentadores de Beccaria, inclusive, a avaliação da inutilidade, ou desnecessidade, da pena de morte configurava um dos pontos mais fortes de sua argumentação. Diferentemente de parte dos deputados brasileiros, para quem a vida humana não entrava no contrato social, Beccaria reconhecia a legitimidade do poder de punição dos soberanos, concentrando suas atenções, contudo, na imposição de limites a este poder e no questionamento de sua real necessidade de efetivação através da morte ${ }^{344}$.

Finalizando a apresentação das vertentes argumentativas contrárias à pena capital, vejamos como parte dos deputados brasileiros destacou as superioridades de um sistema penitenciário desenvolvido quando comparado aos péssimos efeitos sociais

direito civis pode ter servido ao propósito de afastá-los do mundo dos excluídos (os escravos) e, assim, prevenir insurreições populares fundadas na solidariedade de cor (união de cativos e libertos). Tâmis Peixoto Parron. Op. cit.; p.55. Ver ainda: Monica Duarte Dantas. "Dos Statutes ao Código brasileiro de 1830: o levante de escravos como crime de insurreição." Revista do Instituto Histórico e Geográfico Brasileiro, vol. 452, pp. 273-309, 2011. Márcia R. Berbel e Rafael B. Marquese. "La esclavitud en las experiencias constitucionales ibéricas, 1810-1824". In: Ivana Frasquet (org.) Bastillas, cetros y blasones. La independencia en Iberoamérica. Madrid : Fundación Mapfre-Instituto de Cultura, 2006, pp. 347-374; e Andréa Slemian. "Seriam todos cidadãos? O impasse na construção da cidadania nos primórdios do constitucionalismo no Brasil (1823-1824)". In: István Jancsó (org.). A Independência do Brasil: história e historiografia. São Paulo: Hucitec/Fapesp, 2005, pp. 829-847.

${ }^{343}$ APB-CD; sessão de 14 de setembro de 1830; p. 508. Tem-se, nesta fala, um primeiro exemplo do modo com que, a nosso ver, o elemento cativo foi utilizado nas disputas em torno da pena capital. Neste sentido, assim como nos discursos contrários àquela pena parte importante da deputação nacional dispunha livremente das crenças e hábitos dos escravos com o intuito de confirmar seu pretenso destemor perante a morte, assim também os deputados favoráveis à pena capital recorriam ao elemento cativo em justificativas que, de lógicas, possuíam nada ou muito pouco, constituindo-se, por diversas vezes, em retórica quase pura.

${ }^{344}$ Para esta discussão ver: Adriano Cavanna. Storia del diritto moderno in Europa: le fonti e il pensiero giuridico; vol. 2. Milano: Dott. A. Giuffrè Editore, 2005; pp. 199-202 e pp. 211215. Ricardo Campa. "Prefácio". In: Cesaria Beccaria. Dos delitos e das penas. São Paulo: Martins Fontes, 2005; pp. 7-26. 
gerados pela pena de morte. Um dos argumentos mais bem articulados à afirmada superioridade sistema penitenciário fundava-se na desnecessidade de se executar um criminoso depois de efetuada a sua prisão. Para parte importante dos deputados contrários à pena de morte, portanto, valia muito mais investir na construção de um sistema prisional moderno no país, colhendo-se rapidamente os frutos de sua implementação, do que amargar por mais tempo as conseqüências das execuções públicas capitais (justificadas pela inexistência de prisões "decentes" no país).

Uma fala emblemática neste sentido pode ser encontrada, uma vez mais, no primeiro discurso de Rebouças, ainda em 11 de setembro:

Mas diz-se que o systema repressivo penitenciario não é para o Brazil, que se não acha sufficientemente adiantado em civilisação. E não é esse um dos meios de adiantar a civilisação? Não é o Brazil assaz docil a esta reforma, à abolição da iniqua, desmoral, atroz e malvada pena de morte? O systema verdadeiramente repressivo, o penitenciário, produzio na Pensilvânia o effeito de tornar de uma pequena colônia, que começou pelos passageiros do navio Bemvindo, em um estado de mais de um milhão e um quarto de habitantes no decurso de 145 annos. ${ }^{345}$

Replicado brevemente pelo deputado Bernardo Pereira de Vasconcelos que, num primeiro momento, isentou-se de opinar acerca da pena de morte, e "apenas" perguntou a seus colegas se eles não estariam querendo impor ao Brasil (desprovido de cadeias) o sistema punitivo de outras nações, Rebouças respondeu confiante:

Diz-se que não temos cadêas, façamol-as. A constituição as mandou fazer taes quaes para o systema verdadeiramente penitenciario, e a ellas adoptadas com divisões para todos os criminosos segundo a menor ou maior gravidade de seus crimes. Demais disso, senhores, entretanto que essas casas de correcção penitencial se não fazem. Falta-nos os meios de punir crimes capitaes? Não bastarão as mesmas cadêas que os prendem, para que os conservem condemnados a prisão perpetua? ${ }^{346}$

Finalizada a primeira bateria de discursos contrários à pena de morte (interrompida pela supracitada manifestação de Bernardo Pereira de Vasconcelos, na qual o deputado chamou a atenção da Câmara também à ausência de propostas de punições que substituíssem a pena capital e à necessidade de que os deputados decidissem se o código penal compreenderia também os escravos), tiveram início as falas favoráveis à sua manutenção no texto do código criminal. Os discursos que analisaremos na seqüência foram pronunciados respectivamente pelos deputados Rego Barros, Luiz Cavalcanti, Vasconcelos e Paula Souza (cuja fala é a mais emblemática do grupo) e, de um modo geral, não apresentaram a mesma convergência argumentativa das falas

\footnotetext{
${ }^{345}$ APB-CD; sessão de 11 de setembro de 1830; p. 495.

${ }^{346}$ APB-CD; sessão de 14 de setembro de 1830; p. 507.
} 
anteriores. Apesar disso, não deixaram nada a desejar, em termos de articulação política e de conhecimentos teóricos penais, às falas até aqui analisadas.

Primeiro a se manifestar, Rego Barros iniciou seu discurso afirmando não acreditar na impopularidade da pena de morte no Brasil e chamando a atenção à ausência, no país, de prisões seguras como as das nações que a haviam abolido. Discursando, portanto, na mesma direção de Vasconcelos, e ignorando os argumentos apresentados até então, Rego Barros defendeu a pena de morte e sua necessidade no país devido à ausência de um sistema prisional moderno.

Sua principal justificativa, entretanto, girava em torno do necessário controle da população escrava. Rego Barros propunha, nesse sentido, que se abolisse a pena de morte para os crimes políticos, mas que se a mantivesse nos casos de homicídio e insurreição escrava (crime que, como vimos, havia sido incluído no código criminal pela comissão ad hoc das emendas):

A pena de morte deve com effeito ser abolida nos casos politicos, porém não nos casos de homicidio, e para conter a escravatura, pois que esta é a unica pena que a póde conter. Nos erros politicos não a posso admittir, porque elles procedem da má intelligencia das cousas; e mesmo muitas vezes, o partido vencido, seja o bom partido; isto é, aquelle que faria a felicidade da nação se o seguisse. ${ }^{347}$

Rego Barros afirmou ainda, ao final de sua fala, que o voto favorável à pena de morte atuava exclusivamente pelo bem do Brasil e que, neste sentido, não se distinguia em nada da pretensa "humanidade" dos outros votos emitidos. Vale a pena destacar também que, ao final dos debates, a emenda de Rego Barros (pela supressão da pena de morte nos erros políticos) foi a única aceita pela deputação brasileira.

Luiz Cavalcanti falou em seguida e centrou seu discurso em torno de dois eixos principais: a comprovação política da legitimidade da pena capital e o convencimento da deputação acerca dos malefícios de sua abolição. Para Luiz Cavalcanti, portanto, o contrato social não possuía os limites estabelecidos pelos deputados contrários à pena de morte. A seu ver, ao fundar-se politicamente, a sociedade tinha cedido todos os seus direitos aos poderes constituídos, legitimando, portanto, os legisladores nacionais a estabelecer as penas consideradas necessárias.

No que diz respeito aos malefícios da supressão da pena de morte, Luiz Cavalcanti destacou o risco corrido pela Câmara de, abolida esta punição, ver o seu projeto

${ }^{347}$ APB-CD; sessão de 15 de setembro de 1830; p. 512. 
malograr no Senado; chamando a atenção ainda às incompatibilidades existentes entre o grau de civilização do Brasil e um código criminal isento da pena capital:

Eu peço aos honrados membros, que reflictão, que a nossa patria ainda não se acha em um gráo de civilisação, que se possa admittir theorias escriptas por homens philantropicos, e applicados a povos, cuja civilisação se acha no seu auge; mas, ainda mesmo, lancemos os olhos para esses paizes civilisados, e vejamos se entre elles a pena de morte tem desapparecido. Não nos exponhamos aos effeitos de uma experiência, que, talvez se nos torne prejudicial, querendo sómente caminhar pela voz de nosso coração, sem attendermos à nossa posição, circumstancias, e hábitos. $^{348}$

Vê-se que, assim como nos discursos contrários à pena capital, o uso de exemplos históricos foi também fundamental aos defensores da condenação à morte. Neste caso, Luiz Cavalcanti fez referências, um tanto genéricas, a países que considerava altamente civilizados e cujos códigos contavam com a pena de morte, referindo-se, muito provavelmente, à França e à Inglaterra.

Falou na seqüência o deputado Bernardo Pereira de Vasconcelos, cujo discurso concentrou-se na desqualificação dos argumentos de seus opositores e na legitimação política da pena de morte. No que diz respeito ao segundo quesito, Vasconcelos concentrou sua análise sobre dois pontos principais: o artigo 27 da Constituição brasileira, que, a seu ver, confirmava a aceitação da pena de morte pela $\operatorname{Carta}^{349}$; e o argumento da prévia aprovação, pelo Senado, da pena de morte, acatada por ocasião da votação da lei de responsabilidade dos Ministros e Conselheiros de Estado.

Com vistas a deslegitimar os argumentos de seus opositores, Vasconcelos admitiu sua simpatia aos discursos filantrópicos e humanitários enunciados, mas demandou atenção ao fato de não se ter sugerido, até então, punições que substituíssem a pena de morte. Para além disso, o representante mineiro afirmou, por mais de uma vez, acreditar que a deputação já havia construído seu juízo sobre a matéria (deslegitimando, portanto, o debate então em curso) e debochou, de certa forma, dos argumentos religiosos mobilizados por seus opositores:

Disse-se mais, que a pena de morte era até prohibida pelas leis divinas: não sou theologo, nem mesmo é necessario entrar nesta questão. Já mostrei, que esta pena é admissivel pela constituição, e se fosse necessario mostraria, que pelas leis divinas se impõe a pena de morte. ${ }^{350}$

\footnotetext{
${ }^{348}$ Idem. Ibidem.

349 Dizia o artigo 27 da Constituição brasileira de 1824: "Nenhum senador ou deputado, durante a sua deputação, póde ser preso por autoridade alguma, salvo por ordem da sua respectiva Câmara, menos em flagrante delicto de pena capital". Vide: http://www.planalto.gov.br/ccivil 03/Constituicao/Constituiçao24.htm

${ }^{350}$ APB-CD; sessão de 15 de setembro de 1830; p. 512.
} 
Por fim, falou à Câmara o deputado Paula Souza, cujo discurso centrou-se em desmontar os argumentos contrários à pena capital, construindo, ao final, a mais importante das falas em sua defesa. Seu pronunciamento articulou-se, assim, em torno de quatro eixos principais: a defesa de que as leis brasileiras fossem condizentes à realidade nacional; o combate direto à ideia da "eficácia" ou "ineficácia" da pena de morte; a afirmação da necessidade de se manter a pena capital num país repleto de escravos; e a comparação entre as "bárbaras" disposições do Livro V das Ordenações Filipinas e o novo código então em discussão.

A análise do primeiro ponto atacado por Paula Souza permite que identifiquemos, de saída, a força de seu discurso na ocasião. Disse o deputado:

Sr. Presidente, nós estamos fazendo um codigo para uma nação, que já existe, e tem costumes. Se legislassemos para um povo, que ainda não existisse formado em sociedade, um povo inteiramente novo, então seria de utilidade, que não houvesse esta pena; porém no estado em que nos achamos, quer-se fazer um codigo como se nos achassemos no mais alto gráo de civilisação! O codigo admitte a pena de morte em quatro casos sómente, que são aquelles donde podem provir maiores males à sociedade. À consciencia do jury fica a applicação desta pena. Se o jury é a expressão da opinião publica, e se esta opinião for hostil à pena de morte, o jury nunca a applicará. Eis a maneira de a tornar nulla, se a opinião publica for contra ella. ${ }^{351}$

Tratava-se, portanto, de um argumento extremamente articulado e convincente: a pena de morte deveria ser mantida num país que, como o Brasil, ainda não alcançara o ápice de sua civilização; entretanto, caso esta pena fosse tão impopular como se dizia, o júri se responsabilizaria pela sua nulidade ao julgar os únicos quatro casos em que, conforme o projeto apresentado pela comissão mista de 1829, ela era admitida.

Combatendo os ataques à pretensa ineficácia da pena capital (frequentemente enfatizada por seus opositores), Paula Souza recusou a possibilidade de se julgar qualquer pena por semelhante categoria, afirmando que, perante uma enormidade de punições sem eficácia alguma, a pena de morte, por sua "terribilidade", seria certamente a que mais impressão causaria sobre os espíritos.

Entrando especificamente na questão da escravidão, o deputado afirmou:

Quem duvida que tendo o Brazil tres milhões de gente livre, incluindo ambos os sexos e todas as idades, este numero não chegue para arrostar dous milhões de escravos, todos ou quase todos capazes de pegarem em armas! Quem, senão o terror da morte, fará conter esta gente immoral nos seus limites? [...] As penas applicadas à escravatura, disse-se, não deverião entrar no codigo criminal; mas sim fazerem o

${ }^{351}$ Idem; p. 513. 
objecto de uma legislação especial. Além dos escravos, ha no Brazil uma classe de individuos, cujos habitos são em tudo semelhantes aos dos escravos, e que por uma miseravel quantia vão fazer um assassinato. Estes homens só com o terror da morte se podem corrigir. ${ }^{352}$

De acordo com o deputado, as execuções públicas possuíam sim reflexos nos índices de criminalidade nacionais, atuando positivamente, portanto, sobre a repressão do comportamento criminoso. Paula Souza afirmava, ainda, que a exclusão das penas de morte e galés do código criminal favoreceria a criminalidade escrava, já que a pena de prisão (que restaria no diploma penal com a exclusão das outras) representaria antes um prêmio do que um castigo a qualquer cativo.

Para Paula Souza, por pior que se julgasse a instituição da escravidão, sua presença no Brasil tornava necessário um rol de punições fortes e terríveis, como haviam obrado os americanos. Foi neste sentido que o deputado afirmou:

A America do Norte, esse paiz tão recommendavel pela sua liberdade e pelos bons costumes de seus habitantes, cuja legislação penal é talvez a melhor do mundo: na America do Norte, digo, só a Pensylvania não tem a pena de morte. Comparem-se os costumes desses descendentes de William Penn, com os dos nossos concidadãos pouco instruidos, e se verá se póde haver paridade, se o exemplo desse paiz póde influir entre nós. Não se póde negar que a França é um dos paizes mais civilisados do globo, e onde se commettem menos crimes em relação à sua população; comtudo a pena de morte se acha alli estabelecida. ${ }^{353}$

O deputado fez uso, como se vê, do mesmo exemplo (norte-americano) utilizado por aqueles contrários à pena de morte, mas com um sinal invertido, não nos deixando ignorar sua perspicácia política e retórica.

Por fim, como nos debates procedimentais anteriormente analisados, Paula Souza exortou seus colegas a reconhecerem a superioridade do código penal em discussão em comparação ao Livro V das Ordenações Filipinas - e a votarem rapidamente pela sua aprovação. Também neste caso, portanto, apesar de impactante, o discurso construído em nome da pena capital, e pronunciado posteriormente àquele de seus opositores, ignorou os argumentos previamente mobilizados, prescindindo de um debate propriamente dito, e optando por uma exposição ideológica aparentemente desprovida de interlocutores que não seus próprios aliados.

Dentre o último conjunto de falas contrárias à pena de morte, pronunciadas por Lino Coutinho, Antonio Ferreira França, Ribeiro de Andrada, Rebouças e Cunha Matos, chama a atenção a preocupação em desmontar os argumentos então

\footnotetext{
${ }^{352}$ Idem; pp. 513-514.

${ }^{353}$ Idem; p. 514.
} 
mobilizados em seu favor. Atentemos, neste sentido, aos pontos ressaltados por cada um deles.

$\mathrm{Na}$ fala de Lino Coutinho, destaca-se a resposta aos argumentos civilizacionais em defesa da pena de morte:

Disse-se entre muitas cousas, que o povo brasileiro não está capaz para tanta philantropia, e há entre nós costumes barbaros. Oh! Sr. presidente, se formos comparar o Brazil com esses paizes civilisados, por exemplo com a Inglaterra ha no Brazil tantos crimes de homicidio, como em Inglaterra? Basta ler a estatistica dos criminosos de Inglaterra, e quantos se enforcão por dia, apezar de toda a sua civilisação; por consequencia uma semelhante asserção não póde ser admissivel, nem é plausivel para o caso presente. ${ }^{354}$

$\mathrm{Na}$ fala de Antonio Ferreira França chama a atenção, por sua vez, a recusa em acatar as interpretações propagadas do artigo 27 da Constituição imperial. De acordo com Ferreira França, as disposições deste artigo faziam referência à legislação em vigor no país em 1824 (em que se admitia a pena de morte), isentando-se de legitimar a pena de morte na legislação futura.

Ribeiro de Andrada foi outro que se preocupou em contra-argumentar, ponto por ponto, as falas favoráveis à pena de morte. Neste sentido, destacamos de seu discurso a recusa do argumento de que, por destinar-se a um povo já existente, o código criminal deveria refletir o grau de civilização deste mesmo povo ${ }^{355}$, e a negação das justificativas que apelavam à presença da escravidão ${ }^{356}$ e à falta de prisões no país para a legitimação da pena de morte ${ }^{357}$. Chama a atenção ainda o modo com que, reforçando seus pontos de vista, Ribeiro de Andrada fez uso de exemplos históricos internacionais, discorrendo com conhecimento de causa acerca das histórias francesa

\footnotetext{
${ }^{354}$ APB-CD; sessão de 15 de setembro de 1830; p. 513.

${ }^{355}$ Afirmou o deputado, quanto a este ponto: "Allegou-se que este codigo está feito à annos, e feito para um povo dado. Que importa isso? Povo dado era o da Toscana; tinha um codigo penal que admittia a pena de morte, e Leopoldo a fez riscar. Notai que os toscanos são italianos como os outros povos da Italia; regidos pelo mesmo systema politico, dirigidos por um mesmo culto, e o povo mais doce, mais instruido e mais moral. A suavidade pois das penas longe de augmentar os crimes e de enbrutecer este povo contribuio antes a melhoral-o." ABP-CD; sessão de 15 de setembro de 1830; pp. 514-515.

${ }^{356}$ Dentre outras afirmações contrárias a este argumento, Ribeiro de Andrada fez uso da seguinte: “[...]grande parte das hordas africanas admittem a metempsycose, e crêem que morrendo voltão a desfructar as delicias de sua cara patria; e lançando um golpe de vista pelo Brazil, elles são talvez os unicos que se suicidão porque a morte é a noite do dia inquieto e penoso que se chama vida, é o leito de repouso para o desdito escravo. Que terror póde nelles infundir semelhante pena? A Pensilvânia contava muitos negros quando esta pena não foi admittida em seu codigo penal”. Idem; p. 515.

357 "Argumentou-se ainda com a falta de cadêas apropriadas no caso da abolição desta pena. Que singular modo de argumentar! A resposta é obvia, que as fação [...]”. Idem; p. 515.
} 
e inglesa e acerca dos malefícios que a manutenção da pena de morte trouxera a estes países.

Por fim discursaram Rebouças e Carneiro da Cunha, cujas argumentações seguiram a mesma linha de ataque às defesas da pena de morte exposta até aqui. $\mathrm{Na}$ fala de Rebouças destacaram-se: o apelo pela continuação e aprofundamento das discussões sobre a pena de morte em plenário (constantemente sabotada, direta ou indiretamente, pelos discursos favoráveis à pena capital), única possibilidade, a seu ver, de o conjunto da deputação votar de forma consciente e não "sufocada" sobre a questão; e a reafirmação da ineficácia e do atraso histórico-social representado pela manutenção de semelhante punição. Rebouças mobilizou ainda, a certa altura de sua fala, uma infinidade de exemplos históricos, coevos ou não, de abolição da pena capital:

A pena de morte na Pensilvania acha-se abolida por Guilherme Peen, pela effectiva adopção do systema penitencial 70 annos antes que Beccaria publicasse a sua celebre obra, já aqui referida. [...] A mesma pena fôra mandada cessar na Toscana por Leopoldo, e abolida em 1786, depois de uma proveitosa experiencia de 20 annos. [...] Mais outros exemplos tenho eu commemorado de época mais antiga e de muito mais recente sobre o Egypto, e reinado de Sabaco, a Grecia anteriormente a Draco, Roma nos tempos felizes da lei Porsia e do imperador Tito, a Inglaterra no reinado de Alfredo, a Russia sob o Imperio de Izabel e Catharina $2^{\text {a }}$, o imperador Nicoláo na Finlandia etc. Os Srs. deputados hão de recordar-se destes factos historicos disseminados nas obras de differentes escriptores, como sejão: Herodoto, Grócio, Strabo, Lactancio, Tito Livio, e ultimamente em alguns discursos e memorias offerecidas ao concurso de Sellon em Genebra, a sociedade de moral christã na França etc. Basta o lerem-se para desengano a obra de Charles Lucas e o relatório de Levinghston, que estão ao alcance de todos. ${ }^{358}$

Carneiro Cunha, por sua vez, recusou as "vantagens" e benefícios propagados pelos publicistas da pena de morte e, assim como Rebouças, recorreu a exemplos da história nacional para atacá-la:

Se não existisse esta pena não recordariamos com dôr esses dias de luto, e de amarguras em que exhalarão o ultimo suspiro nos cadafalsos da inquisição politica um Antonio Henriques, os Satyros, os Canécas e outros martyres da patria que se sacrificarão defendendo corajosamente nossos direitos, nossa independencia e liberdade. ${ }^{359}$

Vê-se, assim, o modo com que, conscientes de sua deslegitimação da qualidade de interlocutores - haja vista a completa omissão de seus argumentos nos discursos favoráveis à pena capital -, ainda assim os defensores da abolição da pena de morte

\footnotetext{
${ }^{358}$ APB-CD; sessão de 15 de setembro de 1830; p. 516.

${ }^{359}$ Idem; p. 517.
} 
preocuparam-se em desmontar as falas de seus opositores e enfatizar, uma vez mais, os desserviços prestados pela pena de morte no passado, presente e, seguramente, no futuro do Brasil.

Analisemos muito rapidamente, por fim, os breves argumentos mobilizados em torno da manutenção, ou não, da pena de galés no código criminal. O único deputado a manifestar sua oposição à pena de galés foi Antônio Pereira Rebouças, em fala pronunciada aos 14 de setembro de 1830. De acordo com o deputado, ainda que "não tão horrorosa como a pena de morte", por não violar, como aquela, "os princípios naturaes e sociaes os mais sagrados", também a pena de galés deveria ser abolida do diploma penal imperial por não melhorar, mas antes depravar os criminosos:

É preso o homem e lançado na enxouvia, ahi é o seu primeiro collegio de depravação. É condemnado, e passa às galés; ahi a sua academia. Donde resulta, que não só se desmoralisão de todo, como que depravando-se aprendem a commetter sem horror e com sucesso, todos os crimes pelo conhecimento adquirido de prevenir e frustar todas as cautelas e esforços que se lhe opponhão e empreguem. [...] A pena de galés é pois perniciosa em vez de conducente a melhorar o criminoso e reprimir pelo exemplo. Passe, porém, muito embora a pena de galés, e nunca a de morte. ${ }^{360}$

Note-se, contudo, a partir deste trecho, que, ainda ao abordar a temática das galés, a real preocupação de Rebouças repousava sobre a votação da pena capital.

Do lado oposto desta disputa e, portanto, em defesa da pena de galés, manifestaram-se apenas o deputado Vasconcelos e, de forma bastante indireta, o deputado Paula Souza. Para Vasconcelos, a punição era necessária ao Brasil em virtude da ausência de Casas de Correção especificamente destinadas aos trabalhos públicos dos réus. Assim, para o deputado mineiro, a abolição da pena de galés, somada à ausência de prisões apropriadas no país, acabaria por elevar, invariavelmente, os índices de criminalidade nacional:

Emquanto não se estabelecerem as casas, e edificios proprios para isto, que trabalhos, que penas hão de ter aquelles, que merecem ser condemnados a trabalhos publicos? Quaes são as nossas prisões? Por ventura havemos consentir que grandes facinorosos vão commeter delictos para irem para prisões simples e viverem tranquillos? ${ }^{361}$

\footnotetext{
${ }^{360}$ APB-CD; sessão de 14 de setembro de 1830; p. 507.
}

${ }^{361}$ APB-CD; sessão de 15 de setmebro de 1830; p. 513. 
Baseado no raciocínio exposto acima, Vasconcelos mandou à mesa, nesta mesma ocasião, a seguinte emenda: “A pena de galés subsistirá, emquanto não forem feitos os estabelecimentos proprios para os condemnados ao trabalho.

O deputado Paula Souza, por sua vez, fez unicamente menções indiretas à questão das galés, utilizando-a, antes, para a complementação de seus argumentos em defesa da pena capital. Neste sentido, o deputado chamou a atenção aos riscos de se abolir conjuntamente as penas de morte e de galés do código criminal - já que, isto feito, restaria aos escravos apenas as penas de prisão - e afirmou, paralelamente, que a pena de galés não era suficientemente forte e cruel para o controle da população escrava nacional.

Ao final da sessão do dia 15 de setembro, como sabemos, votou-se pela manutenção das penas de morte e de galés no texto do código criminal ${ }^{363}$. Na mesma ocasião, os deputados aprovaram a emenda proposta por Rego Barros ("Extinga-se a pena de morte nos erros políticos.") e rejeitaram aquela sugerida por Paula Souza ("Que no codigo só se conserve a pena de morte no grau maximo do crime de homicidio, e de cabeças de insurreição.”). Já a emenda de Vasconcelos, referente à subsistência da pena de galés no Império, foi retirada pelo próprio deputado antes de qualquer votação ${ }^{364}$.

A nosso ver, o exame e a exposição minuciosa dos argumentos efetivamente mobilizados nas disputas em torno da pena capital abrem, por si sós, possibilidades para uma renovação das interpretações do Código Criminal do Império do Brasil.

Um dos primeiros "resultados" desta análise, portanto, nos parece ser o da complexidade dos discursos pronunciados, de lado a lado, em torno da pena de morte. Neste sentido, ultrapassando os "lugares-comuns" destas falas, podemos perceber em profundidade a rica gama de argumentos utilizados e o modo com que estes superavam a oposição normalmente destacada entre discursos civilizacionais e religiosos.

\footnotetext{
${ }^{362}$ Idem; Ibidem.

${ }^{363}$ Os registros da sessão de 16 de setembro de 1830 contêm, neste sentido, as declarações de votos de parte dos deputados envolvidos na questão. APB-CD; sessão de 16 de setembro de 1830 ; p. 519.

${ }^{364}$ Apesar de retirada da mesa por Vasconcelos, a emenda sugerida pelo deputado mineiro ("A pena de galés subsistirá, emquanto não forem feitos os estabelecimentos proprios para os condemnados ao trabalho.") viria, de certa forma, a compor o texto do código criminal, na forma do artigo 311: "A pena de galés temporaria será substituida pela de prisão com trabalho pelo mesmo tempo, logo que houverem casas de correcção nos lugares, em que os réos estiverem cumprindo as sentenças."
} 
Destaque seja dado, neste sentido, à multiplicidade de exemplos históricos e conhecimentos da teoria ou dogmática mobilizados pelos legisladores brasileiros em suas falas. Para além das inúmeras exemplificações históricas (nacionais e internacionais) transcritas acima, deputados favoráveis e contrários à pena de morte confrontaram suas opiniões baseados também na produção dogmática de juristas e penalistas das mais diversas localidades do globo. Reconhecendo, obviamente, a faceta retórica de parte considerável destas citações, ainda assim não se pode ignorar a ampla circulação de ideias penais em curso no início do século XIX (de que já tratamos brevemente na Introdução) e a sintonia e perspicácia apresentada pelos deputados brasileiros ao fazerem uso das mesmas.

Chamam a atenção, neste sentido, as diversas referências à leitura e conhecimento dos mais importantes teóricos do direito penal ocidental e, em especial, a disputa travada entre os deputados Rebouças e Paula Souza em torno deste conhecimento. Discursando, assim, na sessão de 14 de setembro de 1830, Rebouças afirmou:

Não são occultos a ninguem os escriptos de Eduardo Levingston, e de Charles Lucas, onde se achão conservados infinitos exemplos da verdade que refiro, attestados igualmente por Liancourt, Esquirol, Tallandier, Wright etc. ${ }^{365}$

Paula Souza, por sua vez, respondeu o deputado com a seguinte observação:

Há na verdade um grande numero de escriptores que fallão contra a pena de morte; porém tambem ha muitos outros de opinião contraria, e como esta casa não é o lugar proprio para sustentar o pró e o contra, limito-me a recomendar a leitura destes escriptores aos Srs. deputados, como um correctivo às suas opiniões. ${ }^{366}$

Comentário ao qual Rebouças, por fim, replicou:

Ouvi de outro Sr. deputado que os que defendiamos a abolição da pena de morte parecia que só tinhamos lido o que se acha no corpo da obra de Beccaria, deixando de parte as notas de Diderot. Bem atrazados estiveramos se nos limitassemos à obra dos delictos e das penas; comtudo sempre observarei que tambem o Sr. deputado talvez não queira levar em conta o que disserão outros annotadores de Beccaria, como sejão Morellet e Bielfeld; e que ainda de Diderot visse sómente o lado que lhe pareceu lisongeiro; pois que este mesmo commentador, convindo na pretendida justiça da decretação da pena de morte se fosse necessaria, todavia não se decidio à resolver o problema da necessidade. ${ }^{367}$

Ao longo destes debates, diversos outros "escriptores" foram citados pelos deputados brasileiros. Recorreu-se, assim, por mais de uma vez, à autoridade de teóricos, "filantropos" e "chanceleres" como Bentham, Filangieri, Benjamin Constant,

\footnotetext{
${ }^{365}$ APB-CD; sessão de 14 de setembro de 1830; p. 508.

${ }^{366}$ APB-CD; sessão de 15 de setembro de 1830; p. 513.

${ }^{367}$ Idem; p. 516.
} 
Aguessau, conde de Seze, Gregoire e Legraverend, dentre outros. O fato de estes nomes pulularem em meio às falas dos deputados, sem quaisquer referências mais profundas, nos parece indicativo de um conhecimento, ou reconhecimento, partilhado por não poucos membros da deputação nacional ${ }^{368}$.

Conscientes, assim, da extensão dos argumentos e referências mobilizadas nas disputas em torno da pena de morte, cuidemos em perscrutar os objetivos e projetos políticos envolvidos na manutenção desta pena no código brasileiro, recusando a absolutização do conteúdo dos discursos proferidos à altura dos debates de $1830 \mathrm{e}$ atentando ao modo com que diferentes argumentos foram cambiantemente utilizados pelos deputados a depender do assunto então em pauta ${ }^{369}$.

Nesse sentido, são as justificativas escravistas mobilizadas em torno à pena de morte o principal alvo de nossas observações. Se a religiosidade e obediência dos deputados brasileiros aos preceitos do catolicismo puderam ser questionadas e complexificadas (nesta pesquisa) perante o reconhecimento da força decisória desempenhada por semelhantes argumentos numa disputa polêmica como a que se travava no interior do Parlamento nacional, também a ampla utilização de argumentos de cunho escravista nos pareceu merecedora de um olhar mais apurado.

Deve-se reconhecer, de saída, que, mais do que os religiosos, os argumentos centrados sobre a escravidão possuíam ampla força política à altura dos debates de

\footnotetext{
${ }^{368}$ No que respeita especificamente aos exemplos históricos internacionais mobilizados pelos deputados brasileiros, que acreditamos ter demonstrado suficientemente com a transcrição de trechos de suas falas, chama a atenção, especificamente, a negatividade com que, em geral, os deputados se referiram à França e, principalmente, ao governo de Napoleão. Dentre outros exemplos, destaquemos aqui um trecho da segunda fala pronunciada pelo deputado Ribeiro de Andrada: "Demais, os philantropos francezes, como por exemplo Gregoire, pedirão na convenção, que se riscasse a pena de morte: se ella não foi revogada deve attribuir-se ao estado revolucionario de então; se o codigo penal francez ainda a contém, deve-se esta desgraça ao grande homem que tinha o genio e o instincto do despotismo, deve-se à constituição que roubou aos deputados a proposição directa das leis; e quando a tenha indirecta, a um governo inimigo das novas instituições e ao estado ainda vacillante e revolucionado daquella nação.”

${ }^{369}$ Para um bom modelo de leitura dos discursos políticos imperiais ver: Tâmis Peixoto Parron. A política da escravidão no Império do Brasil, 1826-1865. Dissertação de Mestrado; DH/FFLCH/USP, 2009; pp.13-14. Ao explicitar o modelo conflituoso de interpretação dos discursos políticos do século XIX adotado em sua pesquisa, Parron afirma: "[...]falas de deputados e de senadores, publicações editoriais e representações são condicionadas por mecanismos [...] como a relação governo-oposição, o interesse em apoio eleitoral, o risco de processos por improbidade administrativa etc. Tudo isso torna a palavra precária, pois, espécie de brigada ligeira, feita para desautorizar o inimigo e legitimar o sujeito discursivo do momento, varia de intensidade e natureza na boca de um mesmo político ou ator social conforme as circunstâncias condicionadas por cada um daqueles mecanismos.”; p. 14.
} 
setembro de 1830. Nesse sentido, se os deputados favoráveis à pena capital fizeram uso constante do cativeiro para justificarem suas escolhas - afirmando essencialmente que, num país escravista, a pena de morte era necessária ao controle da população escrava e à manutenção da ordem interna -, os deputados contrários àquela punição também mobilizaram em seus discursos argumentos ligados ao cativeiro, procurando demonstrar veementemente a ineficácia da pena de morte quando dirigida aos escravos. Deste jogo de ideias e argumentações, extraímos a centralidade e quase obrigatoriedade de referências à escravidão por ambos os lados em disputa.

Ainda no que diz respeito ao impacto produzido, no Brasil do século XIX, por argumentos que recorriam aos riscos advindos da escravidão, lembremos do modo com que, então, o exemplo do Haiti e as ameaças de uma revolta interna excitavam os ânimos dos homens públicos e da elite nacional. Não é de se estranhar, portanto, uma vez mais, a ampla recorrência à questão do cativeiro pelos interlocutores do debate sobre a pena capital ${ }^{370}$.

Uma apreciação mais atenta da manutenção da pena de morte no código brasileiro demanda, contudo, que ultrapassemos o caso nacional e analisemos sua aparição em outros diplomas penais do mundo ocidental à época. Prescrita por praticamente todos os códigos do período, à exceção da Leopoldina, a pena de morte era prevista ainda, na grande maioria dos casos, para uma gama muito grande de delitos.

No código prussiano de 1794, por exemplo, conhecido como Algemeines Landrecht, a pena de morte, prevista pelo artigo 47 , estava prescrita aos crimes considerados de alta traição e lesa-majestade (atentados contra a segurança interna e externa do Estado e ofensas à dignidade do governante, de que são exemplos os artigos, 91, 92, 93, 100, 101, 102, 107, 108, 109, 110, 111, 114, 134, 135, 136, 173, 196 e 197), aos juízes que, julgando contrariamente à lei, impusessem a morte ao réu (artigo 387), aos casos mais graves de crimes contra o tesouro público (artigo 425), àquele que oferecesse, mais de uma vez, ajuda a um desertor (artigo 479), ao duelista

\footnotetext{
${ }^{370}$ Ao real assombro causado pelas perspectivas de revolta ou cisão social no país (em decorrência da escravidão), deve-se somar, contudo, o uso discursivo e estratégico então realizado sobre a instituição do cativeiro, em especial por grupos políticos das décadas de 1820 e 1830. Ao analisar, neste sentido, o recurso à ameaça do "haitianismo" no discurso dos deputados brasileiros a esta altura, Alain El Youssef chama a atenção ao uso quase sempre retórico deste evento pela classe política do país e à sua instrumentalização com vistas à defesa de projetos bastante específicos, como o de manutenção da escravidão. Alain El Youssef. Imprensa e Escravidão: política e tráfico negreiro no Império do Brasil (Rio de Janeiro, 1822-1850). Dissertação de Mestrado; DH/FFLCH/USP; 2010. Ver especialmente o capítulo 3 .
} 
que matasse seu oponente (artigo 671) e ainda, dentre outros, aos casos de homicídio (artigo 806, dentre outros) e infanticídio (artigos 965 e 966).

No código austríaco de 1803, por sua vez, a pena de morte era regulada pelo artigo 10 de sua primeira parte e prevista aos delitos compreendidos como alta traição, dentre os quais se incluíam o ataque à segurança pessoal do chefe de governo, os atentados à Constituição e as ameaças à segurança do Estado (artigos 52 e 53). A pena capital estava prevista ainda, neste diploma, ao crime de rebelião (artigo 67), à falsificação de bilhetes de crédito público (artigos 94 e 95; caso em que, tanto o cabeça quanto os cúmplices do crime eram punidos com a morte), aos homicidas (artigo 119) e incendiários (artigo 148).

No código francês de 1810, a pena de morte vinha regulada pelos artigos 12 e 13, aplicando-se a uma grande variedade de crimes considerados atentatórios à segurança interna e externa do Estado (regulados, de um modo geral, entre os artigos 75 e 97 e relativos, dentre outros casos, aos franceses que se armassem contra a França, auxiliassem, de qualquer maneira, seus oponentes numa guerra ou lhes revelassem segredos de Estado; aos funcionários públicos que revelassem segredos de Estado e fornecessem aos inimigos planos internos de fortificação; aos que expusessem o Estado francês à declaração de uma guerra; aos que atentassem contra a vida ou pessoa do imperador e de sua família, ou contra a ordem do governo e de hereditariedade ao trono; aos que excitassem uma guerra civil; aos que comandassem tropas ou divisões de guerra sem ordens expressas do governo; e ainda aos que incendiassem ou destruíssem edifícios, arsenais e outras propriedades do Estado). Para além destes casos, o diploma de 1810 previa a aplicação da pena capital aos crimes de falsificação de moeda e bilhetes de crédito público (artigos 132 e 139), nos casos de violência extrema contra funcionários públicos e agentes do governo (artigo 233), aos crimes de assassinato, parricídio, infanticídio e envenenamento (artigos 295 a 304), aos casos mais graves de atentado à liberdade individual e seqüestro (artigo 344) e no caso de falso testemunho em que fosse imputada a pena de morte ao réu (artigo 361).

Também os códigos bávaro de 1813 e espanhol de 1822 prescreviam a pena de morte a vários de seus crimes públicos e particulares, atestando o fato de que, à época da aprovação do código brasileiro de 1830, ainda que a pena de morte já não viesse prescrita a crimes de caráter moral ou religioso na maioria dos diplomas, não se 
encontrava em voga, no mundo ocidental, um só diploma penal que a tivesse abolido $^{371}$.

Apesar, portanto, de na passagem do século XVIII ao XIX, a legitimidade e utilidade da pena de morte terem sido amplamente discutidas por juristas e teóricos iluministas europeus - num debate que, partindo fundamentalmente da produção teórica de Beccaria, atingiu rapidamente o conjunto dos países em processo de codificação penal -, foram raros os casos em que de fato prescindiu-se de sua aplicação. A presença de fortes argumentos morais, utilitários e humanitários de oposição a esta pena não parecem, portanto, ter angariado forças suficientes para sua abolição no mundo ocidental ${ }^{372}$.

Inseridos no movimento codificacionista em curso à época e atentos aos dispositivos adotados pelos códigos europeus, não causa espanto, assim, que também os legisladores brasileiros tenham optado pela manutenção da pena capital. Surpreende, contudo, que, diferentemente da maioria dos códigos do período, o brasileiro a tenha previsto a tão poucos casos, restringindo sua aplicação aos crimes de homicídio com agravantes, roubo seguido de morte (que não deixa de ser um homicídio agravado) e insurreição escrava. Ao invés de representar um "atraso", portanto, a manutenção da pena de morte no diploma brasileiro, da forma específica com que se deu, atesta antes a particularidade deste código que, formulado para um país escravista, a prescreveu por menos vezes que países europeus que não conviviam internamente com o cativeiro.

No que tange, portanto, à ampla utilização de argumentos escravistas nos embates centrados sobre a pena de morte, ainda que os mesmos representem uma preocupação real dos deputados brasileiros, o reconhecimento de sua constância e força nas discussões não deve levar o pesquisador a atrelar exclusivamente a pena de morte à presença do cativeiro no país. Pelo contrário, uma análise comparativa entre o diploma de 1830 e os códigos penais aprovados à mesma época no mundo ocidental, e

\footnotetext{
${ }^{371}$ Lembremos, neste ponto, que a Leopoldina, diploma toscano de 1786 que abolira a pena de morte, já não vigorava mais à altura de 1830 .

372 Bastante interessante, neste sentido, é o artigo "La question de la peine de mort sous la révolution française ", de Raymond Monnier, no qual o autor discute, entre outras coisas, a demora na abolição da pena capital na França, que só ocorreu em 1981, indagando-se acerca da distância existente entre a inserção desta questão no debate público francês, à altura da Revolução de 1789 , e a resolução final por sua abolição, quase dois séculos mais tarde. In: Xavier Rousseaux, Marie-Sylvie Dupont-Bouchat et Claude Vael (org). Révolutions e Justice Pénale en Europe: modèles français et tradition nationales (1780-1830). L'Harmattan: Paris, 1999 ; pp. 225-242.
} 
o exame interno da regulamentação brasileira da pena capital indicam, antes, um uso discursivo deliberado da escravidão com vistas à manutenção de uma pena que, ao que tudo indica, a maioria dos deputados não tinha de fato a intenção de abolir.

Há que se questionar, portanto, na contra-mão das expectativas, o quanto o argumento da escravidão não foi, em verdade, retoricamente mobilizado para a preservação da pena de morte no país. Ou seja, se o cativeiro fosse a chave explicativa privilegiada para a presença desta punição no código nacional, o esperado, parecenos, seria a restrição de sua aplicação à população cativa - bastava, para isso, um parágrafo a mais na definição do crime de homicídio com agravantes (artigo 192), estabelecendo penas diferenciadas aos livres e escravos, como, de todo modo, fazia o artigo 60 do diploma brasileiro (pelo qual ficava estabelecido que os escravos não poderiam receber outras punições para além de açoites, galés e morte ${ }^{373}$ ), ou ainda que, no caso do crime de insurreição escrava, o artigo 114 (responsável pela explicitação de que, sendo livres os líderes de um movimento pela libertação de cativos, também estes receberiam a pena capital) estabelecesse, pelo contrário que, neste caso, ficavam os livres sujeitos a um outro tipo de punição. Contrariamente a isto, contudo, optou-se pela prescrição da pena de morte aos escravos exatamente nos mesmos casos em que ela era prescrita aos cidadãos livres do país ${ }^{374}$.

Se o artigo 60 do Código de 1830 vedava, portanto, a aplicação de uma série de punições previstas pelo diploma aos réus cativos - impedindo a aplicação aos escravos das penas de prisão, prisão com trabalho, desterro, degredo ou multa, dentre outras -, diferenciando-os, assim, do restante dos indivíduos a que se dirigia o diploma penal; a pena de morte, pelo contrário, só poderia ser aplicada aos escravos nos casos específicos em que também o poderia ser aos livres, não se deixando

\footnotetext{
${ }^{373}$ Dizia o artigo 60 do Código brasileiro de 1830: "Se o réo fôr escravo, e incorrer em pena, que não seja a capital, ou de galés, será condemnado na de açoutes, e depois de os soffrer, será entregue a seu senhor, que se obrigará a trazel-o com um ferro, pelo tempo, e maneira que o Juiz designar. O numero de açoutes será fixado na sentença e o escravo não poderá levar por dia mais de cincoenta."

${ }^{374}$ Neste ponto, vale ressaltar, havia uma diferença sutil entre o texto final do diploma brasileiro e o projeto apresentado por Bernardo Pereira de Vasconcelos, já que, neste último, apesar da não regulamentação do crime de insurreição ou de qualquer outro delito especificamente referente à revolta escrava, havia uma prescrição da pena capital especificamente dirigida aos cativos. Tratava-se do artigo 286 do projeto, de acordo com o qual previa-se a morte ao escravo que incorresse no crime de "forçamento" ou arrombamento de cadeia. Se realizado por um livre, as penas pelo crime de arrombamento de cadeia variavam, de acordo com as circunstâncias, entre a prisão com trabalho por um a seis anos, e as galés por entre quatro e dezesseis anos.
} 
qualquer margem ou latitude decisória aos juízes para a prescrição arbitrária desta punição.

Ou seja, se um réu escravo acusado por furto, agressão física, tentativa de destruição da integridade do Império, resistência às ordens das autoridades, ou qualquer outro crime a que o Código de 1830 prescrevesse penas de galés, prisão com trabalho, degredo ou multa, tinha sua pena obrigatoriamente comutada, à exceção do caso das galés, na pena de açoites, o mesmo nunca poderia ocorrer com a pena de morte. Não havia circunstância alguma, portanto, em que o código abrisse exceções à aplicação da pena capital aos escravos. Talvez tenha sido, inclusive, a certeza da ausência de qualquer possibilidade de arbítrio neste ponto e o reconhecimento da proximidade legada a livres e cativos pela legislação criminal, a estimular, anos mais tarde, a aprovação da lei de 10 de junho de 1835, por meio da qual aumentou-se consideravelmente os casos em que, aos cativos, poder-se-ia prescrever a pena capital, alterando-se ainda a ordem do processo nos casos específicos de crimes cometidos por escravos ${ }^{375}$.

Se nos lembrarmos, neste ponto, dos discursos contrários à pena de morte pronunciados por Antonio Pereira Rebouças e Martim Francisco na sessão de 11 de setembro de 1830, podemos vislumbrar como, em suas falas, ficava implícito o reconhecimento do uso estratégico da escravidão realizado por seus opositores. Ao advogar, assim, pela inutilidade da pena de morte quando direcionada à população cativa, ambos os deputados destacavam não ser esta uma sentença pensada de fato para os escravos. É neste contexto, inclusive, que Rebouças sugere que, se assim o fosse, uma ordenança em separado deveria ser redigida aos mesmos, recusando que, às custas de sua presença, os cidadãos livres do Brasil fossem submetidos a uma legislação ruim.

Paula Souza, por sua vez, em discurso pronunciado aos 15 de setembro, foi enfático ao afirmar a necessidade de manutenção da pena de morte no diploma brasileiro (opondo-se, assim, à elaboração de uma legislação especial para os

\footnotetext{
${ }^{375}$ De acordo com esta lei ficava prevista a aplicação da pena de morte aos escravos e escravas que matassem por qualquer maneira, ferissem gravemente ou fizessem grave ofensa física a seu senhor, à mulher deste, seus descendentes ou ascendentes, ao administrador ou feitor da propriedade e às suas mulheres. A Lei de $\mathrm{n}^{\circ} 4$ de 10 de junho de 1835 pode ser visualizada em: http://www.jusbrasil.com.br/legislacao/104059/lei-4-35. Para uma análise profunda da lei de 1835 ver: Ricardo Figueiredo Pirola. A lei de 10 de junho de 1835: justiça, escravidão e pena de morte. Tese de Doutorado; IFCH/UNICAMP; 2012; especialmente o capítulo 1.
} 
escravos) por conta de uma classe de indivíduos cujos hábitos, em suas palavras, eram em tudo semelhantes aos dos cativos, e que, por uma miserável quantia, se disporiam a cometer um assassinato. A estes homens, dizia o deputado, apenas o terror da morte poderia corrigir $^{376}$.

Vai nesse sentido, portanto, a proposição de Paula Souza de que a pena de morte fosse mantida aos casos de homicídio com agravante e insurreição escrava (e não apenas para os crimes passíveis de serem cometidos por escravos), e sua defesa de que, se fosse verdadeiramente contrária à opinião pública, tal punição não seria aplicada pelo júri popular - a quem caberia os julgamentos destes crimes.

O posicionamento de Paula Souza nos parece fundamental à compreensão do raciocínio implícito à manutenção da pena de morte no Código de 1830 , mostrando como, também no campo jurídico, a inserção da escravidão no Parlamento brasileiro escorou-se no liberalismo e não ignorou os lugares-comuns do pensamento social do século XIX. ${ }^{377}$.

Por ter sido um diploma efetivamente elaborado pelo conjunto da deputação nacional, e não "unilateralmente" promulgado pelo chefe de Estado ou seus ministros e conselheiros mais próximos, à diferença do que ocorrera com parte dos códigos do período (como, por exemplo, o francês), os parlamentares brasileiros tiveram de justificar suas escolhas perante seus pares, discutindo publicamente a adoção da pena capital. Se a conquista de que esta punição fosse debatida em conjunto pode ser imputada a um deputado extremamente liberal como Ernesto Ferreira França, autor das emendas aprovadas na sessão de 6 de maio de 1830, o constrangimento de justificar a pena de morte recaiu sobre aqueles que, apesar de tudo, não estavam dispostos a abdicar de sua presença. Haja vista os argumentos morais e humanitários de oposição à pena de morte então em curso no mundo ocidental, não espanta que a escravidão tenha servido, de certa forma, de álibi aos deputados na defesa desta pena.

Por fim, vale lembrar que se a maioria dos parlamentares brasileiros votou pela presença da pena de morte no texto do diploma penal, tal fato não elimina a importância do projeto jurídico e político implícito à fala de deputados que advogaram verdadeiramente por sua abolição e substituição por um sistema penitenciário no Brasil. Ainda neste ponto, contudo, vale destacar que, centrados

\footnotetext{
${ }^{376}$ Idem; pp. 513-514.

377 Tâmis Peixoto Parron. A política da escravidão no Império do Brasil, 1826-1865. Dissertação de Mestrado; DH/FFLCH/USP, 2009; p.25.
} 
muitas vezes no exemplo norte-americano de abolição da pena capital, ou baseados especificamente no projeto de Edward Livingston, tais deputados ignoraram ou eludiram o fato de a Luisiana e outros estados norte-americanos possuírem, à época, os chamados "Black Codes", normativas exclusivamente dirigidas aos cativos e recheadas de prescrições à morte. Ainda, portanto, que o projeto de Livingston fosse extremamente liberal e tivesse efetivamente interessado os deputados brasileiros envolvidos na elaboração do código criminal, como veremos à frente, foi elaborado para conviver com um código exclusivamente dirigido aos cativos e bastante duro nas punições a eles infligidas $^{378}$.

${ }^{378}$ Monica Duarte Dantas. "Dos Statutes ao Código brasileiro de 1830: o levante de escravos como crime de insurreição.” Revista do Instituto Histórico e geográfico Brasileiro, vol. 452, pp. 273-309, 2011. 


\section{Capítulo 3}

\section{O Código Criminal de 1830: matrizes e influências}

Neste capítulo, pretendemos analisar o texto do Código Criminal do Império do Brasil em profundidade, explicitando o projeto político de fundo por ele representado. Apresentados, assim, o percurso geral traçado por este diploma no interior do Parlamento e os trabalhos empreendidos pelas comissões a ele dedicadas, objetivamos esclarecer os pontos específicos em que tais trabalhos se deram, enfatizando a multiplicidade das alterações e novidades introduzidas, entre os anos de 1829 e 1830, no projeto do código penal imperial.

Para tanto desenvolveremos, num primeiro momento, uma comparação pontual entre os projetos de código criminal apresentados à Câmara baixa e o texto final do código penal brasileiro, explicitando o que se manteve e o que foi eliminado daqueles textos entre 1827 e 1830 - atentando às possíveis causas e fontes destas transformações - para, em seguida (munidos dos resultados de um estudo comparativo cuidadoso elaborado entre o código brasileiro e outros dez códigos ou projetos de codificação penal existentes àquela altura no mundo ocidental), apresentarmos as principais matrizes penais internacionais utilizadas na elaboração do diploma de 1830, identificando os momentos precisos de sua introdução naquele texto.

Antes de darmos início, contudo, a estas análises, é importante que observemos alguns aspectos gerais assumidos pelo Código Criminal do Império do Brasil em seu formato definitivo: lembrando que a redação final deste diploma fora apresentada pela última comissão especial da Câmara a ele dedicada (eleita aos 11 de setembro de 1830 e composta pelos deputados Limpo de Abreu, Paula Souza e Luiz Cavalcanti), aos 19 de outubro de $1830^{379}$.

Composto por 313 artigos, este código dividia-se em quatro partes principais: (I) "Dos crimes e das penas", (II) "Dos crimes Públicos", (III) “Dos crimes Particulares"

\footnotetext{
${ }^{379} \mathrm{O}$ texto entregue pela última comissão do código criminal aos 19 de outubro de 1830 foi aprovado pela deputação brasileira no dia 22 de outubro do mesmo ano, passando pelo crivo do Senado nacional aos 24 de novembro e conquistando, enfim, a sanção imperial no dia 16 de dezembro de 1830 .
} 
e (IV) "Dos crimes policiais"380; contando ainda com 6 artigos referentes às "Disposições Gerais" do documento. Adequando-se, portanto, ao padrão organizacional do direito penal coevo, o código brasileiro não apenas dividia-se - e de forma bastante explícita - entre uma "Parte Geral" e uma "Parte Especial", como também organizava seus delitos (no interior da segunda parte) na seqüência "crimes públicos", "crimes particulares" e "crimes policiais".

No que tange às definições presentes na "Parte Geral" deste diploma, denominada Dos crimes e das Penas e composta por 67 artigos, deve-se ressaltar que o Código de 1830 consagrava já em seu primeiro artigo o princípio da precedência da lei na

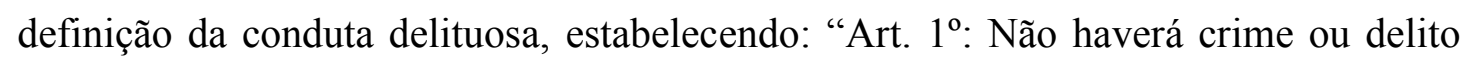
(palavras synonimas neste Código) sem uma lei anterior, que o qualifique". Podemos identificar ainda, nesta seção, a presença de princípios gerais como o da igualdade formal perante a lei, o da publicidade dos crimes e penas e o da sua individualização, confirmando a fundação deste diploma nos preceitos de legalidade e certeza do direito tão importantes à codificação moderna do período. Firmada nestes preceitos, a "Parte Geral" do documento definia seu entendimento de crime e criminoso (com determinações especificamente referentes aos crimes de abuso da liberdade de imprensa), acatava as distinções entre autoria e cumplicidade, definia critérios de inimputabilidade, de crimes justificáveis e circunstâncias agravantes e atenuantes dos delitos, regulava a questão da satisfação dos danos causados pelos réus e definia as penas e o modo da sua execução.

$\mathrm{O}$ código acatava as seguintes punições: morte (arts. 38 a 43); galés (arts. 44 e 45); prisão com trabalho e prisão simples (arts. 46 a 49); banimento, degredo e desterro (arts. 50 a 52); multa (arts. 55 a 57); suspensão do emprego (art. 58); e, por fim, perda do emprego (art. 59). Aos réus escravos, e unicamente a eles, previa-se ainda a pena de açoites (art. 60). Vale destacar, neste ponto, que a pena de banimento, regulamentada pelo artigo 50 do código, não foi prescrita a crime algum de sua "Parte Especial" $" 381$.

\footnotetext{
380 "Código criminal do Império do Brasil", CLIB, 1830, parte primeira, Rio de Janeiro, Typographia Nacional, 1876, pp. 141-190. O índice do Código Criminal de 1830 encontra-se transcrito no anexo IV desta dissertação.

${ }^{381}$ Para Thomaz Alves Jr. a regulamentação da pena de banimento no Código de 1830 parece ter tido unicamente o papel de adequação da legislação penal ao disposto pela Constituição do Império. $\mathrm{O}$ artigo $7^{\circ}, \S 3^{\circ}$ da Carta Constitucional de 1824 prescrevia, nesse sentido: "Perde os direitos de cidadão brasileiro; o que for banido por Sentença". Thomaz Alves Jr.; Annotações theoricas e praticas ao Código Criminal. Rio de Janeiro: Francisco Luiz Pinto \&
} 
$\mathrm{Na}$ medida em que ignorava qualquer tipo de categorização dos crimes admitidos, estabelecendo, pelo contrário, uma sinonímia explícita entre "crimes" e "delitos" diferentemente do que fizera, por exemplo, Clemente Pereira em seu projeto, ao distinguir "crimes" de "contravenções" -, não havia qualquer distinção classificatória entre as punições admitidas pelo código ${ }^{382}$.

$\mathrm{O}$ artigo 33 do diploma regulava que nenhum crime seria punido com penas não estabelecidas pela lei, nem com maior ou menor "rigor" que o estabelecido nos graus máximo, médio e mínimo dos delitos, excepcionados os casos em que aos juízes se permitisse arbítrio. Desta forma, ainda que submetesse e limitasse o sentenciamento dado pelos juízes à letra do código penal, indicando sua necessária adequação ao princípio da proporcionalidade entre crimes e punições, o artigo deixava aberta a possibilidade do arbítrio judicial nos casos permitidos.

Durante o período de cumprimento das sentenças de galés, prisão simples, prisão com trabalho, degredo e desterro, os condenados (que os tivessem) perdiam seus direitos políticos (art. 53). Nos casos de condenação simultânea por mais de um delito, o código determinava que se impusessem sobre os réus as penas estabelecidas

Ca.; Tomo I; 1864; pp. 121-122 e p. 548. Para Zahidé Machado Neto, a não aplicação da pena de banimento no Código de 1830 foi uma opção deliberada dos deputados nacionais, fundada não apenas na maior eficácia de penas como as de prisão (simples ou com trabalho), "mas também na necessidade de preservar para todos o bem da nacionalidade, não admitindo sequer a possibilidade da mancha da extirpação pura e simples dos cidadãos do organismo nacional que se estava construindo. $\mathrm{O}$ empenho de evitar qualquer aproximação com o conceito de morte civil, que à sua maneira encontrava-se no Livro $\mathrm{V}$ das Ordenações, [...], aquele empenho teria sido poderoso incentivo no evitar a inclusão do banimento." Zahidé Machado Neto. Direito penal e estrutura social: comentário sociológico ao Código Criminal de 1830. São Paulo: Saraiva, EDUSP, 1977; pp. 82-83.

${ }^{382}$ Vale a pena recuperarmos, nesse ponto, os elogios dispensados por Thomaz Alves Jr. à ausência de divisão entre as infrações criminais do Código de 1830. Para o comentarista, como mostramos, na ausência de um critério a priori para o estabelecimento da gravidade dos diferentes delitos, fizeram bem os legisladores brasileiros em não adotar qualquer tipo de classificação no código da nação: "Para nós, pois, a não distinção entre crimes e delitos, a sua sinonímia estabelecida no art. $1^{\circ}$ do mesmo código, não deve ser condenada, porque não julgamos que o sistema contrário seja preferível.” Thomaz Alves Jr. Op. cit.; Tomo I; p. 64. Com esta afirmação, parece-nos, Alves Jr. estabelece um diálogo com os comentários feitos por Victor Foucher ao Código brasileiro de 1830 (em sua tradução do mesmo para o francês) quando, a certa altura, o autor critica a sinonímia adotada pelo diploma entre as categorias de crime e delito: "Cependant, si dès le premier pas nous reconnaissons que le législateur du Brésil est dans la voie de la vérité, nous devons signaler une confusion qui nuit à la régularité de la marche, à la division du travail : les expressions crime et délit sont déclarées synonymes par l'article premier du Code brésilien." Victor Foucher. Code Criminel de L'Empire du Brésil. Paris: A L'Imprimerie Royale: 1834; p. xi. A primeira edição da tradução de Victor Foucher foi impressa em 1831. O exemplar que consultamos encontra-se na Biblioteca do Instituto dos Advogados Brasileiros (RJ), sob a referência 1539/44-6. 
para cada um deles, da maior para a menor, com atenção ao grau de intensidade e não ao tempo de duração (art. 61). Caso estas punições não se pudessem impor uma após a outra, impor-se-ia, no grau máximo, a pena do crime maior (art. 62).

Por fim, estabelecia-se que as penas impostas aos réus não prescreveriam em tempo algum (art. 65) e que o perdão ou minoração das sentenças recebidas - no caso de comutação concedida pelo Poder Moderador - não os eximiriam de satisfazer o mal causado em sua plenitude; assim como o perdão porventura concedido pelos ofendidos não eximiria os réus de crimes públicos ou particulares cuja acusação partisse da Justiça (arts. 66 e 67). Conviviam, portanto, nestes dispositivos, concepções extremamente modernas e outras mais antigas, do direito penal coevo. A absoluta independência reservada à Justiça na abertura de processos públicos não condizia, assim, com a não admissão de prescritibilidade às punições ou a aceitação de intervenção judicial pelo Poder Moderador - a qual, por sua vez, imprimia certa imutabilidade e sacralidade ao código brasileiro, para além de indicar uma quebra na autonomia do Judiciário ${ }^{383}$.

Ao longo de suas três outras partes, o Código de 1830 regulava, respectivamente, seus crimes públicos, particulares e policiais revelando, neste ponto, um verdadeiro refinamento organizacional e conceitual em relação aos projetos de Clemente Pereira e Vasconcelos. É interessante observar, aproveitando o ensejo da tríplice divisão dos crimes no código brasileiro, o modo com que a categorização em delitos públicos, particulares e policiais vinha sendo adotada e interpretada por juristas e legisladores do mundo ocidental de inícios do século XIX. Ao que tudo indica, a divisão entre ofensas públicas e particulares, por exemplo, extensamente adotada na codificação penal do período, regeu-se predominantemente por objetivos de organização e clareza

\footnotetext{
${ }^{383}$ Para os juristas Azambuja e Sousa Pinto, autores de um livro de comentários ao Código Criminal do Império do Brasil impresso, no Rio de Janeiro, em 1832, a manutenção do direito de agraciamento pelo Poder Moderador, na Constituição de 1824 e no Código de 1830, era tão má quanto absurda. Para os autores, soava incoerente justificar-se este direito em nome da pretensa amenização por ele imposta às punições do país. Fundados em Benhtam, Azambuja e Sousa Pinto defendiam que uma das principais funções de um código penal era justamente a renovação e amenização das punições admitidas por uma nação, e não o recurso ao direito de agraciar. Sua principal oposição a este artigo fundava-se, contudo, na concepção de soberania sob monopólio do monarca que trazia consigo e na contradição por ele criada quanto à independência do Poder Judiciário, constitucionalmente estabelecida. José Maria Frederico de Sousa Pinto e Bernardes Augusto Nascentes Azambuja. O Código Criminal Explicado ou Analyse Jurídica e Philosophica da Carta de Lei de 16 de Dezembro de 1830. Rio de Janeiro: $\mathrm{Na}$ Typographia de Gueffier e C $\mathrm{C}^{\mathrm{a}}$, 1832; pp. 322-327.
} 
dos códigos e muito pouco por definições ou diferenciações precisas entre os próprios delitos.

Ao abordarem o assunto, diversos juristas reconheciam, por exemplo, o fato de os crimes denominados "particulares" repercutirem com freqüência sobre a totalidade do corpo social, não se mantendo restritos, como sugerido por seu nome, ao âmbito privado. Independentemente disso, contudo, o processo codificador demandou uma organização axiológica dos diplomas penais que pode ser alcançada, entre outros fatores, a partir da adoção de categorizações e subdivisões internas, que, por vezes, resultaram um tanto artificiais. Tendo de se diferenciar os delitos, portanto, venceu a concepção de que seriam crimes públicos aqueles que perturbassem a segurança geral ou produzissem perigo comum à nação, e particulares aqueles que prejudicassem a um ou mais indivíduos designadamente ${ }^{384}$. Os crimes policiais, por sua vez, também denominados "contravenções" em códigos europeus do período, abarcavam fatos que a lei incriminava pelos perigos e males a que podiam dar ocasião, e não necessariamente pelo mal que em si continham ${ }^{385}$.

$\mathrm{Na}$ "Parte Segunda" do Código brasileiro de 1830 - Dos crimes públicos, composta por 111 artigos -, regulamentava-se, portanto, ações que de alguma forma pudessem afetar a Independência da nação, a tranquilidade pública do Império, a integridade do território nacional, a Constituição política do Brasil, a livre reunião da Assembleia Geral, ou o direito de voto dos cidadãos. Tal seção definia ainda os crimes que poderiam ser cometidos contra os funcionários públicos (resistência, desobediência às autoridades) ou pelos próprios funcionários no exercício de suas funções (peita, concussão, prevaricação, irregularidade de conduta, etc.) e, finalmente, delitos cometidos contra o tesouro ou propriedade nacionais (peculato, moeda falsa, contrabando e danificação do patrimônio público).

\footnotetext{
${ }^{384}$ Nas páginas 48 e 49 de suas Annotações teóricas e práticas Thomaz Alves Jr. discorre brevemente acerca desta classificação e de seus significados para o direito penal coevo, fazendo referência constante à obra de autores como Bentham e J. Tissot. Thomaz Ales Jr. Op. cit.; Tomo I; pp. 48-49. Justificando a presença de semelhante categorização em seu projeto de Código Penal para a Luisiana, Edward Livingston é bastante enfático ao afirmar a impossibilidade de se demarcar precisamente a linha de divisão entre ofensas designadamente públicas e particulares, esclarecendo que: "It ought to be distinctly understood, that the division is entirely for the sake of order and arrangement in framing the code (...)." Edward Livingston. "Introductory Report to the Code of Crimes and Punishments"; pp. 144-145. In: A System of Penal Law for the State of Louisiana. Pittsburgh, John L. Kay \& Brother, 1833; pp. 113-197.

${ }^{385}$ Zahidé Machado Neto. Op. cit.; p. 94.
} 
Já na "Parte Terceira" do código, referente aos crimes particulares (composta por 97 artigos), foram regulamentados desde crimes contra a liberdade individual dos sujeitos (redução de pessoa livre à escravidão, cárcere privado, negação de pedido de habeas corpus), até crimes possivelmente cometidos contra sua vida (homicídio, lesões corporais), honra (estupro, rapto), estado civil (poligamia, adultério, fingimentos) e propriedade (furto, roubo, bancarrota, estelionato e dano).

Por sua vez, a "Parte Quarta" do diploma brasileiro de 1830, composta por 32 artigos e dedicada à regulamentação dos chamados crimes policiais, regulava as ofensas contra a religião, moral e bons costumes, tratava do perigo oferecido pelas sociedades secretas e ajuntamentos ilícitos, abordava a questão da presença de vadios e mendigos no interior do corpo social e proibia o porte de determinadas armas pelos cidadãos; abordando ainda os crimes de uso de nomes e títulos supostos e de uso indevido da imprensa.

A inclusão, ou não, de "crimes policiais" ou "contravenções de polícia" nos códigos criminais do século XIX não foi isenta de discussões que, por sua vez, tocaram fundo nas razões de ser do direito penal. Nesse sentido, um código como o bávaro de 1813, optou pela não inserção de crimes policiais entre seus dispositivos e justificou semelhante medida como parte do reconhecimento e da demarcação de uma diferenciação fundamental e necessária entre a justiça e a polícia. Isto porque, para J. A. Feuerbach, autor do Código da Baviera ${ }^{386}$, os chamados crimes policiais, mesmo

\footnotetext{
${ }^{386}$ Paul Johann Anselm Feuerbach (1775-1833), eminente jurista prussiano da passagem do século XVIII ao XIX, foi o responsável pela reforma do direito penal na Baviera, iniciada em 1806 com a abolição da tortura judicial, e concretizada em 1813, com a aprovação do Código penal de sua autoria. A importância deste diploma no mundo ocidental é bastante significativa, haja vista, em especial, a influência que desempenhou na codificação penal de diversas localidades da futura Alemanha, para além da Suécia e cantões da Suíça. Ver o verebete "FEUERBACH, Paul Johann Anselm", na Encyclopaedia Brittanica. O Código penal da Baviera, composto por 459 artigos, dividia-se em três livros principais, dedicados, respectivamente, (I) ao estabelecimento de disposições gerais referentes aos crimes e delitos, (II) à regulamentação dos crimes previstos pelo código e suas punições e (III) à regulamentação dos delitos e suas punições. Vê-se, assim, que o diploma possuía uma bipartição fundamental entre crimes e delitos - regulados, no interior de seus respectivos livros, na sequência: crimes/delitos privados; crimes/delitos públicos -, justificada, pelo artigo $2^{\circ}$ do código, em função das diferentes penas previstas a cada caso. Assumindo, já em seu artigo $1^{\circ}$, a precedência da lei na definição da conduta delituosa, o Código da Baviera acatava, em seu artigo $4^{\circ}$, as penas de morte, "fers", "maison de force", "maison de travail pénal", "forteresse", "perte des honneurs et la dégradation", "prison ou arrêts dans une forteresse" e penas pecuniárias, especificando-as nos 32 artigos subseqüentes. Em seus capítulos II e III, o código definia os critérios de autoria, co-autoria, cumplicidade e auxílio nos crimes/delitos, abordando ainda a questão do "voluntarismo" necessário à sua perpetração e dos casos de tentativa e negligência. Apesar de acatar, de um modo geral, à
} 
que da alçada do legislador, não feriam direitos fundamentais e imutáveis do Estado ou dos homens, possuindo, portanto, caráter relativo e necessariamente cambiável de acordo com a época e o local. Daí a reivindicação de que constituíssem códigos especiais e separados do penal; atitude que, conforme mencionado, não foi a escolhida pelos legisladores do Brasil ${ }^{387}$.

Nas "Disposições Geraes" do Código de 1830, por fim, citava-se os crimes não incluídos no diploma - tais como os crimes de responsabilidade de Ministros e Conselheiros de Estado (regulados pela lei de 15 de outubro de 1827) e os crimes militares e comerciais -, estabelecia-se as regras para o julgamento de indivíduos sentenciados por delitos cometidos anteriormente à promulgação do código penal, sugeria-se um limite temporal à imputação da pena de galés no Império e definia-se os casos em que continuaria ou passaria a ter lugar a acusação por parte da Justiça brasileira.

Passemos, então, à análise comparativa entre o texto do código de 1830 e os textos dos projetos que o antecederam para, ao longo da mesma, nos aproximarmos ainda mais das especificidades e matrizes deste diploma.

\subsection{Os projetos do Código Criminal e a versão final do diploma brasileiro de 1830}

\section{O Projeto de José Clemente Pereira: aproximações, distanciamentos e a filiação francesa de seu direito penal.}

Entre os anos de 1826 e 1827, como vimos, o deputado brasileiro de origem lusitana José Clemente Pereira entregou à Câmara dos deputados dois importantes documentos referentes ao futuro código criminal do Império do Brasil:

proporcionalidade entre delitos e penas e ao princípio da certeza do direito, o capitulo IV do Código bávaro definia os casos em que, aos juízes, era permitido arbítrio, tratando ainda das circunstâncias agravantes e atenuantes dos crimes e do modo de sua aplicação. O capítulo V, por sua vez, regulamentava os crimes/delitos justificáveis e os casos de inimputabilidade e prescrição dos crimes e suas penas. Nas seções especificamente referente aos crimes/delitos privados, o código regulamentava os casos referentes à vida, honra e propriedade dos indivíduos, seguindo, na sequência, à prescrição dos crimes/delitos passíveis de serem cometidos contra o Estado. Code Penal du Royame de Bavière (1813). Traduit de l'Allemand par Ch. Vatel. Paris, Auguste-Durand, Libraire-Éditeur, 1852.

${ }^{387}$ Para a justificativa completa presente no Código Penal da Baviera de 1813 e para comentários específicos sobre a manutenção de crimes policiais no código brasileiro ver: Thomaz Alves Jr. Op. cit.; Tomo I; pp. 42-45. 
primeiramente, aos 3 de junho de 1826, as chamadas "Bases" ao Código Criminal, compostas por princípios gerais que, em sua opinião, deveriam pautar o futuro diploma nacional e, num segundo momento, aos 16 de maio de 1827 , um projeto completo de código penal para o Império, composto por 33 Títulos e 278 artigos.

Para além do desconhecimento a que esteve relegado, até o momento, o segundo projeto elaborado por Clemente Pereira, uma leitura enviesada dos Anais do Parlamento brasileiro - especialmente dos pareceres emitidos pelas comissões parlamentares de 1827 e 1829 - vem reforçando há anos a ideia de que, entregues (exclusivamente) à Câmara as "Bases" de 1826 e o projeto completo de Bernardo Pereira de Vasconcelos, o segundo destes documentos teria sido o único efetivamente estudado e adotado no momento de elaboração do código penal imperial ${ }^{388}$.

Se os pareceres da Comissão especial do código criminal (de 1827) e da comissão mista (de 1829) confirmaram de fato, como vimos, sua preferência pelo projeto de Bernardo Pereira de Vasconcelos, o parecer emitido pela primeira destas comissões, aos 14 de agosto de 1827 fez referência explícita ao recebimento e análise de dois projetos de código, indicando ainda que o projeto de Clemente Pereira não era aquele entregue em 1826, mas sim o projeto completo de 1827. É digna de nota, nesse sentido, a afirmação da comissão de que após meditada leitura, seus membros haviam cotejado "o methodo por um e outro [projetos] adoptado na classificação dos delictos e distribuição das penas”. Se relembrarmos, neste ponto, da composição específica das "Bases", lembraremos também da ausência, neste documento, de qualquer classificação precisa dos crimes e suas penas tal qual citado pelo parecer.

Haja vista, portanto, a existência de um projeto completo de Clemente Pereira e sua avaliação pelas comissões parlamentares de trabalho nacionais, julgamos imprescindível uma análise detida de suas possíveis influências sobre a composição final do Código de 1830, ainda que o seu conteúdo não tenha sido necessariamente o preferido pelos deputados brasileiros.

\footnotetext{
${ }^{388}$ Exceção seja feita, neste ponto, aos comentários teóricos e práticos do jurista Thomaz Alves Jr. ao Código Criminal do Império do Brasil, que não apenas citam o projeto completo de José Clemente Pereira, revelando pleno conhecimento do conteúdo desta fonte, como preocupam-se em pontuar dispositivos e prescrições específicas do Código de 1830 possivelmente advindos daquele projeto. Vale ressaltar aqui que a leitura dos comentário de Alves Jr. só foi por nós empreendida após a descoberta, no arquivo da Biblioteca Nacional, do Projeto de Clemente Pereira, não se devendo, portanto, a este jurista, a detecção de semelhante documento. Thomaz Alves Jr. Annotações theoricas e praticas ao Código Criminal. Rio de Janeiro: Francisco Luiz Pinto \& Ca.; Tomos I (1864) e II (1870).
} 
As primeiras impressões advindas de semelhante análise, contudo, centradas numa comparação formal entre a organização assumida pelo projeto de Clemente Pereira e o Código de 1830, não foram propriamente encorajadoras. Como vimos no primeiro capítulo, o projeto do deputado lusitano, diferentemente do diploma de 1830, compunha-se de 33 títulos subseqüentes, sem a adoção de uma divisão explícita (mas sim inferida) entre uma parte geral e outra especial e sem um ordenamento preciso na regulamentação dos crimes e contravenções específicos e suas penas.

No que diz respeito à pretensa "Parte Geral" deste diploma, composta por seus dois títulos iniciais, Clemente Pereira limitou-a, diferentemente do Código de 1830 e do projeto de Vasconcelos, ao estabelecimento das definições de crime e criminoso e a prescrições gerais relativas às punições admitidas. Nesse sentido, enquanto esta seção de seu diploma possuía 45 artigos, as "Partes Gerais" do código de 1830 e do projeto de Vasconcelos possuíam, respectivamente, 67 e 109 artigos, alguns dos quais compostos por até uma dezena de parágrafos.

A comparação empreendida entre as definições de praxe presentes nas "regras gerais" destes diplomas, contudo, revelou a presença de um elemento comum ao Código de 1830 e ao projeto de Clemente Pereira que nos pareceu interessante e indicativo da possibilidade de utilização efetiva deste projeto pelos deputados mais diretamente envolvidos na elaboração do diploma penal imperial.

Atentemos, assim, à definição de crime presente neste projeto (anteriormente manifesta também nas "Bases" de 1826) e à presença, aí, de um elemento que, por pequeno que fosse, possuía considerável relevância à época de configuração do direito penal ocidental. Tratava-se do voluntarismo necessariamente envolvido nas ações ou omissões que estes documentos compreendiam enquanto crime. De acordo com o projeto de Clemente Pereira, portanto, era crime: “Art. $1^{\circ}$. Toda a infracção voluntaria das Leis criminais" e "Art. $2^{\circ}$. A ommissão voluntaria de hum facto mandado praticar por Lei”. Enquanto, pelo diploma penal de 1830 julgar-se-ia crime ou delito "Toda a acção, ou omissão voluntaria contraria ás Leis penaes.".

A questão do "voluntarismo" necessário à tipificação de um crime, especialmente no que dizia respeito às chamadas omissões delituosas, não se fazia presente, por sua vez, no projeto de Vasconcelos, constituindo um dos únicos, senão o único elemento das definições gerais do Código de 1830 possivelmente advindo do projeto de Clemente Pereira. A importância desta especificação pode ser creditada, entre outras, à ideia de que a efetivação de um crime não poderia advir de "ignorância", erro, ou 
mera "negligência" - como sugerido pela palavra omissão -, mas apenas de uma “inação" propriamente intencional ${ }^{389}$.

De acordo com António Manuel Hespanha, se um dos axiomas do direito penal iluminista moderno era o de que o delito pressupunha intenção e voluntarismo, tal se relacionava ao fato de a ameaça penal funcionar apenas em relação a indivíduos capazes de calcular racionalmente seu delitos e as conseqüências dele advindas. Daí que uma das etapas obrigatórias à criminalização de um indivíduo, para além da definição clara dos bens jurídicos a proteger e das penas que os tutelavam, era a fixação das condições psicológicas que se deveriam verificar no agente do crime para que este pudesse ser punido. Tratava-se, portanto, de uma "teoria do agente", voltada a determinar a sua "culpa" ou intenção - necessariamente pressupostas em todos os crimes -, tópico marcante da doutrina penal na passagem do século XVIII ao XIX ${ }^{390}$.

Se, contudo, a qualificação do "voluntarismo" e da "omissão voluntária" dentre os crimes do Código de 1830 adveio de fato da produção de José Clemente Pereira é coisa que não podemos comprovar ${ }^{391}$, mas, haja vista sua presença neste projeto $\mathrm{e}$ ausência no texto de Vasconcelos, consideramos importante ao menos a menção à possibilidade de ter sido esta a fonte de sua inclusão no código brasileiro.

Para além desta possível inspiração, nenhum outro aspecto da "Parte Geral" do Código de 1830, ao que tudo indica, teve origem no projeto de Clemente Pereira. Ainda que parte das punições previstas pelo deputado lusitano se aproximassem daquelas do texto de 1830, tratava-se, nestes casos, de penas bastante comuns à época, presentes na grande maioria dos códigos ocidentais por nós analisados e sem qualquer detalhe manifesto que indicasse a consulta ou inspiração direta naquele projeto ${ }^{392}$.

${ }^{389}$ Thomaz Alves Jr. Op. cit.; Tomo I; pp. 52-54.

${ }^{390}$ António Manuel Hespanha: "A evolução da doutrina e do ensino do direito penal em Portugal (1800-1910)"; In: Quaderni Fiorentini, 2007; pp. 442-444.

${ }^{391}$ A especificação de "voluntarismo" na caracterização dos crimes encontrava-se presente, para além do projeto de Clemente Pereira, no Código Penal espanhol de 1822 e nos projetos de Código criminal de Pascoal de Melo Freire (para Portugal, datado de 1786) e de Edward Livingston (elaborado para o estado da Luisiana, finalizado em 1824), documentos que, como veremos, influenciaram significativamente a composição do Código Criminal do Império do Brasil. Tal especificação pode ser encontrada ainda nos códigos austríacos de 1787 e 1803, na Algemeines Landrecht prussiana, e no código bávaro de 1813.

${ }^{392}$ Curioso observar, neste ponto, que dentre as punições admitidas em 1830, uma talvez se deva às "Bases" elaboradas por Clemente Pereira em 1826. Trata-se da pena de degredo que, presente nas "Bases", seria excluída pelo próprio Clemente Pereira em seu projeto de 1827, aparecendo, contudo, no texto final de 1830. A definição de degredo presente no texto de 1830 difere, contudo, daquela formulada nas "Bases", deixando em aberto se teria sido esta, ou não, a fonte indubitável de semelhante inclusão. Para além das "Bases" de 1826, a pena de 
Ao longo das Partes Especiais do Código de 1830 e do projeto aqui analisado fomos surpreendidos, por sua vez, pelas semelhanças existentes em quatro pontos bastante específicos. Trata-se dos artigos 100, 101, 102 e 301, de 1830, e de seus artigos congêneres no projeto de Clemente Pereira, de números 60, 58, 59 e 236. Para além destes exemplos, também as proximidades existentes nas definições do crime de conspiração em 1827 e 1830 nos parecem dignas de investigação, a ser apresentada amiúde no subcapítulo 3.3 .

Nos três primeiros casos citados (arts. 100, 101 e 102 de 1830 e arts. 60, 58 e 59 de 1827), referentes a crimes que poderíamos definir como "eleitorais" - localizados, no projeto de Clemente Pereira, no título dos "crimes contra as garantias políticas da Constituição do Império" e, no Código de 1830, no título referente aos "crimes contra o livre exercício dos direitos políticos dos cidadãos" - as aproximações existentes entre os documentos são bastante significativas.

Atentemos especificamente às similitudes existentes entre o artigo 58 do projeto de 1827 e o artigo 101 do Código de 1830. Ainda que os outros artigos citados também guardem proximidades importantes entre si, este caso nos parece revelar com maior verossimilhança a possibilidade aventada acima. Vejamos assim o que diziam, respectivamente, estes artigos:

Art. 58. Se alguem solicitar, para que as Eleições estabelecidas na Constituição Politica do Imperio recaião, ou deixam de recair em determinadas pessoas, ou para o mesmo fim comprar, ou vender votos, será punido com a pena de multa.

Art. 101. Solicitar, usando de promessas de recompensa, ou de ameaças de algum mal, para que as Eleições para Senadores, Deputados, Eleitores, Membros dos Conselhos Geraes, ou das Camaras Municipaes, Juizes de Paz, e quaesquer outros empregados electivos, recaiam, ou deixem de recahir em determinadas pessoas, ou para esse fim comprar ou vender votos.

As semelhanças textuais existentes entre estes artigos ultrapassam, em nossa opinião, a possível dedução de mera coincidência. Haja vista que o projeto de Bernardo Pereira de Vasconcelos não regulou, em momento algum de seu texto, crimes de semelhante natureza, não é possível desconsiderar como fonte de inspiração

degredo podia ser encontrada, àquela altura, no Projeto de Código Criminal de Pascoal de Melo Freire - mais especificamente no $\S 6^{\circ}$ de seu Titulo IV que, em todo caso, não a definia e no Livro V das Ordenações Filipinas - definida entre os parágrafos 140 e 143 . Vale a pena ressaltar aqui que também nestes dois últimos casos os artigos e parágrafos referentes a semelhante sentença são, em muito, distintos do artigo 51 do Código de 1830. 
- se não exclusiva, central - dos deputados envolvidos na elaboração do Código de 1830, o projeto completo de Clemente Pereira.

O caso dos artigos 301 do Código de 1830 e 236 do projeto de Clemente Pereira, referentes ao crime de uso de nomes, títulos ou condecorações falsas, remete-nos ao mesmo tipo de questionamento realizado acima. Ou seja, tanto sua regulamentação exclusiva nos diplomas de Clemente Pereira e de 1830 (e ausência, portanto, no projeto de Vasconcelos), quanto suas inegáveis proximidades textuais e de formulação, apontam para a inspiração exercida pela produção de Clemente Pereira sobre os deputados responsáveis, entre 1829 e 1830, pela implementação das últimas alterações no texto do futuro código criminal. Comparemos, assim, seu conteúdo:

Art. 236. Se a mudança do nome, ou sobrenome, ou o uso de titulos, uniformes, distinctivos, ou condecorações indevidas não tiver outro fim, que o de parecer o que não he, ou ostentar mais do que he, será o réo que commetter este crime punido com multa.

Art. 301. Usar de nome supposto, ou mudado, ou de algum titulo, distinctivo, ou condecoração, que não tenha. Pena - de prisão por dez a sessenta dias, e multa correspondente á metade do tempo.

Vê-se assim que, por reduzidas que fossem, certas semelhanças não permitem que ignoremos o documento elaborado e apresentado à deputação brasileira pelo deputado de origem lusitana. Destaque seja dado, contudo, ao fato de a comparação e busca de identidades entre o diploma de Clemente Pereira e o Código de 1830 ter nos encaminhado prioritariamente, para o destaque das diferenças existentes entre eles. Isto porque foi a partir desta comparação, e da detecção consequencial de uma série de particularidades inerentes ao diploma de Clemente Pereira, que pudemos aventar hipóteses para o curioso desinteresse despertado por seu projeto nos deputados brasileiros mais diretamente envolvidos na elaboração do código penal imperial desinteresse que, entre outros fatores, legou este projeto ao esquecimento.

Nesse sentido, para além da presença de crimes inexistentes nos diplomas de Vasconcelos e de 1830 - como o crime de atentado à vida do imperador (artigo 98, $\S 2^{\circ}$ ), os crimes de desafio (arts. 132 a 138) e assuada (arts. 141 e 142), ou os crimes contra o comércio (arts. 229 a 234) -, e para além ainda da adoção de definições bastante peculiares aos crimes obrigatoriamente regulados pelos códigos do período como os de homicídio (arts. 197 a 206) e ferimentos (arts. 207 a 216) -, deve-se destacar que, diferentemente da grande maioria dos diplomas ocidentais, a "Parte Especial" do projeto de Clemente Pereira iniciava-se com a prescrição de crimes 
contra a religião do Império (divididos em seis artigos referentes, entre outros, a casos de blasfêmia, recusa aos dogmas da religião católica, ridicularização de algum santo ou perturbação de cultos), seguidos pela regulamentação das injúrias possivelmente dirigidas contra o imperador e a família real (ofendendo sua pessoa, desprezando sua imagem ou insultando os membros de sua família).

Para além dos casos citados, as maiores diferenças identificadas entre o projeto de Clemente Pereira, o projeto de Vasconcelos e o Código de 1830 localizavam-se, contudo, na ampla utilização, pelo primeiro destes documentos, de disposições criminais retiradas do Código penal francês de 1810 .

Tinha-se, assim, no projeto de Clemente Pereira, uma divisão entre "crimes" e "contravenções" claramente influenciada pelo diploma francês. No que dizia respeito, por sua vez, à regulamentação das punições, tinha-se neste projeto não apenas uma divisão entre penas correcionais e criminais - subdivididas, por sua vez, em penas "aflitivas e infamantes" e penas exclusivamente "aflitivas" - semelhante à presente no referido código de $1810^{393}$, mas ainda a definição de penas específicas, como a de trabalhos públicos perpétuos e temporários (travaux forcés à perpétuité e travaux forcés à temps) e a de desnaturalização, inegavelmente inspiradas naquele diploma. Contribuem ainda para a aproximação do projeto de Clemente Pereira ao código francês, e seu conseqüente afastamento do diploma brasileiro: a prescrição de um crime especificamente dirigido contra a vida do Imperador (art. 98, $\S 3^{\circ}$ ) regulamentação que, como veremos à frente, inexistia tanto no projeto de Vasconcelos, quanto no texto final de 1830 - e o estabelecimento de punições muito duras ao crime de moedas falsas (art.159) - punido de forma mais branda no projeto de Vasconcelos e fragilmente penalizado, poder-se-ia dizer, no Código de 1830.

Diferentemente do que se poderia imaginar, portanto, as semelhanças entre o projeto de código criminal elaborado por José Clemente Pereira e o código

${ }^{393}$ Inspirado na tríplice divisão adotada pelo código penal francês entre as categorias de crime, delito e contravenção, o projeto de Clemente Pereira pautou-se por uma divisão binária entre crimes e contravenções e pela conseqüente classificação de suas penas em diferentes conjuntos $-\mathrm{o}$ das penas criminais, divididas entre punições aflitivas e infamantes e punições apenas aflitivas, e o das penas correcionais (aplicadas às contravenções). Apesar de frequentemente presente nas codificações penais do período, a adoção deste tipo de categorização foi bastante controversa à época, gerando um diálogo interessante entre juristas de diferentes matizes, exposto por Thomaz Alves Jr. em seus comentários ao Código Criminal do Império do Brasil. Op. cit.; Tomo I; pp. 59-64 e 79-81. Como vimos acima e voltaremos a analisar à frente, o Código brasileiro de 1830 assumiria a ideia de sinonímia entre crimes e delitos e, consequentemente, não adotaria qualquer tipo de divisão para suas punições. O mesmo já havia sido feito por Bernardo Pereira de Vasconcelos em seu projeto. 
napoleônico de 1810, ao invés de confirmarem a tese amplamente difundida de que o direito penal francês se configurou, àquela altura, numa das principais fontes de inspiração do direito brasileiro, podem, pelo contrário, nos auxiliar a compreender os motivos da rejeição sofrida pelo projeto deste deputado - e por vários de seus dispositivos específicos - no momento de formulação do direito penal positivado do Império do Brasil.

Acontece que havia não poucos anos (ao menos desde a Constituinte de 1823) o modelo legislativo francês - especialmente aquele organizado sob os auspícios de Napoleão Bonaparte - vinha sendo fortemente criticado e depreciado pelos políticos do Brasil ${ }^{394}$. No caso específico dos debates parlamentares travados em torno à elaboração do código criminal (analisados no capítulo anterior), tal desqualificação pode ser notada na fala de ao menos dois deputados - Paula Souza (em 11 de setembro de 1830$)^{395}$ e Ribeiro de Andrada (em 15 de setembro de 1830$)^{396}$-, com críticas abertas ao código penal de 1810 e ao governo de Napoleão.

Se, no que diz respeito à influência desempenhada pelo modelo napoleônico sobre Clemente Pereira, podemos, talvez, relacioná-la a seu conservadorismo político e à sua admiração por um modelo de governo forte e autoritário, haja vista sua atuação como Ministro do Império e sua proximidade cada vez maior com o imperador. Na análise específica da rejeição sofrida por seu projeto no Parlamento nacional não podemos negligenciar, para além da desconfiança gerada entre os deputados

${ }^{394}$ Nos debates da Assembleia Constituinte de 1823, comentando a adoção, ou não, do sistema de jurados nas causas cíveis, o padre José Martiniano de Alencar (em discurso pronunciado aos 24 de outubro de 1823) tece uma crítica direta ao modelo de júri escolhido pela França revolucionária ao afirmar: "Todas as Nações que tem tido Jurados o tiveram no Crime e no Civel; e só os Franceses na sua Constituição de 1789 he que tiveram a celebre lembrança de os admitir só no crime, e por isso mesmo jamais tem sido possível aos Francezes serem felizes com os seos Jurados". Acessível em: http://imagem.camara.gov.br/constituinte_principal.asp; p. 142.

${ }^{395}$ Nas palavras de Paula Souza: "Não me recordo de codigo algum do universo feito por assembléas legislativas. Só se póderá apontar o codigo francez; mas todos sabem que elle foi feito pelo conselho de estado de Napoleão ou pelo ministro mais influente e que mesmo é attribuido em parte a Cambaceres.” APB-CD; sessão de 11 de setembro de 1830; p. 490.

${ }^{396}$ De acordo com Ribeiro de Andrada: "[...] os philantropos francezes, como por exemplo Gregoire, pedirão na convenção, que se riscasse a pena de morte: se ella não foi revogada deve attribuir-se ao estado revolucionario de então; se o codigo penal francez ainda a contém, deve-se esta desgraça ao grande homem que tinha o genio e o instincto do despotismo, devese à constituição que roubou aos deputados a proposição directa das leis; e quando a tenha indirecta, a um governo inimigo das novas instituições e ao estado ainda vacillante e revolucionado daquella nação." APB-CD; sessão de 15 de setembro de 1830; p. 515. 
brasileiros pelo modelo de governo adotado na França pós-revolucionária, a fragilidade crescente da figura de Clemente Pereira na Câmara baixa.

Destaque seja dado, nesse sentido, à desconfiança que ele despertara, entre seus pares, por conta de sua proximidade e "intimidade" crescentes com o monarca, e às críticas efusivas que sua atuação como Ministro do Império e Ministro da Guerra, entre 1828 e 1829, gerara entre os representantes do país. Reeleito à Câmara baixa nas eleições de 1828/1829, Clemente Pereira teve sua legitimidade ao cargo questionada pelo bloco liberal da Câmara nos primeiros meses de trabalho da segunda legislatura, quando parte dos deputados tentou efetivamente impedi-lo de assumir a vaga, acusando-o de ser suspeito à causa do Brasil e de professar o absolutismo, criticandoo abertamente ainda por sua atuação como Ministro do Império ${ }^{397}$.

Se somarmos à conjuntura complicada vivida pelo personagem, o fato de que sua explícita inspiração na legislação penal napoleônica de modo algum passaria despercebida pela deputação nacional, é possível agregar uma série de elementos úteis à compreensão da recusa sofrida por sua produção na Câmara dos deputados ${ }^{398}$.

Talvez possamos afirmar, nesse sentido, que contrariamente ao que se tem dito, os deputados brasileiros esforçaram-se, àquela altura, por fugir - na medida do possível -, dos institutos especificamente adotados pelo codificacionismo penal francês, não tendo hesitado, ao que tudo indica, em preterir o projeto de José Clemente Pereira em função de sua explícita filiação àquela corrente do direito penal.

\footnotetext{
${ }^{397}$ Os detalhes da acusação dirigida a Clemente Pereira e o desfecho desta tentativa de afastamento do deputado da Câmara baixa são muito bem analisados no primeiro capítulo da dissertação de mestrado de Mariana Macário. Mariana Pedron Macário. José Clemente Pereira e o debate jurídico do Império: 1830-1850. Dissertação de Mestrado. Faculdade de Direito/USP; 2011; pp. 35-45.

${ }^{398}$ Acrescente-se ainda a esta análise a leitura empreendida por Roderick J. Barman acerca do apreço então nutrido, e publicizado, por d. Pedro I, em relação ao modelo de governo e de poder exercido por Napoleão Bonaparte na França. Haja vista as inúmeras críticas levantadas pela deputação brasileira ao governo e ao modelo legislativo francês, e a rejeição cada vez maior por ela dispensada ao imperador bragantino, torna-se cada vez mais compreensível o afastamento então empreendido pelos deputados brasileiros do modelo legislativo apresentado e defendido por Clemente Pereira. Roderick J. Barman. Op. cit.. Especialmente o Cap. V: "Competing Conceptions of Nationhood"; pp. 130-159.
} 


\section{O Projeto de Bernardo Pereira de Vasconcelos e sua ascendência sobre o Código de 1830.}

Se, por um lado, a elaboração de um projeto completo por Clemente Pereira e a menção a ele feita pela Comissão especial do código criminal de 1827, confirmam a disponibilidade deste documento aos representantes do Parlamento brasileiro nos primeiros atos da elaboração do futuro código penal do Império, por outro, a pequena representatividade de suas formulações na versão aprovada do código indica não ter sido efetivamente este o diploma a dar os principais subsídios às comissões mista de 1829 e ad hoc de 1830, responsáveis pela composição da base essencial do futuro código penal.

A análise do projeto entregue à Câmara, também em 1827, pelo deputado Bernardo Pereira de Vasconcelos, indicou-nos, por sua vez, a extensão com que este foi utilizado na elaboração do Código de 1830. Acompanhando, assim, um juízo comum da historiografia, pudemos detectar diversas proximidades existentes entre dispositivos presentes neste projeto e no código penal do Império. Na contra-mão desta mesma historiografia - excessivamente preocupada em enfatizar a ascendência do projeto de Vasconcelos sobre o Código de 1830 -, nossas conclusões nos desviaram da ênfase nas continuidades existentes entre estes documentos. Com vistas a esclarecer este desacordo, o item que agora se inicia pretende explicitar as diferenças fundamentais existentes entre o projeto elaborado pelo deputado mineiro e o código penal imperial, destacando o sentido mais profundo das alterações aí empreendidas.

Atentemos, de saída, à quase inexistência de estudos preocupados em analisar o conteúdo do projeto de código criminal apresentado à Câmara dos deputados, em 4 de maio de 1827, por Bernardo Pereira de Vasconcelos. Apesar de comumente reconhecido como a principal fonte penal do Código de 1830, este projeto não foi analisado em pormenores por praticamente nenhum dos trabalhos dedicados ao tema $^{399}$. Menções ao seu conteúdo, quando presentes, mantiveram-se subsidiárias à análise do Código de 1830, restringindo-se a comparações superficiais entre partes de

\footnotetext{
${ }^{399}$ À exceção do artigo de Monica Duarte Dantas e de parte da produção dos comentadores do Código Criminal do Império do Brasil, especialmente aquela escrita no próprio século XIX, como a de Thomaz Alves Junior. Bernardino Bravo Lira (como veremos à frente) diz tratar do Projeto de Vasconcelos quando, na verdade, faz referência ao texto final de 1830 (considera os dois um mesmo texto, incorrendo em diversos equívocos analíticos).
} 
seus textos. Ao analisarem, por exemplo, o aparecimento da pena de morte em 1830, diversos estudos citaram por quantas vezes esta pena teria aparecido anteriormente no projeto de Vasconcelos, sem que fossem examinados, ou minimamente questionados, contudo, os casos e contextos específicos em que o fazia ${ }^{400}$.

Um estudo atento do conteúdo deste projeto revelou-nos, assim, não apenas suas múltiplas diferenças em relação ao código finalmente aprovado, mas também, e talvez principalmente, o fato de as alterações empreendidas sobre seu texto (especialmente entre 1829 e 1830) relacionarem-se diretamente a uma proposta política articulada no interior do Parlamento brasileiro - parcialmente efetivada com a aprovação do código penal - , em muito distinta do projeto preconizado por Vasconcelos.

Já pudemos observar anteriormente a organização geral adotada pelo projeto de Bernardo Pereira de Vasconcelos e pelo Código de $1830^{401}$. Atentando novamente à disposição geral das Partes, Títulos e Capítulos em que cada um deles se dividia, são facilmente reconhecíveis as alterações empreendidas, entre um documento e outro, em nível organizacional. À exceção da "Parte Geral" destes diplomas, cujos artigos estão dispostos de forma bastante semelhante, o restante dos dois textos foi pensado numa ordem completamente distinta. Haja vista a importância da distribuição das matérias em um código criminal, este não nos parece um detalhe secundário. Aliás, o aspecto formal de um código constitui um de seus principais elementos, tanto assim que, de acordo com Adriano Cavanna, não importa se o conteúdo normativo de um código é novo ou velho, o importante é que, dentro da forma código, inclusive as velhas normas adquirem novas funcionalidades ${ }^{402}$.

Expandindo nossa comparação à totalidade das prescrições de cada um dos documentos, destaquemos que o Código de 1830 possuía cerca de 88 artigos absolutamente novos em relação ao projeto de Vasconcelos, que teve ainda 59 de seus artigos excluídos entre os anos de 1827 e 1830. Idênticos em um e outro documento, pudemos identificar apenas 15 artigos.

Os números expostos acima advieram de um trabalho comparativo em que, tomando como referência principal o Código Criminal de 1830, cotejamos, um a um,

\footnotetext{
${ }^{400}$ Um exemplo deste tipo de citação pode ser encontrado em: João Luiz Ribeiro. No meio das galinhas as baratas não têm razão: a lei de 10 de junho de 1835: os escravos e a pena de morte no Império do Brasil: 1822-1889. Rio de Janeiro: Renovar, 2005; especialmente p. 21 e p. 27.

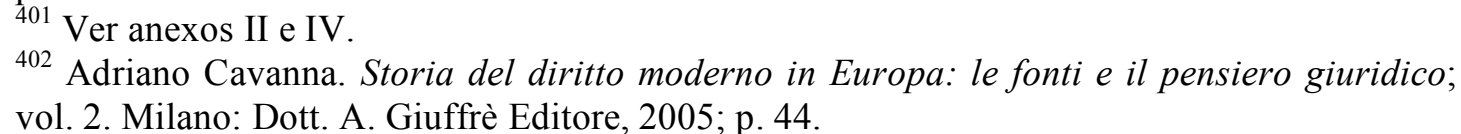
vol. 2. Milano: Dott. A. Giuffrè Editore, 2005; p. 44.
} 
seus 313 artigos com os 334 artigos que compunham o projeto de Vasconcelos. Por meio deste trabalho procuramos detectar tanto os artigos do projeto mantidos exatamente iguais no Código de 1830, quanto aqueles excluídos ou introduzidos entre um momento e outro da elaboração deste diploma. Desde o início da comparação, contudo, foi possível perceber que a grande maioria dos artigos do projeto havia sido modificada ao longo do processo parlamentar, ainda que, em alguns casos, as mudanças tivessem sido de muito pequeno impacto. Demo-nos conta, assim, de que este trabalho não nos forneceria apenas duas categorias de artigos: "iguais aos do projeto" e "diferentes do projeto", mas antes uma série de artigos mais ou menos parecidos aos daquele texto, para além dos conjuntos de artigos inéditos ou excluídos entre um momento e outro. Daí as dificuldades encontradas na sistematização dos dados recolhidos.

De forma geral, podemos afirmar que, para além dos 15 artigos idênticos aos de Vasconcelos encontrados no texto de 1830 (representando cerca de $4,8 \%$ do total de dispositivos do código imperial), 122 outros artigos deste código (cerca de 39\% de seu conteúdo, portanto) podem ser considerados bastante próximos aos daquele projeto, seja em suas definições, seja nas punições estabelecidas. Cientes, assim, de que menos da metade do documento em questão (43,8\%) possui semelhanças significativas com o diploma elaborado pelo deputado mineiro, não podemos deixar de frisar as diferenças existentes entre o restante dos dois textos.

Sendo assim, dentre os mesmos 313 artigos do texto final de 1830 , cerca de $28 \%$ são inéditos e outros $28 \%$ são bastante diferentes das formulações do projeto do deputado mineiro; totalizando uma média de 56\% de artigos (cerca de 176 artigos em números absolutos) que poderíamos classificar como profundamente modificados em relação ao diploma de Vasconcelos ${ }^{403}$.

\footnotetext{
${ }^{403} \mathrm{~A}$ contagem específica de artigos aqui explicitada, bem como sua transformação em porcentagens (calculadas sobre o total de artigos do diploma de 1830) não é, como se pode notar, absolutamente exata, e isto porque não se mostra possível elaborar categorias exatas para a avaliação comparativa dos dispositivos presentes nos documentos em questão. Para além disso, vale salientar que, em vários momentos, ao proceder à comparação do conteúdo de vários parágrafos de um mesmo artigo, o que se percebeu, eventualmente, foi a semelhança de tal ou qual parágrafo, diferenças significativas no parágrafo seguinte, e assim por diante; o que, por si, já torna necessário, na contabilização geral, que se trabalhe por aproximações (considerando-se que eventuais perdas derivadas de tais aproximações, frente, contudo, ao ganho de uma análise comparativa - e de uma melhor compreensão por meio de porcentagens -, mostraram-se um mal menor).
} 
Mesmo no caso das alterações aparentemente menos importantes (referimo-nos aos 122 artigos mencionados anteriormente), ainda assim consideramos ser nossa tarefa refletir e buscar os significados e motivos que teriam levado uma dezena (ou mais) de deputados a dedicar tempo e inteligência à reforma de pretensos detalhes do diploma imperial ${ }^{404}$.

Iniciemos nossa análise pelo exame das alterações empreendidas sobre a "Parte Geral" dos diplomas em questão. Composta por um total de 109 artigos no projeto de Vasconcelos, a "Parte Geral" do Código brasileiro fixou-se em apenas 67 artigos em 1830, sendo que, destes, 29 sofreram modificações que consideramos bastante significativas $^{405}$ e 13 (somados a parágrafos esparsos de outros artigos) ${ }^{406}$ não constavam do projeto inicial. Além disso, atentemos ao fato de que dos 59 artigos do projeto de Vasconcelos eliminados na elaboração do texto de 1830,31 pertenciam à sua Parte Geral ${ }^{407}$. Trata-se, portanto, da parte do projeto que teve o maior número de artigos suprimidos entre 1827 e 1830.

Um primeiro conjunto de alterações realizadas sobre esta seção do projeto pode ser identificado a partir do maior detalhamento imposto a parte de suas definições pontuais, válidas para toda a extensão do código. Dentre elas, destaquemos aquelas referentes aos critérios de autoria e cumplicidade nos crimes, ao estabelecimento

\footnotetext{
${ }^{404}$ Destaque seja dado, contudo, às dificuldades envolvidas na compilação e organização dos dados expostos acima. Comparar o conteúdo dos dois diplomas, para além de tarefa difícil em si mesma, envolve a tomada de posições nem sempre neutras da parte do pesquisador; para as quais gostaríamos de chamar brevemente a atenção do leitor. Há, assim, artigos do Código de 1830 cujo delito vem identicamente definido em relação ao projeto de Vasconcelos, mas cuja punição encontra-se (mais, ou menos intensamente) modificada. Num caso como este, para além das inegáveis similitudes existentes entre os dois diplomas reconhece-se também a presença de uma alteração de importância significativa, ficando a critério do pesquisador, em última instância, a colocação do acento sobre o caráter de continuidade ou ruptura existente entre os documentos.

${ }^{405}$ Artigos 1, 3, 5, 6, 26, 28, 31, 32, 33, 34, 37, 40, 43, 44, 45, 46, 49, 50, 52, 53, 54, 55, 56, $57,60,61,62,65$, e 66 .

${ }^{406}$ Os treze artigos inéditos do diploma de 1830 são os seguinte: artigos 7, 8, 9, 11, 13, 35, 47, $48,51,58,59,64$ e 67 . Já os parágrafos esparsos de outros artigos a que fizemos referência por seu ineditismo são: $\S 4^{\circ}$ do artigo $14 ; \S \S 1,2,3,9,13$ e 14 do artigo 16 ; e $\S \S 2,4,5$ e 6 do artigo 18.

${ }^{407}$ A conta que se deve fazer, entretanto, não é a de 109 artigos menos 31, pois o resultado não seria o de 67 artigos (número de que se compõe a Parte Geral do Código de 1830), mas sim o de 78. Acontece que, para além dos artigos que "desapareceram" entre um texto e outro (Artigos 5, 10, 11, 12, 25, 26, 27, 29, 37, 39, 47, 48, 49, 50, 56, 62, 64, 69, 75, 76, 85, 86, 87, $88,89,94,95,96,98,103,104,11,131,159,163,172,182,183,184,187,188,196,204$, 205, 215, 218, 219, 236, 238, 275, 276, 277, 278, 279, 280, 286, 291, 292 e 295), vários artigos do Projeto de Vasconcelos foram reunidos em um só em 1830, o que reduziu ainda mais o total de artigos de sua Parte Geral.
} 
preciso de regras para a responsabilização penal e satisfação dos males cometidos, à inclusão de novas circunstâncias agravantes e atenuantes dos delitos, entre outras mudanças de caráter tópico, mas não por isso menos importantes.

Já um segundo conjunto de modificações empreendidas sobre esta mesma "Parte Geral", ao qual nos dedicaremos com maior cuidado na sequência, concentrou-se sobre a reformulação do conteúdo propriamente penal do futuro código. Este conjunto de alterações cumpriu, assim, o papel de introduzir uma nova "concepção penal" no Código imperial, compreendendo-se por "concepção penal" não apenas o conjunto específico das punições admitidas pelo diploma (morte, prisão, multa, açoites, etc.) e os detalhes inerentes à sua execução (cumprimento em cadeias, Casas de Correção ou obras públicas, por determinados anos e meses, com ou sem a manutenção de direitos políticos, etc.), mas principalmente o modo com que a prescrição destas punições, e não de outras, e o desenho preciso de sua aplicação - ou não aplicação - a crimes específicos do código, comunicaram as ideias, modelos e teorias penais eleitas pelos legisladores brasileiros no momento de composição do diploma penal imperial.

Primeiramente vale destacar a quase supressão, entre 1827 e 1830, da palavra “castigo", que, no Projeto de Vasconcelos (mais especificamente no Capítulo V do Titulo I), aparecia como sinônimo de pena: “Cap. V: Das penas ou castigos (palavras synonimas)"; sentido que desaparecerá por completo em $1830^{408}$.

No que diz respeito às penas especificamente prescritas por cada diploma, vale a pena atentar para a seguinte tabela de punições:

Tabela I: Aparecimento de cada punição no Projeto de Bernardo Pereira de Vasconcelos e no Código Criminal de 1830.

\begin{tabular}{|l|c|c|}
\hline PENAS PREVISTAS & $\begin{array}{l}\text { PROJETO VASCONCELOS } \\
\text { (artigos) }\end{array}$ & $\begin{array}{l}\text { CÓDIGO DE 1830 } \\
\text { (artigos) }\end{array}$ \\
\hline Morte & 60 a 71 & 38 a 43 \\
\hline Galés & 72 a 76 & 44 e 45 \\
\hline Prisão com trabalho & 77 e 78 & 46 e 49 \\
\hline Prisão simples & 77 & 47 \\
\hline Banimento & 79 e 82 & 50 \\
\hline
\end{tabular}

${ }^{408} \mathrm{O} \S 6^{\circ}$ do artigo 14 do Código de 1830 mencionava não serem considerados crimes, ou serem de todo modo crimes justificáveis, o castigo moderado que os pais dessem a seus filhos, os senhores a seus escravos, os maridos a suas esposas, e os mestres a seus discípulos. Já pelo artigo 158, era considerado crime passível de ser cometido por funcionário público, a omissão no emprego de todos os meios possíveis para a prisão ou castigo dos malfeitores que se encontrassem na jurisdição do respectivo funcionário. Ou seja, nos casos em que apareceu no diploma penal do Império, tal palavra não foi utilizada como sinônimo de pena. 


\begin{tabular}{|l|l|l|}
\hline Desterro & 80 & 52 \\
\hline Degredo & & 51 \\
\hline Infâmia & 85 & \\
\hline Multa & 90 a 93 & 55 a 57 \\
\hline Perda dos objetos do crime & 94 & \\
\hline Caução & 95 & \\
\hline Vigilância da Justiça & 88 e 89 & 58 \\
\hline Suspensão do emprego & & 59 \\
\hline Perda do emprego & & 60 \\
\hline Açoites (só para escravos) & 97 & \\
\hline
\end{tabular}

Um exame profundo destas penas permite a afirmação de que, para além da regulamentação de um distinto rol de punições em cada um dos documentos, também as penas igualmente denominadas nos dois casos não necessariamente pressupunham um entendimento e modo de aplicação comuns. Desta forma, mudanças aparentemente pontuais no que tangia às idades mínima e máxima estabelecidas para o recebimento de determinadas sentenças, ou ainda pequenas alterações no que se referia às autoridades responsáveis pela execução de cada punição, somavam-se, no Código de 1830, a modificações de cunho mais diretamente teórico, como uma outra concepção da pena de morte e um maior detalhamento das especificidades e diferenças existentes entre penas como as de prisão simples, prisão com trabalho e galés.

Assim, enquanto o projeto de Vasconcelos não diferenciava precisamente o modo de execução das penas de prisão simples e prisão com trabalho, regulando-as conjuntamente nos artigos 77 e 78 :

Art. 77. Uma lei particular declarará os trabalhos em que se devem occupar os condemnados à prisão com trabalho, as diversas prisões para os sexos, para os condemnados perpetua ou temporariamente, para os simplesmente detidos, prescreverá o modo de se executarem as sentenças e a applicação dos productos do trabalho.

Art. 78. Emquanto se não levantão os edificios necessarios para o trabalho dos réos, os juizes commutarão as penas de prisão com trabalho em galés, prisão simples ou desterro como lhes parecer de razão.

No Código de 1830, especificava-se claramente as diferenças existentes no cumprimento de cada uma delas. Os artigos 46, 47, 48 e 49 do diploma imperial de 1830 determinavam, portanto, não somente as diferenças precisas existentes entre a prisão simples e a prisão com trabalho, mas explicitavam ainda as especificidades relativas aos recintos em que se cumpriria cada uma delas e o modo com que se 
poderia substituir uma pena pela outra na ausência de "prisões com as comodidades e arranjos necessários ao trabalho dos réus. ${ }^{, 409}$ :

Art. 46. A pena de prisão com trabalho, obrigará aos réos a occuparem-se diariamente no trabalho, que lhes fôr destinado dentro do recinto das prisões, na conformidade das sentenças, e dos regulamentos policiaes das mesmas prisões.

Art. 47. A pena de prisão simples obrigará aos réos a estarem reclusos nas prisões publicas pelo tempo marcado nas sentenças.

No que diz respeito à definição da pena de galés em cada texto, analisemos o conteúdo específico dos artigos 72 de Vasconcelos e 44 do Código de 1830:

Art. 72. Os réos condemnados a galés andarão com calceta no pé, e corrente de ferro, juntos dous a dous, ou separados segundo a qualidade do serviço. Os seus vestidos serão uniformes com rotulo dos crimes nas costas, e de maneira feitos que se facilite o conhecimento delles.

Art. 44. A pena de galés sujeitará os réos a andarem com calceta no pé, e corrente de ferro, juntos ou separados, e a empregarem-se nos trabalhos publicos da provincia, onde tiver sido commettido o delicto, á disposição do Governo.

Uma vez mais, nota-se no diploma de 1830 um maior cuidado com a caracterização precisa da pena referida. Apesar de, num primeiro momento, detalhamentos como estes poderem parecer supérfluos à compreensão do novo caráter impresso pelas alterações penais ao código criminal, buscaremos demonstrar à frente, munidos de um maior número de dados empíricos e históricos, o significado que, em nossa opinião, este conjunto de alterações de fato conteve.

Atentemos agora ao modo com que a pena de morte foi definida em cada um dos documentos. Apesar de bastante parecidos neste ponto, os dois códigos guardavam diferenças que não devemos subestimar. A pena de morte foi regulada, no Projeto de Vasconcelos, entre os artigos 60 e 71; no Código de 1830, por sua vez, entre os artigos 38 e 43 . Nos dois casos instituía-se que a pena de morte se daria na forca e que seria executada, impreterivelmente, nas 24 horas que se seguissem ao estabelecimento irrevogável da sentença - não sendo nunca efetivada, contudo, aos domingos, dias

\footnotetext{
${ }^{409}$ Observemos o conteúdo completo deste artigo: “Art. 49. Emquanto se não estabelecerem as prisões com as commodidades, e arranjos necessarios para o trabalho dos réos, as penas de prisão com trabalho serão substituidas pela de prisão simples, acrescentando-se em tal caso á esta mais a sexta parte do tempo, por que aquellas deveriam impôr-se."
} 
santos ou de festividade nacional ${ }^{410}$. Também na mulher grávida não se cumpriria a sentença, nem seria ela julgada senão decorrido certo intervalo de tempo do parto (15 dias no Projeto de 1827 e 40 dias no Código de 1830).

O procedimento a ser seguido em cada caso era também bastante parecido, mas não idêntico: o réu, preso e trajando vestimentas específicas (alva branca com um rótulo nas costas que declarasse o seu crime no Projeto de Vasconcelos e "vestido ordinário" no Código de 1830), seria conduzido pelas ruas mais públicas até a forca. Acompanhariam-no o Juiz Criminal (juiz de paz no Projeto de Vasconcelos) do local, seu escrivão e a força militar requisitada (além destes, o projeto de 1827 previa ainda a presença dos sacerdotes da localidade). Nos dois códigos, o juiz que acompanhasse o réu presidiria a execução até o fim, passando certidão da mesma nos autos da sentença. Em ambos os textos previa-se também que os corpos dos enforcados seriam entregues às famílias (em caso de demanda ao juiz), com a proibição de serem enterrados com qualquer tipo de ostentação.

Partindo desta pequena descrição, começam já a transparecer os indícios da nova compreensão penal esboçada pelo Código 1830. Observemos, nesse sentido, o modo com que as diferentes vestimentas designadas aos réus em cada caso revelavam a maior exemplaridade depositada sobre a pena de morte no projeto de Vasconcelos, ou ainda o modo com que a significativa diferença representada pelo interregno de 40 dias, previsto pelo Código de 1830, entre o parto e a execução de uma criminosa, e os 15 dias previstos pelo texto de 1827 , desvelava uma mudança de prioridades quando o assunto era a imputação da morte a um criminoso.

Para além dos elementos apontados acima, um pequeno artigo do projeto de Vasconcelos, inexistente no texto de 1830, nos parece crucial à detecção da mudança efetivada. Trata-se do artigo 62 do projeto, com o seguinte conteúdo:

Art. 62. A sentença poderá determinar, que depois de enforcado o réo lhe sejão cortadas a cabeça e as mãos para serem afixadas no lugar do delicto ou no mais próximo.

Menos importante que o teor do artigo em si (que, afinal, encontrava congêneres em vários dos códigos penais ocidentais do período ${ }^{411}$ ), é essencial que atentemos à

\footnotetext{
${ }^{410}$ Pelo Projeto de Vasconcelos o prazo máximo de 24 horas para a execução da sentença poderia ser menor a requerimento do réu.

${ }^{411}$ Veja-se, para tanto, os parágrafos 16, 17 e 18 do Titulo XIII do Projeto de Código Criminal de Pascoal de Melo Freire; o artigo 13 do Código Penal francês de 1810; e o artigo $5^{\circ}$ do Livro I do Código penal da Baviera, de 1813.
} 
sua supressão do texto final de 1830, momento em que, ao que tudo indica, os legisladores brasileiros não admitiriam, sob hipótese alguma, a manutenção de cláusulas legitimadoras de um uso expositivo e martirizante dos cadáveres dos réus que equiparassem à "moderna" pena de morte, os suplícios característicos do Antigo Regime.

Neste sentido, ainda que a avaliação das reformas empreendidas sobre a pena de morte na passagem do século XVIII ao XIX seja de conteúdo extremamente polêmico - haja vista, em especial, a dificuldade de uma análise isenta de juízos de valor quanto à pretensa "humanidade" das correntes do direito penal defensoras de sua abolição, ou ainda quanto às ligações existentes entre tal supressão e as necessidades de adaptação do direito às mudanças político-econômicas e disciplinadoras do mercado de trabalho - fato é que, para os legisladores brasileiros das décadas de 1820 e 1830, a manutenção da pena capital se deu paralelamente à busca pela eliminação de dispositivos penais de Antigo Regime, assumindo, portanto, no interior do código penal, uma roupagem moderna e desvinculada da tortura ${ }^{412}$.

Como veremos com maior cuidado à frente - e como já tivemos a oportunidade de verificar previamente a partir dos debates parlamentares travados em setembro de 1830 -, diferentemente do diploma de Vasconcelos, a pena de morte parece ter sido mantida no texto de 1830 como um recurso último para casos bastante específicos, tendo sido lamentada por grande parte da deputação nacional e cercada por dispositivos que limitavam sua prescrição a casos extremos de atentado à ordem social $^{413}$.

${ }^{412}$ Lembremos, contudo, neste ponto, que a pena de morte fora pouquíssimas vezes aplicada, ao longo do Antigo Regime, em Portugal. De acordo com António Manuel Hespanha, a numerosa prescrição desta punição na legislação portuguesa, da forma cruel em que se dava, desempenhava um papel bastante preciso no interior da estratégia dual de intervenção da coroa, em acordo com a qual o monarca se fazia temer ameaçando e amar não cumprindo. De acordo com o autor, portanto, a punição efetivamente aplicada no sistema penal de Antigo Regime não era nem muito efetiva, nem sequer muito aparente ou teatral, reduzindo-se a alguns poucos casos de morte, degredo, açoites ou penas pecuniárias. António Manuel Hespanha. "Da 'iustitia' à 'disciplina'. Textos, poder e política penal no Antigo Regime.”. In: Anuario de Historia del Derecho Español, Madrid, 1988; pp. 500-521.

${ }^{413}$ Para além de reservada a poucos casos no Código de 1830 , ao longo dos anos a pena de morte foi sendo cercada de uma série de condições e formalidades necessárias à sua execução. Em suas anotações ao Código Criminal do Império do Brasil, Thomaz Alves Jr. faz menção a diversas destas prescrições, como as que (em referência ao processo penal) estabeleciam a necessidade de decisão unânime, ou por dois terços do voto, do júri, para a imposição da pena capital - e isso não apenas no que se referia ao ato principal de um crime, mas também a qualquer das circunstâncias agravantes a ele relacionadas - ou a que determinava que, havendo somente a confissão do réu sobre o crime, ficasse proibida a 
Passemos agora a uma análise comparativa das Partes Especiais do Código de 1830 e do projeto de Bernardo Pereira de Vasconcelos, mantendo nosso foco, contudo, na questão das punições. Analisemos, assim, a quantidade de vezes em que cada uma das penas reguladas por estes diplomas foi prescrita ao longo de suas respectivas Partes Especiais.

Tabela II: Prescrição de cada punição nas Partes Especiais do Projeto de Vasconcelos e do Código de $1830 .^{414}$

\begin{tabular}{|c|c|c|c|c|}
\hline \multirow{2}{*}{ Penas } & \multicolumn{2}{|c|}{$\begin{array}{c}\text { Projeto Vasconcelos } \\
(1827)\end{array}$} & \multicolumn{2}{c|}{ Código de 1830} \\
\cline { 2 - 5 } & $\mathrm{N}^{\text {o }}$ vezes & Porcentagem & $\mathrm{N}^{\mathrm{o}}$. vezes & Porcentagem \\
\hline Morte & 5 & $1,18 \%$ & 4 & $0,8 \%$ \\
\hline Galés Temporárias & 42 & $10 \%$ & 6 & $1,3 \%$ \\
\hline Galés Perpétuas & 20 & $4,7 \%$ & 12 & $2,5 \%$ \\
\hline Total Galés & 62 & $14,7 \%$ & 18 & $3,8 \%$ \\
\hline Prisão com Trabalho & 44 & $10,4 \%$ & 126 & $26,9 \%$ \\
\hline $\begin{array}{c}\text { Prisão perpétua com } \\
\text { trabalho }\end{array}$ & 15 & $3,5 \%$ & 5 & $1 \%$ \\
\hline Total prisão com trabalho & 59 & $13,9 \%$ & 131 & $27,9 \%$ \\
\hline Prisão simples & 75 & $17,7 \%$ & 98 & $20,9 \%$ \\
\hline Prisão perpétua & 3 & $0,7 \%$ & 2 & $0,42 \%$ \\
\hline Total prisão simples & 78 & $18,4 \%$ & 100 & $21,32 \%$ \\
\hline Multa & 100 & $23,7 \%$ & 131 & $27,9 \%$ \\
\hline Perda do emprego & 36 & $8,5 \%$ & 35 & $7,4 \%$ \\
\hline Suspensão do emprego & 25 & $5,9 \%$ & 41 & $8,7 \%$ \\
\hline Banimento & 3 & $0,7 \%$ & 0 & 0 \\
\hline Desterro & 7 & $1,6 \%$ & 5 & $1,06 \%$ \\
\hline $\begin{array}{c}\text { Degredo } \\
\text { Não }\end{array}$ & & 3 & $0,63 \%$ \\
\hline $\begin{array}{c}\text { Suspensão dos direitos } \\
\text { políticos }\end{array}$ & 28 & $6,6 \%$ & Não & 0 \\
\hline $\begin{array}{c}\text { Perda dos Objetos do } \\
\text { crime }\end{array}$ & 13 & $3 \%$ & regulada & Não \\
\hline
\end{tabular}

aplicação de semelhante sentença. Ultrapassado o processo e condenado à morte o réu, restava-lhe a possibilidade de perdão, ou minoração da sentença, pelo Poder Moderador. A partir da década de 1830, a forca, anteriormente conservada, por todo o ano, em praça pública, teve sua armação restrita, por Aviso de 17 de junho de 1835, às ocasiões específicas de execução, contribuindo, portanto, à efetivação de um novo estatuto para a pena capital no Império. Thomaz Alves Jr. Op. cit; Tomo I; pp. 500-505.

${ }^{414}$ Para a elaboração da Tabela II contabilizamos, em sua totalidade, o aparecimento de cada punição específica nos diplomas de Vasconcelos e de 1830. Assim, ainda que as Partes Especiais destes documentos contassem, respectivamente, com 223 e 240 artigos, a divisão das punições admitidas a cada crime entre os graus máximo, médio e mínimo fez com que, por diversas vezes, punições diferentes aparecessem prescritas a um mesmo crime e, portanto, num mesmo artigo. Nestes casos, cada uma das penas foi contabilizada individualmente, daí o número total de penas ultrapassar, em muito, o número absoluto de artigos presentes na Parte Especial de cada um dos documentos. 


\begin{tabular}{|c|c|c|r|c|}
\hline Vigilância da Justiça & 1 & $0,2 \%$ & $\begin{array}{r}\text { Não } \\
\text { regulada }\end{array}$ & \\
\hline Caução $^{415}$ & 0 & & $\begin{array}{r}\text { Não } \\
\text { regulada }\end{array}$ & \\
\hline Infâmia & 0 & & $\begin{array}{r}\text { Não } \\
\text { regulada }\end{array}$ & \\
\hline Talião & 4 & $0,9 \%$ & $\begin{array}{r}\text { Não } \\
\text { regulada }\end{array}$ & $0,21 \%$ \\
\hline Açoite & 1 & $0,23 \%$ & 1 & $100 \%$ \\
\hline $\begin{array}{l}\text { Total de Penas } \\
\text { contabilizadas }\end{array}$ & 422 & $100 \%$ & 469 & \\
\hline
\end{tabular}

A análise desta tabela revela uma mudança significativa na proporcionalidade com que determinadas punições foram prescritas em cada um dos documentos. Enquanto no projeto de Vasconcelos, por exemplo, as penas de galés, temporárias ou perpétuas, configuraram cerca de $14,7 \%$ do total das punições, no Código de 1830 perfizeram apenas 3,8\% do total. Tal relação se inverteu, por sua vez, no caso das penas de prisão com trabalho (também temporárias ou perpétuas), que somaram 13,9\% do total das punições prescritas em 1827 - aparecendo menos vezes, neste documento, que as penas de galés - e quase 28\% das penas prescritas em 1830.

Estes números são ainda mais relevantes quando relacionados às mudanças empreendidas na definição das penas de galés, prisão simples e prisão com trabalho na Parte Geral do código. Neste sentido, a maior precisão consagrada a cada uma destas penas, como visto acima, pode ser compreendida como o passo fundamental de uma redefinição penal qualitativa e quantitativa que atingiu efetivamente todo o conteúdo do diploma imperial.

Ao fixar precisamente as características de uma punição como a de prisão com trabalho, por exemplo, os legisladores brasileiros não só a diferenciavam essencialmente de suas "penas congêneres" no documento anterior (prisão simples e galés, no caso), evitando possíveis confusões entre seus significados e aplicação, como demonstravam sua sintonia com as mais modernas teorias punitivas em vigor no mundo ocidental; majoritariamente elogiosas, então, às penas reabilitadoras pela via do trabalho prisional ${ }^{416}$.

\footnotetext{
${ }^{415}$ Apesar de admitidas, respectivamente, pelos artigos 95 e 85 do projeto de Vasconcelos, as penas de "caução" e "infâmia" não foram prescritas a qualquer crime específico da Parte Especial deste documento.

${ }^{416}$ Ver: Cesare Beccaria. Dos delitos e das penas. São Paulo: Martins Fontes, 2005; Edward Livingston. Report made to the General Assembly of the State of Lousiana of the Plan of a Penal Code for the said State, Nova Orleans, Benjamin Levy \& Co, 1824; e Idem.
} 
Lembremos, neste ponto, que a distinção penal ambígua presente no projeto de Vasconcelos permitira-o intercalar, entre os graus máximo e mínimo de uma mesma sentença, penas absolutamente distintas como a de prisão com trabalho e a de galés ${ }^{417}$, prescrevendo ainda a comutação da primeira pela segunda ${ }^{418}$ e originando, enfim, construções jurídicas impensáveis no interior de uma concepção penal como a presente no texto de 1830 . Isto porque, como nos lembra a historiadora Claudia Trindade, eram profundas as diferenças estabelecidas, pelo código final, entre a pena de prisão com trabalho e a de galés. Pois se ambas pressupunham o labor dos réus, faziam-no baseadas em concepções completamente distintas:

É importante esclarecer que a pena de prisão com trabalho não era o mesmo que galés ou trabalhos forçados, as quais já eram previstas no Livro $\mathrm{V}$ das Ordenações Filipinas e continuariam no Código Criminal. O trabalho forçado, atividade do condenado a pena de galés, era geralmente cumprido na prisão do Arsenal da Marinha e nas obras públicas em geral, conforme já abordamos neste capítulo. Mesmo quando o condenado a galés executava serviços de reparo dentro das prisões, esta atividade nada tinha a ver com a pena de prisão com trabalho. Em outras palavras, trabalho forçado não fazia parte de nenhuma discussão de reabilitação e não podia ser utilizado para cumprimento da pena de prisão com trabalho. ${ }^{419}$

Introductory Report to the Code of Reform and Prison Discipline. In: A System of Penal Law for the State of Louisiana. Pittsburgh, John L. Kay \& Brother, 1833; De acordo com Azambuja e Sousa Pinto: "A pena de prisão é a pena por excelência nas sociedades civilizadas. Quando a esta pena anda ligada a obrigação do trabalho, e justamente é esta a que faz objeto deste artigo, não se atreverá alguém a avançar que ela não tem uma tendência moral." José Maria Frederico de Sousa Pinto e Bernardes Augusto Nascentes Azambuja. Op. cit.; p. 280.

${ }^{417}$ Caso presente, entre outros, no $\S 2^{\circ}$ do art. 311 daquele projeto: "Art. 311 . É crime de traição: $2^{\circ}$. Tentar directamente e de facto desthronisar o imperador, prival-o em todo ou em parte de sua autoridade constitucional, ou alterar a ordem legitima da successão. Pena - galés por doze annos no gráu minimo, prisão perpetua com trabalho no medio, e galés perpetuas no maximo." Para mais exemplos ver nota 313 do Capítulo 2 desta dissertação.

${ }^{418}$ De acordo com o artigo 78 do projeto de Bernardo Pereira de Vasconcelos: "Emquanto se não levantão os edificios necessarios para o trabalho dos réos, os juizes commutarão as penas de prisão com trabalho em galés, prisão simples ou desterro como lhes parecer de razão."

419 Claudia Moraes Trindade. A Casa de Prisão com Trabalho da Bahia, 1833-1865. Dissertação de Mestrado; Universidade Federal da Bahia, 2007; p.42. Entre as páginas 273 e 279 de seus comentários ao Código Criminal de 1830, Sousa Pinto e Azambuja tecem observações acerca da admissão da pena de galés por este diploma, descrevendo-a essencialmente como uma pena corporal que pressupunha o sofrimento físico mas não a morte do réu, devendo por isso ser eliminada do diploma brasileiro. Se a pena de galés possuía, assim, a seu ver, a vantagem da exemplaridade e de poder forçar homens desafeitos ao trabalho à lida cotidiana, possuía também o grave inconveniente de impedir o reingresso na sociedade e a reconquista da dignidade por parte daqueles que a cumprissem. José Maria Frederico de Sousa Pinto e Bernardes Augusto Nascentes Azambuja. Op. cit.; 1832; pp. 273280. 
Também no que se refere à prescrição da pena de morte em cada um dos documentos, para além de uma alteração conceitual na definição (e significado) desta punição, houve uma mudança significativa no que tangia aos casos em que, no Código de 1830, ela poderia ser aplicada.

Vejamos os crimes específicos aos quais cada um dos documentos prescrevia a pena capital. No Projeto de Bernardo Pereira de Vasconcelos a pena de morte poderia ser aplicada em caso de: homicídio com agravantes (art. 149); condenados a galés que incorressem em outros crimes e por eles recebessem penas de galés temporárias, prisão por mais de 4 anos, banimento por 6 anos, desterro por 8, ou daí para cima (art. 103); crime de forçamento de cadeia em decorrência do qual fugisse um prisioneiro condenado à morte, ou no caso de o réu do crime de forçamento ser um escravo (art. 286); grau máximo do crime de tentativa de destruição da Constituição política do Império ( $\left(1^{\circ}\right.$ do art. 311$)$; e, por fim, de acordo com o artigo 313, para o caso de consumação de qualquer um dos delitos previstos pelo artigo 311 do projeto (com exceção do seu $\S 3^{\circ}$, que seria punido, no caso de consumação, com galés perpétuas), compreendidos todos como crimes de traição ${ }^{420}$.

No Código Criminal de 1830, por sua vez, a pena de morte estava prevista para quatro casos: homicídio com agravantes (art. 192); roubo seguido de morte (art. 271); e insurreição escrava, fosse esta encabeçada por escravos (art. 113), fosse por homens livres (art. 114). Interessante observar, neste ponto, o completo ineditismo dos artigos 113, 114 e 271 do texto de 1830 em relação ao Projeto de 1827.

Para além do crime de homicídio com agravantes, portanto, não há quaisquer semelhanças entre os documentos no que diz respeito à prescrição da pena capital ${ }^{421}$,

\footnotetext{
${ }^{420}$ Vejamos quais eram especificamente os delitos regulados pelos oito parágrafos do artigo 311 do projeto de Vasconcelos, reunidos sob a rubrica de crime de traição: "§1 $1^{\circ}$ Tentar directamente e de facto destruir a constituição política do imperio; $\$ 2^{\circ}$ Tentar directamente e de facto desthronisar o imperador, prival-o em todo ou em parte de sua autoridade constitucional, ou alterar a ordem legitima da successão; $\S 3^{\circ}$ Directamente e de facto concorrer para uma falsa justificação da impossibilidade phisica ou moral do imperador; $\S 4^{\circ}$ Directamente e de facto tentar contra a regencia ou regente, afim de prival-a de sua autoridade constitucional; $\S 5^{\circ}$ Oppôr-se de facto à prompta execução das cartas de convocação da assembléa pelo imperador, ou pelo senado nos casos da constituição, art. 47 , § 3 e $4 ; \S 6^{\circ}$ Oppôr-se de facto à reunião da assembléa geral legislativa no prazo marcado na constituição do imperio, ou ao livre exercicio de cada uma das câmaras; $\S 7^{\circ}$ Tentar directamente e de facto destruir a independencia e integridade do imperio; e $\S 8^{\circ}$ Empregar senadores fóra da côrte no anno, em que se tem de convocar a assembléa geral legislativa na fórma da constituição, art. $47, \S 3$ e $4 . "$

${ }^{421}$ Gostaríamos de chamar a atenção, neste ponto, para a inexistência de análises sobre a pena de morte no Código Criminal de 1830 que levem em consideração tais mudanças. Apesar de
} 
tornando-se explícita a efetivação de uma mudança que, como dissemos, mais do que quantitativa, incidiu sobre a concepção desta punição. Não nos parece acidental, nesse sentido, que a prescrição da pena de morte no Código de 1830 seja quase totalmente inédita em relação ao projeto de 1827.

A compreensão das alterações empreendidas sobre o que denominamos aqui a "concepção penal" do código brasileiro, para ser completa, deve perpassar uma série de fatores que vão desde a análise da introdução de novos crimes neste diploma caso, por exemplo, da insurreição escrava e do crime de roubo seguido de morte -, até o exame detido dos debates travados em setembro de 1830 em torno da pena capital. No bojo desta análise, não se deve perder de vista as especificidades da conjuntura política vivida pelo país, as peculiaridades sociais da nação recém-independente e os compromissos e agendas dos deputados e senadores brasileiros em meio a este processo.

Para as alterações empreendidas sobre as penas de prisão com trabalho, prisão simples, galés e morte, foram de fundamental importância, portanto, desde propostas como as realizadas por Rego Barros, Paula Souza e Vasconcelos na sessão de 15 de setembro de 1830 - dedicadas, respectivamente, à abolição da pena de morte nos crimes políticos, à redução da pena capital a dois delitos específicos do código criminal e ao estabelecimento de um prazo definido para o fim dos sentenciamentos

ser, portanto, uma das facetas mais estudadas pela (pequena) bibliografia dedicada a este diploma, não há pesquisas efetivamente preocupadas em pontuar as transformações sofridas pelo projeto de Bernardo Pereira de Vasconcelos, quanto a este quesito, entre 1827 e 1830. Em verdade, como afirmado anteriormente, seja qual for o aspecto analisado do Código de 1830, não há estudos dedicados ao exame destas transformações. Os artigos de Monica Duarte Dantas, "Revoltas, Motins, Revoluções: das Ordenações ao Código Criminal" e Andréa Slemian, "À nação independente, um novo ordenamento jurídico" configuram, nesse sentido, exceções, já que o primeiro se preocupa em pontuar as transformações realizadas, entre o projeto de 1827 e o texto definitivo do código penal, no que dizia respeito especialmente aos crimes políticos, enquanto o segundo aponta, sem uma análise profunda, contudo, para as transformações operadas na prescrição da pena de morte em cada caso. Chama a atenção, de todo modo, o fato de um estudo como o de João Luiz Ribeiro, especificamente dedicado à pena de morte no Império do Brasil, prescindir de semelhante análise. Monica Duarte Dantas, "Revoltas, Motins, Revoluções: das Ordenações ao Código Criminal". In: Idem (org.). Revoltas, motins, revoluções: homens livres pobres e libertos no Brasil do século XIX. São Paulo: Alameda Editorial, 2011; pp. 7-67; Andréa Slemian. "À nação independente, um novo ordenamento jurídico: a criação dos Códigos Criminal e do Processo Penal na primeira década do Império do Brasil. In: Gladys Sabina Ribeiro (org.) Brasileiros e cidadãos: modernidade política, 1822-1890. São Paulo: Alameda, 2008; pp. 175-206. 
às galés no Império ${ }^{422}$-, até, obviamente, a conjuntura política de crise parlamentar e oposição ferrenha ao imperador d. Pedro I, já praticamente incontornável, diga-se de passagem, nos idos de 1829 e 1830. Para além disso, não se deve ignorar o peso do trânsito das ideias penais no mundo ocidental naquele momento, o interesse despertado pelas mesmas em parte da deputação nacional, o apoio buscado em legislações estrangeiras para o delineamento do direito penal brasileiro e as concepções de lei e direito por que se pautaram os legisladores mais diretamente envolvidos na composição do código criminal. Mais à frente (nos subcapítulos $3.2 \mathrm{e}$ 3.3), analisaremos o conteúdo final do Código penal brasileiro de 1830 a partir de todas estas variáveis, mas, antes disso, faz-se necessário um exame ainda mais profundo do texto deste diploma e das alterações empreendidas sobre os projetos apresentados para a discussão dos representantes.

Ainda que tenhamos nos centrado, até o momento, no delineamento propriamente punitivo do futuro código criminal brasileiro, diversas mudanças foram realizadas também na tipificação dos crimes públicos, particulares e policiais deste diploma, e o seu reconhecimento tem importância fundamental para a continuidade de nossa análise. Faz-se necessário, portanto, esboçar um quadro geral destas alterações, explicitando a importância desempenhada pelo Código de 1830 enquanto arma política na conjuntura vivida pelo país, bem como o significado por ele representado na construção de um direito positivado nacional no Império do Brasil.

Cotejando pontualmente, assim, os 111 artigos da seção dos crimes públicos do texto de 1830, aos 107 artigos da mesma seção do projeto de Vasconcelos tem-se que,

\footnotetext{
${ }^{422}$ Ainda que, das três medidas propostas, apenas a primeira tenha sido aceita pela deputação nacional, são inquestionáveis as influências desempenhadas pelas propostas de Paula Souza referente à restrição da pena capital - e Vasconcelos - concernente à abolição imediata das penas de galés, e sua substituição pela pena de prisão com trabalho, assim que o Império dispusesse de Casas de Correção em número suficiente - sobre a arquitetura penal enfim materializada no Código de 1830. Deve-se destacar, contudo, deste conjunto de proposições, a emenda de Rego Barros, que tem interesse não apenas por conta da leitura política que manifesta, mas ainda por ter sido aprovada, sem sobressaltos, na Câmara dos deputados, e efetivamente inserida no texto do código imperial. No que tange à sua leitura política, relembremos que, de acordo com o próprio Rego Barros, se a pena de morte se fazia necessária no Brasil por conta da presença da escravidão e para a punição dos crimes de homicídio, nos crimes políticos ela era dispensável, haja vista a grande probabilidade de o "partido vencido" em uma disputa política ser de fato o "bom partido" - aquele que, caso viesse a vencer no futuro, traria a "felicidade da nação" -, sendo que da pena capital não se poderia voltar atrás. Nota-se nesta fala o eco das cruéis condenações dispensadas a "rebeldes" brasileiros de períodos anteriores (em especial aos membros da Confederação do Equador) e, para além disso, uma possível projeção de que, em se fazendo necessárias novas "revoluções" no Império do Brasil, a classe política conseguisse escapar das punições máximas.
} 
a um conjunto de 49 artigos bastante próximos em ambos os diplomas, contrapunham-se 62 artigos do Código de 1830 significativamente diferentes ou inéditos em relação aos do projeto do deputado mineiro ${ }^{423}$. Para além das diferenças numéricas aqui apresentadas, o exame destas seções enquanto unidades portadoras de sentidos jurídicos e políticos próprios, revelou ser ainda mais profunda a distância que as separava.

As mudanças efetuadas sobre os crimes públicos do projeto de Vasconcelos entre os anos 1829 e 1830 chamam a atenção, assim, por terem introduzido uma série de delitos significativos no momento específico vivido pelo país, tendo modificado também, e massivamente, as penas prescritas a crimes já previstos pelo projeto de 1827.

No que tange aos novos delitos introduzidos neste período, destaque seja dado, no âmbito dos Títulos II e III dos crimes públicos do Código de 1830 - respectivamente referentes aos "crimes contra o livre exercício dos poderes políticos" (arts. 93 a 99) e aos "crimes contra o livre gozo dos direitos políticos pelos cidadãos" (arts. 100 a 106) -, à inclusão de prescrições relativas à defesa da regularidade do sistema representativo no país; à garantia de equilíbrio dos poderes Executivo, Legislativo e Judiciário; e ao bom funcionamento das eleições imperiais. No Titulo IV do diploma, por sua vez, referente aos "crimes contra a segurança interna e pública tranqüilidade do Império", chama a atenção particularmente a inserção de delitos como os de “Conspiração" (arts. 107 a 109) e "Insurreição escrava" (arts. 113 a 115).

Para além dos ineditismos expostos acima, destacam-se também as mudanças introduzidas em categorias preexistentes como as dos crimes de "Rebelião" (art. 110), "Sedição" (arts. 111 e 112), "Resistência" (arts. 116 a 119) e "Moedas Falsas" (arts. 173 a 176).

Atenção especial deve ser dedicada ainda, neste ponto, à exclusão da categoria de traição política (presente em 1827) do texto de 1830, optando-se, então, pela tipificação, em diferentes artigos, de vários dos crimes públicos sob ela anteriormente agrupados. Nesse sentido, crimes como os de tentativa de destruição da Constituição política ou da Independência do Império, de alteração da sua forma de governo ou de deslegitimação do imperador, considerados traição em 1827 e com condenação à

\footnotetext{
${ }^{423}$ Esta comparação revelou, assim, a presença de três artigos idênticos em ambos os diploma, 31 artigos inéditos no texto de 1830, 46 artigos bastante parecidos nos dois casos e 31 artigos cujas transformações entre 1827 e 1830 consideramos bastante significativas.
} 
morte (art. 311), passaram a compor uma série de artigos específicos do Código de 1830 (precisamente os artigos de número $68,85,86,87,88,89,91$ e 92 ) e a serem punidos de maneira bastante mais amena.

No que diz respeito especificamente às novas penas prescritas aos crimes públicos, exemplifiquemos o alcance da mudança empreendida entre os textos de 1827 e 1830 a partir da análise de dois casos específicos: o da pena de galés e o da pena de prisão com trabalho. Enquanto o projeto de Vasconcelos prescrevia a punição às galés, perpétuas ou temporárias, por 43 vezes entre seus crimes públicos, o Código de 1830 as admitia unicamente em 11 casos, sendo que, destes, sete referiam-se ao crime de pirataria ${ }^{424}$ (que aliás, era provavelmente o crime público, à exceção do caso

${ }^{424}$ No que tange ao crime de pirataria, não pudemos encontrá-lo em nenhum dos códigos ou projetos existentes no período (por nós consultados), havendo uma única menção a tal delito no Projeto de Código Criminal de Pascoal de Melo Freire (Titulo XIV, $\S 5^{\circ}$ ) e, ainda assim, com teor muito distinto da definição encontrada no texto final do código brasileiro (quase integralmente advinda do projeto de Bernardo Pereira de Vasconcelos, mas com dois novos parágrafos adicionados pela comissão $a d$ hoc de 1830). Quanto à definição adotada por Vasconcelos (e mantida em 1830), chamou especialmente a atenção a presença de regulamentações referentes ao usufruto, por parte dos navegadores brasileiros, de "cartas de corso" e "cartas de marca", dispositivos frequentemente utilizados nos séculos XVI e XVII, mas já em desuso no mundo ocidental havia algum tempo. Buscando, na legislação portuguesa, a regulamentação de semelhantes dispositivos, deparamo-nos com dois alvarás, passados, respectivamente, em 16 de janeiro de 1764 e 16 de janeiro 1774, por meio dos quais ficava proibido o uso de semelhantes cartas (sem, contudo, a utilização específica da denominação de "carta de corso" ou "carta de marca") pela marinha portuguesa. Analisando, por sua vez, os Commentaries on the Laws of England, de William Blackstone, deparamonos, curiosamente, na seção referente às prerrogativas do rei, com a legitimação das chamadas "cartas de marca" (letters of marque) e com a afirmação de que os portadores de tais cartas não poderiam ser julgados como piratas (Book I, Chapter VII). No texto do Código de 1830, a regulamentação do crime de pirataria aparece envolta em concepção parecida a esta, reconhecendo-se como pirataria (pelos parágrafos $2^{\circ}$ e $6^{\circ}$ do artigo 82 e o parágrafo $1^{\circ}$ do artigo 83) os crimes cometidos em alto-mar por indivíduos ou embarcações desprovidos de cartas de corso ou de marca legítimas. Para além desta semelhança, a análise dos comentários específicos de Blackstone acerca do crime de pirataria (Book IV, Chapter V), revelam ainda mais proximidades entre os dois documentos. Primeiramente, a severidade com que foram prescritas as punições a este crime no Código de 1830 (severidade esta, deve-se frisar, advinda também do projeto de Vasconcelos), aproxima-se da gravidade reconhecida no crime de pirataria por Blackstone. Em segundo lugar, a definição geral do crime se aproxima nos dois casos. Sendo assim, enquanto Blackstone define como pirataria: "commiting those acts of robbery and depredation upon the high seas", o $\S 1^{\circ}$ do art. 83 determina que se comete tal crime: "praticando[-se] no mar qualquer acto de depredação, ou de violência [...]". Para além destes exemplos, o conteúdo do diploma brasileiro aproxima-se das afirmações de Blackstone ao definir como pirataria: o ato de apossar-se de um navio por meio de violência contra o comandante (art. 82, §30); a entrega de um navio a piratas, por um dos membros de sua equipagem ( $\operatorname{art.} 82, \S 4^{\circ}$ ); a oposição, por ameaças ou violência, à defesa de um navio por seu comandante, na ocasião de um ataque por piratas ou inimigos $\left(\operatorname{art.~} 82, \S 5^{\circ}\right.$ ); e a ação de traficar com piratas conhecidos, ou lhes fornecer embarcações, provisões, munições ou qualquer outro auxílio $\left(\operatorname{art.} 84, \S 2^{\circ}\right)$. Todos estes detalhes implícitos ao entendimento de 
de insurreição, mais rigorosamente punido pelo diploma brasileiro ${ }^{425}$ ) e três ao crime de insurreição escrava. Já a pena de prisão com trabalho, prescrita por 34 vezes entre os crimes públicos do diploma do deputado mineiro, aparecia em 98 casos da mesma seção do texto de 1830 .

Em sequência aos crimes públicos, o texto do Código de 1830 regulava os chamados crimes particulares. Como vimos acima, a classificação dos delitos em públicos, particulares e policiais - adotada por uma série de códigos penais do período -, pautava-se antes pela necessidade de organização dos códigos do que por diferenciações de fato essenciais entre as classes de crime. Nesse sentido, foi plenamente reconhecida à época a freqüente extensão dos efeitos dos chamados

pirataria no Código de 1830 podem ser encontrados, por sua vez, entre as páginas 72 e 73 do quarto volume da obra de William Blackstone, em que o autor comenta a compreensão do crime de pirataria pelas leis inglesas. Tal fato sugere, por sua vez, a possibilidade de que Vasconcelos e os legisladores que o sucederam na tarefa de elaboração do código penal brasileiro - haja vista dois dos detalhes citados acima terem sido adicionados pela comissão ad hoc de 1830 ao projeto do deputado mineiro -, tenham tido acesso a obra de Blackstonte, bastante lida àquela altura no mundo ocidental e já traduzida em várias línguas, especialmente o francês. William Blackstone. Commentaries on the laws of England. Books I, II, III, IV. London: Printed by A. Strahan, 1800. Do "Book I" ver: pp. 258-259. Do "Book IV" ver: pp. 71-73. Para o Alvará de 16 de janeiro de 1764 ("Alvará com força de Lei - Pró́be aos comandantes da Armada Real do Estado da índia a abordagem e apreensão de mercadorias de navios mercantes estrangeiros, excepto sendo piratas ou gentios transportando armas ou géneros proibidos"), ver: Antonio Delgado da Silva. Collecção da Legislação Portugueza desde a última compilação das Ordenações. Legislação de 1763 a 1774. Lisboa: Na Typografia Maigrense, 1829. Para o alvará de 16 de janeiro de 1774 (“Alvará com força de Lei - Em que se ordena que as presas feitas sobre os Piratas e Corsários pertençam aos Comendadores, Oficiais e Equipagens das Embarcações de guerra que as apreendem"): Sistema ou Collecção dos Regimentos Reaes. Contem os Regimentos pertencentes à Fazenda Real, Justiça e Militares. Tomo Sexto. Lisboa: Na Officina Patriarcal de Francisco Luiz Ameno, 1791; pp. 199-201. Ambos disponíveis em: http://iuslusitaniae.fcsh.unl.pt./index.php. ${ }^{425}$ Previsto pelos artigos 82, 83 e 84 do diploma de 1830, o crime de "pirataria" fora previamente regulado pelo artigo 331 do projeto de Vasconcelos. Haja vista as poucas alterações introduzidas em seu texto entre um momento e outro (devidas, em sua maioria, a emendas sugeridas pela comissão $a d$ hoc), este crime manteve, em sua versão final, penas bastante rigorosas, como a de galés perpétuas. Inicialmente, pareceu-nos que tamanha severidade poderia ser relacionada, para além da influência desempenhada pela obra de Blackstone, à convenção antitráfico assinada entre Brasil e Inglaterra aos 26 de novembro de 1826 - pela qual ficava estabelecido, entre outras coisas, que o tráfico de escravos na Costa d'Africa fosse julgado crime de pirataria a partir de sua proibição, determinada para dali a três anos. A análise das prescrições do crime de pirataria, contudo, tanto no projeto de Vasconcelos, quanto no de Clemente Pereira e no texto final de 1830, não confirmaram esta impressão, haja vista seu absoluto silêncio no tocante ao comércio de cativos. A lei de 7 de novembro de 1831, por sua vez, pareceu-nos confirmar que, de fato, não era por conta do tráfico de escravos que o crime de pirataria havia sido regulado pelo Código de 1830, já que, pelo artigo $2^{\circ}$ desta lei ficavam prescritas, aos traficantes condenados, as penas estabelecidas pelo artigo 179 do código, relativo não ao crime de pirataria, mas sim ao de redução de pessoa livre à escravidão. 
crimes privados sobre a totalidade do corpo social, optando-se, ainda assim, por classificá-los sob o critério de seu impacto pretensamente limitado (ou limitável) a um ou mais indivíduos designadamente. Eram crimes particulares, portanto, como vimos, aqueles que incidiam sobre a liberdade individual dos sujeitos, sua vida, honra, estado civil ou propriedade.

Vejamos o modo com que estes crimes apareceram nos diplomas de Vasconcelos e 1830. Atentemos de saída ao fato de que, dos 97 artigos presentes nesta seção em 1830 (em oposição aos 99 artigos da seção de crimes particulares do projeto de 1827), sete eram idênticos aos do projeto de Vasconcelos, 42 eram dele bastante próximos, 22 haviam sofrido alterações significativas e 26 eram absolutamente inéditos. Tem-se, desta forma, entre os delitos particulares de 1830, uma bipartição quase exata entre os casos de manutenção e os de renovação em relação ao texto do deputado mineiro.

Dentre o conjunto de alterações detectadas, destaque seja dado à inserção dos crimes de suicídio (art. 196), infanticídio (art. 197), abertura de cartas (arts. 215 a 218) e roubo seguido de morte (art. 271), e ainda às novidades introduzidas no entendimento dos crimes de aborto e adultério (arts. 199 e 200). Uma das mais interessantes novidades presentes neste ponto do diploma penal imperial diz respeito à inserção aí realizada de dispositivos específicos referentes à execução do direito de habeas corpus dos réus (art. 183 a 188) - regulamentação que não encontra paralelo em nenhum outro código criminal do período.

Deve-se ressaltar, contudo, que as modificações realizadas sobre os crimes particulares do futuro código penal possuíam caráter bastante distinto daquelas empreendidas sobre os crimes públicos. Salta aos olhos, assim, a pequena quantidade de intervenções realizadas sobre esta parte do código penal (quando comparada às empreendidas sobre os crimes públicos), especialmente no que se refere à prescrição penal. Ainda assim, se o projeto de Bernardo Pereira de Vasconcelos prescrevera a pena de galés por 19 vezes e a pena de prisão (com ou sem trabalho) por 50 vezes para os crimes particulares, o Código de 1830 as prescreveu, respectivamente, em sete e 74 casos de seus delitos privados.

No que diz respeito, por sua vez, às transformações realizadas sobre os crimes policiais dos diplomas em análise, lembremos do modo com que sua regulamentação nos diferentes códigos do período gerara discussões acaloradas à época. Assim, enquanto códigos como o austríaco de 1803 , o francês de 1810 e o projeto norteamericano da Louisiana, de 1824, optaram por explicitar, na denominação diversa 
dada aos delitos compreendidos como policiais (chamados aí, respectivamente, graves infractions de police, contraventions e misdemeanors), sua diferença em relação às outras categorias criminais presentes em seus diplomas - haja vista o fato de as infrações policiais representarem antes, como vimos, atentados à ordem social e não um mal em si mesmos) -, o código brasileiro de 1830 (seguindo, neste ponto, o projeto de Vasconcelos) limitara-se a denominar "crimes policiais" os delitos aí reunidos.

Constituídos, assim, por 17 artigos em 1827, os crimes policiais passaram a contar com 32 artigos em 1830; destes, 14 muito parecidos com os de 1827, 6 significativamente diferentes e 12 inéditos; o que resulta em mais de $50 \%$ de artigos bastante diferentes ou inéditos em relação ao projeto do deputado mineiro ${ }^{426}$. Chamam principalmente a atenção, neste ponto, a introdução do crime de estabelecimento de casas de jogos (art. 281) e as modificações introduzidas na caracterização de crimes como os de ajuntamentos ilícitos, (arts. 286 a 289 e arts. 291 a 294) e uso indevido da imprensa (arts. 303 e 307).

Ao final desta comparação, salta aos olhos o modo como, tendo perpassado todas as seções do projeto de Vasconcelos, as alterações aí empreendidas privilegiaram indiscutivelmente a concepção penal e os crimes públicos do código imperial. Pensadas conjuntamente, tais alterações apontam para a importância política assumida pelo diploma criminal e para o modo específico com que os deputados brasileiros souberam utilizar este documento: seguindo os padrões legados pelo iluminismo jurídico e pelo processo codificacionista vivenciado pelo ocidente na virada do século XVIII ao XIX, e admitindo a modernização por eles imposta a vários dos dispositivos do projeto sobre o qual trabalhavam, em especial no tocante às suas penas.

Tem-se aqui, portanto, mais um indício do impacto desempenhado pela história da codificação ocidental sobre o Império brasileiro e uma prova do modo com que, aqui, como lá, a positivação das leis penais esteve diretamente relacionada à conjuntura formativa dos Estados nacionais e às contendas políticas então necessariamente travadas.

\footnotetext{
${ }^{426}$ Assim como na comparação entre as Partes Gerais do projeto de 1827 e do Código de 1830 , deve-se ter em mente que parte dos artigos referentes aos crimes policiais do projeto de Vasconcelos foi subdividida em mais de um artigo em 1830, ocorrendo ainda a supressão de artigos entre um momento e outro. Ou seja, a diferenças propriamente conteudísticas devemos somar as alterações organizacionais impostas ao diploma de 1827. Ver nota 407 desta dissertação.
} 
Antes, contudo, de passarmos à consideração dos projetos políticos articulados no interior do Parlamento brasileiro e expressos nas diversas fases de elaboração do diploma penal do Império, é importante - com o objetivo de melhor compreender suas formulações - identificarmos as origens dos dispositivos que o compunham e as matrizes penais utilizadas em sua elaboração, modificações e adaptações.

Sobre que base jurídica teriam se erguido, assim, o projeto de Bernardo Pereira de Vasconcelos e o Código de 1830 e, mais do que isso, a partir de que matrizes penais teriam os legisladores brasileiros operado as mudanças e modernizações aqui reconhecidas? Para além de uma conjuntura política bastante peculiar, que provavelmente atuou como gatilho para parte importante das alterações empreendidas sobre o diploma penal imperial, teriam os legisladores brasileiros se apoiado em algum modelo jurídico preciso? Teriam feito uso, nesse sentido, de alguma fonte penal em especial? Se sim, de qual(is)? É justamente esta a questão a que nos dedicaremos na sequência.

\subsection{Matrizes e influências penais do Código brasileiro de 1830}

A investigação das matrizes utilizadas pelos legisladores brasileiros na elaboração do Código de 1830 deve se iniciar, como não poderia deixar de ser, pela identificação das principais fontes consultadas por Bernardo Pereira de Vasconcelos na elaboração de seu projeto.

As circunstâncias que cercaram a composição do "Projecto do Código Criminal" de Vasconcelos, contudo, restam em grande medida desconhecidas. Na biografia escrita por Otavio Tarquínio de Souza, consta que Vasconcelos não teria comparecido às últimas sessões da Câmara dos deputados de 1826 (mês de agosto) por motivos de saúde, tendo-se retirado na sequência para a vila de Ouro Preto e ali permanecido até o recomeço dos trabalhos no ano seguinte. De acordo com o autor, em Ouro Preto, Vasconcelos teria se recuperado rapidamente de seus desconfortos e dado início à “incansável” escrita de seu projeto de código penal.

No $O$ Universal, de 22 de janeiro de 1827 [...], lê-se o anuncio da "subscrição a $1 \$ 600$ por exemplar do projeto do Código do Império composto por Bernardo Pereira de Vasconcelos, deputado". Quem por doente deixara de comparecer à Câmara nos últimos oito dias da sessão de 1826 e por isso fora admoestado por seus pares, estaria de volta ao Rio, em abril de 1827, com um trabalho que por si só perpetuaria o seu nome e marcaria o progresso das ideias liberais, na sua maior expansão. Deixando Ouro Preto com a despedida pelo $O$ Universal, dirigida "aos amigos, conhecidos e a toda a Província”, ei-lo que chegava à Câmara com os 
originais do projeto de que sairia em grande parte o futuro Código Criminal do Império $^{427}$.

Para o jurista chileno Bernardino Bravo Lira, é importante destacar a rapidez com que, retirado em Vila Rica (antiga denominação de Ouro Preto), Vasconcelos elaborou seu diploma penal ${ }^{428}$. Tratando da personalidade de Vasconcelos e do processo de composição de seu projeto, Bravo Lira afirma:

Apesar de sus limitaciones físicas, molestos dolores a la espalda, desplegó una actividad desbordante. Su genio áspero y su agudeza, le valieron el apodo de Franklin o Mirabeau. Así se explica que en un mínimo de tiempo, no más de siete meses, haya podido componer su proyecto durante una estancia en su Vila Rica natal, entre septiembre de 1826 y abril de $1827 .{ }^{429}$

Quanto às possíveis fontes do direito consultadas e utilizadas por Vasconcelos, Otávio Tarquínio comenta vagamente o conhecimento e uso feito pelo deputado de modelos preexistentes da codificação penal ocidental, enquanto Bravo Lira é enfático no reconhecimento do Código Penal austríaco de 1803 como principal influência de Vasconcelos $^{430}$.

Apesar do protagonismo atribuído ao código austríaco, Bravo Lira não ignora, contudo, a possibilidade de consulta a outras fontes pelo deputado:

Vasconcelos no da luz sobre las fuentes que utilizó. Por supuesto, el libro V de las Ordenações [sic]. Pero como no pretende consolidar el derecho vigente sino codificarlo, es lógico que tuviera en cuenta el Proyecto de Mello Freire y alguno de los códigos más recientes, no solo el austriaco de 1803, sino el francés de 1810, el bávaro de 1813 , y el español de 1822 . No es probable que los tuviera todos a su

${ }^{427}$ Otavio Tarquínio de Sousa. História dos fundadores do Império do Brasil, v.5: Bernardo Pereira de Vasconcelos. Rio de Janeiro: Livraria José Olympio, 1960; p.61.

${ }^{428}$ Bernardino Bravo Lira. "Bicentenario del Codigo Penal de Austria: su proyección desde el Danubio a Filipinas". Op. Cit.; 2004. Ainda que pareça estranha a referência ao caso brasileiro num artigo dedicado à identificação das influências do Código Penal austríaco de 1803, de autoria do jurista Franz von Zeiller (1751-1828), na codificação penal do mundo ocidental, Bravo Lira reconhece neste diploma uma das principais fontes do projeto elaborado por Bernardo Pereira de Vasconcelos.

${ }^{429}$ Idem.

${ }^{430}$ Quanto a tal influência, Bravo Lira afirma: "Naturalmente una obra realizada en estas condiciones no fue ni pudo ser original, es decir, un texto nuevo tal como lo son el CPA [Código Penal Austríaco] y el código civil de Chile. Fue más bien una reelaboración de un texto ya existente. Su labor consistió más bien en poner en artículos el derecho patrio, como lo había hecho Mello Freire, pero esta vez dentro de los moldes del CPA. Trabajó sobre la obra de Zeiller y su tarea fue nada menos que reformular el derecho portugués vigente en Brasil, según el modelo centroeuropeo, el más avanzado de la época.” Op. Cit.; p. 11. Vale a pena ressaltar neste ponto que, no que diz respeito ao reconhecimento do Código austríaco de 1803 como fonte fundamental do projeto de Vasconcelos, Bravo Lira é explicitamente seguido pelo jurista brasileiro José Reinaldo de Lima Lopes. Para tanto, ver: José Reinaldo de Lima Lopes. O Direito na História: lições introdutórias. São Paulo: Atlas, 2009; p. 265. 
alcance en su retiro de Vila Rica. ${ }^{431}$

$\mathrm{O}$ autor hesita, contudo, neste ponto, entre o reconhecimento da consulta de Vasconcelos aos diplomas penais do mundo ocidental e a afirmação de seu completo desapreço pelo emprego de modelos estrangeiros na positivação do direito nacional. Para Bravo Lira, o projeto de Vasconcelos, apesar de organizado de forma similar ao código austríaco de 1803, pode ser considerado totalmente isento de ecletismos ou cópias de dispositivos de outras codificações existentes à altura: "Naturalmente consulta los códigos europeos, pero, no hay nada de eclecticismo. Antes bien, deja en claro su repulsión por el mismo., ${ }^{, 42}$

Vê-se, assim, que na ausência de comprovações documentais, as leituras sobre a elaboração deste projeto foram múltiplas, deslocando-se livremente entre uma abordagem excessivamente generalizante da questão e o reconhecimento incisivo da filiação deste diploma à tradição centro-européia do direito penal ocidental.

Interessados na detecção precisa das matrizes e influências penais operadas sobre este projeto e, especialmente, sobre o texto final do Código de 1830, comparamos pontualmente as disposições presentes em seus textos aos dispositivos de dez códigos penais ou projetos de codificação penal existentes àquela altura no mundo ocidental, para além, obviamente, do conteúdo do Livro V das Ordenações Filipinas ${ }^{433}$.

Desta forma, o texto do projeto elaborado por Vasconcelos entre os anos de 1826 e 1827 foi por nós cotejado (para além do Livro V) com o conteúdo dos seguintes diplomas penais: o Código da Toscana de 1786 (também conhecido como Leopoldina, brevemente apresentado na Introdução desta dissertação) ${ }^{434}$; o Código penal austríaco de 1787 (Josefina), em versão traduzida para o inglês no próprio ano de $1787^{435}$; a Algemeines Landrecht prussiana de 1794, em tradução para o francês de $1801^{436}$; o Código penal austríaco de $1803^{437}$; os Códigos penais franceses de 1791 e

\footnotetext{
${ }^{431}$ Bravo Lira. Op. cit.; p. 11.

${ }^{432}$ Bravo Lira. Op. cit.; p. 8.

433 Silvia Hunold Lara (org.). Ordenações Filipinas: Livro V. São Paulo: Companhia das Letras, 1999.

${ }^{434}$ Nouveau Code Criminel pour le Grande Duche de Toscane (1786). Publié par ordre de Son Altesse Royale Monseigneur Le Grand Duc. Traduit de L'Italien a Lausanne, chez François Grasset et Comp. Libraires \& Imprimeurs, 1787.

${ }^{435}$ The Emperor New Code of Criminal Laws. Published at Vienna, the $15^{\text {th }}$ of January, 1787. Translated from the German, by an officer. Dublin: Printed by John Rea, 1787.

${ }^{436}$ Code General pour lês Etats Prussiens, traduit por les Membres du bureau de Législation étrangère, et publié par ordre du Ministre de la Justice. Paris, Imprimerie de la République, ano IX (1801), 3 volumes. Ver Titulo XX : « Des délits et des peines »; pp. 136-356.
} 
$1810^{438}$; o Código bávaro de $1813^{439}$, cuja versão em francês, por nós consultada, não se encontrava disponível à época, existindo apenas, então, o original em alemão; o Código Penal Espanhol de $1822^{440}$; e o projeto de Código Criminal de Pascoal de Melo Freire, elaborado para Portugal no ano de $1786^{441}$.

Em termos organizacionais, como dito, o projeto de Vasconcelos distinguiu-se, e muito, da maioria dos códigos analisados. Nesse sentido, ainda que a estrutura de seu diploma possua semelhanças pontuais com o código bávaro de 1813 (como abordado ao final do capítulo 1), tais semelhanças não nos pareceram suficientes para que uma filiação direta fosse estabelecida entre estes documentos.

A comparação entre o conteúdo do projeto de Vasconcelos e o dos diplomas penais listados revelou, contudo, a inquestionável utilização, pelo deputado mineiro, de ao menos três destes documentos. Desta forma, dos 334 artigos de que se compunha o projeto de Vasconcelos, 32 basearam-se incontestavelmente no Código Penal Espanhol de 1822, 24 advieram do Código francês de 1810 e 10 deveram sua elaboração ao Projeto Melo Freire.

Ao nos referirmos aqui à "inquestionável utilização", por Vasconcelos, de determinados diplomas penais do período, reportamo-nos especificamente aos casos em que houve transposição clara dos dispositivos destes códigos ao texto elaborado pelo deputado mineiro. É apenas nesse sentido, afinal, que podemos confirmar o emprego efetuado por Vasconcelos de diplomas específicos do período, haja vista o compartilhamento de uma série de normativas presentes em seu projeto por outros códigos coevos - impossibilitando, portanto, que atestássemos um ou outro deles como sua fonte legítima. Nesse sentido, o que se percebe é que o deputado mineiro foi tributário de uma matriz teórica comum, à época, ao conjunto do direito penal

${ }^{437}$ Codice Penale Universale Austriaco coll' Appendice delle Piú Recenti Norme Generali. Seconda edizione ufficiale. Milano, Dall'Imp. Regia Stamperia, 1815. Code Pénal Général de l'empire d'Autriche, par M. Victor Foucher, Paris, Imprimerie Royale, 1833, disponível em http://gallica.bnf.fr.

${ }^{438}$ Lois de la Rébublique Française an IV [...] Code des Delits et des Peines, 1791 ; disponível em http://gallica.bnf.fr, consultado em 07/07/2010; e «Code des délits et de peines ». In : Corps de Droit Français, civil commercial et criminel. Par L. Rondonneau. Paris, Garnery Libraire, 1810 ; pp. 439-486.

${ }^{439}$ Code Penal du Royame de Bavière (1813). Traduit de l'Allemand par Ch. Vatel. Paris, Auguste-Durand, Libraire-Éditeur, 1852.

${ }^{440}$ Código Penal Español, Decretado por las Cortes en 8 de Junio, Sancionado por El Rey, y mandado promulgar en 9 de julio de 1822. Madrid, Imprenta Nacional, año de 1822.

${ }^{441}$ Pascoal José de Mello Freire, Código criminal intentado pela Rainha D. Maria I, Coimbra, Imprensa da Universidade, 1844, "Provas do Direito Criminal" (disponível no site http://www.fd.unl.pt). 
ocidental. Desta feita, procuramos destacar aqui os casos cuja ascendência pôde ser precisamente reconhecida, deixando pouco espaço a dúvidas sobre se Vasconcelos teve, ou não, ao seu alcance os diplomas citados no processo de composição de seu projeto.

Enquanto a influência penal francesa predominou na Parte Geral do projeto, que teve sete de seus artigos inspirados naquele diploma ${ }^{442}$ (e apenas quatro derivados do Código espanhol ${ }^{443}$ e um do projeto Melo Freire ${ }^{444}$ ); os crimes públicos do texto de Vasconcelos foram majoritariamente influenciados pelo diploma espanhol de 1822, que serviu de base a 24 dos 107 artigos que compunham aquela seção ${ }^{445}$ (ao lado de seis artigos diretamente inspirados pelo projeto Melo Freire ${ }^{446}$ e três advindos do diploma francês de $1810^{447}$ ).

No que diz respeito aos crimes particulares prescritos pelo deputado mineiro, houve predomínio também do Código espanhol de 1822, que inspirou sete dos artigos do projeto $^{448}$, ao lado das influências exercidas pelo códigos francês de 1810 (em dois $\operatorname{artigos}^{449}$ ) e pelo projeto Melo Freire de 1786 (também em dois artigo ${ }^{450}$ ). Entre os

${ }^{442}$ Os artigos da Parte Geral do projeto de Vasconcelos diretamente inspirados pelo Código penal francês de 1810 foram os de número: 1, 45, 46, 60, 61, 66 e 72; inspirados, respectivamente nos artigos $2,54,12,25,14$ e 15 do diploma francês.

${ }^{443}$ Os artigos da Parte Geral do diploma de Vasconcelos inspirados no Código penal espanhol de 1822 foram os seguintes: 18, 42, 105 e 106, e 108 e 109. Os artigos do Código espanhol utilizados por Vasconcelos foram, respectivamente: $625\left(\S 6^{\circ}\right), 101$ e 102 , e 163.

${ }^{444} \mathrm{O}$ parágrafo 35 do Titulo IV do projeto português inspirou, assim, o artigo 44 da Parte Geral do diploma de Vasconcelos.

${ }^{445}$ Nesta nota, a especificação dos artigos dos crimes públicos do projeto de Vasconcelos inspirados no diploma espanhol de 1822 vem exposta da seguinte maneira: a cada artigo citado do projeto brasileiro colocou-se entre parênteses o artigo tomado como base no código espanhol. Os casos foram os seguintes: art. 226 (art. 421); art. 231 ( $\S 1,3,4,5$ e 7 do art. 451); arts. 240 e 243 (art.472); arts. 241 e 242 (arts. 471 e 470); arts. 245 e 246 (art. 474); art. 247 (art. 478); art. 250 (art. 481); art. 251 (art. 482); art. 259 (art. 492); art. 260 (art. 493); art. 261 (Art. 495); arts. 262 e 263 (arts. 496 e 497); art. 267 (art. 502); art. 268 (art. 503); art. 269 (art. 505); art. 270 (art. 506); art. 271 (art. 507); art. 272 (arts. 513 e 514); art. 273 (art. 516); e $\S \S 2,3$ e 6 do art. 311 (arts. 221, 226 e 189).

${ }^{446}$ Inspiraram-se no Projeto de Pascoal de Melo Freire os seguintes artigos dos crimes públicos de Vasconcelos - segue-se aqui a mesma organização expositiva da nota anterior: art. 284 (Tit. II, § 15); art. 285 (Tit. XIX, § 3); $\S 1$ e 2 do art. 290 (Tit. XIX, §§ 1 e 2); art. 293 (introdução ao Tit. XVI); art. 294 (Tit. XVI, §13); e art. 302 (introdução ao Tit. XV).

${ }^{447}$ Inspiraram-se no Código penal francês de 1810 os artigos 266,319 e 328 dos crimes públicos de Vasconcelos. Os artigos do diploma francês que lhe serviram de base foram, respectivamente, os artigos 196, 84 e 85 .

${ }^{448}$ Respectivamente (caso brasileiro, seguido pela respectiva influência espanhola, entre parênteses): art. 149 (art. 609); art. 156 (art. 671); art. 157 (art. 672); art. 170 (art. 706); art. 178 (arts. 668. 669 e 670); art. 179 (art. 664); e art. 197 (art. 758).

${ }^{449}$ Artigos 166 e 213 do projeto de Vasconcelos, respectivamente inspirados nos artigos 377 e 199 do código penal francês de 1810 . 
crimes policiais do projeto, por fim, as matrizes inegavelmente utilizadas foram o código francês de 1810 e o projeto Melo Freire, influenciando, cada um deles, a composição de dois artigos do texto brasileiro ${ }^{451}$.

A composição deste quadro geral de influências possui, dentre outros, o objetivo de contextualizar a obra de Vasconcelos na conjuntura internacional do direito penal coevo, situando-a no interior de um movimento codificacionista ocidental de largo alcance e reconhecendo o modo com que a matriz jurídica então disponível foi constantemente ressignificada nos diferentes contextos por que passou.

Haja vista, contudo, a multiplicidade das alterações empreendidas sobre o projeto de Vasconcelos, não basta reconhecer as influências perceptíveis neste texto, fazendose necessária a extensão de semelhante operação analítica ao diploma finalmente aprovado em 1830.

Como vimos no Capítulo 2, entre os anos de 1829 e 1830, o texto do futuro código criminal passou pelas mãos de ao menos três comissões parlamentares de trabalho especificamente dedicadas a alterá-lo e revisá-lo. Cientes dos trabalhos e interferências operadas por estas comissões, pretendemos destacar, na sequência, as fontes penais por elas consultadas e utilizadas, bem como os momentos específicos de sua introdução no texto do código nacional, buscando os possíveis significados subjacentes à sua escolha.

Com este intuito, também a versão final do Código de 1830 foi minuciosamente comparada aos códigos e projetos de codificação penal citados acima, com a novidade de ter-se incluído nesta lista o Projeto de Código Penal elaborado por Edward Livingston para o Estado norte-americano da Luisiana entre os anos de 1822 e 1824, também conhecido como "Code of Offences and Punishments" mãos dos representantes brasileiros somente em 1830, o projeto de Livingston foi

\footnotetext{
${ }^{450}$ Tanto o artigo 164, quanto o parágrafo $2^{\circ}$ do artigo 213 do texto de Vasconcelos basearamse no diploma lusitano elaborado por Melo Freire, fundando-se, respectivamente, no $\S 11$ de seu Titulo 35, e no parágrafo $6^{\circ}$ de seu Titulo 39.

${ }^{451}$ Os artigos franceses utilizados na composição dos crimes policiais do projeto de Vasconcelos foram, respectivamente, os artigos 275 e 276, em que se inspirou a elaboração do artigo 115 do projeto brasileiro; e o artigo 330, utilizado na criação do artigo 160 do projeto brasileiro. Já no caso do projeto Melo Freire, o parágrafo 7 do Titulo 23 parece ter inspirado o parágrafo $2^{\circ}$ do artigo 111 do projeto de Vasconcelos, enquanto o parágrafo 29 do Titulo 36 faria o mesmo para o artigo 126 do diploma brasileiro.

${ }^{452}$ Edward Livingston. A System of Penal Law prepared for the State of Louisiana. NewOrleans: printed by Benjamin Levy, 1824.
} 
excluído da lista dos possíveis códigos consultados por Bernardo Pereira de Vasconcelos.

Os resultados advindos desta nova comparação são, uma vez mais, bastante interessantes e reveladores das escolhas jurídicas e políticas empreendidas pelos deputados e senadores brasileiros das primeiras legislaturas do Império.

Desta forma, dos cerca de 88 artigos inéditos do texto de 1830 (inexistentes, portanto, no projeto de Vasconcelos), 20 resultaram da "transposição" efetiva de dispositivos de outros códigos ocidentais. Nossa comparação revelou, assim, que 17 destes artigos foram diretamente influenciados pelo Projeto de Código Penal da Luisiana, dois advieram do Código Penal francês de 1810 e um do Projeto Melo Freire de $1786^{453}$.

Para além dos artigos inéditos de 1830, também as alterações empreendidas sobre dispositivos preexistentes no texto de Vasconcelos pautaram-se, muitas vezes, pelo uso das fontes citadas. Os códigos consultados e utilizados neste processo foram, por ordem de utilização (da maior para a menor incidência): o projeto de Livingston, o Código Penal Espanhol de 1822, o Código Penal francês de 1810, o Projeto Melo Freire de 1786, e a Leopoldina, também de 1786.

Vejamos, na sequência, o modo com que dispositivos pertencentes aos diferentes códigos citados foram introduzidos no texto do diploma brasileiro.

Apesar de concentrarmos nossa análise na identificação e arrolamento dos artigos "copiados" dos textos de códigos estrangeiros, deve-se ter em mente, uma vez mais, o fato de a influência daquele rol de códigos ultrapassar, muitas vezes, os casos de transposição aqui listados. A identificação destes casos precisos, contudo, como na análise do projeto de Vasconcelos, serviu-nos para que pudéssemos confirmar a consulta e uso efetivo, pelos legisladores nacionais, de uma série de diplomas estrangeiros existentes àquela altura.

\footnotetext{
${ }^{453}$ Os artigos inéditos do código de 1830 advindos do projeto de Edward Livingston foram: art. 64 (baseado no art. 35 do diploma norte-americano); art. 93 (art. 119 no original); art. 94 (art. 118); art. 97 (arts. 124 e 149); art. 98 (art. 205); arts. 113, 114 e 115 (arts. 115, 116 e 117); art. 117 (art. 164); art. 196 (art. 548); art. 253 (art. 349); art. 287 (art. 211); art. 289 (art. 218); art. 291 (art. 219); art. 292 (art. 220); art. 293 (art. 219); art. 294 (art. 218). Os artigos advindos, por sua vez, do Código penal francês de 1810 foram: art. 71 (proveniente dos arts. 76 e 77 do diploma francês); e art. 234 (art. 370). Já os advindo do Projeto Melo Freire de 1786 foram o artigo $6^{\circ}$, influenciado pelo parágrafo 28 do Titulo XXXVI, e o artigo 227, baseado no conteúdo do parágrafo 21 do Titulo XII do diploma português.
} 


\section{O Código penal espanhol de 1822}

Comecemos pela predominante influência exercida pelo Código Penal Espanhol de 1822 na configuração final do texto do Código de $1830^{454}$. Herdeiros, em grande medida, da inspiração exercida já sobre Bernardo Pereira de Vasconcelos, os pontos de influência deste código foram revistos e complementados, contudo, pelas comissões parlamentares de trabalho de 1829 e 1830 .

Assim como no diploma de Vasconcelos, os dispositivos transpostos do Código espanhol foram encontrados predominantemente no Capítulo I ("Prevaricações, abusos e omissões dos funcionários públicos") da seção "Dos Crimes Contra a Boa Ordem e Administração Pública" do Código de 1830 - Titulo V de sua Parte Segunda ("Dos crimes públicos") -, perpassando a definição dos crimes de "concussão", "excesso ou abuso de autoridade ou influência proveniente do emprego", "falta de exacção no cumprimento dos deveres" e "irregularidade de conduta", todos exclusivamente passíveis de serem cometidos por funcionários públicos da nação. Composto por um total de 38 artigos (de número 129 a 166), o Capítulo I teve a redação de cerca de 20 deles proveniente da influência do código espanhol.

Atentemos a dois exemplos emblemáticos desta utilização, materializados nos artigos 144 e 166 do Código de 1830, respectivamente baseados nos artigos 496 e 495 do diploma de $1822^{455}$ :

Art. 496. El funcionario público que en los actos de su oficio y escediéndose de las facultades de mandar, advertir, reprender, corregir ó castigar arregladamente, ofenda, ultraje, injurie ó maltrate de obra, de palabra ó por escrito á alguno de sus subalternos ó dependientes, será suspenso de su empleo ó cargo por dos meses á cuatro años $[\ldots]$.

\footnotetext{
${ }^{454}$ Elaborado a partir de 1820 e promulgado em 1822, o primeiro código penal da Espanha se erige, como a maioria dos modernos códigos europeus, sob a influência direta das ideias do iluminismo penal. Se este documento consagrava, contudo, princípios ilustrados como o da legalidade e certeza do direito, o da proporcionalidade entre delitos e penas, e o de imposição de limites ao arbítrio judicial, ele simultaneamente exprimia um catálogo bastante duro de punições (prescrevendo, dentre outras, as penas de morte, confisco e tortura), mantendo institutos e procedimentos pertencentes às Partidas e ao Fuero Juzgo (que compunham o direito previgente no território espanhol) e não acatando por completo ao princípio da unidade tipológica dos sujeitos de direito. Herdeiro das reformas penais pós-revolucionárias, portanto, nem por isso o código espanhol de 1822 deixava de possuir elementos típicos de um direito penal de Antigo Regime. Francisco Tomás y Valiente. Manual de Historia del Derecho Español. Madrid: Editorial Tecnos, 2011; pp. 496-497.

${ }^{455}$ Para uma visualização completa da estrutura organizativa do Código Penal Espanhol de 1822 consultar seu Índice no anexo V.
} 
Art. 144. Exceder a prudente faculdade de reprehender, corrigir, ou castigar, offendendo, ultrajando, ou maltratando por obra, palavra, ou escripto algum subalterno, ou dependente, ou qualquer outra pessoa, com que se trate em razão de officio. Penas - de suspensão por um a dez mezes.

Art. 495. El funcionario público [...] que sea convencido de incontinencia pública y escandalosa, ó de embriaguez repetida, ó de vicio en juegos prohibidos, [...] ó de manejarse con conocida ineptitud ó desidia habitual en el desempeño de su cargo, perderá tambien su empleo ú oficio, y no podrá tener otro alguno público hasta que no haga constar su completa enmienda [...].

Art. 166. O empregado publico, que fôr convencido de incontinencia publica, e escandalosa; ou de adidos de jogos prohibidos; ou de embriaguez repetida; ou de haver-se com ineptidão notoria; ou desídia habitual no desempenho de suas funcçõs. Penas - de perda do emprego com inhabilidade para obter outro, emquanto não fizer constar a sua completa emenda.

A ascendência desempenhada pelo diploma espanhol sobre a regulamentação dos crimes dos funcionários públicos do Código de 1830 chama a atenção por conta da importância assumida por semelhante questão no momento de formação dos novos Estados nacionais e por sua presença em praticamente todos os códigos penais elaborados entre o final do século XVIII e o início do XIX. Como vimos na Introdução, a superação do regime de "direito comum" na Europa pressupôs, em grande medida, o estabelecimento de limites legais à atuação dos juízes e magistrados nacionais, tornando a regulamentação da responsabilidade dos funcionários do Estado tema praticamente obrigatório no momento de positivação das novas leis.

Herdeira, em grande medida, da redação previamente adotada por Bernardo Pereira de Vasconcelos, a regulamentação dos crimes dos funcionários públicos no diploma brasileiro pode ser relacionada à preocupação explicitada por este deputado, nos primeiros anos da legislatura imperial, com a elaboração de normas reguladoras da atividade e responsabilidade dos empregados da nação. Nos debates parlamentares travados entre 1826 e 1830, a temática da responsabilidade veio constantemente à tona a partir dos posicionamentos de Vasconcelos, fosse questionando, como vimos, se tais prescrições deveriam ou não tomar parte no código penal brasileiro, fosse advogando a centralidade constitucional inerente à regulamentação da questão ${ }^{456}$.

Não deve ter sido aleatória, portanto, sua escolha pelo Código espanhol de 1822. Ainda que, infelizmente, não tenhamos tido acesso a estudos centrados sobre este

${ }^{456}$ Fernando Martínez Pérez. Entre confianza y responsabilidad. La justicia del primer constitucionalismo español (1810-1822). Madrid: Centro de Estudios Políticos y Constitucionales, 1999. Ver especialmente o Capítulo segundo: "Responsabilidad Judicial"; pp. 155-259. 
documento específico ou sua elaboração, sabemos da importância assumida pela questão da responsabilidade no movimento constitucionalista espanhol de inícios do século XIX e do prosseguimento dado a esta preocupação no código penal de 1822, parecendo-nos plausível supor que, conhecedor desta realidade ibérica, Vasconcelos tenha propositalmente procurado no diploma hispânico um modelo para a regulamentação destes crimes.

No interior da experiência gaditana, a gestação de um sistema de responsabilidade desenvolveu-se paralelamente - e, por vezes, em conflito - à assunção do Congresso como depositário privilegiado da soberania nacional, com as Cortes Gerais e Extraordinárias convertendo-se no sujeito a que (em substituição aos antigos monarcas) os juízes e funcionários da nação deveriam a partir de então prestar $\operatorname{contas}^{457}$.

Quando da elaboração da Constituição espanhola de 1812 e da discussão sobre a responsabilidade dos magistrados, não foram incomuns (assim como no Brasil) as críticas direcionadas à atuação arbitrária de parte do funcionalismo público do país. Aprovado o texto constitucional, contudo, mantiveram-se vários dos problemas relativos a esta atuação, tornando necessária a elaboração de novas leis capazes de materializar a imposição e obediência aos ditames da Constituição. Foi neste contexto que surgiu o decreto de 24 de março de 1813, regulamentando as atividades de todos os empregados da nação ${ }^{458}$.

Nos anos que se seguiram, de formação e estabilização do regime liberal espanhol, o sistema de responsabilidades criado pelas Cortes - fortemente ligado à defesa da Constituição e à legitimidade do judiciário - foi se concretizando a partir da recuperação de mecanismos de defesa da lei fundamental e do processo de formação dos códigos nacionais ${ }^{459}$. Deve-se ressaltar, ainda, que foi a partir da criação e desenvolvimento de um sistema de responsabilidade e da resolução progressiva de uma série de conflitos jurisdicionais que, nas palavras Martinéz Pérez, foi-se

\footnotetext{
${ }^{457}$ Idem. Ibidem.

458، "La discusión del proyecto de decreto de responsabilidad se vio jalonada con la comunicación a las Cortes de reclamaciones de responsabilidad contra todos tipos de empleados, motivadas tanto por el incumplimiento de las disposiciones mediante las cuales se pretendía poner en pie el sistema constitucional, como de actuaciones en las que se desconocían las garantías contenidas en el texto constitucional. En todo caso, que la presentación de los casos caminase por delante de las medidas legislativas contribuyó a que se generase más una práctica que un régimen juridico sistematizado en el tratamiento de las infracciones." Idem; pp. 172-173.

${ }^{459}$ Idem; pp. 175-179.
} 
clarificando, aos poucos, o alcance e as competências de cada autoridade estatal, e se estabelecendo um desenho institucional do Estado tendencialmente informado por princípios de obediência, centralização e hierarquia. Daí a importância fundamental desta regulamentação num contexto de aparelhamento estatal como o vivido pela Espanha e, posteriormente, pelo Brasil ${ }^{460}$.

A partir das regulamentações específicas adotadas pelo decreto de 1813 fundadas no preceito de que as autoridades públicas deveriam tornar efetivos os direitos e deveres dos espanhóis, e diretamente relacionadas à garantia da observância e cumprimento da nova ordem política instaurada - o Código penal hispânico de 1822 prescreveu os tipos penais prevaricação, suborno e má conduta, nos quais Bernardo Pereira de Vasconcelos foi buscar inspiração. Neste processo, enfim, a regulamentação brasileira dos crimes de funcionários públicos tornou-se curiosamente herdeira do modelo de responsabilidade que, ao longo das duas primeiras décadas do século XIX, o constitucionalismo espanhol buscara instituir naquele país.

Para além da influência exercida sobre os crimes públicos do diploma brasileiro, o código espanhol de 1822 influiu também na redação de artigos da parte dedicada aos crimes particulares, valendo mencionar a tipificação de crimes como a "bancarrota" e o "roubo". Vejamos inicialmente o caso da bancarrota, respectivamente regulamentada pelos artigos 758 do código espanhol e 263 do código brasileiro:

Art. 758. La quiebra que con arreglo al código ó leyes de comercio fuere declarada fraudulenta, será castigada con la pena de diez á veinte años de presidio [...].

Art. 263. A bancarrota, que fôr qualificada de fraudulenta na conformidade das Leis do commercio, será punida com a prisão com trabalho por um a oito annos. $\mathrm{Na}$ mesma pena incorrerão os complices.

O caso do crime de "roubo", por sua vez, merece atenção especial. Ainda que diversos dos diplomas por nós analisados tenham distinguido, dentre os crimes contra a propriedade, as categorias de "furto" e "furto praticado com violência" denominado por vezes, nos diplomas de origem germânica, raub -, a definição de roubo (enquanto crime de furto com violência) especificamente presente no código brasileiro, como veremos, adveio indubitavelmente do diploma espanhol. Comparemos brevemente, assim, o conteúdo dos artigos 723, 724, 725 e 726 do Código espanhol de 1822 aos artigos 269, 270 e 273 do Código de 1830 correspondentes, no diploma de Vasconcelos, aos artigos 203, 207, 210 e 211.

${ }^{460}$ Idem; p. 181. 
Art. 723. Comete robo el que quita ó toma para sí con violencia ó con fuerza lo ageno.

Art. 724. La violencia ó fuerza se hace á las personas ó á las cosas.

Art. 269. Roubar, isto é, furtar, fazendo violencia á pessoa, ou ás cousas. Penas galés por um a oito annos.

Art. 725. Son fuerza ó violencia hecha á la persona los malos tratamientos de obra, las amenazas, la orden de entregar ó manifestar las cosas, la prohibición de resistir ó de oponerse á que se quiten, y cualquiera acto que pueda naturalmente intimidar, ú obligar á la manifestación ó entrega. Entiéndese que hace fuerza ó violencia é la persona el que roba fingiéndose ministro de justicia ó funcionario público de cualquiera clase, ó alegando una orden falsa de alguna autoridad.

Art. 726. Son fuerza ó violencia hecha á las cosas el escalamiento de edificio, pared ó cerca; la fractura de pared, puerta, ventana, reja, techo, armario, escritorio, cofre, arca, cómoda, maleta, papelera ó de cualquiera otra cosa cerrada, y de las sogas, correas ó ataduras de cualquiera cosa atada; y la abertura de agujeros ó conductos subterráneos, ó por debajo de las puertas ó paredes. Entiéndese que hace fuerza ó violencia á las cosas, el que usa de falsa llave, de ganzúa, o de cualquiera otro instrumento que no sea la llave propia y verdadera, ó de esta sin consentimiento del dueño; ó el que se vale de algun doméstico para abrir alguna cosa, ó introducirse en alguna casa ó lugar cerrado.

Art. 270. Julgar-se-ha violencia feita á pessoa, todas as vezes que por meio de offensas physicas, de ameaças, ou por outro qualquer meio, se reduzir alguem a não defender as suas cousas. Julgar-se-ha violência feita á cousa, todas as vezes que se destruírem os obstáculos á perpetração dos roubos, ou se fizerem arrombamentos exteriores, ou interiores. Os arrombamentos se considerarão feitos todas as vezes que se empregar a força, ou quaesquer instrumentos, ou apparelhos para vencer os obstaculos.

Art. 273. Também se reputará roubo, e como tal será punido, o furto feito por aquele, que se fingir empregado publico, e autorizado para tomar a propriedade alheia.

Para além dos casos citados, o Código espanhol influenciou ainda as disposições presentes em cerca de três artigos da Parte Geral do Código de 1830 - o $\S 6^{\circ}$ do artigo 14, referente a casos de crimes justificáveis; o artigo 63, que fixava a existência de três graus, máximo, médio e mínimo, na imputação de penas aos delitos; e o artigo 66, referente ao perdão ou minoração das penas impostas aos réus - totalizando, afinal, sua ascendência sobre 34 dos 313 artigos do código brasileiro.

Elaborado e aprovado, portanto, num país ibérico cujo substrato legal e o movimento constitucional recente aproximavam-no, de certa forma, da conjuntura política vivida pelo Brasil, o diploma penal espanhol de 1822 acabou por fornecer parte importante das prescrições criminais do Código de 1830. 


\section{O Code of Offences and Punishments e o Code of Procedure de Edward}

\section{Livingston}

Imediatamente após o Código espanhol, tem-se no "Code of Offences and Punishments", de Edward Livingston, o diploma penal mais influente sobre o código brasileiro. Responsável pelos dispositivos presentes em ao menos 24 dos 313 artigos do código, o uso do projeto do jurisconsulto nova-iorquino pelos legisladores imperiais é sem dúvida aquele que causa maior espanto.

De saída, deve-se atentar ao fato de o primeiro artigo do Código de 1830 - "Não haverá crime, ou delicto (palavras synonimas neste código) sem uma Lei anterior, que o qualifique." - dever seu posicionamento no interior do código e sua composição específica, ao que tudo indica, à influência exercida pelo projeto de Livingston. Isto porque este projeto foi o único, dentre os diplomas provavelmente consultados pela deputação nacional ${ }^{461}$, a regulamentar de forma individualizada (ou seja, num único artigo, exclusivamente dedicado à esta questão) e como primeira prescrição do código (entenda-se, como seu parágrafo de número 1), o princípio da precedência da lei na definição da conduta delituosa, ou seja, o nullum crimen, nulla poena sine praevia lege. Dizia o artigo $1^{\circ}$ do projeto de Livingston: "No act or omission done or made before the promulgation of the law which forbids it, can be punished as an offence." $^{\text {"462 }}$

No tocante à seção dos crimes públicos do código brasileiro, a influência desempenhada pelo projeto de Livingston pode ser sentida, fundamentalmente, na elaboração dos crimes regulados pelos Títulos II e III - respectivamente referentes aos "crimes contra o livre exercício dos poderes políticos" (arts. 91 a 99) e aos “crimes contra o livre gozo e exercício dos direitos políticos dos cidadãos" (arts. 100 a 106) - e na inserção do emblemático crime de "Insurreição" escrava, regulado pelos artigos de número 113, 114 e 115.

\footnotetext{
${ }^{461}$ O Código penal austríaco de 1787 regulou também, em seu artigo primeiro, o princípio da precedência da lei na definição da conduta delituosa ("Art. $1^{\circ}$. Every action contrary to law is not a criminal offence, or a capital crime; and no action contrary to law, shall be considered as criminal, but such as shall have been determined to be so by the present criminal code"). Contudo, não há qualquer elemento que indique a efetiva consulta e utilização deste código pela deputação brasileira no processo de elaboração do Código de 1830.

${ }^{462}$ No projeto de Bernardo Pereira de Vasconcelos, por sua vez, este princípio vinha regulado no artigo $2^{\circ}$, juntamente ao estabelecimento da necessária má fé envolvida num ato criminoso: "Art. $2^{\circ}$. Não ha crime sem lei anterior que o qualifique, e sem má fé, isto é, sem conhecimento do mal e intenção de o praticar."
} 
Os delitos regulados pelo Titulo II da seção dos crimes públicos do Código de 1830 interessam-nos fundamentalmente por fazerem referência direta (i) aos atentados possivelmente oferecidos à Assembleia Geral legislativa do Império, ou a quaisquer de suas Câmaras Legislativas (por meio da oposição a seus decretos, da violência a seus membros ou do constrangimento oferecido a seu funcionamento regular); (ii) às ameaças apresentadas às determinações dos poderes Moderador e Executivo; (iii) à violência dirigida a qualquer membro dos poderes Executivo ou Judiciário; e ainda (iv) aos riscos de levantamento de motins ou desordens durante as seções de um Tribunal de Justiça.

Por meio deste título, portanto, o código regulamentava detalhadamente os crimes atentatórios ao bom funcionamento do regime representativo e parlamentar instaurado no Brasil havia poucos anos, revelando a preocupação dos deputados com a criação de mecanismos jurídicos que, de alguma forma, garantissem a estabilidade do regime, o pleno funcionamento de cada um de seus poderes e, acima de tudo, a inviolabilidade do Legislativo. Dentre os sete artigos inéditos presentes neste Titulo II (arts. 93, 94, 95, 96, 97, 98 e 99), ao menos cinco podem ter suas origens atribuídas às disposições presentes no Projeto de Código Penal da Luisiana ${ }^{463}$.

No Titulo III, por sua vez, as preocupações recaem tanto sobre o bom funcionamento das eleições no Império - regulamentando-se, neste sentido, questões relativas ao impedimento, compra ou falsificação do voto dos cidadãos -, quanto sobre a manutenção da normalidade das atividades dos Conselhos Gerais de província $^{464}$, criminalizando-se (exatamente como nos artigos 92, 93 e 94 do título anterior, referentes às ameaças oferecidas às atividades da Assembleia Geral Legislativa) os obstáculos impostos ao seu funcionamento regular e as ameaças possivelmente oferecidas a seus membros.

\footnotetext{
${ }^{463}$ Neste sentido, enquanto a origem dos artigos 93 e 94 do Código de 1830 pode ser identificada nos artigos 118 e 119 do projeto norte-americano (localizados em seu "Book II: Of Offences and Punishments", “Tit. III: Of offences against the Legislative power"), o artigo 97 do diploma brasileiro foi duplamente influenciado pelos artigos 124 e 149 daquele projeto (localizados no mesmo Book II, respectivamente em seus títulos IV e V, "Of offences against the Executive power" e "Of offences against the Judiciary power"); sendo que, finalmente, o artigo 98 de 1830 pode ser facilmente aproximado do artigo 205 de Livingston (Book II, Tit. V, Chapter I, Section II: "Of offences committed by judges or jurors").

${ }^{464}$ Instituídos pelo Titulo $4^{\circ}$, Capítulo V ("Dos Conselhos Geraes de Província, e suas attrbuições") da Constituição brasileira de 1824, os Conselhos Gerais de Província dariam origem, em 1834 (pós Ato Adicional, portanto) às Assembleias Legislativas Provinciais.
} 
Se, no caso do Titulo II, os artigos 91 e 92 tinham precedentes no diploma de Vasconcelos - compondo, respectivamente, os parágrafos $5^{\circ}$ e $6^{\circ}$ de seu artigo 311 , dedicado aos casos de crime de traição -, no Titulo III, todas as prescrições localizadas entre os artigos 100 e 106 representam novidades completas em relação ao texto de 1827, devendo ao menos quatro de seus artigos à influência de Livingston ${ }^{465}$.

Igualmente referentes, portanto, à regulamentação de delitos relativos à estabilidade e bom funcionamento do regime representativo no Império do Brasil (inexistentes no projeto de Bernardo Pereira de Vasconcelos), e igualmente influenciados pelo diploma da Luisiana, os crimes regulados pelos Títulos II e III da seção dos crimes públicos do Código de 1830 são indicativos de como, ainda num momento de oposição política radical ao imperador e busca de alternativas ao governo do país, zelosos do regime parlamentar instituído havia pouco e cientes do papel desempenhado pelo código penal na garantia de sua estabilidade, os deputados foram cuidadosos na busca por um modelo que cumprisse com tais objetivos.

Uma vez mais, o emprego dos dispositivos de um código estrangeiro vê-se justificado pela importância da matéria regulada à formação e estabilização do novo Estado, e pela autoridade e legitimidade do documento utilizado para este fim. Neste ponto, vale destacar, praticamente nenhum outro diploma do período poderia ter oferecido disposições tão maduras referentes ao equilíbrio e bom funcionamento do regime representativo e à manutenção da regularidade do sistema eleitoral, como o projeto de Edward Livingston.

A inserção do crime de insurreição escrava é também bastante emblemática neste sentido, haja vista sua relação direta com a presença da escravidão no território brasileiro e com a tentativa de controle das ameaças representadas pela população cativa à estabilidade interna. Dentre os crimes públicos do diploma de 1830, o delito

\footnotetext{
${ }^{465}$ Enquanto os crimes regulados pelos artigos 100, 101 e 102 do Titulo III do Código de 1830 , podem ter suas origens atribuídas ao projeto de código criminal de José Clemente Pereira (ou a uma legislação eleitoral vigente no país àquela altura), como discutido no capítulo 1, o restante dos artigos deste título, como dissemos, "limitou-se" a regulamentar, para os Conselhos Gerais de província, exatamente o mesmo que os artigos 92, 93 e 94 haviam instituído acerca da Assembleia Geral e das Câmaras Legislativas do Império, possuindo como fonte indireta, portanto, também o projeto de Livingston.
} 
de insurreição destaca-se ainda por ser o único a especificar a condição jurídica dos envolvidos na caracterização do ocorrido ${ }^{466}$.

Incluído em função de emenda sugerida pela comissão ad hoc de 1830, o tipo penal insurreição deve seu sentido fundamental de revolta escrava ao projeto elaborado por Edward Livingston para o estado norte-americano da Luisiana.

Vejamos o que diziam os artigos 113, 114 e 115 do Código brasileiro:

Art. 113. Julgar-se-ha commettido este crime, retinindo-se vinte ou mais escravos para haverem a liberdade por meio da força. Penas - Aos cabeças - de morte no gráo maximo; de galés perpetuas no médio; e por quinze annos no minimo; - aos mais açoutes.

Art. 114. Se os cabeças da insurreição forem pessoas livres, incorrerão nas mesmas penas impostas, no artigo antecedente, aos cabeças, quando são escravos.

Art. 115. Ajudar, excitar, ou aconselhar escravos á insurgir-se, fornecendo-lhes armas, munições, ou outros meios para o mesmo fim. Penas - de prisão com trabalho por vinte annos no gráo maximo; por doze no médio; e por oito no minimo.

No artigo "Dos Statutes ao Código brasileiro de 1830: o levante de escravos como crime de insurreição", Monica Duarte Dantas ${ }^{467}$ revela como, até 1830, o termo “insurreição", ainda que não dicionarizado em língua portuguesa, fora utilizado no Brasil com sentido semelhante ao de rebelião e guerra civil - e não enquanto revolta escrava. A autora se pergunta, então, de onde teria vindo a acepção do vocábulo adotada pelo Código brasileiro de 1830 e, no desenrolar de semelhante análise, traz à tona as origens norte-americanas do termo - enquanto insubordinação escrava - e o curioso percurso traçado pelo mesmo até sua chegada a terras brasílicas.

Ao longo deste artigo, Dantas analisa o processo de dicionarização do vocábulo insurreição em diferentes países da Europa, especialmente França, Espanha, Portugal e Inglaterra; reconhece a transformação do termo e seu uso com sentido de "revolta escrava" nos statutes aprovados nas colônias da Virginia e Carolina do Sul desde fins do século XVII; acompanha a disseminação da palavra por diferentes estados norteamericanos e as transformações por ela sofridas ao longo do tempo - como a inclusão dos livres que auxiliassem cativos em suas rebeliões na categoria de réus deste delito -; até chegar, no século XIX, ao System of Penal Law for the State of Luisiana -

\footnotetext{
${ }^{466}$ Monica Duarte Dantas. "Dos Statutes ao Código brasileiro de 1830: o levante de escravos como crime de insurreição". Revista do Instituto Histórico e Geográfico Brasileiro, vol. 452, pp. 273-309, 2011; p. 275.

${ }^{467}$ Idem.
} 
legislação elaborada por Edward Livingston - e à sua consulta e utilização pelos legisladores brasileiros envolvidos na elaboração do Código penal imperial ${ }^{468}$.

De acordo com Monica Dantas, a presença do crime de insurreição no diploma de Livingston deveu-se, muito provavelmente, à preocupação do jurisconsulto com a eclosão de revoltas escravas na Luisiana, haja vista a presença massiva de cativos neste estado à época, perfazendo cerca de $40 \%$ da população total. Os artigos do projeto norte-americano referentes à insurreição, contudo, referiam-se exclusivamente aos indivíduos livres que participassem ou incitassem os escravos a se revoltar contra seus senhores ${ }^{469}$, e isto porque, diferentemente do Brasil, a Luisiana possuía um diploma especificamente dirigido aos réus escravos, o chamado "Black Code", não se misturando, portanto, regulamentações destinadas a livres e cativos num mesmo código penal $^{470}$.

No caso brasileiro, ainda que a possibilidade de um código exclusivamente dedicado aos escravos tenha sido aventada, como vimos, por Antonio Pereira Rebouças e Bernardo Pereira de Vasconcelos na sessão de 11 de setembro de 1830, o não isolamento das prescrições penais relativas aos cativo num código especial parece ter configurado, desde o início, a principal alternativa do conjunto dos deputados.

${ }^{468}$ A influência do projeto de código criminal de Edward Livingston sobre o código penal brasileiro de 1830 é abordada ainda, pela autora, no artigo "Revoltas, Motins, Revolução: das Ordenações ao Código Criminal". Neste caso, contudo, sua análise ultrapassa o crime específico de insurreição. Monica Duarte Dantas. Op. cit. 2011.

${ }^{469}$ Vejamos, de todo modo, o que diziam os artigos 115, 116 e 117 de Edward Livingston, referentes ao delito de "Of exciting insurrection":

"Art. 115. Any free person who shall aid in any insurrection of slaves against the free inhabitants of this state, who shall join in any secret assembly of slaves, in which such insurrection shall be planned, with design to promote it, or shall excite or persuade any slaves to attempt such insurrections, shall be imprisoned at hard labour for life

Art. 116. By "insurrection", is meant an assembling with ARMS, with intent to regain their liberty by force.

Art. 117. The term to "excite" in the description of this offence, means to offer any persuasion or inducement, which has insurrection for its immediate object. It excludes the construction that would make those guilty who only use language calculated to render the slaves discontented with their state. This, if done with design to promote such discontent, is an offence punishable by fine, not less than fifty, nor more than two hundred dollars; or imprisonment, not less than thirty days, nor more than six months, in close custody."

${ }^{470}$ Para o Black Code norte-americano ver: Monica Duarte Dantas, "Dos Statutes ao Código brasileiro de 1830: o levante de escravos como crime de insurreição". Op. cit.; pp. 299-230. Elaborada em 1806, a lei que futuramente responderia pelo nome de "Black Code" dizia respeito a um "Act prescribing the rules and conduct to be observed with respect to Negroes and other Slaves in the territory". Em sua elaboração, afirma Dantas, os legisladores da Luisiana "incorporaram parte do Code Noir francês, 'modified by spanish practice', o que implica que, em grande parte, a lei de 1806 baseava-se em statutes norte-americanos ou na positivação da common law acerca da escravidão". 
A opção pela inserção do crime de insurreição no Código de 1830 e a escolha consciente de que o mesmo se aplicasse a livres e escravos do país justifica-se, assim, como no caso norte-americano, pela efetiva ameaça representada pela instituição do cativeiro no Brasil (onde 30\% da população, à época da Independência, era formada por escravos), e pelas garantias que o amplo espectro punitivo deste crime dava à segurança nacional. De posse do diploma norte-americano de Livingston, portanto, e altamente influenciados pela teoria jurídica inerente ao seu conteúdo, os legisladores brasileiros se apropriaram de uma prescrição cuja adoção, no contexto nacional, fazia todo o sentido.

Bastante influente, portanto, sobre o rol de crimes públicos do código brasileiro, a ascendência do diploma penal de Livingston far-se-ia sentir também sobre matérias importantes da seção dos crimes particulares, em especial na definição dos crimes de aborto (arts. 199 e 200) e adultério (art. 253), e na introdução do crime de auxílio ao suicídio de outrem (art. 196). Comparemos, a título de exemplo, o conteúdo do artigo 349 do projeto da Luisiana, ao artigo 253 do Código de 1830:

Art. 349. The indictment or information for adultery against the wife must be a joint one, against the woman and the man with whom the adultery is said to have been committed, if he be alive, and the one cannot be found guilty without the other (...).

Art. 253. A accusação por adulterio deverá ser intentada conjunctamente contra a mulher, e o homem, com quem ella tiver commettido o crime, se fôr vivo; e um não poderá ser condemnado sem o outro.

A partir deste e de outros exemplos da seção dos crimes particulares, pode-se notar o modo com que o diploma norte-americano desempenhou sua influência sobre delitos que, na tradição católica ibérica, possuíam teor altamente moralizante e mesmo religioso (como o adultério, aborto e suicídio); possibilitando, a partir de então, que o Estado e o judiciário brasileiros se aproximassem de forma significativamente mais moderna de semelhantes questões.

Ainda no que diz respeito aos crimes particulares do Código Criminal de 1830, chamaram-nos a atenção, desde o início desta pesquisa, as prescrições aí presentes referentes ao direito de habeas corpus dos réus e às garantias de seu cumprimento legal. Isto porque, em geral, este tipo de regulamentação não apareceu em códigos de direito substantivo, como os criminais, mas apenas em códigos de direito adjetivo, como os de processo penal. Se o código penal brasileiro desperta estranheza, portanto, por conta desta regulamentação atípica, estranha-se ainda mais o fato de ter previsto a aplicação do habeas corpus previamente à sua devida definição pelo código de 
processo penal. Ou seja, ainda que aparecesse no diploma de 1830, o direito de habeas corpus dos réus só poderia ser efetivamente implementado no Brasil posteriormente à aprovação do código processual, o que só veio a ocorrer em 1832.

Entre os artigos 183 e 188 do Código de 1830 dispôs-se, portanto, sobre os obstáculos impostos à concessão e ao cumprimento de ordens de habeas corpus legalmente passadas em juízo. Tais prescrições abrangeram desde a recusa de concessão de habeas corpus por um juiz, nos casos recomendados por lei, passando pelos impedimentos ilicitamente impostos por oficiais de justiça ou empregados públicos ao cumprimento destas ordens (fosse através da recusa ou demora na intimação da ordem e apresentação do preso, fosse ocultando ou mudando de prisão o mesmo com intuito de eludir a execução da dita ordem), até chegar aos casos de recusa, da parte de qualquer cidadão do Império, no prestamento de auxílio a um oficial encarregado da execução de uma ordem de habeas corpus.

Cientes de que a inclusão destes artigos no código brasileiro resultara dos trabalhos da comissão ad hoc de $1830^{471}$, mantiveram-se, contudo, algumas dúvidas referentes (i) aos motivos de se introduzir num código de direito substantivo prescrições que remetiam ao direito processual, (ii) à base ou fonte utilizada na formulação das prescrições citadas e (iii) à razão que teria impelido os membros da comissão $a d$ hoc a adotar semelhante construção.

Concentremo-nos, por hora, no segundo dos questionamentos elencados acima, ou seja, no desvendamento das fontes utilizadas pelos legisladores brasileiros na regulamentação dos artigos referentes ao habeas corpus. Isto porque a investigação das causas de sua inclusão no Código 1830 e a compreensão específica desta escolha - a princípio bastante heterodoxa - serão abordadas, em profundidade, no próximo item.

Haja vista a origem inglesa do habeas corpus, sua vinculação direta à Common $L a w^{472}$, sua inexistência em quaisquer dos diplomas penais ocidentais analisados e a identificação de sua inclusão no texto do código brasileiro a partir dos trabalhos realizados pela comissão ad hoc de 1830 (que, sabemos, fora responsável também pela inclusão de diversos dispositivos provenientes do projeto de código criminal da

\footnotetext{
${ }^{471}$ Comissão especial do código - emendas ao projecto do código criminal, 1830. Typographia de Lessa \& Pereira, 1830; pp. 18 e 19.

${ }^{472}$ Ver: Andrei Koerner. $O$ habeas corpus na prática judicial brasileira (1841-1920). Tese de Doutorado, FFLCH/USP, 1998; espacialmente capítulo 1: "O habeas corpus na legislação e no Parlamento imperiais (1832-1841)"; pp. 66-77.
} 
Luisiana), desconfiávamos advirem da produção jurídica de Edward Livingston as prescrições referentes a esta questão.

Tínhamos um problema, contudo, no que se referia ao "Code of Offences and Punishments", já que nele inexistiam regulamentações referentes à questão do habeas corpus. Analisando, contudo, o "Code of Procedure" do mesmo autor" ${ }^{473}$ - parte integrante de seu "System of Penal Law for the State of Louisiana" e, como indica Monica Dantas, entregue por Silvestre Rebello à Câmara dos deputados juntamente com o "Code of Crimes and Punishments" e o "Code of Reform and Prison Discipline" no ano de $1830^{474}$ - detectamos a fonte precisa de inspiração dos deputados brasileiros.

Foi, assim, no Book I ("Of the means of preventing offences; of suppressing those which are continuous, and of employing the military in aid of the civil power"), Title II ("Of suppressing permanent offences"), Chapter VII ("Of suppressing offences against Personal Liberty"), Section 7 ("Penalties for the breaches of the duties enjoined by this chapter") deste "Code of Procedure" de Livingston, que encontramos a matriz utilizada pelos legisladores brasileiros na regulamentação dos atentados oferecidos ao cumprimento do direito de habeas corpus dos réus no Brasil. Os artigos 183 a 188 do Código de 1830 basearam-se, assim, respectivamente, nos artigos 105 (183), 107 (188), 110 e 112 (185), 108 (186), 114 (187) e 115 (188) do diploma procedimental norte-americano. Analisemos dois exemplos desta influência a partir da comparação dos artigos 105 e 108 de Livingston aos artigos 183 e 186 de 1830:

Art. 105. Any judge empowered by this chapter, to issue writs of habeas corpus, who shall refuse to issue such writ when legally applied to, in a case where such writ may lawfully issue, or who shall unreasonably delay the issuing of such writ, or who, in cases where such writ is allowed to issue without any proof, shall WILFULLY omit to issue, or willfully and unreasonably delay the issuing such writ, shall for every offence be fined in the sum of two thousand dollars.

\footnotetext{
${ }^{473}$ Edward Livingston. "Code of Procedure". In: Idem. A System of Penal Law prepared for the State of Louisiana. New-Orleans: printed by Benjamin Levy, 1824. (Documento cedido por Monica Duarte Dantas, a partir de cópia conseguida junto à Biblioteca do Congresso norte-americano).

${ }^{474}$ De acordo com a autora, em carta enviada a Edward Livingston no ano de 1827, José Silvestre Rebello (primeiro encarregado do Império brasileiro em Washington), revelava ter recebido do jurista norte-americano cópias dos três códigos de sua autoria já impressos nos Estados Unidos àquela altura: o código penal, o código de processo penal e o código prisional; repassados, por Rebello, à Câmara dos deputados brasileira, em 1830. Monica Duarte Dantas. Projeto para Bolsa Produtividade CNPq - "O Código do Processo Criminal e a reforma de 1841: debates legislativos e influências estrangeiras na disputa pela implementação de diferentes modelos de organização do Estado"; 2012 (cópia cedida pela autora).
} 
Art. 183. Recusarem os Juizes, á quem fôr permittido passar ordens de - habeascorpus - concedel-as, quando lhes forem regularmente requeridas, nos casos, em que podem ser legalmente passadas; retardarem sem motivo a sua concessão, ou deixarem de proposito, e com conhecimento de causa, de as passar independente de petição, nos casos em que a Lei o determinar.

Art. 108. Any one having the person in his custody, or under his restraint, power or control, for whose relief a writ of habeas corpus is issued, who, with the intent to avoid the effect of such writ, shall transfer such person to the custody, or place him under the power or control of another, or shall conceal him, or change the place of his confinement, with intent to avoid the operation of such writ, or with intent to remove him out of the state, shall be fined in the sum of two thousand dollars, and may be imprisoned in hard labour, not less than one nor more than five years.

Art. 186. Fazer remessa do preso á outra autoridade; occultal-o, ou mudal-o de prisão, com o fim de illudir uma ordem de - habeas-corpus - depois de saber por qualquer modo que ella foi passada, e tem de lhe ser apresentada. Penas - de prisão por oito mezes a tres annos, e de multa correspondente á metade do tempo.

Apesar do estranhamento gerado pela regulamentação de questões referentes ao cumprimento do habeas corpus num código de direito penal substantivo, acreditamos que sua presença no Código de 1830 relaciona-se, em grande medida, ao desejo de imposição de limites, por parte dos deputados brasileiros, à atuação arbitrária dos magistrados nacionais e à tentativa de garantir, de alguma forma, que o código de processo criminal, então em elaboração no país, fosse "obrigado" a regular esta questão. Desta temática, contudo, trataremos amiúde no subcapítulo 3.3.

No que tange, por fim, aos crimes policiais regulamentados pelo Código Criminal do Império do Brasil, a influência do projeto norte-americano fez-se sentir especialmente sobre a definição do delito de "ajuntamentos ilícitos" (arts. 285 a $289)^{475}$. O exame dos artigos 211 e 220 do projeto de Livingston e sua comparação aos artigos 287 e 292 do Código de 1830, possuem, a nosso ver, a vantagem de evidenciar textualmente a influência a que fizemos referência ${ }^{476}$ :

Art. 211. If the purpose of the unlawful assembly be illegally to oppose the collection of any taxes, tolls, imposts, or excises legally imposed, or he execution of any law of the state, or any lawful sentence of a court, or to effect the rescue of a prisioner legally arrested for any crime, the punishment for that offence shall be increased one half.

\footnotetext{
475 Para a organização completa adotada pelo "Code of Offences and Punishments", de Edward Livingston, ver anexo VI.

476 Monica Duarte Dantas, "Revoltas, Motins, Revoluções: das Ordenações ao Código Criminal". Op. cit. Ver especialmente as pp. 28 a 36.
} 
Art. 287. Se o ajuntamento illicito tiver por fim impedir a percepção de alguma taxa, direito, contribuição, ou tributo legitimamente imposto; ou a execução de alguma Lei, ou sentença; ou se fôr destinado a soltar algum réo legalmente preso. Penas - de quarenta a quatrocentos mil réis, além das mais, em que o réo tiver incorrido.

Art. 220. If any free, able-bodied male person, above eighteen years of age and under fifty, shall be called on to aid in arresting the offenders in the manner directed by the last preceding article, and shall refuse or neglect so to do, such person shall be fined fifty dollars.

Art. 292. Os homens livres de mais de dezoito annos de idade, e menos de cincoenta, que sendo convocados pelo Juiz de Paz, ou de ordem sua, para o fim declarado no artigo antecedente, recusarem, ou deixarem de obedecer, sem motivo justo. Penas - de multa de dez a sessenta mil réis.

Uma análise mais profunda da particular regulamentação recebida pelo delito de ajuntamentos ilícitos no Código de 1830 será esboçada, como no caso anterior, unicamente no próximo subcapítulo.

\section{O Código penal francês de 1810}

Em seqüência ao Projeto de Livingston, tem-se no Código Penal francês de 1810 uma importante fonte de inspiração do código brasileiro. Como no caso espanhol, contudo, a influência exercida pelo diploma francês no texto de 1830 foi fundamentalmente herdeira das prescrições adotadas já pelo projeto de Bernardo Pereira de Vasconcelos.

Tal influência fez-se sentir principalmente nos dispositivos presentes na "Parte Geral" e na seção de crimes públicos do código imperial. Assim, no que diz respeito às definições gerais do diploma, pode-se apontar a presença da influência francesa no estabelecimento dos critérios de satisfação dos males advindos do delito ${ }^{477}$ e na definição das penas de morte e de galés ${ }^{478}$.

No que se refere, por sua vez, à compreensão dos crimes de tentativa e cumplicidade, ainda que o código brasileiro tenha copiado as definições dadas a estes delitos pelo diploma francês ${ }^{479}$, não assumiu a indistinção entre crime consumado $\mathrm{e}$

\footnotetext{
${ }^{477}$ Compare-se, para tanto, o artigo 30 do diploma brasileiro, ao artigo 54 do código francês.

${ }^{478}$ No que tange à influência francesa sobre a definição das penas de morte e galés no Código de 1830, valem as observações realizadas, no capítulo 1, sobre a influência do Código de 1810 no projeto elaborado por Bernardo Pereira de Vasconcelos. Vale ressaltar, contudo, no que se refere ao texto final do código brasileiro, que somente seus artigos de número 39 e 42 podem ser efetivamente reconhecidos como transposições do diploma penal francês de 1810 , mais especificamente de seus artigos 25 e 14 .

${ }^{479}$ A título de exemplo, comparemos os artigos $2^{\circ}$ do código francês de 1810 , ao parágrafo $2^{\circ}$ do artigo $2^{\circ}$ do código brasileiro: "Article 2 . Toute tentative de crime qui aura été manifestée
} 
crime intentado presente naquele código. A completa paridade existente, no diploma napoleônico, entre o crime consumado e a tentativa, bem como entre a autoria e a cumplicidade nos delitos - a serem punidos, todos, da mesma maneira -, foi uma das principais marcas do autoritarismo e do caráter punitivo reforçado da legislação penal francesa $^{480}$. No diploma brasileiro, por sua vez, apesar da presença de definição similar à francesa nestes casos, os artigos 34 e 35 estabeleciam que tanto a tentativa quanto a cumplicidade em um crime seriam punidas com as mesmas penas destinadas ao delito consumado, menos a terça parte em cada um dos graus.

O rigor assumido pela legislação francesa neste ponto foi substituído, portanto, no Código de 1830, por uma visão penal consideravelmente mais amena, punindo diferentemente os crimes consumados daqueles simplesmente tentados e os autores dos delitos de seus cúmplices ${ }^{481}$.

No que se refere aos crimes públicos, a ascendência francesa fez-se sentir especialmente na prescrição dos "crimes contra a existência política do Império" especialmente naqueles referentes ao auxílio prestado a nações inimigas contra o Império brasileiro $^{482}$, em alguns detalhes dos artigos relativos aos crimes dos funcionários públicos e numa prescrição como a presente no artigo 178, referente ao “crime de destruição ou danificação de construções, monumentos e bens públicos".

par des actes extérieures et suivie d'un commencement d'exécution, si elle n'a été suspendue ou n'a manqué son effet que par des circonstances fortuites ou indépendantes de la volonté de l'auteur, est considérée comme le crime même. »; "Art. $2^{\circ}$. Julgar-se-ha crime, ou delicto: $\S 2^{\circ}$. A tentativa do crime, quando fôr manifestada por actos exteriores, e principio de execução, que não teve effeito por circunstancias independentes da vontade do delinquente."

${ }^{480} \mathrm{Se}$, como vimos na Introdução (nota 55, p. 38), tal indistinção fora esboçada já pelo código penal francês de 1791, no código de 1810 ela foi explicitamente fixada (no caso da tentativa) pelo artigo 2 das Dispositions Préliminaires do diploma e, ainda, no caso da cumplicidade, pelo artigo 59 do código. Ver, para tanto: Adriano Cavanna. Op. cit.; pp. 594-595; e Roberto Martucci. "Logiche della transizione penale. Indirizzi di politica criminale e codificazione in Francia dalla rivoluzione all'Imperio (1789-1810).”. In: Quaderni Fiorentini per la storia del pensiero giuridico moderno. 36 (2007), Tomo I. Giuffrè editore milano; pp. 131-274; pp. 190-194.

${ }^{481}$ Nas palavras de Cesare Beccaria: "Não é porque as leis não punem a intenção que deixa de merecer uma pena um delito que comece com alguma ação que manifeste a vontade de o executar, ainda que tal pena seja menor que a da execução mesma do delito. A necessidade de prevenir uma tentativa autoriza uma pena. Mas assim como entre a tentativa e a execução pode haver um intervalo, reservar pena maior ao delito consumado pode ocasionar o arrependimento [do réu]. Diga-se o mesmo quando houver vários cúmplices de um delito, e não todos eles executores imediatos, por razões diferentes". Cesare Beccaria. Dos delitos e das penas. São Paulo: Martins Fontes, 2005; Capítulo XXXVII; p. 123.

${ }^{482}$ No tange a estes casos, a influência francesa fez-se sentir, fundamentalmente, sobre os artigos 70 (art. 85), 71 (arts. 76 e 77), 72 (arts. 77 e 83) e 73 (arts. 84 e 85) do Código brasileiro de 1830. Entre parênteses, os artigos do código francês de 1810 em que cada um deles se baseou. 
No que respeita a este último caso, a transcrição do artigo do código de 1810 (artigo 257) e de seu correspondente no caso brasileiro, possui a capacidade de eliminar qualquer dúvida no que tange à utilização do diploma francês pelos deputados do Brasil:

Article 257. Quiconque aura détruit, abattu, mutilé ou dégradé des monuments, statues et autres objets destinés à l'utilité ou à la décoration publique, et élevés par l'autorité publique ou avec son autorisation, sera puni d'un emprisonnement d'un mois à deux ans, et d'une amende de 100 francs à 500 francs.

Art. 178. Destruir, abater, mutilar, ou damnificar monunentos, edificios, bens publicos, ou quaesquer outros objectos destinados á utilidade, decoração, ou recreio publico. Penas - de prisão com trabalho por dous mezes a quatro annos, e de multa de cinco a vinte por cento do valor do damno causado.

Ainda que a transposição efetiva de delitos públicos do código penal francês possa ser aferida unicamente nos exemplos apontados acima, deve-se frisar, de todo modo, a presença de uma série de regulamentações semelhantes, neste e no diploma brasileiro, no âmbito dos crimes públicos. Contudo, no que tange ao conteúdo destas regulamentações, percebe-se que se trata de prescrições reconhecíveis na grande maioria dos códigos penais analisados, referentes a delitos atentatórios à Constituição, à segurança estatal, ao chefe de governo e ao bom funcionamento das instituições políticas. Nestes casos, como nos de inspiração explícita no código francês, chamaram a atenção as significativas diferenças existentes, em cada um dos diplomas, no tocante às punições previstas. Assim, enquanto o código francês de 1810 previa a pena capital a parte considerável dos crimes de atentado à segurança externa e interna do Estado (em especial aos regulados entre os artigos de número 75 e 102), o código brasileiro, como vimos, eliminara a pena de morte de todos os seus crimes políticos admitindo-a apenas, dentre o conjunto dos crimes públicos, aos casos de insurreição escrava.

Em um como noutro documento, porém, a escolha das penas imputadas aos crimes públicos pode ser relacionada à conjuntura política vivida à época da elaboração do diploma. Se, no caso francês, portanto, as instabilidades políticoinstitucionais e o aumento da criminalidade comum gerados no contexto revolucionário contribuíram à faceta autoritária assumida pelo código de 1810; no Brasil, o reconhecimento do papel estratégico a ser desempenhado pelo diploma criminal na luta contra o imperador d. Pedro I, aliado à influência desempenhada, 
sobre os legisladores nacionais, por um modelo de "justiça-cidadã" como o projetado, por Edward Livingston, aos Estados Unidos da América ${ }^{483}$, criaram circunstâncias propícias à adoção de penas leves ao longo de todo o código e, em especial, no caso dos crimes políticos.

No que tange aos crimes particulares, o diploma francês de 1810 influenciou, indubitavelmente, dois artigos específicos relativos aos delitos de calúnia e injúria ${ }^{484}$, podendo ser reconhecido, também - sem que se possa, contudo, atestar sua ascendência -, no conteúdo do artigo 247 do Código de 1830, referente à celebração de matrimônios irregulares (possivelmente inspirado pelo artigo 199 do código francês). Já no que diz respeito aos crimes policiais, parece inegável a influência desempenhada pelos artigos 274, 275 e 276 do código francês de 1810, sobre a regulamentação de parte significativa do crime de mendicância (artigo 296) no diploma brasileiro. Comparemos, assim, seus textos:

Art. 274. Toute personne qui aura été trouvée mendiant dans un lieu pour lequel il existera un établissement public organisé afin d'obvier à la mendicité, sera puni de trois à six mois d'emprisonnement, et sera, après l'expiration de sa peine, conduite au dépôt de mendicité.

Art. 275. Dans le lieux où il n'existe point encore de tels établissements, les mendiants de l'habitude valides seront punis d'un mois à trois mois d'emprisonnemente. [...]

Art. 276. Tous mendiant, même invalides, qui auront usé de menaces, ou seront entrés sans permission du propriétaire ou de personnes de sa maison, soit dans une habitation, soit dans un enclos en dépendant; ou qui feindront des plaies ou infirmités; ou qui mendieront en réunion, à moins que ce ne soit le mari et la femme, le père ou la mère et leurs jeune enfants, l'aveugle et son conducteur. Seront punis d'un emprisonnement de six mois à deux ans.

Art. 296. Andar mendigando: $1^{\circ}$ : Nos lugares, em que existem estabelecimentos publicos para os mendigos, ou havendo pessoa, que se offereça a sustental-os. $2^{\circ}$ : Quando os que mendigarem estiverem em termos de trabalhar, ainda que nos lugares não hajam os ditos estabelecimentos. $3^{\circ}$ : Quando fingirem chagas, ou outras enfermidades. $4^{\text {o }}$ : Quando mesmo invalidos mendigarem em reunião de quatro, ou mais, não sendo pai, e filhos, e não se incluindo tambem no numero dos quatro as mulheres, que acompanharem seus maridos, e os moços, que guiarem os cégos. Penas - de prisão simples, ou com trabalho, segundo o estado das forças do mendigo, por oito dias a um mez.

${ }^{483}$ Para a ideia de "justiça-cidadã" ver: Monica Duarte Dantas. "O Código de Processo Criminal e a Reforma de 1841: dois modelos de organização do Estado (e suas instâncias de negociação)." Conferência apresentada junto ao IV Congresso do Instituto Brasileiro de História do Direito - Autonomia do direito: configurações do jurídico entre a política e a sociedade. São Paulo, Faculdade de Direito/USP, 2009

${ }^{484}$ Compare-se, neste sentido, o conteúdo dos artigos 234 e 241 do Código brasileiro, ao dos artigos 370 e 377 do diploma francês. 
Contabilizando, enfim, as influências precisas do diploma francês de 1810 sobre o código brasileiro, tem-se que 15 dos 313 artigos do Código de 1830 podem ser a ele atribuídos.

Ainda que numericamente menor, quando comparada aos códigos anteriormente analisados, a influência do código francês repousou, contudo, sobre pontos importantes do diploma brasileiro; dentre eles a sua organização. Ainda que não se possa espelhar a estrutura do código brasileiro de 1830 naquela assumida pelo diploma francês, as semelhanças existentes entre as mesmas (e sua comparação com a organização de outros códigos do período) apontam para a fonte francesa como principal inspiração para a disposição geral das matérias no diploma nacional ${ }^{485}$. Lembrando que, em seu aspecto organizacional, o código aprovado em 1830 não se parecia em quase nada com o projeto do deputado mineiro.

\section{O Projeto de Código Criminal de Pascoal de Melo Freire}

Analisando, na seqüência, o Projeto de Código Criminal de Pascoal de Melo Freire $^{486}$, surpreendeu-nos o fato de apenas 13 dos 313 artigos do Código de 1830 evidenciarem a utilização de prescrições dele advindas.

Deste conjunto de artigos, dez corresponderam à manutenção de dispositivos previamente regulados pelo diploma de Vasconcelos - referentes aos crimes de "sedição"487, "resistência"488, "tirada ou fugida de presos do poder da justiça, e arrombamento de cadêas"489," "moeda falsa"490, "parto supposto, e outros

\footnotetext{
${ }^{485}$ Para tal comparação, consultar os anexos IV e VII, respectivamente referentes aos Índices do Código Criminal do Império do Brasil e do Código Penal francês de 1810.

${ }^{486}$ Para o Índice do Projeto Melo Freire ver anexo VIII.

487 Artigo 112 do Código de 1830 ("Não se julgará sedição o ajuntamento do povo desarmado, em ordem, para o fim de representar as injustiças, e vexações, e o máo procedimento dos empregados publicos."), advindo do artigo 294 de Vasconcelos; baseado, por sua vez, no $§ 13$ do Titulo XVI de Melo Freire.

${ }^{488}$ Artigo 118 do Código de 1830, advindo do artigo 284 do projeto de Vasconcelos; baseado, por sua vez, no $\S 15$ do Titulo II do Projeto Melo Freire.

${ }^{489}$ Artigos 120, 121, 122 e 123 do Código de 1830, advindos dos artigos 285 e 290 ( $\S 1$ e 2) do projeto de Vasconcelos; baseados, respectivamente, nos $\S \S 3,1$ e 2 do Titulo XIX do projeto português.

490 Artigo 173 do Código de 1830 ("Fabricar moeda sem autoridade legitima, ainda que seja feita daquella materia, e com aquella fórma, de que se faz, e que tem a verdadeira, e ainda que tenha o seu verdadeiro, e legitimo peso, e valor intrinseco."), advindo do artigo 302 do projeto de Vasconcelos; baseado, por sua vez, na introdução ou definição geral do crime de moeda falsa tal qual regulamentado pelo Titulo XV do projeto de Pascoal de Melo Freire ("He moeda falsa no sentido das leis a que não for cunhada e batida por nosso especial mandado, indaque seja feita daquella matéria e com aquella fórma de que se faz a verdadeira
} 
fingimentos"491 "uso de armas defesas" roubar" ${ }^{\prime 93}$-, dois resultaram das alterações empreendidas, entre 1829 e 1830, sobre o texto do deputado mineiro - caso dos artigos de número 6 e 254 do Código de 1830, cujas formulações finais advieram, respectivamente, do parágrafo 28 do Titulo $\mathrm{XXXVI}^{494}$, e da definição inicial presente no Titulo XXXVIIII (sic) do Projeto Melo Freire $^{495}$-, e um foi ineditamente introduzido no diploma neste mesmo intervalo de tempo. Referimo-nos, neste último caso, ao artigo 227 do Código de 1830, referente ao crime de "rapto", indubitavelmente fundado no parágrafo 21 do Titulo XII do

moeda, e indaque tenha o seu verdadeiro e legitimo peso e valor intrínseco."). A compreensão de "moeda falsa" expressa por Melo Freire provavelmente teve origem na definição do Titulo 12 do Livro V das Ordenações Filipinas, segundo o qual ficava estabelecido que: "Moeda falsa é toda aquela que não é feita por mandado do rei, em qualquer maneira que se faça, ainda que seja feita daquela matéria e forma de que se faz a verdadeira moeda que o rei manda fazer; [...].".

${ }^{491}$ Artigo 255 do Código de 1830, referente ao artigo 213 do projeto de Vasconcelos; baseado, por sua vez, no $\S 6$ do Titulo 39 do projeto Melo Freire.

492 Artigo 298 do Código de 1830, advindo do artigo 111 do diploma de Vasconcelos; fundado no $\S 7$ do Titulo XXIII do projeto português.

493 Artigo 300 do Código de 1830, referente ao artigo 126 do projeto de Vasconcelos; baseado, por sua vez, no $\$ 29$ do Titulo XXXVI do diploma elaborado por Melo Freire.

${ }^{494}$ Responsável pelo estabelecimento dos critérios de cumplicidade nos crimes regulados pelo diploma penal brasileiro, o artigo $6^{\circ}$ do Código de 1830 definia serem cúmplices: $§ 1$. "Os que receberem, occultarem ou comprarem cousas obtidas por meios criminosos, sabendo que o foram, ou devendo sabel-o em razão da qualidade, ou condição das pessoas, de quem as receberam, ou compraram"; e, §2. "Os que derem asylo, ou prestarem sua casa para reunião de assassinos, ou roubadores, tendo conhecimento de que commettem, ou pretendem commetter taes crimes.". A regulamentação de semelhantes questões pelo projeto de Vasconcelos pode ser reconhecida a partir do conteúdo dos parágrafos 5 e 6 de seu artigo 6 , de acordo com os quais, eram considerados sócios de um crime: §5. "Os que occultão e protegem para não serem punidos os condemnados por crimes que não admittem fiança"; e $\S 6$. "Os que occultão as cousas furtadas ou roubadas.”. Há, portanto, nestes casos, apenas uma breve semelhança na regulamentação da sociedade/cumplicidade nos crimes. Pelo parágrafo 28 do Titulo XXXVI do projeto Melo Freire, por sua vez, ficava estabelecido: "Será também punido como ladrão, com respeito ao numero e à quantidade, o que o encobrir ou the der asylo, conselho, e ajuda; e o que comprar as cousas furtadas, sabendo-o, ou tendo justa razão para julgar mal da pessoa que lha vendeo."; reconhecendo-se aí uma proximidade bem mais significativa com a definição de cumplicidade adotada em 1830.

${ }^{495}$ Enquanto o artigo 254 do diploma de 1830 definia, portanto, ser crime de parto suposto: "Fingir-se a mulher prenhe, e dar o parto alheio por seu, ou sendo verdadeiramente prenhe, substituir a sua por outra criança; furtar alguma criança, occultal-a, ou trocal-a por outra", a disposição geral responsável por introduzir, no projeto Melo Freire, o Titulo XXXIX ("Dos partos suppostos"), dizia o seguinte: "A mulher que fingindo-se prenhe der o parto alheo por seu, ou a que substituir outro ao filho próprio, ou ao alheo que se lhe entregou, ou o que se disser seu pai, sem o ser, he reo do crime de parto supposto.. No projeto de Bernardo Pereira de Vasconcelos, dispositivo semelhante foi regulamentado por meio do artigo 217 ("É tambem crime contra o estado domestico, furtar uma criança, occultal-a, substituil-a por outra ou attribuil-a a quem não pertence"), não cabendo dúvidas, portanto, acerca da maior aproximação do Código de 1830 com relação ao projeto Melo Freire. 
diploma português. Comparemos, a título de exemplo, o conteúdo destas duas disposições:

Tit. XII/§21: Aquelle que sem verdadeira força, por dádivas, promessas e afagos, induzir alguma molher virgem ou viuva honesta para sair da casa de seus pais, tutores, ou curadores, ou de outra pessoa, sob cuja governança e guarda estiver, e a levar comsigo e fugir, será degradado para fora do reino até nossa mercê, postoque case com ella. ${ }^{496}$

Art. 227. Tirar para fim libidinoso, por meio de affagos e promessas, alguma mulher virgem, ou reputada tal, que seja menor de dezasete annos, de casa de seu pai, tutor, curador, ou outra qualquer pessoa, em cujo poder, ou guarda estiver. Penas - de prisão por um a tres annos, e de dotar a offendida.

Efetivamente utilizado, portanto, na elaboração ou reelaboração de parte dos artigos do Código de 1830, não deixa de ser pequena, de todo modo, a influência desempenhada pelo projeto de Pascoal de Melo Freire sobre o diploma brasileiro.

Haja vista a importância assumida por semelhante jurista na formação acadêmica de Bernardo Pereira de Vasconcelos e de vários parlamentares brasileiros diplomados na Universidade de Coimbra entre o final do século XVIII e o início do XIX (alunos de Melo Freire ou, de todo modo, influenciados por sua produção jurídica e por seus compêndios de estudo), esperávamos encontrar um maior número de dispositivos advindos de seu texto no projeto do deputado mineiro e no texto final de 1830 . No avesso de nossas expectativas, contudo, tal "transposição" pode ser unicamente reconhecida para 11 casos no primeiro documento e 13 casos, como vimos, no diploma final.

$\mathrm{Na}$ contra-mão, portanto, de uma série de análises em que o projeto Melo Freire foi citado como fonte fundamental à elaboração do Código 1830, o exame comparativo aqui desenvolvido apontou para uma ascendência que, por importante que tenha sido, não foi superior àquela desempenhada, por exemplo, pelo código espanhol de 1822 ou pelo projeto norte-americano de Edward Livingston.

\footnotetext{
${ }^{496}$ Uma vez mais, a regulamentação presente no projeto Melo Freire pode ser atribuída ao Livro V das Ordenações Filipinas, neste caso, ao parágrafo 3 de seu Titulo 18 ("Do que dorme por força com qualquer mulher ou trava dela, ou a leva por sua vontade"). Como no caso do crime de "moeda falsa", contudo, não nos parece possível atribuir ao Livro V a qualidade de fonte dos deputados brasileiros, já que pequenos detalhes revelam ter sido efetivamente o projeto Melo Freire a matriz de inspiração dos legisladores nacionais.
} 


\section{A Leopoldina}

No caso da Leopoldina - diploma que, como vimos na Introdução, representou um passo fundamental na história do iluminismo jurídico, ao mesmo tempo em que manteve uma série de características afeitas ao direito penal de Antigo Regime -, a comparação com o código brasileiro mostrou-se de difícil execução por conta das distâncias organizacionais, discursivas e teóricas que, em termos gerais, separaram estes documentos. Neste sentido, o fato de o código toscano não dividir internamente as regulamentações referentes aos direitos penais substantivo e adjetivo, adotar um discurso demonstrativo e filosófico, não ab-rogar por completo a legislação anterior e aceitar o recurso à heterointegração, aumentou suas distâncias em relação ao código brasileiro e dificultou o trabalho de comparação entre o conteúdo dos dois textos. Ainda assim, acreditamos que uma ascendência efetiva foi desempenhada pela Leopoldina no projeto de Vasconcelos - reconhecidamente a partir da supressão do crime de lesa-majestade -, tendo-se estendido sobre o texto de 1830 por meio da atenuação penal impressa a este documento.

Os reflexos do diploma toscano nos pareceram visíveis, assim, para além da eliminação do crime de lesa-majestade, na militância empreendida pelos legisladores brasileiros por uma reduzida prescrição da pena de morte em seu código criminal haja vista o fato de mesmo os defensores da pena capital, no Brasil, preconizarem sua limitação a pouquíssimos casos -, e na suavidade das punições aí admitidas como um todo, principalmente para o caso dos crimes políticos.

Primeiramente, portanto, chama a atenção a não regulamentação, pela Leopoldina, do crime de lesa-majestade ou de qualquer outro tipo de atentado especificamente dirigido contra a vida do imperador ${ }^{497}$. Dentre o conjunto de diplomas ocidentais por nós analisados, à exceção justamente da Leopoldina, o projeto de Vasconcelos e o Código brasileiro de 1830 foram os únicos a realizarem semelhante exclusão, com grande peso simbólico no período ${ }^{498}$.

\footnotetext{
${ }^{497}$ Nas palavras de Adriano Cavanna: “Anche il tradizionale apice della gerarchia dei reati del diritto penale comune subisce nella Leopoldina una davvero spettacolare decapitazione. Alludiamo al delito di lesa maestà, esemplarmente punito sino a questo momento ai massimi livelli di severità da tutte le legislazioni degli Stati come crime atrocissimo, in stretto parallelo con i delitti di lesa maestà divina (eresia, magia, sacrilegio, bestemmia).”. Op. cit.; p. 355.

498 Dentre os diplomas que analisamos, também o Projeto de Edward Livingston não prescreve o crime de lesa-majestade ou o crime de atentado à vida do imperador. Vale destacar, contudo, neste caso, que tais crime não poderiam aparecer de qualquer maneira em seu projeto, dado ter sido escrito para uma República.
} 
Se, no caso da Leopoldina, a não admissão destes crimes esteve relacionada a um certo posicionamento político da parte de Leopoldo II - que, desta forma, dessacralizava sua própria posição de monarca absoluto, apresentando-se aos súditos como soberano que detinha o poder por consenso dos governados, servindo a um Estado de origem, agora, explicitamente contratual ${ }^{499}$-, no Brasil, semelhante opção fundou-se na defesa, empreendida pelos legisladores nacionais - neste caso, responsáveis diretos pela configuração final do diploma penal ${ }^{500}$-, do Parlamento como lócus por excelência da soberania nacional (afastando-a, portanto, da figura do monarca) e numa prevenção, de sua parte, contra o possível exacerbamento dos poderes de d. Pedro I. Vê-se assim que, se os tempos e as configurações políticas e preceitos jurídicos haviam mudado entre 1786 e 1830, Toscana e Brasil, havia, contudo, um substrato comum que permitira aos deputados brasileiros buscarem inspiração no diploma europeu.

Para além da influência precisa sobre a eliminação do crime de lesa-majestade, é possível reconhecer a importância exercida pela Leopoldina sobre a doutrina ou concepção penal adotada em 1830. Assim como o diploma toscano, portanto, o código brasileiro prescrevera punições bastante mais leves - quando comparado ao conjunto dos diplomas penais do período - a seus crimes públicos, especialmente os políticos, adotando de todo modo, também na seção dos crimes particulares e policiais, uma tabela penal bastante mais amena do que a média.

Neste sentido, ainda que não disponhamos de exemplos precisos - materializados em artigos específicos -, referentes ao emprego da Leopoldina na composição do Código de 1830, este diploma parece ter desempenhado sobre os legisladores brasileiros uma influência antes de tudo teórica, haja vista o reconhecimento, pelos representantes nacionais, da importância desempenhada pelo diploma toscano no interior do movimento do iluminismo jurídico e na reforma do direito criminal então em andamento no mundo ocidental. Destaque seja dado, neste ponto, às freqüentes referências e elogios feitos pelos deputados brasileiros (especialmente nos debates travados em setembro de 1830 acerca da pena capital) à Leopoldina - citada, por mais

\footnotetext{
${ }^{499}$ Adriano Cavanna. Op. cit.; pp. 355-356. Ver nota 42 da Introdução.

${ }^{500}$ Ou seja, ainda que previamente eliminado por Vasconcelos, o crime de lesa majestade ou, de todo modo, a regulamentação de um delito especificamente dirigido contra a vida do imperador, poderia ter sido incluído no diploma criminal brasileiro entre os anos de 1829 e 1830. Recordemos, neste ponto, que o projeto elaborado por Clemente Pereira admitira, no parágrafo $3^{\circ}$ de seu artigo 98 (referente ao crime de conspiração), o caso de atentado à vida do monarca.
} 
de uma vez, por conta de sua "humanidade", "bem sucedida abolição da pena de morte" e pelos resultados positivos dela advindos no controle da criminalidade na Toscana $^{501}$ - e, de todo modo, à consideração e respeito expressos pelos mesmos à teoria penal do iluminismo europeu e à produção de Cesare Beccaria (que, como vimos, encontrara na Leopoldina um dos primeiros exemplares de sua possível efetivação).

\section{Os Códigos penais prussiano, austríaco e bávaro.}

A análise dos códigos penais da Prússia, de 1794, da Áustria, de 1803, e da Baviera, de 1813, não possibilitou, como nos casos anteriores, que atestássemos seu uso efetivo pelos legisladores nacionais. Diferentemente, portanto, dos códigos espanhol, francês e toscano, e dos projetos português e norte-americano, o exame destes diplomas não confirmou sua consulta e uso pelos legisladores brasileiros.

Deve-se frisar, de todo modo, a adequação geral destes documentos aos padrões codificacionistas do período, e a presença, nos mesmos, de uma série de prescrições reconhecíveis em outros diplomas criminais analisados. Como dissemos acima, contudo, a presença de um substrato jurídico comum aos diferentes códigos do período, e em ampla circulação pelo mundo ocidental, bem como sua materialização em prescrições gerais referentes a crimes públicos, particulares e policiais, limitou a confirmação da consulta e utilização de determinados códigos pelos legisladores brasileiros ao reconhecimento efetivo da transposição de dispositivos destes diplomas ao código nacional. No caso dos diplomas prussiano, austríaco e bávaro, tal transposição não pode ser identificada, impossibilitando-nos de confirmar sua utilização ou consulta pelos legisladores envolvidos na elaboração do código penal.

No caso do diploma prussiano de 1794, também conhecido como Algemeines Landrecht, ainda que haja similitudes interessantes entre as regulamentações

\footnotetext{
${ }^{501}$ Enquanto o deputado Rebouças afirmava, assim, aos 11 de setembro de 1830: "A abolição da pena de morte na Toscana por Leopoldo fez que no decurso de mais de 20 annos ahi sómente se perpetrassem cinco assassinios; entretanto que os mais atrozes crimes continuarão em Napoles, Roma, etc."; Ribeiro de Andrada, no mesmo dia, diria: "consultai a historia dos povos onde ainda dura em voga pena tão atroz e barbara; consultai a estatistica dos seus crimes, e vós vereis que annualmente se reproduzem com pequenas differenças para menos ou para mais; consultai pelo contrario a estatistica dos crimes dos povos da Pensilvania, de Berne e da Toscana, onde a pena de morte foi riscada dos seus codigos, e comparai-a com a dos primeiros, e vós vos convencereis da superfluidade de semelhante pena, e do melhoramento progressivo de costumes nos ultimos, porque um systema de leis penaes, suaves, mas sempre executadas é o melhor compendio de moral e de instrucção."
} 
adotadas, nele e no Código brasileiro, aos crimes passíveis de serem cometidos por funcionários públicos, ao delito de fuga de presos do poder da justiça e aos casos de calúnia, injúria e contrabando ${ }^{502}$, ainda assim, não há qualquer exemplo indubitável de sua utilização.

Para o diploma austríaco de 1803, a despeito de nossos esforços, alcançamos conclusão semelhante. Assim, ainda que, pautados por estudos como o de Bernardino Bravo Lira $^{503}$ - para quem são plenamente reconhecíveis as influências desempenhadas pelo código austríaco sobre o projeto de Bernardo Pereira de Vasconcelos e o texto final de 1830 -, tenhamos nos detido com cuidado sobre este documento, não pudemos encontrar, uma vez mais, exemplos incontestes de sua utilização na composição do diploma brasileiro.

Curiosamente, o único artigo de 1803 em que uma aproximação com o caso nacional despertou nossa atenção, foi o de número 196, por meio do qual se regulava a fuga de presos do poder da Justiça quando precedida por planos "astuciosos"; palavra igualmente utilizada pelo artigo 124 do diploma nacional de $1830^{504} \mathrm{e}$ inexistente nos outros códigos analisados. Para além deste caso específico - ao qual, de todo modo, a questão lingüística demanda cuidado especial - as proximidades existentes entre os diplomas brasileiro e austríaco reduziram-se, como no exemplo

\footnotetext{
${ }^{502}$ A partir da transcrição dos artigos 277, 278 e 285 da Algemeines Landrecht, e de sua comparação ao artigo 177 do Código de 1830, vejamos como a regulamentação de contrabando no diploma brasileiro aproximou-se do caso prussiano: "Art. 277. Celui que tente d'importer ou d'exporter les merchandises et objets dont l'Etat a défendu l'importation ou l'exportation, se rend coupable du délit de contrebande.; Art. 278. Quinconque, dans l'importation et l'exportation de merchandises non prohibée en elle-mêmes, tente de se soustraire à l'acquittement de droit d'entrée ou d'accise, commet une fraude.; Art. 285. Le délit de contrebande ou de fraude entraîne immédiatement la confiscation des marchandises qui en sont l'objet."; e "Art. 177. Importar, ou exportar generos, ou mercadorias prohibidas; ou não pagar os direitos dos que são permittidos, na sua importação, ou exportação, é crime de contrabando. Pena - perda das mercadorias ou generos prohibidos, e de multa igual a metade do valor delles.".

${ }^{503}$ Bernardino Bravo Lira. "Bicentenario del Código Penal de Austria: Su proyección desde el Danubio a Filipinas". In: Revista de estudios histórico - jurídicos. Valparaíso 2004, nº 26.

${ }^{504}$ É interessante observar, neste ponto, que a questão da astúcia já se encontrava referida, para este mesmo crime, no projeto de Vasconcelos, mais especificamente em seu artigo 287. Observemos o conteúdo de cada um destes artigos, por ordem cronológica de aparecimento. Código austríaco de 1803: "Art. 196. Quand quelqu'un, par ruse [astúcia] ou par force, facilite à une personne arrêtée pour délit l'occasion de fuir (...). Peine - prison dure de cinq à dix ans.". Projeto de Vasconcelos (1827): “Art. 287. É tambem crime de arrombamento o franquear a fugida aos presos não empregando força, mas meios astuciosos. Pena - galés de 3 a 12 annos de prisão [sic.]". Código Criminal de 1830: "Art. 124. Franquear a fugida aos presos, por meios astuciosos. Penas - de prisão por tres a doze mezes.".
} 
prussiano, a regulamentações gerais e comumente reconhecíveis numa série de códigos do período.

Por fim, no que se refere ao Código bávaro de 1813, para além de uma série de proximidades no tocante à obrigatoriedade de satisfação, pelos réus, dos prejuízos causados por seus delitos; na definição do arbítrio legado aos juízes para a estipulação das sentenças (tema de extrema importância no processo codificacionista como um todo) ${ }^{505}$; e na ausência de prescrição aos crimes e suas penas (que não caducavam neste diploma e nem no brasileiro) ${ }^{506}$; uma coincidência interessante despertou nossa atenção: o estabelecimento comum de um limite diário de 50 chibatadas para o castigo corporal por açoites, prescrito nos dois casos ${ }^{507}$.

Apesar da semelhança, contudo, uma distinção fundamental separava os diplomas neste ponto: enquanto o código penal bávaro previa os açoites, como pena principal, em 15 de seus artigos (incluídos, aí, delitos como os de cumplicidade nos crimes de motim, insurreição ou atentado à paz pública; roubo com circunstâncias agravantes; ofensa ao rei; falta de respeito às autoridades; danos qualificados à propriedade; dentre outros) $)^{508}$, prescrevendo-os, ainda, na qualidade de pena "acessória", como

${ }^{505}$ Neste ponto, enquanto o artigo 33 do diploma brasileiro estabelecia que: "Nenhum crime será punido com penas, que não estejam estabelecidas nas leis, nem com mais, ou menos daquellas, que estiverem decretadas para punir o crime no gráo maximo, médio, ou minimo, salvo o caso, em que aos Juizes se permittir arbítrio.", os artigos 90, 95 e 107 do Código da Baviera prescreviam, em linhas gerais, que os juízes se ativessem às gradações penais estabelecidas pelo código e que, em casos excepcionais, pudessem aumentar uma punição para além dos limites estabelecidos pelo diploma, seguindo, para tanto, leis expressamente formuladas neste sentido.

${ }^{506} \mathrm{O}$ artigo 139 do Código penal bávaro de 1813 prescrevia o seguinte: "Le laps d'un certains temps, n'est pas en soi un titre légal à l'extinction du crime et de la peine encourue." O artigo 65 do Código de 1830, por sua vez, dizia: "As penas impostas aos réos não prescreverão em tempo algum."

${ }^{507}$ No Código da Baviera, tal limitação era prevista pelo artigo de número 25 , de acordo com o qual: "Le châtiment corporel ne pourra jamais excéder le nombre de cinquante coups. Le nombre de coups devra être spécifié dans la sentence. Ledit châtiment sera appliqué sur le dos mis à nu, avec un fouet formé de verges de bouleau réunies. [...]".

${ }^{508}$ A pena de açoitamento estava prevista, assim, no Código bávaro, aos seguintes artigos: art. $98, \S 2^{\circ}$ ("enfants de plus de 8 ans et de moins de 12 , coupables de crimes"); art. $99, \S 5^{\circ}$ ("adolescents de plus de 12 ans et de moins de 16, condmamnés à la prison"); art. 187 ("viol"); art. 188 ("viol avec circonstances aggravantes"); art. 320 ("complices communs d'une émente"); art. $321, \S 6^{\circ}$ ("complices communs d'une insurrection"); art. $333, \S 3^{\circ}$ ("complices communs de trouble à la paix publique"); art. 381 ("vol domestique par gourmandise"); art. 382 ("rétention dans la même hypothèse"); art. 385, §5 ("dommages qualifiés à la propriéte"); art. 404 ("offense au roi"); art. 409, $\S 1^{\circ}$ ("manque de respect à l'autorité"); art. $413, \S 11$ ("co-participants à une émente"); art. 415 ("coalition d'ouvriers"); art. 418 ("mise en liberté de détenus"); art. 436 ("destruction d'écriteaux publics"). De acordo com o tradutor deste diploma: "[...] comme peine principale, le châtiment corporel n'est 
agravamento às penas de trabalhos forçados ou prisão com trabalho, no caso brasileiro, tal punição era exclusiva aos réus cativos, que a recebiam, ainda, unicamente nos casos em que não fossem sentenciados à pena capital ou às galés ${ }^{509}$. Diferentemente do código de 1813 , portanto, no diploma de 1830 esta punição não vinha prescrita em diferentes artigos e casos, reduzindo-se à população cativa e ao que ficara regulado pelo artigo 60 do Código criminal. Dadas as diferenças apresentadas, a proximidade reconhecida na limitação de 50 açoites, nos parece antes fruto de uma coincidência do que de uma efetiva influência.

O percurso traçado até aqui explicita, enfim, o modo com que - mais ou menos intensamente - uma multiplicidade de fontes estrangeiras influenciou a composição do Código Criminal do Império do Brasil.

Analisando a sistemática utilização de diplomas previgentes na composição de novos códigos penais na Europa de finais do século XVIII e inícios do XIX, Adriano Cavanna propôs, um tanto jocosamente, uma "lei da codificação" de acordo com a qual "códigos nascem de códigos":

La storia delle codificazioni ci mostra che ogni codice nasce necessariamente su un cumulo di macerie, cioè sulle rovine di un sistema giuridico preesistente. Ma ci mostra anche che nessun codice riesce ad erigersi se non utilizzando in qualche misura quelle stesse rovine. Le macerie diventano un cantiere. Strane creature, i codici. Ufficialmente segnano un'ora zero nell'esperienza giuridica e, all'insegna di una postulata 'completezza', decollano su una tabula rasa. Eppure non c'è edificio che sia costruito con tanto materiale di reimpiego quanto un codice. ${ }^{510}$

Para Cavanna, portanto, toda dose de originalidade e aperfeiçoamento de um código às circunstâncias específicas de um país, seria unicamente possível dada a existência prévia de um repertório, ou seja, de outros diplomas e de um arcabouço jurídico comum em circulação. Nesse sentido, a regra proposta pelo autor nos parece plenamente aplicável ao caso brasileiro.

appliqué que rarement, lorsque le délit consiste dans un acte de malice, et que le délinquant est jeune, ou qu'il appartient à la classe de ces êtres grossiers et perverties sur lesquels il faut agir par une répression prompte et énergique." Code Penal du Royame de Bavière (1813). Traduit de 1'Allemand par Ch. Vatel. Paris, Auguste-Durand, Libraire-Éditeur, 1852; p. 54, nota 2.

${ }^{509}$ Como vimos acima, o artigo 60 do Código de 1830 estabelecia que: "Se o réo fôr escravo, e incorrer em pena, que não seja a capital, ou de galés, será condemnado na de açoutes, e depois de os soffrer, será entregue a seu senhor, que se obrigará a trazel-o com um ferro, pelo tempo, e maneira que o Juiz designar. O numero de açoutes será fixado na sentença e o escravo não poderá levar por dia mais de cincoenta."

${ }^{510}$ Adriano Cavanna. Op. cit.; pp. 320-321. 
À contabilização das matrizes jurídicas estrangeiras utilizadas na elaboração do Código de 1830 e à deteç̧ão de suas influências precisas sobre este texto devemos unir, agora, o exame das originalidades do código imperial e dos pontos em que o uso de fontes exógenas reverteu-se numa tentativa de adequação deste diploma às circunstâncias políticas e sociais vividas no país recém-independente. Se o diploma penal brasileiro configurou-se, assim, num documento eminentemente eclético, como viemos demonstrando, não por isso esteve menos adaptado à realidade específica a que se destinou ou às expectativas dos legisladores no poder conformador da lei.

Tal adaptação, por sua vez, assumiu não apenas o aspecto de um ajuste de dispositivos penais às circunstâncias políticas e sociais brasileiras, mas também a característica de elaborar, para o país recém-independente, leis que se acreditava capazes de transformação da realidade e alteração dos rumos históricos da nação. Se relembrarmos, assim, da convicção partilhada, na passagem do século XVIII ao XIX, no poder de transformação da realidade por via da renovação legal de um país - cujo exemplo máximo encontramos na crença no direito partilhada pelos revolucionários franceses -, teremos clareza da modernidade das concepções e discursos com que lidavam os deputados brasileiros no momento de composição de seu diploma criminal $^{511}$.

Com o intuito de compreender as proposições jurídicas e políticas subjacentes aos trabalhos das comissões parlamentares que se ocuparam do texto do futuro código brasileiro, e o quanto tal atuação correspondeu, ou não, à realidade do país à época e às expectativas e projetos políticos mais amplos de parte de seus legisladores, analisaremos, na sequência, as especificidades da "concepção penal" enfim assumida

\footnotetext{
${ }^{511}$ Analisando a Revolução Francesa de 1789, Adriano Cavanna destaca a importância dada, pelos revolucionários, ao direito, e a crença então disseminada no poder de regeneração social das leis. De acordo com Cavanna, o "culto fetichista do direito" (direito este entendido exclusivamente como lei) enquanto instrumento messiânico de regeneração moral dos indivíduos e da sociedade, formava parte considerável da mentalidade revolucionária. Adriano Cavanna. Op. cit.; pp. 406-407. Tratando, por sua vez, da concepção específica de lei e de direito por que se pautaram os primeiros parlamentares do Império brasileiro, Andréa Slemian destaca a extrema modernidade desta concepção, fundada na ideia da lei como primeira fonte do direito e na progressiva transformação do direito em um campo estatal cada vez mais relacionado à racionalização das instituições e à garantia dos direitos. De acordo com a autora, portanto, os primeiros deputados do Império estiveram longe de conceber a lei como um instrumento de ficção, apostando, antes, em sua capacidade de transformação efetiva da realidade nacional. Andréa Slemian. "À nação independente, um novo ordenamento jurídico: a criação dos Códigos Criminal e do Processo Penal na primeira década do Império do Brasil". Op. cit.; 2008.
} 
e expressa pelo diploma de 1830 e as mudanças paradigmáticas realizadas sobre crimes específicos de sua Parte Especial.

Antes disso, contudo, gostaríamos de chamar a atenção ao fato de a análise comparativa desenvolvida acima, para além de explicitar as principais fontes e influências legais atuantes sobre os legisladores nacionais, ter despertado nossa atenção para diversas das particularidades do Código de 1830 - e do direito criminal positivado no Império do Brasil - de que provavelmente não teríamos nos dado conta se realizada uma análise exclusiva da documentação brasileira.

Apesar, portanto, da presença de uma sistemática e de um conteúdo programático em grande medida comuns aos mais diversos códigos do período, os diferentes diplomas analisados parecem ter guardado especificidades referentes a seus contextos precisos de elaboração e às circunstâncias políticas, sociais e econômicas que os cercaram; e, com o Brasil, não foi diferente.

Poderíamos destacar assim, dentre outras particularidades do Código de 1830: a ausência de regulamentação dos crimes de lesa-majestade ou alta traição, e de atentado à vida do Imperador ou de sua família, presentes na quase totalidade dos códigos analisados; a forma particular com que se regulamentou, aí, a prescrição (no sentido de caducidade ou obsolescência) dos crimes e de suas penas, e o arbítrio legado aos juízes na atribuição penal; o modo extraordinário com que o elemento cativo apareceu neste texto, explicitando as conseqüências que a presença da escravidão impunha ao código penal brasileiro; e as regulamentações, únicas dentre os diplomas analisados, do crime de pirataria e de regras garantidoras do direito de habeas corpus dos réus.

Ainda que não possamos analisar em profundidade todas as características distintivas apontadas, sua identificação serviu-nos como exemplo da quantidade de dispositivos peculiares ao código brasileiro - em diálogo direto com a história e a política nacionais e fundamentais à compreensão do direito criminal que, com este diploma, buscava-se implementar no país recém-independente -, cuja existência teria passado despercebida na ausência de tal análise comparativa.

Algumas dessas especificidades merecem, contudo, análise pormenorizada, principalmente por permitirem uma visão mais complexa da relação entre o direito e a sociedade no Brasil e um melhor entendimento dos embates travados entre os legisladores no que tangia à positivação das leis penais. 


\subsection{O Código de 1830 como arma política estratégica do legislativo nacional e engrenagem do aparelhamento jurídico da nação.}

Dando início à análise da concepção penal expressa pelo Código Criminal do Império do Brasil, recordemos que entre os anos de 1829 e 1830, a teoria penal implícita ao projeto de Vasconcelos passara por modificações substanciais. Reformulando-se, assim, o conjunto das punições admitidas pelo diploma, alterou-se também a definição pontual de parte das mesmas e sua prescrição aos crimes públicos, particulares e policiais do código. Entre o projeto de 1827 e o Código de 1830 distinguiam-se, portanto, não apenas as onze punições admitidas em cada caso (Tabela I) e o entendimento inerente a parte importante das mesmas, mas também, e talvez principalmente, a proporcionalidade de sua prescrição - especialmente no caso das penas de morte, galés e prisão com trabalho - ao longo das Partes Especiais de cada um dos documentos (Tabela II).

O modo com que penas como as de prisão com trabalho, prisão simples, multa, perda ou suspensão do emprego, entre outras, foram definidas pelo Código de 1830 revela, em comparação aos demais diplomas criminais do período, a extrema modernidade do Código brasileiro e sua adequação ao que de mais novo se produzia no âmbito do direito penal. Exemplo extremo desta conformidade encontra-se na definição dada, em 1830, à pena de prisão com trabalho, e no fato de ser esta a punição por mais vezes prescrita ao longo da Parte Especial do código (ver Tabela II).

Vista àquela altura como a pena por excelência de um código criminal moderno, a prisão com trabalho reunia, para diversos juristas, comentadores e teóricos do direito penal do período, as características necessárias ao cumprimento definitivo dos objetivos punitivos de um código criminal ${ }^{512}$.

\footnotetext{
512 Para esta discussão ver: Cesare Beccaria. Dos delitos e das penas. São Paulo: Martins Fontes, 2005. Edward Livingston. Report made to the General Assembly of the State of Lousiana of the Plan of a Penal Code for the said State, Nova Orleans, Benjamin Levy \& Co, 1824; e, principalmente: Edward Livingston. Introductory Report to the Code of Reform and Prison Discipline. In: A System of Penal Law for the State of Louisiana. Pittsburgh, John L. Kay \& Brother, 1833. De Jeremy Bentham, ver: "A View of the Hard-Labour Bill", "Panopticon; or the Inspection-House", e "Panopticon versus New South Wale". In: The works of Jeremy Bentham, published under the superintendence of his executor, John Bowring. Volume IV. Edinburgh: Simpkin, Marshall, \& Co., London, 1843; pp. 1-248. Nas palavras de Thomaz Alves Junior, a pena de prisão com trabalho era a pena por excelência do sistema de um código bem formulado, preenchendo o fim das punições: "[...] porque por meio della se conseguirá a regeneração ou correcção do homem; por meio do exemplo da mesma se conseguirá a reforma social; e fará parar aquelle que se achar na estrada do crime. Tem quasi,
} 
Ainda que penas como as de morte, galés e açoites também marcassem presença no texto de 1830 , não se deve esquecer, primeiramente, que tais penas eram prescritas pela maioria absoluta dos códigos do período, e, em segundo (e mais importante) lugar, o fato de o código brasileiro configurar-se, àquela altura, num dos documentos em que menos vezes elas foram admitidas como um todo - restringindo-se a pena de açoites, por exemplo, aos réus escravos, admitindo-se pouquíssimas vezes a pena de galés e não se prescrevendo a pena de morte para mais de quatro casos.

Neste sentido, a comparação do texto nacional com outros códigos do período revela como, diferentemente do que fazem crer certas análises, a prescrição, por exemplo, da pena de galés, ou mesmo a manutenção da pena de morte, não dizem exclusivamente respeito (como vimos no capitulo 2) às necessidades de uma sociedade escravocrata e culturalmente atrasada. Foi esta a leitura veiculada, contudo, por trabalhos importantes como os de Zahidé Machado Neto e Jurandir Malerba.

Analisando a presença da pena de galés no diploma de 1830, por exemplo, Machado Neto afirma que sua sobrevivência no código deveu-se a um expediente marcado por características nitidamente coloniais e patriarcais, ignorando, assim, a presença desta punição em uma série de códigos europeus (de países não escravistas, portanto) e o fato de sua regulamentação no Brasil ter sofrido uma drástica redução entre a apresentação do projeto de Vasconcelos e o texto final de $1830^{513}$. Jurandir Malerba, por sua vez, é enfático ao relacionar a manutenção da pena de morte ao que denomina de ideologia do precedente aberto pela escravidão na legislação nacional, ignorando, também ele, a presença desta punição em praticamente todos os diploma penais da época e sua muito reduzida participação no código nacional ${ }^{514}$.

O exemplo mais interessante dos equívocos a que uma leitura restrita do código nacional pode levar encontra-se, contudo, na avaliação, comum aos dois autores, do parágrafo $6^{\circ}$ do artigo 14 do diploma de 1830 , referente aos crimes justificáveis. De acordo com este artigo, ficava estabelecido ser justificável o crime: "Quando o mal consistir no castigo moderado, que os pais derem a seus filhos, os senhores a seus escravos, e os mestres a seus discipulos; ou desse castigo resultar, uma vez que a

se não todas, as qualidades desejáveis de uma pena.” Thomaz Alves Jr. Op. cit.; Tomo I; p. 105.

${ }^{513}$ Zahidé Machado Neto. Op. cit.; pp. 75-87.

${ }^{514}$ Jurandir Malerba. Os Brancos da Lei: liberalismo, escravidão e mentalidade patriarcal no Império do Brasil. Paraná: Editora da Universidade Estadual de Maringá, 1994; pp. 35-41 e pp. 105-113. 
qualidade delle, não seja contraria ás Leis em vigor.”. Tanto para Machado Neto quanto para Malerba, tal disposição fazia referência explícita ao caráter patriarcal de que se revestia a sociedade escravista, amparando o senhor em suas ilicitudes e pondo às claras o valor absoluto aí assumido pela obediência. Ainda que, de um modo geral, a conexão entre esta prescrição e a reverência às hierarquias, típica da sociedade brasileira imperial, não seja de todo descartável, é surpreendente identificar que ela encontrava equivalentes em diplomas tão distintos como o espanhol de $1822^{515}$ e o projeto de Edward Livingston ${ }^{516}$.

Sendo assim, a operação de efetivamente situar o conteúdo do código brasileiro em relação à produção penal do período, pareceu-nos de extrema importância não só por possibilitar a identificação de suas similitudes com os códigos do mundo ocidental, mas também, e talvez principalmente, como dissemos, por permitir que reconheçamos aquelas que foram verdadeiramente as suas particularidades nacionais.

Para um exame preciso da teoria penal implícita ao código brasileiro, e para um esclarecimento de seu posicionamento no tocante aos padrões penais em voga no período, optamos por centrar nossa atenção sobre a prescrição de punições que envolviam o trabalhos dos réus nos diferentes códigos, atentando às distintas compreensões por eles materializadas e a seus significados subjacentes.

Embora o uso da mão de obra dos prisioneiros possa ser identificado já nas workhouses inglesas do século XVI, nas Rasp-huis holandesas da mesma época, ou nas instituições prisionais quackers da Pensilvânia do século XVII, foi apenas na passagem do século XVIII para o XIX que surgiram casas de correção, propriamente

\footnotetext{
${ }^{515}$ Pelo artigo 625 do Código penal espanhol de 1822 ficava estabelecido que: "Los padres ó abuelos que excediéndose en el derecho de corregir á sus hijos ó nietos cuando cometan alguna falta, maten á alguno de estos en el arrebato del enojo, serán considerados siempre, y castigados como culpables de homicidio involuntario cometido por ligereza. Cualquiera otro que excediéndose en igual derecho, cuando legítimamente le competa, incurra en el propio delito con respecto á sus criados, discípulos ú otras personas que esten á su cargo y direccion, será castigado, según el caso respectivo, con arreglo a las disposiciones generales de este capítulo."

${ }^{516} \mathrm{O}$ parágrafo $1^{\circ}$ do artigo 415 do projeto de Livingston, por sua vez, estabelecia que: "Violence offered to the person does not amount to the offence of battery, where it is done in either of the cases, or for either of the purposes hereafter enumerated in this article; that is to say; $1^{\circ}$. In the execution of that right of moderate restraint or correction which is given by law to the parent over the child; the tutor or curator over his minor ward; the master over the apprentice or servant; the schoolmaster over the scholar; or by persons duly authorized to use such restraint or correction towards minor, by persons standing in either of the above relations to them."
} 
ditas, com o objetivo preciso de recuperação dos criminosos pela via do trabalho ${ }^{517}$. Influenciados, neste contexto, pelas teorias punitivas de Cesare Beccaria, Karl Roeder e Jeremy Bentham, entre outros, e atrelados, em maior ou menor medida, aos ideais de utilidade penal e reabilitação dos criminosos pela via do trabalho por elas publicizados $^{518}$, a quase totalidade dos códigos criminais então elaborados contou com punições que pressupunham o trabalho dos condenados.

Tal regulamentação, contudo, não se deu de maneira uniforme, abarcando, antes, nos diferentes diplomas, uma ampla variedade de dispositivos e entendimentos do papel a ser cumprido por semelhantes punições. Nesse sentido, enquanto parte dos códigos fundou-se inegavelmente no ideal de reabilitação dos criminosos pela via do trabalho e na perspectiva de construção de verdadeiros sistemas penitenciários, outra parte situou as penas laborais num espaço intermediário - e bastante confuso - entre a expectativa de regeneração dos delinquentes e as mais cruéis formas de supliciamento dos mesmo.

Assim, enquanto na Leopoldina (Código penal da Toscana de 1786) e na Josefina (Código penal austríaco de 1787), a abolição da pena de morte parece ter sido compensada por um incremento do sofrimento físico envolvido no aprisionamento e

${ }^{517}$ Flávia Maíra de Araújo Gonçalves. Cadeia e Correção: sistema prisional e população carcerária na cidade de São Paulo (1830-1890). Dissertação de Mestrado; FFLCH/USP; 2010; pp. 40-41.

${ }^{518}$ Vale a pena destacar neste ponto que, se Cesare Beccaria preconizava a adoção, pelo códigos criminais do período, das penas de prisão com trabalho (sugerindo-as, especialmente, em substituição à pena de morte), não encontrava lugar em seu pensamento a chamada "teoria da emenda", de acordo com a qual havia um ideal educacional e ressocializador associado à prisão com trabalho. Quem esclarece esta questão é Adriano Cavanna, para quem o silêncio de Beccaria, no que tangia a este ponto, pode ser explicado a partir de duas frentes principais: “1) all'illuminista Beccaria, sostenitore della laicità del diritto penale, ripugnava certamente l'idea di assegnare allo Stato un compito paternalistico di valutazione morale della coscienza del colpevole; 2) la concezione della pena-emenda doveva apparirgli egualmente pericolosa sul piano della certezza del diritto: poiché la pena dovrebbe prolungarsi fino a quando la rieducazione non si sia prodotta, la sua estensione non potrebbe essere fissata previamente dal giudice e al limite essa potrebbe risultare perpetua." Adriano Cavanna. Op. cit.; p. 200. Para autores como Georg Rüsche, Otto Kirchheimer e Michel Foucault, por sua vez, o paradigma penal inaugurado na passagem do século XVIII para o XIX dizia menos respeito à ideia de educação, ressocialização e logo, humanização das punições, do que à necessária adequação das penas ao novo momento sócio-econômico vivido pela Europa e às novas necessidades disciplinarizadoras impostas pelo mercado de trabalho capitalista em formação. Neste sentido, os autores analisam as punições neste período a partir de sua função social complexa - em muito superior à função de repressão aos crimes -, compreendendo os métodos punitivos como parte das tecnologias do poder e o modo com que tais tecnologias se fizeram sentir então nos corpos dos indivíduos. Ver: Georg Rüsche and Otto Kirchheimer. Punishment and Social Structure. New York: Morningside Heights; Columbia University Press, 1939; e Michel Foucault. Vigiar e Punir. Petrópolis: Editora Vozes, 2005. 
trabalho dos condenados ${ }^{519}$; em códigos mais modernos, como o austríaco de 1803, o francês de 1810, o bávaro de 1813 e o espanhol de 1822, a presença de uma nova concepção do trabalho do encarcerado - a ser realizado no interior de casas de correção ou presídios, em ofícios do conhecimento e agrado dos réus, em condições decentes de alimentação e vestimenta etc. -, foi também acompanhada por uma concepção martirizante do uso desta mão de obra. Tal concepção expressou-se, nestes documentos, pela possibilidade de condenação a penas de trabalhos públicos forçados - possivelmente agravados, a depender do diploma, por castigos corporais, exposições públicas humilhantes e uso de correntes, calcetas e bolas de ferro nos pés ${ }^{520}$ - que, por sua vez, não visavam a qualquer tipo de reabilitação social.

519 Pelo artigo 25 da Josefina os sentenciados às "correntes" (chains) deveriam sofrer aprisionamento severo e ser acorrentados a tal ponto que não pudessem mover-se mais do que o suficiente para sua sobrevivência, sofrendo castigos corporais anuais transformados em exemplo para a população; já o seu artigo 27 estabelecia que: "In cases of the most rigorous imprisonment, the criminal is confined day and night the spot assigned him, with a ring of iron fastened about his middle; and he may be loaded with additional irons, if the kind of work imposed on him permit, or the danger of his scape render it necessary. When a criminal is condemned to suffer imprisonment, he has no bed but the floor, no nourishment but bread and water, and all communication, not only with strangers, but with his acquaintance and relations, is refused him". Para Adriano Cavanna, por exemplo, a abolição da pena de morte na Josefina não implicava num ato com vistas à humanização do sistema penal austríaco, mas antes na substituição da pena de morte por penas muito mais terríveis, capazes de infligir terror aos súditos de José II, afastando-os da criminalidade. Adriano Cavanna. Op. cit.; pp. 306-308. Tratando, por sua vez, da recepção da obra de Beccaria na França iluminista, Franco Venturi mostrou como a desconfiança dos philosophes franceses perante medidas consideradas "reformistas", somada à identificação das ideias de Beccaria (especialmente a de substituição da pena de morte pela de trabalhos forçados) como tais, fez não só com que os problemas penais fossem de certa forma negligenciados neste país (o que explicaria o atraso na transformação de seu sistema penal), como também levou a que os philosophes parisienses dessem vazão a uma série de paradoxos, soltando as rédeas de sua fantasia social. Para Venturi, exemplo paradigmático desta "soltura de rédeas" pode ser identificado nas sugestões então elencadas de se fazer dos condenados pelo sistema penal francês verdadeiros escravos empregados na propagação do gênero humano - e, logo, na multiplicação da mão-de-obra -, ou de utilizá-los em experiências médicas. Nas palavras do autor: "Esse é um dos aspectos mais paradoxais e estranhos de toda a casuística do século XVIII sobre as diversas formas que a repressão dos delitos deveria assumir, uma vez descartada a tortura e a pena de morte. É difícil resistir à tentação de afirmar que a imaginação punitiva, que durante séculos ocupou-se em inventar sempre novos tormentos, novas rodas e tenazes, formas mais complexas e espetaculares para esquartejar e cortar em pedaços os delinquentes, trilhava agora caminhos que o novo utilitarismo, o novo cálculo social, a nova concepção das relações entre indivíduo e sociedade, pareciam imperiosamente indicar.”. Franco Venturi. Utopia e Reforma no Iluminismo. Bauru, SP: EDUSC, 2003; pp. 197-215.

${ }^{520}$ O Código espanhol de 1822 é paradigmático nesse sentido, comportando simultaneamente sentenças como a de "trabajos perpetuos", regulada entre os artigos 47 e 49 do código e facilmente definível como uma pena de trabalho infamante, a ser cumprido num estabelecimento exclusivo e em isolamento, sempre com corrente nos pés e nos trabalhos mais duros e penosos disponíveis; e as de "presidio" ou "reclusion en una casa de trabajo" - 
No caso do projeto português elaborado por Pascoal de Melo Freire, temos que seu Titulo IV, responsável pela listagem das punições admitidas, deixava subentendida a necessária realização de trabalhos no cumprimento da pena de prisão, sem maiores detalhes, contudo, acerca de sua aplicação. $O$ exame completo do documento revela, porém, como - apesar de não reguladas pelo Titulo IV - também aí eram admitidas as penas de galés e "servidão nas obras públicas", confirmando o caráter torturante envolvido no cumprimento de serviços pelos criminosos ${ }^{521}$.

Se observarmos agora a prescrição das penas de prisão com trabalho e galés no projeto de Vasconcelos, identificaremos facilmente a presença das mesmas permanências descritas acima. Como exposto no subcapítulo anterior, Vasconcelos pensara as penas de galés e prisão com trabalho de forma bastante aproximada em seu projeto, prescrevendo-as desordenadamente, e por diversas vezes, para um mesmo delito $^{522}$ e admitindo, por meio de seu artigo 78, que na ausência de Casas de correção no Império brasileiro, a pena de prisão com trabalho fosse comutada na de galés ${ }^{523}$.

artigos 56 a 61 -, que pressupunham o trabalho dos réus no interior de presídios ou casas de trabalho, cumprindo serviços proporcionais às necessidades do local ou ao seu porte físico e sem correntes.

${ }^{521}$ Para o caso específico de Portugal, a admissão de punições envolvendo o trabalho dos réus foi remetida, por Patrícia Ann Auferheide, aos séculos XVII e XVIII - momento em que o trabalho forçado dos prisioneiros nas galés (obras públicas, docas, fortes, construção de estradas etc.) teria visado garantir a mão de obra necessária ao Estado em desenvolvimento. Ainda de acordo com esta autora, a reorganização penal levada a cabo no século XVIII teria mantido as penas de trabalho forçado, e admitido as Casas de correção em Portugal, não em sintonia com os novos intuitos reabilitadores em voga no restante da Europa, mas sim com vistas ao suprimento da mão de obra necessária ao país e a suas colônias. Tem-se aqui, portanto, num estudo de caso específico, uma explicação para a aparente contradição implícita à adoção simultânea de instituições modernas de trabalho prisional e de um uso "atrasado" desta mesma mão de obra. Contradição que, como vimos, não parece ter se restringido ao caso português. Para autores como Rüsche, Kirchheimer e Foucault, como vimos, esta situação não configurava, por sua vez, contradição alguma. Patrícia Ann Aufderheide. Order and violence: social deviance and social control in Brazil, 1780-1840. Tese de doutorado apresentada à Universidade de Minnesota, 1976; pp. 295-299.

${ }^{522}$ A comprovação de que Vasconcelos prescrevera as penas de galés e prisão com trabalho a partir de uma concepção bastante próxima - de castigo pela via do labor -, encontra-se no fato de, por diversas vezes, tais sentenças terem sido misturadas entre os graus máximo e mínimo dos delitos de seu projeto. Assim, por exemplo, a provocação de nação estrangeira a declarar guerra ao Império deveria ser punida, pelo artigo 319, com galés por dez anos no grau mínimo, prisão perpetua com trabalho no médio, e galés perpétuas no máximo. Vale a pena destacar ainda, neste ponto, que todas as sentenças semelhantes a do artigo 319 foram corrigidas, entre 1829 e 1830 , pelas comissões parlamentares de trabalho responsáveis pela revisão do texto do diploma penal, estando completamente ausentes, portanto, do texto definitivo do Código de 1830.

${ }^{523}$ De acordo com o artigo 78 do projeto de Vasconcelos: "Emquanto se não levantão os edificios necessarios para o trabalho dos réos, os juizes commutarão as penas de prisão com trabalho em galés, prisão simples ou desterro como lhes parecer de razão." 
Tal substituição de uma pena pela outra, contudo, e a própria confusão em sua regulamentação, não foram admitidas pelo Código de 1830, uma vez que, como vimos, a punição via prisão com trabalho pressupunha, aí, uma reabilitação da qual os sentenciados a galés estavam definitivamente excluídos. A maior clareza conceitual no tocante à pena de trabalho prisional e seu distanciamento de penas "congêneres", foi acompanhada ainda, no diploma de 1830, por uma queda abrupta no sentenciamento às galés e por um crescimento exponencial das prescrições à pena de prisão com trabalho (ver Tabela II); adotada, então, como a "punição por excelência" do código brasileiro ${ }^{524}$.

Se houve um diploma legal produzido nesta época em que o sentenciamento dos prisioneiros ao trabalho esteve eminentemente vinculado à perspectiva de sua regeneração social e moral - eliminado-se por completo a admissão ou inclusão de suplícios e humilhações no seu cumprimento -, este diploma foi o "Code of Offences and Punishments" de Edward Livingston ${ }^{525}$. Neste projeto de código penal que, dentre os analisados, foi o que por mais vezes prescreveu a pena de prisão com trabalho, apenas o trabalho prisional era admitido (artigos 98 a 101), devendo ser realizado, portanto, exclusivamente no interior das penitenciárias, coletiva ou solitariamente ${ }^{526}$.

Retomando, nesse sentido, as prescrições do Código brasileiro de 1830, tem-se que, enquanto a admissão conjunta de penas degradantes (galés) e regeneradoras (prisão com trabalho) pela via do trabalho, aproximava-o de uma série de projetos e diplomas em voga no mundo ocidental àquela altura, a definição e prescrição claramente distanciada destas punições entre si (não dando margem a confusões entre seus objetivos) o diferenciava da grande maioria deles, assemelhando-o, ao que tudo indica, da teoria penal esboçada pelo projeto de Livingston. Já a amplitude da prescrição das penas de prisão com trabalho neste código e a relativa suavidade penal aí consequentemente impressa também nos parecem atribuíveis à influência exercida

\footnotetext{
${ }^{524}$ A proporcionalidade de prescrição da pena de prisão com trabalho aumentara, entre 1827 e 1830 , de $13,9 \%$ para $27,9 \%$ do total de punições admitidas, configurando-se na pena mais atribuída do diploma penal imperial. Vale lembrar, por fim, que a atribuição das penas de galés e prisão simples no projeto de Vasconcelos configuravam, respectivamente, $14,7 \%$ e $18,4 \%$ do total das punições, ambas, portanto, superiores à punição por trabalho prisional. Ver Tabela II.

${ }^{525} \mathrm{~A}$ System of Penal Law prepared for the State of Louisiana. New-Orleans: printed by Benjamin Levy, 1824.

${ }^{526}$ Para mais detalhes, ver: Edward Livingston: "Introductory Report to the Code of Reform and Prison Discipline". In: A System of Penal Law for the State of Louisiana. Pittsburgh, John L. Kay \& Brother, 1833; pp. 305-354.
} 
pelo "Code of Offences and Punishments" norte-americano (para além, como dissemos, da ascendência "teórica" desempenhada pela Leopoldina).

Se aliarmos, assim, à modernidade impressa pela pena de prisão com trabalho no código de 1830 (tanto no que diz respeito à sua definição, quanto ao conteúdo e à forma da sua aplicação), uma análise dedicada à manutenção da pena capital e de penas corporais infamantes, como as galés e os açoites, em seu texto, veremos que também os pontos de aparente "atraso" do código podem e devem ser relacionados ao contexto jurídico em que se inseria o diploma brasileiro, às especificidades políticosociais do país recém-independente e à necessidade de adequação de seu texto a esta realidade.

O teor dos debates e propostas aventadas no Parlamento brasileiro, em setembro de 1830, em torno de temáticas como a manutenção das penas de morte e galés no diploma penal imperial e sua restrição, ou não, a crimes e intervalos de tempo específicos, dá-nos clareza do modo com que as propostas e resoluções então tomadas relacionavam-se, simultaneamente, ao modelo de regulamentação penal em curso no mundo ocidental e às particularidades da sociedade brasileira de então. Nesse sentido, a decisão final pela continuidade destas penas pode ser relacionada tanto ao desejo primordial de preservação e garantia da ordem interna - fundado no reconhecimento de diversos modelos de codificação estrangeiros em que se havia prescrito largamente estas penas -, quanto à constatação de que a composição social do Brasil, e a presença da escravidão em seu seio, demandavam punições de caráter ameaçador e exemplar, sem as quais, ao seu ver, não se poderia controlar a escravaria e a população mais pobre do país ${ }^{527}$.

Se, por um lado, a larga prescrição da pena de prisão com trabalho e um dispositivo como o presente no art. 311 do Código de 1830 - limitando o sentenciamento às galés à construção de uma rede de Casas de Correção no território nacional e definindo que, a partir de então, semelhantes sentenças fossem comutadas na prisão com trabalho - indicavam a presença indiscutível de um projeto penal

\footnotetext{
${ }^{527}$ Vale a pena destacar, neste ponto, que se o projeto de código criminal de Edward Livingston eliminara, por completo, a prescrição à pena capital de seu texto, seu autor não teve de lidar, contudo, com a possível inadequação deste diploma ao controle da população escrava dos Estados Unidos, haja vista a presença aí, de um "Black Code" exclusivamente dedicado à regulamentação dos crimes cometidos por cativos e recheado de condenações à morte. Ver: Monica Duarte Dantas, "Dos Statutes ao Código brasileiro de 1830: o levante de escravos como crime de insurreição." Revista do Instituto Histórico e geográfico Brasileiro, vol. 452, pp. 273-309, 2011.
} 
moderno e com objetivos punitivos precisos para o país; por outro lado, a manutenção das penas de morte e galés demonstravam que tais legisladores não puderam fechar os olhos à realidade em que viviam.

\section{Conjuntura política e formulação penal em finais do Primeiro Reinado}

A interpretação ensaiada acima ganha concretude quando, ao exame das alterações e compromissos empreendidos na definição do equilíbrio penal do Código de 1830, somamos a análise de dispositivos específicos adotados em sua Parte Especial e atentamos ao modo com que a reelaboração sofrida nestes casos (entre 1829 e 1830) relacionou-se ao momento político vivido pelo país e às opções estratégicas então tomadas pelos legisladores nacionais.

Haja vista serem majoritariamente públicos os crimes a que nos dedicaremos na sequência, gostaríamos de destacar, antes de mais nada, as alterações organizacionais propositalmente empreendidas sobre esta seção do projeto de Vasconcelos.

Observemos, assim, que enquanto no projeto de 1827 , os crimes públicos vinham regulados ao final do documento, mais especificamente em seu Titulo IV e após a prescrição, portanto, dos crimes policiais e particulares, no Código de 1830 tal regulamentação se dava na "Parte Segunda" do diploma, imediatamente depois do estabelecimento de suas disposições gerais ${ }^{528}$. Para além de seus distintos posicionamentos no interior de cada um dos códigos, também a ordem eleita para a regulamentação de delitos públicos específicos era diferente em cada caso. Desta forma, enquanto o Titulo IV do Projeto de Vasconcelos partia da regulamentação dos crimes dos funcionários públicos e dos crimes contra o tesouro público para, ao final da seção, tratar dos crimes atentatórios à segurança política do Império, o Código de 1830 regulava inicialmente os delitos que ofereciam ameaça à existência política do país ou à sua segurança interna e externa, para somente então abordar crimes contra a boa ordem e administração estatal ou contra o tesouro e a propriedade públicas.

Embora um importante jurista e bom comentador do diploma brasileiro, como Thomaz Alves Junior, defenda a insignificância de questões referentes à ordem dos delitos no interior dos códigos penais ${ }^{529}$, o acúmulo de diferenças organizacionais

\footnotetext{
${ }^{528}$ Ver anexos II e IV.

${ }^{529}$ Alves Jr. acreditava comprovar a indiferença existente na ordem de classificação dos delitos num código criminal dando como exemplo as diferentes organizações adotadas por códigos penais como o francês, o bávaro, o espanhol e o português. Há, contudo, controvérsias no que diz respeito a semelhante posicionamento, já que, para alguns juristas, a
} 
entre o projeto de 1827 e o texto final do código, nesta, como em outras de suas seções, não nos parece acidental ou de importância secundária, devendo ser examinado, antes, em consonância com as alterações teóricas e políticas detectadas.

Haja vista a importância estratégica, ao que tudo indica, depositada pelos parlamentares brasileiros na formulação do código penal entre os anos de 1829 e 1830, parece ter sido consciente a opção realizada pela regulamentação prioritária dos crimes públicos e ainda pela prescrição inicial, no interior desta seção, dos crimes políticos possivelmente atentatórios à segurança do governo e território nacional. A grande maioria dos códigos do período, inclusive, havia adotado tal organização, prescrita pelo próprio Beccaria na obra Dos delitos e das penas. De acordo com este autor, na escala de desordens a pautar a organização de um código penal, o primeiro nível deveria ser necessariamente ocupado pelos delitos potencialmente destrutivos da sociedade ${ }^{530}$.

Passemos, assim, à análise de parte dos delitos políticos do Código de 1830, e do delito policial de ajuntamento ilícitos presente em seu texto, destacando o significado subjacente à sua formulação final. Na sequência, examinemos as particularidades inerentes à regulamentação do crime de moedas falsas e o aparecimento da regulamentação do habeas corpus no diploma penal imperial, atentando, uma vez mais, a suas origens, influências e contextualização política.

ordem adotada na prescrição dos delitos influi diretamente na compreensão e qualidade de um diploma penal ou de seções específicas do mesmo. Analisando o Titulo XIX de seu "Code of Crimes and Punishments" (nome que, na versão de 1833 do System of Penal Law de Livingston, recebeu o "Code of Offences and Punishments", de 1824), composto por crimes denominados contra a pessoa (como, por exemplo, os de "assault and battery", "false imprisonment", "rape", "abortion", "homicide" e "duels"), o jurista norte-americano Edward Livingston foi bastante explícito na defesa do caráter pedagógico que, a seu ver, possuía a regulamentação dos crimes em ordem crescente, ou seja, dos mais suaves aos mais fortes. De acordo com Livingston, portanto: "By beginning with the lowest injury that can be offered to the person, an assault, you lay the foundation for comprehending the definitions and descriptions of all the others which are only aggravations, either in degree or by intent.". A Introdução ao Código penal da Baviera (1813), por sua vez, estabelecia que a prescrição de crimes particulares previamente aos públicos, operada no diploma, devia-se não apenas à sua superioridade numérica, mas também ao fato de a definição precisa de determinados crimes públicos demandar um conhecimento prévio da legislação concernente aos particulares. Thomaz Alves Jr. Op. cit.; Tomo I; pp. 40-42. Edward Livingston. "Introductory Report to the Code of Crimes and Punishments". IN: A System of Penal Law for the State of Louisiana. Pittsburgh, John L. Kay \& Brother, 1833; pp. 113-197; p.179. Code Penal du Royame de Bavière (1813). Traduit de l'Allemand par Ch. Vatel. Paris, Auguste-Durand, LibraireÉditeur, 1852.

${ }^{530}$ Giovanni Tarello. Storia della cultura giuridica moderna. Bologna: Società editrice il Mulino, 2010; p. 476. 


\section{Dos crimes contra a existência política do Império e dos crimes de conspiração, rebelião e ajuntamentos ilícitos.}

Uma análise estrutural da seção dos crimes públicos do Código brasileiro (ver o Índice do Código Criminal do Império do Brasil - anexo IV), revela a inexistência de qualquer diferenciação precisa entre os crimes políticos e não políticos por ele admitidos. Haja vista a abolição da pena de morte justamente no que tangia aos crimes políticos do código imperial (vide proposição de Rego Barros), a ausência de semelhante especificação foi considerada uma falha grave por Thomaz Alves Junior. É ele mesmo, portanto, quem nos apresenta uma boa definição do que seriam os crimes políticos num código criminal:

Segundo pensa o muito erudicto Ortolan, para se conhecer se um delicto é politico deve-se indagar o seguinte:

$1^{\circ}$. Qual é a pessoa directamente offendida por este delicto?

$2^{\circ}$. Em que especie de direito o Estado se julga offendido?

$3^{\circ}$. Que genero de interesse tem elle na repressão?

Desde que o Estado fôr a pessoa offendida, o direito fôr concernente à sua organisação social e politica, e o interesse concernente a essa mesma organisação, temos um delicto politico. ${ }^{531}$

Nesse sentido, podem ser considerados políticos os crimes regulamentados pelos artigos $68,69,85,86,87,88,89,90,91,92,93,94,95,96,97,98,99,100,101,102$, 103, 104, 105, 106, 107, 108, 109, 110, 111 e 112 do Código de 1830, relativos, respectivamente: aos casos de ameaça à existência política do Império - de que são exemplos a tentativa de destruição de sua Independência ou Constituição, o estímulo à declaração de guerra ao Brasil por uma nação estrangeira e os crimes cometidos contra o chefe de governo -; aos atentados contra o livre exercício dos poderes políticos - impedindo-se a reunião dos órgãos legislativos nacionais, ameaçando qualquer um de seus membros ou usando de violência contra os representantes dos poderes Executivo, Moderador e Judiciário -; aos crimes contra o livre gozo e exercício dos direitos políticos dos cidadãos - conturbando as eleições imperiais -; e aos crimes contra a segurança interna e pública tranquilidade do Império - de que são exemplos a conspiração, a rebelião e a sedição.

Se atentarmos inicialmente aos crimes regulados pelos artigos $68,85,86,87,88$, 89, 90, 91 e 92 - referentes, todos, ao título dos delitos contra a existência política do

531 Thomaz Alves Junior. Annotações theoricas e praticas ao Código Criminal. Rio de Janeiro: Francisco Luiz Pinto \& $C^{a}$.; Tomo II (1870), pp. 16-17. 
Império -, confirmaremos serem os mesmos resultados diretos da reconfiguração empreendida pelos parlamentares, entre o projeto de Vasconcelos e o diploma de 1830, do tipo penal anteriormente denominado "traição".

Sob nova roupagem no texto definitivo do código, os artigos reunidos sob a categoria "traição" em 1827 (artigo 311 do projeto), passaram a se referir, individualmente, aos seguintes crimes: (art. 68) tentativa de destruição da Independência ou integridade do Império; (art. 85) tentativa de destruição da Constituição ou forma de governo; (art. 86) tentativa de destruição de um ou mais artigos da Constituição; (art. 87) tentativa de destronização do Imperador, de privação de sua autoridade constitucional ou de alteração da ordem legítima da sucessão; (art. 88) tentativa de justificar, com falsidade, a impossibilidade física ou moral do imperador; (art. 89) privação do Regente ou Regência, em parte ou no todo, de sua autoridade constitucional; (art. 91) oposição à convocação da Assembleia Geral; e (art. 92) oposição à reunião da Assembleia Geral.

Ainda que os crimes especificamente regulados por estes artigos fossem praticamente os mesmos que, no diploma de Vasconcelos, compunham o artigo 311, sua dissociação completa da categoria de traição e o próprio desaparecimento desta categoria dos tipos penais previstos pelo Código de 1830 implicaram uma mudança de caráter significativamente mais profundo do que à primeira vista poderia parecer.

Neste sentido, para além de sua desvinculação da ideia de quebra de fidelidade ou deslealdade ao monarca ${ }^{532}$, destaca-se a atenuação penal sofrida por estes delitos no intervalo de tempo considerado. Se, no diploma de Vasconcelos, o crime de tentativa de destruição da Independência ou integridade do império brasileiro (regulado pelo $\S 7^{\circ}$ do artigo 311) era punido, assim, com 10 anos de galés no grau mínimo, prisão

${ }^{532} \mathrm{O}$ Titulo VI do Livro V das Ordenações Filipinas assim definia o crime de lesa-majestade ou traição: "Lesa-majestade quer dizer traição cometida contra a pessoa do rei ou seu real estado, que é tão grave e abominável crime, e que os antigos sabedores tanto estranharam que o comparavam à lepra, porque assim como esta enfermidade enche todo o corpo, sem nunca mais se poder curar, e empece ainda aos descendentes de quem a tem e aos que com ele conversam, pelo que é apartado da comunicação com a gente, assim o erro da traição condena o que a comete e empece e infama aos que de sua linha descendem, posto que não tenham culpa." Dentre os delitos compreendidos como "traição" no Livro V estavam: tramar a morte do rei, sua mulher ou parentes mais próximos; guerrear contra o próprio rei, nos exércitos inimigos; dar conselho aos inimigos do rei em seu desserviço ou de seu real Estado; fazer "conselho" ou "confederação" contra o rei e seu Estado, ou levantar-se contra ele, ou para isso dar ajuda ou conselho; auxiliar a fuga de um condenado pelo crime de traição; ferir ou matar a outrem na presença do rei; dentre outros. A estes crimes o Livro V previa a morte natural cruel e o confisco de bens. In: Silvia Hunold Lara. Ordenações Filipinas: Livro V. São Paulo: Companhia das Letras, 1999. 
perpétua com trabalho no grau médio e galés perpétuas no máximo; em 1830, a este mesmo delito (regulado pelo artigo 68) estava prevista a aplicação da pena de prisão com trabalho por entre cinco e quinze anos. No caso da tentativa de destruição da Constituição política do Império, enquanto o grau máximo previsto pelo diploma de Vasconcelos era a morte, no Código de 1830 a maior punição possível era a prisão com trabalho por quinze anos. Consumado qualquer um destes delitos, o artigo 313 do projeto de 1827 previa a execução, "logo que se possa", da pena capital aos réus, enquanto o texto final do código previa, nos casos mais graves, a pena de prisão perpétua com trabalho no grau máximo, a prisão com trabalho por vinte anos no grau médio e por dez no mínimo.

Paralelamente, portanto, ao peso simbólico representado pela supressão do crime de traição, diretamente vinculável à ideia de lesão a um Estado personalizado e, nesse sentido, envolto numa concepção de direito e de soberania real de que os deputados brasileiros buscavam desvincular o Brasil, a separação dos delitos previamente reunidos sob esta categoria e a atenuação punitiva por eles sofrida, indicam sua nova compreensão, a partir de então, como atentados direcionados à segurança do Estado e à ordem pública e não mais ao poder encarnado na pessoa do monarca ${ }^{533}$.

Para além disso, a diminuição das penas prescritas a crimes como os de tentativa de modificação do texto constitucional ou destronização do imperador e, mais do que isso, a eliminação da pena de morte nesses casos, nos parecem relacionáveis à ponderação, por parte dos deputados brasileiros, de que poderiam ser eles mesmos os réus destes delitos num futuro próximo. Neste ponto, a memória da forte repressão imposta às revoluções de 1817 e 1824, travadas no norte do Brasil, fundada na ideia de lesa-majestade e traição à pátria, deve ter pesado na escolha dos legisladores ${ }^{534}$.

\footnotetext{
${ }^{533}$ À maneira, portanto, da abolição da crime de lesa-majestade pela Leopoldina, também no Brasil esta medida representou uma dessacralização do monarca e sua apresentação aos súditos não mais na qualidade de soberano que detinha um poder divino, mas enquanto rei por consenso dos governados e servidor de um Estado de origem contratual (ver nota 42 da Introdução). Diferentemente do caso toscano, contudo, em que a abolição do crime de lesamajestade foi de iniciativa do próprio Leopoldo II, no Brasil, a eliminação do crime de traição do código penal, e a recomposição política e teórica implícita a tal atitude, foram fruto do trabalho dos legisladores nacionais e estiveram diretamente relacionados à sua oposição a d. Pedro I e a uma tentativa de retirar do imperador as prerrogativas de um poder autoritário e unidimensional. Para uma análise da abolição do crime de lesa-majestade na Leopoldina ver: Adriano Cavanna. Op. cit.; pp. 355-356.

534 Para este assunto ver: Monica Duarte Dantas. "Revoltas, motins, revoluções: das Ordenações ao Código Criminal”. Op. cit.; 2011.
} 
Não estamos desconsiderando, com isso, o fato de a formulação final do diploma de 1830 encontrar-se profundamente ancorada no desejo de acomodação do texto penal brasileiro às modernas prescrições do codificacionismo ocidental, mas, ainda assim, nossa análise não deve prescindir do reconhecimento das particularidades da conjuntura política de fins da década de 1820. Como afirmado anteriormente, a comparação entre os crimes políticos do código brasileiro e dos códigos que o precederam no mundo ocidental apontou para uma leveza incomum das punições prescritas no caso nacional, com a abolição completa da pena de morte e a prescrição majoritária da pena de prisão com trabalho. Inspirados, portanto, pelas teorias e práticas penais em voga na Europa e nos Estados Unidos, os responsáveis pela elaboração do Código Criminal do Império do Brasil impuseram-lhe particularidades impossíveis de serem plenamente reconhecíveis na ausência de uma comparação sistemática com a produção penal do período ou quando isoladas do quadro político nacional.

À altura dos debates de setembro de 1830, quando se discutiu intensamente, no plenário da Câmara baixa, a manutenção, ou não, da pena de morte dentre as punições previstas pelo diploma brasileiro, foi com a seguinte argumentação que Rego Barros opôs-se à sua prescrição no caso dos delitos políticos:

A pena de morte deve com effeito ser abolida nos casos politicos, porém não nos casos de homicidio, e para conter a escravatura, pois que esta é a unica pena que a póde conter. Nos erros politicos não a posso admittir, porque elles procedem da má intelligencia das cousas; e mesmo muitas vezes, o partido vencido, seja o bom partido; isto é, aquelle que faria a felicidade da nação se o seguisse. ${ }^{535}$

Possivelmente fundado numa avaliação do passado recente do país e nas expectativas de alteração de seus rumos políticos num futuro próximo, o deputado atentava para as inversões de "partido" e as mobilizava com o intuito de uma reformulação das práticas punitivas do país.

A análise dos tipos penais "Conspiração" e "Rebelião" mostra, por sua vez, como também a formulação destes delitos, em 1830, esteve relacionada à reelaboração sofrida pelo crime de traição; corroborando o alcance e o sentido das alterações a que fizemos referência até aqui.

Enquanto o delito de conspiração (artigos 107 a 109 do Código de 1830) dizia respeito à concentração de vinte ou mais pessoas com o intuito de secretamente

${ }^{535}$ APB-CD; sessão de 15 de setembro de 1830; p. 512. 
planejar quaisquer dos crimes mencionados nos artigos $68,69,85,86,87,88,89,91 \mathrm{e}$ 92 - sem que tal planejamento precisasse sequer começar a reduzir-se a ato -; o crime de rebelião era definido (pelo art. 110) como a reunião de uma ou mais povoações (que compreendessem juntas mais de 20 mil pessoas) cuja intenção fosse a de perpetrar, ou seja, reduzir a ato, os mesmos crimes políticos designados no caso anterior.

Se atentarmos à definição destes crimes, veremos que os artigos a que ambos fazem referência (arts. 68, 69, 85, 86, 87, 88, 89, 91 e 92 ) são, novamente, quase exatamente os mesmos em que se "dividira", no texto de 1830 , o crime de traição anteriormente previsto por Vasconcelos. Fundados, respectivamente, nos artigos 312 e 318 do projeto do deputado mineiro, as ideias de "conspiração" (inexistente, sob esta denominação, no projeto de Vasconcelos, como veremos à frente) e "rebelião" (regulada de forma incompleta naquele projeto) relacionavam-se diretamente, já no diploma de 1827, à ideia de traição.

Enquanto o artigo 312 reconhecia, portanto, como crime de traição: “O concerto entre mais de 20 pessoas para perpetrar qualquer dos crimes do artigo antecedente [art. 311], ainda que não se principie a reduzir a acto [...].”; o artigo 318 estabelecia, exatamente nos termos que seguem: "É crime de rebellião a perpetração dos crimes do artigo .... por uma povoação ou povoações de mais de trinta mil pessoas, ou auxiliar o inimigo no caso de invasão. Pena do artigo .... $§ 1^{\circ}$.”. Neste último caso, ainda que o projeto não tenha citado o artigo específico a que relacionava a ideia de rebelião, não restam dúvidas de que se referia ao artigo 311, prevendo como punição, igualmente, as penas previamente prescritas pelo parágrafo $1^{\circ}$ daquele artigo: "no gráu minimo prisão perpetua com trabalho, no gráu medio galés perpetuas, no gráu maximo morte.".

Se, no que tange ao artigo 312, a novidade representada pelo Código de 1830 esteve na explícita denominação do concerto de mais de 20 pessoas para a perpetração de determinados delitos políticos, como crime de conspiração (artigo 107), no caso do artigo 318 (artigo 110 em 1830), o texto final do código brasileiro não só complementou as informações lacunares no projeto de Vasconcelos, como diminuiu (de 30 para 20 mil) o limite populacional necessário para a qualificação de uma rebelião, excluindo ainda desta categoria o delito de auxílio a inimigos em caso de invasão. 
Em ambos os casos, uma vez mais, o Código de 1830 diminuiu em muito as punições previstas. Se, no projeto de Vasconcelos, tanto os delitos compreendidos pelo artigo 312, quanto o crime de rebelião, poderiam receber, no grau máximo, a pena de morte, no médio, as galés perpétuas e, no mínimo, a prisão perpétua com trabalho; em 1830 estas penas foram reduzidas, no caso de conspiração, ao desterro para fora do Império por entre quatro e doze anos, e, no caso de rebelião, à prisão perpétua com trabalho no grau máximo, e à prisão com trabalho por 20 ou 10 anos nos graus médio e mínimo.

Diretamente associado a estas alterações, o desvencilhamento dos dois tipos penais da ideia de traição representou a grande novidade imposta pelo Código de 1830.

Se procurarmos, no conjunto de diplomas ocidentais analisados no subcapítulo anterior, o modo com que os crimes de conspiração e rebelião vinham sendo regulamentados à época, veremos que, no que tange ao primeiro caso, o código brasileiro foi o único, para além do diploma penal francês de 1791, a desvencilhar de fato o delito de conspiração da imputação de traição ${ }^{536}$.

Diretamente vinculado à ideia de quebra de fidelidade à pátria, ao delito de conspiração os códigos do período prescreviam, sem exceção, a pena capital ${ }^{537}-\mathrm{em}$

\footnotetext{
${ }^{536} \mathrm{Em}$ todos os códigos ou projetos de codificação penal em que a ideia de conspiração esteve claramente posta, ela esteve diretamente conectada aos tipos penais de traição, alta traição ou lesa-majestade. Assim se dá, por exemplo, no artigo 89 do Código penal francês de 1810; nos artigos 188, 189, 190 e 221 do Código penal espanhol de 1822; no parágrafo 10 do Titulo XIII do Projeto de Código Criminal de Pascoal de Melo Freire, de 1786; no artigo 52 do Código penal austríaco de 1803; e ainda nos artigos 50, 299, 300, 302 e 304 do Código penal bávaro de 1813. A opção brasileira pela sua regulamentação em separado pode ter advindo do projeto de código criminal apresentado à Câmara baixa, em 1827, por José Clemente Pereira. Apesar de a compreensão de conspiração esboçada pelo artigo 98 do projeto de Clemente Pereira não ser diretamente responsável pelo entendimento assumido por este crime em 1830 (que, como vimos, adveio do artigo 312 de Vasconcelos), tanto o artigo 99 deste projeto (incontestavelmente fonte para a elaboração do artigo 108 de 1830) quanto o fato de a conspiração vir aqui, e somente aqui, desvinculada da categoria de "traição política", tornam o projeto de Clemente Pereira, indubitavelmente, matriz de grande importância para a deputação nacional.

${ }^{537}$ Apesar de o Código francês de 1791 desvencilhar a ideia de conspiração daquela de traição, admitindo como traição unicamente os crimes atentatórios à segurança externa do Estado e compreendendo haver conspiração unicamente nos casos de ameaça à ordem interna, também nele, aos casos de conspiração, estava prevista majoritariamente a pena capital. Ver: Monica Duarte Dantas. "Revoltas, motins, revoluções: das Ordenações ao Código Criminal". Op. cit.; 2011; nota 100. Para as relações possivelmente existentes entre a prescrição do crime de conspiração no código de 1791 e a opção deliberada dos legisladores franceses pela não regulamentação dos casos de crimes não consumados, ver: Roberto Martucci. Op. cit.; pp. 190-194.
} 
alguns casos, com confisco de bens ${ }^{538}$. Em vários dos casos analisados, ainda, bastava a reunião de um ou mais indivíduos para que se incorresse neste crime ${ }^{539}$, enquanto, no Brasil, era necessária a presença de vinte ou mais pessoas para sua imputação.

No que se refere ao crime de rebelião, apesar de parte dos códigos do período o terem regulamentado (e, como em 1830, de forma desvencilhada das categorias de traição ou lesa-majestade ${ }^{540}$ ), destaca-se, de todo modo, a originalidade da definição adotada no diploma nacional ${ }^{541}$ e o fato de se considerar rebelião unicamente a reunião (para a perpetração de determinados delitos políticos) de uma ou mais povoações que, juntas, compreendessem mais de vinte mil pessoas.

Ainda que a definição deste limite refira-se à quantidade de habitantes da povoação, ou povoações, enredada nos acontecimentos, e não propriamente ao número de pessoas envolvidas na rebelião, o texto do artigo não é explícito quanto a este ponto, tendo-se lido com freqüência este limite como o estabelecimento de um mínimo de pessoas necessário à qualificação do crime ${ }^{542}$. Não deixa de ser curiosa, de

${ }^{538}$ Vide artigo 97 do Código penal francês de 1810 e artigos 45 e 46 do Código penal austríaco de 1787.

${ }^{539}$ Enquanto os código franceses de 1791 e 1810, e o diploma austríaco de 1803, não estabelecem qualquer definição quanto ao número de indivíduos necessários à execução do crime de conspiração, para o código espanhol de 1822 (artigo 188), assim como para o austríaco de 1787 (artigos 45 e 46), bastava um único indivíduo para a sua qualificação. O projeto de Pascoal de Melo Freire, por sua vez, estabelecia, no $\$ 10$ de seu Titulo XIII (referente aos casos de traição), que a conjuração de três ou mais pessoas para perpetração de crimes contra o Estado era suficiente à imputação do crime de alta traição; enquanto, pelo Código da Baviera, de 1813, bastavam duas pessoas para a formação de um "complot" (artigo 50), julgando-se crime de alta traição a organização de um complot cujo fim fosse atacar a independência do Estado, a segurança pessoal de seu chefe ou a constituição (artigo 300).

${ }^{540}$ Identificamos a regulamentação do crime de rebelião, de forma desassociada da ideia de traição, no artigo 66 do código austríaco de 1803 e nos artigos 274 e 275 do código espanhol de 1822. Ainda que a denominação "rebelião" tenha aparecido também no parágrafo 5 do Titulo XIII do Projeto Melo Freire, tal crime vinha compreendido, aí, enquanto traição.

${ }^{541}$ Em seus comentários ao Código Criminal de 1830, Thomaz Alves Jr. afirma ter encontrado uma constante confusão entre os tipos penais rebelião, sedição e resistência nos códigos penais por ele consultados, destacando por diversas vezes a originalidade da compreensão esboçada no código brasileiro. Thomaz Alves Jr. Op. cit; Tomo II; pp. 286-297.

${ }^{542}$ Nos comentários ao Código Criminal de 1830 redigidos por Anastácio Falcão (publicados, no Rio de Janeiro, em 1831), são constantes as críticas à leveza das punições admitidas nos crimes públicos do diploma e ao aparente descaso legado pelos legisladores à sua definição. Neste sentido, o autor censura abertamente a definição dada ao crime de rebelião, em especial por considerar extremamente elevado e mal pensado o mínimo de 20 mil pessoas para a sua imputação. De acordo com Falcão, a reunião de um número muito menor de indivíduos poderia ser já atentatória à segurança do Império. Para o jurista, inclusive, por oferecer um perigo muito maior à segurança do Estado que o crime de homicídio, seria preferível que o código tivesse prescrito a pena capital aos casos de rebelião, conspiração e auxílio a nações inimigas, do que aos casos de assassinato. Anastácio Falcão. Código Criminal do Império do Brasil analysado por José Anastácio Falcão, advogado portuguez; segundo o systema dos 
todo modo, a distância existente entre a quantidade de indivíduos necessária a uma conspiração (vinte pessoas) e a uma rebelião, especialmente quando se entende a conspiração enquanto possível fase inicial do movimento rebelde.

Se, por um lado, portanto, podemos afirmar que, entre 1829 e 1830, os legisladores brasileiros suprimiram a categoria de traição sem terem de abrir mão de dispositivos considerados necessários à segurança do Estado nacional em construção $^{543}$, uma análise histórica deste mesmo documento, dos homens envolvidos em sua elaboração e do trajeto político por ele percorrido, traz à tona seu caráter de "arma política", explicitando o modo com que os representantes envolvidos em sua elaboração souberam imprimir ao código, simultaneamente e em conformidade com o novo paradigma penal do período, as garantias necessárias à ordem pública nacional e os dispositivos jurídicos convenientes às suas pretensões políticas.

Mantendo, nesse sentido, os limites de 20 e 20 mil pessoas necessárias à qualificação respectiva dos crimes de conspiração e rebelião - limites que, em linhas gerais, não fugiam do que ficara previamente estabelecido pelo projeto de Vasconcelos -, os representantes brasileiros não parecem ter buscado facilitar o enquadramento destes crimes pelo judiciário. Também no que tangia às punições previstas ao crime de rebelião, sua restrição aos denominados "cabeças" do conflito sem que se tenha definido, contudo, ao longo do diploma, o que precisamente qualificava os cabeças de um crime ${ }^{544}$, parece ter buscado dificultar, em mais uma frente, a definição precisa deste delito e a imputação de seus autores, protegendo, de certa forma, os indivíduos possivelmente envolvidos num levante contra o Estado.

A esta altura da exposição, o recurso à análise do delito policial de "ajuntamentos ilícitos" - apesar de um tanto deslocada no interior da análise dos crimes políticos do código nacional - possui a vantagem de aclarar ainda mais a tentativa empreendida

melhores criminalistas, com interessantes Nottas extraidas do maginifico, e maravilhôso Systema Penal, e Repressivo contra a Pena de Morte, escripto por M. Charles Lucas, advogado em Paris, e o mais vigoroso e constante Defensor dos Direitos da Humanidade. Rio de Janeiro: Typ. Imp. e Const. de É. Seignot-Plancher, 1831; pp. 41-50.

${ }_{543}$ Diretamente relacionados, portanto, nos diferentes códigos em que apareceram, à prerrogativa de manutenção da ordem e defesa do Estado, a inserção dos crimes de rebelião e conspiração no diploma brasileiro parece ter atuado com vistas à preservação de garantias do funcionamento normal do Estado brasileiro, ainda que ausente, aí, a regulamentação potencialmente repressora expressa pela imputação de traição.

${ }_{544}$ A punição exclusiva aos "cabeças" de um crime ou, de todo modo, a referência a esta categoria específica de criminosos, aparece não apenas no caso do crime de rebelião, mas também nos casos de sedição (artigo 111), insurreição (artigos 113, 114 e 115) e ajuntamentos ilícitos (artigo 290). 
pelos deputados brasileiros de minorar o impacto e a punibilidade de certos crimes de perturbação à ordem no Brasil, reforçando o ponto de vista que viemos desenvolvendo até aqui ${ }^{545}$.

Como demonstrado no subcapítulo anterior, os deputados brasileiros inspiraramse diretamente no diploma penal de Edward Livingston para a regulamentação do crime de ajuntamentos ilícitos no Código de 1830 (artigos 285 a 294), tendo modificado, neste processo, a prescrição anteriormente estabelecida pelos artigos 117, 118 e 119 do projeto de Vasconcelos - de acordo com os quais ficava proibido o ajuntamento de mais de vinte pessoas, em lugar público, não tendo fim permitido por lei ou, tendo-o, se mostrasse tendência perigosa. Para além de regulamentar o modo com que deveriam agir, nestas situações, o juiz de paz da localidade e os indivíduos acusados pelo crime, o projeto de Vasconcelos estabelecia, em seu artigo 119, que se os ditos ajuntamentos tivessem por fim a realização de delitos contra o Estado, deveriam ser punidos como tais, ou seja, como crimes públicos (aos quais estavam previstas, como vimos, penas como as de morte, galés e prisão perpétuas).

Tal regulamentação, por sua vez, desaparece do Código de 1830, em que o ajuntamento ilícito é definido como a reunião de três ou mais pessoas com a intenção de se ajudarem mutuamente para a realização de algum delito, prevendo-se, no caso de execução do mesmo, a pena de multa de vinte a duzentos mil réis (artigo 285). Por meio deste diploma ficava estabelecido ainda que, no caso de o ajuntamento ilícito buscar impedir a recepção de algum tributo, ou destinar-se a soltar um réu legalmente preso, a multa fosse de quarenta a quatrocentos mil réis.

Às vésperas da Abdicação de d. Pedro I, a reunião suspeita de indivíduos nas ruas das cidades brasileiras deixava de configurar, portanto, um delito grave, possivelmente punido com as penas dos crimes públicos do diploma, para ser punido exclusivamente com multas; indicando como, também neste caso, a atuação dos legisladores nacionais pode ser relacionada à tentativa de adaptação do código penal às metas de oposição ao imperador d. Pedro I - inclinando este documento, como diria Thomas Flory, a favor dos dissidentes e revolucionários políticos.

\footnotetext{
${ }^{545}$ A análise dos próximos parágrafos foi previamente desenvolvida por Monica Duarte Dantas no artigo "Revoltas, motins, revoluções: das Ordenações ao Código Criminal". Op. cit.; pp. 30-33.
} 


\section{Moeda Falsa}

Com o intuito, uma vez mais, de aproximar as escolhas jurídicas impressas no Código de 1830 à conjuntura política vivida pelo país às vésperas da Abdicação de $\mathrm{d}$. Pedro I, interessa-nos discutir, na sequência, a peculiar regulamentação recebida pelo crime de falsificação de moedas no texto do código criminal. Prescrito entre os artigos 173 e 176 do diploma de 1830, o crime de moeda falsa assumiu, neste texto, definição bastante parecida àquela previamente estabelecida pelo projeto de Vasconcelos.

Era moeda falsa, portanto, de acordo com estes documentos, (i) aquela fabricada sem autoridade legítima, ainda que feita com a matéria e da forma utilizada na confecção da verdadeira, e ainda que equivalentes o seu peso e valor intrínseco em relação à oficial, e (ii) aquela fabricada sem determinação de autoridade competente e sem a matéria e peso equivalentes à moeda real. A imputação pelo delito de falsificação de moedas incluía, em um como noutro diploma, a falsificação de papéis de crédito, a introdução, no Brasil, de moeda falsa fabricada em país estrangeiro e a introdução dolosa de moeda falsa ou papel de crédito falso semelhante aos distribuídos nas estações públicas. Por fim, os diplomas previam que se punisse também a diminuição do peso da verdadeira moeda ou o incremento de seu valor por qualquer artifício.

No que tangia, portanto, à definição deste crime, o código brasileiro não apresentava novidades significativas em relação ao projeto de Vasconcelos e tampouco se diferenciava do conjunto dos diplomas penais do período - nos quais o delito de falsificação era regulado de maneira mais ou menos parecida à descrita acima. A análise cuidadosa da regulamentação do crime de moedas falsas no Código de 1830 chama a atenção, contudo, pela maneira demasiadamente amena com que foram previstas suas punições.

A análise específica deste crime nos dez diplomas penais ocidentais a que fizemos referência prévia, revela claramente o deslocamento do código brasileiro no tocante à sua punição. Neste sentido, enquanto a totalidade destes diplomas prescreveu, ou a pena de morte ${ }^{546}$, ou penas severas de trabalhos forçados ${ }^{547}$ ao delito de moedas falsas

\footnotetext{
${ }^{546}$ Foi este o caso dos códigos penais francês de 1791 (Artigo 2/Parte II/Titulo I/Seção VI); austríaco de 1803 (artigos 92 a 106) e francês de 1810 (artigos 132 a 138).

${ }^{547}$ Foram previstas penas severas de trabalho forçado - bastante diferentes, contudo, em seus detalhes, em cada um dos documentos - nos códigos penais toscano de 1786 (artigo 94 - pena de trabalhos públicos temporários ou perpétuos); austríaco de 1787 (artigos 68 a 75 - pena de severe imprisonment); prussiano de 1794 (artigos 252 a 269 - penas de réclusion dans un
} 
- tendo o projeto de Vasconcelos previsto, ao grau máximo deste crime, a pena de galés de dois a oito anos -, o diploma brasileiro de 1830 previu a pena de prisão simples ou com trabalho, a um máximo de oito anos.

De um modo geral, o que fazia com que este crime fosse tão severamente punido nos códigos penais da época era sua associação direta à ideia de ofensa às autoridades e ameaça ao bem público estatal. Neste sentido, na qualidade de crime contra o tesouro público, a falsificação de moedas e papéis de crédito tendia a receber o rigor punitivo dos mais sérios atentados à ordem interna. A seguir-se este raciocínio, sua extrema amenização no diploma de 1830 não representaria mais do que o prosseguimento da diretriz de diminuição penal nos crimes públicos adotada pelos legisladores que, entre 1829 e 1830, reformaram o projeto de Bernardo Pereira de Vasconcelos.

Esta, contudo, não configura justificativa suficiente se, expandindo o foco de nossas observações, atentarmos aos sérios problemas enfrentados pelo Brasil, ao longo de praticamente todo o Primeiro Reinado, com a falsificação das moedas de cobre.

Como vimos no capitulo 1, a crise financeira desencadeada pelo esvaziamento dos cofres brasileiros quando do retorno de d. João VI a Portugal, em 1821 - momento em que parte do séqüito régio descontou no Banco do Brasil as notas ou bilhetes de crédito de que dispunha, esgotando as moedas de ouro e prata de seus cofres e acabando com o lastro de grande quantidade de papel-moeda ainda em circulação no país -, desembocara em tentativas de saneamento que, elevando ainda mais a circulação de papel-moeda ${ }^{548}$ e fabricando grande volume de moedas de cobre, deram azo a uma derrama de moedas falsificadas nas praças comerciais ${ }^{549}$.

fort, supplice infamant de verges e condamnation aux travaux de fortifications la vie durant); bávaro de 1813 (artigos 341 a 348 - penas de maison de force); e espanhol de 1822 (artigos 379 a 387 - pena de trabajos perpetuos). Também o projeto de Pascoal de Melo Freire previa, em seu Titulo XV, a punição por infâmia, perda de todos os bens e trabalho perpétuo nas obras públicas mais penosas ao acusado pelo crime de falsificação de moedas; enquanto o projeto de Edward Livingston, por sua vez, estabelecia a pena de imprisonment at hard labour por entre 7 e 15 anos aos sentenciados por este mesmo crime.

${ }_{548}$ De acordo com Alexander Trettin, as cédulas de papel-moeda emitidas pelo Banco do Brasil "tinham como garantia ou lastro os depósitos em metal precioso feitos nesta instituição. Assim, elas eram aceitas como moeda pois aqueles que as recebiam confiavam (por isso moeda fiduciária) que, se necessário fosse, poderiam descontá-las no Banco. O valor em notas seria então convertido em moedas de ouro e prata. Além da credibilidade da instituição bancária, a garantia da confiabilidade baseava-se em grande medida no curso legal que se expressava na prática pela aceitação por parte das repartições públicas de tal moeda." 
No que tange ao papel-moeda, o período entre 1821 e 1825 correspondeu a uma grande difusão de notas pelo Banco do Brasil, acompanhada por seu resgate contínuo, mas sempre inferior à emissão. Entre 1825 e 1826, por sua vez, houve uma queda no volume de emissões, provavelmente causado, entre outros motivos, pelas constantes críticas que se seguiram à política de emissão contingencial do regime, tornando a situação do meio circulante no país tema constante dos debates políticos. A partir de 1826, contudo, a deflagração da Guerra da Cisplatina tornou necessária a arrecadação de recursos para a campanha militar, aumentando-se novamente a produção de dinheiro e incrementando-se o volume de papel-moeda em circulação em 43,5\% em apenas um ano ${ }^{550}$.

Já no que se refere às moedas de cobre, o governou ampliou consideravelmente sua cunhagem a partir de 1822 - emitindo ordens para sua fabricação nas Casas da Moeda da Corte e da Bahia, e em oficinas monetárias nas províncias de Goiás, Mato Grosso e São Paulo; e enviando moedas já cunhadas no Rio de Janeiro ou Bahia para outras províncias do Império. Neste período, pode-se reconhecer uma forte queda na produção de moedas de ouro e prata no país, com as moedas de cobre passando a corresponder a cerca de $83 \%$ do valor total de moedas cunhadas na Corte ${ }^{551}$.

Se, como afirmado anteriormente, portanto, a cunhagem de moedas de cobre e a emissão de papel-moeda foram estratégias financeiras utilizadas desde o início do governo de d. Pedro I para o aumento das fontes de renda da Coroa, o aumento na emissão de papel-moeda a partir de 1826 fez com que, já em 1828, o mercado não mais comportasse semelhante alternativa. Reduzindo a emissão de papel-moeda e sem capacidade de fabricar dinheiro para o governo, o Banco do Brasil acabou liquidado, como vimos, em 1829. A possibilidade de fabricação contingencial de dinheiro reduziu-se, assim, a partir mais ou menos do ano de 1828, à cunhagem de moedas de cobre, que superou a produção de notas do Banco do Brasil ${ }^{552}$.

Contrariando, contudo, os princípios relativos à moeda fiduciária, o Bando do Brasil passou a emitir papel-moeda em um montante superior ao seu capital. Para o ano de 1821, portanto, o autor detecta que a reserva em moeda metálica do banco equivalia a $12 \%$ do valor total de cédulas em circulação. Alexander Trettin. O derrame de moedas falsas de cobre na Bahia (1822-1829). Dissertação de Mestrado; UFBA; 2010; pp. 34-37.

${ }^{549}$ Vantuil Pereira. Ao Soberano Congresso: direitos do cidadão na formação do Estado Imperial brasileiro (1822-1831). São Paulo: Alameda, 2012; pp. 125-126.

${ }_{550}^{50}$ Alexander Trettin. Op. cit.; pp. 37-38.

${ }^{551}$ Idem; pp. 41-44.

${ }^{552}$ Idem; pp. 44-45. 
Aumentando-se assim, por todo o Império, o volume de moedas de cobre, facilitou-se, em muito, a inserção de moedas falsas no país. O negócio era lucrativo aos falsificadores por conta da desproporção existente entre o valor intrínseco deste metal e o valor que ele recebia posteriormente à cunhagem. Fabricadas com urgência, e em grande quantidade, pelas casas oficiais, as moedas de cobre pecavam, em muitos casos, pela falta de qualidade, imperfeições físicas e variações de peso e espessura, o que, por sua vez, facilitava a confusão entre as moedas oficiais e as falsas. Para além da famosa derrama de moedas falsas ocorrida na Bahia a partir de $1823^{553}$, o problema rapidamente espalhou-se pelo país, atingindo diversas outras províncias.

Em abril de 1831, contudo, o problema da falsificação de moedas de cobre ainda não havia sido solucionado, tornando ainda mais difícil a compreensão da específica regulamentação recebida por este delito no Código de 1830.

No caso particular da província da Bahia, uma única tentativa para sanar o meio circulante fora posta em prática entre abril e maio de 1828, ainda, portanto, no Primeiro Reinado: "tratava-se do resgate ou, como era chamado à época, do troco da moeda falsa de cobre." ${ }^{554}$ Por meio do decreto imperial de 27 de novembro de 1827 e do edital de 27 de março de 1828, ficara estabelecido que a população da Bahia entregasse suas moedas de cobre em postos fixos da província e que, em troca, recebesse moedas de cobre do peso, valor e tipo daquelas fabricadas na Corte, ou cédulas emitidas pelo Tesouro. A operação, contudo, resultou em grande fracasso, já que a quantidade de cobre circulante era muitíssimo maior do que a inicialmente calculada pelas autoridades ${ }^{555}$.

Neste contexto, foram freqüentes as reclamações de políticos brasileiros - tanto na Câmara quanto no Senado - em relação à impunidade de que desfrutavam os falsificadores de moeda. Uma decisão do Ministério da Justiça de 22 de julho de 1828 , por exemplo, afirmava que:

Sua Majestade o Imperador tem visto com muita estranheza a impunidade, com

\footnotetext{
553 "Na Bahia, já em 1826, a Cidade do Salvador teve sua praça comercial paralisada por causa dos efeitos da circulação de um grande volume de tais moedas. Estimava-se que dois terços das moedas em circulação eram falsificadas. Essa peculiaridade baiana se explica provavelmente por dois motivos: pelo fato de que, na Cidade do Salvador existisse uma Casa da Moeda que produzia, segundo testemunhos da época, peças de inferior qualidade em comparação às produzidas no Rio de Janeiro; e por terem sido produzidas em caráter emergencial durante a guerra de independência cerca de 45.000 moedas de 80 réis em uma oficina monetária montada na então vila da Cachoeira.” Alexander Trettin. Op. cit.; p. 50.

${ }_{554}^{55}$ Idem. Ibidem.

${ }^{555}$ Idem; pp. 128-150.
} 
que os públicos fabricadores de moeda falsa têm espalhado mais de cinco milhões de cobre nessa província [Bahia], na presença de um Presidente, de uma Relação e de muitos Magistrados territoriais, sem que até hoje tenha aparecido um procedimento forte punindo os crimes, que acredite o zelo e a integridade de tantas autoridades a quem pela lei incumbia proceder contra os autores de um crime de conseqüências tão funestas. ${ }^{556}$

Mesmo após a medida do resgate das moedas falsas, sua adulteração continuou freqüente na Bahia, tendo o governo optado, então, muito provavelmente na tentativa de exemplificar o limite a que chegara sua paciência com a questão, pela condenação à morte de um indivíduo julgado por este crime: Manuel Joaquim de Santana. Nem esta medida, contudo, solucionou a questão e, para o ano de 1829, Alexander Trettin reconhece que a falsificação de moedas passou a ser um problema nacional, atingindo, sobretudo, as "Províncias do Norte" e Minas Gerais ${ }^{557}$.

Ainda que, possivelmente, a lembrança da execução de Santana tenha influenciado a decisão dos deputados brasileiros pela atenuação das punições previstas ao crime de moedas falsas, acreditamos ser possível identificar, na conjuntura financeira do país àquela altura, justificativas mais plausíveis para semelhante opção.

Em sua dissertação de mestrado, Alexander Trettin chama constantemente a atenção à importância que, ao longo do Primeiro Reinado, a moeda de cobre assumiu no Brasil. Isto porque as moedas de ouro e prata possuíam valores elevados para as pequenas transações do dia-a-dia, enquanto a cédula mais baixa emitida pelo Banco do Brasil era de quatro mil réis, valor também alto para pequenas transações. Sendo assim, a moeda de cobre, destinada a servir de troco e complementar quantias mais altas, tinha papel central no acesso a bens de consumo cotidianos pela população.

$\mathrm{Na}$ cidade do Rio de Janeiro, contudo, a partir de 1826, as moedas de cobre desaparecem de circulação. Para Trettin, tal desaparecimento, apesar de possivelmente ligado à troca das moedas de cobre por ouro contrabandeado e outras transações comerciais realizadas nos portos da Corte, relacionava-se, fundamentalmente, ao envio das moedas fabricadas no Rio de Janeiro para outras províncias, pelo próprio governo, a fim de socorrer as dificuldades financeiras do

\footnotetext{
${ }^{556}$ Decisão do Ministério da Justiça em 22 de julho de 1828. In: Coleção das leis do Império do Brasil. Disponível em: http://www2.camara.leg.br/atividadelegislativa/legislacao/publicacoes/doimperio. APUD: Alexander Trettin. Op. cit.; p. 145.

${ }^{557}$ Idem; pp. 146-150.
} 
país. Sendo assim, a ausência de moedas de importância fundamental às transações cotidianas deve ter agravado os problemas financeiros enfrentados no Rio de Janeiro.

Neste sentido, o desestímulo dos deputados brasileiros à punição dos falsificadores de moeda, impresso nos artigos 173 a 176 do diploma penal, pode ser interpretado, num primeiro momento, a partir do receio de que, eliminadas as moedas falsas de cobre, a circulação deste material se anulasse por completo, trazendo um caos ainda maior à já delicada situação monetária do país. Corrobora esta hipótese, a adoção de estratégia semelhante, ainda em 1827, pelo presidente da província da Bahia, Gordilho de Barbuda. Deparando-se com a incalculável quantidade de moedas falsas em circulação na província, o presidente teria determinado, em 25 de novembro de 1827, que seu trânsito fosse mantido e que as moedas de cobre fossem aceitas nas operações comerciais até que se encontrasse uma solução ao problema ${ }^{558}$.

Por um outro viés, a específica regulamentação adotada pelo Código de 1830 no tocante ao crime de moedas falsas e, em especial, a leveza das punições atribuídas aos falsificadores - apesar das constantes reclamações acerca desta questão ao longo do Primeiro Reinado -, pode ser relacionada também ao particular posicionamento adotado pelos deputados brasileiros diante da crise monetária nacional.

À altura de 1829, a grave situação enfrentada pelo Brasil neste âmbito e o atraso na aprovação de uma política orçamentária para o Império (de competência da Câmara dos deputados), levaram o monarca a convocar uma reunião extraordinária da Assembleia Geral para o mês de abril que, uma vez mais, contudo, falhou em propor uma lei para o orçamento.

De acordo com Roderick J. Barman, a inércia dos deputados na proposição de soluções aos problemas financeiros do Império, apesar de aparentemente contrastante com seu zelo em debater a questão, era não só justificável, como também deliberada, uma vez que a seriedade e os perigos advindos da situação monetária do país demandavam um posicionamento cauteloso da parte dos legisladores ${ }^{559}$.

Para Barman, contudo, não só a delicadeza da situação e a cautela dos deputados estava envolvida em semelhante atraso:

An element of policy must also have influenced the deputies, since what Mirabeau had remarked of France in 1789 was true for Brazil in 1829: 'The deficit is the nation's greatest asset'. While the financial crisis continued, the imperial regime

\footnotetext{
${ }^{558}$ Alexander Trettin. Op. cit.; p. 126.

559 Roderick J. Barman. Brazil: the forging of a nation, 1798-1852. Califórnia: Stanford University Press, 1988; pp. 154-155.
} 
would remain dependent on the General Assembly. To render the government solvent was to surrender the deputies' decisive advantage in the political struggle. ${ }^{560}$

A resolução da crise financeira imperial, enfim, poderia retirar das mãos dos deputados uma vantagem considerável nas lutas políticas então travadas. Seguindo, assim, as pistas abertas por este historiador, também a regulamentação dada ao crime de moedas falsas no Código de 1830 pode ser avaliada enquanto parte da estratégia de oposição dos deputados brasileiros ao governo de d. Pedro I e de manutenção da dependência e submissão do monarca em relação ao Legislativo. Sendo assim, as leves punições atribuídas a este crime podem ter objetivado, em alguma medida, manter a confusa situação financeira imperial, preservando, desta forma, a preeminência dos deputados na luta política nacional.

\section{Habeas Corpus}

Vale analisar, por fim, ainda que brevemente, os motivos que teriam impelido os legisladores brasileiros a regulamentar, no código de direito penal substantivo da nação, questões referentes ao direito de habeas corpus dos réus. Como referido no subcapítulo anterior, o aparecimento de artigos relativos ao habeas corpus no Código de 1830 deveu-se, fundamentalmente, à influência desempenhada, sobre os deputados brasileiros, pela produção penal de Edward Livingston.

Detectada, contudo, a fonte de inspiração dos legisladores nacionais, não se dissolvem ou perdem a validade os questionamento relativos aos motivos de se introduzir, num código de direito substantivo, prescrições que remetiam ao direito processual, ou à razão que teria impelido os membros da comissão ad hoc a prescrever, em 1830, um direito cuja aplicação efetiva dependia da aprovação, no país, de um código de processo penal.

Ao nosso ver, como afirmado anteriormente, tais escolhas relacionavam-se ao desejo dos deputados brasileiros em estabelecer limites à atuação arbitrária dos magistrados do país. Tema recorrente nos debates sobre a necessária reforma da administração da justiça no Brasil, as reclamações direcionadas à prática cotidiana dos magistrados perpassavam, dentre outras questões, os atentados constantemente impostos pelos mesmos à liberdade dos cidadãos. Neste sentido, não foram incomuns as denúncias de prisões arbitrárias realizadas Império afora - publicizadas tanto nos

${ }^{560}$ Idem; p. 155. 
jornais, quanto por meio de petições encaminhadas à Câmara baixa ao longo de toda a primeira legislatura ${ }^{561}$ - e o descontentamento dos deputados com semelhantes $\operatorname{abusos}^{562}$.

A temática, de todo modo, não era nova, haja vista o decreto passado aos 23 de maio de 1821 , e assinado pelo príncipe regente d. Pedro, referente à garantia das liberdades individuais no Reino Unido ${ }^{563}$. Por meio deste decreto, ficava estabelecido (i) que nenhuma pessoa livre do Brasil pudesse, dali em diante, ser presa sem ordem escrita do juiz ou magistrado criminal do território, exceto no caso de flagrante delito; (ii) que nenhum juiz ou magistrado criminal expedisse ordem de prisão sem proceder a culpa formada, com a inquirição de ao menos três testemunhas; (iii) que, achando-se presos aqueles considerados criminosos, se lhes fizesse imediata e sucessivamente $o$ processo, mantendo abertas e públicas as provas de modo a se facilitar os meios de justa defesa; e (iv) que em hipótese nenhuma alguém pudesse ser secretamente lançado em masmorra estreita, escura ou infecta, ficando abolido pelo texto, o uso de correntes, algemas, grilhões e quaisquer outros ferros em homens ainda não julgados. Por fim, o decreto estabelecia que a contravenção legalmente provada de suas disposições fosse punida com o perdimento do emprego e a inabilidade perpétua para qualquer outro em que houvesse jurisdição.

Vê-se, assim, que a necessária restrição dos abusos infligidos pela magistratura à população, especialmente por meio de prisões injustas e não justificadas, era temática antiga no Brasil, assumindo força especial, contudo, no momento de positivação das leis penais da nova nação. A proibição a prisões arbitrárias no Império apareceria,

${ }^{561}$ As prisões arbitrárias não se restringiram, obviamente, ao período do Primeiro Reinado no Brasil, tendo perpassado todo o regime imperial. Haja vista a concentração de nossos estudos, contudo, neste período específico da história, fazemos referência restrita ao mesmo. Para um exame da atividade peticionária no Império brasileiro ver: Vantuil Pereira. Ao Soberano Congresso: direitos do cidadão na formação do Estado Imperial brasileiro (1822-1831). São Paulo: Alameda, 2012; e Roberto Nicolas Puzzo Ferreira Saba. As vozes da nação: a atividade peticionária e a política do início do Segundo Reinado. Dissertação de Mestrado; DH/FFLCH/USP; 2010.

${ }^{562}$ Não nos esqueçamos que o habeas corpus vinha regulado, no diploma de 1830 , na sessão dos delitos particulares referentes aos crimes contra a liberdade individual, aparecendo ao lado de delitos especificamente referentes à prisão arbitrária - sem culpa formada ou ordem legal -, à manutenção de presos incomunicáveis e à recusa dos juízes em passar, no prazo marcado pela Constituição, nota com o motivo da prisão e nomes do acusador e testemunhas do crime.

563 Disponível na Coleção das Leis do Império do Brasil em: http://www2.camara.leg.br/atividade-legislativa/legislacao/publicacoes/doimperio. 
nesse sentido, tanto no projeto constitucional de 1823, quanto Constituição outorgada de 1824.

Como explicar, contudo, que o habeas corpus tenha aparecido no código de direito penal substantivo brasileiro previamente à sua devida criação e definição por um código processual? Uma hipótese plausível para semelhante inversão de percurso, nos parece, reside na quase obrigatoriedade que ela impunha à regulamentação do direito de habeas corpus na legislação penal adjetiva então em elaboração.

Contribui a esta conjectura o fato de o único projeto de código processual cuja análise pelos deputados brasileiros previamente a 1830 podemos atestar, não regulamentar, em momento algum, a questão do habeas corpus. Tratava-se, mais especificamente, do projeto elaborado pelo Ministro da Justiça, Teixeira de Gouveia, ainda em 1829, e apresentado à deputação em 20 maio daquele ano ${ }^{564}$. Ainda que, ao que tudo indica, outros dois projetos de código processual tivessem sido elaborados e mandados à impressão, pelos deputados Silva Maia e Bernardo Pereira de Vasconcelos, ainda em $1829^{565}$, por não terem sido descobertos até o momento - e por não sabermos, em ultima instância, se foram de fato impressos e analisados pelo conjunto dos deputados previamente à aprovação do código criminal -, não podemos elucubrar acerca da presença ou ausência, em seus textos, da regulamentação do habeas corpus ${ }^{566}$.

O que podemos, confirmar, de todo modo, é que o aparecimento desta questão entre os artigos 183 e 188 do Código de 1830 deveu-se, indubitavelmente ao conteúdo do "Code of Procedure" de Edward Livingston. De posse, portanto, do diploma processual norte-americano e cientes da importância assumida pelo habeas corpus no interior de uma justiça liberal e fundada na garantia dos direitos dos cidadãos - como a que intentavam criar para o Brasil -, os deputados podem ter buscado assegurar, com os instrumentos de que dispunham - no caso, o texto do código penal então em elaboração -, a regulamentação futura de semelhante dispositivo no código de

\footnotetext{
${ }^{564}$ O projeto de Teixeira de Gouveia foi publicado ao final do tomo 5 do ano de 1829 dos Anais da Câmara dos Deputados. APB-CD; pp. 111-129. Disponível em: http://imagem.camara.gov.br/diarios.asp. Buscar pela data de 03 de setembro de 1829 .

${ }^{565}$ APB-CD; sessão de 15 de junho de 1829; pp. 97-99.

${ }^{566}$ Para uma abordagem recente sobre o obscuro processo de composição do Código de Processo Criminal brasileiro de 1832, ver: Monica Duarte Dantas. Projeto para Bolsa Produtividade $\mathrm{CNPq}$ - "O Código do Processo Criminal e a reforma de 1841: debates legislativos e influências estrangeiras na disputa pela implementação de diferentes modelos de organização do Estado"; 2012 (cópia cedida pela autora).
} 
processo criminal, contando que os responsáveis por sua aprovação não iriam permitir semelhante descompasso entre os diplomas penais adjetivo e substantivo do país - o que, de fato, não fizeram.

A inserção do direito de habeas corpus no Código de 1830 esteve relacionada, ao nosso ver, ao mesmo projeto de oposição reconhecido na regulamentação dos delitos públicos do diploma. Neste sentido, que à diminuição das punições previstas a parte importante dos crimes políticos deste código tenha se seguido o aparecimento do habeas corpus, não nos parece uma simples coincidência, mas antes o indício de um intento preciso dos opositores do imperador, buscando garantir a si próprios a possibilidade de um enfrentamento "seguro" ao governo.

\section{Estado, justiça e direitos dos cidadãos: o projeto político e os modelos jurídicos em disputa na elaboração do Código Criminal.}

No item anterior, analisamos o modo com que a adoção de determinados artigos e regulamentações pelo Código de 1830 esteve relacionada à particular conjuntura política vivida pelo país e ao projeto oposicionista levado a cabo pelos deputados brasileiros na luta contra d. Pedro I. Inerente a uma situação conjuntural, contudo, é sua particular tendência à transformação e, neste sentido, os anos que se seguiram à aprovação do código vieram rapidamente demonstrar o quanto de seu conteúdo poderia ser atribuído a objetivos políticos precisos e o quanto do mesmo devia-se a um projeto mais amplo e duradouro de Justiça, Estado e cidadania para o país.

No ano imediatamente posterior à promulgação do diploma penal - ano que representou, de fato, o primeiro de sua longa vigência -, duas leis vieram rapidamente alterar partes de seu texto. Para além de revelarem a presença de concepções impressas neste documento - não necessariamente partilhadas pelo conjunto dos legisladores brasileiros, tais alterações mostraram o quanto a nova realidade política do país - o pós-Abdicação - trouxera consigo a necessidade de um remodelamento de parte dos dispositivos previamente adotados, com ênfase no endurecimento das "brandas" punições previstas a parte dos delitos do código penal.

Aos 6 de junho de 1831, o Parlamento aprovou, assim, a primeira lei adicional ao texto do código, intensificando as prevenções do poder público no tocante às reuniões e manifestações políticas populares. Por meio de seu artigo primeiro ficava 
estabelecido que os delitos compreendidos no artigo 285 do código de 1830, responsável pela definição do crime policial de ajuntamentos ilícitos (ao qual, lembremos, o diploma previa unicamente a punição por multas) fossem punidos, a partir de então, com a prisão por um a três meses. Já seu artigo segundo proibia todo ajuntamento noturno de cinco ou mais pessoas nas ruas, praças e estradas, sem algum fim justo e reconhecido, sob a ameaça, uma vez mais, de punição por entre um e três meses de prisão. $\mathrm{O}$ artigo seguinte previa a observação de indivíduos suspeitos, de dia ou de noite, pelas rondas e oficiais de justiça do país; enquanto o artigo de número quatro proibia o pagamento de fiança pelos presos em flagrante por delitos policiais $^{567}$

Em outubro de 1831, um novo projeto de lei sugerido pelo Senado e discutido na Câmara dos deputados, propôs, dentre outras coisas, que se intensificasse ainda mais o rigor das punições previstas a parte dos crimes policiais do diploma nacional.

Se nos últimos meses de 1830, portanto, o Senado havia recomendado a aprovação imediata do código criminal composto pelas sucessivas comissões parlamentares - sugerindo apenas que as possíveis correções de seu texto fossem deixadas ao que a prática mostrasse digno de reforma ${ }^{568}$-, em outubro do ano seguinte os membros da Câmara alta proporiam, entre outras coisas, a proibição do uso e porte de determinadas armas e instrumentos perfurantes no país; o aumento das punições estabelecidas aos vadios e mendigos; e o necessário estabelecimento de punições aos motins, tumultos e assuadas não especificados no diploma penal.

Ao discutirem o conteúdo deste projeto, transformado em lei aos 26 de outubro de $1831^{569}$, os deputados brasileiros pronunciaram interessantes avaliações sobre o diploma aprovado na sessão anterior ${ }^{570}$. Para parte importante destes representantes, as leis criminais do Império vinham sendo desrespeitadas por conta de sua extrema

${ }^{567}$ Disponível em: http://www2.camara.leg.br/legin/fed/lei sn/1824-1899/lei-37207-6-junho1831-563560-publicacaooriginal-87651-pl.html. Os artigos subseqüentes desta lei, de número 5 a 19, referiam-se, no geral, a detalhes relativos à ordem do processo a ser adotada no julgamento dos crimes policiais.

${ }_{568}$ Ver nota 189 do Capítulo 1.

569 Disponível em: http://www2.camara.leg.br/legin/fed/lei sn/1824-1899/lei-37623-26outubro-1831-564670-publicacaooriginal-88611-pl.html. Parte dos artigos desta lei, contudo, não se referia ao conteúdo substantivo do Código de 1830, regulamentando, antes, questões relativas, uma vez mais, à ordem processual a ser admitida nos casos de crimes policiais.

570 APB-CD, sessão de 8 de outubro de 1831; p. 223 e seguintes. Disponível em: http://imagem.camara.gov.br/diarios.asp 
suavidade, mostrando-se ineficazes no tocante à manutenção da ordem interna e proteção à segurança individual dos cidadãos.

Para um deputado como Evaristo Ferreira da Veiga (eleito pela província de Minas Gerais), por exemplo, a comparação entre os códigos penais de outras nações, como os Estados Unidos da América, e o caso brasileiro, deixava patente o quão mais rigorosas eram as punições previstas por estes diplomas aos crimes policiais. De acordo com este deputado, e vários de seus colegas, quando da aprovação do diploma criminal brasileiro, ficara estabelecido que, por não ser obra perfeita, fosse este emendado, com o passar do tempo, nos pontos considerados necessários, devendo-se, agora, acatar à iniciativa do Senado.

Para Evaristo da Veiga, os criminosos brasileiros zombavam do diploma penal do Império e de suas fracas punições, chamando-as de leis de água de colônia. Em suas palavras, posteriormente a qualquer movimento revolucionário (e a referência, aqui, parece-nos relacionada aos movimentos populares gerados quando da Abdicação de $d$. Pedro I) era comum que indivíduos oportunistas, interessados em praticar atos contrários às leis, se multiplicassem pelo país, devendo-se, contra estes homens, aprovar leis mais fortes. Em sua opinião, o grande número de indivíduos presos pelos juízes de paz do Império no último ano era um indicador fiel do aumento na criminalidade do país e da pouca severidade com que, portanto, o código punia os crimes previstos $^{571}$.

Opondo-se àqueles para quem o momento era inoportuno a uma reforma nas leis penais do Império - haja vista o furor das paixões que haviam antecedido e sucedido os acontecimentos de abril de 1831 -, deputados como Augusto Xavier de Carvalho (Paraíba do Norte) insistiram que a extrema brandura das penas do código vinham acentuando o atrevimento dos criminosos, fazendo-se necessária a aprovação imediata de leis mais fortes que afastassem do Brasil os "anarquistas".

Aludindo, por sua vez, ao "oportunismo" político envolvido na aprovação do código criminal no ano anterior, Luiz Francisco de Paula Cavalcanti de Albuquerque, membro da última comissão parlamentar dedicada ao exame do código, relembrou

\footnotetext{
${ }^{571}$ É possível, contudo, que o aumento no número de indivíduos presos pelos juízes de paz, se devesse à atuação bem-sucedida destes magistrados locais e à amplificação do alcance da justiça no país. Para o assunto ver: Ivan Vellasco. As seduções da ordem: violência, criminalidade e administração da Justiça - Minas Gerais, século XIX. São Paulo: EDUSC, 2004.
} 
seus colegas de que votara contra o documento naquela ocasião. Para além disso, de acordo com os Anais:

Notou mais que havia quem fizesse leis só para os outros, havendo o Sr. Ministro da Justiça actual, elle e sua gente, votado para que se fizessem leis brandas e para que passasse o código criminal que hoje regia, e achavão agora má a dita lei por ser muito doce e por isso querião fazer severa, afim de a applicarem aos outros. ${ }^{572}$

A fala de Luiz Cavalcanti é bastante clara, portanto, ao reconhecer o modo com que, aprovado o código criminal na sessão anterior em razão do momento específico vivido pelo país e dos benefícios que possivelmente traria à luta política nacional, parte de seus dispositivos era avaliada agora, pelos mesmos deputados que o haviam defendido, como demasiadamente branda e insuficiente para o controle da criminalidade nacional.

Aprovada a lei então em discussão, foram seus artigos de número 3, 4, 5 e 7 os responsáveis pela reformulação de parte dos dispositivos previamente estabelecidos pelo código penal. De acordo com o artigo $3^{\circ}$ ficava prevista a pena de prisão com trabalho por um a seis meses no caso de uso, sem licença, de pistola, bacamarte, faca de ponta, punhal, sovelas, ou qualquer outro instrumento perfurante; duplicando-se as penas na reincidência e mantendo-se as prescrições do Código de 1830 no tocante às armas proibidas em geral ${ }^{573}$. Pelo artigo $4^{\circ}$ ficava estabelecido que as penas impostas aos vadios, pelo artigo 295 do código, fossem elevadas para a prisão com trabalho por um a seis meses (o Código de 1830 havia estabelecido a punição de oito a vinte quatro dias de prisão com trabalho a este crime), e pelo dobro no caso de reincidência. $\mathrm{O}$ artigo $5^{\circ}$ estabelecia que as ofensas físicas leves, as injúrias e calúnias não impressas e as ameaças fossem, a partir de então, processadas como crimes policiais (isenta a possibilidade de fiança no caso de flagrante, de acordo com o previsto pela lei adicional aprovada aos 6 de junho do mesmo ano) e o $7^{\circ}$ previa que qualquer

\footnotetext{
${ }^{572}$ APB-CD; sessão de 08 de outubro de 1831; p. 226.

${ }^{573}$ Pelo artigo 297 do Código de 1830 ficava estabelecido que aqueles que usassem de armas ofensivas e proibidas receberiam pena de prisão por 15 a 60 dias, para além de multa correspondente e perda das armas. Pelo artigo 299, por sua vez, ficava estabelecido que: "As Camaras Municipaes declararão em editaes, quaes sejam as armas offensivas, cujo uso poderão permittir os Juizes de Paz; os casos, em que as poderão permittir; e bem assim quaes as armas offensivas, que será licito trazer, e usar sem licença aos occupados em trabalhos, para que ellas forem necessarias."
} 
tumulto ou assuada não especificados pelo código fossem punidos com um a seis meses de prisão com trabalho.

Num primeiro momento, portanto, foi aos crimes policiais de atentado à ordem pública que as atenções dos deputados e senadores brasileiros se dirigiram, reforçando os mecanismos de controle estatal sobre a população nas ruas das cidades do país.

Dois anos mais tarde, uma nova lei adicional ao código foi promulgada, referindose, desta vez, ao crime de falsificação de moedas. Como nos casos anteriores, a nova lei, aprovada em 3 de outubro 1833, aumentou as punições impostas aos condenados pelos crimes de moedas falsas, prevendo em seu artigo $8^{\circ}$ que os fabricantes e introdutores de moeda falsa no país fossem punidos com a pena de galés para a ilha de Fernando de Noronha - pelo dobro do tempo determinado, no Código Criminal, à prisão por este crime - e que, em caso de reincidência, fossem punidos com galés perpétuas para o mesmo local. Em seu artigo $9^{\circ}$, a lei estabelecia ainda que na mesma pena incorressem os fabricantes, introdutores e falsificadores de notas, cautelas, cédulas e papéis fiduciários da nação ou do banco, de qualquer qualidade e denominação que fossem ${ }^{574}$.

Da pena de prisão com trabalho por entre um e oito anos, portanto, o crime de falsificação de moedas e papéis de crédito passava a ser punido, em consonância com a maioria dos diplomas criminais do período - e com a gravidade dos problemas que, como vimos, trazia ao Brasil -, com a pena de galés, temporárias ou perpétuas, para uma ilha distante da costa nacional.

Dois anos mais tarde, aos 6 de junho de 1835, mais uma lei imperial ligada ao Código de 1830 foi aprovada pelo Parlamento, alterando, dentre outras coisas, os casos de prescrição da pena de morte aos réus cativos. De acordo com seu artigo $1^{\circ}$ ficava prevista a aplicação da pena capital aos escravos ou escravas que matassem por qualquer maneira, "propinassem" veneno, ferissem gravemente ou realizassem grave ofensa física contra seu senhor, a mulher deste, seus descendentes ou ascendentes, o administrador ou feitor da propriedade e suas respectivas mulheres. Se o ferimento ou

\footnotetext{
${ }^{574}$ A lei também prescrevia, mais ou menos como ocorrera na Província da Bahia, em 1828, que as moedas de cobre fossem trocadas, desta vez em todo o Império, por cédulas emitidas pelo governo. A lei de 3 de outubro de 1833 pode ser consultada em: http://www2.camara.leg.br/legin/fed/lei/1824-1899/lei-52-3-outubro-1833-565027publicacaooriginal-88924-pl.html.
} 
ofensa física fossem leves, dizia o artigo, a pena seria de açoites, proporcionalmente às circunstâncias mais ou menos agravantes ${ }^{575}$.

Lembremos neste ponto, que, pelo Código de 1830, os escravos poderiam ser condenados à morte, como os livres, unicamente nos casos de homicídio com agravantes, roubo seguido de morte e crime de insurreição. Se um escravo matasse seu senhor, portanto, e este crime fosse considerado isento de circunstâncias agravantes, não se poderia, sob hipótese alguma, imputar a pena de morte ao réu. $\mathrm{O}$ mesmo valia para os casos de insurreição e roubo seguido de morte, em que a pena capital só se verificava no grau máximo. De acordo com a nova lei, pelo contrário, a imputação de morte aos cativos ficava assegurada nos casos de crime de homicídio, envenenamento e graves ferimentos ou ofensas físicas infligidos a seus senhores e feitores, ou aos familiares destes, mesmo na ausência de circunstâncias agravantes.

De acordo com Ricardo Pirola, a lei de 10 de junho de 1835 foi interpretada, por muitos anos, como uma resposta parlamentar às revoltas escravas ocorridas no período regencial. Se num primeiro momento, portanto, foi historiograficamente relacionada ao levante dos Malês, ocorrido, na Bahia, no próprio ano de 1835, a posterior descoberta de que seu primeiro projeto fora apresentado dois anos antes, em 1833 , transferiu à insurreição de Carrancas o gatilho da elaboração do projeto $^{576}$. Na opinião de Pirola, contudo, os motivos implícitos à proposição da futura lei de 10 de junho - apresentada ao Parlamento juntamente a um "pacote" legal visando à salvaguarda do país, haja vista a desconfiança geral de que um plano restauracionista era arquitetado, de Portugal, pelo ex-imperador d. Pedro -, não são tão óbvios como à primeira vista poderia parecer, devendo-se investigar com mais vagar, para além das revoltas escravas ocorridas nas províncias da Bahia, Minas Gerais e São Paulo no período, a articulação da nova lei às intenções de reformulação dos códigos criminal e de processo penal aprovados no início da década de $1830^{577}$.

\footnotetext{
575 A Lei de $\mathrm{n}^{\mathrm{o}} 4$ de 10 de junho de 1835 pode ser visualizada em: http://www.jusbrasil.com.br/legislacao/104059/lei-4-35. Os artigos subseqüentes desta lei referiam-se, por sua vez, ao direito penal adjetivo, alterando os procedimentos judiciais especificamente destinados ao julgamento de réus escravos. Para uma análise detalhada do processo de elaboração e aprovação final desta lei ver: Ricardo Figueiredo Pirola. A lei de 10 de junho de 1835: justiça, escravidão e pena de morte. Tese de Doutorado; IFCH/UNICAMP; 2012; especialmente o Capítulo 1.

${ }^{576}$ Ricardo Figueiredo Pirola. Op. cit.; pp. 44-48.

${ }^{577}$ Idem; pp. 48-109.
} 
Independentemente das inúmeras conexões passíveis de serem realizadas entre a aprovação desta lei e as condições político-sociais do Brasil em inícios da década de 1830, é inegável que sua composição deveu-se ao reconhecimento, por parte dos legisladores nacionais, da insuficiência das leis criminais em relação à população cativa do país. Para tanto, como destacado no capítulo 2, parece ter sido decisivo, no âmbito do direito penal substantivo, o fato de o código prescrever de forma praticamente igual a pena capital a réus livres e escravos ${ }^{578}$. Num contexto politicamente conturbado como o vivido pelo Brasil desde pelo menos 1831, o acirramento das ameaças dirigidas à contenção da população cativa parece ter figurado, assim, como uma das prioridades dos dirigentes da nação.

Analisadas as principais leis criminais que reformaram o conteúdo do Código de 1830, e identificada sua importância e relação com a mudança conjuntural vivida no Brasil a partir da Abdicação de d. Pedro I, destaca-se, de todo modo - especialmente quando comparados os históricos dos diplomas penais substantivo e adjetivo do país o fato de terem sido poucas as alterações empreendidas sobre o texto deste código desde sua aprovação ${ }^{579}$. Lembremos, neste ponto, que o diploma de 1830 vigiu, no país, ao longo de praticamente todo o período imperial, sendo substituído por um novo código penal unicamente em 1890, pouco depois de proclamada a República.

O que esta vigência nos diz, contudo, sobre o conteúdo do diploma brasileiro de 1830 e sobre as escolhas políticas materializadas em seu texto, é o que nos dedicaremos a analisar na sequência.

Como examinado nos Capítulos 1 e 3 desta dissertação, o projeto completo de código criminal entregue por Clemente Pereira à Câmara dos deputados em 1827 não

\footnotetext{
${ }^{578}$ Para as inúmeras conexões existentes, ainda, entre a aprovação da lei de 10 de junho de 1835 e a ordem do processo penal prescrita pelo Código de Processo Criminal brasileiro de 1832, ver: Ricardo Figueiredo Pirola. Op. cit.; Capítulo 1; pp. 23-112.

579 No caminho oposto ao trilhado pelo Código de 1830, foram múltiplas e de grande importância as alterações empreendidas sobre o texto do Código de Processo Criminal brasileiro (de 1832), aprovadas pelo Parlamento em 3 de dezembro de 1841. De acordo com Ivan Vellasco: "A lei de 3 de Dezembro reformaria radicalmente a estrutura judiciária, redefinindo poderes e atribuições, alterando aspectos processuais importantes e centralizando seu controle em mãos do Ministério da Justiça.”. Ivan Vellasco. Op. cit.; pp. 134-135. Para uma reflexão aprofundada sobre o assunto ver: Monica Duarte Dantas. "O Código de Processo Criminal e a Reforma de 1841: dois modelos de organização do Estado (e suas instâncias de negociação)." Conferência apresentada junto ao IV Congresso do Instituto Brasileiro de História do Direito - Autonomia do direito: configurações do jurídico entre a política e a sociedade. São Paulo, Faculdade de Direito/USP, 2009; e Idem. Projeto para Bolsa Produtividade CNPq - "O Código do Processo Criminal e a reforma de 1841: debates legislativos e influências estrangeiras na disputa pela implementação de diferentes modelos de organização do Estado"; 2012
} 
era, em si, um projeto pouco elaborado, atrasado ou avesso às particularidades nacionais. Pelo contrário, e apesar de sua grande diferença em relação ao projeto de Bernardo Pereira de Vasconcelos, este documento mostrou-se bem redacionado, moderno e afeito às particularidades do novo Estado nacional. Neste sentido, não apenas regulamentava os principais delitos públicos, particulares e policiais presentes nos diplomas criminais do período - garantindo aos cidadãos do Império brasileiro parte importante de seus direitos -, como prescrevia, majoritariamente, penas de prisão simples e multa, regulando por poucas vezes as penas de trabalhos públicos forçados ou galés, e por menos vezes ainda a pena de morte (prevista em seis artigos do diploma, sendo unicamente dois deles referentes a crimes públicos ${ }^{580}$ ).

Fundado essencialmente, contudo, sobre o diploma penal francês de 1810 (ainda que, como vimos, resignificando-o em diversas passagens), e redigido, de todo modo, por um indivíduo considerado "suspeito" por parte significativa dos membros das primeiras legislaturas - haja vista sua proximidade crescente com a figura de d. Pedro I -, o projeto de Clemente Pereira acabou, em grande medida, negligenciado pelos parlamentares mais diretamente envolvidos na elaboração do código criminal.

Preferido pelos deputados nacionais, o projeto de Vasconcelos não se diferenciava, contudo, daquele de Clemente Pereira, por uma maior modernidade ou adequação aos preceitos do liberalismo jurídico então em voga. Pelo contrário, se não dispunha sobre crimes especificamente dirigidos contra a vida do Imperador e não iniciava sua Parte Especial com a regulamentação de crimes religiosos (como fizera Clemente Pereira), o projeto do deputado mineiro prescrevia a pena de morte para um maior número de crimes públicos ${ }^{581}$ e adotava uma organização bastante distinta do

\footnotetext{
${ }^{580}$ A pena de morte estava prevista, assim, no projeto de Clemente Pereira, aos casos em que os cidadãos do Império pegassem em armas contra o Brasil (artigo 80); aos cabeças do crime de conspiração (artigo 100); ao que matasse seu oponente num desafio (artigo 133); aos que cometessem homicídio voluntário (artigo 198) ou matassem alguém por dinheiro, ou interesse equivalente (artigo 197); e, por fim, aos que matassem a outrem por envenenamento (artigo 204).

${ }^{581}$ Se o projeto de Clemente Pereira previa, assim, a pena de morte, aos crimes públicos regulados pelos artigos 80 e 100, o projeto de Vasconcelos a prescrevera aos crimes públicos de forçamento de cadeia e tentativa de destruição da Constituição política do Império e para a consumação de qualquer dos delitos regulados pelos artigos $1^{\circ}, 2^{\circ}, 4^{\circ}, 5^{\circ}, 6^{\circ}, 7^{\circ}$ e $8^{\circ}$ do artigo 311, responsável pela regulamentação dos casos de "traição".
} 
modelo em circulação à época ${ }^{582}$, admitindo ainda penas "atrasadas" como as de infâmia, banimento e talião (ver Tabela II).

Se a preferência pelo projeto de Vasconcelos não parece residir, portanto, sobre seu maior liberalismo ou modernidade, quando comparado ao de Clemente Pereira, seu maior distanciamento em relação à fonte penal francesa e a oposição política declarada de seu autor ao imperador d. Pedro I podem ter influído positivamente sobre sua escolha pelos legisladores nacionais.

Ainda assim, como vimos, este projeto seria profundamente modificado, entre 1829 e 1830, pelos representantes brasileiros envolvidos na elaboração do código penal do país. Aceita, portanto, a modernidade implícita também ao projeto do deputado mineiro - que acatara os mais importantes princípios do liberalismo jurídico, como o da certeza e legalidade do direito, adotando os padrões ocidentais de codificação dos crimes públicos, particulares e policiais, e abdicando da regulamentação de crimes como o de lesa-majestade e atentado à vida do imperador há que se reconhecer, contudo, tratar-se de um liberalismo distinto daquele enfim adotado em 1830 .

Reconhecidamente mais autocrático que o código finalmente promulgado, o projeto de Vasconcelos colocava um maior poder de opressão nas mãos do Estado (haja vista, dentre outros exemplos, a admissão do crime de traição) e não se preocupava, na mesma medida em que o Código de 1830, com a garantia de direitos fundamentais dos cidadãos, regulados, no diploma final, por artigos como o de número 9 (que atestava não serem criminosos os que fizessem análises razoáveis da Constituição e das leis existentes, ou que censurassem os atos do governo e da administração, em termos "posto que vigorosos, decentes e comedidos"), pelos Títulos II e III de seus crimes públicos (referentes à defesa do regime parlamentar e representativo da nação e à garantia da estabilidade de seu sistema eleitoral), ou pelos artigos relativos à garantia de aplicação do direito de habeas corpus dos réus.

Comparados os conteúdos dos projetos de 1827 e do Código penal de 1830, enfim, reconhece-se plenamente a presença de mais de um liberalismo em disputa no Primeiro Reinado, no Brasil. Fruto das concepções jurídicas de um oposicionista ferrenho ao governo de d. Pedro I, ainda assim o projeto de Vasconcelos não

\footnotetext{
${ }^{582}$ Como analisado no capítulo 1 , diferentemente da maioria dos códigos do período, o deputado mineiro optara por organizar a Parte Especial do seu projeto regulamentando, nesta sequência, crimes policiais, particulares e públicos.
} 
contemplava uma série de preceitos importantes a parlamentares cujas ideias, enfim, sairiam vitoriosas nas disputas em torno à codificação penal ${ }^{583}$.

Entre os opositores do diploma de Vasconcelos, portanto, havia já projetos de Justiça, Estado e cidadania, distintos dos materializados pelo texto do deputado mineiro.

Desta feita, considerando-se a existência de posições divergentes no âmbito do Parlamento - e não estamos pensando aqui no projeto de Clemente Pereira, e sim nas diferenças que separavam as proposições de Vasconcelos daquelas adotadas pelas comissões subseqüentes ou, de todo modo, expostas pelos deputados que se pronunciaram -, posições, ademais, defendidas por representantes comumente identificados por sua oposição ao monarca, torna-se inevitável destacar a existência de antagonismos políticos para além daqueles que separavam opositores e defensores do governo, ou seja, divisões internas ao próprio grupo dos chamados "liberais moderados". Se indivíduos como Bernardo Pereira de Vasconcelos, Antonio e Ernesto Ferreira França, Francisco de Paula Souza e Melo e Luiz Francisco de Paula Cavalcanti de Albuquerque posicionavam-se todos, portanto, contrariamente ao imperador, deve-se admitir, de todo modo, as inúmeras diferenças que, neste, como em outros campos da política nacional, separavam suas concepções e posicionamentos.

Neste âmbito, a vitória política do Código de 1830 deixa de representar a vitória de um bloco de oposição ao imperador, para ser compreendida como a vitória de um grupo específico da Câmara dos deputados. Se representantes (oposicionistas) como Paula Souza e os Ferreira França, portanto, saíram vitoriosos desta disputa - haja vista, no que tange ao primeiro deles, a manutenção da pena de morte a casos reduzidos do diploma criminal e, quanto aos parlamentares baianos (eleitos, o pai, pela própria província da Bahia, e o filho, por Pernambuco), a efetiva transposição de preceitos do projeto de Edward Livingston ao código brasileiro -, indivíduos como

\footnotetext{
${ }^{583}$ Aprovado, assim, o projeto apresentado por Vasconcelos, não só se teria, no Império, uma admissão muito mais ampla das penas de morte e de galés, como "pequenas" diferenças com grandes repercussões. No que tangia, por exemplo, ao crime policial de ajuntamentos ilícitos, estava o mesmo propenso a ser punido, pelo artigo 119 de Vasconcelos, como um delito público (aos quais estavam previstas punições como a morte e as galés ou prisão perpétuas), o que, por si só, indica a gravidade das modificações empreendidas entre 1829 e 1830 e a distância a separar os projetos jurídicos em disputa. Em 1830, por sua vez, tal regulamentação foi excluída do diploma brasileiro, prevendo-se, ao crime de ajuntamentos, penas exclusivamente pecuniárias
} 
Vasconcelos e Luiz Cavalcanti, por sua vez, contrários também ao governo de $\mathrm{d}$. Pedro I, saíram deste embate com certo amargor: o primeiro, claramente descontente com as alterações impostas a seu projeto (em especial no tocante à diminuição da pena de morte e à utilização do diploma de Livingston ${ }^{584}$ ) e o segundo, declarando-se "vencido" (posteriormente, viemos a saber, por conta da brandura das punições acatadas pelo diploma) no parecer da última comissão mista dedicada ao código penal.

Os diferentes posicionamentos destes deputados no tocante à configuração do direito penal e as próprias modificações empreendidas sobre o texto do futuro Código de 1830 revelam, assim, o modo com que a composição deste diploma esteve relacionada, para além dos embates com d. Pedro I, às disputas travadas em torno do melhor modelo de direito penal substantivo a ser adotado no Império do Brasil.

Sendo assim, por importante que tenha sido a conjuntura política para certas escolhas jurídicas impressas neste código - materializadas na regulamentação de crimes públicos como os de conspiração, rebelião e falsificação de moedas, ou ainda na prescrição de um dispositivo como o de habeas corpus -, havia um projeto político e jurídico mais profundo a sustentá-las, assim como ao restante do código penal. Ligado a um modelo de "justiça cidadã" como o norte-americano ${ }^{585}$, este projeto previa, para o Estado brasileiro em formação, uma justiça penal que, para além do controle da ordem interna, visava à garantia de direitos aos cidadãos.

Em absoluta conformidade, portanto, com o modelo jurídico penal em circulação àquela altura no ocidente, o Código de 1830 parece ter, inclusive, superado este modelo em sua extrema atenuação penal e por meio da eliminação de crimes como os de traição e lesa--majestade; materializando ainda, em seu texto, a recusa dos parlamentares por um modelo de soberania concentrado na figura do monarca, e sua reivindicação do Parlamento como lócus privilegiado de exercício do poder político.

${ }^{584}$ Aos 14 de maio de 1830, quando, recém recebido o projeto de Edward Livingston, a Câmara dos deputados discutia seu destino, Vasconcelos irritou-se com a insistência dos Ferreira França para que este documento fosse traduzido para o português. A certa altura de seu pronunciamento, inclusive, Vasconcelos foi enfático em afirmar que: "Dos codigos nada tiramos". Para o deputado, portanto, não havia urgência na consulta ao diploma de Livingston e isso porque, de sua parte, ao que nos parece, não interessava que as prescrições daquele projeto viessem alterar o conteúdo do seu .

585 Monica Duarte Dantas. "O Código de Processo Criminal e a Reforma de 1841: dois modelos de organização do Estado (e suas instâncias de negociação)." Conferência apresentada junto ao IV Congresso do Instituto Brasileiro de História do Direito - Autonomia do direito: configurações do jurídico entre a política e a sociedade. São Paulo, Faculdade de Direito/USP, 2009 
A atenção ao trâmite parlamentar percorrido pelo Código Criminal do Império do Brasil, de 1827 a 1830, revela, assim, as complexidades inerentes à elaboração deste diploma e as incontáveis escolhas políticas envolvidas em sua composição, mostrando como, diferentemente do que por vezes se fez crer, o conteúdo materializado neste diploma não foi acidental, representando, antes, a vitória de um determinado projeto de Estado e de Justiça para o Brasil.

Faz-se necessário, portanto, que, para além do Código penal, as pesquisas de História do Direito focadas no Império do Brasil atentem efetivamente à atuação parlamentar e ao trâmite seguido na elaboração das leis que acabaram por definir (ou redefinir, em certos casos) a estrutura do novo Estado nacional, buscando, no percurso de sua elaboração, o modo com que diferentes atores e sub-grupos políticos posicionaram-se e recusando, enfim, a redução dos parlamentares a "blocos" com atuação política pré-definida. Por importante que seja a identificação de frentes políticas majoritárias no Parlamento brasileiro ao longo do Primeiro Reinado, reconhecidas em grupos como o dos liberais moderados, "exaltados" e restauradores, é necessário atentar ao modo com que, em grande parte das discussões e projetos específicos em disputa, estes grupos se rearticularam em diversos outros, explicitando, por exemplo, no caso do código criminal, a presença de leituras múltiplas e projetos distintos no tocante ao liberalismo jurídico e à organização da justiça no país ${ }^{586}$.

No caso específico desta dissertação, portanto, para além da descoberta das minúcias envolvidas na elaboração do Código de 1830, das importantes diferenças existentes entre seu texto e aquele apresentado, em 1827, por Bernardo Pereira de Vasconcelos, e do modo com que seu conteúdo adequou-se ao modelo de direito penal vigente no mundo ocidental - respeitando, contudo, as particularidades políticosociais do Brasil recém-independente -, o exame cuidadoso de seu trâmite parlamentar pode revelar indícios acerca da composição da Câmara dos deputados em finais do Primeiro Reinado e da presença, em seu seio, de uma multiplicidade de

\footnotetext{
${ }^{586}$ No primeiro capítulo do livro O Pacto Imperial, Miriam Dolhnikoff demonstra, por exemplo, como dentre os políticos liberais do Parlamento brasileiro, havia projetos bastante heterogêneos de organização do aparato político-institucional do novo Estado em formação. Para além da oposição entre os ditos liberais exaltados e moderados, destaca a autora, internamente ao segundo grupo é possível identificar projetos distintos de organização estatal, em especial no tocante à adoção, ou não, do federalismo, e à recusa, ou incentivo, à reforma constitucional. Miriam Dolhnikoff. O Pacto Imperial: origens do federalismo no Brasil do século XIX. São Paulo: Globo, 2005; especialmente pp.23-28.
} 
posicionamentos encobertos pela oposição comum ao imperador e pelo objetivo explícito, no caso, de aprovação do novo código penal. 


\section{FONTES E REFERÊNCIAS BIBLIOGRÁFICAS}

\section{FONTES}

\section{Projetos de Códigos Penais e Códigos Penais promulgados entre 1786 e 1830:}

"Projecto de código Criminal apresentado em sessão de 4 de maio de 1827 pelo deputado Bernardo Pereira de Vasconcellos", Anais do Parlamento Brasileiro Câmara dos Srs. Deputados, 1829, tomo $3^{\circ}$, Rio de Janeiro, Typographia de Hypolito José Pinto \& Cia, 1877, 95-109.

PEREIRA, José Clemente. "Projecto do Código Criminal do Império do Brasil". Biblioteca Nacional; seção de obras raras. Ex. 2: C, 05, 11. Projeto Especial (2001). Localização do microfilme: OR 00168[2].

"Código Criminal do Império do Brasil", Coleção das Leis do Império do Brasil, 1830, parte primeira, Rio de Janeiro, Typographia Nacional, 1876; pp. 141-190.

"Comissão especial do código - emendas ao projecto do código criminal, 1830". Typographia de Lessa \& Pereira, 1830. Arquivo da Biblioteca Nacional (RJ); Localização: V, 257, 3, 8, nº6.

Nouveau Code Criminel pour le Grande Duche de Toscane (1786). Publié par ordre de Son Altesse Royale Monseigneur Le Grand Duc. Traduit de L'Italien a Lausanne, chez François Grasset et Comp. Libraires \& Imprimeurs, 1787.

FREIRE, Pascoal José de Mello, Código criminal intentado pela Rainha D. Maria I, Coimbra, Imprensa da Universidade, 1844, "Provas do Direito Criminal" (disponível no site http://www.fd.unl.pt).

The Emperor New Code of Criminal Laws. Published at Vienna, the $15^{\text {th }}$ of January, 1787. Translated from the German, by an officer. Dublin: Printed by John Rea, 1787.

Code General pour lês États Prussiens, traduit por les Membres du bureau de Législation étrangère, et publié par ordre du Ministre de la Justice. Paris, Imprimerie de la République, ano IX (1801), 3 volumes.

Lois de la Rébublique Française an IV [...] Code des Delits et des Peines, 1791 ; disponível em http://gallica.bnf.fr, consultado em 07/07/2010 .

Codice Penale Universale Austriaco coll' Appendice delle Piú Recenti Norme Generali. Seconda edizione ufficiale. Milano, Dall'Imp. Regia Stamperia, 1815.

Code Pénal Général de l'empire d'Autriche, par M. Victor Foucher, Paris, Imprimerie Royale, 1833, disponível em http://gallica.bnf.fr.

Corps de Droit Français, civil commercial et criminel. Par L. Rondonneau. Paris, Garnery Libraire, 1810. 
Código Penal Español, Decretado por las Cortes en 8 de Junio, Sancionado por El Rey, y mandado promulgar en 9 de julio de 1822. Madrid, Imprenta Nacional, año de 1822.

Code Penal du Royame de Bavière (1813). Traduit de l'Allemand par Ch. Vatel. Paris, Auguste-Durand, Libraire-Éditeur, 1852.

ASHER, C.W., Abrégé des codes criminels de l'Autriche, la Prusse et la Saxe. Présenté au troisième Congrès international de statistique, en vertu et aux termes des conclusions prises aux congrès de Bruxelles et Paris, Hamburg, 1857.

LIVINGSTON, Edward. A System of Penal Law prepared for the State of Louisiana. New-Orleans: printed by Benjamin Levy, 1824.

LIVINGSTON, Edward. A System of Penal Law for the State of Louisiana. Pittsburgh, John L. Kay \& Brother, 1833.

\section{Anais do Parlamento Brasileiro:}

Anais da Câmara dos Deputados - 1826-1830. Os anais da Câmara dos Deputados estão disponíveis no site: http://www2.camara.gov.br/documentos-epesquisa/publicacoes

Anais do Senado Federal - 1826-1830. Os Anais do Senado estão disponíveis no site: http://www.senado.gov.br/publicacoes/

\section{Obras de Referência:}

ALVES JUNIOR, Thomaz. Annotações theoricas e praticas ao Código Criminal. Rio de Janeiro: Francisco Luiz Pinto \& C ${ }^{\text {a }}$; Tomo I (1864) e Tomo II (1870).

Barão de Javari. Organizações e programas ministeriais. Regime parlamentar no Império, $2^{\mathrm{a}}$ ed., Rio de Janeiro, 1962 (obra redigida em 1889, por determinação da Câmara dos deputados).

BECCARIA, Cesare. Dos delitos e das penas. São Paulo: Martins Fontes, 2005.

BENTHAM, Jeremy. The Collected Works of Jeremy Bentham, edited by J.H. Burns, J.R. Dinwiddy, and F. Rosen (volumes 1-5, London, Athlone Press, 1968-1981; volumes 6- 10, Oxford, Clarendon Press, 1984).

BENTHAM, Jeremy The Works of Jeremy Bentham. Bristol: Thoemmes, 1995, 11 vols.

BLACKSTONE, William. Commentaries on the laws of England. Books I, II, III, IV. London: Printed by A. Strahan, 1800. 
BLUTEAU, Raphael. Vocabulário portuguuez e latino, Coimbra, Colegio das Artes da Companhia de Jesus, 1712. Disponível em: 143.107.31.159/catalogo_eletronico/consultaDicionarios.asp.

FALCÃO, José Anastácio. Código Criminal do Império do Brasil analysado por José Anastácio Falcão, advogado portuguez; segundo o systema dos melhores criminalistas, com interessantes Nottas extraidas do maginifico, e maravilhôso Systema Penal, e Repressivo contra a Pena de Morte, escripto por M. Charles Lucas, advogado em Paris, e o mais vigoroso e constante Defensor dos Direitos da Humanidade. Rio de Janeiro: Typ. Imp. e Const. de É. Seignot-Plancher, 1831.

FOUCHER, Victor. Code Criminel de L'Empire du Brésil. Paris: A L'Imprimerie Royale: 1834.

LIVINGSTON, Edward. Report made to the General Assembly of the State of Louisiana of the Plan of Penal Code for the said State. Nova Orleans, Benjamin Levy \& Co., 1822.

MONTESQUIEU, Charles-Louis de. O Espírito das Leis. São Paulo: Martins Fontes, 2005.

S. A. Sisson. Galeria dos Brasileiros Ilustres. Brasília: Senado federal, 1999, vol.1.

Também disponível em:

http://www.brasiliana.usp.br/bbd/handle/1918/01139110\#page/1/mode/1up.

SILVA, Antonio de Moraes. Diccionario da Lingua Portugueza, Lisboa, Typographia Lacerdina, 1813.

Disponível

em:

143.107.31.159/catalogo_eletronico/consultaDicionarios.asp.

SOUSA PINTO, José Maria Frederico de e AZAMBUJA, Bernardes Augusto Nascentes. O Código Criminal Explicado ou Analyse Jurídica e Philosophica da Carta de Lei de 16 de Dezembro de 1830. Rio de Janeiro: Na Typographia de Gueffier e Ca, 1832.

\section{REFERÊNCIAS BIBLIOGRÁFICAS}

ÁLVARES ALONSO, Clara. "La legitimación del sistema. Legisladores, Jueces y juristas en españa (1810 - 1870)" (I), Historia Constitucional (revista electrónica), n. 4, 2003 (disponível em http://hc.rediris.es/04/index.html). 
ÁLVARES ALONSO, Clara. "La legitimación del sistema. Legisladores, Jueces y juristas en españa (1810 - 1870)" (II), Historia Constitucional (revista electrónica), n. 5, 2004 (disponível em http://hc.rediris.es/04/index.html).

ARMITAGE, João. História do Brasil desde o periodo da chegada da família de Bragança, em 1808, até a abdicação de d. Pedro I, em 1831: compilada à vista dos documentos públicos e outras fontes originais formando uma continuação da História do Brasil, de Southey. Belo Horizonte: Itatiaia; São Paulo: Editora da Universidade de São Paulo, 1981.

AUFDERHEIDE, Patricia Ann. Order and violence: social deviance and social control in Brazil, 1780-1840. Tese de doutorado apresentada à Universidade de Minnesota, 1976.

AZEVEDO, Vicente Alves de. "O Código Criminal do Império - apreciação histórica e jurídica." In: Pandectas Brasileiras: registro de doutrina, jurisprudência dos tribunais e legislação; Rio de Janeiro, v. $8,1^{\circ}$ e $2^{\circ}$ semestre de 1930; pp. 685695.

BARBOSA, Samuel Rodrigues. "Complexidade e Meios Textuais de Difusão e Seleção do Direito Civil Brasileiro Pré-Codificação". In: Ricardo Marcelo Fonseca, Airton Cerqueira Leite Seelander (orgs.). História do Direito em Perspectiva. Curitiba: Juruá, 2009; pp. 361-374.

BARMAN, Roderick J. Brazil. The Forging of a Nation, 1789-1852. Standford: Standford University Press, 1988.

BASILE, Marcello Campos. O Império em construção: projetos de Brasil e ação política na Corte Regencial. Rio de Janeiro, UFRJ/IFCS, Tese de doutorado, 2004.

BERBEL, Márcia Regina. A nação como artefato: deputados do Brasil nas cortes portuguesas (1821-1822). São Paulo: HUCITEC/Fapesp, 1999.

BERBEL, Márcia Regina. "Os apelos nacionais nas cortes constituintes de Lisboa (1821-1822)". In: Jurandir Malerba. A Independência brasileira: novas dimensões. Rio de Janeiro: Editora FGV, 2006; pp.181-208.

BERBEL, Márcia Regina. "A Constituição Espanhola no mundo luso-americano (1820-1823)”. In: Revista das Índias, 2008, vol. LXVIII, num. 242; pp. 225-254.

BERBEL, Márcia e MARQUESE, Rafael. "La esclavitud en las experiencias constitucionales ibéricas, 1810-1824”. In: Ivana Frasquet (org.) Bastillas, cetros y blasones. La independencia en Iberoamérica. Madrid : Fundación MapfreInstituto de Cultura, 2006, pp. 347-374.

BETHELL, Leslie e CARVALHO, José Murilo de. "O Brasil da Independência a meados do século XIX”. In: BETHELL, Leslie (org). História da América Latina. Vol 3: Da Independência a 1870. São Paulo, EDUSP, Imprensa Oficial/ Brasília, FUNAG, 2001, pp. 694 a 720.

BONAVIDES, Paulo e AMARAL, Roberto. Textos políticos da história do Brasil. Brasília: Senado Federal, 2002.

BOSI, Alfredo. “A escravidão entre dois liberalismos.”. In: Dialética da Colonização. São Paulo: Cia. das Letras, 1992; pp.194-245. 
BRAVO LIRA, Bernardino. "Bicentenario del Código Penal de Austria: Su proyección desde el Danubio a Filipinas". Revista de estudios histórico jurídicos. Valparaíso 2004, no. 26, (disponível em http://www.scielo.cl/scielo.php?script=sci arttext\&pid=S0716545520040026000

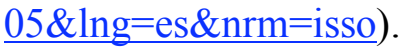

CANCELLI, Elizabeth (org.). Histórias de Violência, Crime e Lei no Brasil. Brasília: Editora Universidade de Brasília, 2004.

CARVALHO, José Murilo de. A Construção da Ordem: a elite política imperial; Teatro de sombras: a política imperial. Rio de Janeiro: Editora UFRJ, RelumeDumará, 1996.

CARVALHO, José Murilo de (org.). Bernardo Pereira de Vasconcelos. São Paulo: Ed. 34, 1999.

CARVALHO, José Murilo de e NEVES, Lucia Maria Bastos Pereira das (org.). Repensando o Brasil do Oitocentos. Cidadania, política e liberdade, Rio de Janeiro: Civilização Brasileira, 2009.

CAVANNA, Adriano. Storia del diritto moderno in Europa: le fonti e il pensiero giuridico; vol. 2. Milano: Dott. A. Giuffrè Editore, 2005.

CLAVERO, Bartolomé. "Codificación y constitución: paradigmas de un binomio". In: Quaderni Fiorentini per la storia del pensiero giuridico moderno; XVIII (1989). Milano: Giuffrè editore; pp. 79-145.

CLAVERO, Bartolomé. Happy constitution: cultura y lengua constitucionales. Madrid: Trotta, 1997.

CLAVERO, Bartolomé. "Código como fuente de derecho y achique de constitución en Europa". In: Revista Española de Derecho Constitucional. Madrid, Año 20; Núm. 60; Septiembre-Diciembre, 2000; pp. 11-43.

COSTA, Emília Viotti da. Da Monarquia à República, momentos decisivos. São Paulo: Fundação Editora da UNESP, 1999.

DAL RI JÚNIOR, Arno. O Estado e seus inimigos: a repressão politica na história do Direito Penal. Rio de Janeiro: Revan, 2006.

DAL RI JÚNIOR, Arno [et al.]. Iluminismo e direito penal. Florianópolis: Fundação Boiteux, 2008.

DANTAS, Monica Duarte. "O Código de Processo Criminal e a Reforma de 1841: dois modelos de organização do Estado (e suas instâncias de negociação)." Conferência apresentada junto ao IV Congresso do Instituto Brasileiro de História do Direito - Autonomia do direito: configurações do jurídico entre a política e a sociedade. São Paulo, Faculdade de Direito/USP, 2009.

DANTAS, Monica Duarte. "Constituição, poderes e cidadania na formação do Estado-nacional brasileiro.” In: Fórum Rumos da Cidadania. São Paulo: Instituto Prometheus de Estudos Ambientais, Culturais e Políticos; 2010.

DANTAS, Monica Duarte (org.). Revoltas, motins, revoluções: homens livres pobres e libertos no Brasil do século XIX. São Paulo: Alameda Editorial, 2011.

DANTAS, Monica Duarte. "Dos Statutes ao Código brasileiro de 1830: o levante de escravos como crime de insurreição." Revista do Instituto Histórico e Geográfico Brasileiro, v. 452, pp. 273-309, 2011. 
DANTAS, Monica Duarte. Projeto para Bolsa Produtividade CNPq - "O Código do Processo Criminal e a reforma de 1841: debates legislativos e influências estrangeiras na disputa pela implementação de diferentes modelos de organização do Estado"; 2012.

DOLHNIKOFF, Miriam. O Pacto Imperial: origens do federalismo no Brasil do século XIX. São Paulo: Globo, 2005.

DOHLNIKOFF, Miriam. "Representação na monarquia brasileira". Almanack Braziliense, n.9, maio de 2006, pp. 41-53.

FIORAVANTI, Maurizio. Constitución: de la antigüedad a nuestros dias. Madrid: Editorial Trotta, 2007.

FIORAVANTI, Maurizio. Los derechos fundamentales. Apuntes de história de las constituciones. Madrid: Editorial Trotta, 1998.

FLORY, Thomas. El juez de paz y el jurado en el Brasil imperial, 1808-1871: control social y estabilidad política en el nuevo Estado. México: Fondo de Cultura Econômica, 1986.

FONSECA, Ricardo Marcelo. "Dall diritto coloniale ala codificazione: appunti sulla cultura giuridica braziliana tra settecento e novecento". In: Quaderni Fiorentini per la storia del pensiero giuridico moderno; n.33/34, 2004/2005, L' Europa e gli "Altri": Il diritto coloniale fra Otto e Novecento - Tomo I; pp. 964-983.

FOUCAULT, Michel. Vigiar e Punir: nascimento da prisão. Petrópolis: Editora Vozes, 2005.

FOUCAULT, Michel. A verdade e as formas jurídicas. Rio de Janeiro: Nau, 1996.

FRANCO, Maria Sylvia de Carvalho. "As idéias estão no lugar.". Revista Cadernos de Debate, n.1, 1976.

GONÇALVES, Flávia Maíra de Araújo. Cadeia e Correção: sistema prisional e população carcerária na cidade de São Paulo (1830-1890). Dissertação de Mestrado; FFLCH/USP; 2010.

GRINBERG, Keila e SALLES, Ricardo (orgs.). Coleção o Brasil Imperial, vol. I (1808-1831). José Olympio, 2010.

GUSMÃO, Helvecio Carlos da Silva. "Ligeiras notas sobre o Código Criminal de 1830" In: Revista do Instituto Histórico e Geográfico Brasileiro. I Congresso de História Nacional, Rio de Janeiro, v.4, 1914; pp. 415-127.

HATCHER, William B. Edward Livingston. Jeffersonian Republican and Jacksonian Democrat. Louisiana State University Press, 1940.

HENDERSON, Jennifer Denise. "A Blaze of reputation and the echo of a name": the legal career of Peter Stephen Du Ponceau in post-revolutionary Philadelphia. Mestrado apresentado à Florida State University - College of Arts and Sciences, 2004.

HESPANHA, António Manuel. "Conclusão". In: José Mattoso (org.). História de Portugal; vol. IV: "O Antigo Regime (1620-1807)”. Lisboa: Editorial Estampa; p. 466-468.

HESPANHA, António Manuel. A História do Direito na História Social. Lisboa: Livros Horizonte, 1978. 
HESPANHA, António Manuel. "Da 'iustitia' à 'disciplina'. Textos, poder e política penal no Antigo Regime.". In: Anuario de Historia del Derecho Español, Madrid, 1988; pp. 493-578.

HESPANHA, António Manuel. "Sábios e Rústicos: a violência doce da razão jurídica.” In: Revista Critica de Ciências Sociais; no 25/26; dezembro de 1988; pp. 31-60.

HESPANHA, António Manuel. . "Justiça e Administração entre o Antigo Regime e a Revolução". In: Hispania: entre derechos propios y derechos nacionales. Atti dell'incontro di studio. Firenze-Lucca 25, 26, 27 Maggio, 1989. Per la storia del pensiero giuridico moderno; 34/35; Tomo I. Milano: Giuffrè editore; pp. 135203.

HESPANHA, António Manuel. História de Portugal moderno, político e institucional. Lisboa: Universidade Aberta, 1995.

HESPANHA, António Manuel. "A Constituição do Império português. Revisão de alguns enviesamentos correntes.". In: João Fragoso, Maria Fernanda Bicalho e Maria de Fática Gouvêa (orgs.). O Antigo Regime nos Trópicos. A dinâmica imperial portuguesa (séculos XVI-XVIII). Rio de Janeiro: Civilização Brasileira; 2001; pp. 163-188.

HESPANHA, António Manuel. Cultura jurídica européia: síntese de um milênio. Portugal: Publicações Europa-América, 2003.

HESPANHA, António Manuel. Guiando a mão invisível: Direitos, Estado e Lei no Liberalismo monárquico português. Coimbra: Almedina, 2004.

HESPANHA, António Manuel. "Depois do Leviathan". In: Almanack Brasiliense, n 5, maio de 2007; pp. 55-65.

HESPANHA, António Manuel. "A evolução da doutrina e do ensino do direito penal em Portugal C. 1800-C.1910”. In: Quaderni Fiorentini per la storia del pensiero giuridico moderno; 36 (2007); pp. 429-502.

HOLANDA, Sérgio Buarque de (org.). História Geral da Civilização Brasileira Tomo II: O Brasil Monárquico. São Paulo: DIFEL, 1970, 5 vols.

HUNT, Charles Haven. Life of Edward Livingston. Nova Iorque, D. Appelton Company, 1864.

JANCSÓ, István (org.). Brasil: formação do Estado e da nação, São Paulo: Hucitec: Fapesp: Unijui, 2003.

JANCSÓ, István (org.). Independência: história e historiografia. São Paulo: Hucitec: Fapesp, 2005.

JOSÉ PALTI, Elias. “The Problem of 'Misplaced Ideas' Revisited: Beyond the 'History of Ideas' in Latin América. In: Journal of History of Ideas; vol.67, n.1 (jan.2006); pp. 149-179; acessado pelo JSTOR em Janeiro de 2011.

KOERNER, Andrei. $O$ habeas corpus na prática judicial brasileira (1841-1920). Tese de Doutorado, FFLCH/USP, 1998.

KOSELLECK, Reinhart. Futuro Passado: contribuição à semântica dos tempos históricos. Rio de Janeiro: Contraponto: Ed. PUC-Rio, 2006. 
LACOMBE, Américo Jacobino. "A Cultura Jurídica”. In: HOLANDA, S. B. de (org). História Geral da Civilização Brasileira, t.2, v.3, pp. 356-357.

LARA, Silvia Hunold (org.). Ordenações Filipinas, Livro V. São Paulo: Companhia das Letras, 1999.

LEITE, Glacyra Lazzari. Pernambuco, 1824: A Confederação do Equador. Recife: Fundaj, Editora Massangana, 1989.

LOPES, José Reinaldo de Lima. "Iluminismo e jusnaturalismo no ideário dos juristas da primeira metade do século XIX". In: István Jancsó, Brasil: formação do Estado e da nação, São Paulo: Hucitec: Fapesp: Unijui, 2003, pp. 195-218.

LOPES, José Reinaldo de Lima. O direito na história: lições introdutórias. São Paulo: Editora Atlas, 2009.

LOPES, José Reinaldo de Lima. "O Diálogo entre Direito e História”. In: RIBEIRO, Gladys Sabina; NEVES, Edson Alvisi; e FERREIRA, Maria de Fátima Cunha Moura (orgs.). Diálogos entre Direito e História: cidadania e justiça. Niterói: EdUFF, 2009.

LOPES, José Reinaldo de Lima. O Oráculo de Delfos: o Conselho de Estado no Brasil-Império. São Paulo: Editora Saraiva: Fundação Getúlio Vargas, 2010.

MACÁRIO, Mariana Pedron. José Clemente Pereira e o debate jurídico do Império: 1830-1850. Dissertação de Mestrado. Faculdade de Direito/USP; 2011.

MALERBA, Jurandir. Os Brancos da Lei: liberalismo, escravidão e mentalidade patriarcal no Império do Brasil. Paraná: Editora da Universidade Estadual de Maringá, 1994.

MARTÍNEZ PÉREZ, Fernando. Entre confianza y responsabilidad. La justicia del primer constitucionalismo español (1810-1822). Madrid: Centro de Estudios Políticos y Constitucionales, 1999.

MARTUCCI, Roberto. "Logiche della transizione penale. Indirizzi di politica criminale e codificazione in Francia dalla rivoluzione all'Imperio (1789-1810).". In: Quaderni Fiorentini per la storia del pensiero giuridico moderno. 36 (2007), Tomo I. Giuffrè editore milano; pp. 131-274.

MATTOS, Ilmar Rohloff de. O tempo saquarema. São Paulo: Hucitec, 2004.

MATTOS, Ilmar Rohloff de. "Construtores e herdeiros. A trama dos interesses na construção da unidade política". Almanack Braziliense, vol.1, maio de 2005, pp. 8-26.

MONTEIRO, Tobias. História do Império: o Primeiro Reinado. Belo Horizonte: Itatiaia/EDUSP, 1982.

MOTA, Carlos Guilherme. 1822: Dimensões. São Paulo: Editora Perspectiva, 1986.

MOTA, Carlos Guilerme (coord.). Os juristas na formação do Estado-nação brasileiro - Volume I - Século XVI a 1850. São Paulo: Quartier Latin, 2006.

NEDER, Gizelene (coord.). "Os estudos sobre a escravidão e as relações entre História e Direito" In: Tempo, Vol. 3 - n 6, Dossiê: Escravidão e África Negra; Dezembro de 1998.

NEQUETE, Lenine. O Poder Judiciário no Brasil a partir da Independência. Porto Alegre: Livraria Sulina Editora, 1973. 
NETO, Zahidé Machado. Direito Penal e Estrutura Social (Comentário Sociológico ao Código Criminal de 1830). São Paulo: Saraiva; EDUSP, 1977.

NEVES, Lucia Bastos das. Corcundas e Constitucionais: a cultura política da Independência (1820-1822). Rio de Janeiro: Revan: FAPERJ, 2003.

NUNES, Tassia Toffoli. Liberdade de imprensa no Império brasileiro: os debates parlamentares (1820-1840). Dissertação de Mestrado; FFLCH/USP; 2010.

OLIVEIRA, Marina Garcia de. Entre nobres lusitanos e titulados brasileiros: práticas, políticas e significados dos títulos nobiliárquicos entre o Período Joanino e o alvorecer do Segundo Reinado. Dissertação de Mestrado; DHFFLCH/USP, 2013.

PARRON, Tâmis Peixoto. A política da escravidão no Império do Brasil, 1826-1865. Dissertação de Mestrado, FFLCH/USP, 2009.

PAULO, Alexandre Ribas de, "O discurso jurídico-penal iluminista no direito criminal do império brasileiro". In: DAL RI JÚNIOR, Arno [et al.]. Iluminismo e direito penal. Florianópolis: Fundação Boiteux, 2008; pp.153-206.

PEREIRA, Aline. Domínios e Império: o Tratado de 1825 e a Guerra da Cisplatina na construção do Estado no Brasil. Dissertação de Mestrado; Universidade Federal Fluminense, 2007.

PEREIRA, Vantuil. Ao Soberano Congresso: direitos do cidadão na formação do Estado imperial (1822-1831). São Paulo: Alameda Editorial, 2010.

PIROLA, Ricardo Figueiredo. A lei de 10 de junho de 1835: justiça, escravidão e pena de morte. Tese de Doutorado; IFCH/UNICAMP; 2012.

POZO, Gilmar de Paiva dos Santos. Imigrantes irlandeses no Rio de Janeiro: cotidiano e revolta no primeiro reinado. Dissertação de Mestrado; FFLCH/USP; 2010.

PRODI, Paolo. Uma história da justiça: do pluralismo dos foros ao dualismo moderno entre consciência e direito. São Paulo: Martins Fontes, 2005.

QUEIROZ, Rafael Mafei Rabelo. A teoria penal de P.J.A. Feuerbach e os juristas brasileiros do século XIX: a construção do direito penal contemporâneo na obra de P.J.A. Feuerbach e sua consolidação entre os penalistas do Brasil. São Paulo, FD/USP, Tese de doutorado, 2009.

RIBEIRO, C. J. de Assis. História do Direito Penal Brasileiro. Rio de Janeiro: Zélio Valverde, 1943.

RIBEIRO, Gladys Sabina. A Liberdade em Construção. Identidade nacional e conflitos antilusitanos no Primeiro Reinado. Rio de Janeiro: Relume Dumará: FAPERJ, 2002.

RIBEIRO, João Luis. No meio das galinhas as baratas não têm razão: a lei de 10 de junho de 1835: os escravos e a pena de morte no Império do Brasil, 1822-1889. Rio de Janeiro: Renovar, 2005.

RIVITTI, Nara de Souza. O medo nos debates legislativos do Brasil imperial: Análise de debates empreendidos na Câmara dos Deputados no período entre 1826 e 1835. TCC, IBCCRIM, 2010. 
RODRIGUES, José Honório. A Assembléia Constituinte de 1823. Petrópolis: Editora Vozes, 1974.

ROSANVALLON, Pierre. "Por uma História Conceitual do Político (nota de trabalho). In: Revista Brasileira de História, São Paulo: v. 15, n 30, 1995; pp. 922.

ROUSSEAUX, Xavier; DUPONT-BOUCHAT, Marie-Sylvie; VAEL, Claude (org). Révolutions e Justice Pénale en Europe : modèles français et tradition nationales (1780-1830). L'Harmattan : Paris, 1999.

RÜSCHE, Georg and KIRCHHEIMER, Otto. Punishment and Social Structure. New York: Morningside Heights; Columbia University Press, 1939.

SABA, Roberto Nicolas Puzzo Ferreira. As vozes da nação: a atividade peticionária e a política do início do Segundo Reinado. Dissertação de Mestrado; $\mathrm{DH} / \mathrm{FFLCH} / \mathrm{USP} ; 2010$.

SALLA, Fernado Afonso. O encarceramento em São Paulo: das enxovias à Penitenciária do Estado. Tese de Doutorado em Sociologia apresentada ao Departamento de Sociologia da FFLCH/USP; 1997.

SANTOS, Maria José Moutinho. "Liberalismo, legislação criminal e codificação. O Código Penal de 1852. Cento e cinqüenta anos da sua publicação.”. In: Revista da Faculdade de Letras/HISTÓRIA. Universidade do Porto, III série, vol. 3, 2002; pp. 97-102.

SCHWARZ, Roberto. "As idéias fora do lugar". In: Ao vencedor as batatas. Forma literária e processo social nos inícios do romance brasileiro. São Paulo: Duas Cidades, 2000; pp.9-32.

SILVA, Nuno J. Espinosa Gomes da. História do Direito português: fontes de direito. Lisboa: Fundação Calouste Gulbenkian, 2006.

SKINNER, Quentin. "Meaning and Understanding in the History of Ideas". In: Idem, Visions of politics. Volume I: regarding method. Cambridge University Press, 2002, pp.57-89.

SLEMIAN, Andréa. "À nação independente, um novo ordenamento jurídico: a criação dos Códigos Criminal e do Processo Penal na primeira década do Império do Brasil.". In: RIBEIRO, Gladys Sabina (org.). Brasileiros e cidadãos. Modernidade política. São Paulo: Alameda, 2008, pp.175-206.

SLEMIAN, Andréa. Sob o Império das Leis: Constituição e unidade nacional na formação do Brasil (1822-1834). São Paulo: Aderaldo \& Rothschild: Fapesp, 2009.

SOUSA, Otavio Tarquínio de. História dos fundadores do Império do Brasil, v.5: Bernardo Pereira de Vasconcelos. Rio de Janeiro: Livraria José Olympio, 1960.

SOUZA, Iara Lis Carvalho. Pátria Coroada. O Brasil como corpo político autônomo, 1780-1831. São Paulo: Ed. da Unesp, 1999.

TARELLO, Giovanni. Storia della cultura giuridica moderna. Bologna: Società editrice il Mulino, 2010.

THOMPSON, E. P. Senhores e Caçadores: a origem da Lei Negra. Rio de Janeiro: Paz e Terra, 1987; especialmente o item 4 do Capítulo 10: "O Domínio da Lei"; pp. 348-361. 
THÓT, Ladislau. “O Código Criminal Brasileiro de 1830. Estudo histórico-jurídico comparativo. Conferência no Instituto de Advogados Brasileiros" In: Pandectas Brasileiras: registro de doutrina, jurisprudência dos tribunais e legislação; Rio de Janeiro, v. 8, $1^{\circ}$ e $2^{\circ}$ semestre de 1930; pp. 119-126.

TOMÁS Y VALIENTE, Francisco. Manual de Historia del Derecho Español. Madrid: Editorial Tecnos, 2011.

TRETTIN, Alexander. O derrame de moedas falsas de cobre na Bahia (1822-1829). Dissertação de Mestrado; Universidade Federal da Bahia; 2010.

TRINDADE, Claudia Moraes. A Casa de Prisão com Trabalho da Bahia, 1833-1865. Dissertação de Mestrado; Universidade Federal da Bahia; 2007.

VELlASCO, Ivan de Andrade. As Seduções da Ordem: violência, criminalidade e administração da justiça: Minas Gerais - século 19. Bauru, SP; São Paulo: EDUSC; ANPOCS, 2004.

VENTURI, Franco. Utopia e Reforma no Iluminismo. Bauru, SP: EDUSC, 2003.

WEHLING, Arno e Maria José. "Cultura jurídica e julgados do Tribunal da Relação do Rio de Janeiro: a invocação da Boa Razão e o uso da doutrina. Uma amostragem.”. In: Maria Beatriz Nizza da Silva (coord.). Cultura Portuguesa na Terra de Santa Cruz. Lisboa: Editorial Estampa, 1995; pp. 235-247.

WEHLING, Arno e Maria José. Direito e Justiça no Brasil Colonial: o Tribunal da Relação do Rio de Janeiro (1751-1808). Rio de Janeiro: Renovar: 2004.

WOLKMER, Antonio Carlos. História do Direito no Brasil. Rio de Janeiro: Gen: Editora Forense, 2009.

YOUSSEF, Alain El. Imprensa e Escravidão: política e tráfico negreiro no Império do Brasil (Rio de Janeiro, 1822-1850). Dissertação de Mestrado; $\mathrm{DH} / \mathrm{FFLCH} / \mathrm{USP} ; 2010$. 
ANEXOS 
Anexo I

Índice das "Bases" apresentadas à Câmara dos Deputados por José Clemente Pereira em sessão de 3 de junho de 1826

\section{Livro primeiro}

Dos crimes e das penas

\section{TITULO I}

Dos crimes em geral e seus autores

\section{Capitulo I}

Dos crimes.

\section{Capitulo II}

Dos autores e dos crimes.

\section{TITULO II}

Das penas

\section{Capitulo I}

Das penas em geral.

\section{Capitulo II}

Da pena de morte.

Capitulo III

Da pena de desnaturalisação.

\section{Capitulo IV}

Da pena de trabalhos publicos.

\section{Capitulo V}

Da pena de prisão

Capitulo VI

Da pena de degredo

Capitulo VII

Da suspensão dos direitos politicos

Capitulo VIII

Da multa 


\section{Anexo II}

Índice do "Projecto do Código Criminal" apresentado à Câmara dos Deputados por Bernardo Pereira de Vasconcelos em sessão de 4 de maio de 1827

\section{Parte Primeira}

Dos crimes e das penas

\section{TITULO I}

Dos crimes e penas em geral

\section{Capitulo I}

Dos criminosos.

\section{Capitulo II}

Dos delictos justificáveis.

\section{Capitulo III}

Das circumstancias aggravantes e attenuantes dos delictos.

\section{Capitulo IV}

Da satisfação.

\section{Capitulo V}

Das penas ou castigos (palavras synonimas!).

\section{Capitulo VI}

Da prescripção e do perdão das penas.

\section{TITULO II}

Dos crimes policiaes

\section{TITULO III}

Dos crimes particulares

\section{Capitulo I}

Dos crimes contra as pessoas.

\section{Capitulo II}

Dos delictos moraes.

\section{Capitulo III}

Dos crimes contra a honra.

\section{Capitulo V}

Dos crimes contra as pessoas e contra a honra.

\section{Capitulo VI}

Dos crimes contra a propriedade.

Secção I

Das destruições e damnificações.

$\underline{\text { Secção II }}$

Dos furtos.

Secção Terceira

Das bancarrotas, estellionato e outros crimes contra a propriedade.

Disposição commum

\section{Capitulo V}

Dos crimes contra a pessoa e contra a propriedade.

\section{Capitulo VII}


Dos crimes contra o estado domestico e civil.

Disposição commum aos delictos particulares

\section{TITULO II}

Dos delictos públicos

\section{Capitulo I}

Dos crimes contra a ordem interior do império.

Secção I

Dos crimes dos empregados públicos.

Secção II

Dos crimes contra a ordem interior commettidos pelos que não são empregados públicos.

Crime commum.

\section{Capitulo II}

Dos delictos contra o thesouro publico.

\section{Capitulo III}

Dos crimes contra a segurança interna do império.

Capitulo IV

Dos crimes contra a segurança externa do império.

\section{TITULO V}

Disposição Geral. 


\section{Anexo III}

Índice do "Projecto do Codigo Criminal do Imperio do Brasil" apresentado à Câmara dos Deputados por José Clemente Pereira em sessão de 16 de maio de 1827

\section{INDEX.}

Dos Titulos e Capitulos, que contem o Projecto do Livro I. do Codigo Criminal.

TITULO I.

CAPITULO I.

CAP. II.

TIT. II.

CAP. I.

CAP. II.

CAP. III.

CAP. IV.

CAP. V.

TIT. III.

TIT. IV.

TIT. V.

TIT. VI.

CAP. I.

CAP. II.

CAP. III.

CAP. IV.

TIT. VII.

CAP. I.

CAP. II.

TIT. VIII.

TIT. IX.

TIT. X.

TIT. XI.

TIT. XII.

CAP. I.

CAP. II.

CAP. III.

CAP. IV.

CAP. V.

TIT. XIII

CAP. I.

CAP. II.

CAP. III.
Dos crimes em geral, e seus autores.

Dos crimes.

Dos autores dos crimes.

Das penas.

Das penas em geral.

Da pena de morte.

Da pena de trabalhos publicos.

Da pena de prizão.

Da pena de multa.

Dos crimes contra a Religião do Imperio.

Das injurias feitas ao Imperador, e Familia Real.

Dos crimes contra as garantias da Constituição

Política do Imperio.

Dos crimes contra a segurança externa do Imperio.

Dos que auxilião nações estrangeiras em damno do Imperio.

Dos que praticão actos hostis, ou indevidos, contra nações amigas, ou neutras.

Das offensas, e injurias feitas aos representantes das nações estrangeiras, aos refens, parlamentarios, e prisioneiros de guerra, e aos que tiverem salvo conducto Imperial.

Do crime de Pirataria.

Dos crimes contra a segurança interna do Imperio.

Do crime de conspiração.

Do crime de sedição.

Das sociedades secretas.

Dos crimes de resistencia publica.

Dos crimes de desobediencia aos mandados das Authoridades constituidas.

Da falta de respeito devido aos que exercem Poder.

Dos crimes contra a tranquilidade publica.

Dos pasquins.

Do uso de armas prohibidas.

Do crime de desafio.

Do crime de tumulto.

Do crime de assuada.

Das prevaricações, abusos, e ommissões das Empregados Publicos.

Do crime de Peculato.

Do crime de Peita.

Do crime de concussão. 
CAP. IV.

CAP. V.

TIT. XIV.

TIT. XV.

TIT. XVI.

TIT. XVII.

TIT. XVIII.

TIT. XIX.

TIT. XX.

TIT. XXI.

TIT. XXII.

TIT. XXIII.

TIT. XXIV.

TIT. XXV.

TIT. XXVI.

TIR. XXVII.

TIT. XXVIII.

CAP. I.

CAP. II.

TIT. XXIX.

TIT. XXX.

TIT. XXXI.

CAP. I.

CAP. II.

CAP. III.

TIT. XXXII.

TIT. XXXIII.
Da falta de exacção dos Empregados Publicos no cumprimento de seus deveres.

Do excesso de auctoridade.

Do crime de Moeda falsa.

Do crime de Falsidade.

Do crime de Perjurio.

Do crime de Calumnia.

Do crime de Injuria.

Dos crimes de Sodomia, Bestialidade, e Molicie.

Do crime de Bigamia.

Do crime de Adulterio.

Do crime de Rapto e Estupro.

Do crime de Lenocinio.

Do crime de Homicidio.

Do crime de Ferimentos.

Do crime de Furto.

Do crime de quebra dolosa.

Dos crimes contra o Commercio publico.

Dos que falsificão mercadorias para vender.

Dos que usão de pezos, medidas, ou balanças falsas, ou falsificadas.

Dos que usão nomes, titulos, uniformes, condecorações, ou distinctivos indevidos.

Do damno causado por culpa, ou dolo.

Dos vadios, mendigos, e jogadores.

Dos vadios.

Dos mendigos.

Dos jogadores.

Das contravenções de Policia, e boa ordem Publica.

Disposições geraes. 


\section{Anexo IV}

Índice do "Código Criminal do Império do Brasil", sancionado pelo imperador

d. Pedro I aos 16 de dezembro de 1830

Parte Primeira

Dos Crimes e das Penas

TITULO I

Dos crimes

\section{Capitulo I}

Dos crimes e dos criminosos (Art. 1 ao 13)

Capitulo II

Dos crimes justificáveis (Art. 14)

Capitulo III

Das circuntancias aggravantes e attenuantes dos crimes - Secções I, II e III. (Art. 15 ao 20)

Capitulo IV

Da satisfação (Art. 21 ao 32)

\section{TITULO II}

Das penas

\section{Capitulo I}

Da qualidade das penas, e da maneira como se hão de impor, e cumprir. (Art. 33 ao 64)

Disposições Geraes (Art. 65 ao 67)

\section{Parte segunda}

Dos crimes públicos

\section{TITULO I}

Dos crimes contra a existência política do Imperio

\section{Capitulo I}

Dos crimes contra a independência, integridade e dignidade da nação. (Art. 68 ao 84)

\section{Capitulo II}

Dos crimes contra a constituição do Império, e forma do seu governo (Art. 85 ao 86)

\section{Capitulo III}

Dos crimes contra o chefe do governo (Art. 87 ao 89)

Disposição Commum (Art. 90)

\section{TITULO II}

Dos crimes contra o livre exercício dos Poderes Políticos. (Art. 91 ao 99)

\section{TITULO III}

Dos crimes contra o livre gozo, e exercício dos Direitos Políticos do Cidadãos. (Art. 100 ao 106)

\section{TITULO IV}


Dos crimes contra a segurança Interna do Império, e publica tranqüilidade.

\section{Capitulo I}

Conspiração. (Art 107 ao 109)

Capitulo II

Rebellião. (Art. 110)

Capitulo III

Sedição. (Art 111 ao 112)

Capitulo IV

Insurreição. (Art. 113 ao 115)

Capitulo V

Resistência. (Art. 116 ao 119)

Capitulo VI

Tirada ou fugida de presos do poder da justiça, e arrombamento de cadêas. (Art. 120 ao 127)

\section{Capitulo VII}

Desobediência às autoridades. (Art. 128)

\section{TITULO V}

Dos crimes contra a boa Ordem, e Administração Publica.

\section{Capitulo I}

Prevaricações, Abusos, e Omissões dos Empregados Públicos.

$\underline{\text { Secção I }}$

Prevaricação. (Art. 129)

$\underline{\text { Secção II }}$

Peita. (Art. 130 ao 132)

$\underline{\text { Seção III }}$

Suborno. (Art. 133 ao 134)

Secção IV

Concussão. (Art. 135 ao 136)

Secção V

Excesso, ou abuso de autoridade, ou influencia proveniente do emprego. (Art. 137 ao 152)

Secção VI

Falta da exacção no cumprimento dos deveres. (Art. 153 ao 165)

Secção VII

Irregularidade de conducta. (Art. 166)

\section{Capitulo II}

Falsidade. (Art. 167 e 168)

Capitulo III

Perjúrio. (Art. 169)

\section{TITULO VI}

Dos crimes contra o Thesouro Publico, e propriedade publica.

\section{Capitulo I}

Peculato. (Art. 170 ao 172)

Capitulo II

Moeda falsa. (Art. 173 ao 176) 


\section{Capitulo III}

Contrabando. (Art. 177)

\section{Capitulo IV}

Destruição, ou damnificação de construcções, monumentos, e bens públicos. (Art. 178)

\section{Parte Terceira}

Dos crimes particulares

\section{TITULO I}

Dos crimes contra a liberdade individual. (Art. 179 ao 191)

\section{TITULO II}

\section{Dos crimes contra a segurança inidividual.}

\section{Capitulo I}

Dos crimes contra a segurança da pessoa e da vida.

Secção I

Homicídio. (Art. 192 ao 196)

Secção II

Infanticídio. (Art. 197 ao 198)

Secção III

Aborto. (Art. 199 ao 200)

Secção IV

Ferimentos, e outras offensas physicas. (Art. 201 ao 206)

Secção V

Ameaças. (Art. 207 e 208)

Secção VI

Entrada na casa alheia. (Art. 209 ao 214)

Secção VII

Abertura de cartas. (Art. 215 ao 218)

\section{Capitulo II}

Dos crimes contra a segurança da honra

Secção I

Estupro. (Art. 219 ao 225)

$\underline{\text { Secção II }}$

Rapto. (Art. 226 ao 228)

Secção III

Calumnia, e injuria. (Art. 229 ao 246)

\section{Capitulo III}

Dos crimes contra a segurança do estado civil, e domestico

Secção I

Celebração do matrimonio contra as leis do Império. (Art. 247 e 248)

Secção II

Polygamia. (Art. 249)

Secção III

Adultério. (Art. 250 ao 253)

Secção IV

Parto supposto, e outros fingimentos. (Art. 254 ao 256) 
TITULO III

Dos crimes contra a propriedade

\section{Capitulo I}

Furto (Art. 257 ao 262)

Capitulo II

Bancarrota, estellionato, e outros crimes contra a propriedade. (Art. 263 ao 265)

Capitulo III

Damno. (Art. 266 ao 267)

Disposição Commum. (Art. 268)

\section{TITULO IV}

Dos crimes contra a pessoa, e contra a propriedade. (Art. 269 ao 274)

Disposição commum aos delictos particulares. (Art. 275)

\section{Parte Quarta}

Dos crimes policiaes

\section{Capitulo I}

Offensas da religião, da moral, e bons costumes. (Art. 276 ao 281)

\section{Capitulo II}

Sociedades secretas. (Art. 282 ao 284)

Capitulo III

Ajuntamentos Illicitos. (Art. 285 ao 294)

Capitulo IV

Vadios e Mendigos. (Art. 295 ao 296)

Capitulo V

Uso de armas defesas. (Art. 297 ao 299)

Capitulo VI

Fabrico, e uso de instrumentos para roubar. (Art. 300)

\section{Capitulo VII}

Uso de nomes suppostos, e titulos indevidos (Art. 301 e 302)

\section{Capitulo VIII}

Uso indevido da imprensa. (Art. 303 ao 307)

Disposições Geraes. (Art. 308 ao 313) 


\section{Anexo V \\ Índice do "Código Penal Español, decretado por las Cortes en 8 de junio, sancionado por el rey, y mandado promulgar en 9 de julio de 1822 "}

\section{TITULO PRELIMINAR}

\section{Capitulo Primero}

De los delictos y culpas (Art. 1 ao 9)

\section{Capitulo II}

De los delincuentes y culpables, y de los que responden de las acciones de otros (Art.

10 ao 27)

\section{Capitulo III}

De las penas y sus efectos, y del modo de ejecutarlas (Art. 28 ao 100)

\section{Capitulo IV}

Del modo de graduar los delictos y aplicar y dividir las penas; de las circunstancias que los agravan o disminuyen; de las penas que se deben aplicar cuando concurren diferentes, y de la esclusion de todo asilo para los que delincan (Art. 101 ao 115)

\section{Capitulo V}

De las reincidências y del aumento de penas en estos casos (Art. 116 ao 121)

\section{Capitulo VI}

De la obligacion que todos tienen de impedir los delitos y de noticiarlos a la autoridad; y de la persecucion, entrega o remision de los delincuentes (Art. 122 ao

\section{Capitulo VII}

Del derecho de acusar los delitosm y de los acusados y procesados

\section{Capitulo VIII}

De los reos ausentes y contumaces (Art. 141 a 143)

\section{Capitulo IX}

De la rebaja de penas a los delincuentes que se arrepientan y enmienden, y de la rehabilitacion de los mismos despues de cumplir sus condenas (Art. 144 a 155)

\section{Capitulo X}

De los indultos (Art. 156 ao 170)

Capitulo XI

De la prescripcion de los delitos y culpas (Art. 171 ao 178)

\section{Capitulo XII}

De la indemnizacion a los inocentes (Art. 179 ao 181)

\section{Capitulo XIII}

De los delitos y delincuentes no comprendidos en este código (Art. 182 ao 187)

\section{PARTE PRIMERA}

\section{De los delitos contra la sociedad}

\section{TITULO PRIMERO}

De los delitos contra la constitucion y orden político de la monarquia

\section{Capitulo I}

De los delitos contra la libertad de la Nacion (Art. 188 ao 218)

\section{Capitulo II}

De los delitos contra el Rey, la Reina o el Príncipe heredero (Art. 219 ao 226)

\section{Capitulo III}

De los delitos contra la religion del Estado (Art. 227 ao 241) 


\section{Capitulo IV}

De los delitos contra la libertad individual de los españoles (Art. 242 ao 246)

Disposiciones comunes a los cuatro capítulos precedentes (Art. 247 e 248)

\section{TITULO II}

De los delitos contra la seguridad interior del Estado

\section{Capitulo I}

De los que comprometen la existência política de la Nacion, o esponen el Estado a los ataques de una potencia estrangera (Art. 249 ao 258)

\section{Capitulo II}

De los delitos contra el derecho de gentes (Art. 259 ao 273)

\section{TITULO III}

De los delitos contra la seguridad interior del Estado y contra la tranquilidad y orden publico

\section{Capitulo I}

De la rebelion y del armamento ilegal de tropas (Art. 274 ao 279)

\section{Capitulo II}

De la sedicion (Art. 280 ao 298)

\section{Capitulo III}

De los motines o tumultos, asonadas ú otras conmociones populares (Art. 299 ao 314)

\section{Capitulo IV}

De las facciones y parcialidades, y de las confederaciones y reuniones prohibidas (Art. 315 ao 320)

\section{Capitulo V}

De los que resisten o impiden la ejecucion de las leyes, actos de justicia o providencias de la autoridad pública, o provocan a desobedecerlas, y de los que impugnan las legitimas facultades del Gobierno (Art. 321 ao 325)

\section{Capitulo VI}

De los atentados contra las autoridades establecidas, o contra los funcionarios públicos cuando proceden como tales, y de los que usurpan o impiden el libre ejercicio de sus funciones, o les compelen en ellas con fuerza o amenazas (Art. 326 ao 337)

\section{Capitulo VII}

De las cuadrillas de malhechores, y de los que roban caudales públicos, o interceptan correos, o hacen daños en bienes o efectos pertenecientes al Estado o al comun de los pueblos (Art. 338 ao 349)

\section{Capitulo VIII}

De los que allanan carceles o establecimentos públicos de correccion o castigo para dar libertad o maltratar a los detenidos y presos; de los alcaides encargados responsables de la fuga, y de los que cooperan o ausilian a ella (Art. 350 ao 357)

\section{Capitulo IX}

De la fabricacion, venta, introduccion y uso de armas prohibidas (Art. 358 ao 362)

\section{TITULO IV}

De los delitos contra la salud publica

\section{Capitulo I}


De los que, sin estar aprobados, ejercen la medicina, cirurjia, farmácia, arte obstetrícia o flebotomia (Art. 363 ao 365)

\section{Capitulo II}

De los boticários que venden o despachan venenos, drogas o medicamentos perjudiciales a la salud sin receta de facultativo aprobado, o equivocando lo que este haya dispuesto (Art. 366 ao 372)

\section{Capitulo III}

De los que venden generos medicinales sin ser boticários (Art. 373 ao 375)

Disposiciones comunes a los precedentes capítulos (Art. 376 ao 378)

\section{TITULO V}

\section{De los delitos contra la fe publica}

\section{Capitulo I}

De la falsificacion y alteracion de la moneda (Art. 379 ao 387)

\section{Capitulo II}

De los que falsifican los sellos de las Córtes, o del Rey, o de las autoridades, y oficinas del Gobierno, o las actas, o resoluciones de las Córtes, las cédulas, títulos, despachos y decretos reales, el papel-moneda, los créditos contra el Estado o contra otros establecimentos públicos (Art. 388 ao 397)

\section{Capitulo III}

De las falsedades, supresiones y omisiones que se cometan en escrituras, actas judiciales ú otros documentos públicos o de comercio (Art. 398 ao 407)

\section{Capitulo IV}

De las falsedades en documentos privados, sellos, marcas y contraseñas de los particulares (Art. 408 ao 416)

\section{Capitulo V}

De la falsificacion o alteracion en los pesos y medidas, y de la falsedad en la venta de metales, pedreria ú otros efectos (Art. 417 ao 420)

\section{Capitulo VI}

De los que violen el secreto que les está confiado por razon del empleo, cargo o profesion pública que ejerzan, y de los que abran o supriman indebidamente cartas cerradas (Art. 421 ao 428)

\section{Capitulo VII}

De los acusadores, denunciadores y testigos falsos; de los perjuros, y demas que en juicio ú oficialmente falten a la verdad (Art. 429 ao 436)

\section{Capitulo VIII}

De la sustraccion, alteracion o destruccion de documentos o efectos custodiados en archivos, oficinas ú otras depositarías publicas: de la apertura ilegal de testamentos cerrados; y del quebrantamiento de secuestros, embargos o sellos puestos por autoridad legitima (Art. 437 ao 446)

\section{Capitulo IX}

De los que se suponen con títulos o facultades que no tienen, o usan de condecoraciones o distintivos que no les estan concedidos (Art. 447 ao 450)

\section{TITULO VI}

De los delitos y culpas de los funcionários públicos en el ejercicio de sus cargos

\section{Capitulo I}

De la prevaricacion de los funcionários públicos (Art. 451 ao 453) 


\section{Capitulo II}

De los sobornos, cohechos y regalos que se hagan a los que ejercen algun empleo o cargo publico (Art. 454 ao 462)

\section{Capitulo III}

Del estravío, usurpacion y malversacion de caudales y efectos públicos por los que los tienen a su cargo (Art. 463 ao 467)

\section{Capitulo IV}

De las estorsiones y estafas cometidas por funcionários públicos (Art. 468 ao 478)

\section{Capitulo V}

De los funcionários públicos que ejercen negociaciones o contraen obligaciones incompatibles con su destino (Art. 479 ao 482)

\section{Capitulo VI}

De los funcionários públicos que no obedecen o no cumplen las leyes ó ordenes superiores: de los que impiden o embarazan, o se conciertan para impedir o embarazar su ejecucion, o la de algun acto de justicia; y los que incurren en otras faltas de subordinacion y asistencia al desempeno de sus obligaciones (Art. 483 ao 491)

\section{Capitulo VII}

De los funcionários públicos de la mala conducta, y de los que tratan mal a sus inferiores y a las personas que tienen que acudir a ellos por razon de su oficio: de los que cometen violencias en el ejercicio de sus funciones; y de los que abusan de la autoridad o poder que tengan por su empleo para asuntos particulares (Art. 492 ao 500)

\section{Capitulo VIII}

De los funcionários públicos que anticipan o prolongan indebidamente sus funciones, o ejercen las que no les corresponden (Art. 501 ao 505)

\section{Capitulo IX}

De los funcionários públicos omisos en perseguir a los delincuentes, y de los que niegan o retardan la administracion de justicia, la proteccion o los remedios legales que deben aplicar, no cooperan y ausilian, debiendo, a los actos del servicio publico (Art. 506 ao 509)

\section{Capitulo X}

De los tribunales y jueces eclesiásticos que hacen fuerza (Art. 510 ao 512)

\section{Capitulo XI}

De otros delitos y culpas de los funcionários públicos en la administracion de justicia (Art. 513 ao 517)

\section{Capitulo XII}

De los delitos de los asentistas, proveedores y empleados públicos que suministran, venden, compran o administran algunas cosas por cuenta del Gobierno (Art. 518 ao 526)

\section{TITULO VII}

\section{De los delitos contra las buenas costumbres}

\section{Capitulo I}

De las palabras y acciones en sítios públicos; y de la edicion, venta y distribucion de escritos, pinturas o estampas de la misma clase (Art. 527 ao 534)

\section{Capitulo II}

De los que promueven o fomentan la prostitucion, y corrompen a los jovenes, o contribuyen a cualquiera de estas cosas (Art. 535 ao 542)

\section{Capitulo III}


De los bígamos y de los eclesiásticos que se casan (Art. 543 ao 551)

Capitulo IV

De los matrimonio clandestinos o faltos de las previas solemnidades debidas (Art. 552 ao 560)

\section{Capitulo V}

Del desacato de los hijos contra la autoridad de sus padres, y del de los menores de edad contra sus tutores, curadores o parientes a cuyo cargo estuviere (Art. 561 ao 568) Capitulo VI

De las desavenencias y escándalos en los matrimônios (Art. 569 ao 572)

\section{TITULO VIII}

De los que rehusan al estado los servicios que le deben

Capitulo único (Art. 573 ao 591)

\section{TITULO IX}

De los delitos y culpas de los impresores, libreros y otras personas en el abuso de la libertad de imprenta

Capitulo único (Art. 592 ao 604)

\section{PARTE SEGUNDA}

De los delitos contra los particulares

\section{TITULO I}

De los delitos contra las personas

\section{Capitulo I}

Del homicídio, envenenamiento, castracion y aborto, y de los que incendian para matar (Art. 605 ao 641)

\section{Capitulo II}

De las heridas, ultrajes y malos tratamientos de obra (Art. 642 ao 660)

\section{Capitulo III}

De las riñas y peleas, aunque no resulte homicídio ni herida, y de los que provoquen o ausilien para ellas (Art. 661 ao 663)

\section{Capitulo IV}

De los raptos, fuerzas y violencias contra las personas, y de la violacion de los enterramientos (Art. 664 ao 682)

\section{Capitulo V}

Del adultério y del estupro alevoso (Art. 683 ao 689)

\section{Capitulo VI}

De los que esponen, ocultan o cambian niños, o comprometen de otro modo su esistencia natural o civil, y de los partos fingidos (Art. 690 ao 698)

\section{TITULO II}

De los delitos contra la honra, fama y tranquilidad de las personas

\section{Capitulo I}

De las calumnias, libelos infamatórios, injurias y revelacion de secretos confiados (Art. 699 ao 718) 


\section{Capitulo II}

De las amenazas de homicídios ú otros daños (Art. 719 ao 722)

\section{TITULO III}

De los delitos contra la propiedad de los particulares

\section{Capitulo I}

De los robos (Art. 723 ao 744)

\section{Capitulo II}

De los hurtos (Art. 745 ao 752)

\section{Capitulo III}

Disposiciones comunes a robos y hurtos (Art. 753 ao 757)

\section{Capitulo IV}

De las quiebras (Art. 758 ao 765 )

\section{Capitulo V}

De las estafas y enganos (Art. 766 ao 772)

\section{Capitulo VI}

De los abusos de confianza (Art. 773 ao 780)

\section{Capitulo VII}

De los que falsifican o contrahacen obras agenas, o perjudican a la industria de otro (Art. 781 ao 786)

\section{Capitulo VIII}

De los incendios y otros daños (Art. 787 ao 806)

\section{Capitulo IX}

De las fuerzas y violencias contra las propiedades, y de los despojos (Art. 807 ao 814)

\section{Capitulo X}

De los que mudan o alteran los términos de las heredades (Art. 815 ao 816) 


\section{Anexo VI}

Índice do "Code of Offences and Punishments", do A System of Penal Law for the Satet of Louisiana, de Edward Livingston (1824)

\section{BOOK I}

Containing General Provisions

\section{Chapter I}

Containing general provisions relative to the operation of the penal laws of this state.

(Art. 1 ao 11)

Chapter II

General provisions relative to prosecutions and trials. (Art. 12 ao 25)

\section{Chapter III}

Of persons amenable to the provisions of this code, and of the circumstances under

which all acts that would otherwise be offences, may be justified or excused. (Art. 26

ao 51)

Chapter IV

Of a repetition of offences. (Art. 52 ao 56)

Chapter V

Of principals, accomplices and accessaries. (Art. 57 ao 74)

\section{BOOK II}

Of Offences and Punishments

\section{TITLE I}

Of the general divisions and descriptions of offences and punishments.

\section{Chapter I}

Definition and divisions of offences. (Art. 75 ao 81)

Chapter II

Of punishments. (Art. 82 ao 108)

TITLE II

Of offences against the sovereign Power of the state.

\section{Chapter I}

Of treason. (Art.109)

Chapter II

Of sedition. (Art. 110 ao 114)

Chapter III

Of exciting insurrection. (Art. 115 ao 117)

\section{TITLE III}

Of offences against the legislative power. (Art. 118 ao 121)

\section{TITLE IV}

Of offences against the executive power.

Chapter I (Art. 122 ao 125)

Chapter II 
Of offences committed by executive officers. (Art. 126 ao 137)

TITLE V

Of offences affecting the judiciary power.

Chapter I

Of offences committed by and against judges or jurors in their official capacity.

$\underline{\text { Section I }}$

Of offences committed by judges or jurors. (Art. 138 ao 147)

$\underline{\text { Section II }}$

Of offences against judges or jurors in their official capacity. (Art. 148 ao 152)

\section{Chapter II}

Of offences against officers of justice and officers of courts (Art. 153 ao 164)

Chapter IV

Of rescue. (Art. 165 ao 170)

Chapter V

Of escape. (Art. 171 ao 174)

Chapter VI

Of breach of prison. (Art. 175 ao 179)

Chapter VII

Of offences committed by officers of justice and officers of courts in their official capacity. (Art. 180)

\section{Chapter VIII}

Of counselors and attorneys at law. (Art. 181 ao 188)

Chapter IX

Of offences by falsely personating another in judiciary proceedings. (Art. 189 ao 190)

Chapter X

Of perjury and false swearing. (Art. 191 ao 204)

\section{Chapter XI}

Offences against the judiciary power committed in a court of justice. (Art. 205 ao 208)

\section{TITLE VI}

\section{Of offences against public tranquility.}

\section{Chapter I}

Of unlawful assemblies and riots. (Art. 209 ao 221)

Chapter II

Of public disturbance. (Art. 222 ao 225)

\section{TITLE VII}

Of offences against the right of suffrage.

\section{Chapter I}

Of bribery and undue influence. (Art. 226 ao 229)

\section{Chapter II}

Of offences committed by judges or other officers of elections. (Art. 230 ao 234)

\section{Chapter III}


Of violence and riots at elections, and of the protection of electors from arrest. (Art. 235 ao 238 )

TITLE VIII

Of offences against the liberty of the press. (Art. 239 ao 244)

TITLE IX

Of offences affecting public records. (Art. 245 ao 252)

TITLE X

Of offences against the current coin and public securities.

\section{Chapter I}

Of offences against the current coin of the state. (Art. 253 ao 260)

Chapter II

Of offences against the public securities. (Art. 261)

\section{TITLE XI}

Of offences affecting the public revenue (Art. 262 ao 268)

\section{TITLE XII}

Of offences which affect commerce and manufactures.

\section{Chapter I}

Of offences which affect foreign commerce. (Art. 269 ao 275)

\section{Chapter II}

Of offences against the laws regulating seamen in the merchant service, and the police of the port. (Art. 276 ao 278)

\section{Chapter III}

Of false weights and measures. (Art. 279 ao 282)

Chapter IV

Of false marks. (Art. 283 ao 285)

Chapter V

Of offences affecting the credit of written instruments. (Art. 286 ao 312)

\section{Chapter VI}

Of fraudulent insolvencies. (Art. 313 ao 322)

\section{TITLE XIII}

Of offences affecting public property (Art. 323)

\section{TITLE XIV}

Of offences affecting the public roads, embankments, bridges, navigable waters, and other property held by the sovereign power for the common use.

General Provision (Art. 324)

\section{Chapter I}

Of the levees and embankments of rivers. (Art. 325 ao 326) 
Chapter II

Of the roads, bridges, and navigable waters. (Art. 327 ao 330)

\section{TITLE XV}

Of offences injurious to public health.

\section{Chapter I}

Of acts injurious to public health or safety. (Art. 331 ao 334)

\section{TITLE XVI}

\section{Of offences against morals}

\section{Chapter I}

Of disorderly houses. (Art. 335 ao 339)

Chapter II

Of offences against decency. (Art. 340 ao 343)

\section{Chapter III}

Of adultery. (Art. 344 ao 349)

\section{Chapter IV}

Of the violation of places of interment. (Art. 350 ao 355)

\section{TITLE XVII}

Of offences which affect persons in the exercise of their religion. (Art. 356 ao 361)

\section{TITLE XVIII}

Of offences affecting reputation.

\section{Chapter I}

Of defamation. (Art. 362 ao 398)

\section{Chapter II}

Of other injuries to reputation by effigies or dramatic representations. (Art. 399 ao 400)

\section{Chapter III}

Of false accusation, and threats of prosecution. (Art. 401 ao 403)

Chapter IV

Of fabricating defamatory papers. (Art. 404 ao 405)

\section{TITLE XIX}

Of offences affecting the persons of individuals.

\section{Chapter I}

Of assault and of battery.

Section I

Of simple assault, or simple assault and battery. (Art. 406 ao 419)

Section II 
Of assault and battery in relation to the person on whom, or by whom it is committed. (Art. 420 ao 424)

Section III

Of assault and battery, aggravated by its commission in a particular place. (Art. 425 ao 428)

Section IV

Of assault and battery aggravated by the intent. (Art. 429 ao 434)

Section V

Of assault and battery, aggravated by the manner and degree in which it is inflicted. (Art. 435 ao 439)

Section VI

General provisions. (Art. 440 ao 442)

\section{Chapter II}

Of false imprisonment.

Section I

Of simple false imprisonment. (Art. 443 ao 449)

$\underline{\text { Section II }}$

Offalse imprisonment aggravated by the purpose of the degree. (Art. 450 ao 456)

$\underline{\text { Section III }}$

Of abduction. (Art. 457 ao 459)

\section{Chapter III}

Of rape. (Art. 460 ao 468)

Chapter IV

Of abortion. (Art. 469 ao 474)

Chapter V

Of injury to the person by malicious potions. (Art. 475 ao 478)

\section{Chapter VI}

On homicide.

Section I

Of homicide in general, and of its different divisions. (Art. 479 ao 491)

Section II

Of justifiable homicide. (Art. 492)

Section III

Of homicide justified by the requisition of law. (Art. 493 ao 498)

Section IV

Of homicide, permitted in the performance of a duty to the state. (Art. 499 ao 504)

Section V

Of homicide permitted in defence of person or property. (Art. 505 ao 512)

Section VI

Of excusable homicide. (Art. 513 ao 514)

Section VII

Of culpable homicide. (Art. 515 ao 547))

Section VIII

Of suicide. (Art. 548)

\section{Chapter VI}

Of duels. (Art. 549 ao 568) 


\section{TITLE XX}

Of offences affecting individuals in their profession or trade. (Art. 569)

\section{TITLE XXI}

Of offences against civil and political rights and conditions

\section{Chapter I}

Of the substitution, exposure of infants, and of falsifying registers. (Art. 570 ao 576)

Chapter II

Of bigamy. (Art. 577 ao 585)

\section{TITLE XXII}

Of offences affecting persons in their profession or trade.

\section{TITLE XXIII}

Of offences affecting private property.

\section{Chapter I}

Of burning and other malicious injury to property. (Art. 586 ao 604)

Chapter II

Of house-breaking. (Art. 605 ao 610)

\section{Chapter III}

Of the acquisition or appropriation of property by fraud or force. (Art. 611)

Section I

Of fraudulent breach of trust. (Art. 612 ao 615)

Section II

Of fraudulent appropriation of property found. (Art. 616 ao 620)

Section III

Of violation of epistolary correspondence. (Art. 621 ao 624)

Section IV

Of obtaining property by false pretences. (Art. 625 ao 644)

Section V

Of theft. (Art. 645 ao 649)

Section VI

Of aggravated theft. (Art. 650)

Section VII

Of theft by effraction. (Art. 651 ao 656)

Section VIII

Of stealing from the person. (Art. 657 ao 661)

$\underline{\text { Section IX }}$

Of robbery. (Art. 662 ao 669)

Section X

Of receiving property, knowing it to be fraudulently obtained. (Art. 670 ao 675)

\section{Chapter IV}

Of attempts to defraud by threats. (Art. 676 ao 682)

Chapter V

Of conspiracy. (Art. 683 ao 689) 
General Provision

Of accessaries. (Art. 690) 


\section{Anexo VII \\ Índice do "Code de délits et des peine" do "Corps de droit français civil, commercial et criminel", de 1810.}

Dispositions Préliminaires (Art. 1 ao 5)

LIVRE PREMIER

Des peines em matière criminelle et correctionnelle, et de leurs effets (Art. 6 ao 11)

\section{Chapitre I}

Des peines em matière criminelle. (Art. 12 ao 39)

Chapitre II

Des peines em matière correctionnelle. (Art. 40 ao 43)

Chapitre III

Des peines et des autres condemnations qui peuvent être prononcées pour crimes et délits. (Art. 44 ao 55)

Chapitre IV

Des peines de la récidive pour crimes et délits. (Art. 56 ao 58)

\section{LIVRE II}

Des personnes punissables, excusable ou responsables pour crimes ou pour délits. Chapitre Unique (Art. 59 ao 74)

\section{LIVRE III}

Des crimes, des délits et de leur punition.

\section{TITRE I}

Des crimes et des délits contre la chose publique.

\section{Chapitre I}

Des crimes et délits contre la sûreté de 1'Etat.

$\underline{\text { Section I }}$

Des crimes et délits contre La sûreté extérieure de l'Etat. (Art. 75 ao 85)

\section{$\underline{\text { Section II }}$}

Des crimes et délits contre La sûreté intérieure de l'Etat.

$\S$ I - Des attentats et complots dirigés contre 1'Empereur et sa famille. (Art. 86 ao 90)

$\S$ II - Des crimes tendant à troubler l'Etat par la guerre civile, l'illégal emploi de la

force armée, la dévastation et le pillage publics. (Art. 91 ao 101)

Disposition Commune aux deux paragraphes de la presente section (Art. 102)

\section{Section III}

De la révélation et de la non-révélation des crimes qui compromettent la sûreté intérieure ou extérieure de l'Etat. (Art. 103 ao 108)

\section{Chapitre II}

Des crimes et délits contre les constitutions de 1'Empire.

$\underline{\text { Section I }}$

Crimes et délits relatifs à l'exercice des droits civiques. (Art. 109 ao 113)

$\underline{\text { Section II }}$

Attentats à la liberté. (Art. 114 ao 122) 
$\underline{\text { Section III }}$

Coalitions des fonctionnaires (Art. 123 ao 126)

Section IV

Empiétements des autorités administrative et judiciaire. (Art. 127 ao 131)

\section{Chapitre III}

Crimes et délits contre la paix publique

$\underline{\text { Section I }}$

Du faux

$\S$ I - Fausse monnaie (Art. 132 ao 138)

$\S$ II - Contrefaction des sceaux de 1'Etat, des Billets de banquet, des Effets publics, et des poiçons, timbres et marques. (Art. 139 ao 144)

$\S$ III - Des faux en écritures publiques ou authentiques, et de commerce ou de banque.

(Art. 145 ao 149)

$\S$ IV - Du faux em écriture privée. (Art. 150 ao 152)

$\S \mathrm{V}-$ Des faux commis dans les Passe-ports, feuilles de route et certificats. (Art. 153 ao 165)

\section{$\underline{\text { Section II }}$}

De la forfaiture et des crimes et délits des fonctionnaires publics dans l'exercice de leurs fonctions. (Art. 166 ao 168)

$\S$ I - Des soustractions commises par les dépositaires publics. (Art. 169 ao 173)

$\S \mathrm{II}-$ Des concussions commises par les fonctionnaires publics. (Art. 174)

$\S$ III - Des délits de fonctionnaires qui se seront ingérés dans des affaires ou

commerces incompatible avec leur qualité. (Art. 175 e 176)

$\S$ IV - De la corruption des fonctionnaires publics. (Art. 177 ao 183)

$\S \mathrm{V}-$ Des abus d'autorité - I Classe: Des abus d'autorité contre les particuliers (Art. 184 a 187$)$

(Art. 188 a 191)

II Classe: Des abus d'autorité contre la chose publique

$\S$ VI - Des quelques délits relatifs à la tenue des actes de l'état civil. (Art.192 a 195)

$\S$ VII - De 1'exercice de l'autorité publique illégalement anticipé ou prolongé. (Art.

196 ao 197)

Disposition particulière (Art. 198)

\section{$\underline{\text { Section III }}$}

Des troubles apportés à l'ordre public par les Ministres des cultes dans l'exercice de leur ministère.

$\S 1-$ Des contraventions propres à compromettre l'Etat civil des personnes. (Art. 199 ao 200)

$\S$ II - Des critiques, censures ou provocations dirigées contre 1'autorité publique dans um discours pastoral prononcé publiquement. (Art. 201 ao 203)

$\S$ III - Des critiques, censures ou provocations dirigées contre l'autorité publique dans um écrit pastoral. (Art. 204 ao 206)

$\S \mathrm{IV}$ - De la correspondance des ministres des cultes avec des cours ou puissances étrangères,sur des matières de religion. (Art. 207 ao 208)

$\underline{\text { Section IV }}$

Résistance, désobéissance, et autres manquements envers l'autorité publiques. 
$\S$ I - Rebellion. (Art. 209 ao 221)

$\S$ II - Outrages et violence envers les dépositaires de l'autorité et de la force publique. (Art. 222 ao 233)

$\S$ III - Refus d'um service dû légalement. (Art. 234 ao 236)

$\S \mathrm{IV}$ - Evasion de détenus, recèlement de criminels. (Art. 237 ao 248)

$\S \mathrm{V}-$ Bris de scellés et enlevement de pièces dans les dépóts publics. (Art. 249 ao 256)

$\S$ VI - Dégradations de monuments. (Art. 257)

$\S$ VII - Usurpation de titres ou fonctions. (Art. 258 ao 259)

$\S$ VIII - Entraves au libre exercice des Cultes. (Art. 260 ao 264)

$\underline{\text { Section V }}$

Associations de malfaiteurs, vagabondage et mendicité.

$\S$ I - Association de malfaiteurs. (Art. 265 ao 268)

$\S$ II - Vagabondage. (Art. 269 ao 273)

$\S$ III - Mendicité. (Art. 274 ao 276)

Dispositions communes aux Vagabonds et Mendiants (Art. 277 a 282)

Section VI

Délits commis par la voie d'ecrits, images ou gravures distribués sans noms d'auteur, imprimeur ou graveur. (Art. 283 ao 289)

Disposition particulière. (Art. 290)

$\underline{\text { Section VII }}$

Des associations au réunions illicites. (Art. 291 ao 294)

TITRE II

Crimes et délits contre des particuliers.

\section{Chapitre I}

Crimes et délits contre les personnes;

$\underline{\text { Section I }}$

Meurtre et autres crimes capitaux, menaces d'attentats contre les personnes.

$\S \mathrm{I}$ - Meurtre, assassinat, parricide, infanticide, empoisonnement. (Art. 295 ao 304)

$\S$ II - Menaces. (Art. 305 a 308)

$\underline{\text { Section II }}$

Blessures et coups volontaires non qualifies meurtre, et autres crimes et délits volontaires. (Art. 309 a 318)

$\underline{\text { Section III }}$

Homicide, blessures et coups involontaires; crimes et délits excusable, et cas où ils ne peuvent être excuses; homicide, blessures et coups qui ne sont ni crimes ni délits.

$\S$ I - Homicide, blessures et coups involontaire. (Art. 319 ao 320)

$\S$ II -Crimes et délits excusable, et cas ou ils ne peuvent être escuses. (Art. 321 ao 326)

$\S$ III - Homicide, blessures et coups non qualifiés crimes ni délits. (Art. 327 a 329)

$\underline{\text { Section IV }}$ 
Attentats aux moeurs (Art. 330 ao 340)

$\underline{\text { Section } \mathrm{V}}$

Arrestations illégales et sequestrations de personnes. (Art. 341 ao 344)

$\underline{\text { Section VI }}$

Crimes et délits tendant à empécher ou détruire la preuve de l'etat civil d'um enfant, ou à compromettre son existence - Enlevement de Mineurs. - Infractions aux lois sur les inhumations.

$\S$ I - Crimes et délits envers 1'Enfant. (Art. 345 ao 353)

$\S$ II - Enlevement de Mineurs. (Art. 354 ao 357)

$\S$ III - Infractions aux lois sur les inhumations. (Art. 358 ao 360)

$\underline{\text { Section VII }}$

Faux témoignage, calomnies, injuries, revelation de secrets.

$\S$ I - Faux témoignage. (Art. 361 ao 366)

$\S$ II - Calomnies, injuries, revelation de secrets. (Art. 367 ao 378)

\section{Chapitre II}

Crimes et délits contre les propriétés.

\section{Section I}

Vols. (Art. 379 ao 401)

\section{$\underline{\text { Section II }}$}

Banqueroutes, Escroqueries, et autres espèces de fraude.

$\S$ I - Banquerrote et escroquerie. (Art. 402 ao 405)

$\S$ II - Abus de confiance. (Art. 406 ao 409)

$\S$ III - Contravention aux règlements sur les maisons de jeux, les loteries, et les maisons de prêt sur gages. (Art. 410 ao 411)

$\S \mathrm{IV}$ - Entraves apportées à la liberte des encheres. (Art. 412)

$\S \mathrm{V}$ - Violation des règlements relatif aux manufactures, au commerce et aux arts.

(Art. 413 ao 429)

$\S$ VI - Délits des fournisseurs. (Art. 430 ao 433)

$\underline{\text { Section III }}$

Destructions, dégradations, dommages. (Art. 434 ao 462)

Disposition Générale. (Art. 463)

\section{LIVRE IV}

\section{Contraventions de police et peines}

\section{Chapitre I}

Des peines. (Art. 464 ao 470)

\section{Chapitre II}

Contraventions et peines.

\section{Section I}


Première classe. (Art. 471 ao 474)

Section II

Deuxième classe. (Art. 475 ao 478)

Section III

Troisième classe. (Art. 479 ao 482)

Dispositions communes aux trios sections ci-dessus. (Art. 483)

Disposition Générale (Art. 484) 
Índice do "Codigo Criminal Intentado pela Rainha D. Maria I com as provas. Autor Paschoal José de Mello Freire", de 1786.

\section{TITULO I}

Dos delitos

\section{TITULO II}

Das pessoas capazes de delinquir

\section{TITULO III}

Dos agentes e complices

\section{TITULO IV}

Das penas

TITULO V

Dos hereges e apostatas

\section{TITULO VI}

Dos basflemas

TITULO VII

Dos perjuros

TITULO VIII

Dos impostores

\section{TITULO IX}

Dos sacrílegos

\section{TITULO X}

Dos usurários

\section{TITULO XI}

Dos adúlteros

\section{TITULO XII}

Dos crimes moraes

\section{TITULO XIII}

Do crime de alta traição

\section{TITULO XIV}

Do crime de lesa magestade

\section{TITULO XV}

Dos que fazem moeda falsa 


\section{TITULO XVI}

Das sedições, tumultos, e outros ajuntamentos

\section{TITULO XVII}

Dos que fazem assuada

\section{TITULO XVIII}

Dos que resitem, ou desobedecem aos julgadores, ou a seus officiaes, ou lhes dizem injurias

\section{TITULO XIX}

Dos que tirão os presos do poder da justiça ou das prisões, e dos presos, que fogem da cadêa

\section{TITULO XX}

Dos que fazem cárcere privado

\section{TITULO XXI}

Dos que se fingem ministros e officiaes de justiça

\section{TITULO XXII}

Dos que tomão ou perturbão a nossa jurisdicção, e dos donatários, que levão direitos, que lhes não pertencem

\section{TITULO XXIII}

Das armas defesas

\section{TITULO XXIV}

Das caças e pescarias defesas

\section{TITULO XXV}

Dos vadios

\section{TITULO XXVI}

Dos jogos e theatros

\section{TITULO XXVII}

Do luxo

\section{TITULO XXVIII}

Dos contrabandos

\section{TITULO XXIX}

Dos que comprão pão, vinho, ou azeite para revender

\section{TITULO XXX}

Do homicidio simples

\section{TITULO XXXI}

Dos homicídio qualificado 


\section{TITULO XXXII}

Dos incendiários

\section{TITULO XXXIII}

Dos que fazem ou acceitão desafio

\section{TITULO XXXIV}

Dos ferimentos

\section{TITULO XXXV}

Das injurias

\section{TITULO XXXVI}

Dos furtos

\section{TITULO XXXVII}

Dos damninhos

\section{TITULO XXXVIII}

Dos falsários

\section{TITULO XXXIX}

Dos partos suppostos

\section{TITULO XL}

Dos burlões e illiçadores

\section{TITULO XLI}

Dos mercadores, que quebrão

\section{TITULO XLII}

Dos que abrem as cartas do serviço do Rei, da Rainha, do Príncipe, ou dos particulares

\section{TITULO XLIII}

Dos receptadores

\section{TITULO XLIV}

Dos que prevaricão nos seus officios

\section{TITULO XLV}

Das provas

\section{TITULO XLVI}

Dos indícios ou presumpções

\section{TITULO XLVII}

Dos confessos 


\section{TITULO XLVIII}

Como se perguntarão aos réos

\section{TITULO XLIX}

Da prova por testemunhas

\section{TITULO L}

Das testemunhas judiciaes

\section{TITULO LI}

Da conformação dos réos entre si e com as testemunhas

\section{TITULO LII}

Da prova por escriptura

\section{TITULO LIII}

Dos delictos occultos e de difficil prova

\section{TITULO LIV}

Das denuncias

\section{TITULO LV}

Das querelas e accusações

\section{TITULO LVI}

Das devassas

\section{TITULO LVII}

Da pronuncia dos réos, das cartas de seguro, caução fidejussoria, guarda do corpo, da homenagem, arresto de bens, e ecercicio dos cargos públicos no cárcere

\section{TITULO LVIII}

Do corpo de delicto

\section{TITULO LIX}

Da informação da justiça

\section{TITULO LX}

Do processo judicial

\section{TITULO LXI}

Como se procederá contra os ausentes, mudos e surdos, menores, cidades, mortos

\section{TITULO LXII}

Do juiz competente

\section{TITULO LXIII}

Da sentença final em Relação

\section{TITULO LXIV}


Das appellações

\section{TITULO LXV}

Da execução da sentença

\section{TITULO LXVII}

Modos, por que se extinguem as obrigações criminaes 


\section{Anexo IX \\ Parecer da Comissão Especial do Código Criminal dedicada à análise e seleção das emendas enviadas pela deputação nacional, julho de $1830^{587}$.}

A Commissão especial do Codigo recebeo, e examinou as emendas que durante o mez de Maio offerecerão ao Projecto do Codigo Criminal os Senhores Deputados Araujo Lima, França filho, Rebouças, Ribas, Custodio Dias, Pinto da Gama, e Carneiro Leão; bem como a Memoria de William de St. ${ }^{\circ}$ Adolfo, e não encontrando meste escripto materia propria para ser proposta como emenda, apprezenta as que the forão offerecidas pelos Srs. Deputados.

A Commissão pensa que a maior parte destas emendas se achão em harmonia com o Sistema geral do Codigo, e que merecem ser adoptadas, ou porque crião (não tenho certeza) delicto novos, esquecidos no Projecto, mas exigidos pela nossa pozição Social, habitos, e costumes, ou porque correigem e adoção algumas penas que pareciam nimiamente asperas, ou porque suprimem artigos desnecessarios, e mesmo contrarios a Constituição do Imperio, ou finalmente porque dão clareza e exactidão a outras que a não tinhão.

A Commissão tem a notar que além das emendas que propõem á consideração da Camara, forão offerecidas pelos mesmos Srs. Deputados outras, que se não referem, por terem seus authores convindo na suppressão, deixando para [ilegível] prezentes a Commissão de Redação aquellas que não continhão alteração de doutrina dos artigos, a que dizião respeito.

Nota mais a Commissão que os Srs. Deputados França filho e Rebouças indicarão em geral que se suprimissem os artigos do Projecto, em que se impunha a pena de morte, e de galez; a Commissão porem não pôde concordar inteiramente com a opinião dos Srs. Deputados (que alias não offerecerão como parecia conveniente emendas a esses artigos substituindo as suas penas por outras) porque a Commissão mixta supõe que o estado atrazado da nossa educação primaria, e o elemento da escravatura que ainda subsiste não permittem que desde ja sejão de todo abulidas aquellas penas: entretanto a Commissão se persuade que o voto philantropico destes Srs. Deputados se acha em parte satisfeito com as emendas propostas por outros Srs., e organizadas pela Commissão. Nestas se omitte totalmente a pena de galez temporarias; a qual bem como a pena de morte se reservão para rarissimos cazos, e nesses mesmos estabelecendo-se trez penas, para os trez diferentes gráos, se provê ao tempo em que a applicação de semelhantes penas haja de tornar-se desnecessaria, ou ante-nacional, pois sem dependencia de medidas futuras do Poder Legislativo, a sua correcção se póde encontrar no Juro Mestrado, são, e imparcial do Jury.

Finalmente pelo que pertence ao Codigo do Doutor Eduardo Livingston que o Sr. Deputado França filho indicou como emenda ao Projecto da Commissão mixta, entende a Commissão que este Codigo com quanto seja muito apreciavel não deve ser preferido ao da Commissão mixta, e nem póde ser adoptado no Imperio já porque foi organizado para um povo que tem interesses, e hábitos diversos, já porque nelle se não punem algumas acções que a nossa forma de governo, costumes, e peculiares circunstancias exigem que sejão criados delictos, já finalmente porque sendo baseadas suas penas em hum Systema completo de Cazas de Correcção, e prizões aperfeiçoadas, não pode por muito tempo ser abraçado no Imperio, onde semelhante

\footnotetext{
${ }^{587}$ Arquivo da Biblioteca Nacional (RJ). Comissão especial do código - emendas ao projecto do código criminal, 1830. Typographia de Lessa \& Pereira, 1830. Localização: V, 257, 3, 8, $n^{\circ} 6$.
} 
Systema por desgraça nem existe esboçado: pelo que entende a Commissão que o Projecto da Commissão mixta deve ser preferido, e adoptado com as Emendas apprezentadas em primeiro lugar, que são aquellas que a Commissão julga em harmonia com o mesmo projecto, e dignas da attenção da Camara, tendo a lembrar que algumas dellas forão emprestadas do mencionado Codigo do Doutor Livingston.

Paço da Câmara dos Deputados 5 de Julho de 1830 - H. H. Carneiro Leão. Antonio Pinto Chichorro da Gama, com restricções, e vencido quanto ás penas de morte, e galez. - J. F. A. B. Munis Barreto. 